\title{
National procedural autonomy revisted: consequences of differences in national administrative litigation rules for the enforcement of environmental European Union law - the case of the EIA directive
}

Citation for published version (APA):

Grashof, F. (2015). National procedural autonomy revisted: consequences of differences in national administrative litigation rules for the enforcement of environmental European Union law - the case of the EIA directive. [Doctoral Thesis, Maastricht University]. Maastricht University.

https://doi.org/10.26481/dis.20151016fg

Document status and date:

Published: 01/01/2015

DOI:

$10.26481 /$ dis.20151016fg

Document Version:

Publisher's PDF, also known as Version of record

Please check the document version of this publication:

- A submitted manuscript is the version of the article upon submission and before peer-review. There can be important differences between the submitted version and the official published version of record. People interested in the research are advised to contact the author for the final version of the publication, or visit the DOI to the publisher's website.

- The final author version and the galley proof are versions of the publication after peer review.

- The final published version features the final layout of the paper including the volume, issue and page numbers.

Link to publication

\footnotetext{
General rights rights.

- You may freely distribute the URL identifying the publication in the public portal. please follow below link for the End User Agreement:

www.umlib.nl/taverne-license

Take down policy

If you believe that this document breaches copyright please contact us at:

repository@maastrichtuniversity.nl

providing details and we will investigate your claim.
}

Copyright and moral rights for the publications made accessible in the public portal are retained by the authors and/or other copyright owners and it is a condition of accessing publications that users recognise and abide by the legal requirements associated with these

- Users may download and print one copy of any publication from the public portal for the purpose of private study or research.

- You may not further distribute the material or use it for any profit-making activity or commercial gain

If the publication is distributed under the terms of Article $25 \mathrm{fa}$ of the Dutch Copyright Act, indicated by the "Taverne" license above,

Download date: 26 Apr. 2023 


\section{NATIONAL PROCEDURAL AUTONOMY REVISITED}

Consequences of differences in national administrative litigation rules for the enforcement of European Union environmental law - The case of the EIA Directive

\section{DISSERTATION}

to obtain the degree of Doctor at

Maastricht University, on the authority of the Rector Magnificus, Prof. dr. L.L.G. Soete in accordance with the decision of the Board of Deans,

to be defended in public

on Friday 16 October 2015, at 14:00 hours

by

Franziska Grashof 
Supervisor:

Prof. Dr. Chris W. Backes

Co-supervisor:

Dr. Mariolina Eliantonio

Assessment Committee:

Prof. Dr. Bruno de Witte (chairman)

Prof. Dr. Jan H. Jans, Groningen

Dr. Sander A. M. L. Jansen

Dr. Matthias Keller, Aachen, Germany

Prof. Dr. Marjan Peeters

Financial contribution:

Fondation Jean Monnet pour l'Europe

(Bourse Henri Rieben, September 2014) 


\section{Acknowledgements}

I would like to thank my supervisors Professor Dr. Chris Backes and Dr. Eliantonio for their constant support, valuable comments on my thesis, and interesting discussions. Moreover, I would like to thank the members of the Assessment Committee, Professor Dr. Bruno de Witte, Professor Dr. Jan Jans, Dr. Matthias Keller, Dr. Sander Jansen and Professor Dr. Marjan Peeters for reading the thesis.

Many thanks go to Professor Dr. Mike Varney and Dr. Marcel Soppe for their critical and helpful comments on my analysis of the enforcement of EIA legislation in English and Dutch courts.

I would like to express my gratitude to Karen Keller, Dr. Matthias Keller, Professor Thijs Drupsteen and Lord Carnwath for inspiring discussions and comments during and after my workshop in Brussels in December 2014. Moreover, I would like to thank Dr. René Seerden for providing me with an insight into the practice of judicial EIA enforcement.

A special thanks to the Fondation Jean Monnet pour l'Europe for having provided me with the possibility of very interesting research at the Ferme de Dorigny and the Institut Suisse de droit compare in Lausanne by granting me the "Bourse Henri Rieben" in September 2014.

I would like to thank Carolin Küpper and Britta Wiedemann for their expertise in natural sciences and environmental engineering which helped me to understand the technical side of EIA procedures, especially when drafting the hypothetical case study.

Many thanks go to Florian Idelberger for his support, patience and encouraging words.

I would like to cordially thank my parents, Dr. Johannes and Jutta Grashof, for their support in every regard. 
The state of the law is December 2014.

The thesis will be published with Europa Law Publishing, ISBN 9789089521804. 


\section{Table of Contents}

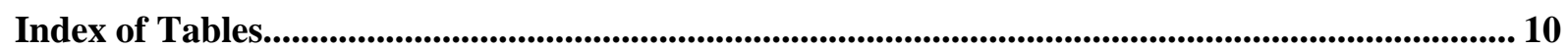

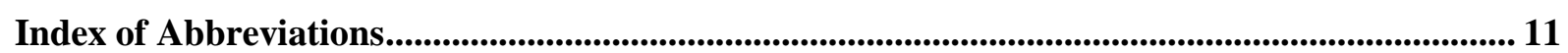

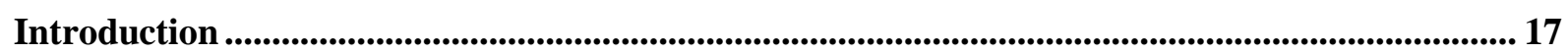

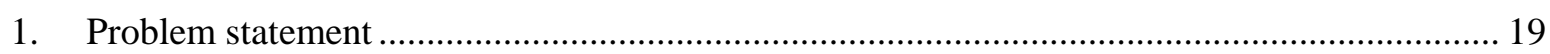

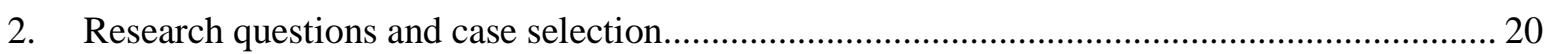

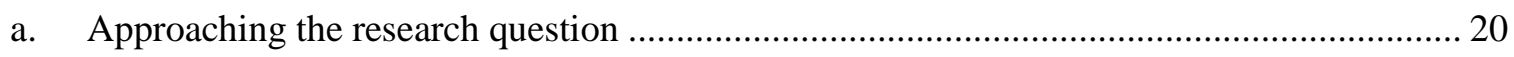

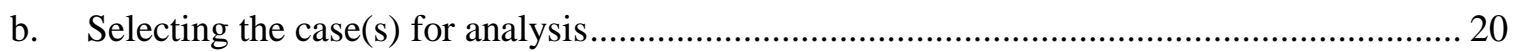

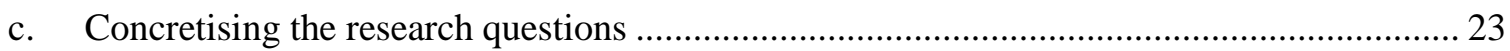

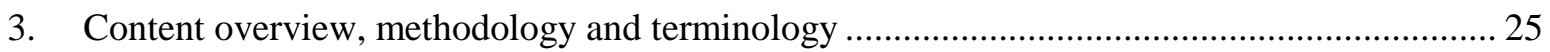

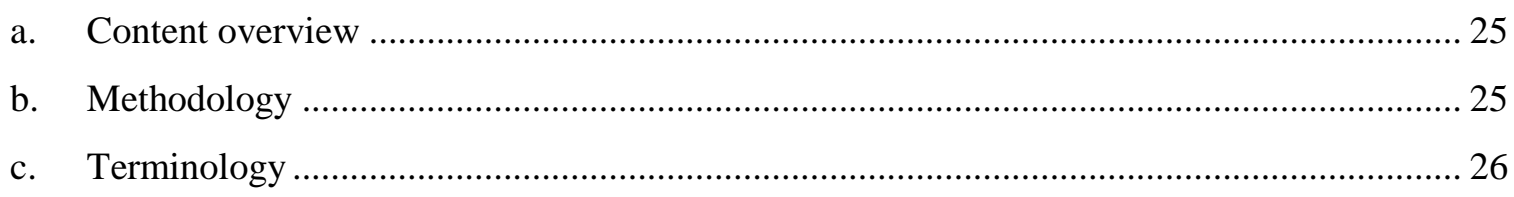

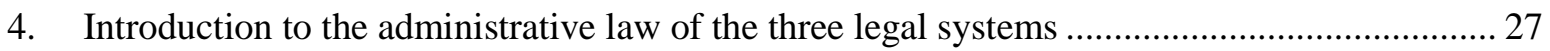

4.1 Introduction to the concept of "state" and "law" in the three legal systems ................................. 28

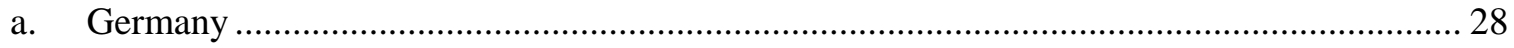

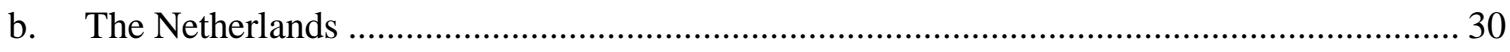

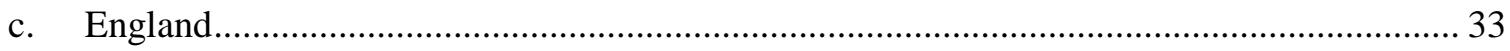

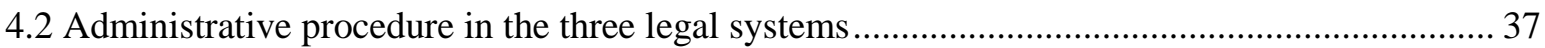

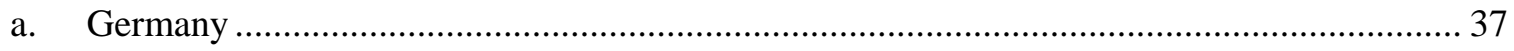

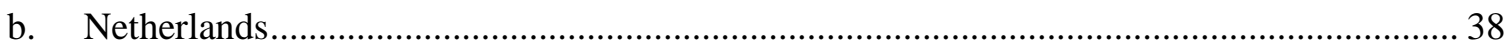

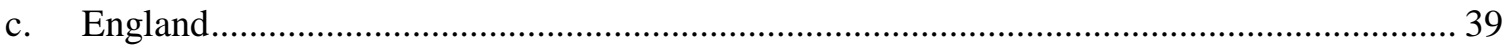

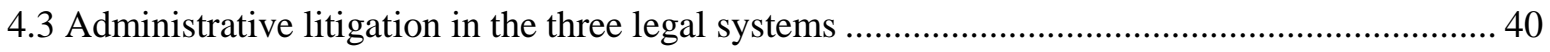

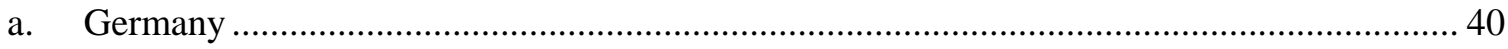

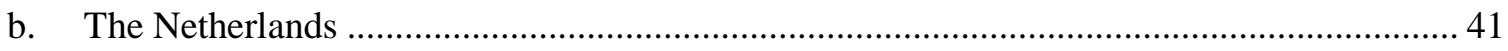

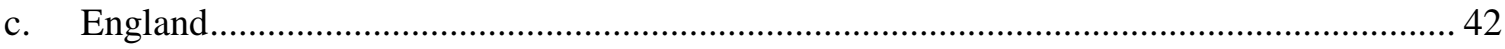

Part I Uniform rules: The EIA procedure of the Union ............................................................. 45

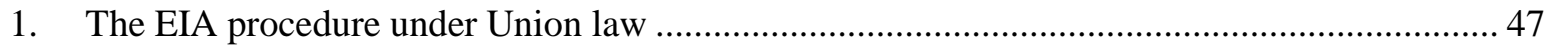

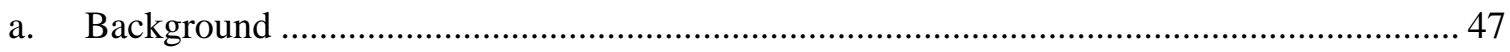

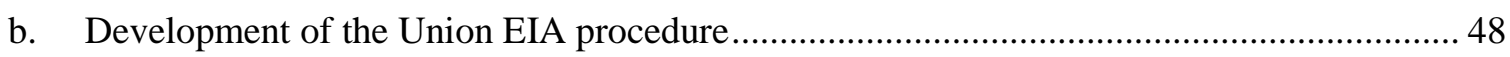

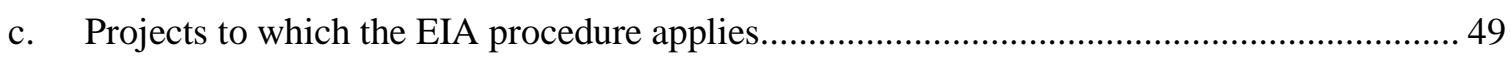

d. The main steps in an EIA procedure according to the EIA Directive ................................... 51

2. The implementation of the EIA Directive in the national legal systems ...................................52 


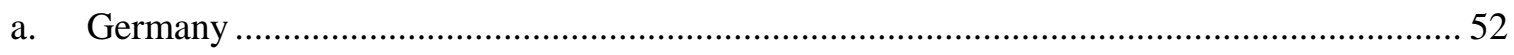

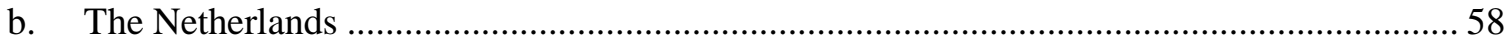

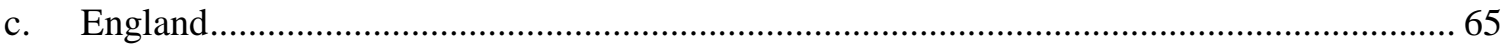

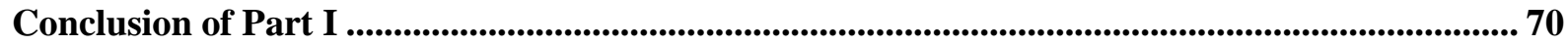

Part II Fragmented enforcement: national rules in EIA cases ....................................................... 71

Chapter 1 The European standard ............................................................................................. 73

1. The effet utile of European Union law and the principle of effectiveness................................. 73

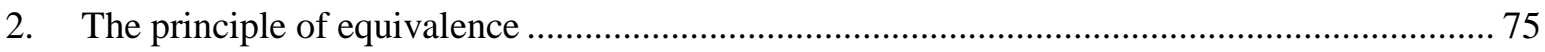

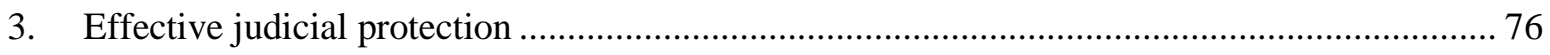

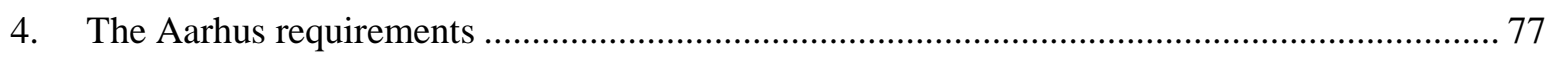

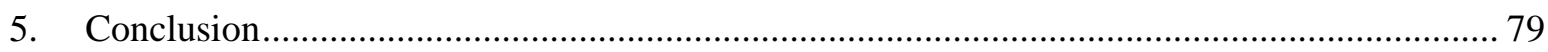

Chapter 2 Access to administrative courts ....................................................................... 80

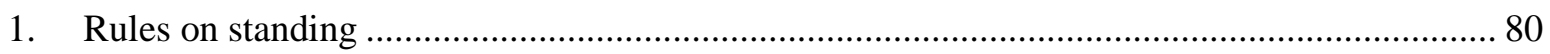

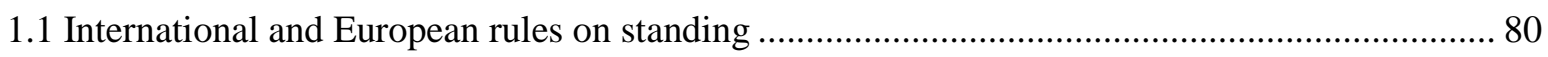

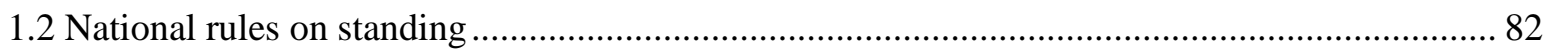

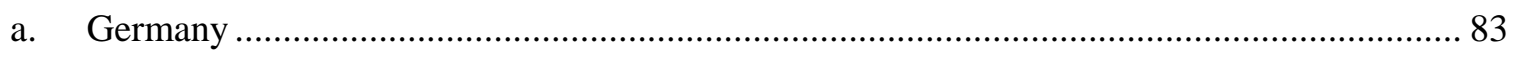

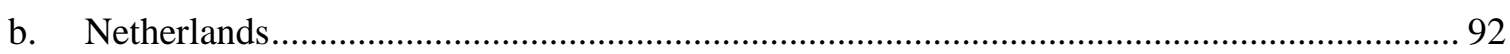

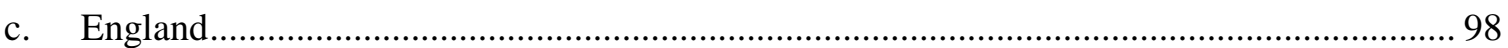

d. Comparison: differences and convergence..................................................................... 104

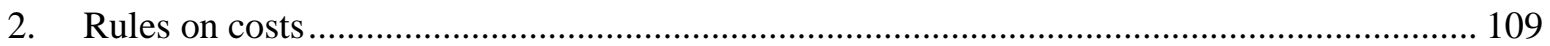

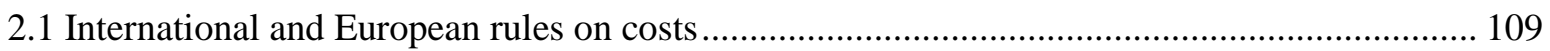

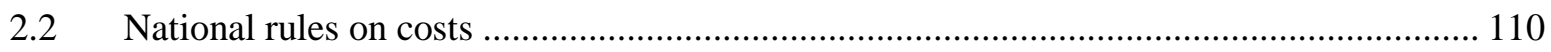

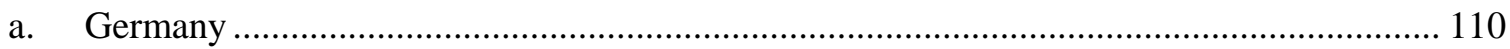

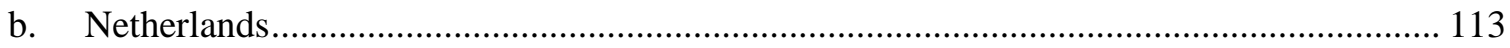

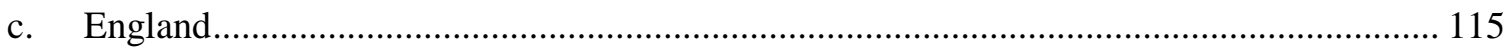

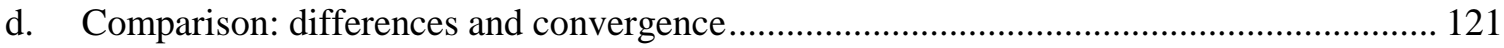

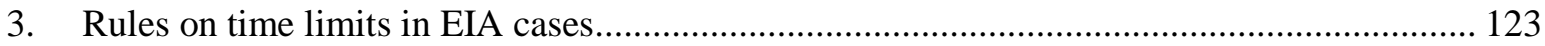

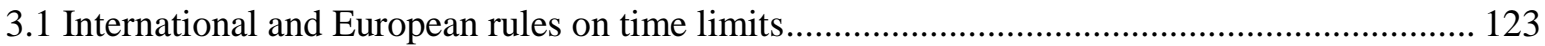

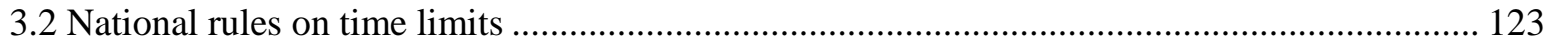

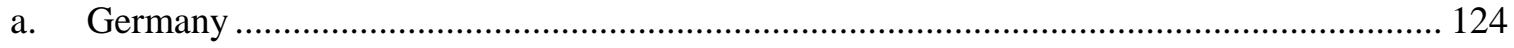

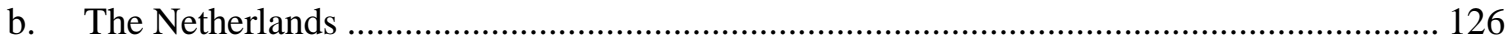

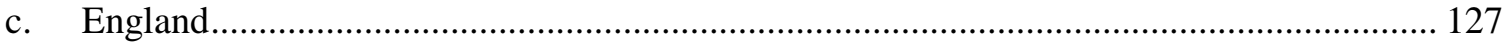

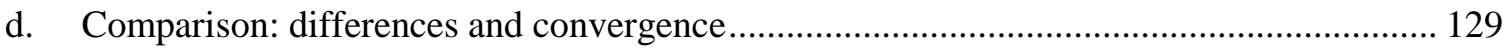

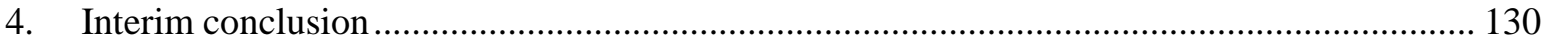


Chapter $3 \quad$ Review in administrative courts........................................................................................... 132

1. International and European rules on the scope of review ..................................................... 132

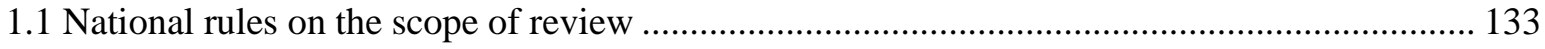

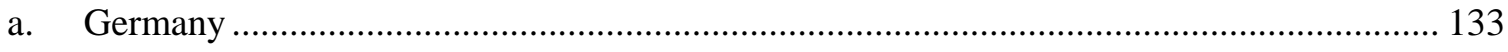

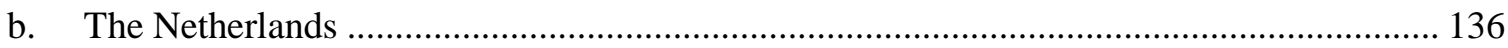

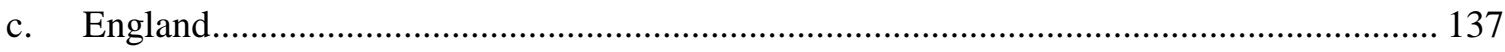

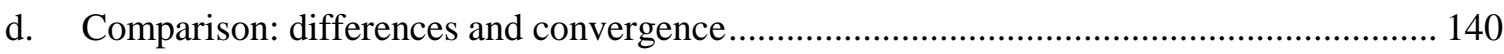

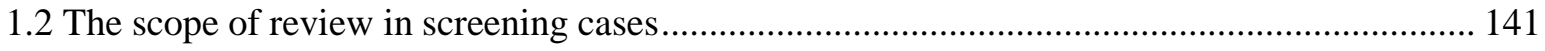

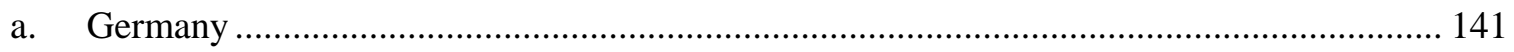

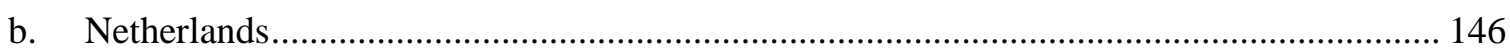

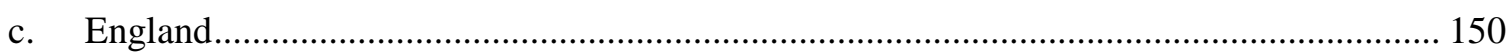

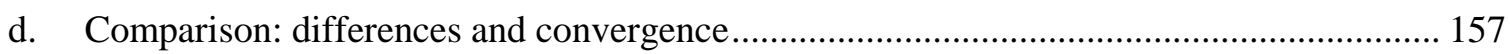

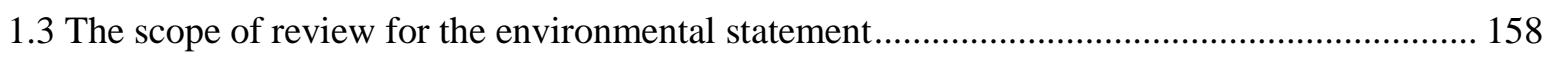

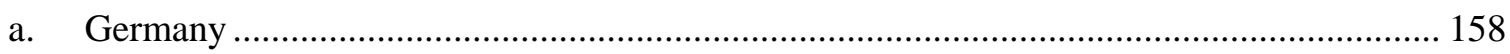

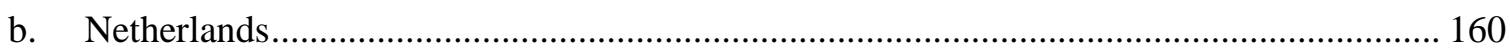

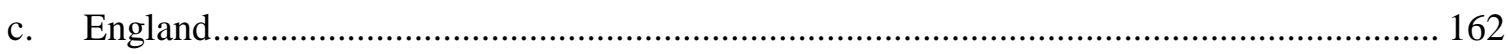

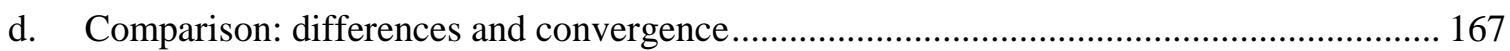

2. Gathering of facts, evidence and the burden of proof ...................................................... 168

2.1 International and European rules on the gathering of facts, evidence and the burden of proof 168

2.2 National rules on the gathering of facts, evidence and the burden of proof ............................... 169

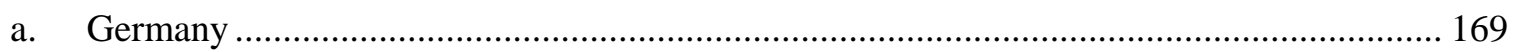

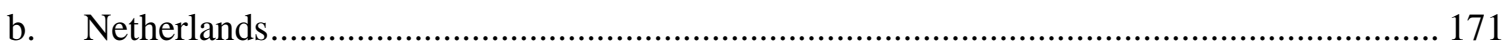

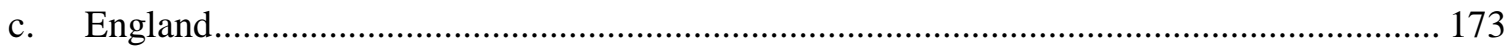

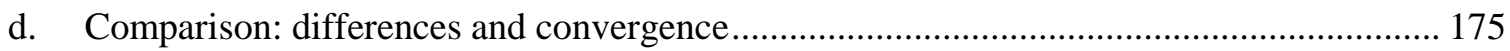

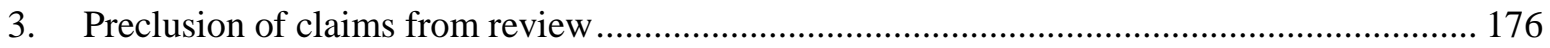

3.1 International and European rules on the preclusion of claims from review ............................. 176

3.2 National rules on the preclusion of claims from review........................................................ 177

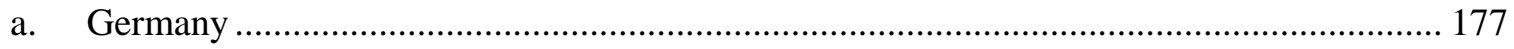

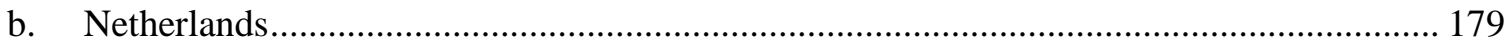

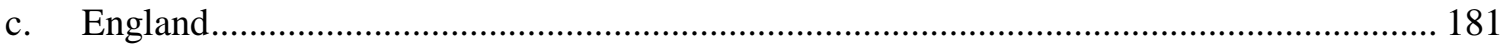

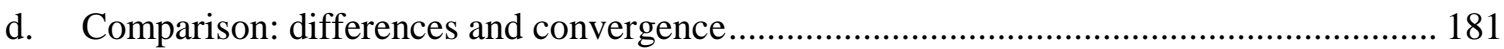

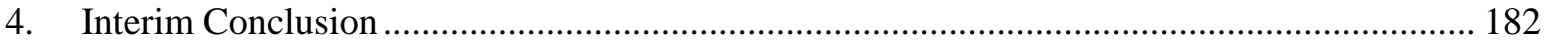

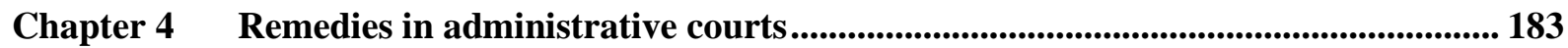

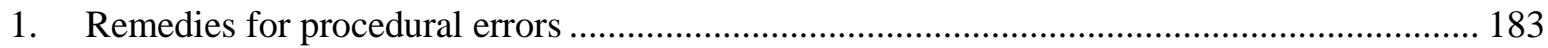

1.1 International and European rules on remedies for procedural errors …................................... 183

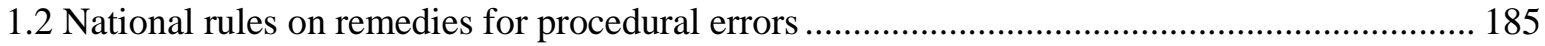




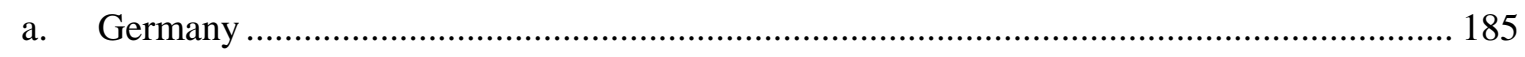

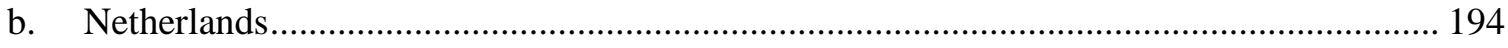

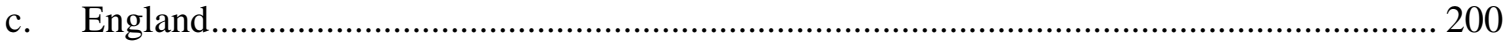

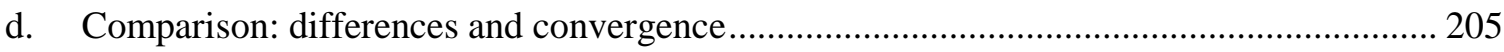

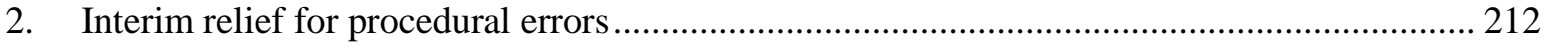

2.1 International and European Union rules on interim relief.................................................... 212

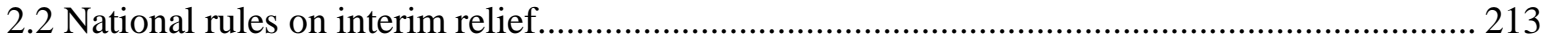

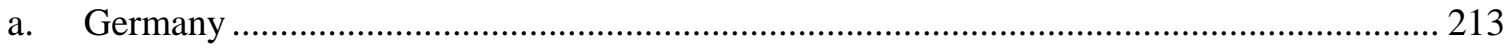

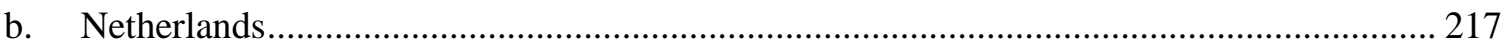

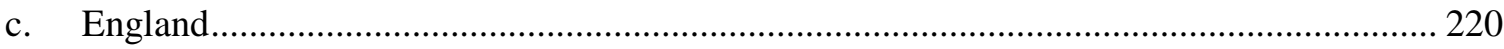

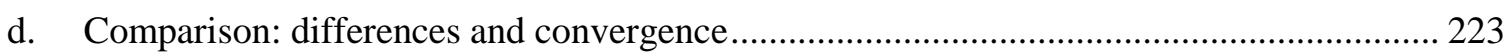

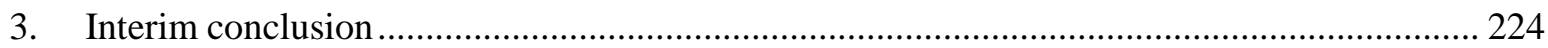

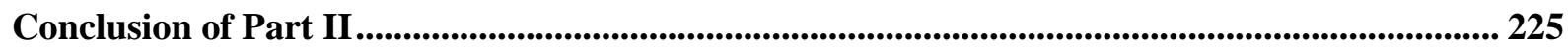

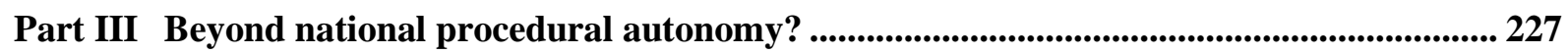

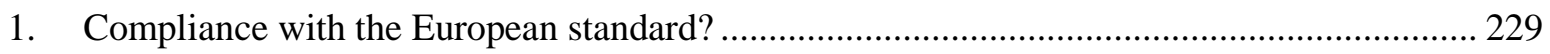

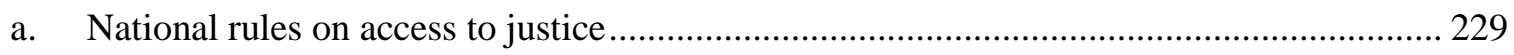

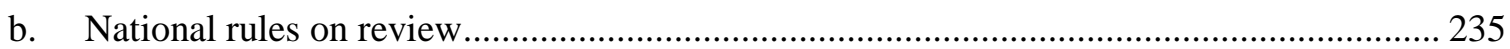

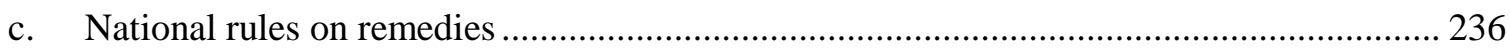

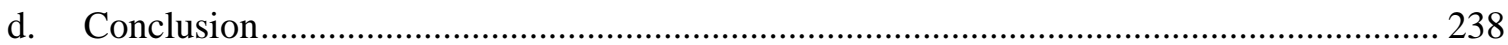

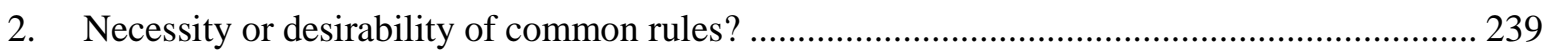

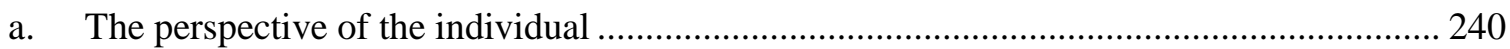

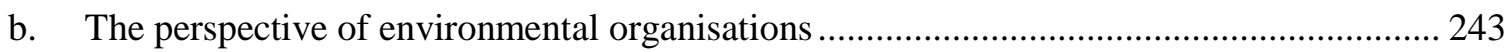

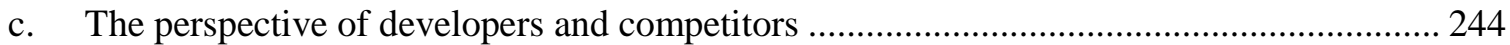

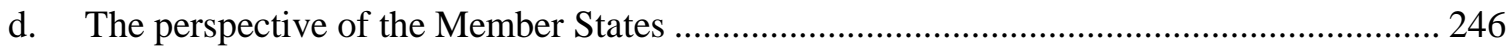

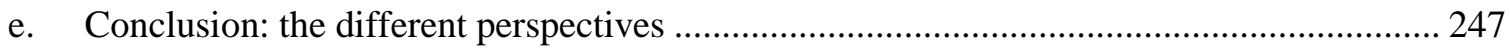

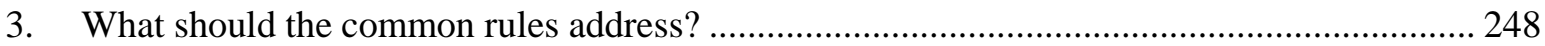

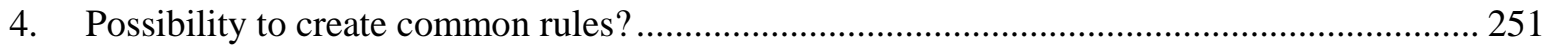

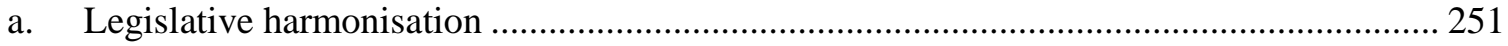

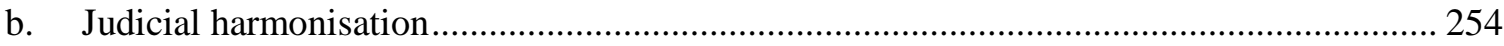

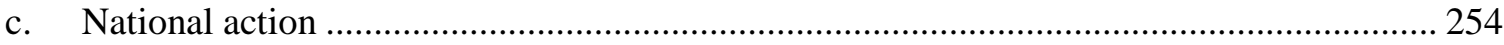

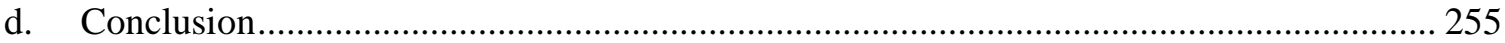

5. The greater context: national procedural autonomy and European integration from a historic

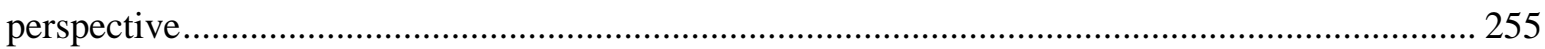

a. The reasons for and the aim of European integration........................................................ 256

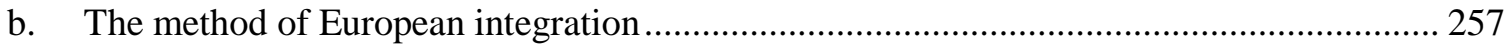

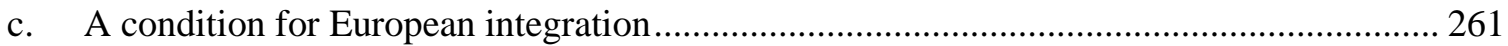




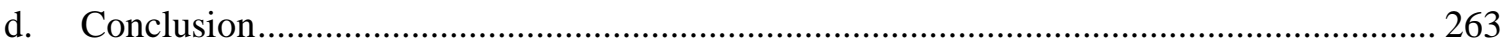

Conclusion of Part III ...................................................................................................................................... 265

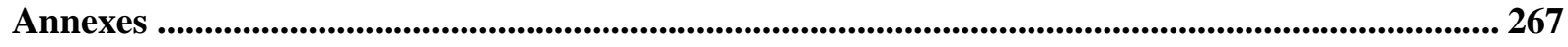

Hypothetical Case Study ..................................................................................................................................... 269

Table of Cases .......................................................................................................................................................... 293

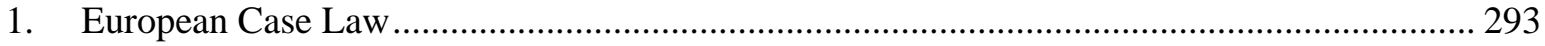

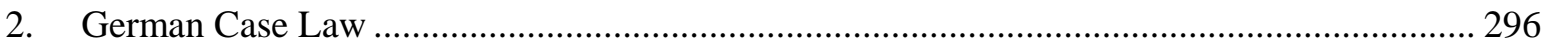

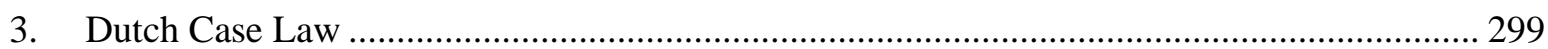

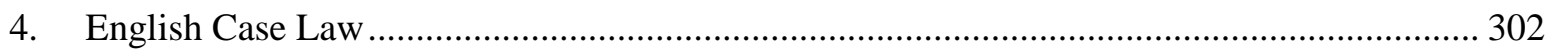

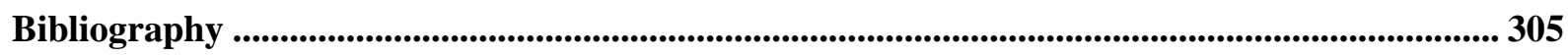

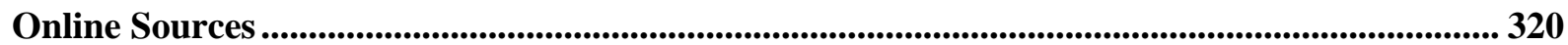

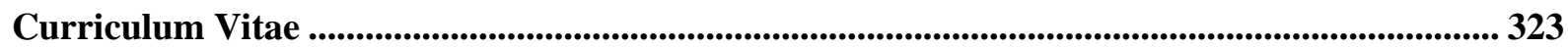




\section{Index of Tables}

\begin{tabular}{|c|c|c|}
\hline Table 1 & Hierarchy of norms in Germany & 29 \\
\hline Table 2 & Hierarchy of norms in the Netherlands & 31 \\
\hline Table 3 & Hierarchy of norms in England & 35 \\
\hline Table 4 & EIA legislation in Germany & 54 \\
\hline Table 5 & EIA legislation in the Netherlands & 60 \\
\hline Table 6 & EIA legislation in England & 67 \\
\hline Table 7 & Rules on standing in EIA claims in 2014 & 108 \\
\hline Table 8 & Rules on costs in EIA claims in 2014 & 122 \\
\hline Table 9 & Rules on time limits in EIA claims in 2014 & 130 \\
\hline Table 10 & General Rules on the scope of review for procedural errors in 2014 & 141 \\
\hline Table 11 & Rules on the scope of review in screening cases in 2014 & 158 \\
\hline Table 12 & Rules on the scope of review for the environmental statement in 2014 & 168 \\
\hline Table 13 & $\begin{array}{l}\text { National rules on the gathering of facts, evidence and the burden of proof } \\
\text { in EIA cases in } 2014\end{array}$ & 176 \\
\hline Table 14 & National rules on the preclusion of claims relative to the EIA in 2014 & 182 \\
\hline Table 15 & $\begin{array}{l}\text { Annulment of the administrative decision for breaches of EIA legislation } \\
\text { in } 2014\end{array}$ & 209 \\
\hline Table 16 & Disregarding procedural errors in EIA cases in 2014 & 210 \\
\hline Table 17 & Correcting procedural errors in EIA cases in 2014 & 211 \\
\hline Table 18 & Rules on interim relief in EIA cases in 2014 & 223 \\
\hline Table 19 & $\begin{array}{l}\text { Incompatibilities of the national rules with the European standard in } \\
2014\end{array}$ & 239 \\
\hline
\end{tabular}




\section{Index of Abbreviations}

\begin{tabular}{|c|c|c|}
\hline Abbreviation & Long Version & Translation/Explanation \\
\hline $\mathbf{A B}$ & $\begin{array}{l}\text { Administratiefrechtelijke } \\
\text { Beslissingen }\end{array}$ & $\begin{array}{l}\text { Journal of administrative court cases } \\
(N L)\end{array}$ \\
\hline ABRvS & $\begin{array}{l}\text { Afdeling Bestuursrechtspraak Raad } \\
\text { van State }\end{array}$ & $\begin{array}{l}\text { Judicial Division of the Council of } \\
\text { State (NL) }\end{array}$ \\
\hline $\mathbf{A C}$ & Appeal Cases & Law Reports (EN) \\
\hline All ER & All England Reports & Law Reports (EN) \\
\hline AMvB & Algemene maatregel van bestuur & $\begin{array}{l}\text { General administrative regulation } \\
(N L)\end{array}$ \\
\hline Art. & Article & \\
\hline Awb & Algemene Wet Bestuursrecht & $\begin{array}{l}\text { General Administrative Law Code } \\
(N L)\end{array}$ \\
\hline Az.: & Aktenzeichen & $\begin{array}{l}\text { Abbreviation for numbering of case } \\
\operatorname{law}(G)\end{array}$ \\
\hline Besl. & Besluit & Administrative decision (NL) \\
\hline Besluit m.e.r. & Besluit milieueffectrapportage & $\begin{array}{l}\text { Environmental Impact Assessment } \\
\text { Regulation }(N L)\end{array}$ \\
\hline BGBI. & Bundesgesetzblatt & $\begin{array}{l}\text { Official Journal of the Federal } \\
\text { Republic of Germany }\end{array}$ \\
\hline BImSchG & Bundesimmissionsschutzgesetz & Federal Immission Control Act $(G)$ \\
\hline BNatSchG & Bundesnaturschutzgesetz & Federal Nature Protection Act $(G)$ \\
\hline BR & Bundesrat & $\begin{array}{l}\text { Constitutional body representing the } \\
\text { states of Germany }\end{array}$ \\
\hline BT & Bundestag & $\begin{array}{l}\text { German Parliament (constitutional } \\
\text { body representing the people of } \\
\text { Germany) }\end{array}$ \\
\hline BVerwG & Bundesverwaltungsgericht & Federal Administrative Court $(G)$ \\
\hline BVerwGE & $\begin{array}{l}\text { Entscheidungen des } \\
\text { Bundesverwaltungsgerichts }\end{array}$ & $\begin{array}{l}\text { Official Collection of Decisions of } \\
\text { the Federal Administrative Court }(G)\end{array}$ \\
\hline C.J.Q. & Civil Justice Quarterly & \\
\hline $\begin{array}{l}\text { Colo. J. Int'l Envl. } \\
\text { L\&Pol'y }\end{array}$ & $\begin{array}{l}\text { Colorado Journal of International } \\
\text { Environmental Law and Policy }\end{array}$ & \\
\hline Commissie m.e.r. & $\begin{array}{l}\text { Commissie voor de } \\
\text { milieueffectrapportage }\end{array}$ & $\begin{array}{l}\text { Netherlands Commission for } \\
\text { Environmental Impact Assessment }\end{array}$ \\
\hline
\end{tabular}




\begin{tabular}{|c|c|c|}
\hline CMLR & Common Market Law Reports & Law Reports (EN) \\
\hline CMLRev & Common Market Law Review & \\
\hline CPR & Civil Procedure Rules & \\
\hline Drs. & Drucksache & $\begin{array}{l}\text { Documents of Legislative Process } \\
(G)\end{array}$ \\
\hline DÖV & Die Öffentliche Verwaltung & Journal of Public Administration $(G)$ \\
\hline ECHR & $\begin{array}{l}\text { European Convention on Human } \\
\text { Rights }\end{array}$ & \\
\hline ECR & European Court Reports & \\
\hline EIA & Environmental Impact Assessment & \\
\hline EIA Directive & Directive 2011/92/EU & \\
\hline EJCL & $\begin{array}{l}\text { Electronic Journal of Comparative } \\
\text { Law }\end{array}$ & \\
\hline ELI & European Law Institute & \\
\hline Env LR & Environmental Law Reports & \\
\hline EPL & European Public Law & \\
\hline ERPL & European Review of Public Law & \\
\hline EuR & Europarecht & Journal of European Law $(G)$ \\
\hline EurUP & $\begin{array}{l}\text { Europäisches Umwelt - und } \\
\text { Planungsrecht }\end{array}$ & $\begin{array}{l}\text { Journal of Environment and } \\
\text { Planning Law }(G)\end{array}$ \\
\hline EWCA & European and Wales Court of Appeal & \\
\hline FFH & Flora Fauna Habitat & \\
\hline FFH Directive & Directive 92/43/EEC as amended & \\
\hline FJME & Fondation Jean Monnet pour l'Europe & \\
\hline GG & Grundgesetz & German Constitution \\
\hline GKG & Gerichtskostengesetz & German Statute on Court Fees \\
\hline JB & Jurisprudentie Bestuursrecht & $\begin{array}{l}\text { Journal of Case Law in } \\
\text { Administrative Matters (NL) }\end{array}$ \\
\hline JCER & $\begin{array}{l}\text { Journal of Contemporary European } \\
\text { Research }\end{array}$ & \\
\hline JEEPL & $\begin{array}{l}\text { Journal for European Environmental } \\
\text { and Planning Law }\end{array}$ & \\
\hline JEL & Journal of Environmental Law & \\
\hline JEPM & $\begin{array}{l}\text { Journal of Environmental Planning and } \\
\text { Management }\end{array}$ & \\
\hline $\mathbf{J M}$ & Jurisprudentie Milieurecht & Journal of Environmental Law (NL) \\
\hline
\end{tabular}




\begin{tabular}{|c|c|c|}
\hline $\mathbf{j} \mathbf{M}$ & juris - die Monatszeitschrift & Monthly Journal $(G)$ \\
\hline JPL & Journal of Planning Law & \\
\hline JPEL & $\begin{array}{l}\text { Journal of Planning and Environment } \\
\text { Law }\end{array}$ & \\
\hline $\mathbf{J R}$ & Judicial Review & \\
\hline LIEI & Legal Issues of Economic Integration & \\
\hline Liverpool L.R. & Liverpool Law Review & \\
\hline L.Q.R. & Law Quarterly Review & \\
\hline $\mathbf{M} \& \mathbf{R}$ & Milieu en Recht & $\begin{array}{l}\text { Journal of Environment and Law } \\
(N L)\end{array}$ \\
\hline n.y.r. & not yet reported & \\
\hline NJW & Neue Juristische Wochenschrift & Journal of German Law \\
\hline NordOeR & $\begin{array}{l}\text { Zeitschrift für Öffentliches Recht in } \\
\text { Norddeutschland }\end{array}$ & $\begin{array}{l}\text { Journal for Public Law in North } \\
\text { Germany }\end{array}$ \\
\hline nr. & Number & \\
\hline NRW & North-Rhine Westphalia & Name of a Land (state) in Germany \\
\hline NTB & $\begin{array}{l}\text { Nederlands Tijdschrift voor } \\
\text { Bestuursrecht }\end{array}$ & Dutch Journal of Administrative Law \\
\hline NuR & Natur und Recht & Journal of Nature and Law $(G)$ \\
\hline NVwZ & Neue Zeitschrift für Verwaltungsrecht & Journal of Administrative Law $(G)$ \\
\hline OJ & Official Journal & European Union \\
\hline OVG & Oberverwaltungsgericht & Higher Administrative Court $(G)$ \\
\hline PCO & Protective Cost Orders & \\
\hline REALaw & $\begin{array}{l}\text { Review of European Administrative } \\
\text { Law }\end{array}$ & \\
\hline reg. & Regulation & Numbering in Statutes (EN) \\
\hline rev. & revised & \\
\hline S. & Sentence & \\
\hline SEA & Strategic Environmental Assessment & \\
\hline SEA Directive & Directive 2001/42/EC & \\
\hline StAB & $\begin{array}{l}\text { Stichting Advisering } \\
\text { Bestuursrechtspraak voor Milieu en } \\
\text { Ruimtelijke Ordening }\end{array}$ & $\begin{array}{l}\text { Independent advisory body for } \\
\text { environmental issues which can be } \\
\text { consulted by administrative judges } \\
(N L)\end{array}$ \\
\hline Stb. & $\begin{array}{l}\text { Staatsblad van het Koninkrijk der } \\
\text { Nederlanden }\end{array}$ & $\begin{array}{l}\text { Official Journal of the Kingdom of } \\
\text { the Netherlands }\end{array}$ \\
\hline
\end{tabular}




\begin{tabular}{|c|c|c|}
\hline TCPA (1990) & Town and Country Planning Act 1990 & \\
\hline TCPR (EIA) 2011 & $\begin{array}{l}\text { Town and Country Planning } \\
\text { (Environmental Impact Assessment) } \\
\text { Regulations } 2011\end{array}$ & \\
\hline TEU & Treaty on European Union & \\
\hline TFEU & $\begin{array}{l}\text { Treaty on the Functioning of the } \\
\text { European Union }\end{array}$ & \\
\hline TK & Tweede Kamer & Dutch House of Representatives \\
\hline TO & Tijdschrift voor Omgevingsrecht & Journal of Environmental Law (NL) \\
\hline UBA & Umweltbundesamt & Federal Environmental Agency $(G)$ \\
\hline UKHL & United Kingdom House of Lords & \\
\hline UKSC & Supreme Court of the United Kingdom & \\
\hline UmwRG (Year) & Umweltrechtsbehelfsgesetz & $\begin{array}{l}\text { Statute on Complementary Rules on } \\
\text { Judicial Review in Environmental } \\
\text { Matters }(G)\end{array}$ \\
\hline UNECE & $\begin{array}{l}\text { United Nations Economic Commission } \\
\text { for Europe }\end{array}$ & \\
\hline UNIDROIT & $\begin{array}{l}\text { Institut International pour l'unification } \\
\text { du droit privé }\end{array}$ & $\begin{array}{l}\text { International Institute for the } \\
\text { Unification of Private Law }\end{array}$ \\
\hline UPR & Umwelt- und Planungsrecht & $\begin{array}{l}\text { Journal of Environmental and } \\
\text { Planning Law }(G)\end{array}$ \\
\hline UVPG & $\begin{array}{l}\text { Gesetz über die } \\
\text { Umweltverträglichkeitsprüfung }\end{array}$ & $\begin{array}{l}\text { Statute on Environmental Impact } \\
\text { Assessment }(G)\end{array}$ \\
\hline VG & Verwaltungsgericht & Administrative Court $(G)$ \\
\hline VGH & Verwaltungsgerichtshof & $\begin{array}{l}\text { Higher Administrative Court in } \\
\text { Bavaria, Baden-Württemberg and } \\
\text { Hesse }(G)\end{array}$ \\
\hline VwVfG & Verwaltungsverfahrensgesetz & $\begin{array}{l}\text { General Code on administrative } \\
\text { procedure }(G)\end{array}$ \\
\hline VwGO & Verwaltungsgerichtsordnung & $\begin{array}{l}\text { General Code on Judicial Review } \\
(G)\end{array}$ \\
\hline Wabm & $\begin{array}{l}\text { Wet algemene bepalingen } \\
\text { milieuhygiëne }\end{array}$ & $\begin{array}{l}\text { Statute on general rules concerning } \\
\text { environmental health }(N L)\end{array}$ \\
\hline
\end{tabular}




\begin{tabular}{|l|l|l|}
\hline Wabo & $\begin{array}{l}\text { Wet algemene bepalingen } \\
\text { omgevingsrecht }\end{array}$ & $\begin{array}{l}\text { Statute on general rules concerning } \\
\text { environmental law }(N L)\end{array}$ \\
\hline WLR & Weekly Law Reports & \\
\hline Wm & Wet milieubeheer & $\begin{array}{l}\text { Environmental Management Act } \\
(N L)\end{array}$ \\
\hline ZPO & Zivilprozessordnung & Code on Civil Procedure $(G)$ \\
\hline ZUR & Zeitschrift für Umweltrecht & Journal of Environmental Law $(G)$ \\
\hline
\end{tabular}


Introduction 


\section{Problem statement}

In the Union, compliance with supranational legislation has to be ensured in a system of composite administration, meaning that rules created by the European legislator are applied and enforced at a national level by national public authorities and national courts. ${ }^{1}$ At the core of this system is the principle of national procedural autonomy, according to which the competence to create rules which govern the national enforcement process lies with the Member States. ${ }^{2}$ This implies that rules on administrative litigation may vary considerably throughout the Union. The European legislator and the Court of Justice have, on various occasions, interfered with the procedural competence ${ }^{3}$ of the Member States regarding the enforcement process of Union law at the national level. ${ }^{4}$ By means of these interventions, the "outer limits" 5 of national procedural autonomy have been defined. Within these "outer limits" national legal systems are allowed to adopt different litigation rules. In civil matters, the harmonisation of civil litigation rules has been discussed intensively, ${ }^{6}$ but, in administrative matters, a similar discussion on a comprehensive harmonisation of litigation rules is currently lacking. ${ }^{7}$ This thesis

${ }^{1}$ Jansen, Schöndorf-Haubold (eds.), The European Composite Administration, 2011.
${ }^{2}$ Case 33/76, Rewe-Zentralfinanz eG und Rewe Zentral AG v Landwirtschaftskammer für das Saarland [1976]
ECR 1989; Case 45/76, Comet BV v Produktschap voor Siergewassen [1976] ECR 2043, paras. 13-16.
${ }^{3}$ Because of this interference, the term "autonomy" is delusive and the term "competence" appropriate: Bobek,
Why there is No Principle of "Procedural Autonomy" of the Member States, in: Micklitz, de Witte (eds.), The
European Court of Justice and the Autonomy of the Member States, 2012, pp. 305-323; Galetta, Procedural Autonomy of EU Member States: Paradise Lost?, 2010.

${ }^{4}$ Craig, de Búrca, EU Law, $5^{\text {th }}$ edition, 2011, pp. 218 ff.; Interference by the Union legislator in environmental matters for example: Directive 2003/35/EC of the European Parliament and of the Council of 26 May 2003 providing for public participation in respect of the drawing up of certain plans and programmes relating to the environment and amending with regard to public participation and access to justice Council Directives 85/337/EC and 96/61/EC, OJ L 156, 25.06.2003, pp. 17-25; Interference by the Court of Justice with regard to national (administrative) litigation rules for example: Case 199/82, Amministrazione delle Finanze dello Stato v SpA San Giorgio [1983] ECR 3595, para. 14; Joined Cases C-87, 88, 89/90, A. Verholen and others v Sociale Verzekeringsbank Amsterdam [1991] ECR I-3757; C-208/90, Theresa Emmott v Minister for Social Welfare and Attorney General [1991] ECR I-4269; C-312/93, Peterbroeck, Van Campenhout \& Cie SCS v Belgian State [1995] ECR I-4599; Interference by the Court of Justice in matters concerning the enforcement of the EIA Directive: C201/02, The Queen, on the application of Delana Wells v Secretary of State for Transport, Local Government and the Regions [2004] ECR I-723; C-263/08, Djurgården-Lilla Värtans Miljoskyddsföreening [2009] ECR I-9967; C-115/09, Bund für Umwelt und Naturschutz Deutschland, Landesverband Nordrhein-Westfalen e.V. $v$ Bezirksregierung Arnsberg [2011] ECR I-3673; C-260/11, The Queen, on the application of David Edwards and Lilian Pallikaropoulos $v$ Environment Agency and Others (Judgment of 11 April 2013); C-72/12, Gemeinde Altrip and Others $v$ Land Rheinland-Pfalz (Judgment of 7 November 2013).

${ }^{5}$ Prechal, Widdershoven, Redefining the Relationship between "REWE-effectiveness" and Effective Judicial Protection, REALaw 2011, issue 2, pp. 31-50.

${ }^{6}$ Storme (ed.), Procedural Laws in Europe, 2003; Kramer, van Rhee (eds.), Civil Litigation in a Globalising World, 2012; Werlauff, Common European Procedural Law, 1999.

${ }^{7}$ Note however the reflections on the (im-)possible harmonisation of rules on remedies in: Chiti, Towards a Unified Judicial Protection in Europe (?), ERPL 1997, pp. 553-573; van Gerven, Bridging the Gap Between Community and National Laws: Towards A Principle of Homogeneity in the Field of Legal Remedies? CMLRev 1995, pp. 679-702; Van Gerven, Of Rights, Remedies and Procedures, CMLRev 2000, pp. 501-536; Harlow, A Common European Law of Remedies?, in: Kilpatrick et al. (eds.), The Future of Remedies in Europe, 2000, pp. 69-83; Eliantonio, The Future of National Procedural Law in Europe: Harmonisation vs Judge-Made Standards in the Field of Administrative Justice, EJCL 2009, vol. 13 (3); The focus of debates in administrative matters is currently on the rules of administrative procedure, i.e. the process governing decision making of public authorities: EP Resolution of 13 January 2013 with recommendations to the Commission on a Law of Administrative Procedure of the European Union (2012/2024(INL)); ReNEUAL Model Rules on EU Administrative Procedure 2014 (available online); Craig, A General Law on Administrative Procedure, Legislative Competence and Judicial 
aims at analysing the consequences of differences between national administrative litigation rules for the enforcement of Union law and at questioning whether the "outer limits" of national procedural autonomy are tight enough or whether common rules for administrative litigation are necessary, desirable and possible in a system in which the creation of law is unitary but the enforcement is fragmented.

\section{Research questions and case selection}

\section{a. Approaching the research question}

In this thesis, three principal research questions are raised. In a first step, the "outer limits" of national procedural autonomy will be examined, resulting in the question:

\section{What is the European standard for national administrative litigation rules?}

After having described the European requirements for national litigation rules, the focus will be on the differences which exist within the "outer limits". For this purpose, the following question is raised:

\section{What are the consequences of differences in national rules on administrative litigation} for the enforcement of Union law?

On the basis of these findings, it will be questioned:

\section{Is it necessary, desirable and possible to develop common rules of administrative litigation throughout the Union?}

The expression of "common rules" shall refer to a Union-wide set of rules for administrative litigation, as opposed to the different rules which currently exist in the different legal orders of the Union. As the questions two and three are very broad, they need some further refinement.

\section{b. Selecting the case(s) for analysis}

In order to analyse the relationship between national litigation rules and rules of Union law, it is first necessary to select a small number of legal systems, as it is factually impossible and conceptually unnecessary to conduct the same study across all 28 Member States. Regarding the factual impossibility, the author's linguistic abilities are restricted to English, Dutch, French and German. Moreover, a study of the enforcement of Union law in all legal systems would require a profound knowledge of 28 separate legal systems which is impossible to handle for a single researcher. Furthermore, for the purpose of this thesis, it is not necessary to conduct the same study in all 28 Member States, because if differences can be shown with regard to some legal systems, it can be assumed that they exist on a large scale among 28 Member States. Thus, three legal systems are chosen which represent different legal traditions within

Competence, EPL 2013, pp. 503-524; Widdershoven, Naar een Europese harmonisatie van het nationale bestuursrecht?, NTB 2014/33, pp. 261-264. 
the European Union. ${ }^{8}$ Specifically, the study will focus on administrative procedural law in the neighbouring countries of Germany, the Netherlands and England. The systems of administrative litigation in these three countries differ in many regards. ${ }^{9}$ Whereas the German legal system separates administrative litigation from civil litigation, by attributing administrative law cases to administrative courts and by applying the rules of a separate code for administrative litigation, in England, such a strict separation traditionally does not exist. ${ }^{10}$ In the Netherlands, similar to Germany, separate rules are applicable to civil and administrative litigations. Another classical distinctive element concerns the focus of litigations: whereas some systems emphasise the control of whether an authority acted lawfully and within its powers (recours objective), other systems primarily aim at the protection of subjective rights of the claimant (recours subjective). ${ }^{11}$ The German legal system is a classical example of a system focusing on the protection of subjective rights. ${ }^{12}$ Contrary to this, the Dutch legal system was originally classified as a system of recours objective, but with the entry into force of the Algemene Wet Bestuursrecht (General Administrative Law Code, abbreviation: Awb), the legislator intended to move towards a system focusing on the protection of individuals, so that today the system comprises elements of both categories. ${ }^{13}$

Furthermore, the analysis will be confined to one piece of European legislation, so that it will be possible to show what the consequences of different national litigation rules are for the enforcement of the same rule(s) of Union law. For the purpose of this thesis, environmental law is particularly interesting, as the national rules of administrative litigation in environmental matters are subjected to the requirements of the Aarhus Convention ${ }^{14}$ to which the Union ${ }^{15}$ and the Member States ${ }^{16}$ are parties. The Union has, to a limited extent, complied with its implementing obligation under article 9 (2) and (4) of the Aarhus Convention by adopting Directive 2003/35/EC. ${ }^{17}$ In 2003, a proposal was made for a comprehensive

\footnotetext{
${ }^{8}$ Overview of different traditions of administrative law from a historic perspective: Wesel, Geschichte des Rechts in Europa, 2010, pp. 451-459 and pp. 579-586; on the current state of different legal traditions in Europe: Ruffert (ed.), Administrative Law in Europe, 2013.

${ }^{9}$ Seerden (ed.), Administrative Law of the European Union, its Member States and the United States, $3^{\mathrm{rd}}$ edition, 2012; in environmental matters: Epiney, Verwaltungsgerichtlicher Rechtsschutz im Umweltrecht im Rechtsvergleich, NVwZ 2014, pp. 465-476.

${ }^{10}$ Von Danwitz, Europäisches Verwaltungsrecht, 2008, pp. 39 f.; Wade, Forsyth, Administrative Law, $11^{\text {th }}$ edition, 2014 , pp. $8 \mathrm{f}$.

${ }^{11}$ Backes, Eliantonio, Administrative Law, in: Hage, Akkermans (eds.), Introduction to Law, 2014, pp. $201 \mathrm{f}$.

${ }^{12}$ Art. 19 (4) GG; this will be further explained in: Introduction, Section 4.3 a.

${ }^{13}$ Essens, Verhoeven, Traditional Variations in the Dutch Administrative Judicial System, in: Caranta, Gerbrandy (eds.), Tradition and Change in European Administrative Law, 2011, pp. 165 f.; Bok, Judicial Review of Administrative Decisions by the Dutch Administrative Courts, Recours Objectif or Recours Subjectif?, in: Stroink, van der Linden (eds.), Judicial Lawmaking and Administrative Law, 2005, pp. 153-162.

${ }^{14}$ UNECE Convention on Access to Information, Public Participation in Decision-making and Access to Justice in Environmental Matters, 25 June 1998.

${ }^{15}$ Council Decision 2005/370/EC of 17 February 2005 on the conclusion, on behalf of the European Community, of the Convention on access to information, public participation in decision-making and access to justice in environmental matters, OJ L 124, 17.5.2005, pp. 1-3.

16 For the state of signatures and ratifications of contracting states, refer to: https://treaties.un.org/pages/ViewDetails.aspx?src=TREATY\&mtdsg_no=XXVII-13\&chapter=27\&lang=en.

${ }^{17}$ Directive 2003/35/EC of the European Parliament and of the Council of 26 May 2003 providing for public participation in respect of the drawing up of certain plans and programmes relating to the environment and 
implementation of article 9 (3) of the Convention ${ }^{18}$ but this proposal was withdrawn in 2014. ${ }^{19}$ Because of the - albeit incomplete ${ }^{20}$ - Union implementing legislation of article 9 (2) and (4) Aarhus Convention, there are, next to the classical requirements for national litigation rules as established by the Court of Justice, ${ }^{21}$ the "Aarhus" requirements in environmental matters. The Union Directive implementing the procedural requirements of the Aarhus Convention only relates to two administrative procedures, ${ }^{22}$ one of them being the Environmental Impact Assessment Procedure as provided for in Directive 2011/92/EU (abbreviation: EIA Directive) and its predecessors. ${ }^{23}$ The EIA Directive has provided for harmonised standards of environmental impact assessments in administrative procedures. The latest amendment to this Directive entered into force in 2014 and has to be transposed within three years. ${ }^{24}$ This amendment is however not addressed in this study, as its implementation period has not yet lapsed. ${ }^{25}$

Selecting a directive in environmental matters is not only interesting because of the influences of the Aarhus Convention, but it is particularly interesting for the purpose of this thesis, as in this area of the law, differences between the litigation regimes of the Member States of the Union have been significant. ${ }^{26}$

Finally, using a directive as a legislative instrument means that this piece of Union legislation is "binding, as to the result to be achieved upon each Member State to which it is addressed, but shall leave to the national authorities the choice of form and methods". ${ }^{27}$ Consequently, room for differences between legal systems is left, but the objectives of the directive have to be met in every Member State. With regard to the EIA procedure, this means that the different procedural steps laid down in the Directive have to be applied equally and enforced in all Member States.

For these reasons, the focus of this research will be on the administrative litigation rules in Germany, the Netherlands and England and their influence on the enforcement of the EIA Directive.

amending with regard to public participation and access to justice Council Directives 85/337/EEC and 96/61/EC, OJ L 156, 25.6.2003, pp.17-25.

${ }^{18}$ Proposal for a Directive of the European Parliament and of the Council on access to justice in environmental matters, COM (2003) 624.

${ }^{19}$ Withdrawal of obsolete Commission proposals, OJ C 153, 21.05.2014, pp. 3-7.

${ }^{20}$ Eliantonio, Collective Redress in Environmental Matters in the EU: A Role Model or a 'Problem Child'?, LIEI 2014, pp. 257-273.

${ }^{21}$ The "classical" outer limits are the principle of effectiveness and equivalence and the principle of effective judicial protection; they will be further discussed in Part II Chapter 1.

${ }_{22}$ Directive 2003/35/EC amended Directive 85/337/EEC (EIA Directive) and Directive 96/61/EC (IPPC Directive).

${ }^{23}$ Directive 2011/92/EU of the European Parliament and of the Council of 13 December 2011 on the assessment of the effects of certain public and private projects on the environment, OJ L 26, 28.01.2012, pp. 1-21.

${ }^{24}$ Directive 2014/52/EU of the European Parliament and of the Council of 16 April 2014 amending Directive 2011/92/EU on the assessment of the effects of certain public and private projects on the environment, OJ L 124, 25.4.2014, pp. 1-18.

${ }^{25}$ According to article 2 Directive 2014/92/EU, the implementation period lapses on 16 May 2017.

${ }^{26}$ Ebbesson (ed.), Access to Justice in Environmental Matters in the EU, 2002; Sadeleer et al. (eds.), Access to Justice in Environmental Matters and the Role of NGOs, 2005.

${ }^{27}$ Article 288 TFEU. 


\section{c. Concretising the research questions}

After having selected the object of analysis, the research questions can be refined. This thesis will specifically pose the following questions:

\section{What is the European standard for national administrative litigation rules?}

After having described the standard adopted by the Court of Justice so far it can be asked:

\section{What are the consequences of differences in rules on administrative litigation in environmental matters in Germany, the Netherlands and England for the enforcement of the EIA Directive?}

In order to answer this question, several sub questions will be raised. First, the relevant rules of the different legal systems have to be compared. In splitting up national judicial procedures into their various components, one finds rules on access, review and remedies. Thus, the first sub-question is:

\subsection{What are the rules on access, review and remedies in the three legal systems selected and in how far do they differ from each other?}

This question has already been addressed by numerous scholars, ${ }^{28}$ but it forms the basis for any further considerations and has to be addressed for this purpose. After an examination of national litigation rules, it will be asked:

\subsection{How are these rules applied in EIA cases?}

By describing the application of national procedural rules in cases dealing with the EIA procedure, and by comparing their reasoning and outcomes, it will be possible to discern the consequences which these rules have for the enforcement of the same piece of Union legislation. In this context, it has to be noted that rules on administrative litigation in the three legal systems are not static. They are subject to national reforms and they are influenced by the Union legislation and case law of the Court of Justice. The process of Europeanisation has been described extensively in literature. ${ }^{29}$ This thesis will, in comparing the national litigation rules and their application in national cases raise the question:

\footnotetext{
${ }^{28}$ For example: Von Danwitz, Europäisches Verwaltungsrecht, Springer, 2008; Glaser, Die Entwicklung des Europäischen Verwaltungsrechts aus der Perspektive der Handlungsformenlehre, 2013; Schneider (ed.), Verwaltungsrecht in Europa, 2007; Schwarze, Europäisches Verwaltungsrecht, $2^{\text {nd }}$ edition, 2005; Seerden (ed.), Administrative Law of the European Union, its Member States and the United States, $3^{\text {rd }}$ edition, 2012.

${ }^{29}$ For example: Andenas, Jacobs (eds.), European Community Law in the English Courts, 1998, Dougan, National Remedies Before the Court of Justice, 2004; Ehlers, Die Europäisierung des Verwaltungsprozeßrechts, 1999; Eliantonio, The Europeanisation of Administrative Justice?, the influence of the ECJ's case law in Italy, Germany and England, 2009; Jans et al., Europeanization of Public Law, 2007; In environmental matters: Jans et al. (eds.), National Courts and EU Environmental Law, 2013; Wennerås, The Enforcement of EC Environmental Law, 2007; Influences of the Aarhus Convention on the national legal systems: Pallemaerts (ed.), The Aarhus Convention at Ten, 2011
} 
2.3 To what extent and due to which triggers have national litigation rules in environmental matters been in a process of convergence?

Convergence refers to the process of creating similar rules in administrative litigation in the legal systems. It will be questioned how international and national influences induced an approximation between the systems.

The answer to the second research question will form the basis for revisiting the principle of national procedural autonomy. The third research question is therefore:

3. Is it necessary, desirable and possible to develop common rules of administrative litigation in environmental matters in the Union?

Before discussing the necessity, desirability and possibility of harmonising activities at the Union level, it will first be asked:

\subsection{Are the three Member States complying with the existing European standard for environmental litigation?}

After having determined whether the existing standard is complied with, it can be questioned:

3.2 Is it necessary or desirable to develop common rules beyond the limits prescribed by the Union?

If this question can be answered affirmatively, it will be necessary to ask:

\subsection{Is it possible to develop common rules of administrative litigation in environmental matters in the Union?}

This question will assess whether there is a legal basis and whether there are other non-legislative mechanisms for the creation of common rules of administrative litigation in environmental matters in the Union.

At the end of this thesis, the findings will be placed in the greater context of the process of European integration. For this purpose, the role of the principle of national procedural autonomy in the construction of the European Union will be assessed from a historic perspective and it will be asked whether it is possible to draw inspiration from this perspective for future developments of litigation rules in the Union. 


\section{Content overview, methodology and terminology}

\section{a. Content overview}

This study is divided into three parts. "Part I" provides for a presentation of the EIA Directive and the transposition of its requirements into the laws of the three Member States selected (descriptive part). "Part II" deals with the first and second research questions. To begin with, the European requirements for national litigation rules will be described. Next, the rules on access to courts, review in courts and remedies are compared and it is analysed how they are applied in EIA cases. It is then assessed whether there are convergences between the legal systems and it will be asked what the consequences of differences in national rules on administrative litigation are with respect to the enforcement of the EIA Directive (analytical part). In "Part III" it will be debated whether it is necessary, desirable and possible to develop a common standard for environmental litigation (normative part).

\section{b. Methodology}

In Part I, the content of the EIA Directive is presented, followed by a description of the implementing legislation in the Member States. This description is based on the national statutes and academic writing.

Part II consists of a comparative analysis of national litigation rules and their application in EIA cases. To begin with, there will be a description of the respective rules on administrative litigation in environmental matters as they are found in the statutes and the case law in each of the three systems. Next, the application of these rules in national cases dealing with EIA legislation will be analysed. As rules on administrative litigation in environmental matters and their application in EIA legislation have been in a constant process of modification, a rough overview of this development will be given, starting from the end of the 1980s, when the EIA Directive had to be implemented and the enforcement of this piece of legislation by means of administrative litigation started. The cases mentioned in commentaries and scholarly writing are the starting point for the case law analysis. The complete cases are found via the following websites: for Germany: www.juris.de; for the Netherlands: www.rechtspraak.nl; for England: www.westlaw.uk. In order to find additional case law on a specific rule, the term "Environmental Impact Assessment" (or the German or Dutch term ${ }^{30}$ ) is searched for in combination with the number of the respective rule or the name of concept under consideration. For example, in order to find cases on standing for environmental organisations in the 1990s and early 2000s in the Netherlands, the terms "MER" and "20.6" are used. In Germany, the same is done for "Umweltverträglichkeitsprüfung" and "42 Abs. 2 VwGO" and in England for "Environmental Impact Assessment" and "standing". Depending on the period of EIA enforcement under consideration as indicated in the headings of the respective sections in the chapters, filters in time are necessary, to investigate which judgments were delivered in a certain period. For example, in the first period of rules

\footnotetext{
${ }^{30}$ For the German search engine: "Umweltverträglichkeitsprüfung"; for the Dutch search engine "MER" or "milieueffectrapportage" (in some Dutch cases, the EIA is only utilised in its abbreviated form, which made it necessary to look for both expressions).
} 
on standing in EIA cases in Germany, the filter "1990" to "2006" is used. As far as the Dutch case law is concerned, the database of the Commissie m.e.r. is consulted additionally, where it is possible to utilise specific filters provided for on this website in EIA cases. For example, the filter "bestuurlijke lus", which is a key word in the search engine, can be used in combination with "m.e.r. - beoordeling". This is of particular relevance, as the term "bestuurlijke lus" is usually not utilised in the orders and judgments of Dutch courts, so that this term will deliver only few results on the website of www.rechtspraak.nl. Hence, at the website of the Commissie m.e.r. very specific cases can be found depending on the heading of the section in the respective chapters.

The findings of the comparative analysis on differences in litigation rules and their implication for the enforcement of the EIA Directive are, in a second step, verified or falsified in a workshop with judges from the three legal systems. For this workshop, a hypothetical case study is prepared which has to be solved by the judges with a focus on national litigation rules. By this means, the concrete (legal) consequences of differences between the national litigation for the same factual situation to which Union EIA legislation is applicable become apparent. The case study consists of two scenarios, one focusing on an environmental screening and one dealing with an obligatory EIA. A distinction is made between four different claimants: an individual, an action group, an environmental organisation and a competitor. Furthermore, ten different claims are presented, five relating to case scenario one and five relating to case scenario two. These claims concern the omission of certain procedural requirements and flaws in the procedure. It is questioned whether the different claimants have standing with regard to the separate claims. Next, the scope of review is assessed and it is asked what remedy can be sought. For further details, please consult the annex to this thesis. In Part II, reference will be made to "the workshop" if a certain result of the case study, as discussed in the workshop, is mentioned, where this is relevant.

Part III of this thesis will be argumentative in nature. It will be discussed whether there is the need or at least the desirability of further harmonising measures. Moreover, the findings of the thesis will be placed in the historical context of European integration and the legal construction of the Union. In order to understand the role of the principle of national procedural autonomy and its implications in the integration process, the "starting point" for European (Union) integration shall be reconsidered. This last section of the thesis specifically concentrates on the ideas of Jean Monnet (1888-1979) as a political "founding father" of the process of European integration and on the ideas of Michel Gaudet (19152003), who, as the president of the legal service of the European executives between 1958 and 1969, contributed to the integration process from a legal perspective. For this purpose, the documentation centre and the archives of the Jean Monnet Foundation (Lausanne) were consulted.

\section{c. Terminology}

A comparative legal study in one language necessitates translations. The sources consulted for Parts I and II are in German, Dutch and English and in Part III, additional documents in French are referred to. For a comparative analysis written in English, this means that German, Dutch and French legal 
terminology has to be translated into English. This is problematic in many respects, as specific legal terms have specific meanings in the national context and cannot be easily translated into English. For example, the legal instrument of a "Verwaltungsakt" is different from a "decision", ${ }^{31}$ and both instruments are different from a "besluit". ${ }^{32}$ Moreover, some Dutch and German legal concepts are unknown in the English legal system, such as the German concept of "subjektiv-öffentliches Recht", which makes translations difficult. Nevertheless, in order to ensure the readability of this thesis, it is necessary to find English expressions for foreign terms and concepts. The starting point for translations is the Maastricht Collection. ${ }^{33}$ Moreover, for the German and the Dutch legal systems, translations of statutes are available online. ${ }^{34}$ However, these translations are not always consistent in their terminology and do not offer complete translations of all statutes relevant for this thesis. For this reason, translations by the author are necessary. The two main sources on which these translations are based are legal dictionaries and the eur-lex database, which provides for bilingual displays of Union documents. In the comparative analysis, it will be indicated which of the translations was used.

After these remarks on terms and concepts in the different legal systems, it is necessary to highlight some foundations underlying the different administrative legal systems before describing the detailed procedural rules applicable in these systems. Readers who are acquainted with the framework of the three legal systems are invited to directly continue reading Part I.

\section{Introduction to the administrative law of the three legal systems}

Administrative law can be defined as "the law that concerns relations between the administration (governments) and private individuals." 35 This definition contains three elements: the individual, the state and their relationship. The concept of "government" and the "construction" of the relationship between the state and the individual differ in the three legal systems selected. These differences shall be described in this section by giving an explanation of the concepts of "state" and "administration" and by providing for an overview over "the law" governing the relationship between "the administration" and the individual (section 4.1). After this, an introduction to administrative procedure (section 4.2) and administrative litigation (section 4.3) in the three legal systems will be given.

\footnotetext{
${ }^{31}$ Kleve, Schirmer, England und Wales, in: Schneider (ed.), Verwaltungsrecht in Europa, vol. 1, 2007, p. 98.

${ }^{32}$ See: Seerden, Wenders, Administrative Law in the Netherlands, in: Seerden (ed.), Administrative Law of the European Union, its Member States and the United States, $3^{\text {rd }}$ edition, 2012, p. 112.

${ }^{33}$ Kornet, Hardt (eds.), Selected National, European and International Provisions from Public and Private Law, $3^{\text {rd }}$ edition, 2013.

${ }^{34}$ The German Ministry for Justice and Consumer Protection makes available a number of translated statutes under: www.gesetze-im-internet.de/Teilliste_translations.html; in the Netherlands, an English translation of the general administrative statute can be found on www.rijksoverheid.nl (in the following abbreviated as: available online).

${ }^{35}$ Seerden (ed.), Administrative Law of the European Union, its Member States and the United States, $3^{\text {rd }}$ edition, 2012, p. 1.
} 


\subsection{Introduction to the concept of "state" and "law" in the three legal systems}

\section{a. Germany}

\section{(i) The state}

The Bundesrepublik Deutschland (Federal Republic of Germany) is a democratic and social republic ${ }^{36}$ with a federal president as its head of state ${ }^{37}$, with a federal government composed of the federal chancellor and the federal ministers, ${ }^{38}$ and with a federal parliament, the Bundestag, representing the people $^{39}$ and the Bundesrat representing the states. ${ }^{40}$

The Federal Republic of Germany is a federation of sixteen states, which all have their own constitution, parliament, executive and judiciary. Therefore, next to the law of the federation, the Bundesgesetzgebung, there is the law of the states, the Landesgesetzgebung, and next to the administration of the federation, the Bundesverwaltung, there is the administration of the states, the Landesverwaltung. The relationship between the states and the federation is governed by the German constitution, the Grundgesetz of 1949 (abbreviation: GG). It provides that the constitutional orders of the states have to be in conformity with the requirements of the constitution. ${ }^{41}$ Furthermore, article 30 GG stipulates that the states are in principle competent regarding the exercise of state power, as long as there are no other rules stipulating that the federation is competent. In case of a conflict between the law of the federation and the law of the states, the law of the federation prevails according to article $31 \mathrm{GG}$

In principle, article $83 \mathrm{GG}$ provides that (federal and state) statutes are executed by the states, unless the constitution provides for something different. The execution of federal laws by the states is governed by the German constitution, which distinguishes between the execution of federal laws through the states on their own account ${ }^{42}$ and the execution through the states on behalf of the federation (delegated administration). ${ }^{43} \mathrm{Next}$, with regard to certain matters, the federation is responsible for the execution of its laws. ${ }^{44}$

\footnotetext{
${ }^{36}$ Art. 20 (1) GG.

${ }^{37}$ Art. 54 ff. GG.

${ }^{38}$ Art. 62 GG.

${ }^{39}$ Art. 38 ff. GG.

${ }^{40}$ Art. 50 ff GG.

${ }^{41}$ Art. 28 (1) 1, (3) GG.

${ }^{42}$ Art. 84 GG.

${ }^{43}$ Art. 85 GG. This concerns for example the administration of federal taxes through the administration of the states (cf. art. 108 (2) 1 GG).

${ }^{44}$ Art. 86 GG.
} 
The states are autonomous in designing the structure of their administration, which means that there are differences between the states. ${ }^{45}$ However, "nowadays the various State organisations have adjusted themselves to harmonise with each other to a large extent". ${ }^{46}$

(ii) The Law governing the relationship between the state and the individual and other entities

Being a federal system, there are two main layers of legal norms in Germany. The table below and its subsequent explanation illustrate these two layers:

Table 1: Hierarchy of norms in Germany

\begin{tabular}{|c|c|}
\hline Constitution & Grundgesetz \\
\hline Federal Statute & Bundesgesetz \\
\hline General Federal Administrative Order & Bundesrechtsverordnung \\
Federal By-Law & Satzung des Bundes \\
& \\
\hline
\end{tabular}

\begin{tabular}{|c|c|}
\hline Constitution & Länderverfassung \\
\hline State Statute & Landesgesetz \\
\hline State Regulation & Rechtsverordnungen \\
State By-Law & Satzung des Landes \\
& \\
\hline
\end{tabular}

On the federal level, the Grundgesetz is the highest legal norm. Below this, there are Bundesgesetze (Federal Statutes), which are adopted following the legislative procedure in parliament. Next, there are Bundesrechtsverordnungen (Federal Regulations), which are adopted by the federal executive and Satzungen des Bundes (Federal By-Laws) adopted by independent public bodies. On the level of the states, there are the Landesverfassungen (State Constitution), the Landesgesetze (State Statutes), Landesverordnungen (State Regulations), and Satzungen des Landes (State By-Laws). ${ }^{47}$

General rules on administrative procedure are codified in the Verwaltungsverfahrensgesetz (Code of administrative procedure, abbreviation: $\mathrm{VwVfG}){ }^{48}$ There is a federal VwVfG applicable to the execution of laws by the federation and there are state VwVfGs applicable to the execution of laws by

\footnotetext{
45 Art. 28 GG.

${ }^{46}$ Schröder, Administrative Law in Germany, in: Seerden (ed.), Administrative Law of the European Union, its Member States and the United States, $3^{\text {rd }}$ edition, 2012, p. 49.

${ }^{47}$ Maurer, Allgemeines Verwaltungsrecht, $18^{\text {th }}$ edition, 2011, $\$ 4$ at $14 \mathrm{ff}$.; at $44 \mathrm{ff}$.

${ }^{48}$ Verwaltungsverfahrensgesetz, as published on 23. Januar 2003, BGB1. I pp. 102-125, with the latest amendment of 25 July 2013, BGBl. I p. 2749.
} 
the states. ${ }^{49}$ The VwVfGs of the states, however, are largely identical to the VwVfG of the federation. ${ }^{50}$ Special rules on administrative procedure are found in various statues. If these rules are applicable, the $\mathrm{VwVfG}$ only has a subsidiary function. ${ }^{51}$ For example the EIA procedure is regulated in a separate statute, the Gesetz über die Umweltverträglichkeitsprüfung (Statute on environmental impact assessment; abbreviation: UVPG). ${ }^{52}$ Further details will be explained in Part I on the implementation of the EIA Directive in the Member States.

\section{b. The Netherlands}

\section{(i) The state}

The Koninkrijk der Nederlanden (Kingdom of the Netherlands) is a constitutional monarchy and a unitary but decentralised state. ${ }^{53}$ The Kingdom of the Netherlands was created after the Napoleonic wars in $1814 / 15$ by the Congress of Vienna. ${ }^{54}$ The Grondwet, the Dutch constitution, was originally adopted in 1815 but was subject to several reforms. The latest major reform took place in $1983 .{ }^{55}$

The Dutch state is a constitutional monarchy. The head of state is the King or Queen, a descendant of the royal dynasty of Oranje-Nassau. The government consists of the King and the cabinet, the latter being composed of the Prime-Minister and other ministers. ${ }^{56}$ The Parliament consists of two chambers, the Eerste Kamer (First Chamber), which constitutes the representation of the provinces and the Tweede Kamer (Second Chamber), which is elected by the Dutch people. ${ }^{57}$

The Kingdom of the Netherlands is a unitary state, meaning that there is one central authority, the legislator, and several sub-entities deriving powers from the legislator. "Decentralisation" in the Dutch legal order is divided in territorial and functional decentralisation. ${ }^{58}$ Territorial decentralisation means that decentralised authorities are vested with regulatory and administrative power within a certain territory. ${ }^{59}$ Article 123 (1) Grondwet provides for the possibility to create and delete provincies (provinces) and gemeenten (municipalities) by statute. Each province consists of the (directly elected) provinciale staten (regional parliament), the gedeputeerde staten (regional government) and the commissaris van de Koning (King's commissioner). ${ }^{60} \mathrm{~A}$ municipality has a gemeenteraad (local parliament), the college van burgemeerster en wethouders (municipal government) and the

\footnotetext{
${ }^{49}$ Schmitz, § 1 VwVfG, in: Stelkens et al. (eds.), VwVfG Kommentar, 2014, at 60.

${ }^{50}$ Maurer, Allgemeines Verwaltungsrecht, $18^{\text {th }}$ edition, 2011, $\S 5$ at $17 \mathrm{ff}$.

51 Ibid., pp. 115 f.

${ }^{52}$ Gesetz über die Umweltverträglichkeitsprüfung (UVPG), 24.02.2010, BGBl. I pp. 94-128.

${ }^{53}$ Heringa, Kiiver, Constitutions Compared, $3^{\text {rd }}$ edition, 2012, pp. $68 \mathrm{ff}$.

54 Ibid.

${ }^{55}$ Besselink, The Kingdom of the Netherlands, in: Besselink et al. (eds.), Constitutional Law of the EU Member States, 2014, pp. $1189 \mathrm{ff}$.

${ }^{56}$ Art. 42 Grondwet.

${ }^{57}$ Art. 51 (1) Grondwet.

${ }^{58}$ Besselink, The Kingdom of the Netherlands, in: Besselink et al. (eds.), Constitutional Law of the EU Member States, 2014, pp. $1231 \mathrm{ff}$.

${ }^{59}$ Art. 124 (1) Grondwet.

${ }^{60}$ Art. 125 Grondwet.
} 
burgermeester (major). ${ }^{61}$ On 1 January 2015, there are twelve provinces and 393 municipalities. ${ }^{62}$ Functional decentralisation means that decentralised authorities are responsible for undertaking the treatment of specific tasks. An example of these authorities are the water management boards. ${ }^{63}$

Article 107 (2) Grondwet stipulates that rules on administrative law are regulated by statute. In this statute, the Awb, a definition of an administrative authority is given, which is

“(a) an organ of a legal entity which has been established under public law, or (b) another person or body vested with any public authority." ${ }^{\prime 4}$

The creation and exercise of public power by administrative authorities has to pay regard to the principle of legality, meaning that there must be a legal norm allowing for the creation and exercise of public power. ${ }^{65}$ The creation of public powers is called attributie (attribution of power) ${ }^{66}$ Powers are attributed to the authorities of the State, the provinces and municipalities. By delegatie (delegation) this power can be transferred from an administrative organ to another entity which then exercises the power in its own name and responsibility ${ }^{67}$ By mandaat (mandate) an administrative authority empowers another entity to exercise power in the name and responsibility of the administrative authority. ${ }^{68}$

(ii) The law governing the relationship between the state and the individual and other entities

The various layers of legal norms in the Netherlands are illustrated by the table below, which will be explained in the following paragraphs:

\section{Table 2: Hierarchy of norms in the Netherlands}

\begin{tabular}{|l|l|}
\hline Constitution & Grondwet \\
\hline Statute & Wet (plural: wetten) \\
\hline General administrative regulation & Algemene maatregel van bestuur (AMvB) \\
\hline Ministerial decrees & Ministeriële verordeningen \\
\hline Provincial decree & Provinciale verordeningen \\
\hline
\end{tabular}

On the national level, the Grondwet is the highest legal norm. ${ }^{69}$ Below this, there are wetten (statutes), which are adopted by legislative procedure in parliament. One level further down, there are Algemene

\footnotetext{
${ }^{61}$ Art. 125 Grondwet; Heringa et al, Staatsrecht, $11^{\text {th }}$ edition, 2012, pp. 235 ff.

${ }^{62}$ See: www.cbs.nl, Methoden, Classificaties, Gemeentelijke Indeling, 2015 (last visited: 26.04.2015).

${ }^{63}$ Besselink, The Kingdom of the Netherlands, in: Besselink et al. (eds.), Constitutional Law of the EU Member States, 2014, p. 1233.

${ }^{64}$ Art. 1:1 Awb, Maastricht Collection.

${ }^{65}$ Damen et al., Bestuursrecht, vol.1, $4^{\text {th }}$ edition, 2013, pp. $47 \mathrm{ff}, 165 \mathrm{f}$.

${ }^{66}$ Ibid., pp. 165 f.

${ }^{67}$ Art. 10:13 Awb.

${ }^{68}$ Art. 10:3 Awb.

${ }^{69}$ Besselink, The Kingdom of the Netherlands, in: Besselink et al. (eds.), Constitutional Law of the EU Member States, 2014, p. 1203.
} 
maatregelen van bestuur (general administrative regulations; abbreviation: AMvB), and Koninklijke Besluiten (royal decrees). These are legal instruments which are adopted by the government. ${ }^{70} \mathrm{AMvBs}$ concretise the content of statutes. Below this, there are Ministeriële Verordeningen (ministerial orders), and, one layer further down, one finds provincial and municipal ordinances. ${ }^{71}$

Article 107 (2) Grondwet states that a "Statute provides general rules of administrative law."72 This statute is the Algemene Wet Bestuursrecht (General Code of Administrative Law; abbreviation: Awb). The parts of the Awb, called tranches, entered into force in several steps. The first and second tranche of the Awb entered into force in $1994,{ }^{73}$ the third in $1998^{74}$ and the fourth in $2009 .{ }^{75}$

The Awb provides for general administrative rules. Chapters 1 and 2 Awb contain general rules and definitions, chapters 3, 4 and 5 deal with the administrative procedure and chapters 6 to 9 concern the administrative review. Chapter 10 sets out rules on the organisation of competences (delegation, mandate). Articles are cited by first indicating the chapter and then the concrete article: for example, the definition of the besluit (administrative decision) is found in chapter 1, article 3, section 2, cited as 1:3 (2) Awb.

Next to these general rules, there are numerous laws dealing with specific administrative topics, amending, concretising or derogating from the general administrative rules. In environmental matters, there has been a broad patchwork of numerous statutes. Since the 1980s, the Dutch history of environmental law is a history of reordering and of the "bundling of" this patchwork. ${ }^{76} \mathrm{~A}$ first combination of some of the various environmental statutes into one integrated statue was realised with the Wet algemene bepalingen milieuhygiëne (Statute on general rules concerning environmental health; abbreviation: Wabm) of $1980 .{ }^{77}$ This statute was later combined - together with a number of other environmental statutes - in the Wet milieubeheer (Environmental Management Act; abbreviation: Wm), which entered into force in $1993 .^{78}$ The Wm provided, inter alia, for a special procedural regime for the

\footnotetext{
${ }^{70}$ Art. 89 (1) Grondwet.

${ }^{71}$ De Blois, Grondslagen van het recht: Hoofdlijnen, $6^{\text {th }}$ edition, 2012, p. 116.

72 Maastricht Collection.

${ }^{73}$ Wet van 4 juni 1992, houdende algemene regels van bestuursrecht (Algemene wet bestuursrecht), Stb. 1992, 315; Beschikking van de Minister van Justitie van 20 december 1003, houdende plaatsing in het Staatsblad van de tekst van de Algemene wet bestuursrecht, zoals deze luidt met ingang van 1 januari 1994, Stb. 1994, 1.

${ }^{74}$ Wet van 20 juni 1996 tot aanvulling van de Algemene wet bestuursrecht (Derde tranche Algemene wet bestuursrecht), Stb. 1996, 333; Besluit van 11 december 1997 houdende vaststelling van het tijdstrip van inwerkingtreding van de derde tranche van de Algemene wet bestuursrecht, de Wet Justitie-subsidies en enkele aanpassingswetten, Stb. 1997, 581.

${ }^{75}$ Wet van 25 juni 2009 tot aanvulling van de Algemene wet bestuursrecht (Vierde tranche Algemene wet bestuursrecht), Stb. 2009, 264; Besluit van 25 juni 2009 tot vaststelling van het tijdstrip van inwerkingtreding van de vierde tranche van de Algemene wet bestuursrecht en de Aanpassingswet vierde tranche Awb, Stb. $2009,266$.

76 Beijen (ed.), Hoofdlijnen Milieubestuursrecht, $2^{\text {nd }}$ edition, 2012, pp. 62 ff; Broek, Bundeling van omgevingsrecht, 2012.

${ }^{77}$ Wet van 13 juni 1979, houdende regelen met betrekking tot een aantal algemene onderwerpen op het gebied van de milieuhygiëne, Stb. 1979, 442.

${ }^{78}$ Besluit van 27 januari 1993, houdende vaststelling van het tijdstip van inwerkingtreding van de wetten van 2 juli 1992, Stb. 214 en Stb. 415, tot wijziging van de Wet algemene bepalingen milieuhygiëne, van de wet van 24
} 
adoption of permits. ${ }^{79}$ Moreover, this statute derogated from the general judicial review procedure of the Awb. First, the Wm provided that applications for judicial review of certain permits had to be made directly to the judicial department of the Council of State, ${ }^{80}$ meaning that cases were only dealt with in one instance. ${ }^{81}$ Second, until 2005, the Wm (in connection with the Awb) contained the possibility for an actio popularis. ${ }^{82}$ In 2010, the Dutch legislator made another attempt at reordering the various statutes of environmental law by adopting the Wet algemene bepalingen omgevingsrecht (Statute on general rules concerning environmental law, abbreviation: Wabo). ${ }^{83}$ The novelty of the latter statute is the introduction of the single omgevingsvergunning (environmental permit) which is granted for certain projects for which, in former times, different permits were needed. ${ }^{84} \mathrm{~A}$ modified version of the $\mathrm{Wm}$ still exists next to the Wabo. The reform also had implications for litigation in environmental matters: before the new law entered into force, many cases in environmental matters were directly brought to the administrative division of the Council of State. Since the reform, the court of first instance usually is the rechtbank (administrative court) and it is then possible to bring an appeal against a judgment to the administrative division of the Council of State. ${ }^{85}$ In any event, the Dutch legislator strives for a more far-reaching integration of environmental statutes in the planned Omgevingswet (Environmental Code). ${ }^{86}$ The environmental impact assessment procedure is regulated in the $\mathrm{Wm}$ and a general administrative order, the Besluit milieueffectrapportage (Environmental Impact Assessment Regulation; abbreviation: Besluit m.e.r). ${ }^{87}$

\section{c. England}

\section{(i) The state}

England forms part of the United Kingdom of Great Britain and Northern Ireland. Thus, instead of referring to England as a "state", it is appropriate to refer to England as a legal system within the "state" United Kingdom of Great Britain and Northern Ireland. Generally, as explained by Andrew Le Sueur in his essay on "Tradition in English Administrative Law", it is difficult to determine the British concept of statehood:

juni 1992, Stb. 348, tot wijziging van de Wet geluidhinder en van het enkele bepalingen van den Woningswet, Stb. 1993, 59.

${ }^{79}$ For an explanation of the old system in English refer to: Seerden, Heldeweg, Public Environmental Law in the Netherlands, in: Seerden et al. (eds.), Public Environmental Law in the European Union and the United States, 2002, pp. $375 \mathrm{ff}$.

${ }^{80}$ Art. $20.1 \mathrm{Wm}$ (old).

${ }^{81}$ Backes et al., Milieurecht, $6^{\text {th }}$ edition, 2006, p. 318.

${ }^{82}$ This possibility was regulated in the old provision art. 20.6 (2) $\mathrm{Wm}$.

${ }^{83}$ Wet van 6 november 2008, houdende regels inzake een vergunningstelsel met betrekking tot activiteiten die van invloed zijn op de fysieke leefomgeving en inzake handhaving van regelingen op het gebied van de fysieke leefomgeving (Wet algemene bepalingen omgevingsrecht), Stb. 2008, 496.

${ }^{84}$ Art. 2.1 and 2.2 Wabo.

${ }^{85}$ Beijen (ed.), Hoofdlijnen Milieubestuursrecht, $2^{\text {nd }}$ edition, 2012, p. 250.

${ }^{86}$ Kamerstuk II, 2013-2014, 33962, nr. 2 (Voorstel van Wet).

${ }^{87}$ Besluit van 4 juli 1994, houdende uitvoering van het hoofdstuk Milieu-effectrapportage van de Wet milieubeheer, Stb. 1994, 540, as amended. 
"A second overarching national tradition, I refer to the fact that in Britain we do not have a clear political or legal concept of 'the state' on which to build administrative law. At a practical level, there is no standard constitutional or legal definition of the executive or executive power [...] At a theoretical level, it is said that the British do not care much about the idea of the state." 88

The history of the United Kingdom as a political entity began with the Act of Union of 1707, when Scotland and the Kingdom of England were integrated into the Kingdom of Great Britain. ${ }^{89}$ In the beginning of the $19^{\text {th }}$ century, Ireland became part of the Kingdom of Great Britain (United Kingdom of Britain and Ireland). Since the partition of Ireland, only its Northern part continued to belong to the United Kingdom. ${ }^{90}$

The United Kingdom is a constitutional monarchy. The constitution does not consist of one comprehensive document like in Germany or the Netherlands, but of a set of laws, principles, case law, and custom. ${ }^{91}$ A fundamental doctrine of UK constitutional law is the doctrine of "parliamentary sovereignty", referring to the (absolute) supremacy of the legislative power. ${ }^{92}$ Parliament is divided into two chambers: the House of Commons, representing the people of the UK, and the House of Lords, which is composed of hereditary peers, life peers and Bishops of the Church of England. ${ }^{93}$

The government consists of the Prime Minister, who is appointed by the Queen and the Cabinet, which is composed of ministers selected by the Prime Minister. ${ }^{94}$ Ministers are usually responsible for and heads of the Central Government Departments of State. ${ }^{95}$ In this function, they are called "Secretary of State". The government department responsible for planning and local government is the Department for Communities and Local Government. ${ }^{96}$

The United Kingdom is a unitary state, meaning that there is one central legislative body. ${ }^{97}$ Decentralisation in the United Kingdom is referred to as "devolution", being "a process whereby Parliament adopts statutes in order to create sub-national authorities and whereby it hands them over legislative powers that they can exercise for themselves". ${ }^{98}$ England does not have a separate legislative body, but Wales, Scotland and Ireland are each vested with different degrees of decision-making

\footnotetext{
${ }^{88}$ Le Sueur, Tradition in English Administrative Law, in: Ruffert (ed.), Administrative Law in Europe: Between Common Principles and National Traditions, 2013, p. 30.

${ }^{89}$ Leyland, The Constitution of the United Kingdom, 2012, p. 20.

${ }^{90}$ Ibid.

${ }^{91}$ Lange, The United Kingdom of Great Britain and Northern Ireland, in: Besselink et al. (eds.), Constitutional Law of the EU Member States, 2014, p. 1656; Heringa, Kiiver, Constitutions Compared, $3^{\text {rd }}$ edition, 2012 , p. 37.

92 Thompson, Jones, Administrative Law in the United Kingdom, in: Seerden (ed.), Administrative Law of the European Union, its Member States and the United States, $3^{\text {rd }}$ edition, 2012, p. 179.

${ }^{93}$ Lange, The United Kingdom of Great Britain and Northern Ireland, in: Besselink et al. (eds.), Constitutional Law of the EU Member States, 2014, pp. $1672 \mathrm{ff}$.

${ }^{94}$ Ibid., pp. 1664-1669, 1677, 1678.

${ }^{95}$ Leyland, The Constitution of the United Kingdom, 2012, p. $160 \mathrm{f}$.

${ }^{96}$ Bell et al., Environmental Law, $8^{\text {th }}$ edition, 2013, p. $111 \mathrm{f}$.

${ }^{97}$ Leyland, The Constitution of the United Kingdom, 2012, p. $243 \mathrm{f}$.

${ }^{98}$ Heringa, Kiiver, Constitutions Compared, $3^{\text {rd }}$ edition, 2012, p. 64.
} 
authority. ${ }^{99}$ The Scottish Parliament is vested with a general power to create laws within the limits of competence conferred on it. ${ }^{100}$ Also, the Northern-Ireland Assembly is empowered to legislate in the remit of its competence. ${ }^{101}$ Contrary to this, the Welsh Assembly is not vested with a general legislative competence, but it is empowered to regulate specific subject matters. ${ }^{102}$

\section{(ii) The law regulating the relationship between the state and the individual and other entities}

In the UK, there are three legal systems: the legal system of England and Wales, the legal system of Scotland and the legal system of Northern-Ireland. ${ }^{103}$ This thesis is confined to the English legal system. In England, the sources of administrative law are "Parliament and those whom Parliament has authorized to legislate, plus courts and tribunals." 104 Thus, "the law" comprises both, statutes (primary and secondary legislation) and cases law (common law). ${ }^{105}$ Contrary to the multi-layered system of legal norms in Germany and the Netherlands, the hierarchy of norms in England basically consists of two layers, namely "acts of parliament" and by means of delegated legislation, orders and statutory instruments and by-laws. ${ }^{106}$ Moreover, the common law provides for rules that have to be observed by the administration. ${ }^{107}$

\section{Table 3: Hierarchy of norms in England}

\begin{tabular}{|l|}
\hline Acts of Parliament \\
\hline Orders, Statutory Instruments, By-laws \\
\hline
\end{tabular}

In England, the emergence of administrative law as a separate discipline of law is a relatively new development. According to the British jurist Albert Venn Dicey (1835-1922),
"In many continental countries, and notably in France, there exists a scheme of administrative law - known to the Frenchmen as droit administratif - which rests on ideas foreign to the assumptions of our English common law, and especially to what we have termed the rule of law."108

He noted that "The words 'administrative law', which are its most natural rendering, are unknown to English judges and counsel, and are in themselves hardly intelligible without further explanation.”109

\footnotetext{
${ }^{99}$ Leyland, The Constitution of the United Kingdom, 2012, p. $243 \mathrm{ff}$.

100 Sections 28-30 Scotland Act 1998.

${ }^{101}$ Sections 5 and 6 Northern Ireland Act 1998.

${ }^{102}$ Section 21 Government of Wales Act 1998; Leyland, The Constitution of the United Kingdom, 2012, pp. $253 \mathrm{f}$.

${ }^{103}$ Feldman (ed.), English Public Law, 2009, at $1.23 \mathrm{f}$.

${ }^{104}$ Cane, Administrative Law, $5^{\text {th }}$ edition, 2011, p. 17.

${ }^{105}$ Leyland, The Constitution of the United Kingdom, 2012, pp. $26 \mathrm{ff}$.

106 Thompson, Jones, Administrative Law in the United Kingdom, in: Seerden (ed.), Administrative Law of the European Union, its Member States and the United States, $3^{\text {rd }}$ edition, 2012, p. 192; Bell et al, Environmental Law, $8^{\text {th }}$ edition, 2013, p. 92 ff.

${ }^{107}$ Leyland, The Constitution of the United Kingdom, 2012, pp. $27 \mathrm{f}$.

${ }^{108}$ Dicey, Introduction to the Law of the Constitution, $8^{\text {th }}$ edition, 1915, pp. $324 \mathrm{f}$.

${ }^{109}$ Ibid., p. 326.
} 
This position has influenced the development of public law in England for many years, so that no separate doctrine of administrative law comparable to the continental doctrines was developed. ${ }^{110}$ This does not mean that there was no law dealing with executive powers before the middle of the $20^{\text {th }}$ century, but it was simply not considered as a separate subject matter. ${ }^{111}$

Today, Cane distinguishes three main aspects of administrative law. ${ }^{12}$ First, administrative law concerns the "institutional framework" of the administration. Second, it describes a "normative framework", meaning the "functions, powers and duties of public administrators and the ('policy') objectives of public administration". The normative framework is statutory and non-statutory in nature. Third, administrative law deals with the "accountability of public administrators for the performance of their functions, the exercise of their powers, and the discharge of their duties". ${ }^{113}$

In the absence of a "general" codification of administrative law like in Germany or the Netherlands, rules can be found in many different statues and procedures are governed by various principles of law. Environmental law in England consists of numerous legislative instruments. ${ }^{114}$ A coherent framework is lacking. ${ }^{115}$

In the following chapters, the rules of the Town and Country Planning Act 1990 (abbreviation: TCPA (1990)), and of the Town and Country Planning Regulations (Environmental Impact Assessment) 2011 (abbreviation: TCPR (EIA) 2011) ${ }^{116}$ will become relevant. The TCPA (1990) regulates the development of land in England and Wales. Part two of the TCPA (1990) sets out rules on the creation of structure and local plans and part three TCPA (1990) is devoted to rules for the "control over development", including stipulations on the grant of planning permission. The act was subject to changes under the Planning and Compensation Act 1991, the Planning and Compulsory Purchase Act 2004, the Planning Act 2008 and the Localism Act 2011. ${ }^{117}$ The EIA procedure is regulated in the TCPR (EIA) 2011, which will be explained in detail in Part I.

\footnotetext{
${ }^{110}$ Harlow, Law and administration, $3^{\text {rd }}$ edition, 2009, p. 4 ff.

${ }^{111}$ For a historical overview on the development of English administrative law since the $17^{\text {th }}$ century: Wade, Forsyth, Administrative Law, $11^{\text {th }}$ edition, Oxford University Press, 2014, pp. $10 \mathrm{ff}$.

${ }^{112}$ Cane, Administrative Law, $5^{\text {th }}$ edition, Oxford University Press, 2011, pp. $11 \mathrm{ff}$.

${ }^{113}$ Ibid.

${ }^{114}$ An updated overview on the most important statutes only for planning law can be found on: UKELA, Law Search, http://www.environmentlaw.org.uk/rte.asp?id=80 (last visited 26.04.2015).

115 Jones, Public Environmental Law in the United Kingdom, in: Seerden (ed.), Public Environmental Law in the European Union and the United States, 2002, p. 446; Scotford, Oliver, The state of UK environmental legislation: opportunities for reform?, ELRev 2013, pp. 225-229.

${ }^{116}$ The Town and Country Planning (Environmental Impact Assessment) Regulations 2011, SI 2011, No. 1824.

${ }^{117}$ Bell et al. Environmental Law, $8^{\text {th }}$ edition, 2013, p. 406.
} 


\subsection{Administrative procedure in the three legal systems}

The term "administrative procedure" refers to the formalised action of administrative authorities. This section will describe the concept of administrative procedure in Germany, the Netherlands and England.

\section{a. Germany}

The German Verwaltungsverfahren (administrative procedure) is defined in $\S 9 \mathrm{VwVfG}$ as

"The activity of public authorities having an external effect which aim at the assessment of the legal requirements for the preparation of and the adoption of an administrative decision or to the conclusion of a public contract; it shall include the adoption of the administrative decision or the public contract." 118

The administrative decision is defined in $§ 35 \mathrm{~s} .1 \mathrm{VwVfG}$ as an

"Order, decision or other sovereign measure which an authority takes in order to regulate a specific case under public law and which is aimed at direct external legal effect."119

Traditionally, procedural law was considered to have a subservient function with respect to the substantive administrative decision. ${ }^{120}$ As the law already determines what the "right" decision is, the administrative procedure shall serve the finding of the "single correct decision", ${ }^{121}$ which results, as will be seen, ${ }^{122}$ in possibilities for an administrative judge to disregard procedural errors or to correct them at a later stage of the judicial procedure. ${ }^{123}$ This German approach stands in contrast to the European legal system which emphasises the need of properly conducted administrative procedures. ${ }^{124}$

The rules of the VwVfG are in principle also applicable in environmental matters. However, they can be modified or amended by more specific environmental statutes. For example in environmental matters, the Bundes-Immissionsschutzgesetz (Federal Immission Control Act, abbreviation: BImSchG) ${ }^{125}$ has to be mentioned, which aims, according to its $\S 1$, at the protection of human beings, animals and plants,

\footnotetext{
118 Own translation.

119 Maastricht Collection.

${ }^{120}$ Schmitz, § 1 VwVfG, in: Stelkens et al. (eds.), VwVfG Kommentar, 2014, at 4; This position today however is subject to debates: Hufen, Siegel, Fehler im Verwaltungsverfahren, 2013, pp. 36 ff.; Quabeck, Dienende Funktion des Verwaltungsverfahrens und Prozeduralisierung, 2010, chapter 2; Pünder, Administrative Procedure - Mere Facilitator of Material Law versus Cooperative Realization of Comon Welfare, in: Pünder, Waldhoff (eds.), Debates in German, Public Law, 2014, pp. 239 -260.

${ }^{121}$ Hufen, Verwaltungprozessrecht, $9^{\text {th }}$ edition, 2011, p. 15.

122 Part II, Chapter 4, Section 1.2 (a).

${ }^{123}$ Sachs, § 45 VwVfG, in: Stelkens et al. (eds.), VwVfG Kommentar, 2014, at 10-12.

124 The discrepancy between the German and the European approach has been subject to analysis by, for example: Grünewald, Die Betonung des Verfahrensgedankens im deutschen Verwaltungsrecht durch das Gemeinschaftsrecht, 2010; this conception of administrative procedure is especially debated in the context of the EIA: Schlecht, Die Unbeachtlichkeit von Verfahrensfehlern im deutschen Umweltrecht, Einwirkungen der AarhusKonvention und des Gemeinschaftsrechts auf die Grenzen gerichtlicher Kontrolle, 2010.

125 Gesetz zum Schutz vor schädlichen Umwelteinwirkungen durch Luftverunreinigung, Geräusche, Erschütterungen, und ähnliche Vorgänge (Bundes-Immissionsschutzgesetz), 17.05.2013, BGBl. I pp. 1274-1311.
} 
the soil, water, the atmosphere, cultural assets and other material goods against harmful effects and to prevent the development of harmful environmental effects. This protection shall be ensured where negative effects arise from installations. ${ }^{126}$ The $\mathrm{BImSchG}$ provides the administrative procedure for the grant of permits for the establishment and operation of certain ${ }^{127}$ installations. ${ }^{128}$ The EIA procedure in Germany is integrated in the various permit procedures regulated by special administrative law. ${ }^{129}$ Thus, in many cases, the EIA forms part of a permit procedure under the BImSchG. ${ }^{130}$

\section{b. Netherlands}

The general administrative procedure in the Netherlands is regulated in chapters 3 and $4 \mathrm{Awb}$. Since the entry into force of the Awb in 1994, the procedural rules were subject to several important reforms. Initially, there existed different special administrative procedures for the adoption of decisions but this changed in 2005. Since then, there are only two administrative procedures: the "usual" administrative procedure provided for in chapter $4 \mathrm{Awb}$ and the uniforme openbare voorbereidingsprocedure (uniform public preparation procedure) provided for in chapter 3.4 Awb. ${ }^{131}$

The "usual" administrative procedure applies to cases in which a beschikking is taken, meaning a decision with regard to an individual in a specific case. ${ }^{132}$ The uniform preparation procedure is applicable whenever the legislator determines by statute that this procedure shall be applicable. ${ }^{133}$

There are two main differences between these two procedures: the first difference relates to participation, the second relates to the possibilities to challenge decisions. ${ }^{134}$

The usual administrative procedure begins with the application for an administrative decision upon which the administrative authority adopts a decision. ${ }^{135}$ In the uniform preparation procedure, the authority first adopts a draft decision upon which persons having an interest in the decision may comment. ${ }^{136}$ Only after the submission of comments, the final decision is taken. ${ }^{137}$ This procedure is mainly declared applicable in cases which concern the interests of various parties. ${ }^{138}$

The second difference between the procedures relates to complaint mechanisms against the administrative decision. Whereas a decision taken by the usual administrative procedure must first be attacked in bezwaar, meaning by an objection procedure at the administrative authority before litigation

\footnotetext{
$126 \S 2$ (1) BImSchG.

127 The installations to which the BImSchG applies are enumerated in the general administrative order 4. BImSchV.

$128 \S 4$ (1) s. 1 BImschG, $\S 10$ BImSchG. The German expression for installation is Anlage.

$129 \S 2$ (1) s. 1 UVPG.

$130 \S 10$ (4) BImSchG and the 9. BImSchV.

${ }^{131}$ Wet van 24 januari 2002 tot wijziging van de algemene wet bestuursrecht, de Provinciewet en de Gemeentewet in verband met de samenvoeging van de afdelingen 3.4 en 3.5 van de Algemene wet bestuursrecht tot één uniforme openbare voorbereidingsprocedure (Wet uniforme openbare voorbereidingsprocedure Awb), Stb. $2002,54$.

${ }^{132}$ Damen et al., Bestuursrecht, vol. 1, $4^{\text {th }}$ edition, 2013, p. 347.

133 Art. 3:10 Awb.

134 Seerden, Wenders, Administrative Law in the Netherlands, in: Seerden (ed.), Administrative Law of the European Union, its Member States and the United States, $3^{\text {rd }}$ edition, 2012, p. 130.

135 Art. 4:1 Awb.

136 Art. 3:16 (1) Awb.

${ }^{137}$ Wijk et al., Hoofdstukken van Bestuursrecht, 2014, p. 291.

${ }^{138}$ Damen et al., Bestuursrecht, vol. 1, $4^{\text {th }}$ edition, 2013, p. 371.
} 
in courts is possible, a decision taken in the uniform public preparation procedure can be directly challenged in court. ${ }^{139}$

The rules of the Awb on administrative procedure are in principle also applicable in environmental matters. However, they are modified or amended by more specific environmental statutes. An example for modification is the procedure for the grant of an environmental permit under the Wet algemene bepalingen omgevingsrecht (Statute on general environmental law; abbreviation: Wabo (2010)). ${ }^{140}$ Regarding environmental impact assessment, the Wet milieubeheer (Statute on environmental administration; abbreviation: $\mathrm{Wm}$ ), provides for modifications of the general administrative procedure of the Awb as will be explained in Part I of this thesis. The Dutch legislator currently aims at integrating even more procedures in a new Omgevingswet (Environmental Code). ${ }^{141}$

\section{c. England}

Contrary to what was explained with regard to Germany and the Netherlands, English law does not provide for a single statue on general administrative procedural law ${ }^{142}$ and there is no clearly defined concept of "administrative decision". ${ }^{143}$ Instead, English doctrine provides for the concept of due process with a focus on the protection of procedural rights. ${ }^{144}$ Apart from this general concept of due process, there are various statutes regulating different administrative procedures.

Many cases in environmental matters, and especially in EIA matters, arise in the context of planning law. Thus, for the purpose of this thesis, some basic notions have to be explained. The grant of planning permission is governed by the Town and Country Planning Act 1990 (abbreviation: TCPA (1990)). According to section 57 (1) TCPA (1990) "planning permission is required for the carrying out of any development of land". A definition of "development" is given in section 55 stipulating that:

"development, means the carrying out of building, engineering, mining or other operations in, on, over or under land, or the making of any material change in the use of any buildings or other land."

This section continues defining the term "building operations", which includes the "(a) demolition of buildings, (b) rebuilding, (c) structural alterations of or additions to buildings, and (d) other operations normally undertaken by a person carrying on business as a builder". ${ }^{145}$ After a determination of this broad scope of application, various developments are exempted from the requirement of planning

\footnotetext{
${ }^{139}$ Art. 7:1 Awb; accordingly, the general rule is that an objection procedure has to be followed, unless the procedure under chapter 3.4 Awb was followed.

${ }^{140}$ Chapter 3 Wabo.

${ }^{141}$ Kamerstuk II, 2013-14, 33 962, nr. 2 (Voorstel van Wet).

${ }^{142}$ Kleve, Schirmer, England und Wales, in: Schneider (ed.), Verwaltungsrecht in Europa, vol. 1, 2007, p. 91.

${ }^{143}$ Glaser, Die Entwicklung des Europäischen Verwaltungsrechts aus der Perspektive der Handlungsformenlehre, 2013, pp. $106 \mathrm{ff}$.

${ }^{144}$ Wade, Forsyth, Administrative Law, $11^{\text {th }}$ edition, 2014, p. $405 \mathrm{ff}$.

${ }^{145}$ Section 55 (1A) TCPA 1990.
} 
permission in section 55 (2) TCPA. For example, the use of land for agriculture and forestry do not need planning permission. ${ }^{146}$

The procedure for an application for planning permission is regulated by the Town and Country Planning (Development Management Procedure) (England) Order 2010, abbreviation: TCPO (2010). Section 6 TCPO 2010 provides for requirements relative to the form and content of the application. Part III TCPO 2010 sets out detailed consultation requirements. Generally, anyone can respond to a planning consultation. Schedule 5 to the TCPO lists the consultees relative to the type of development. In many cases the Environment Agency has to be consulted. The public authority then determines whether to grant planning permission. The decision has to be notified indicating the reasons for granting or refusing permission. ${ }^{147}$ The precise rules on the EIA procedure will be explained in Part I.

\subsection{Administrative litigation in the three legal systems}

The principal topic of this thesis is the differences in national rules on administrative litigation in the Union. Part II will give a detailed description of the different litigation systems and their implications for the enforcement of the EIA Directive. Therefore, this section will focus on some basic information on administrative litigation in Germany, the Netherlands and England.

\section{a. Germany}

Judicial review in Germany finds its constitutional basis in article 19 (4) s. 1 GG which stipulates:

"If someone's rights are violated by public authority, he has recourse to the courts."148

In Germany, administrative courts are completely independent from the executive and they are separate from the ordinary courts. The Verwaltungsprozessrecht (law on administrative litigation) is the law applicable to those legal disputes which are brought to court under $\S 40$ (1) 1 Verwaltungsgerichtsordnung (Statute on Administrative litigation; abbreviation: VwGO). Accordingly, an application to an administrative court can be made if the case concerns a public dispute that is not of a constitutional nature. There are different types of administrative litigation procedures depending on the remedy sought. To begin with, claimants can apply for the annulment of an administrative decision (in the sense of $\S 35 \mathrm{VwVfG}$ as explained above) if this administrative decision infringes the claimant's subjective rights. ${ }^{149}$ Furthermore, claimants can apply to the court to order the administrative authority to take an administrative decision. ${ }^{150}$ Another litigation procedure concerns the request for a certain action (not an administrative act) of the administrative authority. ${ }^{151}$ Moreover, a claimant can ask the

\footnotetext{
146 Section 55 (2) e TCPA 1990.

147 Section 31 TCPO 2010.

148 Maastricht Collection.

$149 \S 42$ (1) first alternative VwGO.

$150 \S 42$ (2) second alternative VwGO.

151 This form of litigation is not explicitly regulated by the VwGO but derived from various provisions.
} 
court to find that a certain legal relationship exists or that it does not exist. ${ }^{152}$ Finally, under certain circumstances, it is possible to apply for a judicial review of administrative orders and by-laws. ${ }^{153}$

The German system, as based on article 19 (4) GG, is a system of recours subjective. This means that judicial review in Germany is not concerned with an objective control of legality but with the enforcement of subjective rights. Thus, by means of judicial review, an individual has the Befugnis (power) to ascertain the enforcement of their individual rights. This echoes in the norms governing the admissibility of a claim for judicial review and in the powers of the court for awarding a remedy. In principle, a claim will only be admissible and successful if there is an infringement of a subjective right under public law. It will be seen later in this thesis that this approach conflicts with many requirements of environmental law which ultimately led to modifications of the judicial review system. ${ }^{154}$

The administrative court system in Germany consists of three layers. The first instance courts in administrative matters are the Verwaltungsgerichte (abbreviation: VG). The second instance courts are the Oberverwaltungsgerichte (abbreviation: OVG). In some of the Länder the court of second instance is called Verwaltungsgerichtshof (abbreviation: VGH). ${ }^{155}$ The OVGs are the appellate courts for claims against judgments of the VG. In certain cases concerning big and highly technical projects, ${ }^{156}$ the OVGs are courts of first instance. The VG and the OVG are courts of the states. Both rule on the facts and the law in a case. As a third layer, at the federal level, there is the Bundesverwaltungsgericht (Federal Administrative Court; abbreviation: BVerwG) situated in Leipzig. It is generally a court of Revision (appeal) and only in very exceptional circumstances a court of first instance. ${ }^{157}$ Deciding on appeal, the BVerwG only rules on the law not on the facts of a case.

\section{b. The Netherlands}

A unitary judicial review procedure in the Netherlands was only created with the entry into force of the Awb in 1994. Before this year, each area of administrative law was connected to a specific set of rules of judicial procedure. ${ }^{158}$ The introduction of the unitary judicial procedure is seen as a turning point, turning away from an objective control of administrative decisions towards procedural law that focuses on the protection of the rights of the individual. ${ }^{159}$ Today, the beroep bij de bestuursrechter (application for judicial review at the administrative court) gives a claimant in the Netherlands the possibility to

\footnotetext{
${ }^{152} \S 43$ (1) first alternative VwGO.

$153 \S 47$ (1) nr. 2 VwGO.

${ }^{154}$ Part II, Chapter 2, Section 1.2 a; Part II Chapter 4, Section 1.2 a.

${ }^{155}$ Bavaria, Baden-Württemberg, Hesse.

${ }^{156}$ Enumerated in $\S 48$ VwGO.

$157 \S 50$ (1) VwGO.

${ }^{158}$ Damen et al., Bestuursrecht, vol. 2, 2012, p. 41.

159 Polak, Veranderende perspectieven van de bestuursrechter, in: Barkhuysen et al. (eds.), Bestuursrecht harmoniseren: 15 jaar Awb, 2010, pp. 99 ff.
} 
challenge an administrative decision. ${ }^{160}$ Legal protection against administrative action not qualifying as an administrative decision can only be pursued in the ordinary courts. ${ }^{161}$

In administrative matters, the Dutch court structure provides for two layers. The court of first instance is the administrative division at the rechtbank (district court). An appeal can be brought before a court of second instance against a judgment of the first instance court. ${ }^{162}$ In the Netherlands, there are several courts of second instance depending on the subject matter of the case. ${ }^{163}$ Many cases are dealt with by the Afdeling Bestuursrechtspraak van de Raad van State (Judicial division of the Council of State; abbreviation: ABRvS).

\section{c. England}

The point of departure for the English system of administrative control has been the principle of parliamentary sovereignty, which has resulted in a factually supreme position of the parliament with regard to administrative courts. ${ }^{164}$ This principle has influenced the self-perception of judges in England. ${ }^{165}$ Moreover, until the second half of the $20^{\text {th }}$ century, English legal doctrine followed Dicey's claim that "all governmental bodies were subject to ordinary Common and Statute Law and disputes arising with such bodies should be tried in the ordinary courts of the land." 166 Today, this situation has changed, although there is still no clear cut separation of administrative law from other branches of law which would be similar to the distinction drawn in civil law countries. ${ }^{167}$

General claims of judicial review are dealt with in the administrative division of the High Court. The procedural rules to be followed are prescribed in the Civil Procedure Rules 1998 (abbreviation: CPR) and their corresponding Practice Directions. ${ }^{168}$ According to section 54.1 (2) a CPR, "“a claim for judicial review' means a claim to review the lawfulness of (i) an enactment; or (ii) a decision, action or failure to act in relation to the exercise of a public function." The claim for judicial review provides for a uniform procedure that can be brought against different forms of public action. As far as public law remedies are concerned, English procedure distinguishes between quashing orders, prohibitory orders and mandatory orders. ${ }^{169}$ A quashing order can be directed against a decision of a public body, ${ }^{170}$ which

\footnotetext{
160 Art. 8:1 (1) Awb.

${ }^{161}$ Damen et al., Bestuursrecht, vol. 2, 2012, pp. 395 ff.; Seerden, Wenders, Administrative Law in the Netherlands, Seerden (ed.), Administrative law of the European Union, its Member States and the United States, 2012, p. 117.

162 Schlössels, Stroink, Kern van het bestuursrecht, $4^{\text {th }}$ edition 2013, p. $343 \mathrm{f}$.

163 Afdeling Bestuursrechtspraak van de Raad van State, Centrale Raad van Beroep, College van Beroep, Gerechtshof Leeuwaarden; for an overview of the different courts competent in different subject matters: Polak, Roelfsema, Bestuursrechtspraak, in: Muller, Cleiren (eds.), Rechterlijke Macht, $2^{\text {nd }}$ edition, 2013, pp. $200 \mathrm{f}$.

${ }^{164}$ Kleve, Schirmer, England und Wales, in: Schneider (ed), Verwaltungsrecht in Europa, vol. 1, 2007, p. 119.

${ }_{165}$ Own translation. Kleve, Schirmer, England und Wales, in: Schneider (ed), Verwaltungsrecht in Europa, vol. 1, 2007, p. 119.

${ }^{166}$ Glidewell, English Administrative Law: Past, present and future, Liverpool L. R. 1993, issue 1, p. 3.

167 Wade, Forsyth, Administrative Law, $11^{\text {th }}$ edition, 2014, pp. 8-13.

${ }^{168}$ Part 54 of the Civil Procedure Rules (CPR) deals with judicial review and statutory review.

${ }^{169}$ Section 54.2 CPR.

${ }^{170}$ Wade, Forsyth, Administrative Law, $11^{\text {th }}$ edition, 2014, pp. 509 f.
} 
is comparable to the German action for annulment ${ }^{171}$ and the Dutch institution of litigation at the court. Furthermore, a prohibitory order aims at preventing a public body from exceeding or continuing to exceed its jurisdiction. ${ }^{172}$ Finally, with a mandatory order, a public authority may be ordered to issue an administrative decision or to carry out an action. ${ }^{173}$ Next to these public law remedies, English procedure provides for private law remedies: injunctions and declarations. ${ }^{174}$ According to the former, a court can compel the administration to carry out an action or to refrain from carrying out an action. ${ }^{175} \mathrm{~A}$ declaration determines a right or the legal position of a party, but it has as such no legal effect. ${ }^{176}$

In April 2014, special "planning courts" were created. These are divisions of the High Court dealing with specific actions for judicial review enumerated in section 54.21 (2) CPR. Inter alia, planning courts deal with "European Union environmental legislation and domestic transpositions, including assessments for development consents, habitats, waste and pollution control." ${ }^{177}$ Section 54.23 CPR sets out that the rules of the CPR apply to planning claims unless the law provides otherwise.

Next to judicial review procedures, English law provides for statutory appeal procedures. For the purpose of this thesis, special attention has to be devoted to the statutory appeal under section 288 TCPA. This procedure is available to persons who are "aggrieved" by decisions taken by the Secretary of State under the rules of the TCPA. The grounds of review however "approximate to judicial review grounds" ${ }^{178}$. Under section 288 TCPA the court is restricted to the remedy of quashing orders. If the statutory regime under section 288 TCPA applies, applicants cannot have recourse to general judicial review procedures. ${ }^{179}$

To conclude, having provided for an overview on the content of this piece of research and an introduction to the three legal systems under consideration, in the following part, the "uniform rules", which are analysed in Part II, will be described.

\footnotetext{
${ }^{171}$ Kleve, Schirmer, England und Wales, in: Schneider (ed.), Verwaltungsrecht in Europa, vol. 1, 2007, p.133, 134.

${ }^{172}$ Kleve, Schirmer, England und Wales, in: Schneider (ed.), Verwaltungsrecht in Europa, vol. 1, 2007, p. 135; Wade, Forsyth, Administrative Law, $11^{\text {th }}$ edition, 2014, pp. $510 \mathrm{ff}$.

${ }^{173}$ Kleve, Schirmer, England und Wales, in: Schneider (ed.), Verwaltungsrecht in Europa, vol. 1, 2007, pp. 135

f.; Thompson, Jones, Administrative Law in the United Kingdom, in: Seerden (ed.), Administrative Law of the European Union, its Member States and the United States, $3^{\text {rd }}$ edition, 2012, p. 210; Wade, Forsyth, Administrative Law, $11^{\text {th }}$ edition, 2014, pp. $520 \mathrm{f}$.

174 Section 54.3 CPR.

175 Thompson, Jones, Administrative Law in the United Kingdom, in: Seerden (ed.), Administrative Law of the European Union, its Member States and the United States, $3^{\text {rd }}$ edition, 2012, p. 210; Wade, Forsyth, Administrative Law, $11^{\text {th }}$ edition, 2014, pp. $478 \mathrm{ff}$.

176 Wade, Forsyth, Administrative Law, $11^{\text {th }}$ edition, 2014, pp. $483 \mathrm{ff}$.

177 Section 54.21 (2) (vii) CPR.

${ }^{178}$ Bell et al., Environmental Law, $8^{\text {th }}$ edition, 2013, p. 443.

${ }^{179}$ Ibid., p. 337.
} 
Part I Uniform rules: The EIA procedure of the Union 
This part is dedicated to the "uniform" rules created by the Union legislator of which the enforcement in the national courts will be analysed in Part II. The rules of the Environmental Impact Assessment (EIA) procedure of the Union are "uniform" to the extent that they prescribe the main steps and the basic content of the EIA procedure which creates a level playing field the Union. This section will describe the requirements of the EIA procedure according to European law (section 1) and will trace the implementation of this piece of Union legislation in the national legal systems (section 2).

\section{The EIA procedure under Union law}

\section{a. Background}

The EIA is a procedural instrument whereby environmental effects are assessed before consent is given for a project, so that the potential effects of the project on the environment can be taken into consideration by the administrative authority when taking its decision. ${ }^{180}$ This procedure aims at giving effect to the precautionary principle and the prevention principle. ${ }^{181}$ The precautionary principle has been referred to as the principle of in dubio pro natura. ${ }^{182}$ It requires that action is taken to prevent or minimise the risk of damage to the environment in case of scientific uncertainty. ${ }^{183}$ The prevention principle entails that action should be taken at an early stage in order to protect the environment in advance. ${ }^{184}$

The origins of the EIA can be traced back to the USA where a similar procedure was already introduced in 1969. ${ }^{185}$ Drawing inspiration from existing procedures in the USA and other states, the Union has been developing harmonised standards for an EIA procedure in the Member States since the 1980s. ${ }^{186}$ The Union obliges its Member States to implement two assessment procedures. The first procedure concerns certain projects. The rules governing this procedure were initially adopted with Directive 85/337/EEC, which entered into force in 1985 and had to be implemented by the Member States by 3 July $1988 .{ }^{187}$ The second procedure prescribed by the Union requires an environmental assessment of plans and programmes. For this purpose, Directive 2001/42/EC was adopted (abbreviation: SEA Directive) ${ }^{188}$ aiming at an assessment of environmental impacts at an earlier stage than the EIA

\footnotetext{
${ }^{180}$ Preamble of Directive 2011/92/EU, at 2; Article 2 and 8 Directive 2001/92/EU; Krämer, EU Environmental Law, $7^{\text {th }}$ edition, 2012, p. 155.

${ }^{181}$ Preamble Directive 2011/92/EU, at 2.

182 Backes, Verschuuren, The Precautionary Principle in International, European and Dutch Wildlife Law, Colo. J. Int'l Envl. L. \& Pol'y 1998, p. 44.

${ }^{183}$ Macrony (ed.), Principles of European Environmental Law, 2004, 38 ff.

184 Jans, Vedder, European Environmental Law, $4^{\text {th }}$ edition, 2012, pp. 47 f.; Macrony (ed.), Principles of European Environmental Law, 2004, p. 38.

${ }^{185}$ National Environmental Policy Act of 1969 (Public Law 91-190, 42 U.S.C. 4321-4347, 1 January 1970).

${ }^{186}$ Noble, Introduction to Environmental Impact Assessment, $2^{\text {nd }}$ edition, 2010, pp. 7, 13 f.; Wood, Environmental Impact Assessment: A Comparative Review, $2^{\text {nd }}$ edition, 2003, p. 35.

${ }^{187}$ Directive 85/337/EEC on the assessment of the effects of certain public and private projects on the environment, OJ L 175, 5.07.1985, pp. 40-48.

${ }^{188}$ Directive 2001/42/EC of the European Parliament and of the Council of 27 June 2001 on the assessment of the effects of certain plans and programmes on the environment, OJ L 197, 21.07.2001, pp. 30-37.
} 
procedure, namely when plans are drawn up. The focus of this study is on the EIA Directive and not the SEA Directive.

\section{b. Development of the Union EIA procedure}

The Union legislation on the EIA procedure has been in a constant process of reform with the result that Directive 85/337/EEC has been amended several times. First, Directive 97/11/EC extended the scope of application of the EIA procedure by means of adding new categories of projects which had to be subjected to the EIA procedure. ${ }^{189}$ Moreover, an Annex III was added to the Directive which deals with certain criteria that have to be taken into consideration at the screening stage. ${ }^{190}$ Furthermore, Directive 97/11/EC implemented the requirements of the Convention on Environmental Impact Assessment in a Transboundary Context (ESPOO) of $1991^{191}$ in prescribing a procedure according to which Member States are obliged to inform other Member States on the likelihood of significant effects on the latters' territories. ${ }^{192}$

Second, Directive 2003/35/EC ${ }^{193}$ was adopted in order to transpose ${ }^{194}$ articles 9 (2) and (4) of the Aarhus Convention, ${ }^{195}$ to which the Union had become a party. ${ }^{196}$ This amendment to Directive 85/337/EEC introduced requirements on public participation and provided for new rules on access to justice. ${ }^{197}$ As far as access to justice is concerned, article 10 a Directive 85/337/EEC as amended by Directive 2003/35/EC ${ }^{198}$ stipulated that:

"Member States shall ensure that, in accordance with the relevant national legal system, members of the public concerned: (a) having a sufficient interest, or alternatively; (b) maintaining the impairment of a right, where administrative procedural law of a Member State requires this as a precondition; have access to a review procedure before a court of law or another independent and impartial body established by law to challenge the substantive or procedural

\footnotetext{
${ }^{189}$ Council Directive 97/11/EC of 3 March 1997 amending Directive 85/337/EEC on the assessment of the effects of certain public and private projects on the environment, OJ L 73, 14.3.1997, pp. 5-15.

${ }^{190}$ Art. 1 (6) in conjunction with Annex III Directive 97/11/EC; in the consolidated version: Article 4 (3) Directive 2011/92/EU.

${ }^{191}$ UNECE Convention on Environmental Impact Assessment in a Transboundary Context, 25 February 1991.

192 Art. 1 (9) Directive 97/11/EC. In the consolidated version: Article 7 Directive 2011/92/EU.

${ }^{193}$ Directive 2003/35/EC of the European Parliament and of the Council of 26 May 2003 providing for public participation in respect of the drawing up of certain plans and programmes relating to the environment and amending with regard to public participation and access to justice Council Directives 85/337/EEC and 96/61/EC, OJ L 156, 25.06.2003, pp. 17-25.

${ }^{194}$ In the preamble of Directive 2003/35/EC, the Community legislator makes clear that this Directive is adopted with a view to the ratification of the Aarhus Convention (at $5 \mathrm{ff}$.).

${ }^{195}$ UNECE Convention on Access to Information, Public Participation in Decision-Making and Access to Justice in Environmental Matters, 25 June 1998.

${ }^{196}$ Council Decision 2005/370/EC of 17 February 2005 on the conclusion, on behalf of the Community, of the Convention on access to information, public participation in decision-making and access to justice in environmental matters, OJ L 124/1, OJ L 124, 17.5.2005, pp. 1-3.

${ }^{197}$ Art. 3 Directive 2003/35/EC.

${ }^{198}$ In the consolidated version of 2011: Art. 11 Directive 2011/92/EU.
} 
legality of decisions, acts or omissions subject to the public participation provisions of this Directive".

Third, Directive 2009/31/EC ${ }^{199}$ amended the Annexes enumerating the projects which had to be subjected to an EIA or a screening by adding the requirement of an EIA for projects concerning the transport, the capture and storage of carbon dioxide. ${ }^{200}$ With Directive 2011/92/EU, the initial directive and its three amendments have been consolidated into one Directive. ${ }^{201}$

On 15 May 2014, a new amendment to the EIA Directive entered into force. Directive 2014/52/EU ${ }^{202}$ has to be implemented by the Member States by 16 May $2017 .{ }^{203}$ The new directive aims at mitigating shortcomings of the former directive and therefore provides for a range of new requirements. ${ }^{204}$ For the purpose of this study, articles referred to are from the consolidated version of the initial directive and its amendments, Directive 2011/92/EU, unless otherwise indicated.

\section{c. Projects to which the EIA procedure applies}

The EIA Directive is applicable to "the assessment of the environmental effects of those public and private projects which are likely to have significant effects on the environment." 205 The term "project" is further defined in article 1 (2) EIA Directive as "the execution of construction works or of other installations or schemes" and "other interventions in the natural surroundings and landscape including those involving the extraction of mineral resources". The Court of Justice has, on several occasions, emphasised that the Directive has a broad scope and purpose and that the term "project" has to be interpreted widely. ${ }^{206}$

The EIA Directive distinguishes two types of projects. First, Annex I to the Directive lists twenty four projects for which an EIA is mandatory ${ }^{207}$ For those projects, it is already assumed that they have

\footnotetext{
${ }^{199}$ Directive 2009/31/EC of the European Parliament and of the Council of 23 April 2009 on the geological storage of carbon dioxide and amending Council Directive 85/337/EEC, European Parliament and Council Directives 2000/60/EC, 2001/80/EC, 2004/35/EC, 2006/12/EC, 2008/1/EC and Regulation (EC) No 1013/2006, OJ L 140, 5.06.2009, pp. 114-135.

${ }^{200}$ Art. 31 Directive 2009/31/EC.

${ }^{201}$ Directive 2011/92/EU of the European Parliament and of the Council of 13 December 2011 on the assessment of the effects of certain public and private projects on the environment, OJ L 26, 28.01.2012, pp. 1-21.

${ }^{202}$ Directive 2014/52/EU of the European Parliament and of the Council of 16 April 2014 amending Directive 2011/92/EU on the assessment of the effects of certain public and private projects on the environment, OJ L 124, 25.04.2014, pp. 1-18.

${ }^{203}$ Art. 2 (1) Directive 2014/92/EU.

${ }^{204}$ For example, the new Directive introduces the requirement of penalties at the national level for the infringement of rules of the Directive (article 10a). Moreover, it requires reasonable time frames (no shorter than 30 days) for public participation (articles 6 (3) and (7)). Furthermore, decisions by the authority have to be taken within a reasonable time (article 8 a (5)).

${ }^{205}$ Art. 1 Directive 2011/92/EU.

${ }^{206}$ C-72/95, Aannemersbedrijf P.K. Kraaijeveld BV v Gedeputeerde Staten van Zuid-Holland [1996] ECR I-5431, para. 31 and 39; C-435/97, World Wildlife Fund (WWF) and Others v Autonome Provinz Bozen and Others [1999] ECR I-5613, para. 40; C-227/01, Commission v Spain [2004] ECR I-8253, para. 46; C-2/07, Paul Abraham and others v Région Wallonne and others [2008] ECR I-1197, para. 32; C-142/07, Ecologistas en Acción-CODA v Ayuntamiento de Madrid [2008] ECR I-6097, para. 28; C-263/08, Djurgården-Lilla Värtans Miljoskyddsföreening [2009] ECR I-9967 para. 29.

${ }^{207}$ Art. 4 (1) EIA Directive in conjunction with Annex I.
} 
significant environmental impacts and therefore there must be an environmental assessment. ${ }^{208}$ The annex includes crude-oil refineries, thermal power stations and nuclear power stations and installations dealing with nuclear fuel, installations for the processing of iron and steel, installations for the extraction of asbestos, chemical installations, the construction of certain railway lines and airports, projects relating to inland water-way traffic, waste disposal installations, ground water extraction or artificial recharge schemes, works for the transfer of water resources between river basins, water treatment plants, the extraction of petroleum and natural gas for commercial purposes, the construction of dams and of pipelines, installations of the intensive rearing of poultry or pigs, industrial plants for the production of pulp from timber or paper, quarries and open-case mining, and certain overhead electrical power lines, installations for the storage of petroleum, sites for the geological storage of carbon dioxide and installations for the capture of $\mathrm{CO}_{2} \cdot{ }^{209}$ The annex specifies thresholds and cases for these projects, in which an EIA is mandatory.

Second, Annex II to the Directive lists projects for which national authorities have to determine by "screening" whether an EIA has to be undertaken. Member States may determine under which conditions projects are subject to an assessment, either through a case-by-case examination or by adopting thresholds or criteria. ${ }^{210}$ Annex II concerns projects relative to agriculture, silviculture and aquaculture, extractive industry, energy industry, production and processing of metals, the mineral, chemical, textile, food, leather, paper and rubber industry, infrastructure projects, other projects and tourism and leisure. When assessing whether a project falls under Annex II, the selection criteria of Annex III have to be taken into account. ${ }^{211}$ Annex III lists certain characteristics of projects such as its size, ${ }^{212}$ some criteria regarding the location of projects such as the existing land use ${ }^{213}$ and characteristics of the potential impact such as the extent of the impact and its probability ${ }^{214}$ which have to be considered when deciding whether an EIA has to be undertaken.

Apart from designating projects for which an EIA is mandatory or for which a screening has to be done, the Directive provides for rules excluding certain projects from the scope of application of the EIA Directive. Member States are allowed to exclude on a case-by-case basis, projects serving national defence purposes ${ }^{215}$ and the Directive does not apply to projects adopted by a legislative procedure. ${ }^{216}$ Moreover, article 2 (3) EIA Directive allows Member States to exempt a certain project from the provisions of the Directive. Such an exemption has to be notified to the Commission. ${ }^{217}$ Then, the

\footnotetext{
${ }^{208}$ Bell et al., Environmental Law, $8^{\text {th }}$ edition, 2013, p. 461.

${ }^{209}$ Annex I to Directive 2011/92/EU.

${ }^{210}$ Art. 4 (2) EIA Directive in conjunction with Annex II.

211 Art. 4 (3) EIA Directive.

${ }^{212}$ Annex III, nr. 1 (a) Directive 2011/92/EU.

213 Annex III, nr. 2 (a) Directive 2011/92/EU.

${ }^{214}$ Annex III, nr. 3 (a) Directive 2011/92/EU.

215 Art. 1 (3) Directive 2011/92/EU.

${ }^{216}$ Art. 1 (4) Directive 2011/92/EU.

217 Art. 2 (3) c EIA Directive.
} 
Member States have to "consider whether another form of assessment would be appropriate". ${ }^{218}$ In such cases the public has to be informed. ${ }^{219}$

\section{d. The main steps in an EIA procedure according to the EIA Directive}

The EIA procedure as laid down in Directive 2011/92/EU consists of the following five steps:

Step 1: Determination of the obligation to carry out an EIA: the screening

To begin with, the competent authority has to decide whether or not an EIA has to be conducted for a specific project. ${ }^{220}$ For this purpose, it is assessed whether the project constitutes one of the types of projects listed in Annex I, meaning that an EIA is mandatory. ${ }^{221}$ If this is the case, the next step in the procedure is the "scoping" (step 2) or the draft of the environmental statement (step 3). If the project does not fall under Annex I, it has to be questioned whether the project constitutes one of the types of projects listed in Annex II. ${ }^{222}$ In this assessment, the criteria of Annex III have to be taken into consideration. ${ }^{223}$ Thus, it is asked whether in this specific case it is probable that there are significant effects, meaning that an EIA has to be conducted. If this is the case, the next step in the procedure is the "scoping" (step 2) or the draft of the environmental statement (step 3). If this is not the case, the EIA procedure stops.

Step 2: Scoping

The term "scoping" refers to a process whereby the authority designates the information that should be supplied by the developer. ${ }^{224}$ In case the project either falls under Annex I or in case that the authority comes to the conclusion that the project falls under Annex II and III, the developer may - and this is left to the discretion of the Member States - request the authority to give a scoping opinion.

$\underline{\text { Step 3: Preparing the environmental statement }}$

According to article 3 EIA Directive, the assessment has to take place with regard to "(a) human beings, fauna and flora; (b) soil, water, air, climate and the landscape; (c) material assets and the cultural heritage; (d) the interaction between the factors referred to in points (a), (b) and (c)."

\footnotetext{
218 Art. 2 (3) a EIA Directive.

219 Art. 2 (3) b EIA Directive.

${ }^{220}$ In the European terminology the term screening refers to "the process by which a decision is taken on whether or not EIA is required for a particular project", which starts with a determination of whether a project falls under Annex I or II (European Commission, Guidance on EIA, Screening, 2001(available online)).

${ }^{221}$ Art. 4 (1) EIA Directive.

${ }^{222}$ Art. 4 (2) EIA Directive.

${ }^{223}$ Art. 4 (3) EIA Directive.

${ }^{224}$ Art. 5 (2) EIA Directive.
} 
For the assessment, the developer has to collect and submit information to the public authority. This includes the preparation of an environmental statement which is a report ${ }^{225}$ on possible environmental effects of the project. The environmental statement has to contain at least the following information: "(a) a description of the project comprising information on the site, design and size of the project; (b) a description of the measures envisaged in order to avoid, reduce and, if possible, remedy significant adverse effects; (c) the data required to identify and assess the main effects which the project is likely to have on the environment; (d) an outline of the main alternatives studied by the developer and an indication of the main reasons for his choice, taking into account the environmental effects; (e) a nontechnical summary of the information referred to in points (a) to (d)." 226

Step 4: Information and consultation of the public

Article 6 EIA Directive requires that the public is informed and consulted. If applicable, article 7 requires that other Member States whose territory might be affected by the project have to be informed as well.

Step 5: The final administrative decision

Finally, article 8 EIA Directive requires that the authority takes the environmental statement into account in its final decision. The public has to be informed about the decision ${ }^{227}$ and the decision must be challengeable in court. ${ }^{228}$

These five steps of the EIA procedure have to be followed in the Member States of the Union. In the next section, it will be shown how the rules of the Directive have been implemented in the laws of the legal systems of Germany, the Netherlands and England.

\section{The implementation of the EIA Directive in the national legal systems}

According to Directive 85/337/EEC, the Member States had to implement the rules of the Union EIA procedure by 3 July $1988 .{ }^{229}$ In the following, a brief overview over the transposition of the rules into the national laws of Germany, the Netherlands and England will be given and the national legal frameworks of the EIA in 2014 will be presented respectively. Furthermore, some remarks on the national experiences with the EIA procedure will be made.

\section{a. Germany}

Before the Union legislator obliged Germany to introduce an EIA procedure, there was no such procedure regulated by statute in the German legal system. Although the German government had already stressed the importance of preventive action in environmental planning in the beginning of the

\footnotetext{
${ }^{225}$ In the English EIA terminology the term "environmental statement" relates to the EIA, whereas the term "environmental report" relates to the SEA. Here, the term "report" is used as synonym for "statement".

${ }^{226}$ Art. 5 (3) EIA Directive.

${ }^{227}$ Art. 10 Directive 2011/92/EU.

${ }^{228}$ Art. 11 Directive 2011/92/EU.

${ }^{229}$ Art. 12 (1) Directive 85/337/EEC.
} 
1970s, attempts to introduce a statutory EIA procedure failed. ${ }^{230}$ The EIA Directive was implemented with a delay of two years by the Gesetz über die Umweltverträglichkeitsprüfung (Statute on EIA; abbreviation: UVPG) in $1990 .{ }^{231}$ The UVPG was drafted as a separate piece of legislation which was amended according to the requirements of Directive 97/11/EC, ${ }^{232}$ and it was redrafted in $2005^{233}$ and $2010^{234}$ respectively. With the implementation of Directive 2009/31/EC, the UVPG was amended in 2012. ${ }^{235}$ A peculiarity of German law is a special statute for judicial enforcement of environmental law and particularly the EIA procedure, which was created in 2006, the Umweltrechtsbehelfsgesetz (statute for litigation in environmental matters) abbreviation: UmwRG (2006). ${ }^{236}$ As will be seen at a later point in this thesis, ${ }^{237}$ the German system of access to administrative courts in environmental matters had to be reformed under Union pressure. ${ }^{238}$ Since 2013, the reformed UmwRG (2013) is in force, ${ }^{239}$ however further adjustments are expected. ${ }^{240}$

\section{(i) The legal framework of the EIA procedure in 2014}

The EIA procedure is integrated into the general administrative procedures for the decision on the admissibility of projects. The UVPG is applicable to environmental assessments for projects (EIA) and to environmental assessments for plans (SEA) and consists of six parts and four annexes. Annex 1 provides a list of projects subject to an obligatory EIA (column 1) and a list of projects that may be subject to an EIA (column 2). Annex 2 implements the criteria of Annex III of the EIA Directive. Annex 3 provides a list of plans and programmes subject to an SEA and Annex 4 enumerates the criteria for the screening in SEA cases. The structure of the UVPG is illustrated by the table below. This table may be helpful for understanding the case law analysis in Part II of this thesis.

\footnotetext{
${ }^{230}$ Erbguth, Schink, UVPG Kommentar, $2^{\text {nd }}$ edition, 1996, Einleitung, at 1 a f.

${ }^{231}$ Gesetz zur Umsetzung der Richtlinie des Rates vom 27 Juni 1985 über die Umweltverträglichkeitsprüfung bei bestimmten öffentlichen und privaten Projekten (85/337/EWG), 12.02.1990, BGB1. I pp. 205-214.

${ }^{232}$ Gesetz zur Umsetzung der UVP-Änderungsrichtlinie, der IVU-Richtlinie und weiterer EG-Richtlinien zum Umweltschutz, 27.07.2001, BGB1. I pp. 1950-2021.

${ }^{233}$ Bekanntmachung der Neufassung des Gesetzes zur Umweltverträglichkeitsprüfung, 25.06.2005, BGB1. I pp. $1757-1790$.

${ }^{234}$ Bekanntmachung der Neufassung des Gesetzes über die Umweltverträglichkeitsprüfung, 24.02.2010, BGB1. I pp. 94-128.

${ }^{235}$ Gesetz zur Demonstration und Anwendung von Technologien zur Abscheidung, zum Transport und zur dauerhaften Speicherung von Kohlendioxid, 17.08.2012, BGBl. I pp. 1726-1753.

${ }^{236}$ Gesetz über ergänzende Vorschriften zu Rechtsbehelfen in Umweltangelegenheiten nach der EG-Richtlinie 2003/35/EG (Umweltrechtsbehelfsgesetz), 7.12.2006, BGBl. I pp. 2816-2818.

${ }^{237}$ Part II, Chapter 2, Section 1.2 (a); Part II, Chapter 4, Section 1.2 (a).

${ }_{238}$ C-115/09, Bund für Umwelt und Naturschutz Deutschland, Landesverband Nordrhein-Westfalen eV $v$ Bezirksregierung Arnsberg [2011] ECR I-36.

${ }^{239}$ Gesetz zur Änderung des Umwelt-Rechtsbehelfsgesetzes und anderer umweltrechtlicher Vorschriften, 21.01.2013, BGB1. I pp. 95-100.

${ }^{240}$ The legislator will have to react on the Court of Justices judgment in C-72/12, Gemeinde Altrip and Others $v$ Land Rheinland-Pfalz (Judgment of 7 November 2013) and on the infringement procedure initiated against Germany: C-137/14, European Commission v Federal Republic of Germany (Action brought on 21 March 2014).
} 
Table 4: EIA legislation in Germany

\begin{tabular}{|c|c|c|c|c|c|c|}
\hline \multirow{2}{*}{\multicolumn{3}{|c|}{$\begin{array}{l}\text { Gesetz zur Umsetzung der Richtlinie des } R \\
\text { öffentlichen und privaten Projekten }(85 / 337 / E \\
\text { Parts } 1 \text { to } 6\end{array}$}} & \multicolumn{2}{|c|}{$\begin{array}{l}\text { Rates vom 27. Juni } 1985 \text { üt } \\
\text { WG), Abbreviation: UVPG }\end{array}$} & \multicolumn{2}{|c|}{ ie UVP bei bestimmten } \\
\hline & & & Annex 1 & & Annex 2 & Annex 3, 4 \\
\hline \multicolumn{3}{|c|}{ Transposed provisions of the EIA and SEA Directive } & $\begin{array}{l}\text { Transposed Annex } \\
\text { I EIA Directive }\end{array}$ & $\begin{array}{l}\text { Transposed } \\
\text { Annex II EIA } \\
\text { Directive }\end{array}$ & $\begin{array}{l}\text { Transpose } \\
\text { d Annex III } \\
\text { EIA } \\
\text { Directive }\end{array}$ & $\begin{array}{l}\text { Transposed } \\
\text { SEA Annexes }\end{array}$ \\
\hline$\S \S 3 a-14$ & $\S \S 14 a-14 n$ & $\begin{array}{l}\S \S 15-19 \text { b } \\
\text { and } \\
\S \S 20-23\end{array}$ & Column 1 & Column 2 & & \\
\hline $\begin{array}{l}\text { Rules for } \\
\text { projects }\end{array}$ & $\begin{array}{l}\text { Rules for plans } \\
\text { and } \\
\text { programmes }\end{array}$ & $\begin{array}{l}\text { Special rules } \\
\text { for projects } \\
\text { and plans in } \\
\text { specific } \\
\text { procedures }\end{array}$ & $\begin{array}{l}\text { Projects for } \\
\text { which an EIA is } \\
\text { obligatory }\end{array}$ & $\begin{array}{l}\text { Projects for } \\
\text { which an EIA } \\
\text { may be } \\
\text { necessary }\end{array}$ & & \\
\hline
\end{tabular}

(ii)

The main steps in the EIA procedure in Germany

Step 1: Determination of the obligation to make an EIA

According to $\S 3$ a s. 1 UVPG, the administrative authority has to determine whether an obligation to conduct an EIA exists. This determination is either done upon the request of the developer or after a developer requested the authority to deliver a scoping opinion or after the commencement of an administrative procedure concerning the admissibility of a project. ${ }^{241}$ An EIA is obligatory if a project falls under the criteria and thresholds listed in Annex 1 UVPG. ${ }^{242}$ This obligation also exists if several projects of the same nature (cumulative projects) will be realised which are closely interrelated ${ }^{243}$ and if the alteration or extension of an existing project, for which there was no obligation so far to make an EIA fulfils the criteria or exceeds the thresholds for the first time. ${ }^{244}$

\footnotetext{
${ }^{241}$ Diens, § 3a UVPG, in: Hoppe, Beckmann (eds.), UVPG Kommentar, $4^{\text {th }}$ edition, 2012, at 6-9.

${ }^{242} \S 3 \mathrm{~b}(1) \mathrm{UVPG}$.

${ }^{243} \S 3$ b (2) UVPG.

${ }^{244} \S 3$ b (3) UVPG.
} 
A separate procedure for the determination of whether or not an EIA may be necessary on a case-bycase basis was only introduced to the UVPG in $2001 .{ }^{245}$ Before this year, the annexes to the UVPG provided for an exhaustive list of cases in which an EIA had to be carried out. ${ }^{246}$ Since 2001, § 3c UVPG requires that the authority has to conduct a pre-assessment of whether, for projects listed in column 2 of Annex 1 UVPG, an EIA has to be undertaken, paying regard to the criteria of Annex 2 UVPG. Thereby, a distinction is made between the Vorprïfung des Einzelfalls (general screening) and a Standortbezogene Vorprïfung (screening focusing on the location of the project).

\section{Step 2: Scoping}

According to $\S 5 \mathrm{~s} .1 \mathrm{UVPG}$, a developer may request a scoping opinion from the authority before the commencement of the administrative procedure. Otherwise, the public authority may consider it necessary to give a scoping opinion after the commencement of the administrative procedure. In this case, the authority shall consult with the developer to determine the nature and scope of the information required in the administrative procedure. ${ }^{247}$

\section{Step 3: Preparing the environmental statement}

Rules on the scope and content of the environmental information are enshrined in $\S 6$ UVPG. Accordingly, the developer has to submit all relevant materials to the competent authority. ${ }^{248}$ $\S 6$ (3) UVPG provides for a list of information which has to be submitted at least, namely information on the characteristics of the project, measures for the protection of the environment, the potential significant effects on the environment and a description of alternatives as far as they have been considered. Moreover, a non-technical summary has to be made. On a case-by-case basis, additional information enumerated in § 6 (4) UVPG has to be submitted. The fact that the UVPG lays the burden to provide the relevant materials on the developer does not mean that the competent authority is exempted from the obligation to collect all relevant information. ${ }^{249}$ On the contrary, the authority has to collect all the relevant information under the general rules of administrative procedure. ${ }^{250}$

Step 4: Information and consultation of the public

$\S 7$ UVPG requires the information and consultation of other public authorities and § 8 UVPG provides for rules on the submission of information on a project to authorities of other states. § 9 UVPG sets out

\footnotetext{
${ }^{245}$ Bekanntmachung der Neufassung des Gesetzes über die Umweltverträglichkeitsprüfung, 5.09.2001, BGBl I pp. $2350-2375$.

${ }^{246}$ Diens, § 3 UVPG, in: Hoppe, Beckmann (eds.), UVPG Kommentar, $4^{\text {th }}$ edition, 2012, at 2.

$247 \S 5$ s. 1, 3 UVPG.

248 \& 6 (1) UVPG.

${ }^{249}$ Gassner, UVPG Kommentar, 2006, § 6 at 4-6; Hofmann, § 6 UVPG, in: Landmann, Rohmer (eds.), Umweltrecht, Komentar, 2014, at 3; Kment, § 6 UVPG, in: Hoppe, Beckmann (eds.), UVPG Kommentar, $4^{\text {th }}$ edition, 2012, at 2 .

$250 \S 24 \mathrm{VwVfG}$.
} 
the rules for the participation of the public and § 9a UVPG for the participation of the transnational public.

\section{Step 5: The final administrative decision}

Pursuant to $\S 11$ UVPG, the administrative authority issues a summary description of potential environmental impacts on the basis of the information submitted by the developer and the consultation of other public authorities and the public. Furthermore, the authority describes measures which may prevent, reduce or mitigate significant adverse effects. § 12 UVPG requires that the summary description is taken into consideration when taking the final administrative decision.

\section{Experiences with the EIA in Germany}

Expectations as to the effectiveness of the EIA were high. In this context, the minister for environmental affairs, Klaus Töpfer, is often cited as describing the EIA as the Königsweg (the king's path) of environmental policy. ${ }^{251}$ The Bundestag asked for an "optimal transposition" of the Directive. ${ }^{252}$ Contrary to this, the implementation of the Directive was received less enthusiastically. The early implementation was criticised for not constituting the required optimal transposition of the Union requirements. ${ }^{253}$ Instead, the implementing legislation only fulfilled the minimum requirements of the EIA Directive. ${ }^{254}$

In 1997, Schwab conducted an empirical study on first experiences with the new rules. ${ }^{255} \mathrm{He}$ revealed that the high expectations were only moderately met. With regard to permits for installations, only about twenty had been subjected to an EIA, partially on voluntary basis. Moreover, it was only possible to distinguish three procedures for the modification of an existing installation with an integrated EIA. Most procedures $(95 \%)$ in which an EIA was conducted were found in the areas of water and waste management. At the outset, it was not possible to find a refusal of permission because of an EIA. Thus, the study concluded that the EIA was not an instrument to prevent the construction of installations. Moreover, for the public and on site visits, the EIA was almost irrelevant. ${ }^{256}$

Ten years later, a study on the implementation of the EIA in Germany was conducted under the umbrella of the federal environmental authority. It analysed success and failure at the various steps of the EIA procedure. As regards the stage of screenings, it was found that, in a large percentage of cases, the

\footnotetext{
${ }^{251}$ Erbguth, Schink, UVPG Kommentar, $2^{\text {nd }}$ edition, 1996, § 12, at 16; Schink, Auswirkungen des EG Rechts auf die Umweltverträglichkeitsprüfung nach deutschem Recht, NVwZ 1999, p. 13; Steinberg, Chancen zur Effektuierung der Umweltverträglichkeitsprüfung durch die Gerichte?, DÖV 1996, p. 231.

${ }^{252}$ The request to draft an "optimal transposition" of the Directive was initially formulated by the Bundestag in Plenarprotokoll 10/38 and BT Drs.10/613, at 8.

${ }^{253}$ Soell, Dirnberger, Wieviel Umweltverträglichkeit garantiert die UVP?- Bestandsaufnahme und Bewertung des Gesetzes zur Umsetzung der EG-Richtlinie über die Umweltverträglichkeitsprïfung, NVwZ 1990, p. 707.

254 Erbguth, Der Entwurf eines Gesetztes über die Umweltverträglichkeitsprüfung: Musterfall querschnittsorientierter Gesetzgebung aufgrund des EG Rechts?, NVwZ 1988, pp. 969 - 977.

${ }^{255}$ Schwab, Die Umweltverträglichkeitsprüfung in der behördlichen Praxis, NVwZ 1997, p. 429.

${ }^{256} \mathrm{Ibid}$.
} 
conclusion was reached that no EIA was necessary. ${ }^{257}$ The scoping exercise and the quality of material submitted were evaluated as being good, but there was still a need for improvement. What seemed to be rather problematic was the quality of the environmental statement and its evaluation. Moreover, it was described that there was still uncertainty regarding the requirement that the environmental statement has to be taken into consideration in the final decision permitting a project. No increase in quality could be detected for the period between 1999 and 2005. Finally, from a purely practical point, authorities were often overwhelmed by the information submitted and lacked sufficient capacity to assess the materials properly. ${ }^{258}$ The latter point has not only triggered debate in practice, but also in legal literature, where it has been debated how the authority should take the information into consideration when taking the administrative decision. ${ }^{259}$

Moreover, it has been discussed in how far alternatives have to be taken into account. The UVPG requires, ${ }^{260}$ in $\S 6(3) \mathrm{nr} .5$, that the developer has to submit an overview of the most important alternative solutions for the project that were considered and a statement of reasons why the developer decided for the project under consideration. However, the precise meaning of this norm has been the subject of controversial discussion. Some authors have argued that the evaluation of alternative solutions constitutes the "heart" of the EIA ${ }^{261}$ with the consequence that such an assessment of alternatives is obligatory. ${ }^{262}$ In contrast to that, it has been argued that the UVPG does not provide for an obligation for the developer or the authority to make an assessment of alternatives. ${ }^{263}$ The wording and the legislative history of $\S 6$ (3) nr. 5 UVPG do not support the assumption that the developer is required to find an alternative solution. ${ }^{264}$ Instead, the norm requires simply that the developer has to submit an overview of alternative solutions if he considered them. The latter view was also adopted by the courts. ${ }^{265}$ Nevertheless, the lack of an obligation to consider alternatives in the UVPG does not mean that alternatives do not have to be assessed in any case. Rather, such an obligation exists in certain special administrative procedures, in which the requirement to evaluate alternatives exists. ${ }^{266}$ Whether

\footnotetext{
${ }^{257}$ Führ et al., Evaluation des UVPG des Bundes, ZUR 2009, p. 60.

${ }^{258}$ Ibid., p. 61.

${ }^{259}$ Erbguth, Schink, UVPG Kommentar, $2^{\text {nd }}$ edition, 1996, § 12, at 22; Mayen, Die UVP nach dem UVP Gesetz und der UVP Verwaltungsvorschrift, NVwZ 1996, pp. 319-326; Soell, Dirnberger, Wieviel Umweltverträglichkeit garantiert die UVP?, NVwZ 1990, pp.708 f.

${ }^{260}$ Transposing art. 5 (3) EIA Directive.

${ }^{261}$ Bunge, Die Umweltverträglichkeitsprüfung von Projekten, DVB1 1987, p. 823.

${ }^{262}$ Erbguth, Rechtliche Anforderungen an Alternativprüfungen in (abfallrechtlichen) Planfeststellungsverfahren und vorgelagerten Verfahren, NVwZ 1992, p. 218 f.; Erbguth, Schink, UVPG, Kommentar, $2^{\text {nd }}$ edition, 1996, § 2, at 22 f.; Soell, Dirnberger, Wieviel Umweltverträglichkeit garantiert die UVP? Bestandsaufnahme und Bewertung des Gesetzes zur Umsetzung der EG-Richtlinie über die Umweltverträglichkeitsprüfung, NVwZ 1990, p. 710.

${ }^{263}$ Beckmann, Der Rechtsschutz des Vorhabenträgers bei der Umweltverträglichkeitsprüfung, NVwZ 1991, p. 430 .

${ }^{264}$ Beckmann, § 12 UVPG, in: Hoppe, Beckmann (eds.), UVPG Kommentar, $4^{\text {th }}$ edition, 2012, at $44 \mathrm{ff}$.

${ }^{265}$ BVerwG, Decision of 14 May 1996, Az.: 7 NB 3/95, BVerwGE 101, 166; OVG Lüneburg, 8 March 2006, Az.: 7 KS 145/02, juris, para. 70.

266 The evaluation of alternatives takes place, for example, in the realm of Planfeststellungs-procedure; Kment, $\S 6$ UVPG, in: Hoppe, Beckmann (eds.), UVPG Kommentar, $4^{\text {th }}$ edition, 2012, at 21; Beckmann, $\S 12$ UVPG, in: Hoppe, Beckmann (eds.), UVPG Kommentar, $4^{\text {th }}$ edition, 2012, at $54 \mathrm{ff}$.
} 
and how the German rules on the assessment of alternatives will change because of the obligation to implement Directive 2014/02/EU remains to be seen. ${ }^{267}$

In later chapters of this thesis, it will be explained why and to what extent the enforcement of the EIA procedure in German courts was extremely difficult. But already in this part on experiences with the EIA, some remarks on this issue have to be made. The treatment of the EIA procedure by German courts has been criticised since the beginning of EIA enforcement. ${ }^{268}$ In order to implement the obligations of the Aarhus Convention and Directive 2003/35/EC, a separate statute for environmental litigation was adopted in 2006, the Umweltrechtsbehelfsgesetz, abbreviation: UmwRG. An empirical evaluation of this study for the period between 2006 and 2012 shows that the newly created rules for environmental litigation in many cases did effectively contribute to the better enforcement of environmental rules. ${ }^{269}$ However, this result has to be seen in context: whereas the average number of EIAs in Germany amounts to 775 per year, the average number of claims brought under the newly created rules for environmental litigation was $12 .{ }^{270}$

To conclude, in Germany, the EIA Directive has been implemented with the UVPG and the UmwRG. The practical application of the implementing legislation has been difficult due to a number of obstacles. This situation shall be compared with the implementation process in the Netherlands in the next section.

\section{b. The Netherlands}

In the Netherlands, discussions on the introduction of an EIA procedure were already going on before Member States were obliged to implement Directive 85/337/EEC in national law. A bill was drafted in $1981^{271}$ and the first provisions on the EIA procedure were introduced in the Wet algemene bepalingen milieuhygiëne (Statute on general rules concerning environmental health; abbreviation: Wabm) in 1986..$^{272}$ This early legal framework of the EIA procedure had to be modified several times and it has been adapted to European law requirements since Member States were obliged to transpose Directive $85 / 337 /$ EEC by 3 July 1988. Although the provisions in the Wabm were in some points more far reaching than the European regulation, ${ }^{273}$ the European Commission initiated an infringement procedure against the Netherlands in 1990. ${ }^{274}$ In 1993 the Dutch EIA procedure was reformed and incorporated in

\footnotetext{
${ }^{267}$ Paluch, Werk, Zum aktuellen Sachstand und zur Bewertung der europäischen Beschlüsse zur Änderung der UVP-Richtlinie, NuR 2014, pp. 400-405.

${ }^{268}$ Schink, Auswirkungen des EG Rechts auf die Umweltverträglichkeitsprüfung nach deutschem Recht, NVwZ 1999, p. 13.

${ }^{269}$ Führ et al., Evaluation von Gebrauch und Wirkung der Verbandsklagemöglichkeiten nach dem UmwRG, Dessau-Roßlau, Februar 2014, p. 12.

${ }^{270}$ Ibid.

${ }^{271}$ Kamerstuk II, 1980-1981, 16 814, nr. 2.

${ }^{272}$ Chapter 4 A, Stb. 1986, 211.

${ }^{273}$ The Netherlands had voluntarily adopted some additional elements in the EIA procedure, namely a scoping procedure with broad participation of the public and a consultation of administrative bodies, an obligation to describe alternatives, a mandatory advisory report by the Commissie m.e.r. and the EIA procedure not only for projects, but also for plans. Overview given by the Commissie m.e.r., Views and Experiences 2012, Series No. 11, p. 5; Commissie m.e.r., Environmental Impact Assessment in the Netherlands, Utrecht, 1996, p. 3.

${ }^{274}$ Pokorný-Versteeg, Milieu-effectrapportage in Nederland en de aangrenzende EU-lidstaten, 2003, p. 60.
} 
the Wet milieubeheer (Environmental Management Act; abbreviation: Wm). ${ }^{275}$ Chapter $7 \mathrm{Wm}$ prescribes the administrative procedure to be followed and includes information on the content of the EIA. Additionally, the Besluit m.e.r. (Environmental Impact Assessment Regulation) entered into force in 1994. ${ }^{276}$ This order specifies in which cases there needs to be an EIA. After the adaptation of the Wm and the Besluit m.e.r. to the new requirements of Directive 97/11/EC, ${ }^{277}$ a ground-breaking reform with the aim of simplifing the Dutch EIA procedure was initiated in the beginning of the new millennium which culminated in the entry into force of a new procedure on 1 July $2010 .{ }^{278}$ The reform process of the Dutch EIA procedure continues further. This is not only due to the obligation to transpose the requirements of the new EIA Directive (2014) into national law, but also because of the planned transfer of the rules of the Wm into a new Omgevingswet. ${ }^{279}$ This transfer will imply substantive changes in the procedure, ${ }^{280}$ which will however not be further discussed, as these changes are irrelevant for the discussion on the enforcement of the EIA procedure in Dutch courts until 2014.

The legal framework of the EIA procedure in 2014

The EIA procedure is regulated in Chapter $7 \mathrm{Wm}$ and the Besluit m.e.r. ${ }^{281}$ Whereas the $\mathrm{Wm}$ regulates the outer framework and the steps of the EIA procedure, the Besluit m.e.r. lists the cases and thresholds in which an EIA or screening has to be conducted. ${ }^{282}$ The Annex to the Besluit m.e.r. consists of four subsections (A to D). Subsection A provides for definitions of some terms. Subsection B is repealed. By reference to subsections $\mathrm{C}$ and $\mathrm{D}$, it is determined whether an EIA is obligatory for a certain plan or project or whether a screening for a project has to be made. Subsection $\mathrm{C}$ and $\mathrm{D}$ respectively present a table consisting of four columns. In column 1, activities are described. In column 2 certain cases are presented. Column 3 lists specific planning procedures and column 4 lists specific decision-making procedures for projects.

\footnotetext{
${ }^{275}$ Wet van 4 februari 1994 tot wijziging van de regeling van de milieu-effectrapportage in de Wet milieubeheer, Stb. 1994, 99.

${ }^{276}$ Besluit van 4 juli, houdende uitvoering van het hoofdstuk Milieu-effectrapportage van de Wet milieubeheer (Besluit milieu-effectrapportage), Stb. 1994, 540.

277 Wet van 20 april 1999 to wijziging van bepalingen in de Wet milieubeheer met betrekking tot milieueffectrapportage, Stb. 1999, 208 and Besluit van 7 mei 1999, houdende wijziging van het Besluit milieueffectrapportage 1994 alsmede uitvoering van artikel 2, derde lid, van de Tracéwet, Stb. 1999, 224.

${ }^{278}$ Wet van 17 december 2009 tot wijziging van de Wet milieubeheer en enkele daarmee verband houdende wetten (modernisering van de regelgeving over de milieueffectrapportage), Stb. 2010, 20.

${ }^{279}$ Regels over het beschermen en benutten van de fysieke leefomgeving (Omgevingswet), Kamerstuk II, 20132014, 33962, nr. 2.

${ }^{280}$ Soppe et al., En weer een moderniseringsslag... Of vormt de Omgevingswet dan toch het eindstation voor een eigentijds m.e.r.-systeem?, TO 2013, pp. 55 - 67; Hoevenaars, M.e.r.: Omgevingswetinstrument bij uitstek!, TO 2013, pp. 154-160.

${ }^{281}$ Besluit van 21 februari 2011 tot wijziging van het Besluit milieueffectrapportage en het Besluit omgevingsrecht (reparatie en modernisering milieueffectrapportage), Stb. 2011, 102.

${ }^{282}$ For this purpose, article $7.2 \mathrm{Wm}$ stipulates that these cases have to be regulated by general administrative order.
} 
Subsection C lists plans and projects for which an EIA is mandatory. ${ }^{283}$ As far as plans under subsection $\mathrm{D}$ are concerned, an EIA is mandatory if the thresholds of column 2 are exceeded. ${ }^{284}$ As far as decisions under subsection D are concerned, it has to be assessed in each case whether or not an EIA has to be conducted. The thresholds and cases in column 2 of subsection D give indications for this assessment. Even if a project stays below the thresholds listed in column 2, it has to be assessed, taking the criteria of Annex III of the Directive into consideration, whether or not an EIA is necessary. The judicial review of administrative decisions is governed by the Awb.

The structure of the legal framework described can be illustrated by the following table:

Table 5: EIA legislation in the Netherlands

\begin{tabular}{|l|l|l|l|}
\hline \multicolumn{2}{|l|}{ Wet milieubeheer } & SEA for plans \\
\hline General Provisions & EIA for projects & $\begin{array}{l}\text { Transposition of SEA } \\
\text { Directive }\end{array}$ \\
\hline $\begin{array}{l}\text { Transposition of EIA and SEA } \\
\text { Directive }\end{array}$ & \multicolumn{2}{|l|}{ Transposition of EIA Directive } & Sections 7.3 to 7.5 \\
\hline Sections 7.1 to 7.2 & Sections 7.6 to 7.9 & \\
\hline & $\begin{array}{l}7.6,7.7 \\
\text { General } \\
\text { provisions }\end{array}$ & $\begin{array}{l}7.8 \\
\text { Simplified } \\
\text { preparation } \\
\text { procedure }\end{array}$ & $\begin{array}{l}\text { Extended } \\
\text { preparation } \\
\text { procedure }\end{array}$ \\
\hline
\end{tabular}

\begin{tabular}{|c|c|c|c|c|c|c|c|c|c|}
\hline $\begin{array}{l}\text { Besluit } \\
\text { milieueffect- } \\
\text { rapportage }\end{array}$ & \multicolumn{9}{|c|}{ Annex to the Besluit milieueffectrapportage } \\
\hline $\begin{array}{l}\text { General } \\
\text { Provisions }\end{array}$ & $\begin{array}{l}\text { Subsection } \\
\text { A }\end{array}$ & \multicolumn{4}{|c|}{ Subsection C } & \multicolumn{4}{|c|}{ Subsection D } \\
\hline & \multirow[t]{3}{*}{$\begin{array}{l}\text { Definitions of } \\
\text { terms }\end{array}$} & \multicolumn{4}{|c|}{$\begin{array}{l}\text { Plans and Projects for which an EIA is } \\
\text { mandatory }\end{array}$} & \multicolumn{4}{|c|}{$\begin{array}{l}\text { Plans for which an EIA is mandatory } \\
\text { and Projects for which a screening } \\
\text { has to be made }\end{array}$} \\
\hline & & 1 & 2 & 3 & 4 & 1 & 2 & 3 & 4 \\
\hline & & Activity & Case & Plan & Project & Activity & Case & Plan & $\begin{array}{l}\text { Projec } \\
\mathrm{t}\end{array}$ \\
\hline
\end{tabular}

${ }^{283}$ Art. 7.2 (1) a Wm in conjunction with article 2 (1) Besluit m.e.r and subsection C of the Annex.

${ }^{284}$ On the confusing categorisation of plans see: Soppe, Art. 7.2 Wm, in: T\&C Milieurecht, $5^{\text {th }}$ edition, 2013. 
As mentioned in the introductory part to this section, the Dutch EIA procedure was reformed in 2010. Since this reform, a distinction is made between a simplified and an extended preparation procedure. ${ }^{285}$ Whereas the extended procedure is applicable in all cases of EIAs for plans and complex decisions, the simplified procedure has to be followed in cases of certain projects. In the extended preparation procedure, certain additional requirements have to be fulfilled that do not have to be fulfilled in the simplified preparation procedure. ${ }^{286}$ An important element in the Dutch EIA procedure is the involvement of an independent advisory body, the Commissie voor de milieueffectrapportage (abbreviation: Commissie m.e.r.) which will be presented in detail at a later point in this section. ${ }^{287}$

The case law analysis in Part II extends to cases before and after the introduction of this new procedure, which means that there are cases on EIA under the old and under the new regime. Therefore, the following presentation of the steps in the Dutch EIA procedure will refer to both the old and the new procedure and it will explain the differences between the simplified and the extended procedure under the new rules.

\section{$\underline{\text { Step 1: Determination of the obligation to make an EIA }}$}

Article 7.2 (1) Wm stipulates that by general administrative order those activities are designated which have or may have a significant impact on the environment. This general administrative order is the Besluit m.e.r. Projects for which an EIA is obligatory are designated by article 7.2 (1) a Wm in conjunction with subpart $\mathrm{C}$ of the Annex to the Besluit m.e.r. Administrative decisions for which authorities have to determine on a case-by-case assessment whether the project has to be subjected to an EIA are designated by article 7.2 (1) b Wm in conjunction with subpart D, column 1, 2 and 4 of the Annex to the Besluit m.e.r. The Dutch term for this procedure is m.e.r. beoordelingsplicht (obligation to determine whether an EIA is needed). Rules on this procedure are laid down in section $7.6 \mathrm{Wm}$ (articles 7.16 to 7.20 ). Article $7.17 \mathrm{Wm}$ provides that the administrative authority has to pay due regard to the criteria of Annex III of the EIA Directive when making this assessment.

Step 2: Scoping

\section{Simplified procedure}

According to article $7.24 \mathrm{Wm}$, the simplified procedure starts with a notification by the developer to the competent authority on a project for which an EIA has to be carried out. The developer may request that the authority gives a scoping opinion. ${ }^{288}$ The authority then has to issue a scoping opinion within six

\footnotetext{
${ }^{285}$ Art. 7.24 to $7.26 \mathrm{Wm}$ regulate the simplified procedure, article $7.27 \mathrm{Wm}$ provides for the extended procedure.

${ }^{286}$ Beijen (ed.), Hoofdlijnen Milieubestuursrecht, $2^{\text {nd }}$ edition, 2012, pp. 208-211.

${ }^{287}$ Part I, 2. b. (iii).

${ }^{288}$ Art. 7.24 (2) Wm.
} 
weeks. ${ }^{289}$ If the developer does not request a scoping opinion, the authority can nevertheless, on its own motion, issue a scoping opinion. ${ }^{290}$ This is not an obligatory step, however. ${ }^{291}$ According to article 7.25 Wm, the authority consults with several administrative bodies and experts and the developer. However, it is not obligatory to consult the Commissie m.e.r. ${ }^{292}$

\section{Extended procedure}

According to article $7.27 \mathrm{Wm}$, the extended procedure starts with the notification of the developer to the competent authority on a project for which an EIA has to be carried out. The administrative authority consults with various bodies and experts and the developer. Subsequently, article $7.27 \mathrm{Wm}$ prescribes that the notification is made public indicating when and where materials are made available for consultation and saying whether the Commissie m.e.r. or another independent body will give advice on the project. ${ }^{293}$ There is no obligation to consult the Commissie m.e.r., but it is possible to ask this independent body for advice on a voluntary basis. ${ }^{294}$

The "old" procedure

According to the EIA procedure, as it was in place before 2010, the notification had to be made public and statutory consultees had to submit comments. ${ }^{295}$ There was always an obligation to consult with the Commissie m.e.r. ${ }^{296}$

Step 3: Preparing the environmental statement

\section{Simplified and extended procedure}

According to article $7.22 \mathrm{Wm}$, the developer prepares the environmental statement. Article 7.23 Wm sets out a list of issues which have to be addressed in the environmental statement. This consists of an explanation of the objective of the proposed project, a description of the project and of alternatives, an overview of other (earlier) decisions concerning the project and the EIA, a description of the current state of the environment and the expected developments of the environment with and without the project and their comparison. Moreover, mitigating and compensating measures have to be assessed.

\section{The "old" procedure}

The requirements for the content of the environmental statement were regulated in article $7.10 \mathrm{Wm}$ until the reforms of 2010. This article prescribed one peculiarity of the Dutch EIA that was abandoned with

\footnotetext{
${ }^{289}$ Art. $7.26 \mathrm{Wm}$.

290 Art. 7.24 (3) Wm.

${ }^{291}$ Beijen (ed.), Hoofdlijnen Milieubestuursrecht, $2^{\text {nd }}$ edition, 2012, p. 209.

${ }^{292}$ Soppe, Art. 7.25 Wm, in: Koeman, Uylenburg (eds.), T\&C Milieurecht, $5^{\text {th }}$ edition, 2013.

${ }^{293}$ Soppe, Art. 7.27 Wm, in: Koeman, Uylenburg (eds.), T\&C Milieurecht, $5^{\text {th }}$ edition, 2013.

${ }^{294}$ Beijen (ed.), Hoofdlijnen Milieubestuursrecht, $2^{\text {nd }}$ edition, 2012, p. 211.

${ }^{295}$ Art. 7.12 and $7.13 \mathrm{Wm}$ (before 2010).

${ }^{296}$ Pokorný-Versteeg, Milieueffectrapportage in Nederland en de direct aangrenzende EU-lidstaten, 2003 , p. 77.
} 
the reforms. Accordingly, a developer had to describe all reasonable alternatives, which included the assessment of the "most environmentally friendly alternative". ${ }^{297}$

\section{Step 4: Information and consultation of the public}

\section{Simplified procedure}

The environmental statement and a draft decision are made available to the public so that they have the opportunity to comment on both. An independent expert may be requested to give advice on the EIA but this is not mandatory. ${ }^{298}$

\section{Extended procedure}

The environmental statement has to be submitted to the Commissie m.e.r. which has to give advice on the adequacy and quality of the information provided. Moreover, the public is informed and invited to comment on the EIA and the project. ${ }^{299}$

\section{The "old" procedure}

According to article 7:14 Wm, the Commissie m.e.r. had to give advice on the content of the EIA in any EIA procedure. ${ }^{300}$

\section{Step 5: The final administrative decision}

Article 7.35 (1) Wm states that the administrative authority has to take any environmental impact as described in the environmental statement into consideration when taking an administrative decision. ${ }^{301}$ Moreover, the administrative decision has to explain how the administrative authority took the EIA report in consideration, how alternatives were assessed and how comments on the EIA report were dealt with. ${ }^{302}$ Additionally, in cases in which the Commissie m.e.r. issued a report, the administrative decision must state in how far this advice was considered. ${ }^{303}$

Until the reform of the EIA in 2010, the overall impression in Dutch legal literature and practice ${ }^{304}$ on the implementation and enforcement of the EIA was rather positive, despite some complications in the

\footnotetext{
297 Art. 7.10 (3) Wm (before 2010).

${ }^{298}$ Beijen (ed.), Hoofdlijnen Milieubestuursrecht, $2^{\text {nd }}$ edition, 2012, pp. 209, 210.

${ }^{299}$ Art. 7.32 Wm.

${ }^{300}$ Soppe, Art. 7.14 Wm, in: Koeman, Uylenburg (ed.), T\&C Milieurecht, $3^{\text {rd }}$ edition, 2009; Pokorný-Versteeg, Milieu-effectrapportage in Nederland en de direct aangrenzende EU-lidstaten, 2003, p. 78.

${ }^{301}$ On the specific problem of this article with regard to the extended margin of appreciation granted to the public authority see: Soppe, Art. 7.35 Wm, in: Koeman, Uylenburg (eds.), T\&C Milieurecht, $5^{\text {th }}$ edition, 2013.

302 Art. 7.37 (1) Wm.

${ }^{303}$ Art. 7.37 (2) Wm.

${ }^{304}$ A brief summary of the empirical studies on the effectiveness of the EIA is given by Runhaar et al., Naar een toekomstbestendige m.e.r., Utrecht, 2011, p. $35 \mathrm{f}$.
} 
beginning ${ }^{305}$ and cases decided by the Court of Justice on the implementing legislation. ${ }^{306}$ In its early days, the Dutch EIA procedure was "widely regarded as the strongest in Europe". ${ }^{307}$ Although the Dutch procedure is still comparatively effective, it is no longer seen as the strongest in Europe. ${ }^{308}$ Especially since the reforms of the EIA legislation of 2010, the procedure has been weakened in several regards. For example, under the old law many projects in the Netherlands had been subjected to the EIA regime even if this was not prescribed by the Union. However, through the reforms many of these additional projects are no longer included in the list of mandatory EIAs or screenings. ${ }^{309}$ Moreover, the Dutch EIA procedure had a very strong focus on the description of alternatives, which has been treated as the "heart" of the EIA procedure. ${ }^{310}$ According to article $7.10 \mathrm{Wm}$ as it was framed before 2010, a developer had to describe all reasonable alternatives to a proposed project and there had to be a motivation for the choice of one alternative. ${ }^{311} \mathrm{~A}$ peculiarity was the requirement to assess the "most environmentally friendly alternative" for a project, ${ }^{312}$ although it should be stressed that this requirement did not bind the public authority to choose this alternative ulitmately. ${ }^{313}$ The obligation to assess the most environmentally friendly alternative was abandoned with the reform of the EIA rules in $2010 .^{314}$

Furthermore, the independent Commissie m.e.r. has been strongly involved in the EIA process, giving advice on the EIA procedure and the content of the EIAs. According to article $7.14 \mathrm{Wm}$ as it applied before 2010, the Commissie m.e.r. had to give advice on the content of the environmental statement to be drafted by the developer. For this purpose, it had to submit a report on the content of the EIA to the administrative authority within nine weeks after application by the developer. ${ }^{315}$ In the meantime, the administrative authority debated with the developer about the guidance to be given on the content of the environmental statement. ${ }^{316}$ After this process, the public authority had to determine the framework of the specific EIA. ${ }^{317}$ The authority was not bound by the advice given by the Commissie m.e.r., but it had

\footnotetext{
305 Wood, Environmental Impact Assessment, A Comparative Review, $2^{\text {nd }}$ edition, 2003, p. 67 f.

${ }^{306}$ C-72/95, Aannemersbedrijf P.K. Kraaijeveld BV v Gedeputeerde Staten van Zuid-Holland [1996] ECR I-5431; C-81/96, Burgemeester en wethouders van Haarlemmerlide en Spaarnwoude v Gedupteerde Staten van NoordHolland [1998] ECR I-3936; C-255/08, Commission of the European Communities v Kingdom of the Netherlands [2009] ECR I-167.

${ }^{307}$ Commissie m.e.r., Environmental Impact Assessment in the Netherlands, Utrecht, 1996, p. 3; Runhaar et al., Naar een toekomstbestendige m.e.r., Utrecht, 2011, pp. 41, 46.

${ }^{308}$ Runhaar et al., Naar een toekomstbestendige m.e.r., Utrecht, 2011, p. 46.

${ }^{309}$ In the Dutch terminology this is referred to as "koppen". See: Nota van Toelichting on the Besluit milieueffectrapportage en het Besluit omgevingsrecht (reparatie en modernisering milieueffectrapportage), Stb. 2011, 102.

${ }^{310}$ Pokorný-Versteeg, Milieu-effectrapportage in Nederalnd en de direct aangrenzende EU-lidstaaten, 2003, p. 71.

${ }^{311}$ Soppe, Art. $7.10 \mathrm{Wm}$, in: Koeman, Uylenburg (eds.), T\&C Milieurecht, $3^{\text {rd }}$ edition, 2009.

312 Art. 7.10 (3) Wm (before 2010).

${ }^{313}$ This is not required by the Directive and was emphasised by the Dutch courts, see for example: ABRvS 12 August 1996, nr. F03.96.0396, AB 1997/135 (with a comment by Backes); Pieters, Katern Jurisprudentie milieueffectrapportage: jurisprudentie en toelichting, 2002, pp. $106 \mathrm{f}$.

${ }^{314}$ Wet van 17 december 2009 tot wijziging van de Wet milieubeheer en enkele daarmee verband houdende wetten (modernisering van de regelgeving over de milieueffectrapportage), Stb. 2010, 20.

315 Art. 7.14 (2) Wm (before 2010).

${ }^{316}$ Art. 7.14 (3) Wm (before 2010).

${ }^{317}$ Art. 7.15 Wm (before 2010).
} 
to take it into consideration. ${ }^{318}$ The EIA then had to be conducted by the developer according to the framework prescribed by the public authority. The developer was allowed to derogate from the guideline but, if he did so, he had to give reasons for his choice. ${ }^{319}$ The environmental statement was subsequently sent to the Commissie m.e.r. ${ }^{320}$ and it gave advice on the statement. ${ }^{321}$ For example, in 2005, 223 statements of advice were issued by the Commissie m.e.r. ${ }^{322}$ As far as issuing of guidance is concerned, the public authorities followed the Commission's advice in $84 \%$ of the cases. The legal framework on the involvement of the Commissie m.e.r. changed with the reforms in 2010, to the extent that the obligation to consult the Commissie m.e.r. was abolished for many cases. However, such an obligation continues to exist in the extended procedure. Moreover, the Commissie m.e.r. can be asked for advice voluntarily. In this context it should be noted that a strong increase of the fees for such a consultation might lead to less voluntary requests. ${ }^{323}$ In 2012, the Commissie m.e.r. gave advice 224 times $^{324}$ and, in 2013, this number rose to $251 .^{325}$ The number of cases in which advice was requested voluntarily declined from $45 \%$ in 2012 to $25 \%$ in 2013, which is likely due to the rise of fees to be paid for advice by the Commissie m.e.r. ${ }^{326}$ The actual influence of the advice on administrative decision making is stable and on a high level. ${ }^{327}$

To conclude, contrary to what was seen in Germany, the Dutch EIA framework was considered to be very strong and efficient for a long time. In the following section, this situation will be compared to the implementation of the EIA Directive in the English legal system.

\section{c. England}

When England was obliged to transpose the obligations of the EIA Directive into national law, the government was of the opinion that the existing system of planning law sufficiently paid attention to environmental concerns. ${ }^{328}$ The Town and Country Planning Act 1971 already required a type of environmental assessment according to which public authorities had to include measures for the improvement of the physical environment in the written statement of a structure plan. ${ }^{329}$ Under the existing procedures, environmental impacts were assessed to a certain degree, but not in a way and

\footnotetext{
${ }^{318}$ Soppe, Art. 7.14 Wm, in: Koeman, Uylenburg (eds.), T\&C Milieurecht, Kluwer, 2009.

319 Pokorný-Versteeg, Milieu-effectrapportage in Nederalnd en de direct aangrenzende EU-lidstaaten, 2003, p. 79.

${ }^{320}$ Art. 7.20 Wm (before 2010).

${ }^{321}$ Art. 7.26 Wm (before 2010).

${ }^{322}$ Commissie m.e.r., Jaarverslag 2005, p. 12 (available online).

${ }^{323}$ Wet van 14 mei 2014 tot wijziging van de Wet milieubeheer (tarieven Commissie voor de milieueffectrapportage), Stb. 2014, 173.

${ }^{324}$ Commissie m.e.r., Jaarverslag 2012, p. 7 (available online).

${ }^{325}$ Commissie m.e.r., Jaarverslag 2013, p. 4 (available online).

326 Ibid.

${ }^{327}$ Commissie m.e.r., Jaarverslag 2012, p. 23 (available online); Commissie m.e.r., Jaarverslag 2013, p. 8 (available online).

${ }^{328}$ House of Commons Select Committee on the European Communities, $11^{\text {th }}$ Report, Environmental Assessment of Projects, Session 1980-81, HMSO, London, 1981, para. 31; Mertz, The European Economic Community Directive on environmental assessments: how will it affect United Kingdom developers?, JPEL 1989, p. 484.

${ }^{329}$ Section 7 Town and Country Planning Act 1971.
} 
intensity as prescribed by the EIA Directive. ${ }^{330}$ In order to comply with the Community requirements fully, the Town and Country Planning (Assessment of Environmental Effects) Regulations 1988 for England and Wales were adopted. ${ }^{331}$ As these Regulations did not cover all projects listed in the Annexes of the EIA Directive, various specific EIA Regulations have been issued for these projects. ${ }^{332}$ In 1999 , the system was reformed in order to implement the requirements of Directive 97/11/EC. ${ }^{333}$ For this purpose, the Town and Country Planning (Environmental Impact Assessment) (England and Wales) Regulations 1999 were adopted. ${ }^{334}$ Additionally, the non-binding Circular 2/99 provides for guidelines on the English EIA system. ${ }^{335}$ Since 1999, the Regulations were amended several times to adapt to Union legislation and case law. In 2011, English EIA legislation was again subject to modifications, ${ }^{336}$ taking into consideration the rulings in Baker ${ }^{337}$ and Mellor. ${ }^{338}$ Hence, in 2014 the Town and Country Planning (EIA) Regulations 2011 (abbreviation: TCPR (EIA) 2011) ${ }^{339}$ are applicable to many EIA proceedings.

\section{(i) The legal framework of the EIA procedure in England}

The TCPR (EIA) 2011 set out the framework of EIA assessment in England. There are six annexes to the Regulations, numbered schedule 1 to 6 . Schedule 1 lists those projects for which an EIA is mandatory. Schedule 2 contains those projects for which an EIA has to be conducted when significant environmental effects are likely to occur. For this purpose, schedule 2 sets thresholds which have to be considered in the light of the criteria listed in schedule 3, which are the characteristics and the location of the project and the characteristics of the potential impact. Moreover, Circular 2/99, giving guidance on the EIA procedure under the TCPR (EIA) 2011, lists "screening factors" which have to be taken into consideration, being specifically the size, nature and location of the project. Projects which fall outside the planning regime but which require an EIA according to EU law may be subjected to the EIA obligation according to regulations of separate consent procedures. ${ }^{340}$ The statutory framework can be illustrated by the following table (excluding schedule 5 and 6 ).

\footnotetext{
${ }^{330}$ Holder, Environmental Assessment, The Regulation of Decision Making, 2006, p. 48.

331 Town and Country Planning (Assessment of Environmental Effects) Regulations 1988, SI 1988, no. 1199.

332 The number of these separate regulations amounted to around 40: Wood, Ten Years On: An empirical analysis of UK Environmental Statement Submissions since the Implementation of Directive 85/337/EEC, JEPM, 2000, p. 723.

${ }^{333}$ Wood, Environmental Impact Assessment, $2^{\text {nd }}$ edition, 2003, p. 56.

334 The Town and Country Planning (Environmental Impact Assessment) (England and Wales) Regulations 1999, SI 1999 no. 293.

${ }_{335}$ Department for Communities and Local Government, Circular 02/99: Environmental impact assessment, 12 March 1999 (available online).

${ }^{336}$ Explanatory Memorandum to the Town and Country Planning (Environmental Impact Assessment) Regulations 2011, SI no. 1824.

${ }^{337} R$ (Baker) $v$ Bath and North East Somerset Council [2009] EWHC 595.

${ }^{338} R$ (Mellor) v Secretary of State for Communities and Local Government [2009] EWCA 1201 and C-75/08, The Queen on the application of Christopher Mellor v Secretary of State for Communities and Local Government [2009] ECR I-3799.

339 Town and Country Planning (EIA) Regulations 2011, SI 2011, no. 1824.

${ }^{340}$ Bell et al., Environmental Law, $8^{\text {th }}$ edition, 2013, p. 461.
} 
Table 6: EIA legislation in England

\begin{tabular}{|c|c|c|c|c|c|}
\hline \multicolumn{6}{|c|}{ Town and Country Planning (EIA) Regulations 2011} \\
\hline \multirow{4}{*}{$\begin{array}{l}\text { Parts } 1 \text { to } \\
13\end{array}$} & Schedule 1 & \multicolumn{2}{|l|}{ Schedule 2} & Schedule 3 & Schedule 4 \\
\hline & $\begin{array}{l}\text { Implementation } \\
\text { of Annex I EIA } \\
\text { Directive }\end{array}$ & \multicolumn{2}{|c|}{$\begin{array}{l}\text { Implementation of Annex II } \\
\text { EIA Directive }\end{array}$} & $\begin{array}{l}\text { Implementation } \\
\text { of Annex III EIA } \\
\text { Directive }\end{array}$ & \\
\hline & \multirow{2}{*}{$\begin{array}{l}\text { Projects for } \\
\text { which an EIA } \\
\text { is obligatory }\end{array}$} & \multicolumn{2}{|c|}{$\begin{array}{l}\text { Projects for which an EIA } \\
\text { may be necessary }\end{array}$} & \multirow{2}{*}{$\begin{array}{l}\text { Selection } \\
\text { Criteria for } \\
\text { Schedule } 2\end{array}$} & \multirow{2}{*}{$\begin{array}{l}\text { Information to } \\
\text { be included in } \\
\text { Environmental } \\
\text { Statement }\end{array}$} \\
\hline & & $\begin{array}{l}\text { Column1 } \\
\text { Description } \\
\text { of } \\
\text { Development }\end{array}$ & $\begin{array}{l}\text { Column2 } \\
\text { Applicable } \\
\text { Thresholds } \\
\text { and } \\
\text { Criteria }\end{array}$ & & \\
\hline
\end{tabular}

Circular 2/99

(ii) The main steps in the EIA procedure in England

\section{Step 1: Determination of the obligation to carry out an EIA}

The decisionmaker decides whether or not a proposed development is an EIA development as defined in reg. 2 (1) TCPR (EIA) 2011. For this purpose the development is assessed against the criteria of schedule 1 or schedule 2 in conjunction with schedule 3.

Part two of the TCPR (EIA) 2011 sets out the screening procedure. Screening becomes relevant in two situations. First a developer may in a first step request a screening opinion from the planning authority. In case he is dissatisfied with the conclusion reached by the public authority on the screening, he may ask the Secretary of State for a screening direction. If the Secretary of State finds that the project has to be accompanied by an EIA, the developer may request a scoping opinion. In case the Secretary of State finds that no EIA procedure has to be followed, the developer can directly submit a planning application. When determining whether an EIA has to be conducted or not, the authority has to refer to schedule 2, 
providing for thresholds and criteria and to schedule 3, being the implementation of Annex III of the EIA Directive.

Second, if a developer submits a planning application without any previous request for screening or scoping, the authority has to prepare a screening opinion. ${ }^{341}$ It is also possible that a developer, being convinced that his project falls under the EIA Regulations, will submit a planning application together with an environmental statement to the public authority asking for a scoping opinion without a previous request for a screening opinion.

\section{Step 2: Scoping}

The request for a scoping opinion is regulated in reg. 13 of the TCPR (EIA) 2011. The public authority then assesses the adequacy of the environmental statement and may if it deems it inadequate request further information or may recommend the withdrawal of the initial request for a scoping opinion. In preparing the scoping opinion, the public authority has to consult the statutory consultation bodies. ${ }^{342}$ These bodies are named in regulation 2(1) (c) TCPR (EIA) 2011, including Natural England and the Environment Agency.

\section{Step 3: Preparation of the environmental statement}

After having received a positive screening opinion, the developer has to draft an environmental statement. This environmental statement has to include at least the information listed in in schedule 4 to the EIA Regulations 2011. Procedures on the submission of environmental statements are set out in part 5 of the EIA Regulations 2011. The Circular gives further guidance, for example on the assessment of alternatives.

\section{Step 4: Information and consultation of the public}

Section 16 TCPR (EIA) 2011 provides that the developer has to submit, together with his application for planning permission, a copy of the environment statement to be forwarded to the Secretary of State and has to indicate the names of those persons to whom the environmental statement has been or will be sent. The public authority has to forward the statement to any consultation body who did not yet receive the environmental statement. Additionally, where the authority is aware of a person who is likely to be affected and who is unlikely to become aware of the environmental statement via local advertisement, the authority also has to send a copy to this person. The publication of the application for planning permission is regulated in section 13 of the TCPO (Development Management Procedure) (England) 2010.

Step 5: The final administrative decision

\footnotetext{
${ }^{341}$ Reg. 7 TCPR (EIA) 2011.

${ }^{342}$ Reg. 13 (4) TCPR (EIA) 2011.
} 
When the public authority is satisfied with the environmental statement, the authority determines the planning application. In any event, the relevant planning authority or the Secretary of State or an inspector shall not grant planning permission or subsequent consent pursuant to an application to which this regulation applies unless they have first taken the environmental information into consideration, and they must state in their decision that they have done so. ${ }^{343}$

\section{(iii)}

\section{Experiences with the EIA in England}

One of the main problems of the implementation of the EIA procedure in English law has been the fragmented nature of legislation. ${ }^{344}$ Next to the problem of piecemeal legislation, it was found that there is a lack of effective public participation, often being too little and too late. ${ }^{345}$ As far as the quality of environmental statements is concerned, many have been deficient, ${ }^{346}$ but they have improved over the years, ${ }^{347}$ with the result that, in 1999 , it was observed that over half of the environmental statements were of good quality regarding their comprehensiveness, objectivity and clarity of information. ${ }^{348}$ As to the content of environmental statements, it was found that only about 50\% of Environmental Impact Statements discussed alternatives in the period between 1991 and $1999 .{ }^{349}$ Furthermore, there was only little consideration of cumulative impact. ${ }^{350}$ The actual impact of the environmental statement on decision making was considered to be rather weak. ${ }^{351}$ An evaluation of the perspectives of planners, consultees and developers on the extent to which an environmental statement influenced planning decisions revealed that the majority believes that there is only "some" influence. ${ }^{352}$

Twelve years later, in 2011, the Institute for Environmental Management and Assessment (IEMA) conducted a study on the state of the EIA in England. The screening and scoping stages were still considered to be too ineffective. ${ }^{353}$ Regarding the screening, there is a need for more consistency and better quality. As far as the scoping is concerned, it is considered that it takes too long and that is not specific enough. The reasons for this are "risk aversion, poor planning of the assessment, and

\footnotetext{
${ }^{343}$ Reg. 3 (4) TCPR (EIA) 2011.

${ }^{344}$ Glasson, The First 10 years of the UK EIA System: Strength and Weaknesses, Opportunities and Threads Planning Practice \& Research 1999, issue 3, p. 363 ff.

345 Ibid.

${ }^{346}$ Annex for the United Kingdom, Report from the Commission of the Implementation of Directive 85/337/EEC on the assessment of the effects of certain public and private projects on the environment, COM (93) 28 final, p. 264 (with references).

${ }^{347}$ Glasson et al., EIA - Learning from Experience: Changes in the Quality of Environmental Impact Statement for UK Planning Projects, JEPM 1997, pp. 451-464, Wood, Environmental Impact Assessment, $2^{\text {nd }}$ edition, 2003 , p. 209.

${ }^{348}$ Glasson, The First 10 years of the UK EIA System: Strength and Weaknesses, Opportunities and Threads, Planning Practice \& Research 1999, issue 3, p. 265.

349 Ibid., p. 368.

${ }^{350}$ Ibid., p. 368.

${ }^{351}$ Wood, Environmental Impact Assessment, $2^{\text {nd }}$ edition, 2003, p. 227 f.

${ }^{352}$ Glasson, The First 10 years of the UK EIA System: Strength and Weaknesses, Opportunities and Threads, Planning Practice \& Research 1999, issue 3, p. 365.

${ }^{353}$ Institute of Environmental Management and Assessment, The State of Environmental Impact Assessment in England, Special Report, June 2011 (available online).
} 
commercial realities". ${ }^{354}$ However, according to the literature, EIA is, despite these deficiencies, seen as a "central tool" for environmental protection. ${ }^{355}$

\section{Conclusion of Part I}

This Part has described the "uniform" rules subject to the analysis of Part II and has provided for an overview over the implementation of the EIA Directive in the three Member States under consideration. To sum up, the respective implementing laws differed in certain aspects: whereas the Netherlands provided for a very elaborate EIA procedure which had a practical impact on decision making since the beginnings of EIA enforcement, this was clearly not the case in England, where the EIA system developed slowly and only under European pressure. In Germany, expectations were initially high, but the national legislation only consisted of a minimalistic transposition of the EIA Directive. Contrary to the Dutch system, in the English and German systems there was no obligation to assess alternatives to the proposed development and there was no obligation to consult an independent advisory body already at the screening stage. With the Dutch reforms of the EIA procedure, these differences have diminished. In any event, although there are differences in the specific scope of EIA procedures in these three legal systems, all three systems prescribe the basic steps required by the EIA Directive: there are rules on screening, the environmental statement and public participation. In the next part, it will be analysed how these "European steps", focusing specifically on step one and two, were enforced by national courts.

\footnotetext{
${ }^{354}$ Institute of Environmental Management and Assessment, The State of Environmental Impact Assessment in England, Special Report, June 2011 (available online), p. 4.

${ }^{355}$ Bell et al., Environmental Law, $8^{\text {th }}$ edition, 2013, p. 480.
} 
In this part, it will be analysed how the uniform rules of the EIA Directive described in the previous part have been judicially enforced in the different legal systems of Germany, the Netherlands and England. According to the principle of national procedural autonomy, Member States are competent to create the rules governing the enforcement process. However, they have to comply with some European requirements. In chapter 1, a condensed overview over these European requirements will be given. After having described the European standard for national litigation rules, the different national litigation systems will be compared in chapters 2 to 4 . It will be explained to what extent the European standard has influenced the development of national litigation rules and in how far national systems developed independently from Union interference. The leading question is what the consequences of the remaining differences between the legal systems are for the enforcement of the EIA Directive. In chapter 2, rules on access to administrative courts will be analysed, followed by an examination of rules on review in chapter 3 and rules on remedies in chapter 4.

\section{Chapter 1 The European standard}

The competence of Member States for the creation of national litigation rules is limited by Union requirements. These requirements are provided for in the case law of the Court of Justice and in legislation. In the following, these European rules and principles forming the "European standard" for national administrative litigations in environmental matters will be described.

\section{The effet utile of European Union law and the principle of effectiveness}

The Court of Justice has constantly stressed the importance of Union law taking effect (effet utile) in the national legal orders ${ }^{356}$ and that, to this end, national procedural rules should not make the enforcement of Union rules excessively difficult or impossible (principle of effectiveness). ${ }^{357}$

Effectiveness of a rule means that the rule is made operative. ${ }^{358}$ More precisely, effectiveness can be understood as the "degree to which a rule contributes to achieving the goals of that rule". ${ }^{359}$ In order to guarantee the effectiveness of rules, state actors are bound to the rules and have the task of effectuating

\footnotetext{
356 This was already in the background to Case 26/62, NV Algemene Transport- en Expeditie Onderneming van Gend \& Loos v Netherlands Inland Revenue Administration [1963] ECR 1 and it was made explicit in case 106/77, Amministrazione delle Finanze dello Stato v Simmenthal SpA [1978] ECR 629.

${ }_{357}$ Case 33/76, Rewe-Zentralfinanz $e G$ and Rewe-Zentral AG v Landwirtschaftskammer für das Saarland [1976] ECR 1989, para. 5; Case 68/79, Hans Just I/Sv Danish Ministry for Fiscal Affairs [1980] ECR 501, para. 25; Case 199/82, Amministrazione delle Finanze dello Stato v SpA San Giorgio [1983] ECR 3595; Joined Cases 430 to 431/93, Jeroen van Schijndel v Stichting Pensioenfonds voor Fysiotherapeuten [1995] ECR I-4705, para. 19; C- 327/00, Santex SpA v Unità Socio Sanitaria Locale n. 42 di Pavia [2003] ECR I-1877, paras. 55-57; C-295 to 298/04, Vincenzo Manfrediv Lloyd Adriatico Assicurazioni SpA [2006] ECR I-6619, para. 62; C-260/11, The Queen, on the application of David Edwards and Lilian Pallikaropoulos $v$ Environment Agency and Others (Judgment of 11 April 2013) para. 33; C-416/10, Jozef Križan and Others v Slovenská inšpekcia životného prostredia (Judgment of 15 January 2013) para. 147.

358 Andersen, The Enforcement of EU Law, 2012, p. 39.

${ }^{359}$ Nollkaemper, The Role of National Courts in Inducing Compliance, in: Cremona (ed.), Compliance and the enforcement of EU Law, 2012, p. 161.
} 
them. ${ }^{360}$ The judiciary and litigation procedures help the effectuation of rules in case of conflict. Lacking a fully-formed enforcement system, international law systems need to find ways to ensure compliance with their rules. The argument of the effet utile is a "structural characteristic" 361 of such an international order which aims at ensuring that law is made operative. ${ }^{362}$ In Simmenthal the Court of Justice held:

"Any provision of a national legal system and any legislative, administrative or judicial practice which might impair the effectiveness of Community law by withholding from the national courts having jurisdiction to apply such law the power to do everything necessary at the moment of its application to set aside national legislative provisions which might prevent Community rules from having full force and effect are incompatible with those requirements which are the essence of Community law." 363

From this quote, it follows that national litigation rules which impair the effet utile of Union law contravene the system of Union law. Similar to this judgment, the Court of Justice held in Factortame:

"It must be added that the full effectiveness of Community law would be just as much impaired if a rule of national law could prevent a court seised of a dispute governed by Community law from granting interim relief in order to ensure the full effectiveness of the judgment to be given on the existence of the rights claimed under Community law. It follows that a court which in those circumstances would grant interim relief, if it were not for a rule of national law, is obliged to set aside that rule." 364

The reference to the "full effectiveness" of law suggests that there are different degrees of effectiveness, i.e. one could think of "low effectiveness" or "partial effectiveness". One might be tempted to assume that the court specifies the degree to which a rule achieves the aim of that rule. Research has shown that there is no consistency in the utilisation of the "effectiveness-terminology". ${ }^{365}$ The better view is therefore to understand the principle of effet utile as a principle that requires that the law is applied at all and that it produces the effects it intends. This is a very basic requirement.

For the national procedure by which the enforcement of Union law takes place, the Court of Justice has created the principle of effectiveness as a "European standard". ${ }^{366}$ The principle of effectiveness aims at ensuring the effet utile of Union law in providing for a rule of operationalisation. In Rewe, the Court of Justice held that national rules should not make "impossible in practice the rights which the national

\footnotetext{
${ }^{360}$ Schmidt- Assmann, Das allgemeine Verwaltungsrecht als Ordnungsidee, $2^{\text {nd }}$ edition, 2004, p. 56.

${ }^{361}$ Seyr, Der Effet Utile in der Rechtsprechung des Europäischen Gerichtshofs, 2008, p. 279.

${ }^{362}$ Already the Permanent Court of International Justice referred to the effectiveness of a certain rule and also the International Court of Justice uses it as an argument, see: Seyr, Der Effet Utile in der Rechtsprechung des Europäischen Gerichtshofs, 2008, pp. 95 f.

${ }^{363}$ Case 106/77, Amministrazione delle Finanze dello Stato v Simmenthal SpA [1978] ECR 629, para. 22.

${ }^{364}$ C-213/89, The Queen $v$ Secretary of State for Transport, ex parte: Factortame Ltd and others [1990] ECR I2433, para. 21.

${ }^{365}$ Seyr, Der Effet Utile in der Rechtsprechung des Europäischen Gerichtshof, 2008, pp. $281 \mathrm{ff}$.

366 König, Der Äquivalenz- und Effektivitätsgrundsatz in der Rechtsprechung des EuGH, 2011; Kulms, Der Effektivitätsgrundsatz, 2013.
} 
courts are obliged to protect". ${ }^{367}$ In later case law, the court added the requirement that national rules should not make it "excessively difficult" to exercise rights under Union law. ${ }^{368}$ Moreover, the court extended the principle to the impossibility or excessive difficulty of applying Union law. ${ }^{369}$ All of this taken together is referred to by the Court of Justice as the "principle of effectiveness". ${ }^{370}$ Thereby, the Court does not specify the absolute degree to which a rule is made or has to be made operative to achieve the goal of that rule. Instead, a minimum level of conduct is prescribed which is necessary for making Union law operative at all in cases in which national authorities failed to comply with their obligations under Union law. If a rule bars a claimant from accessing courts (impossibility), the law remains without effect. In case it is excessively difficult for an individual or organisation to exercise their rights, there is no or only a very low degree to which a rule contributes to achieving the aim of that rule. Hence, the principle of effectiveness aims at preventing non-enforcement and to ensure the application of Union law in national courts.

In environmental matters, the reference to the effet utile can be a forceful argument for the Court when assessing the compatibility of national judicial review provisions with Union law. ${ }^{371}$ Environmental rules often do not directly aim at the protection of individuals which, as will be discussed later in detail, may render the enforcement of such rules difficult. ${ }^{372}$ The effet utile principle is however "neutral" regarding the addressee of a Union rule, meaning that it requires the application of a rule independent of whether it protects individuals or nature. ${ }^{373}$ Hence, from the perspective of the effet utile principle, it simply suffices that there is a Union rule. If there is a Union rule, this rule has to be enforced. Otherwise the rule would remain without effect. ${ }^{374}$

\section{The principle of equivalence}

The principle of equivalence as established by the Court of Justice requires, that within one state, the same procedural rules are applicable to cases under national law and to cases under European law. ${ }^{375}$ As this principle is restricted to the application of the law in one single Member State, it is of minor importance for the present study, which is concerned with differences that result from procedural rules

\footnotetext{
${ }^{367}$ Case 33/76, Rewe-Zentralfinanz eG et Rewe-Zentral AG v Landwirtschaftskammer für das Saarland [1976] ECR 1989, para. 5.

${ }^{368}$ C-6/90, Andrea Francovich and Danila Bonifaci and others v Italian Republic [1991] ECR I-5357, para. 43.

${ }^{369}$ Wennerås, The Enforcement of European Environmental Law, 2007, p. 86.

${ }^{370}$ C-255/00, Grundig Italiana SpA v Ministero delle Finanze [2002] ECR I-8003, para. 33.

${ }^{371}$ C-182/10, Marie-Noëlle Solvay and Others v Région wallonne (Judgment of 16 February 2012) para. 48; C263/08, Djurgården-Lilla Värtans Miljoskyddsföreening [2009] ECR I-9967, para. 45.

372 This is especially the case in Germany: Part II Chapter 2, Section 1.2 (a).

${ }^{373}$ Wennerås, The Enforcement of European Environmental Law, 2007, p. 84

${ }^{374}$ See for example the argumentation of the Court of Justice in C-115/09, Bund für Umwelt und Naturschutz Deutschland, Landesverband Nordrhein-Westfalen e.V. v Bezirksregierung Arnsberg [2011] ECR I-3673, para. 46.

375 Joined Cases 205-15/82, Deutsche Milchkontor GmbH and others v Federal Republic of Germany [1983] ECR 2633, para. 23; Case 240/87, Deville v Administration des impôts [1988] ECR 3513, para. 12; C-261/95, Rosalba Palmisani v Istituto nazionale della previdenza sociale (INPS) [1997] ECR I-4025, para. 27; C-231/96, Edilizia Industriale Siderurgica Srl (Edis) v Ministero delle Finanze [1998] ECR I-4951, para. 34; C-453/99, Courage Ltd v Bernard Crehan and Bernard Crehan v Courage Ltd and Others [2001] ECR I-6297, para. 29.
} 
in different Member States. The Court of Justice does not require that the same procedural rules are applied to the same rule of Union law in all Member States.

\section{Effective judicial protection}

According to the principle of effective judicial protection, a principle common to the constitutional traditions of the Member States, individuals must be able to enforce their rights under Union law in (national) courts. ${ }^{376}$ The principle of effective judicial protection is also derived from article 6 ECHR, which provides for the right to a fair trial. ${ }^{377}$ Article 6 (3) TEU stipulates that the fundamental rights as guaranteed by the ECHR and the constitutional traditions common to the Member States are fundamental principles of Union law. Moreover, article 19 (1) TEU requires that "Member States shall provide remedies sufficient to ensure effective legal protection in the fields covered by Union law". The Court of Justice has stressed that the Treaties do not require the creation of new remedies before national courts ${ }^{378}$ unless the structure of the national legal system would make the respect for the rights of individuals impossible. ${ }^{379}$ Hence, if the effectiveness of Union law and the protection of rights under Union law are not ensured at the national level, Member States are obliged to create new remedies. ${ }^{380}$ Finally, article 47 of the Charter provides for the right to an effective remedy and the right to a fair trial. This article binds public authorities of the Union and public authorities of the Member States when implementing Union law $^{381}$ and it is also applicable to horizontal relationships between citizens. ${ }^{382}$ It should be noted that the principle of effective judicial protection can be subjected to limitations if these restrictions comply with the principle of proportionality. ${ }^{383}$

\footnotetext{
${ }^{376}$ Case 222/84, Marguerite Johnston v Chief Constable of the Royal Ulster Constabulary [1986] ECR 1651, para. 18; Case 222/86, Union nationale des entraîneurs et cadres techniques professionnels du football (Unectef) v Georges Heylens and others [1987] ECR 4079, para. 14; C-97/91, Oleificio Borelli SpA v Commission of the European Communities [1992] ECR I-6313, para. 14; C-402/05, Yassin Abdullah Kadi and Al Barakaat International Foundation v Council of the European Union and Commission of the European Communities [2008] ECR I-6351, para. 335; C-432/05, Unibet (London) Ltd and Unibet (International) Ltd v Justitiekanslern [2007] ECR I-2271; Joined cases C-317-20/08, Rosalba Alassini v Telecom Italia SpA (et al.) [2010] ECR I-2213, para. 47.

377 Depite the wording of article 6 ECHR, the article does not only apply to civil and criminal proceedings, but also to administrative proceedings: Meyer-Ladewig (ed.), Europäische Menschenrechtskonvention, $3^{\text {rd }}$ edition, 2011, Art. 6 ECHR, at 4.

${ }^{378}$ Case 158/80, Rewe-Handelsgesellschaft Nord mbH and Rewe-Markt Steffen v Hauptzollamt Kiel [1981] ECR 1805 , para. 44 ,

${ }^{379}$ C-432/05, Unibet (London) Ltd and Unibet (International) Ltd v Justitiekanslern [2007] ECR I-2271, para. 41; C-583/11 P, Inuit Tapiriit Kanatami and Others v European Parliament and Council of the European Union (Judgment of 3 October 2013) para. 104.

${ }^{380}$ C-213/89, The Queen $v$ Secretary of State for Transport, ex parte: Factortame Ltd and others [1990] ECR I2433, paras. 19-21.

${ }^{381}$ Article 51 (1) Charter; Jarass, Charta der Grundrechte der Europäischen Union, $2^{\text {nd }}$ edition, 2013, Art. 47, at 4; Voet van Vormizeele, Art. 47 Charter, in: Schwarze et al. (ed.), EU-Kommentar, $3^{\text {rd }}$ edition, 2012, at 5-7.

382 That the principle of effective judicial protection applies in horizontal relationships was already emphasised by the Court in Case 14/83, Sabine von Colson and Elisabeth Kamann v Land Nordrhein-Westfalen [1984] ECR 1891, para. 23; Hofmann, Art. 47 Charter, in: Peers et al. (eds.), The EU Charter of Fundamental Rights, 2014, at $47.72 \mathrm{ff}$.

${ }^{383}$ Blanke, Art. 47 Charter, in: Callies, Ruffert (eds.), EUV, AEUV, Kommentar, $4^{\text {th }}$ edition, 2011, at 7; Hofmann, Art. 47, in: Peers et al. (eds.), The EU Charter of Fundamental Rights, 2014, at $47.82 \mathrm{ff}$.
} 
In the Union, the possibility for individuals to initiate litigation is seen as a key mechanism to aid the enforcement of Union law. ${ }^{384}$ Thus, effective judicial protection is, similar to the principle of effectiveness, a mechanism for the operational effectiveness of Union law. ${ }^{385}$ It ensures the effet utile. But these two principles are not identical. They have different rationales and purposes. ${ }^{386}$ Whereas the principle of effectiveness directly aims at the effectuation of Union law, the principle of judicial protection aims at giving individuals the possibility to challenge Union law infringements, as an element of a system governed by the rule of law. ${ }^{387}$

\section{The Aarhus requirements}

In 1998, the international Aarhus Convention ${ }^{388}$ was adopted, to which the European Union $^{389}$ and its Member States ${ }^{390}$ are parties. This Convention aims at ensuring, among other things, that the contracting parties provide for "wide access" to justice in environmental matters. ${ }^{391}$ "Wide access", as the objective of the Aarhus Convention is a political decision acknowledging the need for improved judicial enforcement mechanisms. This is expressed in the preamble of the Convention, stating that "effective judicial mechanisms should be accessible to the public, including organisations, so that its legitimate interests are protected and the law is enforced." With this objective, "mere pro forma participation" 392 shall be avoided. However, the Aarhus Convention only sets minimum standards, ${ }^{393}$ which are still rather broad and vague, which means that more concrete rules have to be adopted on a national level. ${ }^{394}$

The Aarhus Convention created three sets of rules which are commonly referred to as the three Aarhus pillars. ${ }^{395}$ The first pillar aims at guaranteeing public access to information on the environment, ${ }^{396}$ the second pillar consists of rules on public participation in public decision making affecting the

\footnotetext{
${ }^{384}$ Jacobs, The evolution of the European Legal Order, CMLRev 2004, p. 308.

385 C-46/93, Brasserie du Pêcheur SA v Bundesrepublik Deutschland and The Queen v Secretary of State for Transport, ex parte: Factortame Ltd and others [1996] ECR I-1029, para. 72.

${ }^{386}$ Prechal, Widdershoven, Redefining the Relationship between „REWE-effectiveness “ and Effective Judicial Protection, REALaw 2011, issue 2, pp. 31-50.

${ }^{387}$ Ibid.

${ }^{388}$ UNECE Convention on Access to Information, Public Participation in Decisionmaking and Access to Justice in Environmental Matters, 25 June 1998.

${ }^{389}$ Council Decision 2005/370/EC of 17 February 2005 on the conclusion, on behalf of the European Community, of the Convention on access to information, public participation in decision-making and access to justice in environmental matters, OJ L 124, 17.5.2005, pp. 1-3.

${ }^{390}$ For the state of signatures and ratifications of contracting states, refer to:

https://treaties.un.org/pages/ViewDetails.aspx?src=TREATY\&mtdsg_no=XXVII-13\&chapter=27\&lang=en (last visited: 26.04.2015).

391 Art. 9 (2) s. 2 Aarhus Convention.

${ }^{392}$ Ebbesson, Information, Participation and Access to Justice: the Model of the Aarhus Convention, 2002, pp. 3, 5 (available online).

${ }^{393}$ Ebbesson, Access to Justice at the National Level, in: Pallemaerts (ed.), The Aarhus Convention at Ten, 2011, p. $247 \mathrm{f}$.

${ }^{394}$ Regarding the implementation at the national level of Art. 9 (3) and 9 (4), it was found that "the overall status of the implementation [...] can, therefore, be descrIbid in the same terms as in the Milieu Report, that is, diverging, random and inconsistent.", Darpö, Effective Justice?, 2012, pp. 10 f. (available online).

${ }^{395}$ Ebbesson et al., The Aarhus Convention: An Implementation Guide, $2^{\text {nd }}$ edition, 2014, p. 19 (available online). 396 Art. 4 Aarhus Convention.
} 
environment ${ }^{397}$ and the third pillar sets common standards for environmental litigation in the contracting states. ${ }^{398}$ The central provision on environmental litigation is article 9 of the Aarhus Convention. According to article 9 (1), any person whose right to access information as prescribed by the Convention is infringed shall have the ability to institute judicial proceedings. This rule requires a wide access to courts in litigations concerning the first pillar of the Aarhus Convention. Next, article 9 (2) Aarhus Convention recognises in principle that there are different concepts of access to court in the contracting states. This article requires that members of the public concerned "having a sufficient interest, or, alternatively, maintaining impairment of a right, $[\ldots]$, have access to a review procedure before a court of law" in actions concerning activities named in article 6. Finally, article 9 (3) requires that members of the public have access to courts with regard to acts and omissions infringing rules of environmental law.

The Union has so far only partially complied with its obligation to implement the third pillar of the Aarhus Convention. ${ }^{399}$ As far as article 9 (1) is concerned, Directive 2003/4/EC on public access to information was adopted including provisions on judicial protection. ${ }^{400}$ Moreover, the requirements of articles 9 (2) and (4) were inserted in Directive 2003/35/EC on public participation and access to justice in environmental matters. ${ }^{401}$ This Directive however only concerns access to justice with regard to the administrative procedures prescribed in the IPPC and the EIA Directive. Next to Directive 2003/35/EC, a proposal for a directive on access to justice for the implementation of article 9 (3) was made in $2003^{402}$ but the bill was withdrawn in $2014 .{ }^{403}$ Despite this lack of complete implementation, the Union rules on access to justice which have been adopted under the Aarhus Convention oblige the national legal systems to align their national litigation rules with the European rules. ${ }^{404}$ Compared to the "classical" requirements for national litigation rules presented in the previous sections, the Aarhus standard is more concrete as it does not only require that the law is applied and enforced but it enumerates certain adjectives specifying how the law shall be enforced. ${ }^{405}$ The precise requirements will be examined in the respective sections on national rules. Here, it suffices to state that the Aarhus Convention requires a

\footnotetext{
${ }^{397}$ Art. 6 to 8 Aarhus Convention.

398 Art. 9 Aarhus Convention.

${ }^{399}$ Eliantonio, Collective Redress in Environmental Matters in the EU: A Role Model or a 'Problem Child'?, LIEI 2014, pp. 257-273.

${ }^{400}$ Directive 2003/4/EC of the European Parliament and of the Council of 28 January 2003 on public access to environmental information and repealing Council Directive 90/313/EEC, OJ L 41, 14.2.2003, pp. 26-32.

${ }^{401}$ Directive 2003/35/EC of the European Parliament and of the Council of 26 May 2003 providing for public participation in respect of the drawing up of certain plans and programmes relating to the environment and amending with regard to public participation and access to justice Council Directives 85/337/EEC and 96/61/EC, OJ L 156, 25.6.2003, pp. 17-25.

402 Proposal for a Directive of the European Parliament and the Council on access to justice in environmental matters, COM (2003) 624.

${ }^{403}$ Withdrawal of Obsolete Commission Proposals, OJ C 153, 21.05.2014, pp. 3-7.

${ }^{404}$ On the actual state of implementation of article 9 (3) of the Aarhus Convention see: Darpö (ed.), Effective Justice?, 2012 (available online).

405 This setting of concrete minimum standards is seen as "turning point for Community EIA law", Ryall, Effective Judicial Protection and the Environmental Impact Assessment Directive in Ireland, 2009, p. 263.
} 
"wide access to justice", ${ }^{406}$ "adequate and effective remedies", ${ }^{407}$ and a procedure which is "fair, equitable, timely and not prohibitively expensive". ${ }^{408}$ Moreover, courts have to review the "substantive and procedural legality of decisions". ${ }^{409}$ Granted, the adjectives "wide", "fair", "equitable" and "not prohibitively expensive" are still very broad and leave room for interpretation. However, to a certain extent they concretise the framework for national litigation rules in environmental matters.

\section{Conclusion}

This chapter has shown that the classical requirements of the Union primarily only describe "outer limits" for national litigation systems. The principles and rules created by the Court of Justice are meant to ensure that in the European order, Union law can be enforced in national courts at all. This is only a minimum standard for national litigation rules. In environmental matters, the Aarhus Convention added some further requirements. However, these requirements are still rather vague and need further precision. In the following sections, it will be seen how these European rules have induced or influenced reform processes at the national level. The focus will be on the national differences which persist despite the European influence and it will be asked how these differences affect the enforcement of Union law.

\footnotetext{
406 Art. 9 (2) b Aarhus Convention.

${ }^{407}$ Art. 9 (4) Aarhus Convention.

408 Art. 9 (4) Aarhus Convention.

${ }^{409}$ Art. 9 (2) b Aarhus Convention.
} 


\section{Chapter 2 Access to administrative courts}

The issue of access to justice has attracted a lot of attention in the last years. Access to administrative courts in the European Union has been subject to two extensive studies conducted under the umbrella of the European Parliament and the European Commission respectively. First, standing requirements before the Court of Justice and civil, administrative and criminal courts in the various Member States of the Union were analysed and compared. ${ }^{410}$ Second, a study on the implementation of articles 9 (3) and (4) of the Aarhus Convention in the national legal orders revealed large differences on standing requirements in environmental matters and on cost risks in environmental proceedings. ${ }^{411}$ The overall conclusion which was drawn in these studies is that legal systems on standing vary significantly and make a comparison hardly possible. ${ }^{412}$ Moreover, in environmental matters, international and European Union law creates certain standards on access, but the implementation of these standards is described as "diverging, random and inconsistent". ${ }^{413}$

The aim of this chapter is to trace the application of national rules on access specifically in EIA cases and to discuss whether their difference and inconsistency has consequences for the enforcement of the EIA Directive. For this purpose, this chapter describes the legal frameworks of the three states under consideration with regard to standing (section 1), costs (section 2) and time limits (section 3) and illustrates how these rules affect enforcement in EIA cases. Each section will begin with pointing to the concrete legislative requirements with which national litigation rules have to comply under the Aarhus Convention and Union legislation and by giving a brief illustration on the interpretation of these rules by the Court of Justice. Next, the national rules will be compared and their application in national case law will be traced.

\section{Rules on standing}

In the European Union, Member States are in principle free to design their rules on standing. ${ }^{414}$ However, they have to implement the international law obligations arising from the Aarhus Convention and obligations arising from European law which will be described first (1.1), followed by an analysis of the application of national rules in EIA cases and some observations on differences and convergences between the legal systems (1.2).

\subsection{International and European rules on standing}

Under international law, rules on standing in environmental matters are laid down in article 9 of the Aarhus Convention. Article 9 (2) of the Aarhus Convention obliges the contracting parties to provide

\footnotetext{
${ }^{410}$ Eliantonio et al., Standing up for your Rights in Europe, 2012.

411 Darpö, Effective Justice?, 2012 (available online).

412 Eliantonio et al., Standing up for your Rights in Europe, 2012, p. 81.

413 Darpö, Effective Justice?, 2012, p. 7 (available online).

${ }^{414}$ Joined Cases C-87, 88, 89/90, A. Verholen and others v Sociale Verzekeringsbank Amsterdam [1991] ECR I3757, para. 24.
} 
for access to judicial review procedures concerning permit procedures and the adoption of administrative decisions with regard to certain activities. Access has to be granted to the "public concerned", but the Convention leaves discretion to the contracting parties to make access dependent from the existence of a sufficient interest or on the existence of a right which has been impaired. This rule of the Aarhus Convention is transposed to article 11 of the EIA Directive. As explained previously, article 9 (3) of the Aarhus Convention, providing for access to courts for the members of the public with regard to acts and omissions infringing rules of environmental law, has so far not been implemented by the Union. ${ }^{415}$ Before turning to the interpretation of the Court of Justice of the requirements emanating from the Aarhus Convention, some general remarks about the jurisprudence of the Court of Justice on standing requirements will be made.

The basic principle for rules on standing was formulated by the Court of Justice in Verholen, in which the Court held that "it is in principle for national law to determine an individual's standing and legal interest in the proceedings". ${ }^{416}$ However, the Court stressed that the national legislation must not undermine the right to effective judicial protection. ${ }^{417}$ This was repeated in later case law. ${ }^{418}$ Furthermore, in a case concerning the claim brought by an Austrian association for breeders of ponies against the official recognition of another organisation of breeders, the Court of Justice held that the relevant Union decision did not confer a right on this organisation. Hence, it was not contrary to Union law to deny standing in this particular case. ${ }^{419}$ In environmental matters, the issue of whether an individual can rely on a right under Union law was at issue in the case of Dieter Janecek. ${ }^{420}$ Mr. Janecek applied for an order which would oblige the administrative authority to make an air quality action plan for the area in which he was living so that Union legislation on air quality would be complied with. ${ }^{421}$ In the preliminary ruling, the Court of Justice held that individuals must be able to rely on the relevant norms of the Air Quality Directive ${ }^{422}$ and must be in a position to challenge infringements in court. ${ }^{423}$ As far as the application of article 9 of the Aarhus Convention is concerned, the Court held in the case of the Slovak Brown Bear that it was competent to rule on the application of article 9 (3) Aarhus Convention even though there was (and still is) no Union legislation on this article. ${ }^{424}$ Moreover, the

\footnotetext{
415 Part II, Chapter 1, Section 4.

416 Joined Cases C-87, 88, 89/90, A. Verholen and others v Sociale Verzekeringsbank Amsterdam [1991] ECR I- 3757, para. 24.

${ }^{417}$ Ibid., para. 24.

${ }^{418}$ C-13/01, Safelero Srl v Prefetto di Genova [2003] ECR I-8679, para. 50; C-174/02, Streekgewest Westelijk Noord-Brabant v Staatssecretaris van Financiën [2005] ECR I-85, para. 18.

419 C-216/02, Österreichischer Zuchtverband für Ponys, Kleinpferde und Spezialrassen v Burgenländische Landesregierung [2004] ECR I-10683, paras. 36, 38-40.

${ }^{420}$ C-237/07, Dieter Janecek v Freistaat Bayern [2008] ECR I-6221.

421 Ibid., para. 2.

${ }^{422}$ Article 7(3) of Council Directive 96/62/EC of 27 September 1996 on ambient air quality assessment and management (OJ L 296, 21.11.1996, p. 55-63) as amended by Regulation (EC) No 1882/2003 of the European Parliament and of the Council of 29 September 2003, OJ L 284, 31.10.2003, pp. 1-53.

${ }^{423}$ Case C-237/07, Dieter Janecek v Freistaat Bayern [2008] ECR I-6221, para. 39.

${ }^{424}$ C-240/09, Lesoochranárske zoskupenie VLK v Ministerstvo životného prostredia Slovenskej republiky [2009] ECR I-1255, paras. 38, 43.
} 
Court then found that article 9 (3) does not have direct effect, as it is not sufficiently precise. ${ }^{425}$ However, the national court should interpret its national provisions in the light of the objectives of the Aarhus Convention:

“... so as to enable an environmental protection organisation, such as the zoskupenie, to challenge before a court a decision taken following administrative proceedings liable to be contrary to EU environmental law so that standing should be granted." 426

Apart from this case in which the Court of Justice had to interpret article 9 (3) of the Aarhus Convention, the Court had to decide several cases dealing with Directive 2003/35/EC implementing the Aarhus Convention. Rules on standing under this Directive were at issue in the reference for preliminary ruling from a German court in Trianel. In this case, the Court stressed the importance of a wide access to justice, holding that environmental organisations must not be barred from challenging decisions under the EIA Directive even if this aims only at the protection of environmental interests. ${ }^{427}$ This case instigated important reforms of German law and any further discussion of the judgment shall therefore be postponed to the section on standing in Germany. Furthermore, in the case of Djurgarrden the Court had to rule on a Swedish rule according to which environmental organisations had to have at least 2000 members in order to be granted standing in court. The Court found that this requirement violated the Aarhus rule of a "wide access to justice". ${ }^{428}$ After this overview of the international and European requirements on standing, the focus will now shift to the national legal frameworks.

\subsection{National rules on standing}

On the national level in the Union, there are three different concepts underlying the rules on standing. To begin with, Member States may provide for an actio popularis, meaning that anyone can bring litigations to court. Next, a distinction can be made between Member States which adopt a rights-based approach and those which follow an interest-based approach when regulating access to courts. A rightsbased system is a system in which claimants have to show that an administrative measure infringes upon their subjective rights in order to access an administrative court. Contrary to this, interest-based systems "usually require a direct, actual and certain interest". ${ }^{429}$

Whereas Germany follows the rights-based approach, the English and Dutch legal systems provide for interest-based access to justice. ${ }^{430}$ In this section, the rules on standing will be described and it will be

\footnotetext{
${ }^{425}$ Ibid., para. 45.

${ }^{426}$ Ibid., para. 51.

${ }^{427}$ C-115/09, Bund für Umwelt und Naturschutz Deutschland, Landesverband Nordrhein-Westfalen eV $v$ Bezirksregierung Arnsberg [2011] ECR I-36.

${ }^{428}$ C-263/08, Djurgården-Lilla Värtans Miljoskyddsföreening [2009] ECR I-9967.

${ }^{429}$ Eliantonio et al., Standing up for Your Right(s) in Europe, 2013, p. 66.

${ }^{430}$ Ibid., p. 67.
} 
explained how their application in EIA cases developed under the influence of the Aarhus Convention and Union legislation.

\section{a. Germany}

\section{National rules on standing}

The basis for the German rights-based system is article 19 (4) s. 1 GG which stipulates:

"If someone's rights are violated by public authority, he has recourse to the courts."431

This constitutional provision makes clear that access to courts in public matters is made dependent on the infringement of a claimant's rights. The corresponding rule on access to administrative courts is $\S 42(2)$ VwGO:

"If not otherwise provided statutorily, the legal action is only admissible if the claimant asserts that his rights have been infringed upon by the administrative decision or the refusal or the omission thereof." ${ }^{332}$

The question is what qualifies as a subjective right under public law. To begin with, subjective rights under public law are enshrined in the German constitution. ${ }^{433}$ The allegation of the infringement of a fundamental right leads to locus standi of the applicant in administrative courts. For example, in the case of an administrative decision burdening the addressee of the administrative decision, there will be at least an infringement of the constitutional right, namely the general freedom of action. ${ }^{434} \mathrm{In}$ construction law, a claimant's right to property as enshrined in the constitution ${ }^{435}$ and as concretised in statutes, may become relevant if the neighbour to a planned building alleges the infringement of his right. ${ }^{436}$

Moreover, rights can be derived from statutes. For the purpose of having standing in court, the right provided for in this statute must be construed as a "subjective public right" of the applicant. This means that the applicant must be entitled to this right under public law. ${ }^{437}$ Many norms of administrative law protect the public interest and not the individual. An individual may only rely on provisions which at

\footnotetext{
${ }^{431}$ Maastricht Collection.

${ }^{432}$ Based on the Maastricht Collection; the term "administrative act" is changed to "administrative decision.

${ }^{433}$ Gärditz, § 42 VwGO, in: Gärditz (ed.), VwGO Kommentar, 2013, at 63 ff. and 75 ff.; Sennekamp, § 3 Verfahren "Erste Instanz", Klagebefugnis, in: Quaas, Zuck (eds.), Prozesse in Verwaltungssachen, 2008, at 150; Wahl, Vorbemerkung zu § 42 (2) VwGO, in: Schoch et al. (eds.), VwGO Kommentar, 2014, at 45.

434 Allgemeine Handlungsfreiheit: art. 2 (1) GG; Sennekamp, § 3 Verfahren "Erste Instanz", Klagebefugnis, in: Quaas, Zuck (eds.), Prozesse in Verwaltungssachen, 2008, at 136; Sodan, § 42 (2) VwGO, in: Sodan, Ziekow (eds.), VwGO, Kommentar, $4^{\text {th }}$ edition, 2014, at 383.

435 Art. 14 GG.

${ }^{436}$ Sodan, $\S 42$ VwGO, in: Sodan, Ziekow (eds.), VwGO Kommentar, $4^{\text {th }}$ edition, 2014, at 436.

${ }^{437}$ Gärditz, § 42 VwGO, in: Gärditz (ed.), VwGO, Kommentar, 2013, at 50 ff.
} 
least also aim at the protection of the individual, which is then called a Schutznorm (provision of protection $\left.^{438}\right) .439$

In Germany, it is disputed to what extent rules on administrative procedure provide for subjective rights. Thereby, a distinction is made between absolute and relative procedural rights. ${ }^{440}$ Whereas the alleged infringement of a relative procedural right will as such not suffice to have standing, absolute procedural rights "protect the individual" and, for this reason, standing will be granted if an applicant alleges a possible infringement of an absolute procedural right. ${ }^{441}$ There are only a few recognised absolute procedural rights and these mainly consist of rights of participation. ${ }^{442}$ As far as the EIA is concerned, the traditional position is that the rules of the UVPG generally do not aim at the protection of individuals; thus they are only qualified as relative procedural rules. ${ }^{443}$ In how far this interpretation had to change will be explained in the following section describing the application of this German doctrine in EIA cases.

The requirement that a right has to be infringed is not only assessed by the court at the stage of admissibility of the claim but also at the stage of deciding on the merits of the case. ${ }^{444}$ For the stage of access to court, it suffices that the claimant alleges that there is the possibility of an infringement of a subjective right. ${ }^{445}$ The claim will only be successful if at the stage of the assessment of merits of the case an infringement of subjective rights can be established. ${ }^{446}$

In the area of environmental law, which by its nature mostly does not confer subjective rights on individuals, and more precisely regarding the subject matter of the EIA, consists mostly of relative procedural law, this restrictive approach led to enforcement deficits and came, for this reason, under European Union pressure. ${ }^{447}$ This process of broadening standing possibilities in environmental matters in Germany will be traced in the following section.

\footnotetext{
438 This translation of the term "Schutznorm" is derived from C-137/14, European Commission v Federal Republic of Germany (Action brought on 21 March 2014), which refers to the "Schutznormtheorie" as "protective provision theory".

${ }^{439}$ Gärditz, § 42 VwGO, in: Gärditz (ed.), VwGO, Kommentar, 2013, at 54.

${ }^{440}$ Held, Individualrechtsschutz bei fehlerhaftem Verwaltungsverfahren, NVwZ 2012, pp. 464 f; Wahl, Schütz, § 42 (2) VwGO, in: Schoch et al. (eds.), VwGO Kommentar, 2014, at 72 ff; Gärditz, § 42 VwGO, in: Gärditz (ed.), $V w G O$, Kommentar, 2013, at $78 \mathrm{ff}$.

${ }^{441}$ Wahl, Schütz, § 42 (2) VwGO, in: Schoch et al. (eds.), VwGO Kommentar, 2014, at $72 \mathrm{ff}$.

${ }^{442}$ For example the right of municipatlities to participate in certain Planfeststellungs-procedure (for example $\S 114$ (3) $\mathrm{WaStrG}$ ) and the right of participation of environmental associations under nature protection law ( $\$ 63$ BNatSchG); Happ, $\S 42$, in: Eyermann, VwGO Kommentar, $14^{\text {th }}$ edition, 2014, at 83 b; Gärditz, $\S 42$ VwGO, in: Gärditz (ed.), VwGO, Kommentar, 2013, at 81.

${ }^{443}$ Appel, Subjektivierung von UVP- Fehlern durch das Umweltrechtbehelfsgesetz?, NVwZ 2010, pp. 473- 479; Wahl, Schütz, § 42 (2) VwGO, in: Schoch et al. (eds.), VwGO Kommentar, 2014 at 214; another position is adopted by: Gärditz, $\$ 42$ VwGO, in: Gärditz, VwGO, Kommentar, 2013, at 82 (the rules of the UVPG aim at the protection of the health and the property of individuals).

444 \& 113 (1) 1 VwGO.

${ }^{445}$ This is the so-called Möglichkeitstheorie; Wahl, Schütz, § 42 (2), in: Schoch et al. (eds.), VwGO Kommentar, 2014, at 67.

${ }^{446}$ Gerhardt, § 113 VwGO, in: Schoch et al. (eds.), VwGO Kommentar, 2014, at 5.

${ }^{447}$ C-72/12, Gemeinde Altrip and Others v Land Rheinland-Pfalz (Judgment of 7 November 2013).
} 


\section{National Rules on standing in EIA cases}

The development of standing requirements in EIA cases can be divided into three periods. The first period begins with the entry into force of the EIA implementing legislation, the UVPG of $1990 .{ }^{448}$ This period lasts until the entry into force of the Umwelt-Rechtsbehelfsgesetz (Statute on complementary rules on judicial review in environmental matters pursuant to Directive 2003/35/EC; abbreviation: UmwRG in 2006). ${ }^{449}$ The second period runs until the Court of Justices judgment in Trianel, ${ }^{450}$ which marks the beginning of a third period of EIA enforcement.

(i) First period: Standing in courts 1990 - 2006

In first period, § 42 (2) VwGO was applicable in litigations dealing with environmental and procedural matters, such as the EIA. In 1993, the VGH München held that:

"The statute on Environmental Impact Assessment does not by itself grant standing. Its provisions in no way support the assumption that in the case of their infringement, standing is granted outside the scope of $\S 42$ (2) VwGO, nor that they open the possibility for an actio popularis unknown to German law. According to their purpose and aim, the provisions do not provide for the possibility to claim an infringement of procedural rules, which an individual of whom a subjective right was not infringed in the sense of $§ 42$ (2) VwGO, cannot claim." ${ }^{451}$

This emphasised that the procedural norms of the UVPG did not aim at the protection of third parties. ${ }^{452}$ Therefore, the allegation of an infringement of procedural rules of the UVPG was not sufficient in order to be granted standing in court. Hence, any claimant, including individuals and environmental organisations, could only have access to the courts if they could claim the infringement of a rule which at least also protects the rights of individuals.

It should be noted that in Germany in the 1990s, it was generally very difficult to receive standing in environmental matters. Especially environmental organisations were hardly able to challenge decisions vitiated by breaches of environmental law, as those rules usually did not provide for subjective rights. ${ }^{453}$ The situation improved to some extent when some Länder introduced special rules on standing for environmental organisations in nature protection law (which is distinct from the EIA legislation), but

\footnotetext{
${ }^{448}$ Gesetz zur Umsetzung der Richtlinie des Rates vom 27. Juni 1985 über die Umweltverträglichkeitsprüfung bei bestimmten öffentlichen und privaten Projekten (85/337/EWG), 12.02.1990, BGBl. I pp. 205-214.

${ }^{449}$ Gesetz über ergänzende Vorschriften zu Rechtsbehelfen in Umweltangelegenheiten nach der EG Richtlinie 2003/35/EG, 7.12.2006, BGBl. I pp. 2816-2818.

${ }_{450}$ C-115/09, Bund für Umwelt und Naturschutz Deutschland, Landesverband Nordrhein-Westfalen eV $v$ Bezirksregierung Arnsberg [2011] ECR I-36.

${ }^{451}$ Own translation. VGH München, Judgment of 26 January 1993, Az.: 8 A 92.40143, NVwZ 1993, 906.

${ }^{452}$ This was already argued before the implementation of Directive 85/337/EC into German law: Bunge, Die Umweltverträglichkeitsprüfung von Projekten, DVBl 1987, pp. 819 ff.; Erbguth, Schink, UVPG Kommentar, $2^{\text {nd }}$ edition, 1996, Einleitung, at 117.

${ }^{453}$ An overview over the dabate that lasted for almost 40 years is given by: Koch, Die Verbandsklage im Umweltrecht, NVwZ 2007, pp. 369 - 378.
} 
these laws varied in their scope and application. ${ }^{454}$ In 2002, the federal legislator created the possibility for environmental organisations to have access to administrative courts in nature protection matters by adopting the Bundesnaturschutzgesetz (Federal Nature Protection Act; abbreviation: BNatschG). ${ }^{455}$ The Länder which did not yet provide for this possibility had to align their state legislation with the federal legislation. Amended in 2009, ${ }^{456} \S 64$ BNatschG provides that officially recognised environmental organisations can bring litigations without alleging the violation of an individual right under public law in a certain number of cases. This mainly concerns decisions on plans having implications for nature and landscapes ${ }^{457}$ and the approval of plans in which public participation is required. ${ }^{458}$ Moreover, standing can be granted in cases which concern the exemption of prohibitions in nature protection areas. ${ }^{459}$ However, these rules did not form a basis upon which environmental organisations could challenge the omission of or flaws in EIAs. Therefore, in the first period of EIA enforcement, the possibility to receive standing as an environmental organisation or as an individual claimant was extremely limited. ${ }^{460}$

\section{(ii) Second Period: Standing in courts $2006-2013$}

The second period of judicial enforcement of the rules of the EIA Directive began with the entry into force of the UmwRG (2006). ${ }^{461}$ This statute was created in order to implement the obligations of the third pillar of the Aarhus Convention and article 10 a Directive 85/337/EC ${ }^{462}$ creating locus standi for environmental organisations in a number of environmental cases. It was drafted as an exception to $\S 42$ (2) VwGO. ${ }^{463}$ The central norm on standing for environmental organisations of the new statute was $\S 2$ (1) nr. 1 UmwRG (2006). Accordingly, recognised ${ }^{464}$ environmental organisations were able to seek judicial protection against decisions if they were able to claim that (1) the law which was violated aimed at the protection of the environment, (2) that this law created a subjective right for individuals and (3) that it was of significance for the administrative decision. These requirements had to be fulfilled cumulatively. The second requirement was that the environmental organisation had to allege the infringement of a norm which aimed at protecting a subjective right under public law which was based

\footnotetext{
${ }^{454}$ For example, the Land Bremen introduced the possibility for NGOs to bring a claim in nature protection matters already in 1979 with the Gesetz über Naturschutz und Landschaftspflege of 17 September 1979, Gbl. p. 345; In North-Rhine Westphalia such a law was only introduced with the Gesetz zur Sicherung des Naturhaushalts und zur Entwicklung der Landschaft (Landschaftsgesetz - LG), 21 July 2000, GV.NRW, p. 568; see also: Schmidt, Zschiesche, Rosenbaum, Die naturschutzrechtliche Verbandsklage in Deutschland, 2004, pp. $23 \mathrm{ff}$.

${ }^{455}$ Gesetz zur Neuregelung des Rechts des Naturschutzes und der Landschaftspflege und zur Anpassung anderer Rechtsvorschriften (BNatSchGNeuregG), 25.03.2002, BGBl. I p. 1193-1218.

${ }^{456}$ Gesetz zur Neuregelung des Rechts des Naturschutzes und der Landschaftspflege, 29.07.2009, BGB1. I p. 2542.

${ }^{457} \S 64$ (1) in conjunction with $\S 63$ (1) Nr. 3, (2) Nr. 6 BNatschG.

$458 \S 64$ (1) in conjunction with $\S 63$ (1) Nr. 4, (2) Nr. 7 BNatschG.

${ }^{459} \S 64$ (1) in conjunction with $\S 63$ (1) Nr. 2, (2) Nr. 5 BNatschG.

${ }^{460}$ Schlacke, Rechtsschutz durch Verbandsklage, NuR 2004, p. 629.

${ }^{461}$ Gesetz über ergänzende Vorschriften zu Rechtsbehelfen in Umweltangelegenheiten nach der EG Richtlinie 2003/35/EG, 7.12.2006, BGBl. I pp. 2816-2818.

462 Art. 11 Directive 2011/92/EU.

${ }^{463}$ Ziekow, Das Umwelt-Rechtsbehelfsgesetz im System des deutschen Rechtsschutzes, NVwZ 2007, p. 261.

${ }^{464} \S 3$ UmwRG; see: Part II, Chapter 2, Section 1.2. a., (iv).
} 
on the Schutznormtheorie. ${ }^{465}$ For the purpose of being granted standing in court, an environmental organisation did not have to allege the infringement of a right of its own, but it had to allege the infringement of a rule that creates individual rights under public law. ${ }^{466}$ Therefore, any infringement of an objective rule of law like for example nature protection law or rules of administrative procedural law was not challengeable under the UmwRG (2006). ${ }^{467}$ Although the intention of the UmwRG was to broaden access to courts for environmental organisations and to grant standing also in other cases than nature protection law, the factual capacity of environmental organisations to gain standing remained narrow. In literature, the incompatibility of this newly created norm with Union law was discussed intensively. ${ }^{468}$ The $O V G$ Münster finally referred a question for preliminary ruling to the Court of Justice ${ }^{469}$ which held that access to court as regulated by $\S 2$ (1) nr. 1 UmwRG was too narrow. ${ }^{470}$ According the Court of Justice:

"it would be contrary to the objective of giving the public concerned wide access to justice and at odds with the principle of effectiveness if such organisations were not also allowed to rely on the impairment of rules of EU environment law solely on the ground that those rules protect the public interest." ${ }^{471}$

The Union legislation implementing article 9 (2) of the Aarhus Convention aims at the introduction of access to courts for non-governmental organisations regarding any Union rule of environmental law which is implemented by the Member States or which are directly applicable in Member States. ${ }^{472}$ After this ruling of the Court of Justice, the national court held that the provision of the UmwRG insufficiently transposed the requirements of the EIA Directive ${ }^{473}$ and that, due to the impossibility of interpreting the provision consistently with Union law, the Directive had to be applied directly by the court. ${ }^{474}$ The

\footnotetext{
465 Ibid.

466 This is referred to as "Schutznormakzessorietät"; Spieth, Appel, Umfang und Grenzen der Einklagbarkeit von UVP Fehlern nach Umweltrechtsbehelfsgesetz, NuR 2009, p. 314.

${ }^{467}$ Schlacke, Das Umwelt-Rechtsbehelfsgesetz, NuR 2007, p. 11.

468 Berkemann, Umweltrechtsbehelfsgesetz (UmwRG) auf dem gemeinschaftsrechtlichen Prüfstand, NordOeR 2009, p. 336; Dippel, Niggemeyer, Europarechtswidrigkeit des § 2 Abs. 1 Nr. 1 UmwRG? Zugleich Besprechung von OVG NRW Vorlagebschluss vom 5.3.2009, EurUP 2009, p. 199; Eckardt, Schenderlein, Gerichtlicher Kontrollumfang zwischen EU-Bürgerfreundlichkeit und nationaler Beschleunigungsgesetzgebung, NVwZ 2008, p. 1060; Franzius, Objektive Rechtskontrolle statt subjektiver Rechtsschutz, NuR 2009, p. 384; Gärditz, Klagerechte der Umweltöffentlichkeit im Umweltrechtsbehelfsgesetz, EurUP 2010, p. 215; Gellermann, Europäisierte Klagerechte anerkannter Umweltverbände, NVwZ 2006, pp. 8, 9; Genth, Ist das neue UmweltRechtsbehelfsgesetz europarechtskonform?, NuR 2008, pp. 28 ff; Kment, Das neue Umwelt-Rechtsbehelfsgesetz und seine Bedeutung für das UVPG - Rechtsschutz des Vorhabenträgers, anerkannter Vereinigungen und Dritter, NVwZ 2007, pp. 274 ff; Schlacke, Das Umwelt-Rechtsbehelfsgesetz, NuR 2007, p. 11; Schmidt, Kremer, Das Umwelt-Rechtsbehelfsgesetz und der ,weite Zugang zu Gerichten“, ZUR 2007, p. 57; Ziekow, Das UmweltRechtsbehelfsgesetz im System des deutschen Rechtsschutzes, NVwZ 2007, p. 259; see also: OVG Lüneburg, Decision of 10 March 2010, Az.: 12 ME 176/09, NuR 2010, 290, 292.

469 OVG Münster, 5 March 2009, nr. 8 D 58/08, NVwZ 2009, 987- 991.

${ }^{470}$ C-115/09, Bund für Umwelt und Naturschutz Deutschland, [2011] ECR I-03673.

${ }^{471}$ Ibid., para. 46.

${ }^{472}$ Ibid., para. 48.

${ }^{473}$ OVG Münster, Judgment of 1 December 2011, Az.: 8 D 58/08.AK, NuR 2012, 342, 343.

${ }^{474}$ Ibid., NuR 2012, 342, 344.
} 
environmental organisation was therefore granted standing in the national court. ${ }^{475}$ In the aftermath of the ruling of the Court of Justice in Trianel, the German legislator redrafted the UmwRG, which demarks the beginning of the third period of enforcement.

\section{(iii) Third Period: Standing in Courts after Trianel}

Since 2013, a modified version of the UmwRG regulates access to courts in environmental matters. ${ }^{476}$ As far as the rule on standing for environmental organisations is concerned, the requirement that an environmental organisation has to allege the infringement of a norm that confers rights on individuals has been deleted. ${ }^{477}$ The current version of the UmwRG (2013) ${ }^{478}$ stipulates that a recognised environmental organisation can bring litigations pursuant to the rules of the VwGO challenging administrative decisions falling under the scope of the UmwRG (2013), without alleging the infringement of their own rights. ${ }^{479}$ For this purpose, the environmental organisation has to claim that a decision or its omission contradicts legal norms on environmental protection which may be of relevance for the decision. ${ }^{480}$ Moreover, the environmental organisation has to claim that the decision or its omission concerns their statutory tasks on environmental protection. ${ }^{481}$ Finally, the environmental organisation must have been allowed to participate in the administrative procedure and must have made submissions in that procedure, unless it did not have the possibility to make submissions, contrary to the law. ${ }^{482}$ On the basis of this new rule, environmental organisations have been granted standing in German courts since 2013. ${ }^{483}$ However, it is clear from the wording of the rule that it only applies to environmental organisations, meaning that other public interest groups are not covered by this provision.

The position of individuals under the new legislation is unclear. The question is whether individuals can rely on $\S 4$ (1), (3) UmwRG (2013) in order to gain standing in courts. This rule states that the annulment of an administrative decision may be requested if an obligatory EIA or an obligatory screening was not conducted or if the screening was wrongful. ${ }^{484}$ This rule also applies to litigations brought by

\footnotetext{
475 Ibid., NuR 2012, 342, 344.

${ }^{476}$ Gesetz zur Änderung des Umwelt-Rechtsbehelfsgesetzes und anderer Umweltrechtlicher Vorschriften, 21.01.2013, BGB1. I pp. 95-100.

477 Art. 1 (2) a), aa) Gesetz zur Änderung des Umweltrechtsbehelfsgesetzes und anderer umweltrechtlicher Vorschriften, 21.01.2013.

${ }^{478}$ Gesetz über ergänzende Vorschriften zu Rechtsbehelfen in Umweltangelegenheiten nach EG Richtlinie 2003/35/EG (Umwelt-Rechtsbehelfsgesetz - UmwRG) as officially published on 8.04.2013 (BGB1. I p. 753) with last the last amendment of 7.08. 2013, BGB1. I p. 3154.

479 § 2 (1) UmwRG (2013).

$480 \S 2$ (1) nr. 1 UmwRG (2013); The Aarhus Compliance Committe has found that this restriction contravenes the Aarhus Convention: Decision V/9h of the Meeting of the Parties on compliance by Germany with its obligations under the Convention (ECE/MP.PP/2014/2/Add.1); Bunge, Rechtsbehelfe in Umweltangelegenheiten, Vorgaben der Aarhus-Kovention und das deutsche Recht, NuR 2014, p. 609.

${ }^{481} \S 2$ (1) nr. 2 UmwRG (2013).

$482 \S 2$ (1) nr. 3 UmwRG (2013).

483 OVG Koblenz, Decision of 2 April 2014, Az.: 1 B 10249/14; OVG Münster, Decision of 23 July 2014, Az.: 8 B 356/14, NuR 2014, 663-668; juris, para. 47.

${ }^{484} \S 4$ (1) UmwRG (2013).
} 
participants in the administrative procedure as defined in the VwGO. ${ }^{485}$ The Federal Administrative Court is of the opinion that $\S 4$ UmwRG is not relevant for the assessment of the admissibility of a claim. ${ }^{486}$ Instead, the applicable provision on standing for individuals is $\S 42$ (2) VwGO, meaning that they have to allege the infringement of a (mostly substantive) right under public law. According to the court, the rules of the EIA procedure do not provide for subjective rights.

This approach leads to frictions between the stage of the admissibility of a claim, which is made dependent on the infringement of a subjective right, and the stage of the assessment of the merits of the case, where there is no such requirement. ${ }^{487}$ Discussing this problem in an obiter dictum, the $O V G$ Münster raised doubts on the compatibility with Union law, since the claims of all those members of the public concerned which are not granted standing as environmental organisation under the UmwRG (2013) are not admissible without an alleged infringement of subjective substantive rights. ${ }^{488}$ Hence, independently of whether there is or is not a procedural error in the EIA process, these claims would already be barred at the stage of assessing the admissibility of the claim and could therefore not be dealt with at the stage of assessing the merits. ${ }^{489}$ The court doubts that this is compatible with the requirement of a wide and effective access to justice. ${ }^{490}$ Furthermore, the court stresses that there are no reasons for the fear that a changed position of individuals would lead to a hidden actio popularis as only those individuals would be granted standing whose interest were infringed. ${ }^{491}$

In a claim for interim relief brought to the VG Aachen, the court stressed that the effective judicial enforcement of the EIA procedure is put in the hands of the applicants who, in this case, are property owners of buildings near the development concerned. ${ }^{492}$ Contrary to the position adopted by the Federal Administrative Court, ${ }^{493}$ the VG Aachen held that in relying on $§ 4$ (1), (3) UmwRG, the applicants have to be treated as claimants alleging the infringement of a subjective right in the sense of $\S 42$ (2) VwGO. ${ }^{494}$ Therefore, the claim was admissible. In this regard, the court stressed that the Federal Republic of Germany has itself contributed to the creation of the Aarhus Convention and Directive 2003/35/EC and that it is therefore bound by it and has to transpose this obligation sufficiently. ${ }^{495}$

\footnotetext{
$485 \S 4$ (3) UmwRG (2013).

${ }^{486}$ BVerwG, Judgment of 20 December 2011, Az.: 9 A 30/10, NVwZ 2012, 573, 574; BVerwG, Judgment of 2 October 2013, Az.: 9 A 23/12, NVwZ 2014, pp. 367, 369; BVerwG, Judgment of 17 December 2013, Az.: 4 A 1/13, BVerwGE 148, 353, 364, at 41.

${ }^{487}$ Seibert, Verbandsklagen im Umweltrecht, NVwZ 2013, p.1046; Ziekow, Verfahrensfehler im Umweltrecht notwendige Nachjustierungen im deutschen Verwaltungsrecht, NuR 2014, 234.

${ }^{488}$ OVG Münster, Decision of 23 July 2014, Az.: 8 B 356/14, NuR 2014, 664; juris, para. 22.

${ }^{489}$ Ibid.

${ }^{490}$ Ibid., NuR 2014, 664, 663; juris, paras. 22-30.

${ }^{491}$ Ibid., NuR 2014, 664, 665; juris, paras. 34-36.

${ }^{492}$ VG Aachen, Decision of 28 November 2014, Az.: 3 L 224/13, juris, para. 16.

${ }^{493}$ BVerwG, Judgment of 20.12.2011, Az.: 9 A 30/10, NVwZ 2012, 573-575; BVerwG, Decision of 27 June 2013 , Az.: 4 B 37/12, NuR 2014, 117-118.

${ }^{494}$ VG Aachen, Decision of 28 November 2014, Az.: 3 L 224/13, juris, paras. 36-38.

${ }^{495}$ Ibid., para. 38.
} 
How these judgments of the two courts in North-Rhine Westphalia will be received by Federal Administrative Court and jurisprudence in general remains to be seen. In the workshop, it was clearly expressed that further changes in jurisprudence are expected.

To conclude, having traced the development of the German rules on standing in EIA cases, the situation in December 2014 is as follows: the position of individuals with regard to EIA enforcement remains unclear. So far, it is still assumed that they must allege the infringement of a (substantive) subjective right to gain standing. Officially recognised environmental organisations are granted standing if they fulfil the requirements of $\S 2$ UmwRG (2013). Other public interest groups have no standing under the UmwRG (2013). They may only have standing if they can allege the infringement of their own rights. Finally, competitors, pursuing only financial interests, will not be granted standing in EIA cases. It should be noted already at this point that the widening of access to courts for environmental organisations in 2013 was accompanied by the creation of new limitations in $\S 4$ a UmwRG (2013). The reason for restricting access again was - according to the legislator - to prevent unjustified delays in permit procedures. ${ }^{496}$ These restrictions will be dealt with in detail in the relevant chapters of this thesis. $^{497}$

\section{(iv) The recognition of environmental organisations}

So far, this section has illustrated, how the restrictive standing requirements under German law had to broaden under international and European pressure. It was already mentioned that environmental organisations have to be recognised by the German state in order to access courts in EIA cases. ${ }^{498}$ This section will devote some additional attention to the requirement of recognistion, because it is not possible to be granted standing in court without being (previously) recognised by the German state.

Depending on the geographic area in which the organisation pursues its activities, it is either the Umweltbundesamt (Federal Environmental Agency), or a public authority of the Länder, which is competent to decide on the application for recognition. ${ }^{499}$ Due to this division of competences and because of an overlap between different statutes, ${ }^{500}$ the exact number of recognised environmental organisations is difficult to determine. ${ }^{501}$ According to a list published by the Federal Environmental Agency in 2014, 103 environmental organisations were recognised by the Federation. ${ }^{502}$ This is a very

\footnotetext{
496 BR Drs. 469/12, pp. $40 \mathrm{f}$.

${ }^{497}$ Part II, Chapter 3, Section 1.3 a; Part II, Chapter 4, Section 2.2. a.

$498 \S \S 2$ (1), 3 UmwRG (2013).

${ }^{499}$ A public authority of a Land is competent to decide on the application of an association operating in that Land (§ 3 (3) UmwRG (2013)); an environmental organization operating in more than one Land and foreign environmental organisations have to address their application to the Federal Environmental Agency (\$ 3 (2) s. 1 UmwRG (2013)).

${ }^{500}$ In Germany, there are two statutes under which the recognition of environmental organisations is required, namely the BNatSchG and the UmwRG. Before the UmwRG was adopted, it was only possible to apply for recognition under the BNatSchG. Some of the organisations which are recognized under the BNatSchG have reapplied for recognition under the UmwRG.

${ }^{501}$ Schmidt et al., Die Verbandsklage im Umwelt- und Naturschutzrecht, 2014, p. 40.

${ }^{502}$ UBA, Vom Bund anerkannte Umwelt- und Naturschutzvereinigungen, 10 March 2014 (available online).
} 
small number if compared to the total number of groups which are active in the environmental field. ${ }^{503}$ For example, Greenpeace and WWF are not recognised as environmental organisations under the UmwRG (2013). One reason for the small number of recognised environmental organisations is, that the rules on recognition in the UmwRG are very restrictive. $\$ 3$ UmwRG enumerates five requirements which have to be fulfilled cumulatively.

First, the environmental organisation must, according to its statutes, primarily promote the protection of the environment. ${ }^{504}$ This aim must be an intrinsic value of the organisation, meaning that the organisation must not pursue own commercial interests, but that it must act for altruistic reasons. ${ }^{505}$ Moreover, the organisation has to promote the protection of the environment on a permanent basis. With this rule, $a d$ hoc associations are hindered to access administrative courts. ${ }^{506}$ Second, in the moment of recognition, the environmental organisation must have existed for at least three years and must have been active in the area of environmental protection. ${ }^{507}$ Third, considering its organisational structure and activities, the environmental organisation must show that it is actually capable to pursue the aims as indicated in its statues. In order to determine whether or not this requirement is fulfilled, the competent authority has to consider the type and the scope of the activities of the organisation in the past, the number of members and the capacity of the organisation. ${ }^{508}$ Fourth, the organisation must only pursue aims for the public benefit. ${ }^{509}$ Fifth, the membership in an environmental organisation must be open to everyone who supports the aims of the organisation. ${ }^{510}$ Also legal persons can be members of environmental organisations. A member is defined as a person who is entitled to vote in the general meeting of the association. ${ }^{511}$ Thus, it is not sufficient that a person supports an organisation financially. The ratio for this is that environmental organisations should have internal democratic structures. ${ }^{512}$ The procedure for the recognition is governed by the general rules of the VwVfG. ${ }^{513}$ The environmental organisation does not have to pay any fees for the application. ${ }^{514}$ In case that the five requirements are fulfilled, the competent authority is obliged to grant the status of a recognised environmental organisation (bound decision). ${ }^{515}$ In the administrative decision on the recognition, it has to be indicated which tasks the environmental organisation intends to carry out according to its statutes. ${ }^{516}$

\footnotetext{
${ }^{503}$ Schmidt et al., Die Verbandsklage im Umwelt- und Naturschutzrecht, 2014, p. 42.

$504 \S 3$ (1) s. 2 nr. 1 UmwRG (2013).

505 Fellenberg, Schiller, § 3 UmwRG, in: Landmann, Rohmer (eds.), Umweltrecht, 2015, at 12.

${ }^{506}$ BT Drs. 16/2495, p. 13.

$507 \S 3$ (1) s. 2 nr. 2 UmwRG (2013).

508 § 3 (1) s. 2 nr. 3 UmwRG (2013).

$509 \S 3$ (1) s. 2 nr. 4 UmwRG (2013).

$510 \S 3$ (1) s. 2 nr. 5 UmwRG (2013).

511 Ibid.

512 BT Drs. 16/12274, p. 78 f.

${ }^{513}$ Fellenberg, Schiller, § 3 UmwRG, in: Landmann, Rohmer (eds.), Umweltrecht, 2015, at 34.

$514 \S 3$ (2) s. 3 UmwRG (2013).

${ }^{515}$ Erbguth, Schlacke, Umweltrecht, $5^{\text {th }}$ edition, p. 279.

516 § 3 (2) s. 3 UmwRG (2013).
} 
In principle, these rules also apply to foreign environmental organisations in transboundary cases. ${ }^{517} \mathrm{As}$ they cannot be expected to know about the German recognition procedure, § 2 (2) s. 2 UmwRG provides that standing can be granted in case that an organisation is not yet recognised, but if an application for recognition has been made, and if the competent authority did not yet decide on the application. ${ }^{518}$ However, if no application for recognition is made, the court will deny standing. For example, in a case concerning modifications of an airport in the border region between Germany and the Netherlands, the claim of a Dutch environmental organisation was inadmissible, because it did not make an application for the recognition as an environmental organisation with the Federal Environmental Agency. ${ }^{519}$ The German court considered that even if an application had been made, it would have been unlikely that the organisation had fulfilled the requirements of the UmwRG. The court doubted that, according to the statutes of the organisation, the protection of the environment was the primary aim of the organisation. Instead, the court found that the organisation was concerned with the general interests of the citizens living in the Dutch region concerned. Therefore, the first requirement of $\S 3$ (1) UmwRG was not fulfilled. ${ }^{520}$ This case shows that the recognition procedure constitutes an additional hurdle for (foreign) environmental organisations when accessing courts in Germany. Pursuant to the list published by the Federal Environmental Agency in 2014, there is only one foreign organisation which is officially recognised by the German federation. ${ }^{521}$ The question arises whether a foreign organisation can reasonably be expected to draft its statutes and to conduct its activities in conformity with the German requirements for the case that it might want to access a court in Germany. The compatibility of the German recognition procedure with Union law will be considered in part III. For the purpose of this part, it can be concluded that the requirement of recognition constitutes another restrictive element of the German rules on standing. In the following section, these restrictive rules on standing will be compared to the respective Dutch rules.

\section{b. Netherlands}

\section{National rules on standing}

The Netherlands provides for an interest-based system of judicial review. The basic rule is that belanghebbende (interested parties) can bring a litigation before the administrative courts. ${ }^{522}$ The term "interested party" is defined in article 1:2 (1) Awb as "the person whose interest is directly affected by an administrative decision". ${ }^{523}$ The question is what constitutes an "interest". The courts have developed several criteria according to which an "interest" can be established: a claimant needs to have its own

\footnotetext{
$517 \S 3$ (1) s. 1 UmwRG; the application for recognition has to be made with the Federal Environmental Agency (§ 3 (2) UmwRG (2013).

${ }^{518}$ BT Drs. 16/2495, p. 12.

${ }^{519}$ VG Münster, Judgement of 18 March 2011, Az.: 10 K 2540/09, juris, para. 21.

${ }^{520}$ Ibid., para. 22.

521 The Swiss organisation „Aqua Viva - Rheinaubund”; UBA, Vom Bund anerkannte Umwelt- und Naturschutzvereinigungen, 10 March 2014, (available online).

${ }^{522}$ Art. 8:1 Awb.

${ }^{523}$ Maastricht Collection.
} 
and personal, an objectively determinable, an actual and a direct interest. ${ }^{524}$ The requirement of an "own and personal" interest means that a person may only make a claim on his behalf and that he has to be distinct from other persons. ${ }^{525} \mathrm{Next}$, the interest must be objectively determinable, meaning that it should not only be based on the subjective perception of the claimant. ${ }^{526}$ Moreover, the interest of the claimant is not sufficient if his claim is merely based on hypothetical consequences of the administrative decision. ${ }^{527}$ Finally, there has to be a direct connection between the claimant and the administrative decision. ${ }^{528}$

Next to this provision on persons qualifying as an interested party, 1:2 (3) Awb provides that "as regards legal persons, their interests are considered to include the general and collective interest which they particularly promote by virtue of their objectives and as shown by their actual activities." ${ }^{529}$ Thus, legal persons stipulating in their statutes that they deal with certain public interests, may challenge administrative decisions with regard to general and collective interests. Additionally, the legal person has to conduct actual activities. Environmental organisations can be qualified as interested parties in accordance with article 1:2 (3) Awb and are granted standing in administrative courts on this basis. The wording of article 1:3 (3) Awb is not restricted to environmental organisations. Other interest groups not primarily concerned with environmental objectives may also qualify as interested parties.

The Dutch legal framework as it is applied today in environmental matters is restrictive if compared to the approach adopted two decades ago. Dutch rules on access to courts have undergone a process of change in the last twenty years. ${ }^{530}$ In the following, the process of the restriction of standing possibilities in environmental matters in the Netherlands will be outlined.

\section{National rules on standing in EIA cases}

The development of standing requirements in EIA cases can be divided into two periods. The first period starts with the implementation of the EIA Directive in the Netherlands and ends with the abolition of the actio popularis in 2005 , which demarks the beginning of a process of restriction which until today is characterising discussions on standing in the Netherlands.

(i) First Period: Standing in courts in 1990 - 2005

In the 1990s, the Dutch provisions on access to courts in environmental matters were very liberal. ${ }^{531}$ This was mainly due to fact that environmental organisations could have standing and that the Dutch

\footnotetext{
${ }^{524}$ Damen et al., Bestuursrecht, vol. 2, $4^{\text {th }}$ edition, 2012, p. 79; Schlössels, Stroink, Kern van het bestuursrecht, $4^{\text {th }}$ edition, 2013, pp. 53 ff; Note that the categorisation of jurisprudence may be slightly different: Tak, Het Nederlands bestuursprocesrecht in theorie en praktijk, vol. 1, $5^{\text {th }}$ edition, 2014, p. $649 \mathrm{ff}$.

525 Tak, Het Nederlands bestuursprocesrecht in theorie en praktijk, vol. 1, $5^{\text {th }}$ edition, 2014, p. 649 ff.

526 Ibid., p. 683.

${ }^{527}$ Damen et al., Bestuursrecht, vol. 2, $4^{\text {th }}$ edition, 2012, p. 79.

${ }^{528}$ Tak, Het Nederlands bestuursprocesrecht in theorie en praktijk, vol. 1, $5^{\text {th }}$ edition, 2014, p. $700 \mathrm{ff}$.

${ }^{529}$ Maastricht Collection.

530 Tolsma et al., The Rise and Fall of Access to Justice in The Netherlands, JEL 2009, pp. 309-321.

${ }^{531}$ Backes, Netherlands, in: Ebbesson (ed.), Access to Justice in Environmental Matters in the EU, 2002, p. 379.
} 
system provided for a form of an actio popularis in cases in which the extensive preparation procedure under the Awb was followed. ${ }^{532}$ In this procedure, anyone, not only the interested party, was entitled to submit comments on a planned project. ${ }^{533}$ People who actively participated in this procedure were subsequently granted standing in administrative courts. ${ }^{534}$ For this purpose, the old article 20.6 (2) Wm provided that:

"An application for judicial review against an administrative decision as described in (1) can be made by

a. Those that raised concerns against the draft decision

b. The consultants who took the opportunity to advice on the draft decision

c. Those that raised concerns about alterations of the draft proposal in the final administrative decision

d. Interested parties who can reasonably not be blamed for not raising concerns about the draft decision." 535

Hence, in fact, anyone having participated in the preparation procedure, could have access to the courts in environmental matters. ${ }^{536}$ The precondition to participate in the preparation procedure was taken very seriously by the courts. For example, in a case in which several claimants brought litigations against a permit for a pig fattening farm, the court held that the question by one claimant, who had simply asked why a request for an EIA was rejected, cannot be treated as a concern voiced in the sense of article 20.6 (2) a Wm. ${ }^{537}$ In the same case two claimants submitted that an EIA screening should have been conducted because, according to them, the project for which the permit was granted, was functionally and technically connected to two other projects, which had to be taken into consideration for the assessment whether or not an EIA was necessary. The court found that the applicants did not raise this concern in the preparation procedure. For this reason, this submission was inadmissible. ${ }^{538}$

In another case concerning a waste treatment installation, the claimants alleged that the administrative authority failed to draft an environmental statement. ${ }^{539}$ These claimants, who lived in the surroundings of the installation, did not make any objections to the draft decision in the preparation procedure as they were not informed about the project. However, the applicable rule provided for an obligation to send

\footnotetext{
${ }^{532}$ The extended preparation procedure as applicable under the Awb before the reforms in 2005. For further information on the development of Dutch rules on administrative procedure, please refer to the introductory part of this thesis.

${ }^{533}$ The relevant provision before the reform of 2005 was article 3:24 (1) Awb providing that "een ieder" (everyone) may object to a draft decision.

534 Seerden, Heldeweg, Public Environmental Law in the Netherlands, in: Seerden et al. (eds.), Public Environmental Law in the European Union and the United States, 2002, p. 379.

${ }^{535}$ Own translation.

${ }^{536}$ Backes, Netherlands, in: Ebbesson (ed.), Access to Justice in Environmental Matters in the EU, 2002, pp. $382 \mathrm{f}$.

${ }^{537}$ ABRvS 8 August 2000, E03.98.0103, para. 2.3.

${ }_{538}$ Ibid., para. 2.3; 3 I.

${ }^{539}$ ABRvS 18 September 2000, nr. E03.98.1705, M\&R 2001/71 (with a comment by Verschuuren) para. 2.3.
} 
information on the draft decision to persons living in the surroundings. ${ }^{540}$ The court came to the conclusion that the authority failed to inform these claimants which rendered participation impossible. Thus, these claimants could have standing on the basis of article 20.6 (2) d Wm as they qualified as claimants who cannot be blamed for not participating in the procedure ${ }^{541}$ Being granted standing, they claimed that an EIA should have been conducted. The court came to the conclusion that the waste treatment installation (capable to process of 113,000 t of waste) exceeded the threshold of 25,000 t, meaning that an EIA was obligatory. As a consequence, the decision was quashed. ${ }^{542}$

Next to this broad possibility for anyone to participate in environmental proceedings, there has been the possibility for environmental organisations to institute administrative litigatinos under the rules of the Awb. Environmental organisations have been qualified as "interested parties" since the 1970s and this was later codified in article 1:2 (3) Awb. ${ }^{543}$ Accordingly, an association was an interested party if the issue affected the association's objectives having regard to the association's statutes and actual activities. In 2002, it was found that "NGOs very often object against [sic] environmental decisions. In practice, in almost all cases their appeal is allowed. Of course, NGOs have access to justice like anyone else in the case of a (multi-stage) actio popularis. ${ }^{, 544}$

An example of these broad standing possibilities is the case of test drillings for natural gasoline in the North Sea. ${ }^{545}$ In this case, several environmental organisations, including, among others, the Stichting Natuur en Milieu and Greenpeace, claimed that the environmental statement did not fulfil the requirements of the applicable legislation. ${ }^{546}$ The majority of these environmental organisations were granted standing and were able to challenge infringements of EIA provisions. Only two out of ten environmental organisations did not qualify as interested parties in the sense of 1:2 (3) Awb. ${ }^{547}$ The reason for not admitting the applications of one of these two organisations was that the interest of that association was not impaired by the test drillings. According to the statutes of the association, its aim was the protection of nature in the province of North-Holland, which does not extend to the place where the test drillings should have taken place. Hence, the organisation's application was not admitted. ${ }^{548}$

This overview of the Dutch rules and case law in the 1990s has illustrated that, in the Netherlands, access to justice was "wide" if compared to the situation in Germany ${ }^{549}$ at that time. The obligation of article 9 (2) of the Aarhus Convention requiring access to the court for the public concerned, in cases in which

\footnotetext{
${ }^{540}$ Art. 3:19 (2) Awb in conjunction with art. $13.4 \mathrm{~b} \mathrm{Wm}$ (both provisions as applicable in 2000).

${ }^{541}$ ABRvS 18 September 2000, nr. E03.98.1705, M\&R 2001/71 (with a comment by Verschuuren) para. 2.2.3.

542 Ibid., para. 3.

${ }^{543}$ Backes, Netherlands, in: Ebbesson (ed.), Access to Justice in Environmental Matters in the EU, 2002, p. 387.

${ }^{544}$ Ibid.

${ }^{545}$ Rechtbank Leeuwwaarden 17 July 1998, 97/40 WET; 97/41 WET; 97/42 WET; 97/44 WET; 97/45.

${ }^{546}$ Art. $7.10 \mathrm{Wm}$ (on the content of an EIA).

${ }^{547}$ Rechtbank Leeuwwaarden 17 July 1998, 97/40 WET;97/41 WET; 97/42 WET; 97/44 WET; 97/45, para. 2.2.1.

${ }^{548}$ Ibid., para. 2.2.1.

${ }^{549}$ See the previous section: Part II, Chapter 2, Section 1.2, a.
} 
the administrative decision was taken in a procedure with public participation, ${ }^{550}$ was complied with and environmental organisations could access courts to claim that rules of environmental law were violated. Since these times, the wide possibilities to have access to the courts in the Netherlands have undergone a process of restriction as will be seen in the following section.

Second Period: Standing in courts since 2005

According to Tolsma, de Graaf and Jans, the "fall of access to justice in the Netherlands" was caused by three main developments: the abolition of the actio popularis, the development of case law of the Council of State regarding the interpretation of the term "interested party" and the introduction of the relativiteitsvereiste. ${ }^{551}$ In this section these three causes will be explained briefly.

First, with the reform of the Dutch administrative procedure in 2005 , the actio popularis was abolished ${ }^{552}$ Since this reform, participation in administrative procedures is only possible for interested parties as defined in article 1:2 Awb. ${ }^{553}$ One argument forwarded in favour of the abolition of participation for everyone was that the abolition of the actio popularis would reduce the number of applications for judicial review. In the legislative process, however, the parliament observed that this was not the main reason. ${ }^{554}$ Instead, the abolition would "be a signal" that the government seriously wanted to reduce unnecessary litigation and further streamline the administrative procedures in environmental law. ${ }^{555}$

Second, jurisprudence has restricted access to courts in specific cases. In 2008, the Council of State denied standing of an association which brought a claim against a permit for a poultry farm. ${ }^{556}$ The aim of this association was to promote a healthy and sustainable environment and good spatial planning. The court rejected the claim as the association could not qualify as an interested party in the sense of the Awb. The court found that the objectives enumerated in the statute of the association were not specific enough in order to find a concrete public interest which the association intended to promote. The court continued by assessing the actual activities of the association. The association in practice gave opinions on decisions and brought legal suits. This kind of activity was, according to the court, not sufficient to

\footnotetext{
${ }^{550}$ Art. 6 Aarhus Convention.

${ }^{551}$ Tolsma et al., The Rise and Fall of Access to Justice in The Netherlands, JEL 2009, issue 2, pp. 315 ff.

552 Wet van 26 mei 2005 tot aanpassing van diverse wetten aan de Wet uniforme openbare voorbereidingsprocedure Awb (Aanpassingswet uniforme openbare voorbereidingsprocedure Awb), Stb. 2005, 282.

553 Tolsma et al., The Rise and Fall of Access to Justice in The Netherlands, JEL 2009, issue 2, p. 315.

${ }^{554}$ Kamerstuk II, 2003-2004, 29 421, nr. 3 (Memorie van Toelichting), pp. 3, 4.

${ }^{555}$ Ibid.

${ }^{556}$ ABRvS 1 October 2008, nr. 200801150/1, AB 2008/348 (with a comment by Michiels).
} 
qualify as an interested party in the sense of article 1:2 (3) Awb. ${ }^{557}$ This ruling was followed by the courts in other cases. ${ }^{558}$

Third, a central element in this process of constriction is the introduction of a so-called relativiteitsvereiste (requirement of connection) in the Dutch administrative legal order. ${ }^{559}$ The Crisisen herstelwet $(\mathrm{Chw})^{560}$ of 2010 provided in its article $1.9^{561}$ that:

"The administrative judge does not annul an administrative decision because it infringes written or unwritten rules or general principles if this rule or principle evidently does not aim at protecting the interest of those who want to rely on it." $" 562$

In 2012, this requirement of connection became generally applicable in Dutch administrative law with the creation of article 8:69 a Awb, ${ }^{563}$ which has the same wording as article 1.9 Chw. The newly created rule does not aim at preventing the admissibility of a claim in the courts, but its purpose is to prevent the annulment of an administrative decision once standing in courts has been granted at the stage of admissibility. ${ }^{564}$ Thus, the admissibility of the claim of individuals and environmental organisations is still assessed according to the question of whether they can be qualified as interested parties under the general rules of administrative law. ${ }^{565}$ However, when it comes to the merits of the case, the rule in question must aim at the protection of the interest of the claimant. Any further discussion shall therefore be postponed to be addressed in the chapter on remedies under Dutch law. ${ }^{566}$

Having traced this development of rules applicable to judicial review in EIA matters in the Netherlands, the state of affairs in 2014 is the following: individuals can receive standing in EIA cases if they are interested parties in the sense of article 1:2 (1) Awb. This also includes competitors making a claim

\footnotetext{
${ }^{557}$ Ibid., para. 2.4 .

${ }^{558}$ See for example: ABRvS 14 January 2009, nr. 200800497/1; ABRvS 9 September 2009, nr. 200802966/1, J M 2008/141 (with a comment by van Velsen); ABRvS 2 May 2012, nr. 201011273/1/A4; ABRvS 12 December 2012, nr. 201206403/1/T4; ABRvS 27 February 2013, nr. 201112182/1/R3.

559 The introduction was subject to controversial debates: Backes, Europeesrechtelijke implicaties van het relativiteitsvereiste, in: Addink et al., Grensverleggend bestuursrecht, 2008, pp. 297-308; Backes, Crisistijden voor de waarborgfunctie van het bestuursrecht? De algemeen bestuursrechtelijke aspecten van de Crisis-en herstelwet, M\&R 2009, issue 10, pp. 624, 625; Poorter, De belanghebbende, 2003, pp. 98 ff; Schreuder-Vlasblom, Relativiteit in het bestuursrecht; een discussiebijdrage, NTB 2007/8, pp. 43-52; Schlössels et al., Een Schutznorm in het bestuursproces: selectief winkelen bij de buren?, NTB 2007/34, pp. 245-248; Schueler, Een relativiteitsleer in wording, in: NTB 2011/38, pp. 265 - 271; Verburg, Relativiteit in de Crisis-en herstelwet en in het voorstel Wet aanpassing bestuursprocesrecht of: Hoe moet het nou met het zeggekorfslakje, NTB 2011/3, pp. 10-17; Waard, Relativiteit en rechtsbescherming, NTB 2007/2, pp. 7-14, Waard, Bestuursrechtelijke rechtsbeschermingsleer en relativiteit, NTB 2007/9, pp. 53-60.

560 Wet van 18 maart 2010, houdende regels met betrekking tot versnelde ontwikkeling en verwezenlijking van ruimtelijke en infrastructurele projecten (Crisis- en herstelwet), Stb. 2010, 135, 136, 137.

${ }^{561}$ Art. 1.9 Chw applied until 1. January 2013, Stb. 2012, 682.

562 Own translation.

${ }^{563}$ Wet van 20 december 2012 tot wijziging van de Algemene wet bestuursrecht en aanverwante wetten met het oog op enige verbeteringen en vereenvoudigingen van het bestuursprocesrecht (Wet aanpassing bestuursprocesrecht), Stb. 2012, 684 .

${ }^{564}$ ABRvS 19 February 2014, nr. 201303313/1/A4, M\&R 2014/80 (with a comment by Soppe) para. 3.

${ }^{565}$ Art. 1:2 Awb.

${ }^{566}$ Part II, Chapter 4, Section 1.2 b.
} 
because of economic interests. Environmental organisations and other interest groups can have standing under article 1:2 (3) Awb.

In conclusion, this section illustrated that the development in the Netherlands with regard to access to court went in the opposite direction as the process in Germany. Whereas the German system has been broadening its provisions on access under European pressure, the Dutch system has been in a process of restriction. In the next section the findings in Germany and the Netherlands will be compared with the English system on standing.

\section{c. England}

\section{National rules on standing}

Under the English judicial review system, applicants are granted standing by the courts if they can prove that they have sufficient interest. ${ }^{567}$ The test for standing consists of two stages. ${ }^{568}$ First, at the permission stage, those cases are filtered "where the applicant is a busy-body, or a crank, or a mischief-maker, or motivated by ill-will or some improper purpose". ${ }^{569}$ Second, at the stage of the hearing, the sufficient interest is assessed in the light of the legal and factual context of the case. ${ }^{570}$ "Sufficient interest" can always be established when the claimant is the addressee of an administrative action. ${ }^{571}$ Moreover, there are various examples of cases in which claimants were granted standing when they challenged a decision concerning another individual, the public in general or a sector of the public. ${ }^{572}$ However, the courts decide on a cases-by-case basis and representational standing will not be granted in any case. For example, standing was denied in the case of a company that was set up for the protection of the remains of Rose Theatre, which brought a claim for judicial review against the decision of the Secretary of State not to list the site as a protected monument. ${ }^{573}$ In this case, Schiemann J held that the group could not be granted standing, since the people in the group did not have sufficient interest. ${ }^{574} \mathrm{He}$ noted that:

"The law does not see it as the function of the courts to be there for every individual who is interested in having the legality of an administrative action litigated." 575

This quote stresses that not just anyone will be granted standing in English courts. However, if compared to the German rules described previously, the English test is very broad. English courts have been willing

\footnotetext{
567 Section 31 (3) of the Supreme Court Act 1981.

568 Wade, Forsyth, Administrative Law, $11^{\text {th }}$ edition, 2014, p. 587.

${ }^{569}$ Lewis, Judicial Remedies in Public Law, $4^{\text {th }}$ edition, 2009, at 10-007.

${ }^{570} R v$ Inland Revenue Commissioners ex parte National Federation of the Self-Employed and Small Business Ltd [1982] AC 617 (630 D).

571 Wade, Forsyth, Administrative Law, $11^{\text {th }}$ edition, 2014, p. 584.

572 Lewis, Judicial Remedies in Public Law, $4^{\text {th }}$ edition, 2009, at 10-014 f.

${ }^{573} R v$ Secretary of State for the Environment, ex parte Rose Theatre Trust [1990] 1 QB 504.

${ }^{574}$ Ibid. (522).

${ }^{575}$ Ibid. (522).
} 
to grant standing to environmental organisations and other public interest groups in various cases. ${ }^{576} \mathrm{~A}$ leading case in this regard is the case of Greenpeace which brought a claim against the grant of authorisations for operations on a nuclear site. ${ }^{577}$ The operator, British Nuclear Fuel, argued that Greenpeace was not entitled to the relief sought as it did not have sufficient interest in the matter. This argument was not accepted by Otton J presiding over the case, who held:

"Thus I approach this matter primarily as one of discretion. I consider it appropriate to take into account the nature of the applicant and the extent of the applicant's interest in the issues raised, the remedy Greenpeace seeks to achieve and the nature of that relief sought." ${ }^{578}$

As to the nature of the applicant, he observed that Greenpeace has a great number of supporters, 400,000 , in the UK. Moreover, Greenpeace has consultative status with the UN Economic and Social Council. He found that Greenpeace has a genuine concern for the environment and "that concern naturally leads to a bona fide interest in the activities carried on by BNFL at Sellafield and in particular the discharge and disposal of radioactive waste. ${ }^{579}$ Furthermore, he recognised the expertise of Greenpeace which individual employees of BNFL or neighbours do not have and which would hinder them from bringing an effective claim. Finally, he rejected the view that Greenpeace is a "meddlesome busybody" in bringing the claim. ${ }^{580}$ Therefore, standing was granted but the claim was finally dismissed for other reasons.

Also in other cases, English courts were willing to grant standing where only public interests were involved. This was explicit in the case of the World Development Movement, a pressure group concerned with British development aid given to other countries. ${ }^{581}$ The group challenged a decision of the Secretary of State concerning the funding of a hydro-electric power station on the Pergau River in Malaysia. The court held that the merits of the case "are an important if not dominant factor", ${ }^{582}$ when deciding the issue of locus standi. Thus, even if there was no geographical proximity between the claimants and the location of the project, several factors were important for the consideration of standing of the group, namely:

"The importance of vindicating the rule of law, as Lord Diplock emphasised [1982] A.C. 617; the importance of the issue raised, as in Ex parte Child Poverty Action Group [1990] 2 Q.B.

\footnotetext{
${ }^{576} R$ vSecretary of State for Social Services, ex parte Child Poverty Action Group [1990] 2 QB 540 (546, 547); $R v$ Secretary of State for Employment, ex parte Equal Opportunities Commission [1992] 1 All ER 545; $R v$ Secretary of State for the Environment, ex parte Kirkstall Valley Campaign Ltd [1996] 3 All ER 304, [308][309]; Endicott, Administrative Law, $3^{\text {rd }}$ edition, 2015, pp. 425, 426; Sheridan, United Kingdom, in: Sadeleer et al. (eds.), Access to justice in environmental matters and the role of NGOs, 2005, pp. 156-159.

${ }^{577} R$ v Her Majesty's Inspectorate of Pollution and Ministry of Agriculture Fisheries and Food, ex parte Greenpeace Ltd. (No. 2) [1994] 2 CMLR 548 (QB).

${ }^{578}$ Ibid. [78].

${ }^{579}$ Ibid. $[81]$.

${ }^{580} \mathrm{Ibid}$. [76].

${ }^{581} R$ v Secretary of State for Foreign and Commonwealth Affairs, ex parte World Development Movement [1995] 1 WLR 386.

${ }^{582}$ Ibid. (395).
} 
540; the likely absence of any other responsible challenger, as in Ex parte Child Poverty Action Group and Ex parte Greenpeace Ltd. (No. 2) [1994] 4 All E.R. 329; the nature of the breach of duty against which relief is sought (see per Lord Wilberforce, at p. 630D, in Ex parte National Federation of Self-Employed and Small Businesses Ltd.); and the prominent role of these applicants in giving advice, guidance and assistance with regard to aid: see Ex parte Child Poverty Action Group [1990] 2 Q.B. 540, 546H." ${ }^{, 53}$

This broad approach was also adopted in the case of Dixon, which concerned the challenge of a conditional planning permission for the extension of limestone extraction operations. ${ }^{584}$ The applicant was a local resident but was not a landowner and did not have any other right that could be infringed by the extraction operations. The court found:

"Mr Dixon is plainly neither a busybody nor a mere troublemaker, even if the implications of his application are troublesome for the intended respondents. He is, on the evidence before me, perfectly entitled as a citizen to be concerned about, and to draw the attention of the court to, what he contends is an illegality in the grant of a planning consent which is bound to have an impact on our natural environment." 585

From these cases, it follows that individuals, environmental organisations and other public interest groups, including ad hoc groupings, may be granted standing in English courts if they can show "sufficient interest" in the subject matter. Regarding this liberal approach Woolf J. held:

"... it would be regrettable if a court had to come to the conclusion that in a situation where the need for the intervention of the court has been established this intervention was prevented by rules as to standing." $" 586$

One important exception to this liberal approach concerns cases brought on the infringement of rights that flow from the ECHR. Here, only the individual or legal person concerned by the administrative measure or omission can claim that his right under the Convention was infringed upon, ${ }^{587}$ meaning that public interest groups cannot bring representative actions. ${ }^{588}$

From this section, it follows that access to English courts is "wide" as far as rules on standing are concerned. Nevertheless, recent reforms of the civil procedure rules and the planning law system have introduced a new entry barrier. The application for judicial review consists of two steps. First an application in writing is made upon which the court will decide whether to grant permission to proceed or not. If permission to proceed is granted, the application for judicial review will be decided by the

\footnotetext{
583 Ibid. (395).

${ }^{584} R$ v Somerset County Council, ex parte Dixon [1998] Env LR $111(118,119)$.

585 Ibid. (121).

${ }^{586} R$ v Attorny General, ex parte Imperial Chemical Industries PLC [1985] 1 CMLR 588 (QB) [97].

${ }^{587}$ Section 7 (3) Human Rights Act 1998.

${ }^{588}$ Bell et al., Environmental Law, $8^{\text {th }}$ edition, 2013, p. 341.
} 
court. In case the permission is not granted, the applicant may request the reconsideration of its application to proceed in an oral hearing. Since 1 July 2013, section 54.12 (7) CPR provides that in case the court refuses to proceed with the application for judicial review and finds that "the application is totally without merit in accordance with rule 23.12 , the claimant may not request that decision to be reconsidered at the hearing." This means that the party will not be able to apply anew for permission to proceed in an oral procedure. The background to this new filter is that "weak, frivolous and unmeritorious cases could be filtered out at as early a stage as possible, reducing delays and costs." 589 The practical consequences of this rule for judicial review proceedings are not yet clear.

Finally, as far as appeals under section 288 TCPA are concerned, "aggrieved persons" may resort to this remedy. According to Bell, "this includes all parties who appeared at the inquiry or made representations (though this is not a rigid test), as well as the appellant, the local planning authority, and owner and occupiers of the site". ${ }^{590}$

\section{National rules on standing in EIA cases}

The liberal approach adopted under English law also applies in principle in EIA cases. This does not mean that standing is granted in any case, but since the beginnings of EIA enforcement, there are examples of individuals being granted standing in courts to challenge infringements of EIA legislation. For example, the case of Beebee ${ }^{591}$ concerned a claim against a planning permission for housing development in an area which, after planning permission was granted, was meant to become part of a site of special scientific interest under the Wildlife and Countryside Act. The applicants in this case were representatives of the Worldwide Fund for Nature and the British Herpetological Society. Schiemann J granted standing to both parties, mainly because of their financial contribution to the maintenance of the site. He observed:

"The position of the Worldwide Fund for Nature (the current name for the World Wildlife Fund) is that it had been involved in the conservation of the Dorset heathlands for over 15 years, has made grants to the BHS since 1971 to assist them in carrying out their work on habitats for sand lizards and smooth snakes, and is an accredited participant at meetings of the contracting parties to the Berne Convention since 1986." ${ }^{\circ 92}$

Therefore, the two environmental organisations were granted standing in this case.

In the early years of EIA litigation, there is also an example of a rather restrictive approach to standing. This was the case of Twyford Parish Council ${ }^{593}$ which concerned an authorisation of the Secretary of

\footnotetext{
${ }^{589}$ Ministry of Justice, Reform of Judicial Review, Government response, April 2013, p. 19, at 75.

${ }^{590}$ Bell et al., Environmental Law, $8^{\text {th }}$ edition, 2013, p. 443.

${ }^{591} R$ v Poole Borough Council, ex parte Beebee [1991] JPL 643 (QB).

592 Ibid.

${ }^{593}$ Twyford Parish Council and Others v Secretary of State for the Environment and Another [1992] 1 CMLR 276. 
State to build a six-lane motorway. The applicants, one of them being Twyford Parish Council, submitted that the Secretary of State had been obliged to make an EIA and to give the members of the public an opportunity to express their opinion on this issue. Mc Cullough J, in obiter dictum discussed the situation in which an individual can rely on the failure of a Member State to implement a directive and he found that only individuals who suffered from the decision may be granted standing. In this regard he states:

"The first question is perhaps to decide what is meant by 'relying upon' rights and 'asserting' rights. I take both expressions to assume that such rights have been infringed. And by infringement I mean that the individual has suffered in some way from the failure to accord him his rights [...] The other, and I think much more likely, interpretation of the words in question is that the Court was saying that an individual whose rights has been infringed, in the sense that he had suffered as a result of the failure, could rely upon the directive as against others than the State. ${ }^{\circ 94}$

With respect to the applicants, the judge held:

"no prejudice, let alone any substantial prejudice, to the applicants has been shown. [...] The highest Mr. Mole was able to put it was to say [...] that an environmental statement and a nontechnical summary might have saved the applicants time, trouble and money." 595

What follows from these lines is that, due to the fact that there was no infringement of a right of the applicants, no standing was granted. This line of argumentation should however not be generalised and it should be noted that at this point the Commission had already initiated infringement proceedings against the UK on the implementation of the EIA Directive, in which it also questioned the decision in Twyford..$^{596}$

A recent example for the rather broad standing possibilities if compared to German rules on standing is the case of Save Britain's Heritage (abbreviation: SAVE), an association campaigning for the preservation of historic buildings. The association sought a declaration that a demolition direction was unlawful, should not be given effect and that planning permission was necessary for the demolition of a Brewery. SAVE argued that an EIA was necessary. The issue of standing was not addressed. Although

\footnotetext{
${ }^{594}$ Ibid. [60], [62].

595 Ibid. [82].

596 The UK had received a letter by the Commission on 17 October 1991 under article 169 EC Treaty; Salter, Environmental assessment: the challenge from Brussels, JPEL 1992, p. 17; the infringement procedure concerning the Twyford case was however closed in 1992: European Commission Press Release 92/51, 31 July 1992; Environmental Impact Assessment: European Community decisions, JPEL 1992, pp. 913 - 918.
} 
the association's case was dismissed on the merits in first instance, ${ }^{597}$ their case was successful at the court of appeal. ${ }^{598}$

Another case which illustrates that access to English courts is "wide" is the case of Edwards who wanted to challenge the grant of a permit to a local cement factory. ${ }^{599}$ Inter alia, he complained that the environmental statement was not published.

'So what is known about Mr Edwards? The claim form gives little away. It simply said that he was "a resident of Rugby who is affected by the operation of the [Company's] works and is concerned about the effects of the operations now permitted". It did not even give his address. In a subsequent witness statement, he said that he had lived in Rugby all his life, except while serving in the RAF, and he identified a large number of addresses in Rugby at which he had lived. A local councillor has said that at least at some of the places he had lived, he would have been affected by pollution from the Company's works. But she made no comment about his last address (wherever that was), and she states that he is currently homeless — though still in Rugby, I was told. ${ }^{600}$

Moreover, Edwards did not actively participate in the consultation process and only got involved when a local group campaigning against the factory searched for a "volunteer" who would be eligible for legal aid to make a claim for judicial review. ${ }^{601}$ Keith $\mathrm{J}$ found that the simple fact that Edwards was an inhabitant of the city proved that he had sufficient interest. ${ }^{602}$

Finally, the recent Scottish ${ }^{603}$ case of Walton illustrates that also under statutory review the test of an "aggrieved party" is broad. ${ }^{604} \mathrm{Mr}$. Walton challenged the road scheme adopted for the construction of a bypass near Aberdeen. His application was unsuccessful at the first instance court. At the Supreme Court, the question was whether Mr. Walton was an "aggrieved party". Lord Reed held that he was for a number of reasons: Mr. Walton had made representations to the Ministers and had participated in the local inquiry; he is a member of a local environmental organisation and the chairman of the local group opposing the project. Although he lives at "some distance from the Fastlink", the traffic will increase and he was not a "mere busybody". ${ }^{605}$ Furthermore, if the claim had been brought as a judicial review

\footnotetext{
${ }^{597} R$ (Save Britain's Heritage) v Secretary of State for Communities and Local Government and another [2010] EWHC 979 (Admin.); [2011] EnvLR 6.

${ }^{598} R$ (Save Britain's Heritage) v Secretary of State for Communities and Local Government and another [2011] EWCA Civ 334; [2011] 2 CMLR 48.

${ }^{599} R$ (Edwards) v Environment Agency [2004] EWHC 736 (Admin); [2004] 3 All ER 21.

${ }^{600} \mathrm{Ibid}$. [10].

${ }^{601} \mathrm{Ibid} .[12]-[13]$.

${ }^{602} \mathrm{Ibid}$. [15].

${ }^{603}$ The ruling on the issue of standing has the same relevance for the Scottish as for the English legal system: Lord Carnwath at para. 102: 'I have nothing to add to Lord Reed's discussion of the expression "person aggrieved", which confirms, as I understand it, that Scottish practice on these matters is, or should be, in line with that south of the border'.

${ }^{604}$ Walton $v$ The Scottish Ministers [2012] UKSC 44; [2013] 1 CMLR 28.

${ }^{605} \mathrm{Ibid}$. [88].
} 
claim, Mr. Walton would have been an interested party. ${ }^{606}$ The judgment therewith confirmed the broad approach to standing, not only under Scottish but also under English law. ${ }^{607}$ The other issue dealt with by the Court concerned the discretion to grant a remedy, but that discussion will be postponed to the chapter on remedies. ${ }^{608}$

In the workshop ${ }^{609}$ organised with judges from the three legal systems, it was emphasised that, in England, access to justice is "wide" as regards rules on standing. Whereas in Germany and the Netherlands not all claimants were admitted to court, in England, property owner A, the action group in the village, the environmental organisation, and the competitor would have been granted standing in court.

In conclusion, the approach adopted by the English courts on the question of standing is very liberal. Individuals, competitors, environmental organisations, and other interest groups are admitted to the courts in order to challenge infringements of EIA legislation if they have a sufficient interest (judicial review) or if they are are aggrieved parties (statutory appeal), which are rather light tests.

\section{d. Comparison: differences and convergence}

This section has traced the main lines of development of rules on standing in EIA cases in the three legal systems selected. When the Member States had to implement the initial version of the EIA Directive, legal systems on locus standi varied greatly. In Germany, courts held that the transposing legislation, the UVPG, did not provide for rights which could form the basis for a claim in administrative courts. Thus, an important group, namely environmental organisations, was practically excluded from contributing to the enforcement of Union law. In contrast, the Netherlands provided for an actio popularis and environmental organisations were regarded as interested parties under the Dutch rules of judicial procedure. Also in England, environmental organisations have been granted standing in environmental cases in the 1990. As a result, different types of claimants had very different chances of being admitted to courts depending on the legal system in which they were pursuing their claims because of different rules on standing. These differences, which originally existed, have been diminishing to a certain extent, meaning that there are piece-meal processes of convergence of the administrative litigation systems of the Member States. An important trigger for this process was the adoption of the Aarhus Convention in 1998. However, also national reforms, independent from Union interference have contributed to the convergence of national legal systems in environmental EIA claims.

To begin with the role of the Aarhus Convention in this process, it has to be recalled that article 9 (2) requires that Member States have to give the public concerned the possibility to have access to the courts

\footnotetext{
${ }^{606}$ Ibid. [96].

${ }^{607}$ McCracken, Edwards, Standing and discretion in environmental challenges: Walton, a curate's egg, JEPL 2014, pp. 304-314.

${ }^{608}$ Part II, Chapter 4, Section 1.2, c.

${ }^{609}$ See the Annex for the hypothetical case study.
} 
in claims concerning decisions that were taken in administrative procedures with public participation, such as the EIA procedure. Access may be made dependent on the infringement of an interest or a right, but article 9 (2) s. 3 of the Aarhus Convention expressly refers to environmental organisations which "shall be deemed to have rights capable of being impaired for the purpose" of this paragraph. Under these rules and the respective implementing legislation of the Union, Germany was forced to reform its system on standing for environmental organisations. On the basis of the national statute for judicial review in (certain) environmental matters from 2013, recognised environmental organisations have the possibility to challenge decisions without alleging the infringement of a rule that at least also protects the rights of individuals. There has been convergence between the German legal system and the other two legal systems to the extent that in all three legal systems, environmental organisations are now able to challenge decisions infringing EIA legislation. Contrary to this, there has been no convergence triggered by article 9 (2) of the Aarhus Convention as it pertains to the ability of other public interest groups or individuals to have access to the courts in EIA claims. Furthermore, it should be stressed that differences between the legal systems remain as far as the recognition of associations as environmental organisations is concerned. In Germany, environmental organisations need to be recognised by the state in order to be granted standing in German courts in EIA claims, whereas in England and in the Netherlands, judges decide whether or not an association is an interested party in the case at issue. In this regard, there are no convergences between the legal systems under the influence of the Aarhus Convention.

National reforms which have initiated a process of convergence have been described in the section on the Dutch legal system. With the abolition of the actio popularis, the Dutch legal system made the first step towards a more restrictive approach to access to justice. Since 2005, it is no longer possible for everyone who participated in the administrative procedure to have access to the courts. Moreover, the introduction of the relativiteitsvereiste has moved the Dutch legal system in the direction of the German legal system, but important differences remain. The first difference concerns the moment in which the "requirement of connection" is dealt with in the courts. In claims for annulment under German general procedural administrative law, the issue is dealt with twice, first at the stage of access ${ }^{610}$ and subsequently when assessing the merits of the claim. ${ }^{611}$ In environmental claims, environmental organisations are granted standing under the special rules implementing the requirements of the Aarhus Convention without the need to claim the infringement of a rule that at least also protects the rights of an individual. ${ }^{612}$ For the success of such a claim, a rule has to be infringed which aims at the protection of the environment, and the interests of the environmental organisation, as provided for in its statues, have to be affected. ${ }^{613}$ Hence, in environmental matters in Germany, the Schutznorm requirement is a hurdle for access to the courts for any claimant not being a recognised environmental organisation

\footnotetext{
$610 \S 42(2) \mathrm{VwGO}$.

$611 \S 113(1) \mathrm{VwGO}$.

${ }^{612} \S 2$ (1) UmwRG; under nature protection law, standing is granted on the basis of § 64 BNatSchG.

${ }^{613} \S 2(5)$ UmwRG.
} 
bringing a claim on the basis of special procedural rules. In the Netherlands, the relativiteisvereiste is not a hurdle for access to the courts, but it only plays a role when the judge has to determine whether or not the remedy sought can be granted. Therefore, the Dutch rule will be dealt with in more detail in the section on remedies.

The second difference is that under German law, the general rules require that rule in question at least also protects the rights of individuals, whereas the Dutch rule stipulates that a remedy is not granted if the rule obviously does not aim at protecting the interests of the claimant. What the difference between "rights" and "interests" in a concrete case means can be illustrated by comparing the interpretation of the rules of the EIA Directive in the two legal systems. The German case of Trianel arose because according to the rules at that time, environmental organisations were only granted standing in administrative courts if they could allege the infringement of a rule which at least also protects the rights of individuals. According to German doctrine and jurisprudence, the rules of the EIA procedure did not provide for such rights. Thus, in EIA cases, environmental organisations could not challenge an infringement of EIA legislation. Contrary to this, in the Netherlands, provisions of the EIA procedure may aim at the protection of the interests of the claimant, which means that if an EIA rule concerns the interests of the claimant, the relativiteitsvereiste does not prevent the decision from being annulled. Hence, there are differences between the two legal systems, but the aim of both rules is the same, namely to prevent an objective control of administrative decisions by introducing a requirement of connection between the rule infringed and the claimant.

Furthermore, a very cautious convergence between the German and the Dutch legal systems can be observed, as regards the criteria which an environmental organisation has to fulfil for the purpose of accessing administrative courts in environmental matters. In 2008, the Dutch Council of State stressed the importance of the specific designation of the tasks of an environmental organisation in their statutes. If the tasks as indicated in the statutes are too general and if there are no related activities, the organisation is not an interested party in the sense of the Awb and the claim is inadmissible. Comparable to this, in Germany, environmental organisations have to specify the aims which they want to pursue in their statutes, and the primary aim has to be the protection of the environment. Moreover, the organisation has to show actual activities aiming at environmental protection. Otherwise, the organisation cannot be recognised by the state which is a prerequisite to be granted standing in court. Although the German rule is still (much) narrower than the Dutch rule, one may still speak of a very cautious approximation between the legal systems.

To conclude, in 2014, the rules on standing for environmental organisations are similar in the three legal systems under consideration. But this is not the case with rules on standing for individuals, competitors and other public interest groups. As a consequence of this, courts in the three Member States dealing with the same set of facts come to different judgments. As was proven in the workshop, under the English legal system, all four claimants would be granted standing in court, whereas in Germany only 
the claim of the environmental organisation would have been admissible if one follows the leading jurisprudence of the Federal Administrative Court. It was however stressed that according to the opinion of the North-Rhine Westphalian judges, the German legal system will have to broaden access in environmental matters in order to implement the requirements of the Aarhus Convention. In the Netherlands, the individual would not be granted standing and also the claim of the public interest group would probably not have been admissible. However, the competitor and also the environmental organisation would be granted standing in Dutch courts.

In the end of this section on standing rules, it can be observed that in the past 27 years of EIA enforcement the chances of accessing courts in EIA claims have been different depending on the rules on standing in the three legal systems. The following table gives an overview summarising the similarities and differences in rules on standing in 2014: 
Table 7: Rules on standing in EIA claims in $\mathbf{2 0 1 4}$

\begin{tabular}{|c|c|c|c|}
\hline & Germany & The Netherlands & England \\
\hline Individuals & $\begin{array}{l}\$ 42(2) \text { VwGO } \\
\text { infringement of an } \\
\text { individual right under } \\
\text { public law }\end{array}$ & $\begin{array}{l}\text { Article 1:2 (1) Awb } \\
\text { Interested natural } \\
\text { persons }\end{array}$ & $\begin{array}{l}\text { Interested Parties } \\
\text { (Judicial Review) } \\
\text { Aggrieved Parties } \\
\text { (Statutory Appeal) }\end{array}$ \\
\hline $\begin{array}{l}\text { Environmental } \\
\text { Organisations }\end{array}$ & $\begin{array}{l}\S 2 \text { (1) UmwRG } \\
\text { Officially recognised } \\
\text { environmental } \\
\text { organisation; } \\
\text { No necessity to claim } \\
\text { the infringement of rule } \\
\text { which creates individual } \\
\text { rights under public law }\end{array}$ & $\begin{array}{l}\text { Art. 1:2 (3) Awb } \\
\text { Interested legal } \\
\text { persons }\end{array}$ & $\begin{array}{l}\text { Interested Parties } \\
\text { (Judicial Review) } \\
\text { Aggrieved Parties } \\
\text { (Statutory Appeal) }\end{array}$ \\
\hline $\begin{array}{l}\text { Other Public Interest } \\
\text { Groups }\end{array}$ & $\begin{array}{l}\text { § } 42 \text { (2) VwGO } \\
\text { infringement of an } \\
\text { individual right under } \\
\text { public law }\end{array}$ & $\begin{array}{l}\text { Art. 1:2 (3) Awb } \\
\text { Interested legal } \\
\text { persons }\end{array}$ & $\begin{array}{l}\text { Interested Parties } \\
\text { (Judicial Review) } \\
\text { Aggrieved Parties } \\
\text { (Statutory Appeal) }\end{array}$ \\
\hline
\end{tabular}

Next to rules on the standing of claimants, rules on costs may constitute a hurdle for access to court. Therefore, the next section will deal with costs and cost risks. 


\section{Rules on costs}

Although the Member States of the Union have the competence to create rules on costs for environmental litigation, they have to implement the requirements arising from the Aarhus Convention and the respective Union legislation. This section will first provide a brief overview of international rules on costs (2.1), followed by an illustration of rules on costs in EIA cases and some final considerations on differences and convergences between the legal systems (2.2).

\subsection{International and European rules on costs}

Article 9 (4) of the Aarhus Convention requires that judicial procedures shall not be "prohibitively expensive". According to the implementation guide, this means that the public, comprising individuals and non-governmental organisations, should not be prevented from bringing claims to courts because of costs and the contracting states should provide for mechanisms to reduce costs. ${ }^{614}$ Article 11 (4) EIA Directive repeats this requirement stating that any such procedure shall not be "prohibitively expensive." The Court of Justice had to interpret this expression in several cases. In Commission v Ireland the Court had to rule on the implementation of the obligation that procedures should not be prohibitively expensive in Irish law. ${ }^{615}$ According to the Court, the requirement did not prevent courts from making cost orders. ${ }^{616}$ However, a mere practice by courts on costs orders was not seen as a sufficient implementation of the respective Union rules. ${ }^{617}$ Furthermore, the Court of Justice had to interpret the requirement of "not prohibitively expensive costs" in the case of Edwards ${ }^{618}$ and in Commission v UK. ${ }^{619}$ In Edwards, the Court of Justice held that the determination of whether costs are prohibitively expensive cannot only be assessed by paying regard to the financial situation of the claimant, but that it also has to be based on an objective analysis of costs. ${ }^{620}$ Moreover, the fact that a claimant was not deterred from bringing a claim is not decisive for the determination of whether costs are prohibitively expensive. ${ }^{621} \mathrm{In}$ Commission $v$ UK, the court stressed that costs for proceedings need to be predictable. ${ }^{622}$ A more detailed analysis of these cases will be postponed to the section on costs in England. For the moment, it suffices to say that the Aarhus Convention and the respective Union rule only prescribe the outer limits for the cost regime in the national legal systems which means that rules can differ, as will be described in the following section.

\footnotetext{
${ }^{614}$ Ebbesson et al., The Aarhus Convention: An Implementation Guide, $2^{\text {nd }}$ edition, 2014 (available online), p. 203. ${ }^{615}$ C-427/07, Commission of the European Communities v Ireland [2009] ECR I-6277.

${ }^{616} \mathrm{Ibid}$, . para. 92.

${ }^{617}$ Ibid., para 94.

${ }^{618}$ C-260/11, The Queen, on the application of David Edwards and Lilian Pallikaropoulos v Environment Agency and Others (Judgment of 11 April 2013).

${ }^{619}$ C-530/11, European Commission v United Kingdom of Great Britain and Northern Ireland (Judgment of 13 February 2014).

${ }^{620}$ Ibid., para. 40.

${ }^{621}$ C-260/11, The Queen, on the application of David Edwards and Lilian Pallikaropoulos v Environment Agency and Others (Judgment of 11 April 2013) para. 43.

${ }^{622}$ C-530/11, European Commission v United Kingdom of Great Britain and Northern Ireland (Judgment of 13 February 2014) para. 58.
} 


\subsection{National rules on costs}

The comparison of national rules on costs in environmental litigation is a very complex and technical issue, including the necessity of empirical research, which would require a separate research on its own. ${ }^{623}$ For the purpose of this research, with the aim of finding the main differences between litigation systems and analysing their impact on the enforcement of the EIA Directive, it suffices to concentrate on the comparison of general rules. This section will therefore only focus on court fees and cost orders in the three legal systems and describe their implications for the enforcement of environmental law.

\section{a. Germany}

\section{National rules on costs}

According to $§ 161(1)$ VwGO "the court shall rule on the costs in the judgment or, if the proceedings are concluded by other means, by order." ${ }^{24} \S 154$ VwGO sets out the basic principle that the losing party has to bear the costs of the litigation. In case the administrative authority loses the case, it has to bear the costs of the claimant, including the court fees and other expenditures. Vice-versa, if the claim of the claimant is not successful, he has to bear the costs of the administrative authority. In case a party only wins on certain grounds but loses on others, the costs of the parties are distributed among the parties having regard to proportionality or the costs are offset against each other. ${ }^{625}$ In case a party withdraws a claim, that party has to bear the costs. ${ }^{626}$ Moreover, "costs arising by the fault of a party concerned may be imposed on the latter". ${ }^{627}$ Third parties may only be ordered to pay for costs if they made applications or an appeal. ${ }^{628}$

Pursuant to $\S 162$ (1) VwGO, costs comprise court fees and the costs a party incurred because of the litigation, including the pre-litigation phase. The calculation of court fees follows a table which is annexed to the Gerichtskostengesetz (statute on court fees; abbreviation: GKG.) ${ }^{629}$ This calculation is based on the Streitwert (value of the claim). In principle, the value of the claim is determined by the court at the moment that the claim is submitted to the court. ${ }^{630}$ The court will base its decision on the submission by the claimant. ${ }^{631}$ In case there are not sufficient indications about costs in the submissions,

\footnotetext{
${ }^{623}$ Comparative research on court fees: Faure, Moerland, Griffierechten, Een vergelijkende beschrijving van griffierechten-en vergelijkbare stelsels in een aantal landen van de Europese Unie, 2006; comparative research on costs in general, but before reforms in England took effect: Hodges et al., Costs and Funding of Civil Litigation: A Comparative Study, 2009.

${ }^{624}$ Translation by the Federal Ministry of Justice and Consumer Protection, available online (translated by Neil Musset).

${ }^{625} \S 155(1) \mathrm{VwGO}$.

$626 \S 155(2) \mathrm{VwGO}$.

${ }^{627} \S 155$ (4) VwGO; translation provided online by the Federal Ministry of Justice and Consumer Protection (Neil Musset).

$628 \S 154(2) \mathrm{VwGO}$.

${ }^{629}$ Gerichtskostengesetz, 27.02.2014, BGBl. I pp. 154-217.

${ }^{630} \S 63(1) 1$ GKG.

${ }^{631} \S 52(1),(3)$ GKG.
} 
the judge shall assume that the value of the claim amounts to $€ 5,000 .{ }^{632}$ Additionally, judges may consult a non-binding catalogue on the value of the claim which provides guidelines for the assessment of costs. ${ }^{633}$ Annex 2 to the GKG contains a table indicating which fee has to be paid relative to which value of the claim. For example, if the value of the claim amounts to $€ 5,000$, the fee is $€ 146$. This fee then has to be multiplied by a factor indicated in Annex 1 to the GKG depending on the form of action brought in court. For example, in a claim for judicial review at a first instance court the factor for multiplication is " 3,0 ". This means that the court fees amount to $€ 146 \times 3,0=€ 438$.

Next to court fees, a losing party will also have to pay for other costs which the winning party incurred because of the claim for judicial review. ${ }^{634}$ This includes the fees paid to the lawyer. ${ }^{635}$ Moreover, travelling costs and costs for communication are eligible for reimbursement. ${ }^{636}$ Furthermore, the costs which the winning party incurred in order to obtain private expert statements can, under certain circumstances, be included in the calculation of costs. ${ }^{637}$

Individuals and legal persons can apply for legal aid according to $§ 166 \mathrm{VwGO}$, which declares that the civil litigation rules on legal aid are applicable in administrative litigations. ${ }^{638}$ Legal aid is granted upon request, in case a party is, because of their personal and economic situation, not, or only in instalments, able to pay for the judicial procedure. For this purpose, the envisaged enforcement in court must have a reasonable chance of success and must not seem mischievous. ${ }^{639}$

\section{National rules on costs in EIA cases}

As explained in the introduction, the determination of the amount of court fees follows the rules of the GKG and the guidelines given by the non-binding catalogue on the value of the claim. In this catalogue, the value of claims brought by environmental organisations was set at an amount of least $€ 15,000$ in 2004. ${ }^{640}$ Since 2013, the catalogue sets out that the usual value of the claim is between $€ 15,000$ and $€ 30,000 .{ }^{641}$ In an application for legal aid decided by the OVG Münster in 2008, it was questioned whether the amount indicated in the catalogue of 2004 was compatible with the requirement that the procedure should "not be prohibitively expensive". ${ }^{642}$ The court answered this question affirmatively. ${ }^{643}$

\footnotetext{
$632 \S 52(2)$ GKG.

${ }^{633}$ Streitwertkatalog für die Verwaltungsgerichtsbarkeit (in der Fassung der am 31. Mai/1. Juni 2012 und am 18 Juli 2013 beschlossenen Änderungen) (available online).

$634 \S 162(1) \mathrm{VwGO}$.

${ }^{635} \S 162$ (2) s. 1 VwGO; The costs of lawyers are calculated on the basis of the Rechtsanwaltsvergütungsgesetz (RVV), 5.05.2004, BGBl. I pp. 718-788.

${ }^{636}$ Neumann, $\$ 162$ VwGO, in: Sodan, Ziekow (eds.), VwGO Kommentar, $4^{\text {th }}$ edition, 2014, at 28, 51; Olbertz, $\S 162$ VwGO, in: Schoch et al. (eds.), VwGO Kommentar, 2014, at 18, 19, 26.

${ }^{637}$ Neumann, $\S 162$ VwGO, in: Sodan, Ziekow (eds.), VwGO Kommentar, $4^{\text {th }}$ edition, 2014, at 31-42; Olbertz, $\S 162$ VwGO, in: Schoch et al. (eds.), VwGO Kommentar, 2014, at 27-30.

${ }^{638} \S \S 114$ ff. or 569 (3) nr. 2 ZPO.

639 § 114 (1) s. 1 ZPO.

${ }^{640}$ Nr. 1.2 Streitwertkatalog für die Verwaltungsgerichtsbarkeit in der Fassung von Juli 2004, NVwZ 2004, pp. $1327 \mathrm{ff}$.

${ }^{641}$ Nr. 1.2 Streitwertkatalog für die Verwaltungsgerichtbarkeit in der Fassung der am 31. Mai, 1 Juni 2012 und am 18. Juli 2013 beschlossenen Änderungen.

${ }^{642}$ OVG Münster, Decision of 30 April 2008, Az.: 8 D 20/08.AK, NuR 2009, 63, 64; juris.

${ }^{643}$ Ibid., juris, para. 23.
} 
It found that the determination of the value of the claim at $€ 15,000$ would ensure that procedures are not prohibitively expensive. ${ }^{644}$ This amount was at the lower end of the spectrum of costs in litigations in comparable proceedings. According to the court, the total amount was not disproportionate if compared to the nature and extent of the project disputed in the procedure for judicial review. Moreover, as experience showed, environmental organisations which might be granted standing did not refrain from bringing a claim because of costs. ${ }^{645}$ In this case, the application was made by a recognised environmental organisation which wanted to challenge a permit granted for the extension of a waste incinerating plant. This environmental association was ordered to pay $€ 968$ court fees and lawyers' fees of $€ 1,584.80{ }^{646}$ The court refused the application for legal aid as the assets of the association could cover these fees. ${ }^{647}$ It should be noted that the value of the claim of $€ 15,000$ was the minimum amount indicated in the 2004 catalogue and that in practice courts have set the value of the claim at a higher amount, arguing that this was still in compliance with Union law. ${ }^{648}$

Contrary to the opinion of the OVG Münster that costs usually do not prevent an environmental organisation from bringing claims to court, empirical research has shown that costs in Germany are one of the main obstacles to litigation. ${ }^{649}$ The reason for this is not only the application of the loser pays principle, which significantly increases the risk of litigation, but also the fact that even if the environmental organisation wins the case, the lawyer's fees are (often) only partially refunded. ${ }^{650}$ The Aarhus Convention and the implementing Union legislation did not change the situation as the European obligations were only taken into account "pro forma". ${ }^{651}$ Also in the literature, doubts on the compatibility of the German rules with the requirement of the Aarhus Convention are raised. ${ }^{652}$ It is argued that the lack of any cost cap and the absence of the possibility to exempt a losing party from the payment of costs could contravene the Union requirement that litigation should not be "prohibitively expensive" as interpreted by the Court of Justice in Commission v Ireland. ${ }^{653}$ Moreover, the argument of the German court according to which experience shows that environmental associations do not refrain

\footnotetext{
${ }^{644} \mathrm{Ibid}$., this holding was reaffirmed in another case: OVG Münster, Decision of 5 November 2009, Az.: 8 B 1342/09.AK, NuR 2010, 204.

${ }^{645}$ OVG Münster, Decision of 30 April 2008, Az.: 8 D 20/08.AK, NuR 2009, 63, 64; juris, para. 23.

${ }^{646}$ Ibid., juris, para. 5.

${ }^{647} \mathrm{Ibid}$., juris, para. 23.

${ }^{648}$ BVerwG, Decision of 31 January 2006, Az.: 4 B 49/05, NVwZ 2006, 823, 829; VGH Kassel, Judgment of 16 September 2009, Az.: 6 C 1005/08.T, juris, para. 162; OVG Lüneburg, Decision of 17 December 2008, Az.: 12 OA $347 / 08$, juris, para. 8 .

${ }^{649}$ Führ et al., Evaluation von Gebrauch und Wirkung der Verbandsklagemöglichkeiten nach dem UmwRG, Dessau-Roßlau, Februar 2014, p. 13; Seibert, Verbandsklagen im Umweltrecht, NVwZ 2013, p. 1048; Slepcevic, Litigating for the environment, 2009, p. 149.

${ }^{650}$ Slepcevic, Litigating for the environment, 2009, p. 149.

${ }^{651}$ Ibid., p. 173; the rulings of the Court of Justice in Commission v Ireland and Edwards had so far no concrete impact on the German rules on costs: Sauer, Rechtsschutz in Umweltangelegenheiten im Umbruch, ZUR 2014, p. 201.

${ }^{652}$ Ziekow, Europa und der deutsche Verwaltungsprozess - Schlaglichter auf eine unendliche Geschichte, NVwZ 2010, p. 798.

${ }^{653}$ C-427/07, Commission of the European Communities v Ireland [2009] ECR I-6277; Berkemann, Das "nicht übermäßig teure" gerichtliche Verfahren im Umweltrecht, jM 2014, p. 473 (the decision of the OVG Münster is "erschreckend realitätsfremd"); Ziekow, Europa und der deutsche Verwaltungsprozess - Schlaglichter auf eine unendliche Geschichte, NVwZ 2010, p. 798.
} 
from bringing a case to court because of costs, ${ }^{654}$ cannot stand in the light of the judgment of the Court of Justice in Edwards, in which it was expressly held that the fact that a claimant was not deterred from bringing a claim is not sufficient to establish that costs are not prohibitively expensive. ${ }^{655}$ Kremer calculated the potential costs in an environmental claim in which the value of the claim was set at $€ 30,000$ and which was dealt with in three instances and he came to the conclusion that the cost risk lies at $€ 22,000$ (if two lawyers are involved) and $€ 31,000$ (if three lawyers are involved). ${ }^{656}$ In addition to that, the necessity to consult experts increases the cost risk significantly, which means that claimants may be faced with costs between $€ 50,000$ and $€ 100,000 .{ }^{657}$ These costs risks may certainly have a deterrent effect on the decision whether or not to litigate in environmental matters.

As set out in the introduction, in Germany, there is the possibility to apply for legal aid. However, so far, there is no known case in which legal aid to an environmental organisations was granted and there is usually no private legal insurances for environmental claims. ${ }^{658}$

Considering the system of costs in Germany in its entirety, it can be doubted that it complies with the requirement emanating from the Aarhus Convention that procedures should not be prohibitively expensive. ${ }^{659}$ In the following section, the German system will be compared to the Dutch system on costs.

\section{b. Netherlands}

\section{National rules on costs}

Costs in administrative litigation in the Netherlands have been rather low. The Dutch government planned to increase court fees but a first bill proposing full cost recovery ${ }^{660}$ was strongly criticised and finally had to be abandoned. ${ }^{661}$ Today, article 8:41 Awb lists the amount to be paid when applying for judicial review at the court of first instance. For special cases falling under a statute for reduced court fees that applies, among others, to claims against decisions concerning unemployment or sickness, the fee is $€ 45$. In all other cases, individuals are charged $€ 165$. Legal persons have to pay $€ 328$ when applying for judicial review. Article 8:108 (1) Awb stipulates that article 8:41 (3) Awb is applicable in cases of an appeal to the court of second instance.

\footnotetext{
${ }^{654}$ OVG Münster, Decision of 30 April 2008, Az.: 8 D 20/08.AK, NuR 2009, 63, 64, juris, para. 23.

${ }^{655}$ C-260/11, The Queen, on the application of David Edwards and Lilian Pallikaropoulos v Environment Agency and Others (Judgment of 11 April 2013) para. 48; Berkemann, Das “nicht übermäßig teure” gerichtliche Verfahren im Umweltrecht, jM 2014, p. 473.

${ }^{656}$ Kremer, Anmerkung zum Urteil des EuGH vom 13.2. 2014, Rs. C-539/11 und vom 11.4.2014, Rs. C-260/11, ZUR 2014, p. 348; comparable calculation: Schmidt et al., Die Verbandsklage im Umwelt- und Naturschutzrecht, 2014, p. $165 \mathrm{f}$.

${ }^{657}$ Kremer, Anmerkung zum Urteil des EuGH vom 13.2. 2014, Rs. C-539/11 und vom 11.4.2014, Rs. C-260/11, ZUR 2014, p. 349.

${ }^{658}$ Ibid.

${ }^{659}$ Berkemann, Das “nicht übermäßig teure” gerichtliche Verfahren im Umweltrecht, jM 2014, p. 473 f.; Kremer, Anmerkung zum Urteil des EuGH vom 13.2. 2014, Rs. C-539/11 und vom 11.4.2014, Rs. C-260/11, ZUR 2014, p. 348, Schmidt et al., Die Verbandsklage im Umwelt- und Naturschutzrecht, 2014, p. 172.

${ }^{660}$ Kamerstuk II, 2011/2012, 33 071, nr. 2 (Voorstel van Wet).

${ }^{661}$ Kamerstuk II, 2012/2013, 33 071, nr. 11.
} 
In a judgment on an application for judicial review, the judge decides on the reimbursement of court fees. In case the judge decides that the claim for judicial review is successful, the administrative authority will have to reimburse the court fees of the claimant. ${ }^{662}$ In case the claim is not successful, the judge will not order the reimbursement of court fees. ${ }^{663}$ Additionally, article 8:75 (1) Awb vests the administrative judge with the power to make a cost order. Usually, only administrative bodies are ordered to pay costs. Natural and legal persons may be subject to a cost order in case of an abuse of procedural law. ${ }^{664}$ The amount of procedural costs is calculated according to the Besluit proceskosten bestuursrecht (Administrative Order on litigation costs in administrative matters). ${ }^{665}$ Article 1a-f of this administrative order provides for an exhaustive list of costs that are eligible for a cost order, including the costs of a lawyer, witnesses and experts, travel expenses, costs that one incurs because a party or interested party has to be at court, costs for communication and where this is necessary in some cases, the costs of doctors. The calculation of the lawyer's fees follows a system of points attached to the administrative order.

Furthermore, in the Netherlands, an elaborate legal aid system exists and private legal insurances are offered. The provision of legal aid in the Netherlands has its basis in the Dutch Constitution. According to article 17 "no one may be prevented against his will from being heard by the courts to which he is entitled to apply under the law". Furthermore, article 18 of the Constitution stipulates that "everyone may be legally represented in legal and administrative proceedings. Rules concerning the granting of legal aid to persons of limited means shall be laid down by Act of Parliament." Rechtsbijstand 2009 (Legal Aid Act) establishes the system for the provision of legal aid in the Netherlands. The monitoring of the provision of legal aid is entrusted to the Raad voor Rechtsbijstand (Legal Aid Board).

\section{National rules on costs in EIA cases}

That the costs of litigation in the Netherlands have been rather low can be illustrated by reference to the following examples. In the case of test drillings for natural gasoline in the North Sea in the 1990s, the claimants were successful with their claim and the court simply found that the State of the Netherlands had to reimburse the court fees of the applicants amounting to $f 400 .{ }^{667}$ Moreover, the court did not see any reason that there should be a cost order. ${ }^{668}$

In a more recent case concerning a permit for the alteration of a pig rearing installation, the applicants successfully argued that the EIA screening was insufficiently done. ${ }^{669}$ The court ordered the

\footnotetext{
${ }^{662}$ Art. 8:74 (1) Awb.

${ }^{663}$ Damen et al., Bestuursrecht, vol. 2, $4^{\text {th }}$ edition, 2012, p. 351.

${ }^{664}$ Art. 8:75 (1) Awb.

${ }^{665}$ Besluit van 22 december 1993, houdende nadere regels betreffende de proceskostenveroordeling in bestuursrechtelijke procedures, Stb. 1993, 763.

666 Translation provided by the Minstry of Interior and Kingdom Relations (available online).

${ }^{667}$ Rechtbank Leeuwarden, 17 July 1998, nr. 97/40 WET;97/41 WET;97/42 WET;97/44 WET;97/45.

${ }^{668}$ Ibid.

${ }^{669}$ ABRvS 21 November 2012, nr. 201103782/1/A4.
} 
administrative authority to pay the costs of the first claimant amounting to $€ 922.12$ of which $€ 874.00$ count for legal aid and it had to reimburse the court fee of $€ 152$. Regarding the second claimant, the court ordered the reimbursement of $€ 1,334.60$ of which $€ 1,092.50$ counted for legal aid and to reimburse the court fees of $€ 152 .{ }^{670}$

An illustration of a cost order in a case in which the claim was clearly unsuccessful is the case of a claimant challenging a permit granted for the excavation of ground on a lot of 2.25 ha and $30-90 \mathrm{~cm}$ depth. The court found that no EIA screening was required in such a case. As to the costs, the court simply found that there was no reason for a cost order. ${ }^{671}$

Another costs issue which does not concern litigation fees, but which is relevant for understanding costs in EIA procedures, relates to the costs which the Commissie m.e.r. charges for giving advice in the administrative procedure. In Part I, it was explained that this independent advisory body is sometimes obligatorily involved in the EIA process and sometimes on a voluntary basis. Before July 2014 the costs of this advice were publicly subsidised. Since then, a new statute prescribes that the Commissie m.e.r. has to fully cover its costs through the advice given. ${ }^{672}$ The basic costs for an EIA advice amounts to $€ 29,000$, but there are exceptions for small projects. ${ }^{673}$

In conclusion, costs in environmental litigation in the Netherlands are comparatively low, which is mainly due to the fact that court fees are relatively low and that, in principle, only the public authority can be ordered to pay the costs in case it loses the case.

\section{c. England}

\section{National rules on costs}

In England, costs for environmental litigation have traditionally been very high because of the system of cost orders and high court fees and costs of lawyers. ${ }^{674}$ As far as cost orders are concerned, the rule is that an unsuccessful party to litigation is ordered to pay the costs of the successful party ${ }^{675}$ Moreover, the English rules on court fees are based on a policy of full cost recovery, meaning that the actual price of proceedings and the modernisation of the litigation system should be covered by the payment of court fees. ${ }^{676}$ The amount of court fees in England is determined in fees orders. For civil and administrative proceedings, the Civil Proceedings Fees Order 2014 (abbreviation: CPFO (2014)) is applicable. ${ }^{677}$ In

\footnotetext{
${ }^{670}$ Ibid., Beslissing VI.

${ }^{671}$ ABRvS 9 April 2014, nr. 201308340/1/R4, para. 9.

${ }^{672}$ Wet van 14 mei 2014 tot wijziging van de Wet milieubeheer (tarieven Commissie voor de milieueffectrapportage), Stb. 2014, 173.

673 The costs for advice can be found on the website of the Commissie m.e.r.: www.commissiemer.nl, Advisering, Tarieven.

${ }^{674}$ Report of the Working Group on Access to Environmental Justice, Ensuring Access to Environmental Justice in England and Wales, 2008, (available online).

675 Rule 44.3 (2) CPR.

${ }^{676}$ Faure, Moerland, Griffierechten, Een vergelijkende beschrijving van griffierechten- en vergelijkbare stelsels in een aantal landen van de Europese Unie, 2006, p. 67.

677 The Civil Proceedings Fees (Amendment) Order 2014, SI 2014, no. 874 (L.17).
} 
the explanatory memorandum to the latest version, it is stated that the fees "for judicial review (1.9) have been increased to cover the full cost of the process". ${ }^{678}$ According to point 1.9 (a) of the CPFO (2014), the permission to apply for judicial review costs $£ 140$. In case permission is granted, $£ 700$ has to be paid to proceed with the judicial review. Furthermore, legal representation in England is comparatively expensive and costs for lawyers constitute the main element of litigation costs. ${ }^{679}$ This is due to the specific "architecture" of legal procedures in common law jurisdictions, where the centre of gravity lays with the services provided by lawyers. ${ }^{680}$ For example, the collection of evidence, including acquiring expert statements, is often done by lawyers. ${ }^{681}$

In order to allow for a certain level of protection against excessive costs for the losing party, courts have developed a system of protective cost orders (abbreviation: PCO). The leading case in this regard is the Corner House case, in which it was held that:

“(1) A protective costs order may be made at any stage of the proceedings, on such conditions as the court thinks fit, provided that the court is satisfied that: (i) the issues raised are of general public importance; (ii) the public interest requires that those issues should be resolved; (iii) the applicant has no private interest in the outcome of the case; (iv) having regard to the financial resources of the applicant and the respondent(s) and to the amount of costs that are likely to be involved, it is fair and just to make the order; and (v) if the order is not made the applicant will probably discontinue the proceedings and will be acting reasonably in so doing." ${ }^{962}$

From this case, it follows that in public interest litigations, claimants can be exempted from costs or costs are capped. In general, the English costs system for litigations was strongly criticised and had to be reformed. The reforms particularly concerned environmental matters, which will be described in the following section.

\section{National rules on costs in EIA cases}

In this section, an overview of the development of the English system on costs in environmental cases, including EIA cases, will be given. To begin with, a brief outline of the discussions at the national level will be provided, followed by a description of the intervention from the international and European level. In the end, the current national regime for costs in environmental matters will be explained.

\footnotetext{
${ }^{678}$ Explanatory Memorandum to the Civil Proceedings Fees (Amendment) Order 2014, No. 874 (L.17), 2004, at 3.3.

${ }^{679}$ Hodges et al., Costs and Funding of Civil Litigation: A Comparative Study, 2009, p. 5. According to this study, English lawyers charge between 128 and $472 €$ per hour. Uncertainty of the duration of proceedings and the absence of a regulation of lawyer's fees lead to the fact that lawyer's costs are not predictable.

${ }^{680}$ Ibid., p. 40.

${ }^{681}$ Ibid.

${ }^{682} R$ (Corner House Research Ltd) $v$ Secretary of State for Trade and Industry [2005] EWCA Civ. 192; [2005] 1 WLR 2600 [74].
} 
In a national report on costs in civil litigation, in 2009, Jackson LJ found that especially in environmental cases, costs constituted a barrier to access to justice. ${ }^{683}$ Moreover, a working group guided by Sullivan LJ identified excessive costs as the key element limiting access to justice in environmental matters. ${ }^{684}$ In further empirical research, it was found that $56 \%$ of cases in which clients were advised by lawyers to proceed with litigation, this was not done because of costs. ${ }^{655}$ These findings meant that the English system of costs did not ensure that litigation was "not prohibitively expensive" and that consequently, the CPR had to be reformed in order to accommodate the requirements of the Aarhus Convention and the respective Union directives. ${ }^{686}$

A case concerning EIA, in which the (non-)compliance of the English system of costs with the Aarhus Convention was at issue, was the case of an architect specialised in the conservation of historic buildings who brought a claim for judicial review against a planning permission for the redevelopment of land in the vicinity of an ancient monument. He applied for PCO but this application was dismissed by the court of first instance. On appeal, Sullivan LJ held:

"I accept the claimant's submission that in an article 10a case there is no justification for the application of the issues of "general public importance"/"public interest requiring resolution of those issues" in the Corner House conditions. Both the Aarhus Convention and the Directive are based on the premise that it is in the public interest that there should be effective public participation in the decision-making process in significant environmental cases (those cases that are covered by the EIA and IPPC Directives) [...] In summary, under EU law it is a matter of general public importance that those environmental decisions subject to the Directive are taken in a lawful manner, and, if there is an issue as to that, the general public interest does require that that issue be resolved in an effective review process. The Corner House principles are judgemade law and in accordance with the Marleasing principle (Marleasing SA v La Comercial Internacional de Alimentación SA (Case C-106/89) [1990] ECR I-4135) those judge-made rules for PCOs must be interpreted and applied in such a way as to secure conformity with the Directive." ${ }^{\prime 67}$

For these reasons, the judge at the first instance court was not entitled to reject the application for PCO. ${ }^{688}$ Moreover, in this case it was discussed whether a subjective or an objective approach should be adopted

\footnotetext{
683 Jackson, Review of Civil Litigation Costs: Final Report, The Stationery Office, 2010.

${ }^{684}$ Report of the Working Group on Access to Environmental Justice, Ensuring Access to Environmental Justice in England and Wales, 2008 (available online).

${ }^{685}$ The Environmental Law Foundation, Cost Barriers to Environmental Justice, A Report in Association with BRASS, December 2008 (available online).

${ }^{686}$ See the summary on the discussion on costs by Carnwath LJ in: Morgan v Hinton Organics (Wessex) Ltd [2009] EWCA Civ 107; [2009] Env LR 30 [47].

${ }^{687} R$ (Garner) v Elmbridge Borough Council [2010] EWCA Civ 1006 ; [2012] PTSR 250 [39].

${ }^{688}$ Ibid. [40].
} 
when deciding whether costs are "prohibitively expensive". The court held that a purely subjective approach, which only focussed on the means of the individual claimant, was not compatible with the EIA Directive, but that it was acnecessary question whether costs would be prohibitively expensive for an ordinary member of the public concerned. ${ }^{689}$

These discussions on the national level were supported and influenced by international and European developments, which shall be described in the following section.

On the international level, the Aarhus Compliance Committee had to express its opinion on the English cost regime several times and found that costs were prohibitively expensive. ${ }^{690}$ In the Union, the Court of Justice had to rule on the requirement of "not prohibitively expensive costs" with regard to English rules in two cases. ${ }^{691}$ The first case was a reference for preliminary ruling referred to the Court of Justice in the case of Edwards and Pallikaropoulos concerning a cost order according to which Mrs. Pallikaropoulos, after having lost her case in the national courts, was ordered to pay the costs of the public authority. ${ }^{692}$ The Court of Justice held that courts, in deciding on cost orders, have to make an objective analysis of the amount of costs and have to take the claimant's financial situation into consideration. ${ }^{693}$ Moreover, the court

"may also take into account the situation of the parties concerned, whether the claimant has a reasonable prospect of success, the importance of what is at stake for the claimant and for the protection of the environment, the complexity of the relevant law and procedure, the potentially frivolous nature of the claim at its various stages, and the existence of a national legal aid scheme or a costs protection regime." ${ }^{\prime 694}$

Additionally, the fact that the claimant was not deterred from bringing a claim is not sufficient for the conclusion that costs are in compliance with the Aarhus requirement. ${ }^{695}$ Taking this guidance by the Court of Justice into account, the national court found in the end that the cost order of $£ 25,000$ against Mrs. Pallikaropoulos could be upheld. ${ }^{696}$

In a second case, the European Commission had brought infringement proceedings against the UK for failing to comply with its obligations under the Union directives implementing the Aarhus

\footnotetext{
${ }^{689}$ Ibid. [46].

${ }^{690}$ Communication ACCC/C/2008/23; Communication ACCC/C/2008/33, Communication ACCC/C/2009/38.

${ }^{691}$ C-260/11, The Queen, on the application of David Edwards and Lilian Pallikaropoulos v Environment Agency and Others (Judgment of 11 April 2013); C-530/11, European Commission v United Kingdom of Great Britain and Northern Ireland (Judgment of 13 February 2014).

${ }^{692}$ C-260/11, The Queen, on the application of David Edwards and Lilian Pallikaropoulos v Environment Agency and Others (Judgment of 11 April 2013).

${ }^{693}$ Ibid., para. 40.

${ }^{694}$ Ibid., para. 46.

${ }^{695}$ Ibid., para. 47.

${ }^{696} R$ (on the application of Edwards and another (Appellant)) $v$ Environment Agency and others (Respodents) (No.2) [2013] UKSC 78; [2014] WLR 55.
} 
Convention. ${ }^{697}$ In its judgment, the Court of Justice had to deal with the general costs regime applicable in environmental litigations. After repeating the findings in Edwards, the Court assessed the English rules on PCOs, which it considered to be incompatible with Directive 2003/35/EC. ${ }^{698}$ The court held that the

"regime laid down by case-law does not ensure the claimant reasonable predictability as regards both whether the costs of the judicial proceedings in which he becomes involved are payable by him and their amount, although such predictability appears particularly necessary because, as the United Kingdom acknowledges, judicial proceedings in the United Kingdom entail high lawyers' fees". ${ }^{699}$

Furthermore, the Court of Justice had to rule on the practice of "cross-undertakings" in claims for interim relief. This practice required the applicant, if he lost the case, to undertake to reimburse any loss of profit that resulted from not proceeding with the project. As environmental cases often involve big constructions in which costs may amount to several hundred thousand pounds, this posed a barrier to justice for individuals and environmental organisations which were unable to provide these sums of money ${ }^{700}$ As a consequence, there were few applications for interim injunctions in environmental cases. In this context, the Commission started infringement proceedings against the UK and Ireland which resulted in a judgment delivered by the Court of Justice in 2014 in which it was found that such a practice conflicts with the principle that environmental proceedings should not be prohibitively expensive. ${ }^{701} \mathrm{In}$ this respect, the Court of Justice held that:

"The requirement that proceedings not be prohibitively expensive cannot be interpreted as immediately precluding the application of a financial guarantee such as that of the crossundertakings where that guarantee is provided for by national law. The same is true of the financial consequences which might, as the case may be, result under national law from an action that constitutes an abuse." 702

Nevertheless, the Court stressed that such costs must not be prohibitively expensive. ${ }^{703}$ In this regard the Court found that the argumentation of the UK did not show that costs are not prohibitively expensive. ${ }^{704}$ Therefore, the Court found that

${ }^{697}$ C-530/11, European Commission v United Kingdom of Great Britain and Northern Ireland (Judgment of 13 February 2014).

${ }^{698} \mathrm{Ibid}$., para. 57.

${ }^{699} \mathrm{Ibid}$., para. 58.

${ }^{700}$ Report of the Working Group on Access to Environmental Justice, Ensuring Access to Environmental Justice in England and Wales, 2008, (available online), p. 37.

${ }^{701}$ C-530/11, European Commission v United Kingdom of Great Britain and Northern Ireland (Judgment of 13 February 2014).

${ }^{702}$ Ibid., para. 67.

${ }^{703}$ Ibid., para. 68.

${ }^{704} \mathrm{Ibid}$., para. 69. 
"it is also necessary to uphold the Commission's argument that the system of cross-undertakings in respect of the grant of interim relief constitutes an additional element of uncertainty and imprecision so far as concerns compliance with the requirement that proceedings not be prohibitively expensive." 705

\section{(iii) Reform of the CPR}

As a consequence of these European judgments, the communications of the Aarhus compliance committee and national criticism, the English legislator finally redrafted the rules on costs in claims falling under the scope of the Aarhus Convention. ${ }^{706}$ For this purpose, a separate section was inserted in the CPR which limits costs in "Aarhus Convention Claims", which is applicable to

"a claim for judicial review of a decision, act or omission all or part of which is subject to the provisions of the UNECE Convention on Access to Information, Public Participation in Decision-Making and Access to Justice in Environmental Matters done at Aarhus, Denmark on 25 June 1998, including a claim which proceeds on the basis that the decision, act or omission, or part of it, is so subject." 707

Practice Direction 45 sets the costs limit at $£ 5,000$ if the claimant is an individual. In other cases, the costs are capped at $£ 10,000$ and for the defendant the limit is at $£ 35,000$.

A case brought by Save Britain's Heritage (SAVE) 2014, can serve as an example to illustrate the application of the new English rules on costs in EIA cases. ${ }^{708}$ SAVE made an application for judicial review of a decision to grant planning consent retrospectively for the demolition of and the erection of new buildings. ${ }^{709}$ Inter alia, the association challenged the environmental statement, which, in their opinion, did not adequately assess the impact of the project on certain heritage assets. This challenge failed however. ${ }^{710}$ With regard to the application of the Aarhus cap, Mitting J held:

"Adopting an extremely broad brush approach, principally to reflect the fact that on ground 1 the successful local planning authority are only entitled to the cost of preparing the acknowledgement of service, and secondly only because they have in one small respect fallen foul of the requirements of decision making, I intend to order that the claimant pay 70 per cent of the local planning authority's costs, subject to the Arrhus [sic] cap of $£ 10,000$. I anticipate

\footnotetext{
705 Ibid., para. 71.

${ }^{706}$ Civil Procedure (Amendment) Rules 2013, SI 2013, nr. 262 (L. 1).

${ }^{707}$ Section 45.41 (2) CPR.

${ }^{708} R$ (on the application of Save Britain's Heritage) $v$ Gateshead Metropolitan Borough Council [2014] EWHC 896 (Admin).

${ }^{709}$ Ibid. [1].

${ }^{710}$ Ibid. [28].
} 
that will avoid the need for that which I order, a detailed assessment if not agreed of the local planning authority's costs. Anything else? “711

The cost cap in Aarhus Convention claims only concerns claims for judicial review, which means that where a statutory appeal is brought, the cap of section $45.41 \mathrm{CPR}$ is not applicable. In the case of Venn, who applied to quash a planning permission granted for the construction of a dwelling in the garden of a neighbouring property as this contravened the local plan policy, the Court of Appeal held that by excluding statutory appeals from the scope of application of the Aarhus cap, the English rules were not compliant with the Aarhus Convention. ${ }^{712}$ However, Sullivan LJ held:

"This Court is not able to remedy that flaw by the exercise of a judicial discretion. If the flaw is to be remedied action by the legislature is necessary. We were told that the government is reviewing the current costs regime in environmental cases, and that as part of that review the Government will consider whether the current costs regime for Aarhus claims should make provision for statutory review proceedings dealing with environmental matters." ${ }^{213}$

To conclude, costs in England for environmental litigation have traditionally been very high. Due to international pressure and national criticism, the system was reformed and now provides for a cost cap for Aarhus Convention claims.

\section{d. Comparison: differences and convergence}

This section has shown that in 27 years of EIA enforcement in the Union, the possibilities for bringing claims to administrative courts have been very different because of rules on costs. Since the beginning of EIA enforcement in the 1990s, costs in the Netherlands have not been preventing claims from being brought, while, at the same time, the English system of costs practically constituted a barrier for access to justice in many cases. The description of these differences focused on the system of court fees and cost orders. Whereas in England and in Germany the calculation of court fees is based on a policy to fully recover the costs of court proceedings, in the Netherlands a bill for full cost recovery was proposed but was later withdrawn because of strong criticism, meaning that the costs are comparatively low. So far, there are no convergences between the legal systems. As far as rules on court orders are concerned, there are also no convergences of the principles underlying the systems as such. In England and in Germany, the loser has to pay the winner's costs, whereas in the Netherlands, only the administrative authority is usually ordered to pay costs in case of defeat. If a claim for judicial review is not successful, the applicant will not be ordered to pay costs. Thus, the costs risks for bringing litigations in environmental matters have been higher in Germany and in England than in the Netherlands. Due to the reform of the English legal system introducing a cost cap for "Aarhus Convention Claims", the costs

\footnotetext{
${ }^{711}$ Ibid. [57].

712 Venn v Secretary of State for Communities and Local Government [2014] EWCA Civ 1539; [2015] CMLR 52 [34].

${ }^{713} \mathrm{Ibid}$. [35].
} 
actually incurred in England are now much lower than before. In this regard one may also speak of an approximation of legal systems. Such a cost cap does not exist in Germany, meaning that claimants may be ordered to pay more than English claimants in case of defeat. This means that the cost risks for bringing claims in Germany are higher than in England and of course in the Netherlands, leading to different enforcement chances of environmental law in the three legal systems.

The following table provides for a concluding overview over similarities and differences in the three legal systems:

Table 8: Rules on costs in EIA claims in 2014

\begin{tabular}{|l|l|l|l|}
\hline Court fees & Germany & Netherlands & England \\
\hline Cost orders & Full cost recovery & No full cost recovery & Full cost recovery \\
& $\begin{array}{l}\text { Calculated on the basis } \\
\text { of the Streitwert }\end{array}$ & $\begin{array}{l}\text { Table with fixed court } \\
\text { fees }\end{array}$ & $\begin{array}{l}\text { Table with fixed court } \\
\text { fees }\end{array}$ \\
\hline Loser pays principle & One way cost shifting & $\begin{array}{l}\text { Loser pays principle } \\
\text { Cost cap in "Aarhus } \\
\text { Convention Claims" }\end{array}$ \\
\hline
\end{tabular}




\section{Rules on time limits in EIA cases}

In principle, Member States of the Union are free to set time limits for bringing litigations to court, however they have to ensure that their rules are compatible with international and European Union requirements. These requirements will be presented first (3.1), and then the rules on time limits of the three legal systems in EIA cases will be described and some concluding remarks on differences and convergences between the legal systems will be provided (3.2).

\subsection{International and European rules on time limits}

Under international law, article 9 (4) of the Aarhus Convention requires that judicial procedures shall be "timely". The implementation guide of the Aarhus Convention explains that timeliness means that Member States should "ensure an 'expeditious' review process", explicitly naming the possibility of introducing time limits for entire court proceedings. ${ }^{714}$ However, the Convention does not prescribe a specific time limit. Article 11 of the EIA Directive repeats the wording of the Aarhus Convention, in requiring that procedures have to be timely.

The Court of Justice has, on many occasions, expressed its view on national time limits. The Rewe ruling giving rise to the development of the principles of effectiveness and equivalence concerned time limits. ${ }^{715}$ The Court of Justice held that the limits have to be reasonable $e^{716}$ and clarified this in further jurisprudence. ${ }^{717}$ Moreover, if a Member State fails to transpose a directive, this state may not rely on the delay of a claimant when this individual institutes a lawsuit at the national court in order to enforce a right flowing from this directive. ${ }^{718}$ Of particular importance for the purpose of the following comparative analysis is the judgment of the Court of Justice in Uniplex ${ }^{719}$ concerning English time limits for judicial review which will be discussed after the applicable time limits in Germany and the Netherlands have been described.

\subsection{National rules on time limits}

In this section, rules on time limits in the three legal systems will be compared. The focus will be on two types of time limits. The first type concerns the time limit for bringing litigations to court after an administrative decision was taken. The second type concerns the time limit for substantiating the claim,

\footnotetext{
${ }^{714}$ Ebbesson et al., The Aarhus Convention: An Implementation Guide, $2^{\text {nd }}$ edition, 2014, p. 201 (available online). ${ }^{715}$ Case 33/76, Rewe-Zentralfinanz eG et Rewe-Zentral AG v Landwirtschaftskammer für das Saarland [1976] ECR 1989.

716 Ibid., para. 5.

717 Case 45/76, Comet v Produktschap voor Siergewassen [1976] ECR 2043, paras. 17 f.; C-90/94, Haahr Petroleum Ltd v Åbenrå Havn et al. [1997] ECR I-4085, paras. 58 ff; C-188/95, Fantask A/S e.a. v Industriministeriet (Erhvervministeriet) [1997] ECR I-6783, paras. 48, 49; C-261/95 Palmisani v Istituto Nazionale della Previdenza Sociale [1997] ECR I-4025, para. 28; C-231/96, Edilizia Industriale Siderurgica Srl (Edis) v Ministero delle Finanze [1998] ECR I-4951, paras. 27, 35; C-327/00, C- 327/00, Santex SpA v Unità Socio Sanitaria Locale n. 42 di Pavia [2003] ECR I-1877, paras. 50 ff ; C-445/06, Danske Slagterier v Bundesrepublik Deutschland [2009] ECR I-2119, paras. 48, 49; Jans et al., Europeanisation of Public Law, 2007, p. 294 ff; Craig, de Búrca, EU Law, $5^{\text {th }}$ edition, 2011, pp. 234 f.

${ }^{718}$ C-208/90, Theresa Emmott v Minister for Social Welfare and Attorney General [1991] ECR I-4269.

${ }^{719}$ C-406/08, Uniplex (UK) Ltd v NHS Business Services Authority [2010] ECR I-817.
} 
meaning the time for the submission of arguments and evidence. A different type of time limit concerns rules that preclude the submission of certain arguments if they were not raised at an earlier stage of the administrative (planning) process. These are, however, no time limits for bringing a claim to court, but limits for basing the claim on specific substantive grounds. Whereas the first and the second type of time limits will be dealt with in this section, the third type will be further analysed in the section on the scope of review. ${ }^{720}$

\section{a. Germany}

\section{National rules on time limits}

In Germany, the time limit for bringing an action for annulment is laid down in $\S 74$ (1) VwGO. ${ }^{721}$ Accordingly, the application must be made one month after the notification of the administrative decision. Applications, which are made after that this time limit lapsed, are inadmissible, unless the delay is excusable. ${ }^{722}$ In case there is no proper notification about the possibility to litigate, i.e. the notification does not contain any information on the time limits or the information is incorrect, the time limit is extended to one year after the notification. ${ }^{723}$ Formal requirements on the content of the action for annulment are regulated in $\S 82$ (1) VwGO stipulating that the application must state the object for challenge and that it must be accompanied by evidence. ${ }^{724}$ If the application is incomplete, the court many order a time limit for the completion of the application. ${ }^{725}$

Another time limit concerns the substantiation of the claim. The general rule is laid down in $\S 87 \mathrm{~b} \mathrm{VwGO}$, according to which the court has discretion to order a time limit for a statement of facts by the applicant ${ }^{726}$ and to order the parties to designate or submit further explanations and evidence. ${ }^{727}$ The court is entitled to reject evidence submitted after that time limit has lapsed, if this would delay the proceedings and if the applicant does not sufficiently excuse the delay and if the applicant was informed about possible consequences of delay. ${ }^{728}$ In any event, the interests of the defendant, who needs to have a real possibility to react on the new submissions, have to be kept in mind, which means that the time

\footnotetext{
${ }^{720}$ Part II, Chapter 3.2.

${ }^{721}$ In cases in which an objection has to be lodged with the administrative authority before the claim is brought to court ( $\S 68(1), 70$ (1) VwGO), the time limit is one month after the delivery of the administrative decision on objection ( $\$ 74(1) \mathrm{s} .1$ ); if no administrative objection is necessary, § 74 (1) s. 2 VwGO applies (time limit of one month); in cases, in which a claimant wants to challenge a by-law (especially under construction law), § 47 (2) s. 1 VwGO provides for a time limit of one month.

$722 \S 60$ (1) VwGO.

${ }^{723} \S 58$ (2) VwGO.

724 § 82 (1) s. 3 VwGO.

725 \$ 82 (2) s. 2 VwGO.

$726 \S 87$ b (1) VwGO.

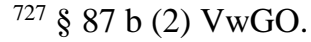

$728 \S 87$ b (3) VwGO.
} 
limit must be clear and reasonable. ${ }^{729}$ The time limit may be extended before it lapses. ${ }^{730}$ In the literature it is observed that the practical relevance of this paragraph is rather limited. ${ }^{731}$

\section{National rules on time limits in EIA cases}

The rules on time limits are generally also applicable in EIA cases, unless the UmwRG provides for more specific rules. Hence, the time limit of one month for making an application for the annulment of an administrative decision is also applicable to EIA claims. ${ }^{732}$ However, $§ 2$ (4) UmwRG provides for a special time limit for making an application of annulment if the administrative decision ${ }^{733}$ was not sufficiently notified to the environmental organisation or not published contrary to the law. ${ }^{734}$ In these cases, a time limit of one year starts running from the day on which the environmental organisation knew or should have known about the administrative decision. In a case concerning the challenge of a permit for the construction of a certain part of a coal-fired power station, an environmental organisation was clearly delayed, so that the claim was inadmissible. ${ }^{735}$ The administrative decision dated from 12 December 2007, but the challenge was only brought to court on 14 September 2009. The environmental organisation had only received a copy of the permit in September 2009. However, on the basis of the evidence submitted, it remained beyond doubt that the environmental organisation already knew about the permit for more than one year before instituting litigations in the administrative court. ${ }^{736}$

Until 2013, the UmwRG did not contain any special rule for the substantiation of the claim, but special legislation in certain areas provided for specific some time limits. $\S 87 \mathrm{~b} \mathrm{VwGO} \mathrm{has} \mathrm{only} \mathrm{played} \mathrm{a} \mathrm{minor}$ role in EIA case law. In the relevant databases, only few cases concerning the submission of documents in a case concerning an EIA could be found. ${ }^{737}$ Since 2013, the rules relative to the substantiation of the claim stricter, because $§ 4 \mathrm{a}$ (1) UmwRG (2013) provides for a new fixed time limit of six weeks for all EIA claims, starting from the date of application for annulment. In case that explanations and evidence are submitted after that the time limit lapsed, the general rule of $\S 87 \mathrm{~b}$ (3) VwGO applies, which provides that the court may reject these submissions if they would delay proceedings and if the delay is not excusable. ${ }^{738}$ Upon application, this time limit can be extended, but this lies in the discretion of the

\footnotetext{
${ }^{729}$ Ortloff, Riese, § 87 b VwGO, in: Schoch et al. (eds.), VwGO Kommentar, 2014, at 22.

730 Ibid., at 23.

${ }^{731}$ Geiger, $\S 87$ b, in: Eyermann (ed.), VwGO Kommentar, 2014, at 3; Ortloff, Riese, § 87 b VwGO, in: Schoch et al. (eds.), VwGO Kommentar, 2014., at 47.

${ }^{732}$ See for example the delayed claim challenging a construction decision under the time limit of $47 \mathrm{VwGO}$ : OVG Sachsen-Anhalt, Judgment of 26 October 2011, Az.: 2 K 10/10, juris.

${ }^{733}$ The administrative decision must fall under the scope of the UmwRG (§ 1 (1) s. 1 UmwRG).

734 The same rule applies when an objection has to be made with the administrative authority; see: OVG Koblenz, Decision of 2 April 2014, Az.: 1 B 10249/14, DVB1 2014, 940-942, juris, paras. 4 ff.

${ }^{735}$ OVG Münster, Decision of 24 September 2009, Az.: 8 B 1342/09.Ak, NuR 2010, 198, 199; juris, para. 33.

${ }^{736}$ Ibid., juris, para. 46-53.

${ }^{737}$ BVerwG, Judgment of 15 September 1999, Az.: 11 A 22/98, UPR 2000, 116-117; OVG Münster, Judgment of 11 February 2009, Az.: 11 D 45/06.AK, juris.

${ }^{738} \S 4 \mathrm{a}(1)$ s. 2 UmwRG (2013).
} 
court. ${ }^{739}$ A six-week time limit already existed in some cases concerning special planning law and was introduced for claims under the UmwRG (2013) in order to mitigate the newly created "broad" access possibilities of environmental organisations. ${ }^{740}$ However, it is expected that the time limit will not lead to an acceleration of proceedings. ${ }^{741}$ In the end, it is disputed whether this new restriction burdens environmental organisations excessively. ${ }^{742}$

The lack of comprehensive case law on environmental impact assessments for projects and late submission of documents suggests that at least the old rules according to which the court had complete discretion to set a time limit for further substantiation did not affect EIA enforcement. It remains to be seen how the six-week time limit is applied by courts and whether the courts will make use of their discretion to prolong periods where EIA material is at issue.

\section{b. The Netherlands}

\section{National rules on time limits}

In the Netherlands, the time limit for bringing a claim to the administrative court is provided for in article 6:7 Awb, according to which a time limit of six weeks applies. The period starts with the day of the publication of the decision. ${ }^{743}$ After that the time limit has lapsed, the application to the court is inadmissible, meaning that the claim will not be dealt with. ${ }^{744}$ This is a strict rule with the consequence that the court has no discretion to derogate from it. By this means, legal certainty is provided. ${ }^{745}$ Nevertheless, in certain, but very limited, circumstances, the application to the court can be admissible even if the claimant was delayed. ${ }^{76}$ For example, courts decided that claims are in principle admissible, when there was no or no proper notification about the possibility to challenge the administrative decision. ${ }^{747}$

As far as the substantiation of the claim is concerned, article 8:58 Awb stipulates that all parties to the proceedings (not only the claimant) can submit additional written documents until ten days before the hearing takes place. However, the court has discretion whether or not to accept these documents. This means that article 8:58 Awb does not constitute a guarantee for parties that those documents will be considered. ${ }^{78}$ Moreover, the court may decide to consider documents submitted shortly before or at the

\footnotetext{
739 § 4a (1) s. 3 UmwRG (2013).

${ }^{740}$ BT-Drs. 17/10957, p. 17; Balensiefen, Umwelt-Rechtsbehelfsgesetz, 2013, § 4a, at 2.3.

${ }^{741}$ Fellenberg, Schiller, Vorbemerkung UmwRG, in: Landmann, Rohmer (eds.), Umweltrecht, Kommentar, 2014, at 53 .

${ }^{742}$ No excessive burden: Seibert, Verbandsklagen im Umweltrecht, NVwZ 2013, p. 1046; may be burdensome: Schmidt et al., Die Verbandsklage im Umwelt- und Naturschutzrecht, 2014, p. $87 \mathrm{f}$.

743 Art. 6:8 Awb.

${ }^{744}$ Van Buuren, Art. 6:7 Awb, in: van Buuren, Borman (eds), $T \& C A w b, 8^{\text {th }}$ edition, 2013; Marseille, Tolsma, Geschilbeslechting door de bestuursrechter, 2013, p. 22.

${ }^{745}$ Damen et al, Bestuursrecht, vol. 2, $4^{\text {th }}$ edition, 2012, p. 169, at 425.

746 Art. 6:11 Awb.

${ }^{747}$ Van Buuren, de Poorter, Art. 6:11 Awb, in: van Buuren, Borman (eds), $T \& C A w b, 8^{\text {th }}$ edition, 2013; Damen $e t$ al, Bestuursrecht, vol. 2, $4^{\text {th }}$ edition, 2012, pp $171 \mathrm{ff}$., at $443 \mathrm{ff}$.

${ }^{748}$ Marseille, Tolsma, Geschilbeslechting door de bestuursrechter, 2013, p. 52.
} 
day of the hearing, if this is compatible with the principle of a goede procesorde (due process). ${ }^{749}$ This means that the parties must have an adequate possibility to react on the new documents, so that the principle of audi alteram partem is observed and that other principles of procedural law are complied with. ${ }^{750}$ Article 8:58 Awb only concerns written documents which relate to the grounds of review and arguments already brought forward previously. Otherwise, if these documents constitute new grounds for review or new arguments, this article is not applicable. ${ }^{751}$ The rules on the submission of new arguments or grounds for review, which were mainly developed in jurisprudence, will be dealt with in a later section. ${ }^{752}$

\section{National rules on time limits in EIA cases}

Searching for case law in the relevant databases, a similar observation as in Germany can be made. There is very little case law on time limits in EIA cases. Regarding the application of article 8:58 Awb, no case concerning an EIA for projects was found in which a document relating to the EIA was submitted too late and therefore excluded from review. In a case concerning an application against a renewed permit for a horse and pig breeding installation, the court made clear that submitting evidence eleven days before the trial took place suffices to be considered at the hearing. The defendant actually reacted to these documents during the hearing and considering the content and nature of the document there was no violation of the principle of due process. ${ }^{753}$ The lack of case law on this issue suggests that there are no "problems" regarding the substantiation of EIA claims in the Netherlands.

\section{c. England}

\section{National rules on time limits}

In England, the general rule is laid down in section 54.5 (1) CPR stating that applications for judicial review have to be made "promptly" and "no later than three months after the grounds to make the claim first arose". This rule was applicable to any application for judicial review. This has changed to some extent since the Court of Justice's ruling in Uniplex. ${ }^{754}$ In this reference for preliminary ruling, the Court of Justice ruled that with regard to the enforcement of the specific Union public procurement regulation at stake, English litigation rules were in breach of Union law. According to the Court, the English rules were not sufficiently clear and precise and the discretion of the national court created too much uncertainty. ${ }^{755}$ In the aftermath of this ruling, the English legislator adopted more stringent rules for cases brought under the Union rules on public contracts. ${ }^{756}$ This reform however did not concern other

\footnotetext{
${ }^{749}$ Kamerstuk II, 1991/1992, 22495, nr. 3 (Memorie van Toelichting), p. 137 f; Pot, Art. 8:58 Awb, in: De Graaf et al.(eds.), Sdu commentaar Awb, 2014.

${ }^{750}$ Damen et al, Bestuursrecht, vol. 2, $4^{\text {th }}$ edition, 2012, pp. 242, at 627.

${ }^{751}$ Borman, Art. 8:58 Awb, in: van Buuren, Borman (eds), $T \& C A w b, 8^{\text {th }}$ edition, 2013.

${ }^{752}$ Part II, Chapter 3, Section 3, b.

753 ABRvS 17 December 2008, nr. 200708825/1, para. 2.4.1.

${ }^{754}$ C-406/08, Uniplex (UK) Ltd v NHS Business Services Authority [2010] ECR I-817.

755 Ibid., para. 43.

756 The Public Procurement (Miscellaneous Amendments) Regulation 2011, SI 2011, nr. 2053.
} 
areas of law apart from the rules on public procurement. In environmental matters, a derogation from the promptness requirement was introduced with a reform in 2013, when the national legislator decided to modify the rules regarding time limits for claims brought under the English planning law system. ${ }^{757}$ Since 1 April of that year, judicial review cases dealing with decisions under planning law have to be brought within a time limit of six weeks. ${ }^{758}$ Moreover, defendants and other parties, if they wish to contest the claim, support it on other grounds or submit evidence have to do so within 35 days after permission for the application was given ${ }^{759}$ According to the explanatory memorandum to this reform, "the policy intention for shortening time limits is to reduce delay" "760 in proceedings. Through this means, the time limit of judicial review in planning cases is aligned with the time limit that applies under the rules of statutory appeal ${ }^{761}$ in planning law. ${ }^{762}$ The reform was preceded by a government consultation, in which the majority of consultees opposed the shortening of time limits. ${ }^{763}$ However, especially from the side of business and public authorities, the reform was supported, as the brief time limit would reduce the period of uncertainty in which legal challenges might be brought and as the reform would clarify the Uniplex ruling. ${ }^{764}$

Regarding the further substantiation of the claim, it is up to the courts discretion to give directions as to evidence. ${ }^{765}$ This may especially be the case if the applicant wishes to reply to submissions made by the defendant. In this regard, it is observed that it is common practice that judges allow the parties of the proceedings to file and serve additional evidence. ${ }^{766}$ The other parties must however have sufficient time to react on this evidence. ${ }^{767}$

\section{National rules on time limits in EIA cases}

An illustration for the handling of the 'promptness' requirement after the Court of Justice's ruling in Uniplex, but before the reforms in 2013, is the case of $U$ and Partners (East Anglia Ltd) ${ }^{768}$ This case concerned the construction of a flood defence. Planning permission was granted and the construction activities started. Only two days before the three-month time limit lapsed, the applicant made an application for judicial review claiming that an EIA assessment should have been conducted. The question was whether this application was still admissible, considering the fact that the claim was not

\footnotetext{
757 The Civil Procedure (Amendment No. 4) Rules 2013, SI 2013, nr. 1412 (L.14).

758 Section 54.5 (5) CPR.

${ }^{759}$ Section 54.14 (1) CPR.

${ }^{760}$ Explanatory Memorandum to the Civil Procedure (Amendment No. 4) Rules 2013, SI 2013 nr.1412 (L.14), at 7.3.

${ }^{761}$ Section 288 TCPA.

${ }^{762}$ Explanatory Memorandum to the Civil Procedure (Amendment No. 4) Rules 2013, SI 2013 nr.1412 (L.14), at 7.3.

${ }^{763}$ Reform of Judicial Review: the Government Response, April 2013, at 15.

764 Ibid., at 17.

765 Section 54.16 CPR.

${ }^{766}$ Lewis, Judicial Remedies in Public Law, $4^{\text {th }}$ edition, 2009, at 9-086.

${ }^{767}$ Jackson (ed.), Civil Procedure, vol. 1, 2012, p. 1875.

${ }^{768}$ R (U. \& Partners (East Anglia Ltd)) v Broads Authority [2012] Env LR 5; [2011] ACD 110.
} 
brought promptly. The court argued that the claim should nevertheless be admissible for two main reasons. The first reason is that the claimant had an arguable case. The court found that the authority acted ultra vires when granting planning permission. An EIA would have been necessary. Second, taking Uniplex into consideration, Union law requires precise time limits which are not dependent on judicial discretion. The applicant made its application within the period of three months. Hence, the claim was admissible and also successful on its merits.

\section{d. Comparison: differences and convergence}

From this brief overview of the rules on time limits and their application in EIA cases in the national legal systems, it follows that, in the beginnings of EIA enforcement, the legal systems were different but that, due to national reforms in England, the legal systems have been converging to a great extent. In Germany, applications for judicial review have to be made within a month and in the Netherlands applicants have approximately two more weeks for filing a claim. Contrary to these strict time limits prescribed by statute in the continental legal systems, in England, the requirement was that the claim had to be brought promptly but no later than within three months. Until the reforms of the CPR in 2013, this difference meant that in practice, claimants in England had potentially much more time to bring a claim than claimants in the Netherlands or in Germany. From this perspective, it could be argued that chances of enforcement were higher in England than in the other two states, in that there was simply more time to bring a claim. However, such a conclusion is too simplistic as 'promptness' is not always the same as three months, meaning that, also in England, the time limit may have been shorter in certain cases. In any event, since 2013, a six-week time limit applies, meaning that the requirements in the Netherlands and England with regard to the time limit for making an application are identical. The remaining difference between the German system and the other two systems is unlikely to cause differences regarding the "reach" of EIA enforcement. Therefore, practically, there is a similar treatment of cases.

Next, from a technical point of view, Member States differ regarding the time limits for further substantiating the claim. In Germany, there is a time limit of six weeks after an application for judicial review. In the Netherlands, documents have to be submitted up to ten days before the proceedings commence. In England, the courts have discretion to give directions concerning evidence. In Germany, the time limit may be extended by the court and in the Netherlands the court has to consider documents submitted in the light of the principle of due process. No case was found in which relevant material concerning challenges of the EIA procedure for projects was excluded from review. Any time limit would only become problematic where it barred or diluted the review of (the quality of) the EIA. As long as a system of time limits does not affect the "effectiveness" of EIA enforcement, i.e. as long as it does not make its enforcement impossible, there will be no problem from a European perspective. In this respect it should be stressed that the Union legislation does not provide for concrete quality 
standards for the EIA, so that the preclusion of certain documents or evidence will be difficult to judge in light of Union law.

To summarise, the following table provides for an overview of time limits in EIA cases in 2014:

Table 9: Rules on time limits in EIA claims in 2014

\begin{tabular}{|l|l|l|l|}
\hline & Germany & England & Netherlands \\
\hline $\begin{array}{l}\text { Limit for bringing } \\
\text { the claim }\end{array}$ & $\begin{array}{l}\S 74(1) \text { VwGO } \\
\text { One month }\end{array}$ & $\begin{array}{l}\text { Section 54.5 (5) CPR } \\
\text { Six weeks }\end{array}$ & $\begin{array}{l}\text { 6:7 Awb } \\
\text { Six weeks }\end{array}$ \\
\hline $\begin{array}{l}\text { Limit for } \\
\text { substantiating the } \\
\text { claim }\end{array}$ & $\begin{array}{l}\S 4 \mathrm{a}(1) \text { UmwRG } \\
\text { Six weeks, but } \\
\text { discretion }\end{array}$ & $\begin{array}{l}\text { Section 54.16 CPR } \\
\text { Discretion of the Court }\end{array}$ & $\begin{array}{l}8: 58 \text { Awb } \\
\text { until 10 days before } \\
\text { the hearing takes } \\
\text { place, but not a strict } \\
\text { rule }\end{array}$ \\
\hline
\end{tabular}

\section{Interim conclusion}

In this chapter on access to court, it was shown that, originally, big differences in national litigation rules existed in the Union, but that these differences have to some extent been diminishing under the influence of the Aarhus Convention and because of independent national reforms.

To begin with, in the Netherlands, individuals and environmental organisations were able to access courts in cases in which the legality of an EIA was at stake since the beginning of EIA enforcement. In Germany, such a possibility was only introduced recently under European pressure. Although the national rules have become comparable in this regard, differences continue to exist. These relate to the requirements that have to be fulfilled to qualify as an environmental organisation and as to the question whether and under which conditions other interest groups, not qualifying as environmental organisations, competitors and individuals can have access to the courts in EIA claims.

Next to rules on standing, rules on costs were compared in this chapter. In England, claimants were effectively barred from bringing claims in environmental matters. Whereas in that legal system litigation was very expensive, in the Netherlands litigation costs have been very low. Under the influence of the Aarhus Convention, England introduced cost caps applicable in environmental claims. Despite this convergence between the legal orders, the system of cost orders remains very different, as the Netherlands provides for a system of one-way cost shifting, whereas in Germany and England the loser has to pay the winning parties' costs.

Finally, rules on time limits have been very different but, due to national reforms in England, differences between the three legal systems under consideration diminished. 
The consequence of these differences has been that, when observing the enforcement of the EIA Directive over a period of 27 years, chances of enforcement for the same rule of Union law have been very different depending on the legal system in which litigations have been brought to court. In the Netherlands courts had to decide on many EIA cases from the beginning of EIA enforcement. In contrast to that, in England and in Germany only a few cases were brought to court. As observed, the national rules on access to justice have been in a process of convergence. However, differences continue to exist and because of these differences, enforcement chances still vary within the Union. 


\section{Chapter $3 \quad$ Review in administrative courts}

After having decided on the admissibility of a claim, courts have to control whether there is a discrepancy between the law (what should be there) and reality (what is there). National rules on review define the issues eligible for review and they regulate the intensity with which review is exercised. Moreover, legal systems determine how active a judge has to be with regard to the gathering of facts and they prescribe who has to bear the burden of proof. Finally, in environmental matters, which often involve extensive preparation procedures, legal systems make the challenge of certain issues dependent on prior participation in the administrative procedure in order to exclude that challenges are made at a late stage in the proceedings, which would lead to unjustified delays.

This chapter will begin with a comparison of the scope of review in the three Member States (section 1), followed by an analysis of the rules on the burden of proof (section 2). Thereafter, there will be a description of rules excluding the challenge of certain aspects if they were not raised at an earlier stage in the administrative process (section 3).

\section{International and European rules on the scope of review}

The scope of review comprises two elements. First, the scope of review delimits the issues or the content eligible for review in courts. Second, it determines the intensity with which review is exercised. In the European Union, in accordance with the principle of national procedural autonomy, Member States are in principle free to design their rules on the scope of review. ${ }^{769}$ However, they have to implement the international law obligations arising from the Aarhus Convention and from European law and they have to comply with the classical European standard for litigation as developed by the Court of Justice.

Article 9 (2) of the Aarhus Convention requires that Member States have to review the "substantive and procedural legality of any decision, act or omission". The EIA Directive repeats this requirement in article 11 (1). These rules determine the issues which have to be eligible for review. However, from the plain wording of the norms, no specific intensity of review can be deduced.

In the case law of the Court of Justice, the scope of review was at issue in Altrip. ${ }^{770}$ The case was referred to the Court of Justice for a preliminary ruling by a German court. German legislation, as interpreted by national courts, limited the review of errors relative to the EIA procedure to the complete omission of an obligatory screening or an obligatory EIA. ${ }^{771}$ The Court of Justice held that the Aarhus requirement of a review of the procedural legality of decisions includes a review of errors in an EIA. ${ }^{772}$ The

\footnotetext{
${ }^{769}$ C-120/97, Upjohn Ltd $v$ The Licensing Authority established by the Medicines Act 1968 and Others [1999] ECR I-223.

${ }^{770}$ C-72/12, Gemeinde Altrip and Others $v$ Land Rheinland-Pfalz (Judgment of 7 November 2013).

$771 \S 4$ (1) UmwRG (2006).

${ }^{772}$ C-72/12, Gemeinde Altrip and Others v Land Rheinland-Pfalz (Judgment of 7 November 2013) para. 37.
} 
implications of this judgment for the national legal system will be further described in the sections on the German legal system below.

The intensity of review has not yet been explicitly dealt with in environmental cases. In the general case law of the Court of Justice, the issue was at issue in the case of Upjohn. ${ }^{773}$ In this case, the Court of Justice set its own scope of review as a benchmark for the intensity of review of the Member States. ${ }^{774}$ This means that national courts are in principle not obliged to adopt a more intense standard of review than the Court of Justice. In this ruling, it was stressed that Union institutions are vested with a margin of discretion and that the Court of Justice cannot go further than assessing whether decisions by the institutions were based on accurate information and whether there were no manifest errors or a misuse of power or whether the institution did not exceed the margin of discretion. ${ }^{775}$ The terminology of the "manifest error" was also utilised by the Court of Justice in Commission v UK concerning the EIA Directive. ${ }^{776}$ Although this case primarily dealt with the burden of proof at the Court of Justice, it may have implications for the intensity of review at the national level. ${ }^{777}$ In this case, the Court ruled that the Commission should have presented some evidence to prove that the English authorities made a "manifest error of assessment when they gave consent to the project." 778 Apart from this setting of a minimum standard of review, there is only little interference by the Union with regard to national rules on the intensity of review.

This chapter will compare the rules on the scope of review in Germany, the Netherlands and England and examine the consequences of these differences for the enforcement of EIA rules. First, a general introduction to the scope of review in the Member States shall be given (subsection 1.1), followed by a description of the scope of review in cases concerning the environmental screening (subsection 1.2). After a comparison of the scope of review in screening cases, there will be a comparison of the scope of review in cases concerning the environmental statement (subsection 1.3).

\subsection{National rules on the scope of review}

\section{a. Germany}

In Germany, the review of the legality of procedure can be achieved by challenging the administrative decision taken by the authority, i.e. by claiming that the result is unlawful. In a claim for annulment, the court annuls this decision if it has found that the decision is unlawful and if the decision infringes the

\footnotetext{
${ }^{773}$ C-120/97, Upjohn Ltd $v$ The Licensing Authority established by the Medicines Act 1968 and Others [1999] ECR I-223.

${ }^{774}$ Ibid., para. 35 .

775 Ibid., para. 34.

${ }^{776}$ C-508/03, Commission of the European Communities $v$ United Kingdom of Great Britain and Northern Ireland [2006] ECR I-3969.

${ }_{777}$ Ryall, Effective Judicial Protection and the Environmental Impact Assessment Directive in Ireland, 2009, p. 170 .

${ }^{778}$ C-508/03, Commission of the European Communities v United Kingdom of Great Britain and Northern Ireland [2006] ECR I-3969, para. 91.
} 
claimant's rights. ${ }^{779} \mathrm{~A}$ decision is unlawful if a procedural or a substantive rule was infringed. ${ }^{780}$ For a further explanation on the tensions which arose between the German scope of review and the requirements emanating from the Aarhus Convention, some general remarks about the challengeability of procedural rules in German courts will be made.

To begin with, as mentioned in the Introduction to this thesis, ${ }^{781}$ the relationship between procedural and substantive rules under German doctrine is based on the concepts of the einzig richtige Entscheidung (single correct decision) and the dienende Funktion des Verfahrens (subservient function of procedure) ${ }^{782}$ The concept of the "single correct decision" means that the law already provides for the right decision and that the procedure is only the process in which this single correct decision is found. ${ }^{783}$ Procedure is therefore considered to be the "facilitator" $" 784$ of substantive law. This has consequences for the review of administrative procedures: a decision which is unlawful because of breaches of procedural law does not always lead to the annulment of the administrative decision. ${ }^{785}$ In this regard, $\S 46 \mathrm{VwVfG}$ provides that, except for cases in which an administrative decision is null and void, ${ }^{786}$ the annulment of a procedure cannot solely be requested because of a procedural infringement, if it is obvious that the infringement did not influence the administrative decision. Moreover, there are possibilities to correct procedural infringements during court proceedings. ${ }^{787}$ Furthermore, the scope of review in claim for annulment is restricted to the infringements of the applicant's subjective rights. ${ }^{788}$ Hence, the court does not embark on a control of the objective legality of a rule, but it controls whether the administrative decision infringes the rights of the applicant or a rule aiming at his protection. ${ }^{789}$ Procedural rules, according to traditional German doctrine and jurisprudence, generally do not provide for subjective rights of individuals. ${ }^{790}$ The only exceptions to this is so-called "absolute" procedural rights. ${ }^{791}$ In case an "absolute procedural right" is violated, an applicant can request the annulment of the administrative decision. ${ }^{792}$

The EIA procedure was initially treated by the courts just as any other procedural rule under German law. An error in a screening or an environmental statement could (and still can) only be challenged in

\footnotetext{
$779 \S 113$ (1) VwGO.

${ }^{780}$ Knauff, § 113 VwGO, in: Gärditz (ed.), VwGO, Kommentar, 2013, at 11.

${ }^{781}$ Introduction, Section 4.2 a.

782 Quabeck, Dienende Funktion des Verwaltungsverfahrens und Prozeduralisierung, 2010, chapter 2.

${ }^{783}$ Peuker, $\S 46$ VwVfG, in: Knack, Henneke (eds.), VwVfG, Kommentar, 10 ${ }^{\text {th }}$ edition, 2014, at 11.

${ }^{784}$ Pünder, Administrative Procedure - Mere Facilitator of Material Law versus Cooperative Realization of Common Welfare, in: Pünder, Waldhoff (eds.), Debates in German Public Law, 2014, pp. 239-260.

${ }^{785}$ Sachs, § 46 VwVfG, in: Stelkens et al. (eds.), VwVfG Kommentar, 2014, at 10; Gerhardt, § 113 VwGO, in: Schoch et al. (eds.), VwGO Kommentar, 2014 at 27.

$786 \S 44 \mathrm{VwVfG}$.

$787 \S 45 \mathrm{VwVfG}$.

${ }^{788}$ Gerhardt,Vorbemerkung $\S 113$ VwGO, in: Schoch et al. (eds.), VwGO Kommentar, 2014, at 3; Knauff, $\S 113$ VwGO, in: Gärditz, $V w G O$, Kommentar, 2013, at 14.

${ }^{789}$ Wolff, $§ 113$, in: Sodan, Ziekow (eds.), VwGO Kommentar, $4^{\text {th }}$ edition, at $33 \mathrm{ff}$.

${ }^{790}$ For further explanation refer to Part II, Chapter 2, Section 1.2, a..

${ }^{791}$ Kopp, Schenke, $V w G O$, Kommentar, 20 ${ }^{\text {th }}$ edition, 2014, $\S 42$, at 95; Sennekamp, $\$ 3$ Verfahren ,Erste Instanz “, Klagearten, in: Quaas, Zuck, Prozesse in Verwaltungssachen, 2008, at 198.

${ }^{792}$ Wahl, Schütz, § 42 (2) VwGO, in: Schoch et al. (eds.), VwGO Kommentar, 2014 at 73.
} 
an application for judicial review of the final administrative decision, providing for the "single correct" result. As long as the applicant could not prove that there was a causal link between the infringement of the EIA procedure and the decision, the latter could not be annulled on that ground. ${ }^{793}$ Moreover, it was questionable in how far the EIA provides for rules that at least also protect individual rights under public law. ${ }^{794}$ In the absence of subjective rights and their infringement, the court can in principle not annul an administrative decision. This was however considered to be incompatible with Union law. ${ }^{795}$ In 2006 , the UmwRG was created, ${ }^{796}$ introducing a possibility to request the annulment of administrative decisions in which an EIA was omitted or in which a screening was omitted and not caught up in the process without proving a causal relationship between the error and the decision of the authority. ${ }^{797}$ This, however, did not include the possibility to annul decisions because of a wrongful screening or a wrongful EIA. Since 2013, a wrongful screening can also lead to the annulment of the administrative decision. ${ }^{798}$ The relevant provision is however silent on the consequences of a wrongful EIA.

To sum up, regarding the scope of review, courts have to review the procedural and substantive legality of a decision. As far as the rules of the EIA procedure are concerned, the UmwRG enumerates certain procedural errors which will lead to annulment. Outside the cases regulated in this statute, the claimant has to show that the procedural error influenced the administrative decision.

The German Kontrolldichte (intensity of review) is governed by the "principle of full judicial review". 799 This means that the judicial control encompasses questions of law and of fact. ${ }^{800}$ This Rechtsanwendungskontrolle (control of the application of the law) comprises the interpretation of the legal provision in question, the finding of facts and the application of the law to the facts. ${ }^{801}$ The background to this principle is that the aim of the German judicial review system is, first and foremost the protection of subjective rights. ${ }^{802}$ The protection of the individual requires a review on whether the law aiming at their protection was applied correctly. ${ }^{803}$

Following the principle of full judicial review, the courts have to fully review all rules applicable to administrative processes ${ }^{804}$ and rules of substantive law. ${ }^{805}$ However, in certain instances, the legislator

\footnotetext{
${ }^{793}$ Part II, Chapter 4, Section 1.2, a.

${ }^{794}$ Wahl, Schütz, § 42 (2) VwGO, in: Schoch et al. (eds.), VwGO Kommentar, 2014, at 214.

${ }^{795}$ Kment, § 2 UmwRG, in: Hoppe, Beckmann (eds.), UVPG Kommentar, $4^{\text {th }}$ edition, 2012, at 5 ff.

796 c.f. description of the implementation process in Part I.

797 § 4 (1) UmwRG; Kment, § 4 UmwRG, in: Hoppe, Beckmann (eds.), UVPG Kommentar, $4^{\text {th }}$ edition, 2012, at 17.

798 § 4 (1) s. 2 UmwRG.

${ }^{799}$ Schmidt-Aßmann, Art. 19 Abs. 4 GG, in: Maunz, Dürig, GG Kommentar, 2014, at 183.

${ }^{800}$ Ibid.

${ }^{801}$ Schmidt-Aßmann, Allgemeines Verwaltungsrecht als Ordnungsidee, 2004, chapter 4, at 62-64.

${ }^{802}$ Schmidt-Aßmann, Art.19 Abs. 4 GG, in: Maunz, Dürig, GG Kommentar, 2014, at 8.

${ }^{803}$ Schmidt-Aßmann, Allgemeines Verwaltungsrecht als Ordnungsidee, 2004, chapter 4, at 59.

${ }^{804}$ Redeker, von Oertzen, VwGO Kommentar, $16^{\text {th }}$ edition, 2014, $\S 114$, at 45.

${ }^{805}$ Knauff, § 114 VwGO, in: Gärditz (ed.), VwGO, Kommentar, 2013, at 12, 13,
} 
vests the administration with the power to take the final decision in situations that cannot be fixed by statute. ${ }^{806}$ In these cases, judicial control may be limited to a certain extent.

To begin with, the legislator may create a norm utilising indefinite terminology. Then, the administrative authority may be vested with a certain Beurteilungsspielraum (margin of appreciation), of which the control by the courts can be limited. ${ }^{807}$ This is for example the case where complex technical decisions have to be taken. ${ }^{808}$ In this respect the court is not obliged to make scientific considerations on its own, but judges can rely on expert studies ${ }^{809}$ The scope of review of the court can for example also be limited where the authority has to take a decision on the basis of uncertain forecasts. ${ }^{810}$

Next, the legislator can create a norm in which he leaves discretion to the authority to act in a certain way or not to act. ${ }^{811}$ Then, the administrative authority is vested with a certain Ermessen (margin of discretion) ${ }^{812}$ The courts then examine whether the authority failed to make use of its discretion, ${ }^{813}$ whether it exceeded the margin of appreciation granted ${ }^{814}$ or it misused the margin of appreciation granted..$^{815}$

Bearing these explanations of the general scope of review regarding administrative procedure in mind, the following section will explain how the scope of review is determined in the Netherlands.

\section{b. The Netherlands}

In the Netherlands, the scope of review is not explicitly regulated by statute. ${ }^{816}$ The starting point for the explanation of the grounds of review under Dutch law is article 8:77 (2) Awb, ${ }^{817}$ which provides that in case an application for judicial review is successful, "the judgment shall state which written or unwritten rule of law or general principle of law is judged as being infringed" ${ }^{818}$ From this article it follows that the judge has to check whether in a concrete case "the law" was complied with. ${ }^{819}$ This includes provisions of procedural and substantive law. ${ }^{820}$ As far as procedural law is concerned, the principles of

\footnotetext{
${ }^{806}$ Schmidt-Aßmann, Art.19 Abs. 4 GG, in: Maunz, Dürig, GG Kommentar, 2014, at 184, $188 \mathrm{ff}$.

${ }^{807}$ Schröder, Administrative Law in Germany, in: Seerden (ed.), Administrative Law of the European Union, its Member States and the United States, $3^{\text {rd }}$ edition, 2012, p. 76; Hufen, Verwaltungsprozessrecht, $9^{\text {th }}$ edition, 2013, p. 427.

${ }^{808}$ Redeker, von Oertzen, $V w G O, 16^{\text {th }}$ edition, 2014, $\S 114$, at 56.

${ }^{809}$ Schmidt-Aßmann, Art. 19 (4) GG, in: Maunz, Dürig, GG Kommentar, 2014, at 203.

${ }^{810}$ Knauff, § 114 VwGO, in: Gärditz (ed.), VwGO, Kommentar, 2013, at 32.

$811 \S 114$ s. 1 VwGO, $\S 40$ VwVfG.

${ }^{812}$ Hufen, Verwaltungsprozessrecht, $9^{\text {th }}$ edition, p. 418.

${ }^{813}$ Knauff, § 114 VwGO, in: Gärditz (ed.), VwGO, Kommentar, 2013, at 21.

${ }^{814}$ Ibid., at 22.

815 Ibid., at 24.

${ }^{816}$ Schlössels, Stroink, Kern van het bestuursrecht, $4^{\text {th }}$ edition, 2013, p. 325.

${ }^{817}$ Damen et al., Bestuursrecht, vol. 1, $4^{\text {th }}$ edition, 2013, p. 270, at 668.

${ }^{818}$ Own translation.

${ }^{819}$ Borman, 8:77 (3) Awb, in: van Buuren, Borman (eds.), $T \& C A w b, 8^{\text {th }}$ edition, 2013, at 3; Polak, Roelfsema, Bestuursrechtspraak, in: Muller, Cleiren (eds.), Rechterlijke Macht, $2^{\text {nd }}$ edition, 2013, p. 211.

${ }^{820}$ Seerden, Wenders, The Netherlands, in: Seerden (ed.), Administrative Law of the European Union, its Member States and the United States, $3^{\text {rd }}$ edition, 2012, p. 144.
} 
proper administration, as partially codified in the Awb, play an important role. ${ }^{821}$ The principle of due care of article 3:2 Awb requires a careful preparation of the administrative decision, including a proper gathering of information and consideration of interests. ${ }^{822}$ Moreover, article 3:46 Awb codifies the principle of motivation, meaning that the decision must be based on proper reasons and these reasons have to be made explicit. ${ }^{823}$ In environmental matters, many cases have been annulled on procedural grounds. ${ }^{824}$

Similar to the German legal system, the Dutch legal system provides for a rule which allows that procedural errors are disregard in certain instances. ${ }^{825}$ This however has not led to a restriction of the scope of review. Claimants have always been able to challenge any procedural error (omissions and flaws) in court and courts have reviewed whether a procedural rule was infringed.

The review by Dutch courts extends to a control of law and facts. This means that the judge has the power to interpret the law, check whether the facts were correctly gathered and whether the law was applied correctly to the facts. In case the administrative authority is vested with beoordelingsvrijheid (a margin of appreciation), the intensity of review is limited to a certain extent: if for example an administrative decision is based on expert statements, in principle courts only terughoudend (cautiously) review the administrative decision. ${ }^{826}$ In cases in which the public authority has to make forecasts relating to the future, the intensity of review depends on the type of administrative power with which the decision is taken and on the consequences of the decision. ${ }^{827}$

\section{c. England}

The starting point for a description of the grounds of review under English law is the speech of Lord Diplock in the landmark judgment of Council of Civil Service Unions v Minister for the Civil Service:

"Judicial Review has I think developed to a stage today when without reiterating any analysis of the steps by which the development has come about, one can conveniently classify under three heads the grounds upon which administrative action is subject to control by judicial review. The first ground I would call 'illegality', the second 'irrationality' and the third 'procedural impropriety'. That is not to say that further development on a case by case basis

\footnotetext{
${ }^{821}$ Leemans, De toetsing door de bestuursrechter in milieugeschillen, Over rechterlijke toetsingsintensiteit, bestuurlijke beslissingsruimte en deskundigenadvisering, 2008, pp. $346 \mathrm{f}$.

${ }^{822}$ Van Buuren, Art. 3:2 Awb, in: van Buuren, Borman (eds.), $T \& C A w b, 8^{\text {th }}$ edition, 2013.

${ }^{823}$ De Poorter, Art. 3:46 Awb, in: van Buuren, Borman (eds.), $T \& C A w b, 8^{\text {th }}$ edition, 2013.

${ }^{824}$ In environmental matters, in total $73 \%$ of annulments are annulments because of procedural grounds: Jans, Marseille, The Role of NGOs in Environmental Litigation Against Public Authorities, JEL 2010, issue 3, p. 385.

${ }^{825}$ Art. 6:22 Awb; see further Part II, Chapter 4, Section 1.2, b.

${ }^{826} \mathrm{Klap}$, Rechterlijke toetsing aan vage normen in Nederland en Duitsland, in: Klap et al., Toetsing aan vage normen door de bestuursrechter in het Nederlandse, Duitse, Engelse en Franse recht, 2014, p. 19.

${ }^{827}$ Ibid., p. 16.
} 
may not in course of time add further grounds. I have in mind particularly the possible adoption in the future of the principle of 'proportionality'." 828

As a first ground of review, Lord Diplock names "illegality". This ground of review connects to the ultra vires doctrine, meaning that the court reviews whether an administrative body exceeded its competences. ${ }^{829}$ For this purpose, the Court has to analyse whether the power exercised has been provided for by parliament or common law. In case a power is not defined precisely, the courts have to assess whether there was an illegal abuse of discretion. The leading judgment on the review of discretionary powers was handed down in the case of Associated Picture Houses Ltd. $v$ Wednesbury Corporation from which the following guiding principles emanate: 1 . the exercise of discretion must be real; 2 . if statute provides for matters that the authority must consider, it is obliged to consider them; 3 . the authority can disregard irrelevant matters, bad faith, unreasonableness; and 4. the power must be exercised for proper purposes. ${ }^{830}$

Second, the test of "irrationality" traditionally refers to the Wednesbury test of unreasonableness. Accordingly, the court can only interfere with an administrative decision if it is "so outrageous in its defiance of logic or of accepted moral standards that no sensible person who had applied his mind to the question to be decided could have derived at it." ${ }^{131}$ This definition is rather vague and has been applied with varying degrees of intensity depending on the subject matter of the case ${ }^{832}$ It has been subject to criticism, ${ }^{833}$ but it has not been overruled so far. ${ }^{834}$

Third, Lord Diplock refers to "procedural impropriety" as a ground of review. It concerns rules of natural justice and statutory procedural requirements. ${ }^{835}$ With "rules of natural justice", English law mainly refers to the rule against bias (nemo iudex in causa sua) and the right to be heard (audi alteram partem) ${ }^{836}$ Regarding statutory procedural requirements, a distinction is made between mandatory and directory conditions. ${ }^{837}$ An infringement of mandatory requirements will usually render an

\footnotetext{
${ }^{828}$ Council of Civil Service Unions v Minister for the Civil Service [1985] 1 AC 374 (410).

${ }^{829}$ Kleve, Schirmer, England und Wales, in: Schneider (ed.), Verwaltungsrecht in Europa, vol. 1, 2007, p. 151.

${ }^{830}$ Associated Picture Houses Ltd. v Wednesbury Corporation [1948] 1 KB 223 (682).

${ }^{831}$ Lord Diplock in: Council of Civil Service Unions v Minister for the Civil Service [1985] 1 AC 374 (410).

${ }^{832}$ Craig, Administrative Law, $7^{\text {th }}$ edition, 2012, pp. 648, 649.

${ }^{833}$ Lord Cooke of Thorndon in $R v$ Secretary of State for the Home Department Ex parte Daly [2001] UKHL 26; [2001] 2 AC 532 [32]; moreover, the Wednesbury test is "tautological": Woolf et al., De Smith' Judicial Review, $7^{\text {th }}$ edition, 2013, at 11-019.

${ }^{834}$ Lord Carnwath at the joint UCL-HKU conference 'Judicial review in a changing society', at Hong Kong University, From Rationality to Proportionality in the Modern Law, 14 April 2014 (available online).

${ }^{835}$ According to Lord Diplock ,,basic rules of natural justice.... cover also failure by an administrative tribunal to observe procedural rules that are expressly laid down in the legislative instrument by which its jurisdiction is conferred...." (Council of Civil Service Unions v Minister for the Civil Service [1985] 1 AC 374 (411).

${ }^{836}$ Thompson, Jones, Administrative Law in the United Kingdom, in: Seerden (ed.), Administrative Law of the European Union, its Member States and the United States, $3^{\text {rd }}$ edition, 2012, p. 226; Wade, Forsyth, Administrative Law, $11^{\text {th }}$ edition, 2014, pp. $384 \mathrm{ff}, 405 \mathrm{ff}$.

${ }^{837}$ Feldman (ed.), English Public Law, $2^{\text {nd }}$ edition, 2009, at 15.96; Thompson, Jones, Administrative Law in the United Kingdom, in: Seerden (ed.), Administrative Law of the European Union, its Member States and the United States, $3^{\text {rd }}$ edition, 2012, p. 226; Wade, Forsyth, Administrative Law, $11^{\text {th }}$ edition, 2014, pp. $183 \mathrm{ff}$.
} 
administrative decision void. ${ }^{838}$ Directory requirements should be observed by the administration but their non-observance does not automatically render the administrative decision void. ${ }^{839}$ Whether a rule can be qualified as a mandatory or directory requirement is a matter of interpretation that is left to the courts. ${ }^{840}$

Finally, it has been discussed in how far the principle of proportionality forms a ground of review under English law and how and to what extent it is distinct from "unreasonableness". ${ }^{841}$ According to the Daly case, proportionality has to be distinguished from irrationality in that:

"First, the doctrine of proportionality may require the reviewing court to assess the balance which the decision maker has struck, not merely whether it is within the range of rational or reasonable decisions. Secondly, the proportionality test may go further than the traditional ground of review in as much as it may require attention to be directed to the relative weight accorded to interests and considerations. Thirdly, even the heightened scrutiny developed in $[R$ $v$ Ministry of Defence, ex $p$ Smith 1996 QB 517, 554] is not necessarily appropriate to the protection of human rights [...] the intensity of review, in similar cases, is guaranteed by the twin requirements that the limitation of the right was necessary in a democratic society, in meeting a pressing social need, and the question whether the interference was really proportionate to the legitimate aim being pursued." ${ }^{842}$

Thus, the argument forwarded in this case, is in essence that the test of Wednesbury unreasonableness and the test of proportionality are two distinct concepts, and that the latter tests implies a more intense standard of review. Contrary to this, in the literature, it is argued that also the traditional ground of review, namely the review on the basis of the "unreasonableness" - doctrine, involves a balancing exercise and a reconsideration of the decision-makers choice. ${ }^{843}$ At least, it can be argued there is some overlap between the two concepts. ${ }^{844}$ Moreover, it is debated, whether and to what extent, the test of proportionality is to be preferred over the test of unreasonableness, and whether or not the latter has to

\footnotetext{
838 Thompson, Jones, Administrative Law in the United Kingdom, in: Seerden (ed.), Administrative Law of the European Union, its Member States and the United States, ${ }^{\text {rd }}$ edition, 2012, p. 226; Cane, Administrative Law, $5^{\text {th }}$ edition, 2011, p. 169.

839 Ibid.

${ }^{840}$ Kleve, Schirmer, England und Wales, in: Schneider (ed.), Verwaltungsrecht in Europa, vol. 1, 2007, p. 161.

${ }^{841}$ See on this discussion: De Búrca, Proportionality and Wednesbury Unreasonableness: The Influence of European Legal Concepts on UK law, EPL 1997, pp. 561-586; Lord Carnwath at the joint UCL-HKU conference 'Judicial review in a changing society', at Hong Kong University, From Rationality to Proportionality in the Modern Law, 14 April 2014 (available online).

${ }^{842} R$ (Daly) $v$ Secretary of State for the Home Department [2001] UKHL 26; [2001] 2 AC 532 [27].

${ }^{843}$ Craig, The Nature of Reasonableness Review, Current Legal Problems 2013, p. 149.

${ }^{844}$ Woolf et al., De Smith' Judicial Review, $7^{\text {th }}$ edition, 2013, at 11-010.
} 
be abandonned. ${ }^{845}$ In any event, it is clear that in cases with a human rights or an EU law dimension, a test of proportionaly has to be applied. ${ }^{846}$

In cases brought under section 288 TCPA (1990), grounds of review are basically the same as under judicial review proceedings. ${ }^{847}$ The Secretary of State's decision can be challenged if it was not within the powers of the TCPA and if relevant procedural rules were not complied with. "This will cover bad faith, perverse decisions, failure to take account of relevant factors, taking into account irrelevant factors, errors of law, acting on no evidence, giving inadequate reasons, or a want of natural justice." $" 848$

\section{d. Comparison: differences and convergence}

In this section, the scope of review in the three Member States was described in general.

In all three Member States, the procedural legality of a decision is a ground for review. However, there are differences as to the challengeability of procedural errors and as far as remedies for procedural errors are concerned. Both issues limit the scope of review in practice. In Germany, many rules of procedural law do not confer rights on individuals, which means that, in the judicial protection system focusing on the enforcement of the rights of individuals, claims purely based on the infringement of relative procedural rules will not be admissible. Moreover, not all procedural errors will have the annulment of the administrative decision as a consequence. These issues will be discussed more in detail in the chapter on remedies. In England and in the Netherlands, procedural errors are challengeable in general.

Furthermore, the intensity of review differs. In Germany, the rule is that administrative decisions have to be reviewed in full, but there are some limitations if the authority is vested with a margin of appreciation or discretion. Also in the Netherlands, judges review the procedural and substantive legality of decisions but adopt a cautious approach in cases in which the authority is vested with a margin of appreciation. In England, the general, even if criticised, test for review is the test of Wednesbury unreasonableness.

As far as the general procedural framework is concerned, no clear convergences of rules on the scope of review for procedural errors between the systems can be observed. Specific reforms in the area of environmental procedural law will be an issue in the following sections.

\footnotetext{
${ }^{845}$ For example: for moving towards proportionality: Sales, Rationality, proportionality and the the development of the law, L.Q.R. 2013, pp. 223-241; for retaining Wednesbury: Goodwin, The last defense of Wednesbury, Public Law 2012, pp. 445-467.

${ }^{846}$ Woolf et al., De Smith' Judicial Review, $7^{\text {th }}$ edition, 2013, at 11-09 and 11-073 ff.

${ }^{847}$ Bell et al., Environmental Law, $8^{\text {th }}$ edition, 2013, p. 443.

${ }^{848} \mathrm{Ibid}$.
} 
Table 10: General rules on the scope of review for procedural errors in 2014

\begin{tabular}{|l|l|l|l|}
\hline & Germany & The Netherlands & England \\
\hline Challengeability & $\begin{array}{l}\text { Only if "absolute" } \\
\text { procedural rights }\end{array}$ & Yes & Yes \\
\hline Intensity of review & $\begin{array}{l}\text { Full review, unless } \\
\text { margin of appreciation }\end{array}$ & $\begin{array}{l}\text { Full review, unless } \\
\text { margin of appreciation }\end{array}$ & $\begin{array}{l}\text { Test of Wednesbury } \\
\text { unreasonableness }\end{array}$ \\
\hline
\end{tabular}

In the next section, it will be illustrated how this scope of review was applied in EIA cases. First, there will be a presentation of cases concerning the screening opinion (1.2), followed by a presentation of cases concerning the environmental statement (1.3).

\subsection{The scope of review in screening cases}

In this section the scope of review adopted with regard to environmental screening will be compared. There will first be a description of the issues which can be reviewed followed by an explanation of the intensity of review adopted in screening cases. For this purpose, examples will be given in which a screening was omitted and in which a screening was insufficient because relevant information was missing or because the screening was based on incorrect information.

\section{a. Germany}

The possibility for German courts to review screenings has been practically limited for a long time. In the chapter on standing, it was explained that claimants for a long time could not rely on EIA legislation so that their claims were already stopped at the stage of assessing the admissibility of the claim. Moreover, another limitation that existed was the practical impossibility of being awarded remedies for breaches of the EIA legislation. A detailed explanation on this matter will be given in the chapter on remedies. For the moment, it suffices to say that until the entry into force of the UmwRG (2006), an annulment of an administrative decision could only be requested if there was a concrete possibility that the procedural error had an influence on the administrative decision. With the entry into force of the UmwRG (2006), the law declared two errors fatal for the administrative decision, namely the complete omission of an obligatory EIA or the omission of an obligatory screening. ${ }^{849}$ The new rule did not concern flaws within the screening and the EIA process. The latter were only challengeable according to the general rules, which in practice never led to the annulment of an administrative decision because of a flaw within the EIA process. ${ }^{850}$ Some of these problems were remedied after the Court of Justice's

\footnotetext{
849 § 4 (1) UmwRG (2006).

${ }^{850}$ OVG Schleswig, Decision of 9 July 2010, Az.: 1 MB 12/10, juris - para. 6; VG Neustadt, Decision of 23 May 2012, Az.: 4 L 321/12.NW, juris, para. 36; VG Aachen, Decision of 3 September 2012, Az.: 6 L 250/12, juris, para. 30; VGH Kassel, Judgment of 24 September 2008, Az.: 6 C 1600/07.T, ZUR 2009, pp. 87, 88, juris, para 44; see also the question for preliminary ruling refered to the Court of Justice in Altrip: BVerwG, Decision of 10 January 2012, Az.: 7 C 20/11, NVwZ 2012, pp. 448-451.
} 
judgment in Altrip ${ }^{851}$ and the reform of the UmwRG (2013). ${ }^{852}$ In Altrip, the Court of Justice held that flaws within the EIA must also be challengeable and thereby reviewable ${ }^{853}$ and the new version of the UmwRG provides that courts have to annul an administrative decision if the screening is flawed. ${ }^{854}$

The intensity of review for the screening is determined by statute. $\S 3$ a s. $4 \mathrm{UVPG}^{855}$ stipulates that:

"In case the determination that an EIA shall not be conducted is based on a screening according to $\S 3 \mathrm{c}$, this conclusion reached by the competent authority shall only be reviewed by the courts in judicial review proceedings concerning the admissibility of projects to the extent that the screening was conducted pursuant to the requirements of $\S 3 \mathrm{c}$ and that the result is traceable." ${ }^{856}$

This section prescribes that courts have to control a screening with regard to the procedural steps prescribed in $\S 3 \mathrm{c}$ UVPG and have to review whether the conclusion reached by the authority, i.e. whether an EIA is necessary or not, is plausible. ${ }^{857}$ The procedural steps for the screening consist of a rough assessment of the project, taking into account the criteria of Annex 2 to the UVPG (meaning the implementation of Annex III EIA Directive) ${ }^{858}$ Moreover, preventive and mitigating measures have to be taken into consideration. ${ }^{859}$ Furthermore, it has to be assessed in how far the thresholds for capacity and size are exceeded. ${ }^{860}$ The steps taken and the result have to be documented. ${ }^{861}$

The conclusion reached by the authority can only be reviewed as to its traceability ${ }^{862}$ In the legislative records, it is explained that the result should be tested as to its "plausibility". ${ }^{863}$ These two terms are mostly used synonymously. A further concretisation of this standard of review was developed in the jurisprudence. It was held that the result is not plausible if "the screening is affected by an investigatory error, which weighs as heavy as to have an impact on the result or if the result falls outside the scope of

${ }^{851}$ C-72/12, Gemeinde Altrip and Others $v$ Land Rheinland-Pfalz (Judgment of 7 November 2013).

${ }^{852}$ Gesetz über ergänzende Vorschriften zu Rechtsbehelfen in Umweltangelegenheiten nach EG Richtlinie 2003/35/EG (Umwelt-Rechtsbehelfsgesetz - UmwRG), 8.04.2013, BGB1. I p. 753.

${ }^{853}$ C-72/12, Gemeinde Altrip and Others v Land Rheinland-Pfalz (Judgment of 7 November 2013) para. 37.

${ }^{854} \S 4$ (1) s. 2 UmwRG (2013).

${ }^{855}$ Gesetz über die Öffentlichkeitsbeteiligung in Umweltangelegenheiten nach der EG-Richtlinie 2003/35/EG (Öffentlichkeitsbeteiligungsgesetz), 9.12.2006, BGBl. I p. 2819.

${ }^{856}$ Own translation. The German expression "nachvollziehbar" is translated with "traceable" in order to emphasise what the court does. According to the Oxford Advanced Learner's Dictionary, "to trace" means "to track" something, to find the origin or cause of something, or to describe a process. Other translations of the German term emphasise other nuances: on the eur.lex database, the term "reasonable" is used in order to express that submissions by the Commission have been "nachvollziebar" (Opinion of AG Kokott in C-43/10, Nomarchiaki Aftodioikisi Aitoloakarnanias and Others v Ypourgos Perivallontos, Chorotaxias kai Dimosion ergon and Others (13 October 2011) para. 66); a German dictionary proposes the term "comprehensible" or "understandable" (Pons). ${ }^{857}$ Diens, § 3a UVPG, in: Hoppe, Beckmann (eds.), UVPG Kommentar, ${ }^{\text {th }}$ edition, 2012, at 29, 30; see also: BVerwG, Judgment of 20 Dezember 2011, Az.: 9 A 31/10, BVerwGE 141, 282, 288, at 29.

${ }^{858}$ \& 3 c s. 1 UVPG.

${ }^{859} \S 3$ c s. 3 UVPG.

860 § 3 c s. 4 UVPG.

861 § 3 c s. 6 UVPG.

$862 \S 3$ a s. 4 UVPG.

${ }^{863}$ BR Drs. 551/06, p. 43. 
admissible considerations". ${ }^{864}$ In another case, the court found that the result "lies outside the scope of admissible considerations if generally recognised (scientific) evidence is disregarded, or if an EIA is not conducted, although the screening revealed that a project might have significant impacts on the environment" ${ }^{865}$ Furthermore, investigatory errors have to be relevant for the conclusion reached by the authority, meaning that it is not sufficient that the applicant simply claims that the consideration of an aspect was omitted or wrongly assessed ${ }^{866}$ In an action for interim relief, a claimant alleged that the administrative authority failed in assessing the nutrient contamination of the environment and in taking into consideration several species living in the surroundings of the project. Moreover, the applicant submitted that the assessment of the protection of nature has to be conducted in the summertime, as otherwise one cannot draw any conclusions about the effects on thermophile species. Moreover, he alleged that such an assessment had to be made by a zoologist. With regard to each single claim, the court decided that the applicant did not substantiate his claim and failed to show (plausibly) which consequences the respective omission had for the conclusion of the administrative authority that no EIA was necessary. 867

In reviewing whether the public authority has acted lawfully, the courts have to pay regard to the margin of appreciation with which the public authorities are vested. ${ }^{868}$ An example for this is a case concerning the permission for the establishment and operation of an installation for the intensive rearing of poultry with a capacity of 39,900 broilers. ${ }^{869}$ A screening was carried out because the relevant thresholds were exceeded. ${ }^{870}$ The applicant submitted that the screening was not duly carried out. ${ }^{871}$ In judicial review, the court stressed that a screening only consists of a rough assessment of potential significant negative effects on the environment, meaning that, for example, expert statements are only required at the stage of an EIA. ${ }^{872}$ Furthermore, the court emphasised that it is the authority's task to assess the potential impact of the project and that this assessment cannot be substituted by the courts. ${ }^{873}$ Hence, the scope of review of the court is limited to control whether the authority interpreted the law correctly, whether the facts were completely and correctly investigated, whether the right standard for assessment was applied and whether the authority did not infringe the prohibition of arbitrariness. ${ }^{874}$ This limitation of the scope of review has also been applied repeatedly by the BVerwG. ${ }^{875}$ The court found that the authority duly

\footnotetext{
${ }^{864}$ OVG Hamburg, Decision of 24 February 2010, Az.: 5 Bs24/10, NuR 2010, 344, 345; juris, para. 19 (own translation); see also: OVG Münster, Judgment of 14 October 2013, Az.: 20 D 7/09, DVB1 2014, 185, 188; juris, para. 126; VGH München, Decision of 11 March 2014, Az.: 22 ZB 13.2381, juris, para. 38.

865 OVG Münster, Decision of 1 March 2012, Az.: 8 B 143/11, juris, para. 20 (own translation).

${ }^{866}$ Ibid., juris, para.21.

${ }^{867}$ Ibid., juris, paras. $22 \mathrm{ff}$.

${ }^{868}$ BVerwG, Judgment of 7 December 2006, Az.: 4 C 16/04, BVerwGE 127, 208 at 49.

${ }^{869}$ VG Münster, 17 June 2011, Az.: 10 K 1373/09, juris.

${ }^{870}$ Annex to the UVPG Nr. 7.3.3: screening is necessary if the capacity is of more than 30,000 and less than 40,000 poultry.

${ }^{871}$ VG Münster, Judgment of 17 June 2011, Az.: 10 K 1373/09, juris, para. 16.

${ }^{872}$ Ibid., juris, para. 36.

${ }^{873}$ Ibid., juris, para. 38.

${ }^{874}$ Ibid., juris, para. 40.

${ }^{875}$ BVerwG, Judgment of 16 May 2007, Az.: 3 C 8/06, BVerwGE 129, 27.
} 
considered the distance between the permitted installation and the area in which the applicant's business was situated. According to the court, the authority did not exceed its margin of appreciation. ${ }^{876}$ The screening had to be based on sufficient information, which was not of a purely speculative character. ${ }^{877}$

In certain cases, it may be possible to rely on old information in the screening process. This can be exemplified by a case in which the authority based its considerations on expert opinions provided in previous administrative procedures relating to the same project. ${ }^{878}$ In this case, an initial permit (1) was granted for the establishment and operation of four wind turbines (type A). Before this permit was granted, an EIA was undertaken. The developer did not utilise this permit. ${ }^{879}$ Later, he applied for a permit (2) for the establishment of three wind turbines (of type B) instead of the four wind turbines applied for originally (of type A). The competent authority granted the permit (2) without an EIA. This permit was unsuccessfully challenged in court. ${ }^{80}$ In the following time, the developer erected three wind turbines of a different type (type C). ${ }^{881}$ Since this was a significant alteration to what had been permitted (2), the developer had to apply for a new permit (3) for the already erected wind turbines (type C). This latter permit (3) was granted after the screening ${ }^{882}$ The claimant submitted, inter alia, that this screening (for permit 3) was flawed, as the authority omitted to take into consideration that the sum of the swept area of the wind turbines (type $\mathrm{C}$ ) was bigger than that of the four wind turbines of type A, which would lead to an increased threat for bats. ${ }^{883}$ The court found, after stressing its limited review power, ${ }^{884}$ that there were already previous expert opinions on the marginally smaller swept area and that those opinions concluded that there was no endangerment of the species in question. Therefore the screening was not flawed. ${ }^{885}$ This case shows that courts review whether the screening is based on all relevant information. Another example of a case in which the court had to assess a lack of relevant information in an EIA screening is an action for interim relief brought to the $O V G$ Koblenz concerning a permit granted for the installation of seven wind turbines. ${ }^{886}$ Regarding the potential impact of the wind turbines on the flyway of birds, the public authority based its considerations solely on a report submitted by the developer which stated that no complications were to be expected. However, there was also information available by the public agency for the environment, waterways and trade supervision and the nature protection authority which concluded that there would be adverse effects on the flyway of birds. The court held that this information should have been taken into consideration by the public authority. Hence, the

\footnotetext{
${ }^{876}$ VG Münster, Judgment of 17 June 2011, Az.: 10 K 1373/09, juris, para. 43.

${ }^{877}$ BVerwG, Judgment of 20 December 2011, Az.: 9 A 31/10; BVerwGE 141, 282, 287 at 25; BVerwG, Judgment of 25 June 2014, Az.: 9 A 1/13, NuR 2014, 859, 860; juris, para. 18.

${ }^{878}$ VG Arnsberg, Judgment of 6 December 2012, Az.: 7 K 217/11.

${ }^{879}$ Ibid., juris, para. 6.

${ }^{880}$ Ibid., juris, para 7.

${ }^{881} \mathrm{Ibid}$., juris, para. 8 .

${ }^{882}$ Ibid., juris, paras. 9-12.

${ }^{883}$ Ibid., juris, para. 26.

${ }^{884}$ Ibid., juris, paras. 70-74.

${ }^{885} \mathrm{Ibid}$., juris, para. 75.

${ }^{886}$ OVG Koblenz, Decision of 2 April 2014, Az.: 1 B 10249/14, DVB1 2014, 940-942.
} 
decision was not based on sufficient information. Moreover, the result was not traceable as there was a potential threat to the flyway which, according to the court, would have necessitated an EIA. ${ }^{887}$

Next to considering whether all relevant information was gathered, the courts also review the quality of the information gathered, which may involve complex technical considerations. ${ }^{888}$ For example, in the case of the construction of a motorway junction, the Federal Administrative Court found that, considering the report of the foundation exploration, that the impact of the project on the groundwater was not plausible. ${ }^{889}$ The quality of a screening was, for example, also an issue in an action for interim relief concerning a permit for the alteration of a pig rearing installation. ${ }^{890}$ The court found that the public authority did not duly follow the criteria of the implementing legislation of Annex III. ${ }^{891}$ The screening did not make clear whether the cumulative impact, in conjunction with other projects, was considered, especially concerning a farm located in the south of the developer's installation. ${ }^{892}$ Furthermore, the screening did not reveal any information on the impact of the installation on an area for the extraction of drinking water ${ }^{893}$ In addition to that, the reasoning was held not to be plausible as only the results were documented. ${ }^{894}$ Moreover, an expert report found that the deposition of ammonia would exceed the admissible thresholds. The authority had nevertheless granted permission because the owner of the nearby forest agreed in writing to the deposition of ammonia. The court held that this does not change the finding that the screening is erroneous. ${ }^{895}$ Because of these flaws in the screening, the court found that the screening was not traceable. ${ }^{896}$

In assessing the quality of a screening, the courts rely on expert reports and opinions which they consider carefully. An example of this is a case that was dealt with by the Federal Administrative Court on an administrative decision concerning the reconstruction of a section of highway A $44 .{ }^{897}$ The claimant, a recognised environmental organisation, alleged that the screening, which concluded that no EIA was necessary, was flawed. ${ }^{898}$ The court considered whether the authority made a rough assessment of the potential impacts of the reconstruction on the environment, whether the right legal standards were adopted and whether the result was traceable. For the purpose of assessing the plausibility of the reasoning, the court addressed the alleged flaws and came to the conclusion that the considerations were reasonable. ${ }^{899}$ An issue was that parts of the habitat of the little owl would vanish and that a

\footnotetext{
${ }^{887}$ Ibid.

${ }^{888}$ Philipp-Gerlach, Lukas, Die UVP Vorprüfung in der Rechtsprechung und Praxis, ZUR 2014, p. 551.

${ }^{889}$ BVerwG, Judgment of 20 December 2011, Az.: 9 A 31/10, BVerwGE 141, 282, 288, at 30.

${ }^{890}$ VG Osnabrück, Decision of 21.12.2011, Az.: 2 B 16/11, NuR 2012, 362-367.

${ }^{891}$ The implementing legislation of Annex III of the EIA Directive is schedule 2 of the UVPG; VG Osnabrück, Decision of 21.12.2011, Az.: 2 B 16/11, juris, para. 64.

${ }^{892}$ VG Osnabrück, Decision of 21 December 2011, Az.: 2 B 16/11, juris, NuR 2012, 362, 365, para. 64.

${ }^{893}$ Ibid., NuR 2012, 362, 366; juris, para. 64.

${ }^{894}$ Ibid., NuR 2012, 362, 366; juris, para. 64.

${ }^{895}$ Ibid., NuR 2012, 362, 366; juris, paras. 65-75.

${ }^{896}$ Ibid., NuR 2012, 362, 367; juris, para. 76.

${ }^{897}$ BVerwG, Judgment of 25 June 2014, Az.: 9 A 1/13, NuR 2014, 859 - 864; juris, paras. 15-35.

${ }^{898}$ Ibid., juris, para. 5.

${ }^{899}$ Ibid., juris, paras. 15-35.
} 
compensating area was designated, which, according to the claimant, was insufficient. ${ }^{900}$ The court found that the public authority ordered the construction of nesting aids, the planting of ten tall fruit trees and the creation of a grassland area of 5 ha. During the oral hearing, the court heard the opinion of the director of the ornithological institute of the state environment agency and consulted maps submitted by the defendant. The director explained that the compensating area had to fulfil three functions, namely to serve as breeding area, hiding place during the day and as a feeding area. According to his opinion, the compensating area fulfilled these requirements, and the little owl would migrate to that area with high probability. The court held that this explanation was traceable. ${ }^{901}$

In the workshop, it was confirmed that judges take a very active role in assessing the information on which the screening is based, which involves a detailed study of the materials submitted and in case of uncertainty the consultation of external experts.

In conclusion, the German intensity of review for the screening is thorough. Courts control whether an obligatory screening was done, whether all steps prescribed by the legislation were complied with and whether the conclusion reached is plausible. This standard of review will be compared with the standard of review adopted by courts in the Netherlands in the following section.

\section{b. Netherlands}

Contrary to what was observed with respect to Germany, courts in the Netherlands have not been restricted to only reviewing whether or not a screening was wrongfully omitted, but they have been able to review the authorities' considerations of whether an obligation to conduct a screening exists and to assess errors within the screening. With regard to the correctness of the screening, courts originally applied the thresholds indicated for projects in the annexes to the Besluit m.e.r. very strictly: as long as a project fell below these thresholds, authorities could, according to the courts, conclude that no EIA was necessary. ${ }^{902}$ This changed after the ruling of the Court of Justice in Commission $v$ Netherlands ${ }^{903}$ in 2009, in which the Court held that the Netherlands does not sufficiently take account of the criteria listed in Annex III of the EIA Directive. ${ }^{904}$ Since this ruling, courts not only reviewed whether or not the thresholds were met, but also whether authorities took the criteria enumerated in the annex into account..$^{905}$

The intensity of review for the screening is described as marginal and terughoudend (cautious). ${ }^{906}$ This means that courts check whether or not the requirements of the EIA legislation were observed by the

\footnotetext{
${ }^{900}$ Ibid., juris, paras. 30-33.

901 Ibid., juris, para. 32.

${ }^{902}$ ABRvS 4 June 1999, nr. E03.98.0770, JB 1999/168; ABRvS 8 August 2000, nr. E03.98.0103, M\&R 2000,

213 K; ABRvS 20 March 2002, nr. 200002278/1, M\&R 2002/86 (with a comment by van der Meijden) para. 2.2; ABRvS 10 November 2004, nr. 200304823/1, AB 2005/40, (with a comment by Verschuueren).

${ }^{903}$ C-255/08, Commission of the European Communities $v$ Kingdom of the Netherlands [2009] ECR I-167.

904 The Dutch legislator amended the Wm with Stb 2011, 102.

905 This section will refer to many cases dealing with this issue.

${ }^{906}$ Van Velsen, M.e.r.-beoordeling: geen drempelvrees!, JM 2011, p. 591.
} 
competent authority and whether or not reasons were given. If this is the case, the court will usually not find any breach of procedural rules and the burden for explaining why there was a flaw within the screening lies with the claimant. After 2009, Dutch courts had to review the consideration of the criteria of Annex III in a great number of cases. In many cases in which relevant thresholds were not exceeded, courts held that, even by taking Annex III into account, it was not possible to show why an EIA should have been conducted. ${ }^{907}$ In other cases, the court found that by not taking the criteria of Annex III into account, the decision was not based on sufficient reasons and that it had to be annulled. An example of this is a case concerning a permit granted for the extension of a pig rearing installation in Rucphen. ${ }^{908}$ The court found that the public authority did not consider aspects such the size of the project, the cumulative impact with other projects, the impact on nature, especially nature protection areas, which, according to the claimant might lead to a finding that an EIA is necessary. ${ }^{909}$ Therefore, this claim was successful. A similar case concerned a permit granted for a poultry farm in Peel en Maas. ${ }^{910}$ The claimants alleged that the authority failed to take into consideration the issue of odour and the existence of a nature protection area nearby. The court held that the decision was therefore unduly prepared and not sufficiently motivated, so that it had to be quashed.

In a case concerning a permit for the alteration of a pig farm in Horst aan de Maas, the claimants submitted that the public authority wrongfully omitted to assess whether an EIA should be carried out. The Council of State found that the thresholds of the annexes were not exceeded, ${ }^{111}$ but that the authority failed to take the criteria of Annex III into consideration. Hence, the decision was in breach of articles 3:2 and 3:46 Awb. Therefore, the permission was quashed. However, the administrative authority was allowed to try to correct the procedural error, so that the legal consequences of the administrative decision could be upheld. ${ }^{912}$ Subsequently, the public authority modified the original administrative decision, taking the factors of Annex III into consideration and found that an EIA was not necessary. The reason for this was that the existing pigsties were equipped with systems that guarantee low emissions. Additionally, measures would be taken to limit the use of natural resources, so that the regenerating capacity of the area where the installation is situated would not be touched upon. In addition to that, the authority found that there were no nature protection areas in the direct environment of the

\footnotetext{
907 ABRvS 16 December 2009, nr. 200809273/1/M2, JM 2010/24 (with a comment by van Velsen); ABRvS 13 January 2010, nr. 200902344/1/H1 and nr. 200902348/1/H1, JM 2010/33 (with a comment by van Velsen); ABRvS 7 July 2010, nr. 200902256/1/R1, JM 2010/110 (with a comment by Poortinga); ABRvS 14 July 2010, nr. 200900601/1/M2; ABRvS 29 September 2010, nr. 200905791/1/R3; ABRvS 15 December 2010, nr. 200903460/1/R3, JM 2011/22 (with a comment by Hoevenaars); ABRvS 23 March 2011, nr. 200906485/1/R3; ABRvS 29 June 2011, nr. 201011165/1/M2; ABRvS 9 March 2011, 201006983/1/M2; ABRvS 24 August 2011, nr. 201002095/1/R3; ABRvS 14 September 2011, nr. 201011495/1/M2; ABRvS 9 November 2011, nr. 201002780/1/R1, JM 2011/140 (wih a comment by van Bommel); ABRvS 28 November 2011, nr. 201106128/1/A4, JM 2013/41 (with a comment by Bokelaar); ABRvS 12 June 2013, nr. 201111410/1/A4.

${ }^{908}$ ABRvS 17 March 2010, nr. 200904456/1/M2, JM 2010/62 (with a comment by van Velsen).

${ }^{909} \mathrm{Ibid}$., para. 2.5.4.

${ }^{910}$ ABRvS 23 March 2011, nr. 201001104/1/M2.

${ }^{911}$ ABRvS 21 November 2012, nr. 201103782/1/A4, para. 2.6.2.

${ }^{912}$ For further discussions on this type of remedy refer to Part II, Chapter 4, Section 1.2 b.
} 
installation. Moreover, odour and ammonia emission would decline and they would comply with statutory requirements. Finally, the closest Natura 2000 area was situated 6,100 meters further away. ${ }^{913}$ After this correction by the authority, the claimants submitted that the administrative authority should have concluded that an EIA is necessary. They argued that the authority insufficiently considered the planning regime underlying the decision. Moreover, it was alleged that the authority did not assess the consequences for public health, effects of acidification through the deposition of ammoniac, cumulative effects of odour nuisance, the density of population in the direct surroundings of the installation and effects on the woodlands near the installation. ${ }^{914}$ The Council of State found that the administrative decision was sufficiently motivated and the judges could not find any reason for the allegation that the underlying planning regime was inadequately considered. The claimant also did not explain sufficiently why there would be an adverse impact on public health. Therefore, the applicants could not successfully raise the claim of a flawed screening. In the end, the original administrative decision was quashed.

The failure to consider Annex III was also an issue in a judgment concerning a case of a permit granted to the developer of a poultry farm in Vroomshop. ${ }^{915}$ This judgment was preceded by an interim order by the court to the competent authority to correct the failure to consider the criteria listed in Annex III of Directive 85/337. Reacting to the order, the authority issued a screening opinion stipulating that an EIA was not necessary. The claimants argued that the (renewed) assessment of criteria listed in Annex III was insufficient. They contested that the impact on a Natura 2000 area was not sufficiently taken into consideration. Moreover, it was submitted that the authority failed to address mitigating measures and a thorough analysis of other criteria listed in Annex III. The court subsequently presented a summary of the screening opinion, which stated that there would be no adverse effects on the Natura 2000 area, which was located at a distance of 1,600 meters from the site under consideration and that the question of mitigating measures has to be addressed by the province granting permission under nature protection law. The court continued by finding that the claimants were not able to show that there were factors that would further substantiate their claim. As a result the administrative decision was annulled but the legal consequences were upheld.

In the case of the pig rearing installation of Alphen-Chaan, the court assessed whether the criteria of Annex III were sufficiently taken into consideration. ${ }^{916}$ The competent authority had analysed the deposition of ammonia and the installation was placed in an agricultural area sufficiently distant from nature conservation areas. Additionally, mitigating measures were taken to prevent adverse impacts on the environment. Finally, even though there was a contradiction in the screening opinion relating to the emission of ammonia, the court came to the conclusion that there was incorrect information in the papers but that the calculation was actually done correctly. Therefore, this point did not give rise to any further

\footnotetext{
913 ABRvS 21 November 2012, nr. 201103782/1/A4, para. 6.1.

${ }^{914}$ Ibid., para. 6.

${ }^{915}$ ABRvS 4 July 2012, nr. 20010565/1/A4.

${ }^{916}$ ABRvS 14 March 2012, nr. 201011045/1/A4.
} 
challenge. ${ }^{917}$ To sum up, the general line in these cases has been that courts check whether the authority took the criteria of Annex III into consideration. If this is the case, the authority has complied with its obligation.

Next to these cases in which the courts had to deal with the question of whether all elements of the procedure were followed, in some cases, ${ }^{918}$ the courts had to assess the appropriateness of the information gathered. Also in this respect, the scope of review is in principle cautious ${ }^{919}$ and often there is a simple reference to an expert statement. ${ }^{920}$ An example is a case in which a permit was granted for the installation and operation of a composting plant. ${ }^{921}$ The applicants submitted that the decision not to conduct an EIA was based on false information. ${ }^{922}$ The expert report stated that the composting processes in this plant were different from "usual" composting processes which may lead to another (higher) emission of odour. ${ }^{923}$ The court found therefore that there was a breach of articles 3:2 and $3: 46 .{ }^{924}$ In a case concerning a permit for a waste treatment installation, the claimants argued that odour emissions were not adequately dealt with. ${ }^{925}$ On the basis of several expert reports which were made in the context of the application for the permit, the court found that the public authority completely failed to consider the limits of the odour emissions. Therefore, the screening was based on insufficient information and the claim was successful. ${ }^{926}$

Moreover, in cases in which the public authority is convinced that an EIA has to be conducted, the testing of the courts is also very light. This became evident in the case of a developer challenging the decision of the public authority that an EIA had to be done with regard to excavation activities. ${ }^{927}$ The developer submitted that relevant environmental impacts were already assessed for the purpose of making the request for the permit in which it was concluded that no significant negative effects would occur. The public authority was of the opinion that it was necessary to conduct an EIA in order to specify the potential impact on a nearby Natura 2000 area. The court held that this was not unreasonable and therefore the claim was dismissed. ${ }^{928}$

\footnotetext{
${ }^{917} \mathrm{Ibid}$., para. 2.4.4; the claim was however partially successful as regards other challenges, resulting in the court partially quashing the administrative decision.

${ }_{918}$ The Council of State has only assessed the content of the screening in a limited number of cases; Hoevenaars, Kroniek M.e.r.-regelgeving, M\&R 2014/51, p. 254.

${ }^{919}$ Soppe, Art. $7.17 \mathrm{Wm}$, in: Koeman, Ulyenburg (eds.), $T \& C$ Milieurecht, $5^{\text {th }}$ edition, 2013; Soppe however also stressed that there may be exceptions to this like for example: ABRvS 3 July 2013, nr. 201209539/1/R4, M\&R 2013/127 (with a comment by Soppe and Gudelach).

${ }^{920}$ ABRvS 29 October 2003, nr. 200206313/1, para. 2.1.2; ABRvS 4 May 2005, nr. 200403894/1, para. 2.2.5.

${ }^{921}$ ABRvS 7 February 2007, nr. 200603204/1.

${ }_{922}$ Ibid., para. 2.3.

${ }^{923}$ Ibid., para. 2.5.1.

${ }^{924} \mathrm{Ibid}$., para. 2.5.1.

${ }_{925}$ Rechtbank Oost-Brabant 8 April 2014, nr. SHE 13/774, M\&R 2014/95 (with a comment by Arentz).

${ }^{926} \mathrm{Ibid}$., para. 12.5 .

${ }^{927}$ ABRvS 1 October 2014, nr. 201308398/1/R4, JM 2014/154 (with a comment by Wagenmakers).

${ }^{928}$ Ibid., para. 4.4.
} 
The workshop has shown that if the claimants do not specifically raise a point that raises reasonable doubts on the correctness of the screening, the Council of State will not intervene. The judge will not actively assess whether the information on which the screening is based is sufficient and correct. Hence, contrary to the German judges, Dutch judges in principle do not review the plausibility of the result of a screening by themselves, but they rely heavily on the opinion of advisory bodies in the administrative procedure, which play an important role in assessing the adequacy of the screening.

In conclusion, Dutch courts have practically always been able to review the omissions and the content of the screening. The intensity of review in most cases is marginal and cautious. Usually, it is for the applicant to submit sufficient arguments so that the court will conclude that the competent authority acted illegally. The submission of sufficient arguments will be an issue in the section on the burden of proof.

Having described the scope of review in EIA cases in the Netherlands, the legal system of England will now be addressed.

\section{c. England}

In England, the courts have been reviewing whether or not it is obligatory to carry out a screening pursuant to the EIA legislation and they have been asked to review the quality of the screening. In the beginning of EIA enforcement in England, the question of whether legislation prescribed a screening or not was considered to be a question of judgement and degree and was therefore only reviewable by the courts to a limited degree. ${ }^{929}$ This was however overruled in the case of Goodman, which concerned the grant of planning permission for the construction of storage and distribution facilities. ${ }^{930}$ The claimants, which were residents near the site, brought a claim for judicial review complaining that no EIA was conducted. The question was whether the screening opinion adopted by the administrative authority, according to which the construction of storage and distribution facilities did not fall under schedule 2 of the EIA Regulations, was flawed. In the court of first instance, the judge held that the decision was only reviewable on the grounds of Wednesbury unreasonableness and dismissed the application. The applicants subsequently appealed. Considering the question whether the construction of storage and distribution facilities are "infrastructure projects that are urban development projects" according to schedule 2 of the EIA Regulations, Buxton LJ found:

"These are very wide and to some extent obscure expressions and a good deal of legitimate disagreement will be involved in applying them to the facts of any given case. That emboldened Lewisham to argue, and the judge to agree, that such a determination on the part of the local authority could only be challenged if it were Wednesbury unreasonable. I do not agree. However fact sensitive such a determination may be, it is not simply a finding of fact, nor of discretionary

\footnotetext{
${ }^{929} R$ (Royal Society for the Protection of Birds) $v$ Swale Borough Council [1991] JPL 39.

${ }^{930} R$ (Goodman) v London Borough of Lewisham [2003] EWCA Civ 140; [2003] Env LR 28.
} 
judgment. Rather, it involves the application of the authority's understanding of the meaning in law of the expression used in the Regulation. If the authority reaches an understanding of those expressions that is wrong as a matter of law, then the court must correct that error: and in determining the meaning of the statutory expressions the concept of reasonable judgment as embodied in Wednesbury simply has no part to play." 931

Hence, the correct interpretation of the terms in the annex to the EIA regulation is a question of law, fully reviewable by the courts. Buxton LJ explained that the term "infrastructure" is wider than the usual definition of the Oxford Dictionary, finding that the construction of storage facilities may be covered by schedule 2 of the Regulations. Therefore, he allowed the appeal, quashed the grant of planning permission and ordered the application for planning permission to be remitted to the authority to reconsider the case in light of the judgment. Morland J, agreeing, added that the case has to be seen in the light of the Kraaijeveld judgment in which the Court of Justice emphasised the wide scope and broad purpose of the EIA Directive. For these reasons, the judge found that a project such as the one under consideration may fall under the scope of the Regulations. ${ }^{932}$

Next to reviewing whether or not a screening has to be carried out, courts have to assess the quality of the screening. To begin with, courts emphasised the necessity of a formal screening opinion, giving reasons for the decision whether or not an EIA has to be undertaken. In the case of Lebus, planning permission was granted for the erection of an egg production facility. It was intended to house 12,000 chickens in a building of $1,180 \mathrm{~m}^{2}$. The claimants alleged that there was no formal screening opinion. Hence, Sullivan J had to consider whether there was any document in the planning process which "can sensibly be described as a screening opinion for the purpose of the Regulations". ${ }^{933}$ The competent authority had produced a "screening table" which described a certain impact on the environment and had informally told the developer that no environmental statement was needed. With regard to the summary table Sullivan J held:

"It has been submitted on behalf of the council that the summary table amounts to a screening opinion. In my judgment, it is nothing of the kind. It is no doubt a convenient checklist that had to be gone through in order to reach the necessary statutory opinion. But the necessary statutory opinion as to whether the development is or is not EIA development is nowhere expressed in that document." $" 934$

For this reason, the application for judicial review was allowed.

\footnotetext{
${ }^{931}$ Ibid. [8].

${ }^{932} \mathrm{Ibid}$. [20].

${ }_{933} R$ (Lebus) v South Cambridgeshire District Council [2002] EWHC 2009 (Admin); [2003] Env LR 17 [37].

${ }^{934}$ Ibid. [38].
} 
The issue of a lack of reasons in a screening opinion was at issue in the case of Mellor ${ }^{935}$ This case concerned the determination by the Secretary of State that no EIA was required for a planning application to build a medium secure hospital. Pursuant to earlier jurisprudence in which it was decided that no reasons had to be given for a negative screening direction, ${ }^{936}$ the Secretary of State had not motivated her decision. The claimants requested the national court to make a reference for a preliminary ruling to the Court of Justice, asking whether a public authority, giving a negative screening opinion, was obliged to state reasons. ${ }^{937}$ The Court of Justice found that the Directive itself does not require that reasons are given but it emphasised that it must be possible for third parties and administrative authorities to "satisfy themselves" that EIA legislation was observed. ${ }^{938}$ According to the Court of Justice, it must be possible to review the legality of the reasons of the decision, which means that they have to be made available. ${ }^{939}$ Therefore, an interested party must be able to request reasons for a negative screening opinion. ${ }^{940}$ Moreover, the Court found that a decision must contain sufficient information so that interested parties can conclude whether it was based on an adequate screening and whether or not appeal against the decision can be brought. ${ }^{941}$

A case which builds on the decision of the Court of Justice in Mellor, is the case of Bateman. ${ }^{942}$ In this case, the claimants brought a claim for judicial review against a planning permission for the extension of a grain storage facility, involving the construction of 60 silos (18 meters high and 23 meters in diameter), six holding bins and four bulk bins. The screening opinion stated that an EIA was not required. The claimants submitted that this opinion should be quashed as it was illogical and irrational and did not contain sufficient reasoning to comply with the requirements of the EIA Directive and the national EIA legislation. ${ }^{943}$ In the relevant paragraph of the screening opinion, the council simply enumerated the main impacts which were likely to occur. Moore-Bick LJ found that:

"It is clear that the planning officer's reasons must be read in the context of the letter to which they were a response, but nowhere in them does one find set out a clear statement of her reasons for concluding either that there will be no discernible effects in relation to traffic movements, landscape or noise, or that, if there may be, they will not be sufficiently serious to be regarded as significant." 944

\footnotetext{
${ }^{935} R$ (Mellor) v The Secretary of State for Communities and Local Government [2008] EWCA Civ 213.

${ }^{936} R$ (Marson) $v$ The Secretary of State for the Environment, Transport and the Regions and Parcelforce [1999] 1 CMLR 268.

${ }^{937} R$ (Mellor) $v$ The Secretary of State for Communities and Local Government [2008] EWCA Civ 213; [2009] Env LR D1.

${ }^{938}$ C-75/08, The Queen on the application of Christopher Mellor v Secretary of State for Communities and Local Government [2009] ECR I-3799, para. 57.

${ }^{939}$ Ibid., para. 59.

${ }^{940} \mathrm{Ibid}$., para. 61.

${ }^{941}$ Ibid.

${ }^{942} R$ (Bateman) $v$ South Cambridgeshire District Council [2011] EWCA Civ 157.

${ }^{943}$ Ibid. [8].

${ }^{944}$ Ibid. [21].
} 
Therefore, he concluded:

"Nothing has been put before us to suggest that the planning officer's decision in this case was not carefully and conscientiously considered, nor do I think it can be said that it was not in fact based on information that was both sufficient and accurate. However, I have, somewhat reluctantly, come to the conclusion that the reasons given for her decision do not make it sufficiently clear why she reached the conclusion that an EIA was not required in this case. That is not to suggest that she may not have had perfectly good reasons for reaching that conclusion, just that it is not clear what they were."

Because of this lack of reasoning, the judge held that the entire process was flawed meaning that the planning permission had to be quashed. ${ }^{946}$

The issue of an insufficiently motivated negative screening opinion was also raised in the case of the Wye Valley Action Association, which concerned planning permission granted for the erection of polytunnels. Richards LJ found that

"the reasons given in the screening opinion were adequate, though they could usefully have been fuller [...] It was not incumbent on the council to set out all the considerations it had taken into account, such as the effect of the AONB. It set out the essence of its reasoning and that was enough." 947

Hence, in a screening, it is not necessary, to enumerate all reasons for a negative screening opinion. What follows from these cases following the Court of Justice's judgment in Mellor, however, is that English courts carefully check whether sufficient reasons are given in the screening opinion.

The quality of the screening was also an issue in the case of the Friends of Basildon Golf Course, in which the local authority had granted planning permission for the development of a golf clubhouse, driving range and ancillary facilities. ${ }^{948}$ On the same day that the application for development was submitted, the authority had decided in a "screening opinion" that no EIA was necessary as the project did not fall under Schedule 2 of the EIA Regulations taking the criteria of schedule 3 into account. The first allegation concerned the amount of inert waste material transported to the site to remodel areas of the existing golf course. The screening opinion referred to 50,000 t of material, when in fact 156,000 $t$ were imported. Pill LJ held in this regard that "the amount of waste to be deposited on the site was grossly understated in the Opinion which, as a result, was seriously misleading." 949 The second issue concerned the ecological aspect of the screening opinion, which was simply provided in one sentence

\footnotetext{
945 Ibid. [27].

${ }^{946}$ Ibid. [31].

${ }^{947} R$ (Wye Valley Action Association Ltd) v Herefordshire Council [2011] EWCA Civ 20; [2011] Env LR 20 [47].

${ }^{948} R$ (Friends of Basildon Golf Course) v Basildon DC [2010] EWCA Civ 1432; [2011] Env LR 16.

${ }^{949}$ Ibid. [55].
} 
stating that "The application is to be supported by a detailed ecological report which will include a survey of the wild life on the site and details of a mitigation strategy". The judge in this respect found that this "brevity reflects what appears to me to have been an insufficient analysis of the issues which had arisen". ${ }^{950}$ On these reasons, Pill LJ held that the screening opinion and the planning permission should be quashed. ${ }^{951}$

However, the assessment of whether a certain project is likely to have a significant impact on the environment is a question reviewable on Wednesbury grounds. This was emphasised by the court in Jones $v$ Mansfield.$^{952}$ In this case, Ms Jones challenged the decision of the public authority that it was not necessary to make an EIA with regard to permission for the use of a site as an industrial estate. She was especially concerned about the potential impact of the proposed development on golden plovers and bats. In appeal, the judge, considered that

"Whether a proposed development is likely to have significant effects on the environment involves an exercise of judgment or opinion. It is not a question of hard fact to which there can only be one possible correct answer in any given case. Thus use of the word "opinion" in reg. 2 (2) is, therefore, entirely apt. In my view, that is in itself a sufficient reason for concluding that the role of the court should be limited to one of review on Wednesbury grounds." 953

The public authority in the case had gathered substantial information, so that the judge could find that

"Having regard to the information already available, it was reasonable for the committee to decide that the development would be unlikely to have significant effects in relation to birds and bats. ${ }^{954}$

The appeal was therefore dismissed.

Another case illustrating the light test of the courts with regard to the question whether or not significant effects are to be expected is the case of Long, ${ }^{955}$ concerning the grant of planning permission for the demolition of a cattle market and associated buildings and to redevelop the area. The founding member of an opposition group brought a claim for judicial review against the local authority's decision. The planning permission was preceded by a screening opinion concluding that an EIA was not necessary. Long submitted that the screening conducted by the authority was unlawful, arguing that "the Council failed to have proper regard for, and assess in accordance with the EIA Regulations, the historic, cultural, environmental and socio-economic sensitivity of the site". ${ }^{956}$ Specifically, he argued that the authority

\footnotetext{
${ }^{950} \mathrm{Ibid}$. [59].

${ }^{951} \mathrm{Ibid}$. [63].

${ }^{952} R$ (Jones) v Mansfield DC [2003] EWCA Civ 1408; [2004] Env LR 21.

${ }^{953} \mathrm{Ibid}$. [17].

${ }^{954} \mathrm{Ibid}$. [53].

${ }_{955} R$ (Long) v Monmouthsire City Council [2012] EWHC 3130 (Admin).

${ }^{956}$ Ibid. [30].
} 
did not pay sufficient regard to matters of conservation, the state of watercourses and socio-economic effects. ${ }^{957}$ Hence, he alleged that the authority failed to exercise its judgement within public law limits. Davies J refused the application on all grounds. With regard to the screening decision, she noted that the reasons given were very detailed and clearly referred to the requirements of schedule 3 of the EIA Regulations. Furthermore, matters of conservation were considered and the decision made cannot be described as irrational. ${ }^{958}$ The effects of the demolition of the slaughterhouse were addressed in the screening reasons and the officer report. Moreover, there was no necessity for the authority to include the recommendation of a consultant to extend the adjacent conservation area to the cattle market, as the screening opinion analysed the impact on this conservation area. Furthermore, the reasons given by the public authority for the finding that there was no significant impact on other listed buildings were "succinct" and "its essence is clear". ${ }^{959}$ With respect to the allegation that the public authority did not address the watercourses appropriately, the judge observed that the screening opinion gave detailed consideration to this issue and that regard was paid to the views of statutory consultees. The claimant's submission that socio-economic effects were not properly assessed was neither accepted by the judge, as this matter was fully explored in the screening reasons. ${ }^{960}$ Finally, the judge summarised the rule for the scope of review for screening opinions as follows:

"What is required in screening reasons is the essence of the reasoning, the council provided that, and more. The claimant may disagree with the analysis contained within the reasons or in the documents which accompany them. The approach of the Courts is clear: what has to be shown is Wednesbury unreasonableness. I find that the claimant has not provided a sound evidential base for such a challenge." 961

This judgment illustrates that courts will check whether reasons were given, but they only interfere with the administrative authority's decision if it was Wednesbury unreasonable. Consequently, the assessment of whether there will be a significant impact on the environment is to be decided by the administrative authority and will only be checked to a limited extent.

This can also be seen in the case of Loader ${ }^{962}$ In this case, the appellant appealed the refusal to quash a screening direction by the Secretary of State in which it was decided that the re-development of an established bowling club did not have to be subjected to an EIA. In the screening direction the Secretary of State had found that the development fell within the schedule 2 of the EIA Regulations and that the thresholds of column 2 were exceeded, but that, after having considered the criteria in schedule 3 , it was

\footnotetext{
${ }^{957}$ Ibid. [30]-[42].

${ }^{958}$ Ibid. [92].

${ }^{959}$ Ibid. [94].

${ }^{960} \mathrm{Ibid}$. [97].

${ }^{961} \mathrm{Ibid}$. [98].

${ }^{962} R$ (Loader) v Secretary of State for Communities and Local Government [2012] EWCA Civ 869; [2012] 3 CMLR 29.
} 
not likely that the development would have significant effects on the environment. ${ }^{963}$ The appellant submitted that the Secretary of State had been misdirected in finding that there were no significant impacts on the environment according to Regulation 2 of the Regulations 1999. After having discussed in detail the test which has to be applied for assessing whether some effects are significant, ${ }^{964}$ the appeal was dismissed because the Secretary of State has a degree of freedom in appraising whether a project has to be made subject to an assessment. ${ }^{965}$ It is clear that the decision maker has to pay regard to the precautionary principle and that there is a certain degree of uncertainty with regard to the decision. ${ }^{966}$ However, Pill LJ concluded:

“...I have no doubt that the Inspectorate was entitled to conclude that the proposed redevelopment would not have significant effects on the environment. A checklist was completed and no complaint is made about its contents. Judgment was exercised and reasons were given for the decision [...], which justify the conclusion reached. It may be added that the application for planning permission did not involve the uncertainties which have presented difficulties of analysis in some of the cases considered. Moreover, judgment was exercised, not at the early stage of the procedure when such decisions are often made, but after full consideration of the planning issues by the local planning authority and also by an Inspector appointed by the Secretary of State. Full information as to the nature of the proposal and its likely effects was available. I would dismiss this appeal." 967

This case shows that it is in principle for the authorities to determine what "significant impacts on the environment" are. The judge found that there was a checklist, followed by a reasoned decision. Moreover, she found that the decision was taken after full consideration of all information available. Thus, the court formally controlled whether the criteria were taken into consideration and whether the screening decision was reasoned.

To conclude, under English law, the interpretation of the EIA Regulations is a matter of law fully reviewable by the courts. Moreover, the screening opinion must state adequate reasons. However, the ultimate finding of whether a project is likely to have significant impacts on the environment is left to the public authority and its decision is only reviewable on Wednesbury grounds.

\footnotetext{
963 Ibid. [4].

964 The appellant had argued that "a significant environmental effect, as defined in the Directive, is one that has a real prospect of influencing the outcome of the application for development consent" [41]. The court however held that, considering the approach adopted by Moore-Bick LJ in Bateman that the word "significant" should not be interpreted too rigidly [46].

${ }_{965} R$ (Loader) v Secretary of State for Communities and Local Government [2012] EWCA Civ 869; [2012] 3 CMLR 29 [43].

${ }^{966}$ Ibid.

${ }^{967}$ Ibid. [47], [48].
} 


\section{d. Comparison: differences and convergence}

In this section, the scope of review in the three legal systems was described in cases in which the screening was at issue.

In all three states, the procedural legality of an administrative decision is subject to review. The review of the courts thereby comprises the failure to carry out screenings and flaws in the screening. In Germany, the review of the quality of the screening was practically limited for a long time. Although the UVPG specified the intensity of review with regard to the screening, the UmwRG provided that courts had to annul an administrative decision (only) in cases in which a screening was completely missing, which had as a consequence that flaws in the screening were not qualified as relevant procedural errors. At the same time, courts in the Netherlands and in England have reviewed the quality of screenings. The German situation changed with the reform of the UmwRG in 2013, explicitly stipulating that also in the case of an erroneous screening, in principle courts have to annul the administrative decision. Thus far, the differences which originally existed are diminishing and the legal systems are in a process of convergence.

As far as the intensity of the screening in the three legal systems is concerned, different "tests" are applied. Whereas in Germany statute prescribes that courts have to review the steps of the screening and assess whether the result is plausible, the Netherlands cautiously reviews the authority's screening meaning that the expertise of the administrative authority is not substantially questioned. In England, the test of Wednesbury unreasonableness is applied when reviewing the court's assessment of significant impacts on the environment. The German test is the most intense, as all procedural steps are reviewable - legally and factually - and the result must be plausible to the judge. Contrary to that, the English test is very light. If Wednesbury is taken literally, the court only intervenes if the decision is "so outrageous in its defiance of logic or of accepted moral standards that no sensible person who had applied his mind to the question to be decided could have derived at it". Although this test is subject to criticism and although the intensity of review in practice varies according the concrete issue being considered, the difference between the English and the German system remains, as English judges generally do not test the adequacy of information and the plausibility of the result of the screening. The approach adopted by the Netherlands resembles the English approach to the extent that judges will check whether reasons were given and whether information was gathered, but the result is not controlled as to its plausibility by the judges themselves. However, it has to be stressed that there was a heavy involvement of the Commissie m.e.r. in the Dutch EIA procedure guaranteeing the quality of the procedure and courts can request the input of independent advisory bodies during court proceedings.

An overview over the tests is provided in the following table: 
Table 11: Rules on the scope of review in screening cases in 2014

\begin{tabular}{|l|l|l|l|}
\hline & Germany & The Netherlands & England \\
\hline Challengeability & $\begin{array}{l}\text { Omission of the } \\
\text { screening: § 4 (1) nr. 1 } \\
\text { UmwRG (2013) } \\
\text { Flaws in the screening: } \\
\S 4(1) \text { s. 2 UmwRG } \\
(2013\end{array}$ & $\begin{array}{l}\text { Omission of and flaws } \\
\text { in the screening }\end{array}$ & $\begin{array}{l}\text { Omission of and flaws in } \\
\text { the screening }\end{array}$ \\
\hline $\begin{array}{l}\text { Intensity of } \\
\text { review }\end{array}$ & $\begin{array}{l}\text { Test of Traceability } \\
\text { Test of Cautious } \\
\text { Review }\end{array}$ & $\begin{array}{l}\text { Test of Wednesbury } \\
\text { Unreasonableness }\end{array}$ \\
\hline
\end{tabular}

The consequence of these different standards of review is that in one legal system there is a more thorough quality control of the screening in courts than in another legal system. As long as there are mechanisms to control the quality of the application of the EIA Directive, for example with the involvement of the Dutch Commissie m.e.r. in the EIA process, a light standard of review is mitigated. Through the guaranteed quality control by other independent bodies, differences in national litigation rules become less relevant. However, if there is only a very light quality control of screening in courts, and if there are no independent bodies or other mechanisms to ensure a thorough review, this may, at least in theory, result in a different quality of the screening in the various legal systems. In this regard, it should be noted that the EIA Directive does not prescribe the methods or the scientific standards for the screening. Thus, the quality of the screening may already be different because of these different standards in the different legal systems.

\subsection{The scope of review for the environmental statement}

In this section, the scope of review adopted by national courts with regard to the environmental statement will be compared. First a description of the issues which can be reviewed will be provided, followed by an explanation of the intensity of review adopted in cases in which the quality of the EIA is at issue. For this purpose, examples will be given in which an EIA was omitted and in which an EIA was insufficient because relevant information was missing or because the screening was based on incorrect information.

\section{a. Germany}

The review of environmental statements in German courts was very limited in the past. The reasons for this are the same as for the limited review of the screening. As explained in the introductory section, it was impossible for claimants to access courts when basing the claim only on the allegation that an EIA was wrongfully omitted or flawed. Standing was only granted if applicants could allege the infringement 
of a subjective right under public law and the EIA procedure did not provide for these rights. In cases in which claimants were able to access courts, claimants had to prove that the decision would have been different without the error, in order raise their claim successfully. In 2006, the legislator adopted a statute which stipulated that courts have to annul decisions in which an obligatory environmental impact assessment was wrongfully omitted. ${ }^{968}$ However, access, also of environmental organisations, was made dependent on the infringement of a subjective right, meaning that many cases already failed at the stage of access to courts. Moreover in the statute of 2006, flaws in the EIA process were not mentioned among the errors for which a remedy was available.

A case illustrating the connection between the scope of review and the remedy available is the case of a recognised nature protection association which made an application for judicial review of a permit for the establishment and operation of a combustion installation. ${ }^{969}$ Regarding the EIA, the applicant submitted that central considerations were incomplete and incorrect for the following reasons: the EIA lacked an overall assessment of the environmental effects of the permitted project in relation to other installations. Moreover, the potential increase in traffic due to lorries was not taken into consideration. Furthermore, the increased burdens caused by $\mathrm{NO}^{2}$ emissions were wrongfully assessed. ${ }^{970}$ The court simply found that an EIA was carried out and that therefore the procedural rights of the applicants were complied with. ${ }^{971}$ The UmwRG (2006) did not provide for a remedy for a flawed EIA. According to the court, doubts with regard to the compatibility of the UmwRG (2006) with Union law could only arise if important procedural steps were disregarded, such as for example the participation of the public. ${ }^{972}$ But in the present case, no such error existed. Therefore, the court concluded that the challenges on the formal legality of the decision were extraneous. ${ }^{973}$

The fact that the scope of review of the courts was practically limited to deciding whether an EIA was conducted or not was criticised and finally subject to a reference for preliminary ruling in the case of the municipality of Altrip. ${ }^{974}$ This case concerned an administrative decision under the special water legislation on the construction of an installation for the holding back of water. This construction was deemed necessary to improve the flood control at the Rhine River. The applicants submitted that the EIA was flawed. The first instance court dismissed the claim and the second instance court found that according to the rules of German law at that time, a claimant could not challenge a flawed EIA unless he could show that there was a causal link between the flaw and the administrative decision taken. ${ }^{975}$ The applicants appealed to the Federal Administrative Court which submitted the question on the

\footnotetext{
968 Art. 4 (1) UmwRG (2006).

${ }^{969}$ VGH Kassel, Judgment of 16 September 2009, Az.: 6 C 1005/08.T, NuR 2010, 428-432.

${ }^{970}$ Ibid., NuR 2010, 428, 430; juris, paras. 7, 79.

${ }^{971}$ VGH Kassel, Judgment of 16 September 2009, Az.: 6 C 1005/08.T, NuR 2010, 428, 431; juris, para. 82.

972 VGH Kassel 2009, Judgment of 16 September 2009, Az.: 6 C 1005/08 T, NuR 2010, 428, 431; juris, para. 91.

973 Ibid., NuR 2010, 428, 431; juris, para. 79.

${ }^{974}$ BVerwG, Decision of 10 January 2012, Az.: 7 C 20/11, NVwZ 2012, 448-451; C-72/12, Gemeinde Altrip and Others $v$ Land Rheinland-Pfalz (Judgment of 7 November 2013).

${ }^{975}$ OVG Koblenz, Judgment of 12 February 2009, Az.: 1 A 10722/08, UPR 2009, 316, 317.
} 
compatibility of German law with Union law to the Court of Justice. ${ }^{976}$ The latter held that flaws in an EIA must also be challengeable. ${ }^{977}$ Furthermore, the Court held that a causality requirement is not incompatible with Union law as long as the burden of proof is not on the claimant. ${ }^{978}$

In the aftermath of the Court of Justice's ruling in Altrip, different solutions for the adaptation of the German legal system to Union requirements are discussed. The main options would be that either the German legislator would have to amend $§ 4$ UmwRG or courts would have to interpret $§ 46 \mathrm{VwVfG}$ consistently with Union law. ${ }^{979}$

Contrary to what has been observed with regard to the intensity of review for screening decisions which is regulated by statute, the scope of review for the EIA had not been regulated until 2013. Therefore, the scope of review was in principle governed by the principle of full judicial review and its limitations explained in the introduction. With the reformed UmwRG (2013), a new provision was created stipulating that:

"In so far as the administrative authority is vested with a margin of appreciation for the application of environmental law, a decision by the administrative authority is only reviewable by the courts to the extent that

a. facts were completely and correctly gathered

b. procedural rules and legal principles were complied with

c. the applicable law was disregarded

d. the decision is based on irrelevant considerations." ${ }^{980}$

This provision however only codifies the limited judicial control regarding the margin of appreciation of the administration where the law leaves room for an assessment under indefinite legal terms. ${ }^{981}$

\section{b. Netherlands}

The general line concerning the review of the environmental statement is that Dutch courts test cautiously whether the public authority complied with the requirements prescribed by EIA legislation. This means that courts will only intervene if the claimants can raise substantial doubts with the judges concerning the quality of the environmental statement and it means that courts heavily rely on the

\footnotetext{
${ }^{976}$ BVerwG, Decision of 10 January 2012, Az.: 7 C 20/11, NVwZ 2012, 448-451.

977 C-72/12, Gemeinde Altrip and Others v Land Rheinland-Pfalz (Judgment of 7 November 2013) para. 37.

${ }^{978}$ Ibid., para. 53.

${ }^{979}$ Bunge, Rechtsfolgen von Verfahrensfehlern bei der Umweltverträglichkeitsprüfung, NuR 2014, pp. 305-313; Greim, Das Urteil des EuGH in der Rechtssache Altrip - Meilenstein oder Mosaikstein auf dem Weg zum gebotenen Individualrechtsschutz bei UVP Fehlern, NuR 2014, p. 85 ff.

Klinger, Umweltverträglichkeitsprüfung und Rechtsschutz, ZUR 2014, p. 539 ff.; Meitz, Zur Einklagbarkeit von Mängeln der Umweltverträglichkeitsprüfung (Altrip), ZUR 2014, p. 44; Siegel, Ausweitung und Eingrenzung der Klagerechte im Umweltrecht, NJW 2014, p. 975 (on a restrictive interpretation); Ziekow, Verfahrensfehler im Umweltrecht - notwendige Nachjustierungen im deutschen Verwaltungsrecht, NuR 2014, p. 323.

${ }^{980}$ Own translation, $\$ 4$ a (2) UmwRG (2013).

${ }^{981}$ Schlacke, Die Novelle des Umwelt-Rechtsbehelfsgesetzes- EuGH ante portas?, ZUR 2013, p. 200; Seibert, Verbandsklagen im Umweltrecht, NVwZ 2013, p.1046 (§ 4 a (2) is a superfluous placebo regulation); Wienhues, Die Neufassung des Umwelt-Rechtsbehelfsgesetzes, NordOeR 2013, p. 188.
} 
opinion of experts involved in the EIA process. Thus far, there is no substantial difference compared to the standard of review for the screening.

The Dutch mechanism to guarantee a good quality of the EIA is the statutory obligation to consult the Commissie m.e.r. in certain caes. If this independent advisory body is consulted in the administrative process, courts will in principle rely on its opinion. The statutory position of the Commissie m.e.r. has however been weakened in the last years by several reforms. ${ }^{982}$ Moreover, at the stage of administrative litigations, administrative judges have the possibility to ask the Stichting Advisering Bestuursrechtspraak (abbreviation: $\mathrm{StAB}$ ) for technical advice.

Tracing the case law on the EIA, the heavy influence of opinions of the Commissie m.e.r. can be seen. In the chapter dealing with the implementation of the EIA Directive in the Netherlands, it was explained that the assessment of alternatives has taken an important position in Dutch EIA practice. In administrative litigations, courts were very often required to review the consideration of alternatives in the EIA and thereby heavily relied on the advice given by the Commissie m.e.r. ${ }^{983}$ However, the number of cases on alternatives has declined in the last years. ${ }^{984}$ Furthermore, courts had to review whether the effects on the environment were assessed appropriately by the public authority. Also in these cases, courts, lacking the technical expertise, rely on the opinion given by experts, especially the Commissie m.e.r. ${ }^{985}$ For example, in a case concerning a permit for an installation for the rearing of pigs, the claimant alleged that the EIA was erroneous in several regards. ${ }^{986}$ The court found that, in the administrative process, the Commissie m.e.r. had criticised that the calculation of odour was done insufficiently well. Upon this criticism, the EIA was amended during the administrative procedure. Therefore, the court held that the EIA was not incorrect with the result that the claim of the flawed EIA could not be raised successfully. ${ }^{987}$ In a similar case concerning a permit for a pig rearing installation, claimants alleged that the environmental statement failed to consider the impacts of the project on public health. ${ }^{988}$ The court briefly found that the Commissie m.e.r. had stated in its final opinion on this EIA that - after some amendments to the initial EIA were made in the administrative process preceding the

\footnotetext{
${ }_{982}$ Part I, Section $2 \mathrm{~b}$ (iii).

${ }_{983}$ ABRvS 20 March 2002, nr. 200002547/1, M\&R 2002/98 (with a comment by Verschuuren); ABRvS 5 March 2003, nr. 200106102/1; ABRvS 23 April 2003, nr. 200200160/1, M\&R 2003/130 (with a comment by Verschuuren); ABRvS 21 July 2004, nr. 200305714/1; ABRvS 7 February 2005, nr. 200409578/2; ABRvS 22 November 2006, nr. 200509477/1, M\&R 2007/10; ABRvS 25 February 2009, nr. 200800340/1; ABRvS 2 May 2012, nr. 201105967/1/R1; ABRvS 13 February 2013, nr. 201205534/1/R2; ABRvS 2 October 2013, nr. 201203981/1/A4; ABRvS 23 April 2014, nr. 201211728/1/R2.

${ }^{984}$ Hoevenaars, Kroniek M.e.r.-regelgeving, M\&R 2014/51, p. 253.

${ }_{985}$ ABRvS 5 October 2011, nr. 201003856/1/R3; ABRvS 29 August 2012, nr. 201001848/1/T1/A4; ABRvS 19 June 2013, nr. 201200972/1/A4.

${ }^{986}$ ABRvS 21 January 2004, nr. 200303529/1, JB 2004/122

${ }^{987} \mathrm{Ibid}$., para. 2.4.

${ }^{988}$ ABRvS 29 February 2012, nr. 201012388/1/A4.
} 
grant of permit - all relevant information was taken into account. ${ }^{989}$ Therefore, this claim was not well founded. ${ }^{990}$

Sometimes, courts were required to review whether the right techniques were utilised in the EIA assessment. First, in the case of dredging activities in Hollandsche Diep, the court reviewed the method by which the different alternatives in the EIA were compared (so-called multi-criteria analysis) and in which the court found that certain aspects were not sufficiently taken into consideration, which lead to quashing the decision. ${ }^{991}$ In a more recent case concerning the method for assessing different options for the construction of roads, the court found that the Commissie m.e.r. did not raise any concerns in this regard so that the claim failed. ${ }^{992}$ The quality of an EIA report was also an issue in a number of cases concerning test drillings for natural gasoline in the North Sea. Inter alia, applicants had alleged that the description of the risks of the project was insufficiently presented and that there were failures in the calculation of effects of the drilling. In several claims for interim relief and in the final judgment, the court, taking the reports of the Commissie m.e.r. and the StAB into account, found violations of article $7.10 \mathrm{Wm} .{ }^{993}$ These are however exceptional cases.

In the workshop it was confirmed that the expertise of the administrative authority and independent advisory bodies is not substantially questioned by the courts. Usually, the Commissie m.e.r. is consulted in the process and if no opinion is given, the question would be referred to the StAB. In practice, therefore, the opinion of the defendant is mostly followed.

\section{c. England}

In England, courts have only limited power to review the quality of the EIA reports. Whether the information is adequate to fulfil the requirements of schedule 4 is a decision to be made by the public authority. However, the court intervenes on certain occasions. In the following, cases concerning the lack of a formal environmental statement and the review of the adequacy of environmental information will be presented.

An important case on the enforcement of the EIA provisions in England is the case of Berkeley concerning the complete lack of an environmental statement. Mrs. Berkeley initially brought an action for statutory review under section 288 TCPA (1990) against the grant of planning permission to rebuild part of the stadium of the Fulham football club. This action at the High Court and her appeal were dismissed. Subsequently, the House of Lords considered on appeal whether the grant of planning permission should be quashed because the Secretary of State failed to consider whether there should

\footnotetext{
${ }^{989}$ Commissie m.e.r., Aanvullend Toetsingsadvies over het milieueffectrapport, 12 February 2009, nr. 1755-72 (available online).

990 ABRvS 29 February 2012, nr. 201012388/1/A4, para. 5.5.1.

${ }^{991}$ ABRvS 15 January 1996, nr. E03.940091, AB 1996/296 (with a comment by Backes).

${ }^{992}$ ABRvS 6 October 2010, nr. 200904399/1/R2, para. 2.8.2.

${ }^{993}$ Rechtbank Leeuwaarden 17 July 1998, 97/40 WET; 97/41 WET; 97/42 WET; 97/44 WET; 97/45.
} 
have been an EIA. The problem was that, according to the applicant, no environmental statement was issued. Lord Hoffmann stressed that the EIA Directive not only required that the planning authority had recourse to the necessary environmental information when granting planning permission; additionally, the Directive prescribed that the necessary information had to be acquired by a specific procedure, namely the EIA procedure of which the environmental statement was one element. Therefore he found that:

"The directly enforceable right of the citizen which is accorded by the Directive is not merely a right to a fully informed decision on the substantive issue. It must have been adopted on an appropriate basis and that requires the inclusive and democratic procedure prescribed by the Directive in which the public, however misguided or wrongheaded its views may be, is given an opportunity to express its opinion on environmental issues." 994

Lord Hoffmann emphasises the importance of a duly conducted procedure and holds that a court is not entitled to "retrospectively [...] dispense with the requirement of an EIA", 995 holding that there must be a causal link between the missing procedural step and a wrongful decision. Therefore, even if a court had discretion under section 288 (5) b of the Town and Country Planning Act not to quash a decision, this discretion could not be exercised to uphold a planning permission that was adopted contrary to the requirements of Union law. ${ }^{996}$ The judge continued assessing whether the documents submitted in the planning procedure could amount to an environmental statement. Referring to the Court of Justice's ruling in Commission v Germany, ${ }^{997}$ Lord Hoffman held that in his view the ruling of the Court of Justice "establishes that an EIA by any other name will do as well. But it must in substance be an EIA."998 Applied to the case of Mrs. Berkeley, Lord Hoffmann stated:

"I do not accept that this paper chase can be read as the equivalent of an environmental statement." 999

Therefore, he allowed the appeal and suggested that the grant of planning permission be quashed. It should be noted that Lord Hoffman differentiated between different elements of the EIA procedure:

"I would accept that if there was a failure to observe some procedural step which was clearly superfluous to the requirements of the Directive, it would be possible to exercise the discretion

\footnotetext{
${ }^{994}$ Berkeley $v$ Secretary of State for the Environment and another [2001] 2 AC 603 (HL) 615.

${ }^{995}$ Ibid., 616.

${ }^{996}$ Ibid., 616.

${ }^{997}$ C-431/92, Commission of the European Communities $v$ Federal Republic of Germany [1995] ECR I-2189. This case concerned the question whether consent given to the construction of a power station without EIA but in which all information required by the Directive was supplied by the developer was lawful.

${ }^{998}$ Berkeley $v$ Secretary of State for the Environment and Another [2001] 2 AC 603 (HL) 617.

${ }^{999}$ Ibid.
} 
not to quash the permission without any infringement of our obligations under European law." 1000

In general, this case stresses that English courts put an emphasis on a formally correctly conducted EIA and that they interfere if these formal requirements were not observed.

Moreover, courts review the quality of the EIA procedure to the extent that the decision was taken on the basis of all relevant information. For example, in the case of Cornwall, concerning the grant of planning permission for the extension of an existing landfill site, the county planning authority issued an environmental statement dealing with issues of nature conservation. ${ }^{1001}$ In this statement, concerns about horseshoe bats, a species protected under the Habitats Directive, were raised. It was clear that further surveys had to be conducted to ensure that the bats would not be adversely affected by the development. Nevertheless, the planning authority already granted planning permission, making it subject to conditions, one being that further surveys should be carried out and mitigating measures should be taken. Harrison $\mathrm{J}$ in this respect found that:

"Having decided that those surveys should be carried out, the Planning Committee simply were not in a position to conclude that there were no significant nature conservation issues until they had the results of the surveys. The surveys may have revealed significant adverse effects on the bats or their resting places in which case measures to deal with those effects would have had to be included in the environmental statement. They could not be left to the reserved matters stage when the same requirements for publicity and consultation do not apply. Having decided that the surveys should be carried out, it was, in my view, incumbent on the respondent to await the results of the surveys before deciding whether to grant planning permission so as to ensure that they had the full environmental information before them before deciding whether or not planning permission should be granted."1002

The permission was therefore quashed. What follows from this case is that English judges will review whether all necessary information was available before issuing the administrative decision, meaning that relevant studies could not be made subject to conditions accompanying the administrative decision already taken.

However, if all necessary information was available and if the applicants had an opportunity to comment on the information, it is for the authority to reach a conclusion and not for the courts to interfere with this decision.

The case of Blewett concerned the grant of planning permission for a landfill site which was filled with waste. The planning permission was accompanied by an environmental statement consisting of a lengthy

\footnotetext{
${ }^{1000} \mathrm{Ibid}$.

${ }^{1001} R$ v Cornwall County Council [2001] Env LR 25 (QB).

${ }^{1002}$ Ibid. [62].
} 
document comprising fifteen chapters and seven technical appendices. ${ }^{1003}$ The claimant argued that certain issues relating to the groundwater and to human health and mitigating measures were dealt with inadequately. Specifically, the assessment of the potential impact and the description of mitigating measures were left to be determined later. The judge first started by explaining that it is for the local planning authority to decide whether the information contained in the document is sufficient to be qualified as an environmental statement. He continues, referring to $R v$ Cornwall cited above, that the local planning authority's decision is reviewable on the grounds of Wednesbury. ${ }^{1004}$ This means that, inter alia, the information must be capable of meeting the requirements of schedule 4 of the Regulations. However, the judge stressed that these requirements have to be read in the context of the entire EIA process. ${ }^{1005} \mathrm{He}$ found that "The Regulations recognise that the applicant's assessment of these issues may well be inaccurate, inadequate or incomplete." ${ }^{1006}$ Therefore, rules on publicity give one the opportunity to point out deficiencies in the environmental statement. ${ }^{1007}$ Regarding the allegation that human health issues were not adequately dealt with, the court observes the following:

"It is submitted on behalf of the claimant that the environmental statement did not provide any assessment of the potential health impacts arising out of the proposal. On the contrary, it is plain from para. 13.4.36 that the authors of the environmental statement considered that there were not likely to be any significant effect on human health. It was therefore unnecessary for them to describe mitigation measures in any detail. Those who disagreed with this assessment had an opportunity to put their views to the local planning authority in the consultation process. The report summarised the response of consultees. They included the North Derbyshire Health Authority, which raised no objection." ${ }^{1008}$

Also the Environment Agency was consulted and made its comments, upon which the interested party drafted an addendum report addressing mitigation measures. Both the addendum and the Environment Agency's response were part of the environmental information considered in the report. In this regard, Sullivan J found that:

"If the Environment Agency had had any concern in the light of the geological and hydrogeological information provided in the addendum report as to the remediation proposals contained therein, then it would have said so. Against this background the defendant was fully entitled to leave the detail of the remediation strategy to be dealt with under [a] condition". ${ }^{1009}$

\footnotetext{
${ }^{1003} R$ (Blewett) v Derbyshire CC [2003] EWHC 2775 (Admin); [2004] Env LR 29 [31].

${ }^{1004} \mathrm{Ibid}$. [33].

${ }^{1005}$ Ibid. [40].

${ }^{1006} \mathrm{Ibid}$. [28].

${ }^{1007}$ Ibid. [38], [39].

${ }^{1008} \mathrm{Ibid}$. [44].

${ }^{1009} \mathrm{Ibid}$. [66].
} 
Therefore, this ground of the challenge was rejected. ${ }^{1010}$ Sullivan $\mathrm{J}$ made a final remark on the issue, stating:

"I have dealt with it in some detail because it does illustrate a tendency on the part of claimants opposed to the grant of planning permission to focus upon deficiencies in environmental statements, as revealed by the consultation process prescribed by the Regulations, and to contend that because the document did not contain all the information required in Sch. 4 it was therefore not an environmental statement and the local planning authority had no power to grant planning permission. Unless it can be said that the deficiencies are so serious that the document cannot be described as, in substance, an environmental statement for the purposes of the Regulations, such an approach is in my judgment misconceived." 1011

From this judgment, it can be followed that courts will review whether all necessary information was provided without reviewing the precise content. Instead, it seems to be sufficient, that the consultees, inter alia the Environment Agency, raised no objections. The test proposed by the last judgment is that deficiencies have to be so serious that the document in substance cannot be described as an environmental statement.

Finally, the case of Gray should be mentioned. In this case, Wilkie $\mathrm{J}$ had to decide on an application for judicial review brought against the grant of planning consent for the substantial redevelopment of London Bridge Station and its surroundings. ${ }^{1012}$ Inter alia, Gray submitted that the information provided in relation to the environmental statement was obviously deficient in terms of satisfying the requirements under schedule 4 of the 1999 Regulations. He claimed that "in effect, the local authority was Wednesbury unreasonable in failing so to identify it as sufficiently deficient so as not properly to constitute part of an Environmental Statement at all." ${ }^{1013}$ Specifically, he was of the opinion that the local authority failed to ask for further information and to assess the main alternatives. Specifically, he refers to documents in which several options for building were identified, but in which environmental considerations were not taken into account. ${ }^{1014}$ The judge however refused the appeal, finding it not arguable that there was no environmental statement. ${ }^{1015}$ In the reasoning, he quoted parts of the environmental statement, which mentioned (albeit not always explicitly) various alternatives. Moreover, even if there were deficiencies, they were not fundamental or serious. ${ }^{1016}$ For the standard of review, Wilkie J referred to the powers of the judge under the Regulations and to precedence. With regard to schedule 4 he noted:

\footnotetext{
${ }^{1010} \mathrm{Ibid}$. [67].

${ }^{1011}$ Ibid. [68].

${ }^{1012} R$ (Gray) v London Borough of Southwark, Mayor of London, Secretary of State for Communities and Local Government, English Heritage [2012] EWHC 2653 (Admin).

${ }^{1013}$ Ibid. [16].

${ }^{1014}$ Ibid. [17].

${ }^{1015} \mathrm{Ibid}$. [19].

${ }^{1016}$ Ibid. [20].
} 
"That seems to be the statutory scheme whereby assessing whether information provided is sufficient - that it can reasonably be described as an Environmental Statement - is, in the first instance, for the Local Planning Authority to form a view about. The role of the courts in judicial review in respect of this aspect of the legislation seems to be to review decisions of Local Planning Authorities not to require further information by reference to whether such decisions can be impugned on traditional judicial review grounds. Therefore it is very much a backstop." $" 1017$

Furthermore, Wilkie $\mathrm{J}$ cited the rulings of the cases Blewett ${ }^{1018}$ and Edwards ${ }^{1019}$ in which it was stressed that deficiencies have to be so serious that one could not properly speak of an environmental statement. Also in this judgment, it becomes clear that judges only review the documents cautiously relative to the environmental statement. Ultimately, the standard for review is Wednesbury unreasonableness. The court will only intervene when there are serious deficiencies.

\section{d. Comparison: differences and convergence}

This section has described the different national standards for the scope of review for assessing environmental statements. All three Member States prescribe a review of the legality of the environmental statement. The greatest difference between the Member States consisted in the type of errors challengeable in court. In Germany, for a long time, only the omission of an EIA was challengeable which in practice prevented a detailed review of the environmental statement in courts. The Court of Justice held that this was incompatible with the requirements of the EIA Directive and thereby triggered a process of convergence between the German and the other two legal systems. In the Netherlands and in England, omissions of EIAs and flaws in EIAs, also including flaws in the environmental statement, have been challengeable since the beginnings of EIA enforcement.

As far as the intensity of review is concerned, German courts adopt the most intense standard in assessing whether the facts were rightly and completely gathered, whether procedural rules and criteria of assessment were complied with, whether the applicable law was not disregarded and whether inappropriate considerations were made. In the Netherlands, courts only review administrative decisions cautiously and in England, the test of Wednesbury unreasonableness is applied.

Table 12: Rules on the scope of review for the environmental statement in 2014

\begin{tabular}{|l|l|l|l|}
\hline & Germany & The Netherlands & England \\
\hline Issue for Review & Yes, since Altrip & Yes & Yes \\
\hline
\end{tabular}

${ }^{1017} \mathrm{Ibid}$. [12].

${ }^{1018} R$ (Blewett) v Derbyshire County Council [2003] EWHC 2775 (Admin); [2004] Env LR 29.

${ }^{1019} R$ (Edwards) v the Environment Agency [2008] UKHL 22; [2008] Env LR 34 [38]. 


\begin{tabular}{|l|l|l|l|}
\hline Intensity of Review & $\begin{array}{l}\S 4 \mathrm{a}(2) \text { UmwRG } \\
(2013)\end{array}$ & $\begin{array}{l}\text { Test of Cautious } \\
\text { Review }\end{array}$ & $\begin{array}{l}\text { Test of Wednesbury } \\
\text { Unreasonableness }\end{array}$ \\
\hline
\end{tabular}

The consequence of the different intensity of review is that in one state there is a quality control of the environmental statement in court, whereas in another Member State the quality review in courts is rather limited. This is not problematic per se as there may be other quality control mechanisms in place. In the Netherlands, the obligatory involvement of the Commissie m.e.r. in the process of drafting the environmental statement allows for independent quality control. Differences in the intensity of review between the legal systems becomes relevant if there is no such independent review of the quality of the environmental statement. If such a review does not exist, an incentive for sloppy decision making may be provided.

\section{Gathering of facts, evidence and the burden of proof}

In the European Union, the Member States are in principle free to create rules on the gathering of facts, evidence and the burden of proof, but they have to pay regard to international and European requirements. These requirements shall be described briefly (2.1), followed by a comparison of the national rules in EIA cases (2.2).

\subsection{International and European rules on the gathering of facts, evidence and the burden of proof}

Article 9 of the Aarhus Convention does not address the rules on the gathering of facts, evidence and the burden of proof and therefore leaves it to the contracting states to determine rules on these issues. In the European Union, Member States are also in principle "autonomous" in providing for their own rules on this subject matter. However, in certain pieces of secondary legislation, the European legislator has laid down specific rules on the burden of proof which the Member States have to observe. ${ }^{1020}$ Moreover, the Court of Justice has emphasised that national rules on the burden of proof have to comply with the principles of effectiveness and equivalence ${ }^{1021}$ and the principle of effective judicial protection. ${ }^{1022}$ For example in the case of Michailidis, concerning a claim brought before a Greek court concerning charges paid contrary to Union law, the Court of Justice held that it is in principle for the national courts to evaluate the evidence submitted, but that these rules "must not have the effect of making it virtually

${ }^{1020}$ For example: Art. 8 Directive 2000/34/EC, Art. 10 Directive 2000/78/EC; Von Danwitz, Europäisches Verwaltungsrecht, 2008, pp. 588 f.; Gellermann, $\$ 37$ Rechtsschutz durch deutsche Gerichte, in: Rengeling et al., Handbuch des Rechtsschutzes in der Europäischen Union, $3^{\text {rd }}$ edition, 2014, at 45.

1021 Case 199/82, Amministrazione delle Finanze dello Stato v SpA San Giorgio [1983] ECR 3595, para. 14 ; C- 343/96, Dilexport Srl v Amministrazione delle Finanze dello Stato [1999] ECR I-579, para. 48.

1022 Jans has pointed out that this principle has especially been invoked in equal treatment cases, for example in C- 222/84, Marguerite Johnston v Chief Constable of the Royal Ulster Constabulary [1986] ECR I-1651, para. 20; Jans et al., Europeanisation of Public Law, 2007, pp. $302 \mathrm{ff}$. 
impossible or excessively difficult to secure repayment of a charge levied in breach of Community law." 1023

In environmental matters, an important ruling on the burden of proof was handed down by the Court of Justice in the case of Altrip. ${ }^{1024}$ As this case concerns the German legal system, the discussion will be postponed to the following section on the burden of proof in the Germany.

\subsection{National rules on the gathering of facts, evidence and the burden of proof}

\section{a. Germany}

\section{National rules on the gathering of facts, evidence and the burden of proof}

"The court investigates the facts of the case ex officio; the parties concerned are to be consulted in doing so." ${ }^{1025}$ With this phrase, $\S 86$ (1) s. 1 VwGO codifies the principle of investigation ex officio. ${ }^{1026}$ The judge is not bound by the evidence submitted by the parties, but he is entitled to investigate the facts of the case himself. The idea behind this power of the judge is that there are objectively determined facts of the case that can be explored independently from the parties and that the investigation of facts shall be complete, open and neutral. ${ }^{1027}$ The only limitation to this duty of investigation is set by the relevance of the facts in the light of the judgment to be given. § 108 (1) s.1 VwGO stipulates that the court has to come to its judgment according to its independent conviction based on the overall findings of the case. Furthermore, the court has to specify the reasons upon which the judgment is based. ${ }^{1028}$ The judgment can only be based on facts and evidence on which the parties could comment. ${ }^{1029}$

As a consequence of the principle of ex officio investigation, there are no rules on the formal burden of proof, meaning that the court does not determine which of the parties has to give evidence for the contested facts. It is the court's task to establish the facts. Claimants do not have an obligation to contribute to the gathering of evidence in the administrative process, but they are vested with a right of contribution. Only in some instances the judge can oblige the claimant to contribute to the gathering of evidence especially when the evidence belongs to the domain of the claimant. ${ }^{1030}$ In the following section, it will be shown how these powers were utilised in EIA cases.

\section{National rules on the gathering of facts and the burden of proof in EIA cases}

\footnotetext{
${ }^{1023}$ Joined cases C-441/98 and C-442/98, Kapniki Michaïlidis AE v Idryma Koinonikon Asfaliseon (IKA) [2000] ECR I-7154, para. 36

${ }^{1024}$ C-72/12, Gemeinde Altrip and Others v Land Rheinland-Pfalz (Judgment of 7 November 2013).

1025 Maastricht Collection.

1026 The German expression is Untersuchungsgrundsatz.

${ }^{1027}$ Hufen, Verwaltungsprozessrecht, $9^{\text {th }}$ edition, 2013, p. 536.

$1028 \S 108$ (1) s. 2 VwGO.

1029 § 108 (2) VwGO.

${ }^{1030}$ Hufen, Verwaltungsprozessrecht, $9^{\text {th }}$ edition, 2013, p. 537.
} 
The principle of ex officio investigation by judges also applies in EIA cases. This means that the courts have to actively investigate the facts of the case. In practice, this has not been problematic as the documents of the administrative authority on the EIA process are usually available. ${ }^{1031}$ However, what has been problematic was that the claimants were required to explain that there is a concrete possibility that the administrative decision would have been different without the error in the EIA procedure. ${ }^{1032}$ The basis for this burden of explanation is $\S 46 \mathrm{VwVfG}$, according to which the annulment of an administrative decision cannot be requested solely because of a procedural error if it is obvious that the infringement of the procedural rule did not influence the decision. According to the provision, and the jurisprudence of the German courts, the claimants had to show that there was a causal link between the error and the administrative decision. ${ }^{1033}$ This burden of explanation was reduced with the entry into force of the UmwRG (2006), which no longer required the establishment of such a causal link in cases of the complete omission of a mandatory screening or EIA. ${ }^{1034}$ However, the requirement has continued to exist with respect to errors within the screening or EIA. This remaining requirement that the applicant had to establish a link between the procedural error and the decision came under scrutiny in the reference for preliminary ruling in the case of Altrip. ${ }^{1035}$ In this regard, the Court of Justice held that:

"It appears, [...] that it is in general incumbent on the applicant, in order to establish impairment of a right, to prove that the circumstances of the case make it conceivable that the contested decision would have been different without the procedural defect invoked. That shifting of the burden of proof onto the person bringing the action, for the application of the condition of causality, is capable of making the exercise of the rights conferred on that person by Directive $85 / 337$ excessively difficult, especially having regard to the complexity of the procedures in question and the technical nature of environmental impact assessment."1036

Moreover, the Court stressed that the determination of the causal link is an exercise for the court

"without in any way making the burden of proof fall on the applicant, by relying, where appropriate, on the evidence provided by the developer or the competent authorities and, more generally, on the case-file documents submitted to that court or body" (emphasis added). ${ }^{1037}$

In reaction on the Court's ruling, there is some uncertainty in the literature on how to interpret the Court of Justice's terminology on the "burden of proof". ${ }^{1038}$ As explained, the general rule that the court has

\footnotetext{
${ }^{1031}$ Klinger, Umweltverträglichkeitsprüfung und Rechtsschutz, ZUR 2014, p. 538.

1032 Part II, Chapter 4, Section 1.2 a. (2. aa).

${ }^{1033}$ BVerwG, Judgment of 25 January 1996, Az.: 4 C 5/95, BVerwGE 100, 238, 252. See further Part II, Chapter 4, Section 1.2 a. $1034 \S 4$ (1) UmwRG (2006).

1035 C-72/12, Gemeinde Altrip and Others v Land Rheinland-Pfalz (Judgment of 7 November 2013).

1036 C-72/12, Gemeinde Altrip and Others v Land Rheinland-Pfalz (Judgment of 7 November 2013) para. 52.

${ }^{1037}$ Ibid., para. 53.

${ }^{1038}$ Bunge, Rechtsfolgen von Verfahrensfehlern bei der Umweltverträglichkeitsprüfung, NuR 2014, p. 310; the terminology of the Court of Justice on the burden of proof is considered to be gewöhnungsbedürftig (not easy to get used to): Klinger, Umweltverträglichkeitsprüfung und Rechtsschutz, ZUR 2014, p. 538.
} 
to investigate the facts ex officio also applies in EIA cases, meaning that there is no burden on the party to bring a certain proof. The problem arises in relation to the burden to explain that there is a link between the error and the decision. In this respect, the Court of Justice stresses that the claimant must not be responsible for the establishment of a causal link that the decision would have been different without the procedural error. ${ }^{1039}$

\section{b. Netherlands}

\section{National rules on the gathering of facts and the burden of proof}

Due to a lack of a comprehensive set of Dutch rules on the gathering of facts and the burden of proof, the expression of the "vrije bewijsleer" (liberal doctrine on evidence) was developed. Although it is disputed what this doctrine exactly entails, it is clear that the Awb only contains some rules on evidence for litigations in administrative courts. ${ }^{1040}$ The Awb provides for rules on the summoning of the parties, ${ }^{1041}$ on the questioning of parties and others about information, ${ }^{1042}$ and rules on witnesses, ${ }^{1043}$ experts, ${ }^{1044}$ and local investigations. ${ }^{1045}$ However, there are no detailed rules on the scope of evidence, the burden of proof, the pieces of evidence, and about the question how the judge has to weigh the evidence submitted. ${ }^{1046}$ In principle, the Awb vests the judge with wide investigatory powers and the ability to add factual findings to those presented by the parties. ${ }^{1047}$ With this rule, the judge should be placed in a position to investigate the "material truth" underlying the case and he should be able to take account of the comparably week position of the citizen if compared to the administrative authority. ${ }^{1048}$ However, the judge is not obliged to add factual findings to the submissions to the parties, but this is a discretionary power. ${ }^{1049}$ Research has shown that, in practice, judges make only seldom use of this power. Since the entry into force of the Awb, Dutch administrative judges were rather inactive as far as the establishment of facts is concerned. ${ }^{1050}$ This position is very different if compared to the German legal system, in which judges are obliged to investigate the facts ex officio. ${ }^{1051}$

1039 C-72/12, Gemeinde Altrip and Others v Land Rheinland-Pfalz (Judgment of 7 November 2013) para. 52.

${ }^{1040}$ An overview over the different positions is provided by Schlössels, Een vrije en kenbare bewijsleer?, in: Schlössels et al., Bestuursrechtelijk bewijsrecht: wetgever of rechter?, 2009, pp. $29 \mathrm{ff}$.

${ }^{1041}$ Art. 8:27 Awb.

1042 Art. 8:45 Awb.

1043 Art. 8:33, 8:46 Awb.

1044 Art. 8:34, 8:47 Awb.

1045 Art. 8:50, 8:51 Awb.

1046 Tak, Het Nederlands bestuursprocesrecht in theorie en praktijk, vol. 2, $5^{\text {th }}$ edition, 2014, p. 1304.

1047 Art. 8:69 (3) Awb

${ }^{1048}$ Damen et al., Bestuursrecht, vol. 2, $4^{\text {th }}$ edition, 2012, p. 285, at 688.

1049 De Graaf, Art. 8:69 Awb, in: De Graaf et al.(eds.), Sdu commentaar Awb, 2014.

${ }^{1050}$ Barkhuysen et al., Feitenvaststelling in beroep, 2007, p. XIX. Critical: Polak, Verandernde perspectieven van de bestuursrechter, in: Barkhuysen et al (eds.)., Bestuursrecht harmoniseren: 15 jaar Awb, pp. $110 \mathrm{ff}$.

${ }^{1051}$ Schlössels, Een vrije en kenbare bewijsleer?, in: Schlössels et al., Bestuursrechtelijk bewijsrecht: wetgever of rechter?, 2009, p. 110. 
Generally, Dutch administrative judges depart from an assumption that the administrative decision is correct and that it is the task of the claimant to raise serious doubts about the legality of the decision. ${ }^{1052}$ When examining the evidence before it, the administrative judge considers whether the claimant can show with voldoende aannemelijkheid (sufficient plausibility) that there is a reason why his claim is well founded. ${ }^{1053}$

As far as the rules on burden of proof are concerned, some substantive principles are deduced from the duty of investigation of the administrative body ${ }^{1054}$ and the duty of information of the citizen. ${ }^{1055}$ In this regard, a distinction is made between ambtshalve genomen besluiten (decisions which the public authority takes ex officio) and beschikkingen op aanvraag (decisions which the public authority takes upon application). ${ }^{1056}$ As regards the former category, the administrative body in principle bears the burden of proof. Regarding the latter category, the applicant has to determine the means of evidence. ${ }^{1057}$ Furthermore, principles on the burden of proof in Dutch administrative court proceedings are categorised by three rules of thumb: first, personal (negative) conduct can influence the burden of proof; second, a person who is in possession of proof has to provide it; and third, the burden to provide evidence is on the party which can acquire the proof more easily. ${ }^{1058}$

The absence of a comprehensive set of rules on evidence has been discussed widely, mainly because it created a lot of uncertainty among practitioners and citizens. ${ }^{1059}$ Leaving these abstract discussions aside, it will be illustrated how Dutch courts have dealt with the burden of proof in EIA cases.

\section{National rules on the gathering of facts and the burden of proof in EIA cases}

In cases dealing with the facts of the screening or EIA procedure, one often finds the sentence that the claimants did not make aannemelijk (the claimants could not make it plausible) that the administrative authority made a procedural error ${ }^{1060}$ or that the claimants did not submit any evidence showing the opposite of the evidence on which the administrative authority based its decision. ${ }^{1061}$ This shows that, even though the administrative judge is vested with wide investigatory powers, he or she expects from the claimant the substantiation of why he thinks that the decision was wrong. In the workshop it was

\footnotetext{
1052 Tak, Het Nederlands bestuursprocesrecht in theorie en praktijk, vol. 2, $5^{\text {th }}$ edition, 2014.

1053 Damen et al., Bestuursrecht, vol. 2, $4^{\text {th }}$ edition, 2012, p. 302

${ }^{1054}$ Art. 3:2, 7:11 Awb.

1055 Art. 4:2, 6:5 Awb.

1056 Schuurmans, Bewijslastverdeling in het bestuursrecht, 2005, chapters 4 and 5.

1057 Art. 4:2 Awb.

1058 Damen et al., Bestuursrecht, vol. 2, $4^{\text {th }}$ edition, 2012, p. 297; see also, with different categorisation: Tak, Het Nederlands bestuursprocesrecht in theorie en praktijk, vol. 2, $5^{\text {th }}$ edition, 2014, pp. $1315 \mathrm{ff}$.

1059 Barkhuysen et al., Feitenvaststelling in beroep, 2007; Schlössels et al., Bestuursrechtelijk bewijsrecht: wetgever of rechter?, 2009; Verburg, De bestuursrechter: van des werkmans beste raadsman tot bewijsrechtelijke spelverdeler - 15 jaar bewijsrecht onder de Awb, in: Barkhuysen et al. (eds.), Bestuursrecht harmoniseren: 15 jaar Awb, 2010, p. 262.

${ }^{1060}$ ABRvS 14 November 2012, nr. 201105329/1/A4, para. 4.8; ABRvS 21 November 2012, nr. 201103782/1/A4, para. 6.2; Rechtbank Gelderland, 16 December 2014, nr. AWB-13-4146.

1061 ABRvS 13 July 2005, nr. 200408576/1, para. 2.4.4; Rechtbank Arnhem 15 March 2012 nr. 11/68, 11/69, 11/70, $11 / 71$, para. 3.5.
} 
explained that in case the submissions by the claimant raise serious doubts in the judge, he or she can request the opinion of the $S t A B$ or independent experts.

The question is to what extent the ruling of the Court of Justice in Altrip has relevance for the Dutch legal system. This case concerned the German rule according to which a claimant bringing an action for annulment had to show that the administrative decision would have been different without the procedural error. The Court of Justice decided that this burden must not be put on the claimant. In the Netherlands, there is no requirement to establish a causal link between the error and a wrongful decision in order to request the annulment of the administrative decision. Contrary to German law, in the Netherlands it is generally possible to request the annulment of an administrative decision (simply) on procedural grounds. However, as will be explained in more detail in the chapter on remedies, judges have the possibility to disregard procedural errors if it can be established that an infringement of procedural or substantive rules of law does not prejudice interested parties. ${ }^{1062}$ The question is who bears the burden of establishing that interested parties are not prejudiced by the infringement of the rule. It is suggested that taking the ruling of Altrip into account, it is for the court to establish, on the basis of the file, that the administrative decision would not have been different without the procedural error and that interested parties are therefore not prejudiced. ${ }^{1063}$

\section{c. England}

\section{National rules on the gathering of facts, evidence and the burden of proof}

Contrary to what was described with regard to the German legal system, English judges take a rather passive role as far as the finding of facts is concerned, as this is primarily a matter for the administrative authority and not for the courts. ${ }^{1064}$ In practice, most of the facts of a case are already submitted in writing to the court in the beginning of judicial proceedings. ${ }^{1065}$ The court will come to its judgment on the basis of these writings. Where facts are disputed, there can be cross-examinations, interrogatories and the disclosure of documents. ${ }^{1066}$ However, courts seldom make use of this possibility. ${ }^{1067}$ In any event, courts will interfere if the authority abused its power causing injustice. Hence, where there is "no evidence" 1068 or where there is an error of material fact, ${ }^{1069}$ the courts have to intervene.

\footnotetext{
1062 Art. 6:22 Awb.

1063 Backes, Case comment on C-72/12, Altrip (7 November 2013), AB 2014/54, at 5.

1064 Wade, Forsyth, Administrative Law, 11 ${ }^{\text {th }}$ edition, 2014, p. 227.

1065 Ibid., p. 217.

1066 Cane, Administrative Law, $5^{\text {th }}$ edition, 2011, pp. 254 f.

1067 Wade, Forsyth, Administrative Law, $11^{\text {th }}$ edition, 2014, p. 217; Lewis, Judicial Remedies in Public Law, $4^{\text {rd }}$ edition, 2009, at 9-092 (disclosure), 9-101 (further information), 9-102 (cross-examination).

1068 Wade, Forsyth, Administrative Law, $11^{\text {th }}$ edition, 2014, p. 227.

1069 Ibid., p. 230.
} 
The burden of proof for this is, as a general principle, on the claimant. ${ }^{1070} \mathrm{He}$ has to establish that it is probable that a ground for review exists. ${ }^{1071}$ The defendant subsequently has to show that there is no such ground for review. ${ }^{1072}$ Whether the burden of proof can be shifted depends on the nature of the case. Therefore, there is no clear rule on how much evidence needs to be submitted by the applicant in order to shift the burden. ${ }^{1073}$ However, it is observed that "in practice, judicial review claims rarely, if ever, depend upon who bears the burden of proof on a particular issue."1074

\section{National rules on the gathering of facts and the burden of proof in EIA cases}

As judges take their decisions on the basis of the submissions made by the parties, any cases cited so far can be taken as an example of the English system according to which the judge is reluctant to investigate the facts and where the parties have to provide the evidence on which their claims are based. An example of this approach is the case of Long, in which the claimant argued that the authority did not pay sufficient regard to matters of conservation, the state of watercourses and socio-economic effects of the development. ${ }^{1075}$ The court found that these issues were taken into consideration by the authority, and that the claimant could not prove serious deficiencies. ${ }^{1076}$

In Burridge, the court required that the claimant had to sufficiently substantiate his allegations. In this case, the claimant brought a claim for judicial review of a decision to grant planning permission for the construction of an aerobic digester and combined heat and power plant. ${ }^{1077}$ The court refused the application as there was no need for a further screening opinion. The court considered:

"Yet further, it is clear $[\ldots]$ that if for some reason a further screening opinion was required, its result would be the same. Once more, the claimant has given no reason why it even might have been different. I do not accept that it is not incumbent on a claimant to give any reason why it even might have been different. It is not enough simply to say that something might have been thrown up in a further opinion." 1078

From this quote it follows that claimants have to state why, according to them, a further screening opinion would have been necessary. Hence, although in practice the outcome of cases in England usually does not depend on who bears the burden of proof, a certain level of substantiation of the claim by the claimant is required. However, English courts will have to pay regard to the Court of Justice's ruling in

\footnotetext{
${ }^{1070}$ Ibid., p. 244.

${ }^{1071}$ Lewis, Judicial Remedies in Public Law, $4^{\text {rd }}$ edition, 2009, at 9-115.

${ }^{1072}$ Fordham, Judicial Review Handbook, $6^{\text {th }}$ edition, 2012, at 42.2ff.

${ }^{1073}$ Wade, Forsyth, Administrative Law, $11^{\text {th }}$ edition, 2014, p. 245.

${ }^{1074}$ Lewis, Judicial Remedies in Public Law, $4^{\text {rd }}$ edition, 2009, at 9-115.

${ }^{1075}$ R (Long) v Monmouthsire City Council [2012] EWHC 3130 (Admin.).

${ }^{1076}$ Ibid. [98].

${ }^{1077} R$ (Burridge) v Breckland Distric Council [2012] EWHC 1102 (Admin); [2012] Env LR 36.

${ }^{1078} \mathrm{Ibid}$. [34].
} 
Altrip, requiring a shifted burden of proof where a claimant alleges a flaw in the EIA process which might have had an impact on the administrative decision.

\section{d. Comparison: differences and convergence}

In this section, an overview of the basic rules on evidence and the burden of proof in the three legal systems was given. In comparing the different systems, it becomes clear that the role of the judge in the process of finding facts differs considerably. Whereas in the German legal system courts have to investigate the facts ex officio, in England courts are more reluctant to embark on an investigation of the facts. In the Netherlands, judges are in principle vested with far-reaching investigatory powers, but in practice it is observed that they are not very active in investigating the facts of the case. Furthermore, there is the possibility to ask the independent advisory body StAB for advice, which, as was stressed in the workshop, is done if the judge has serious doubts about the correctness of the information in question. In Germany, there is no such independent body, but judges are very active in assessing the facts of the case themselves and can request an opinion of independent experts. In England there is no independent advisory body comparable to the $S t A B$ and judges usually do not on their own motion delve into the materials to examine whether the scientific information on which an EIA is based is correct. With regard to the role of the judge, no converging tendencies in EIA cases can be observed.

Furthermore, there are differences between the legal systems as far as the burden of proof is concerned. In German administrative litigations, the claimant does not have the burden of proof but he may be required to contribute to the proceedings in disclosing or submitting certain evidence and in explaining why he considers that there is a procedural error. A problem in this regard was that claimants in Germany were required to establish that there was a concrete possibility that a procedural error in the EIA process had an impact on the final administrative decision. In Altrip, the Court of Justice ruled that this burden must not lie with the claimant. Although it is still uncertain how the legislator and courts will implement this ruling, the judgment can be seen as a trigger for convergence between the legal systems. In the Netherlands, claimants do not need to show a causal link between the error and the administrative decision when requesting the annulment of the administrative decision, but it is in principle sufficient to show that there was a procedural error in the EIA process. ${ }^{1079}$ In England, the burden of proof is in principle on the claimant, but it can be shifted, depending on the subject matter of the case and the issue at stake.

The situation in 2014 is as follows:

1079 This question has to be distinguished from the question of whether there must be a link between the error and the interest of the claimant, in the same way as is required for example by 6:22 Awb. For this purpose see: Part II, Chapter 4 . 
Table 13: National rules on the gathering of facts, evidence and the burden of proof in EIA cases in 2014

\begin{tabular}{|l|l|l|l|}
\hline & Germany & Netherlands & England \\
\hline Role of the Judge & Investigation ex officio & $\begin{array}{l}\text { Wide investigatory } \\
\text { powers but practically } \\
\text { not used a lot }\end{array}$ & $\begin{array}{l}\text { In principle, it is for } \\
\text { the parties to establish } \\
\text { the facts; courts may } \\
\text { intervene if necessary }\end{array}$ \\
\hline Burden of Proof & $\begin{array}{l}\text { Does not exist; the } \\
\text { authority has to } \\
\text { investigate the facts; } \\
\text { but burden of } \\
\text { substantiation of claim } \\
\text { on the claimant } \\
\text { (Darlegungslast) }\end{array}$ & $\begin{array}{l}\text { No concrete rules, in } \\
\text { principle on the } \\
\text { claimant }\end{array}$ & $\begin{array}{l}\text { In principle on the } \\
\text { claimant }\end{array}$ \\
\hline
\end{tabular}

\section{Preclusion of claims from review}

In some legal systems, the scope of review of a claim is made dependent on the question whether the applicant raised the issue on which the claim is based in the administrative procedure before the litigation was brought to court. The background to rules precluding certain claims from review in courts is that parties should participate in the administrative procedure as soon as possible and contribute to the decision making with their knowledge, so that the administrative authority has the possibility to take the objectors' submissions into account. According to these rules, the court will not review a case on grounds or evidence that a claimant only submits at the stage of the court proceedings. This section shall first provide for a brief overview of international and European rules (3.1), followed by a comparative description of national rules on preclusion in EIA cases (3.2).

\subsection{International and European rules on the preclusion of claims from review}

Article 9 of the Aarhus Convention and the respective Union implementing legislation does not mention rules precluding the submission of grounds at a later stage, but the aim and purpose of these articles is to provide wide access to courts in environmental matters. Whether the requirement of a wide access to courts precludes national rules adopting rules on preclusion is not yet clear. ${ }^{1080}$

Under Union law, the case law of the Court of Justice on rules precluding pleas based on Union law has primarily focused on the length of time limits. The case of Peterbroeck concerned a national rule which precluded the allegation of an infringement of Union law after a certain period had lapsed. ${ }^{1081}$ The Court

${ }_{1080}$ C-137/14, European Commission v Federal Republic of Germany (Action brought on 21 March 2014).

${ }^{1081}$ C-312/93, Peterbroeck, Van Campenhout \& Cie SCS v Belgian State [1995] ECR I-4599. 
of Justice stressed that it is in principle for the Member States to create rules governing administrative litigation, ${ }^{1082}$ that the time limit as such may be allowed, ${ }^{1083}$ and that, in the concrete case, the rule was incompatible with Union law. ${ }^{1084}$ In later cases, the Court held that the adequacy of time limits has to be assessed on a case-by-case basis depending on the specific circumstances of the procedure under consideration. ${ }^{1085}$ Hence, it remains in principle for the Member States to lay down rules precluding certain allegations from being admitted in court. In the following, these rules in the legal systems of Germany, the Netherlands and England will be described.

\subsection{National rules on the preclusion of claims from review}

\section{a. Germany}

\section{National rules on the preclusion of claims from review}

Under German law, there are several rules on the exclusion of grounds for review in environmental litigations. For example, according to the rules on the Planfeststellungsverfahren (a special administrative decision-making procedure with public participation), objections can only be raised for a certain period and all submissions made after this period can no longer be considered. ${ }^{1086} \mathrm{~A}$ similar rule can be found under the administrative procedure for permits under the Federal Immission Control Act. ${ }^{1087}$ The UmwRG also provides for a rule precluding grounds from review in certain instances. § 2 (3) UmwRG provides that environmental organisations are precluded from making submissions which they could already have made at the administrative procedure stage. This rule does not apply to submissions made by claimants other than environmental organisations. However, they will often be requested to make submissions under other rules on administrative procedures with public participation as those mentioned earlier.

\section{National rules on the preclusion of claims from review in EIA cases.}

An illustration of the application of the rules on preclusion under the UmwRG is a case brought by a recognised environmental organisation against a permit under the Federal Immission Control Act for the construction of a new unit of a coal-fired power plant. ${ }^{1088}$ The claim of the environmental organisation was not successful, as no valid objection to the permit was raised within the public consultation process. The court first discussed the compatibility of the national procedural rules with Union law. ${ }^{1089}$ The judges found that the EIA Directive does not regulate rules precluding objections,

\footnotetext{
1082 Ibid., para. 12.

1083 Ibid., para. 16.

${ }^{1084}$ C-312/93, Peterbroeck, Van Campenhout \& Cie SCS v Belgian State [1995] ECR I-4599, para. 21.

1085 C-473/00, Cofidis SA v Jean-Louis Fredout [2002] ECR I-10875, para. 37; Wennerås, The Enforcement of EC Environmental Law, 2007, pp. 96 ff.

$1086 \S 73$ (4) s. 3 VwVfG.

$1087 \S 10(3)$ s. 5 BImSchG.

1088 OVG Münster, Judgment of 9 December 2009, Az.: 8 D 10/08.AK, ZUR 2010, 316-322.

1089 Ibid., ZUR 2010, 316, 318- 320; juris, paras. 75-118.
} 
meaning that Member States are competent to create rules within the boundaries prescribed by the Court of Justice. The principle of effectiveness is however not violated as the national rules have to be seen in the context of the principle of legal certainty, which is a European principle. Moreover, the national rules are appropriate and suitable as they do not make the submissions excessively burdensome. Despite the (rather short) time limit of six weeks and the limited financial and personal capacities of environmental organisations, the submission of objections is not impossible or excessively difficult, as the standard for making objections is not very high. Therefore, the national rules do not breach Union law. The court continued applying the national rule on preclusion to the claim raised by the environmental organisation. ${ }^{1090}$ Two days before the time limit for lodging objections would lapse, the organisation sent an e-mail to the authority. However, this mail could not qualify as an objection for a number of reasons. Especially, the formal requirements for making an objection electronically were not complied with. Moreover, the organisation was responsible for not lodging its objections on time. Because of the lack of valid objections, the environmental organisation could no longer raise claims against the permit in court. ${ }^{1091}$ The preclusion of the assessment of the claim related to the substantive and the procedural legality of the decision. This also means that also the claim that an EIA was wrongfully omitted was not considered in court. The judgment was subsequently upheld by the Federal Administrative Court. ${ }^{1092}$

In general, German courts ${ }^{1093}$ and legal scholars ${ }^{1094}$ consider the national rules on preclusion to be compatible with Union law, mainly because Union law allows for restrictions of the principle of effectiveness to the extent that legal certainty has to be ensured. Nevertheless, rules on preclusion constitute a hurdle for environmental organisations when bringing claims before German courts ${ }^{1095}$ and, in May 2014, the Commission started infringement proceedings against Germany because of this paragraph in the UmwRG. ${ }^{1096}$

\footnotetext{
${ }^{1090}$ Ibid., ZUR 2010, 316, 320-321; juris, paras. 119-236.

${ }^{1091}$ Ibid., ZUR 2010, 316, 321-322; juris, paras. 237-269.

1092 BVerwG, Decision of 14 September 2010, Az.: 7 B 15/10, NuR 2011, 53-56.

${ }^{1093}$ BVerwG, Decision of 11 November 2009, Az.: 4 B 57/09, NuR 2010, 339-342; BVerwG, Judgment of 29 September 2011, Az.: 7 C 21/09, NVwZ 2012, 176, para. 31 ff.; BVerwG, Decision of 17 June 2011, Az.: 7 B $79 / 10$, juris.

${ }^{1094}$ Balensiefen, Umwelt-Rechtsbehelfsgesetz, 2013, § 2, at 10; Fellenberg, Schiller, § 2 UmwRG, in: Landmann, Rohmer (eds.), Umweltrecht, Kommentar, 2014, at 54; Geismann, Schulz, Ist die materielle Präklusion nach $\$ 2$ Abs. 3 UmwRG europarechtskonform?, NuR 2014, pp. 624-630; Kment, Die Stellung nationaler Unbeachtlichkeits-, Heilungs- und Präklusionsvorschriften im europäischen Recht, EuR 2006, issue 2, pp. 201235; Siegel, Zur Einklagbarkeit der Umweltverträglichkeit, DÖV 2012, p. 713.

${ }^{1095}$ Führ et al., Verbandsklage nach dem UmwRG - Befunde und rechtliche Bewertung, NVwZ 2014, p. 1043.

1096 C-137/14, European Commission v Federal Republic of Germany, (Action brought on 21 March 2014).
} 


\section{b. Netherlands}

\section{National rules on the preclusion of claims from review}

In the Netherlands, similar to what was observed with regard to the German legal system, certain provisions preclude submissions made by applicants at the stage of judicial process if those issues were not raised in the administrative procedure preceding the administrative decision. For this purpose, article 6:13 Awb stipulates that:

"No appeal may be lodged against an order made in respect of an objection or administrative appeal by the interested party if he may reasonably be considered at fault in not having made an objection or lodged an administrative appeal against the original order." 1097

For an understanding of this article, one has to distinguish different types of submissions. ${ }^{1098}$ First, an applicant may want to submit new grounds for the claim, meaning that he wants to submit new reasons that he disagrees with the administrative decision. Article 6:13 Awb does not preclude him from submitting new reasons. Second, an applicant may submit "arguments", meaning that certain reasons for the disagreement are further clarified. Such a clarification is also possible under the reformed judicial review rules. Third, the applicant may want to challenge entire subparts of the decision. Such a submission is excluded by article 6:13 Awb. ${ }^{1099}$ However, an applicant is not precluded from submitting new arguments concerning a subpart of a decision.

Another rule preventing the submission of new grounds in court can be found in a statute which was created in order to accelerate decision making in administrative matters, the Crisis- en herstelwet (abbreviation: Chw). ${ }^{1100}$ Article 1.6a Chw stipulates that, after the time limit for bringing a litigation before the administrative court has lapsed, no further grounds for review can be submitted to the court. This rule is however only applicable to administrative decisions which are enumerated in the annexes to the Chw. Hence, it is not applicable to all challenges brought against administrative decisions.

\section{National rules on the preclusion of claims from review EIA cases}

As far as the application of article 6:13 Awb to EIA claims is concerned, the Council of State held that a claim by an association concerning an omitted EIA did not constitute a subpart of the administrative decision in the sense of article 6:13. ${ }^{1101}$ Therefore, article 6:13 Awb did not prevent claimants from raising the argument of an omitted EIA only at the stage of judicial proceedings.

\footnotetext{
${ }^{1097}$ Translation of the Awb as provided by the Ministry of Interior and Kindom Relations (available online).

1098 Van Buuren, 6:13 Awb, in: van Buuren, Borman (eds.), $T \& C A w b, 8^{\text {th }}$ edition, 2013, at 3b.

${ }^{1099}$ Damen et al., Bestuursrecht, vol. 2, $4^{\text {th }}$ edition, 2012, p. 265.

${ }^{1100}$ Wet van 18 maart 2010, houdende regels met betrekking tot versnelde ontwikkeling en verwezenlijking van ruimtelijke en infrastructurele projecten (Chrisis- en herstelwet), Stb. 2010, 135.

1101 ABRvS 21 January 2009, nr. 200801408/1.
} 
For example, in a case concerning the grant of a permit for intensive poultry farming, the issue of an omitted screening could be raised in court after the litigation was brought to court. ${ }^{102}$ The permit dated from 30 September and the issue of the screening was only raised in a supplementary claim made in the middle of December. The authority argued that this was contrary to the principle of due process, but the court disagreed finding that the authority had adequate opportunities to react on this ground for review. ${ }^{1103}$ In a different case decided on the same day, which concerned a permit for pig farming, the defendants had no possibility to react to the claim concerning the EIA, which meant that these claims could not be assessed because of the principle of due process. ${ }^{104}$

Contrary to this, the effect of article 1.6a Chw has been that, on several occasions, claims relative to an EIA which fall under this statute were excluded from further consideration in court. To begin with a case concerning a decision taken for the construction of a road, the claimants alleged at the hearing in the court that the pubic authority wrongfully failed to carry out an EIA on the decision in connection with other administrative decisions. ${ }^{1105}$ The court found that this issue was only raised after the claim was brought to court and that according to article 1.6a $\mathrm{Chw}$, this claim was excluded from further consideration. ${ }^{1106}$ In another case concerning works to strengthen a dike, the claimants only submitted during the hearing that the environmental statement and the decision were flawed as several aspects were not taken into consideration. ${ }^{1107}$ The court did not consider these claims any further because of article 1.6a Chw. ${ }^{1108} \mathrm{Next}$, in a case concerning the construction of a new starting station for a railway connection, the claimants alleged that the authority wrongfully failed to carry out an EIA for this administrative decision. ${ }^{1109}$ This claim was however only raised during the hearing in court and was therefore excluded from further assessment in court. The compatibility of article 1.6a Chw with Union law was questioned in several cases, but the courts did not find any incompatibility. ${ }^{1110}$ Comparing the Dutch rule with the German "rule on preclusion", the following observations can be made. The Dutch rule is a time limit and does not make, like in Germany, the assessment of a claim dependent on prior participation in the administrative procedure. However the effect of $1.6 \mathrm{a}$ Chw and the German rule of preclusion is the same: the court no longer assesses the EIA claim, because, at a certain point preceding the assessment in court, the issue was not raised. Hence, if the Court of Justice found an infringement of Union law with regard to the German rule, also the Dutch rules would have to come under scrutiny.

\footnotetext{
1102 ABRvS 19 June 2013, nr. 201112097/1/A4.

${ }^{1103}$ Ibid., para. 4.2 .

${ }^{1104}$ Ibid., para. 1.2.

1105 ABRvS 19 December 2012, nr. 201205119/1/R4.

1106 Ibid., para. 3.

1107 ABRvS 29 January 2014, nr. 201308001/1/A4.

${ }^{1108}$ Ibid., para. 14.

${ }^{1109}$ ABRvS 4 June 2014, nr. 201400140/1/R6.

1110 ABRvS 17 November 2010, nr. 201004771/1/M2; ABRvS 2 May 2012, nr. 201105967/1/R1, para. 2.6 ff; ABRvS 20 August 2014, nr. 201306769/1/R6, para. 5 ff; ABRvS 12 November 2014, nr. 201402491/1/R6, para. 7 ff.
} 


\section{c. England}

\section{National rules on the preclusion of claims from review}

Under the English legal system, judicial review of administrative decisions are a means of last resort and any objections to planning procedures should be made as early as possible. But contrary to the German and the Dutch legal systems, there are no rules precluding grounds for review if they were not raised in the administrative proceedings. In principle, once the applicant received permission to proceed with judicial review, he may add new grounds on which he bases his application. The only condition for this is laid down in section 54.15 CPR, which stipulates that "the court's permission is required if a claimant seeks to rely on grounds other than those for which he has been given permission to proceed". In Practice Direction rule 54.15 it is specified that, in this case, notice has to be given to the court up to seven days before the hearing.

\section{National rules on the preclusion of claims from review in EIA cases}

An example of the very broad possibilities under English law to raise grounds during court proceedings is the case of Edwards, discussed earlier. ${ }^{1111}$ As described, Edwards did not actively participate in the consultation process and only got involved when a local group campaigning against the factory searched for a "volunteer" who would be eligible to legal aid when to make a claim. ${ }^{112}$ Edwards was able to challenge the omission of an EIA in court without it being precluded because of the fact that he did not make any representations in the administrative procedure.

To conclude, in England, there are no rules which prevent claimants from raising the issue of wrongful or omitted EIAs in court.

\section{d. Comparison: differences and convergence}

This brief overview of the rules precluding the submission of certain grounds in administrative litigations has illustrated that in Germany it is not, and that in the Netherlands in some specific cases no longer, possible to submit challenges on grounds that were not addressed in the administrative procedure. Contrary to this, there are no strict rules in England preventing claimants from raising new grounds in court. In the case of Germany, the Commission considers that the rules of preclusion are in breach of Union law. If the Court of Justice found that the German rules are contrary to Union law, about which the author of this thesis is not convinced, the Dutch rules may also come under European scrutiny. So far, no international or European development triggered converging processes between the

${ }^{1111}$ Part II, Chapter 2, $1.2 \mathrm{c}$.

${ }^{1112} R$ (Edwards) v Environment Agency [2004] EWHC 736 (Admin.); [2004] 3 All ER 21. 
three legal systems. However, the introduction of article 1.6a Chw by national reform brought the Dutch and the German legal systems closer together.

Table 14: National rules on the preclusion of claims relative to the EIA in 2014

\begin{tabular}{|l|l|l|l|}
\hline & Germany & The Netherlands & England \\
\hline Rule on Preclusion & $\begin{array}{l}\text { § }(3) \text { UmwRG } \\
\text { (and other rules in } \\
\text { specific statutes such } \\
\text { as the BImSchG) }\end{array}$ & §1.6a Chw & non-existent \\
\hline
\end{tabular}

\section{Interim Conclusion}

This chapter compared the scope of review in Germany, the Netherlands and England for omitted and wrongful screenings and environmental statements. Moreover, the burden of proof was comparatively assessed and it was explained to what extent national rules preclude claims on environmental assessment in national litigations. As far as the challengeability of errors in the EIA process is concerned, convergences between the legal systems were detected. Whereas in Germany for a long time it was practically not possible to challenge different types of errors in the EIA process successfully, this was possible in England and the Netherlands. Regarding the intensity of review, it was observed that legal systems have been varying and that these differences continue to exist. Moreover, rules on the burden of proof differ and the exact implications of the ruling in Altrip on this issue are still unclear. Finally, in Germany and to some extent also in the Netherlands, certain rules preclude the assessment of claims relative to the EIA procedure in courts. In England, similar rules do not exist. In this respect, no convergences have been found. In conclusion, this means that, with regard to rules on review, differences continue to exist. The consequence of these differences is that claimants are confronted with different obligations regarding the substantiation of their claim and the proof they have to bring in alleging flaws in the EIA process. Another consequence is that the quality control of the screening and the environmental statement is exercised differently. Thus, there are different chances of success in enforcing Union legislation in court. 


\section{Chapter 4 Remedies in administrative courts}

This chapter will comparatively assess the powers of judges to grant remedies for procedural errors in the EIA process in the legal systems of Germany, the Netherlands and England. The term "remedy" is used in a wide sense as "the legal means to recover a right or to obtain redress for a wrong". ${ }^{113}$

First, the powers of judges to enforce EIA legislation and to redress procedural errors shall be described. For this purpose, rules on different legal consequences for procedural errors will be exposed and subsequently it will be illustrated how courts applied these rules in EIA cases (section 1). Next, the possibility to receive interim relief in the three legal systems will be compared (section 2).

\section{Remedies for procedural errors}

This section will explain how national litigation systems deal with errors in the EIA procedure. ${ }^{1114}$ Generally, there are three possible solutions for how judges can proceed after having established that the EIA procedure was flawed. First, they may annul the administrative decision because of the procedural error. Second, they may decide not to annul the administrative decision despite the procedural error and therewith disregard the fact that the error exists. Third, judges may order or allow the correction of the procedural error by the administrative authority. In the first section, the international and European requirements for national remedies (in EIA matters) will be described (1.1), followed by a comparison of national rules on remedies for procedural errors (1.2).

\subsection{International and European rules on remedies for procedural errors}

Article 9 (4) of the Aarhus Convention provides that the judicial procedures governed by that article shall provide for "adequate and effective remedies, including injunctive relief as appropriate." This part of article 9 (4) of the Aarhus Convention was not copied in article 10 a (later 11) of the EIA Directive. This however does not mean that the Court of Justice did not rule on remedies in the context of environmental and EIA law. Under the framework of the treaties, and especially the obligation to cooperate sincerely with the Union, Member States are under an obligation to remedy breaches of Union $\operatorname{law}^{1115}$ and they have to provide for effective judicial protection. ${ }^{1116}$ The obligation to provide remedies

\footnotetext{
${ }^{1113}$ Hay (ed.), Words and Phrases Legally Defined, vol. 2, $4^{\text {th }}$ edition, 2007, p. 798.

${ }^{1114}$ Comparative research on the treatment of procedural errors: Knill, Winkler, Convergence or Divergence of National Legal and Administrative Structures? Europeanisation Effects of the Environmental Impact Assessment in Germany and England, JEEPL 2006, issue 2, pp. 44-53; Ladeur, Prelle, Environmental Assessment and Judicial Approaches to Procedural Errors - A European and Comparative Analysis, JEL 2001, pp. 185-198; for the Dutch system with comparative remarks: Jans, de Jong, Somewhere between Direct Effect and Rewe/Comet, in: Ladeur (ed.), The Europeanisation of Administrative Law, 2002, pp. 68-92.

${ }_{1115}$ Art. 4 (3) TEU; C-9/90, Andrea Francovich and Danila Bonifaci and others v Italian Republic [1991] ECR I5357, para. 36; C-41/11, Inter-Environnement Wallonie ASBL and Terre wallonne ASBL v Région wallonne (Judgment of 28 February 2012) paras. 43, 44; Jans, Vedder, European Environmental Law, $4^{\text {th }}$ edition, 2012, p. 211.

1116 Art. 47 Charter of Fundamental Rights of the EU.
} 
was stressed in the context of EIA in the reference for preliminary ruling in Wells, in which the Court held:

“... it is for the competent authorities of a Member State to take, within the sphere of their competence, all the general or particular measures necessary to ensure that projects are examined in order to determine whether they are likely to have significant effects on the environment and, if so, to ensure that they are subject to an impact assessment [...] Such particular measures include, subject to the limits laid down by the principle of procedural autonomy of the Member states, the revocation or suspension of a consent already granted, in order to carry out an assessment of the environmental effects of the project in question as provided for by Directive 85/337. The Member State is likewise required to make good any harm caused by the failure to carry out an environmental impact assessment." 1117

From this judgment, it follows that national legal systems are obliged to provide for remedies for breaches of EIA legislation. Furthermore, in the case of Altrip, the Court of Justice found that, in principle, any procedural error in the EIA process must be challengeable in court:

"By requiring Member States to ensure that the members of the public concerned have the opportunity to bring an action challenging the substantive or procedural legality [...] the Union legislature [...] has in no way limited the pleas in law that may be put forward in support of an action." 1118

Nevertheless, the Court also recognised that there may be procedural errors which will not influence the final decision and that, in such a case, it was compatible with the objective of the EIA Directive if someone could not challenge this infringement in court. ${ }^{1119}$ In this regard, the court has to pay regard to the "seriousness of the defect" and it must ensure that the public is not deprived of its guarantees to access information or to participate in decision-making procedures under the EIA Directive. ${ }^{1120}$

Despite these rulings of the Court of Justice, there is no concrete Union rule which would determine when a decision does or does not have to be annulled and under which circumstances procedural errors may be disregarded or healed. The competence to create these rules remains with the Member States and the differences between these rules will be illustrated in the following section.

1117 C-201/02, The Queen, on the application of Delana Wells v Secretary of State for Transport, Local Government and the Regions [2004] ECR I-723, paras. 65, 66.

1118 C-72/12, Gemeinde Altrip et al v Land Rheinland-Pfalz (Judgment of 7 November 2013) para. 47.

1119 Ibid., para. 49.

${ }^{1120}$ Ibid., para. 54. 


\subsection{National rules on remedies for procedural errors}

\section{a. Germany}

\section{National rules on remedies for procedural errors}

Under German law, an administrative decision that was taken in an administrative procedure that did not or only incorrectly follow the law is illegal. ${ }^{1121}$ Nevertheless, an administrative decision, even if it is illegal, has legal force if it is not annulled in an action for annulment. ${ }^{1122}$ In the German Code on administrative procedure, there are two different legal instruments to deal with procedural errors.

First, there are Heilungsvorschriften (rules to "heal" 1123 procedural errors) meaning that the error of the administrative decision is deleted, in either making good the procedural step which was not undertaken or in undoing a procedural step that was wrongfully taken. ${ }^{1124}$ The consequence of this is that the administrative procedure is no longer erroneous or unlawful. ${ }^{1125}$ According to $§ 45$ (1) VwVfG, an infringement of administrative procedural rules, which does not render an administrative decision void, can be corrected in the following cases: (1) the application which is necessary for the adoption of an administrative decision is subsequently made; (2) the necessary reasoning is subsequently provided; (3) the necessary hearing of a participant is subsequently held; (4) the decision of a committee whose collaboration is required for the adoption of the administrative decision is subsequently taken; (5.) the necessary co-operation of another authority is subsequently obtained. ${ }^{1126}$ These procedural steps as listed in $\S 45$ (1) VwVfG, can be corrected until the last instance of court proceedings in which matters of fact are considered. ${ }^{1127}$ A claimant cannot be blamed for not bringing an action for annulment in due time, if the administrative decision lacks the necessary statement of reasons or if the party was not heard although this was necessary. ${ }^{1128}$

Second, the consequence of Unbeachtlichkeitsvorschriften (rules to disregard procedural errors) is that a procedural error has no impact on the legal force of the administrative decision although the error as such remains. Hence, these rules immunise administrative decisions which were taken within defective administrative procedures. ${ }^{1129}$ According to $\S 46 \mathrm{VwVfG}$ the annulment of an administrative decision cannot only be requested on the ground that the administrative decision was adopted in a procedure

\footnotetext{
${ }^{1121}$ Sachs, § 45 VwVfG, in: Stelkens et al. (eds.), VwVfG Kommentar, 2013, at 5; Schmidt-Aßmann, Schenk, Einleitung, in: Schoch et al. (eds.), VwGO Kommentar, 2014, at 212.

${ }^{1122}$ Maurer, Allgemeines Verwaltungsrecht, $18^{\text {th }}$ edition, 2011, $\S 10$ at 38.

1123 The German term "Heilung" literally means "healing".

${ }^{1124}$ Hufen, Siegel, Fehler im Verwaltungsverfahren, $5^{\text {th }}$ edition, 2013, pp. $357 \mathrm{ff}$.

${ }^{1125}$ Maurer, Allgemeines Verwaltungsrecht, $18^{\text {th }}$ edition $\S 10$ at 39; Sachs, $\S 45$ VwVfG, in: Stelkens et al. (eds.), VwVfG Kommentar, 2014, at 21.

1126 Own tanslation based on the Maastricht Collection.

1127 § 45 (2) VwVfG.

1128 \& 45 (3) VwVfG.

${ }^{1129}$ Maurer, Allgemeines Verwaltungsrecht, $18^{\text {th }}$ edition, $\S 10$ at 41.
} 
vitiated by the infringement of rules on procedure, form or local competence, if it is obvious that the infringement did not influence the administrative decision on the matter. ${ }^{130}$

The German rules on remedies for procedural errors have come under pressure, not the least because of the obligation to transpose the EIA Directive into German law. Whereas from a European perspective there is a strong focus on the legality of the administrative procedure itself, German administrative doctrine is based on the concept of a substantively correct decision. ${ }^{1131}$

\section{National rules on remedies for procedural errors in EIA cases}

Parallel to the development of rules on access to courts, rules on remedies concerning breaches of EIA legislation have been undergoing a process of change. In the following section, there will first be a description of the development of the possibility to request the annulment of an administrative decision for breaches of EIA legislation (aa) followed by an explanation of the possibility to correct procedural errors during court proceedings (bb).

aa) The annulment of the administrative decision for breaches of EIA legislation

The development of rules on remedies for breaches of EIA legislation in Germany can be divided into three periods, starting in the 1990s, in which in practice no remedy against breaches of EIA legislation could be sought, continuing with the introduction of the UmwRG (2006) obliging courts to annul administrative decisions in case of an omitted screening or EIA, leading to the post 2013 period in which it was clarified that administrative decisions can be annulled in case of other flaws in the EIA process. Throughout this development, two questions became relevant. The first question was which kind of remedy could be sought for which kind of breach of EIA legislation. The second question was whether a claimant has to fulfil additional requirements in order to receive the remedy, i.e. whether the infringement of a right or an interest has to be established. In the following, the three periods in which these questions became relevant will be illustrated.

\section{(i) Remedies in courts 1990 - 2006}

In the first period of EIA enforcement in Germany, the Federal Administrative Court consistently held that the simple non-compliance with procedural rules did not lead to the annulment of a decision. ${ }^{1132}$ Instead, the procedural error must have influenced the decision of the public authority. ${ }^{1133}$ More precisely, there had to be a concrete possibility that the competent authority would have decided differently without the procedural error, meaning that a causal relationship between the error and the

\footnotetext{
${ }^{1130}$ Own translation.

${ }^{1131}$ Hufen, Siegel, Fehler im Verwaltungsvefahren, $5^{\text {th }}$ edition, 2013, pp. 349 f.; Grünewald, Die Betonung des Verfahrensgedankens im deutschen Verwaltungsrecht durch das Gemeinschaftrecht, 2009, p. 28.

1132 BVerwG, Decision of 22 June 1993, Az.: 4 B 45/93, juris, para. 16; BVerwG, Decision of 23 February 1994, Az.: 4 B 35/94, juris, para. 8; BVerwG, Decision of 30 August 1995, 4 B 185/95, NuR 1996, 198, 199.

${ }^{1133}$ BVerwG, Decision of 30 August 1995, Az.: 4 B 185/95, NuR 1996, 198, 199.
} 
administrative decision had to be established. ${ }^{1134}$ This argumentation reflected the idea of $\S 46 \mathrm{VwVfG}$ that there are certain procedural errors which do not lead to the annulment of an administrative decision unless these errors had an impact on the final decision. ${ }^{1135}$ In cases concerning decisions in a Planfeststellungs-procedure, ${ }^{1136}$ the Federal Administrative Court held that even the complete absence of an EIA does not lead to the infringement of rights, as long as the planning authority considered all important interests. ${ }^{1137}$ Contrary to this, some lower courts had argued that the absence of an EIA would lead to a wrongful consideration of interests, ${ }^{1138}$ which implied the infringement of the claimant's rights. ${ }^{1139}$ This reasoning was however not accepted by the Federal Administrative Court. ${ }^{1140}$ Hence, even in cases in which an infringement of the UVPG was found, claims against planning permissions were not successful. The restrictive approach adopted by the courts was criticised as it rendered judicial protection against infringements of EIA rules nearly impossible. ${ }^{1141}$ Claimants were hardly able to prove that the adoption of an administrative decision would have been different if an EIA was conducted. ${ }^{1142}$ The compatibility of this restriction with EU law was doubted. ${ }^{1143}$

In conclusion, the level of judicial enforcement of the EIA in Germany in this first period of enforcement was weak. In the next section it will be seen in how far this situation did (not) change in the second period of EIA enforcement.

\footnotetext{
${ }^{1134}$ BVerwG, Decision of 12 January 1994, Az.: 4 B 163/93, juris, para. 11; BVerwG, Judgment of 25 January 1996, Az.: 4 C 5/95, BVerwGE 100, 238, 252; BVerwG, Judgment of 10 April 1997, Az.: 4 C 5/96; BVerwGE 104, 236, 244.

${ }^{1135}$ BVerwG, Judgment of 25 January 1996, Az.: 4 C 5 /95, BVerwGE 100, 238, 252.

1136 The Planfeststellungs-procedure is a special procedure for the adoption for administrative decisions with public participation. General rules on this procedure are laid down in $\S \S 72$ to $78 \mathrm{VwVfG}$ but more specific rules can be found in special legislation.

${ }^{1137}$ BVerwG, Judgment of 25 January 1996, Az.: 4 C 5 /95, BVerwGE 100, 238, 252.

${ }^{1138}$ The German expression is "Abwägungsmangel". In a Planfeststellungs-procedure, the authority has to weigh all public and private interests and the courts examine whether this exercise of consideration was duely carried out.

${ }_{1139}$ VGH München, Judgment of 19.10.1993, Az.: 8 A 93.40070, NuR 1994, 244, 245; VGH München, Judgment of 5 July 1994, Az.: 8 A 93.40056, Bay VBl 1995, 304, 306; OVG Koblenz, Judgment of 29 December 1994, Az.: 1 C 10893/92.OVG, ZUR 1995, 146, 149; Hien, Die Umweltverträglichkeitsprüfung in der gerichtlichen Praxis, NVwZ 1997, pp. 423 - 425; Scheidler, Rechtsschutz Dritter bei fehlerhafter oder unterbliebener Umweltverträglichkeitsprüfung, NVwZ 2005, pp. 863 ff., Steinberg, Chancen zur Effektuierung der Umweltverträglichkeitsprïfung durch die Gerichte?, DÖV 1996, pp. 226-229.

1140 BVerwG Judgment of 25 January 1996, Az.: 4 C 5/95, BVerwGE 100, 238, 252; BVerwG, Judgment of 21.03.1996, Az. 4 C 19/94, BVerwGE 100, 370, 376.

${ }^{1141}$ Schink, UVP in der Straßenplanung, Anmerkung zu OVG Koblenz, Urteil vom 29. Dezember 1994, 1 C 10893/92. OVG, ZUR 1995, p. 152; Schink, Die Umweltverträglichkeitsprïfung - eine Bilanz, NuR 1998, p. 179; Scheidler, Rechtsschutz Dritter bei fehlerhafter oder unterbliebener Umweltverträglichkeitsprïfung, NVwZ 2005, pp. $863 \mathrm{ff}$.

${ }_{1142}$ Erbguth, Schink, UVPG Kommentar, 1996, Einleitung, at 129 a.

${ }^{1143}$ Erbguth, Das Bundesverwaltungsgericht und die Umweltverträglichkeitsprüfung, NuR 1997, pp. 261- 266.
} 
The second period of remedies for breaches of EIA legislation started with the entry into force of the UmwRG (2006). ${ }^{1144}$ According to the legislative records, ${ }^{1145}$ the legislator wanted to react to the Court of Justice's ruling in Wells, according to which national judicial procedures must provide for a remedy for the failure to carry out an EIA. ${ }^{1146} \S 4$ (1) UmwRG (2006) provided that the annulment of an administrative decision under the UmwRG could be requested in case that a screening or an EIA was not conducted although it should have been conducted according the UVPG. Originally, the draft bill had provided for a more far-reaching solution, proposing a rule according to which a decision could be annulled in any case of a violation of essential procedural rules. ${ }^{1147}$ This proposal was however abandoned as it was feared that this might lead to considerable delays in planning and investment decisions. ${ }^{1148}$ Therefore, the new rule only dealt with the complete omission of an obligatory screening or the complete omission of an obligatory EIA. For these two scenarios, the requirement of causality was abandoned. ${ }^{1149}$ Thus, since the entry into force of the UmwRG (2006), courts have to annul administrative decisions if they find that a screening or an EIA was wrongfully omitted. ${ }^{1150}$ This applied to claims brought by environmental organisations under $\S 2$ (1) $U m w R G^{1151}$ and to claims brought by other participants, ${ }^{152}$ including individuals, which were granted standing under $§ 42$ (2) VwGO. ${ }^{1153}$

The new rule in the UmwRG left uncertainties about how to treat errors which occurred within the screening process or within the EIA. It was questioned whether § 4 (1) UmwRG could be interpreted as also including other errors than the wrongful omission of a screening or an EIA. The courts found that, according to the clear wording of $\S 4$ (1) UmwRG, only the complete omission of either the obligatory screening or the obligatory EIA could lead to the annulment of the administrative decision without the necessity to prove that there was the concrete possibility that the decision would have been taken differently without the error. ${ }^{154}$ The Federal Administrative Court stressed in a case concerning the reconstruction of a section of the highway A 281 that:

\footnotetext{
1144 Gesetz über ergänzende Vorschriften zu Rechtsbehelfen in Umweltangelegenheiten nach der EG-Richtlinie 2003/35/EG (Umwelt-Rechtsbehelfsgesetz), 7.12.2006, BGB1. I pp. 2816-2818.

1145 BT Drs. 16/2495, p. 13 f.

1146 C-201/02, The Queen, on the application of Delana Wells $v$ Secretary of state for Transport, Local Government and the Regions [2004] ECR I-723, para. 67.

${ }^{1147}$ BT Drs. 16/2495, p. 14.

1148 BT Drs. 552/1/06, p. 11.

${ }^{1149}$ Fellenberg, Schiller, § 4 UmwRG, in: Landmann, Rohmer (eds.), Umweltrecht, Kommentar, 2014, at 2, 8.

${ }^{1150}$ BVerwG, Decision of 27 June 2013, Az.: 4 B 37/12, NuR 2014, 117-118; OVG Magdeburg, Decision of 17 September 2008, Az.: 2 M 146/08, juris.

${ }^{1151}$ For the problem of standing for environmental organisations under the UmwRG (2006) before the Court of Justice's ruling in Trianel refer to Part II, Chapter 2, Section 1.2 a.

$1152 \S 4$ (3) UmwRG (2006) and (2013) referring to $\S 61$ VwGO.

1153 At the stage of access to courts, individuals have to allege the infringement of a subjective right. For this problem, see the discussion in Part II, Chapter 2, Section 1.2.a; Schiller, Fellenberg, § 4 UmwRG, in: Landmann, Rohmer (eds.), Umweltrecht, Kommentar, 2014, at 50, 51.

${ }^{1154}$ OVG Münster, Decision of 15 September 2008, Az.: 8 B 900/08.AK, juris, para. 38; VGH Kassel, Judgment of 24 September 2008, Az.: 6 C 1600/07.T, ZUR 2009, 87, 88; juris, para. 46; VGH Mannheim, Decision of 17
} 
"Errors within the EIA do not constitute a procedural error in the sense of $\S 4$ (1) UmwRG. In these cases, the general rules on administrative procedure apply, including $\S 46 \mathrm{VwVfG}$, in which the requirement of causality between the procedural error and the content of the decision challenged has its basis." 1155

In literature, the narrow scope of $\S 4$ (1) UmwRG was criticised and many scholars doubted that the restriction of the scope to the complete omission of a screening or an EIA was compatible with Union law. ${ }^{1156}$ It was argued that Union law does not restrict the scope of challenges only to two categories of procedural errors. A specific uncertainty concerned the case of screenings which wrongfully came to the conclusion that no EIA was necessary, meaning that, as a result, an EIA was wrongfully omitted. ${ }^{1157}$ The uncertainties were to some extent clarified with the entry into force of the UmwRG (2013) ${ }^{1158}$ and the ruling of the Court of Justice in Altrip ${ }^{1159}$ which demark the beginning of the third period of remedies for breaches of EIA legislation in Germany, as will be explained in the following section.

In 2013, a new sentence was inserted into § 4 (1) UmwRG stipulating that the annulment of an administrative decision which falls under the scope of the UmwRG can be requested if the screening did not follow the procedural requirements prescribed in the UVPG and if the result is not traceable. ${ }^{1160}$ This clarifies that there is a remedy for erroneous screenings, but the UmwRG remains silent on the remedies for wrongful EIAs. ${ }^{1161}$ The latter issue was subject to the reference for a preliminary ruling in the case of Altrip, which concerned an administrative decision under special water legislation on the construction of an installation for the holding back of water. ${ }^{1162}$ This construction was deemed necessary to improve the flood control at the Rhine River. The claimants claimed that the EIA was flawed. The court of first instance dismissed the claim and the court of second instance found that according to the state of German law at that time, a claimant could not challenge a flawed EIA unless he could prove that there was a causal link between the flaw and the administrative decision taken. ${ }^{1163}$ The claimants appealed to the

\footnotetext{
November 2009, Az.: 10 S 1851/09, juris, para. 15; OVG Schleswig, Decision of 9 July 2010, Az.: 1 MB 12/10, juris, para. 6; VG Neustadt, Decision of 23 May 2012, Az.: 4 L 321/12.NW, juris, para. 36; VG Aachen, Decision of 3 September 2012, Az.: 6 L 250/12, juris, para. 37.

${ }^{1155}$ Own translation. BVerwG, Judgment of 24 November 2011, Az.: 9 A 23/10, BVerwGE 141, 171, 174, at 17.

${ }^{1156}$ Genth, Ist das neue Umwelt-Rechtsbehelfsgesetz europarechtskonform?, NuR 2008, p. 31; Kment, Das neue Umweltrechtsbehelfsgesetz und seine Bedeutung für das UVPG - Rechtsschutz des Vorhabenträgers, anerkannter Vereinigungen und Dritter, NVwZ, 2007, p. 274; Kment, Europarechtswidrigkeit des \$ 4 I UmwRG ?, NVwZ 2012, p. 481; Schlacke, Zum Drittschutz bei der Nichtdurchführung einer gebotenen Umweltverträglichkeitsprüfung, ZUR 2006, p. 360; Schlacke, Das Umwelt-Rechtsbehelfsgesetz, NuR 2007, p. 15, Schmidt, Kremer, Das Umwelt-Rechtsbehelfsgesetz und der ,weite Zugang zu Gerichten“, ZUR 2007, p. 63.

${ }_{1157}$ Ziekow, Das Umwelt-Rechtsbehelfsgesetz im System des deutschen Rechtsschutzes, NVwZ 2007, p. 265 ff.

1158 Gesetz zur Änderung des Umwelt-Rechtsbehelfsgesetzes und anderer umweltrechtlicher Vorschriften, 21.01.2013, BGBl. I pp. 95-100; the new rule should clarify the existing uncertainties: BT Drs. 17/10957, p. 17.

${ }^{1159}$ C-72/12, Gemeinde Altrip and Others v Land Rheinland-Pfalz (Judgment of 7 November 2013).

$1160 \S 4$ (1) s. 2 UmwRG.

${ }^{1161}$ Schlacke, Die Novelle des Umwelt-Rechtsbehelfsgesetzes, EuGH ante portas?, ZUR 2013, p. 199.

${ }_{1162}$ C-72/12, Gemeinde Altrip and Others v Land Rheinland-Pfalz (Judgment of 7 November 2013).

${ }^{1163}$ OVG Koblenz, 12 February 2009, Az.: 1 A 10722/08, UPR 2009, 316, 317.
} 
Federal Administrative Court, which submitted the question on the compatibility of the German rule with Union law to the Court of Justice. ${ }^{1164}$ The latter court held that generally, also errors in an EIA must be challengeable. ${ }^{1165}$ But the Court also held that the causality requirement is not incompatible with Union law as long as the burden of proof is not on the claimant. ${ }^{1166}$

How the German legal order will adapt to this ruling is not yet entirely clear. ${ }^{1167}$ Significant procedural errors can no longer be disregarded on the basis of $\S 46$ VwVfG. ${ }^{1168}$ However, the ruling by the Court of Justice does not specify which procedural errors are "significant" and the interpretation of the causality requirement is left to the national legal order. ${ }^{1169}$ In the literature, it is therefore argued that the German legislator should amend $\S 4$ UmwRG to provide for more clarity. ${ }^{1170}$ But it is also possible that courts interpret $§ 46 \mathrm{VwVfG}$ in accordance with Union law. ${ }^{1171}$

The courts have in the meanwhile reviewed alleged errors in screenings ${ }^{1172}$ and in EIAs. ${ }^{1173}$ For example, in the case decided by the $O V G$ Koblenz on a permit granted for the installation of seven wind turbines, the court came to the conclusion that the decision taken by the administrative authority was not based on sufficient information, meaning that the result of the screening was not traceable. ${ }^{1174}$ Therefore, the claim was successful and interim relief was granted.

A crucial question which was posed by the referring court in Altrip was whether article 11 EIA Directive has to be interpreted as meaning that a claim "can be successful and lead to the decision's being annulled only if [...] [the] procedural irregularity affected a substantive legal position of the applicant's, or [...] [that] it must be possible for procedural irregularities to lead to annulment on a greater scale?" 1175 The Court of Justice did not answer this question. The general rule of German law is that an administrative decision can only be annulled if there is a breach of the law and additionally if a subjective right of the claimant is infringed. $\$ 4$ (1), (3) UmwRG makes an exception to this in cases in which a screening or

\footnotetext{
1164 BVerwG, Decision of 10 January 2012, Az.: 7 C 20.11, NVwZ 2012, 448-451.

1165 C-72/12, Gemeinde Altrip and Others $v$ Land Rheinland-Pfalz (Judgment of 7 November 2013) paras. $37 \mathrm{f}$.

1166 Ibid., para. 57.

1167 An overview over the various options to adapt to the Altrip ruling is given by: Klinger, Umweltverträglichkeitsprüfung und Rechtsschutz, ZUR 2014, pp. 539 ff.

1168 Beckmann, Umweltverträglichkeitsprüfung in der praktischen Anwendung, ZUR 2014, p. 543.

${ }^{1169}$ Siegel, Ausweitung und Eingrenzung der Klagerechte im Umweltrecht, NJW 2014, p. 975.

${ }^{1170}$ A proposal for a reformulation of $\S 4$ UmwRG taking into account draft versions in the legislative record on the UmwRG (2006) is made by Bunge, Rechtsfolgen von Verfahrensfehlern bei der Umweltverträglichkeitsprüfung, NuR 2014, pp. $312 \mathrm{f}$.

${ }^{1171}$ Siegel, Ausweitung und Eingrenzung der Klagerechte im Umweltrecht, NJW 2014, p. 975.

1172 OVG Magdeburg, Decision of 13 February 2014, Az.: 2 L 4/13, juris; Bayerischer VGH, Decision of 12 March 2014, 22 ZB 13.2382, juris; OVG Koblenz, Decision of 2 April 2014, 1 B 10249/14, DVBl 2014, 940-942; BVerwG, Judgment of 25 June 2014, Az.: 9 A 1/13, NuR 2014, 859-864; VGH München, Decision of 17 November 2014, Az.: 22 ZB 14.1035, juris.

${ }^{1173}$ BVerwG, Judgment of 24 October 2013, Az.: 7 C 36/11, BVerwGE 148, 155-174.

1174 OVG Koblenz, Decision of 2 April 2014, 1 B 10249/14, DVB1 2014, 940, 942.

1175 C-72/12, Gemeinde Altrip and Others $v$ Land Rheinland-Pfalz (Judgment of 7 November 2013) para. 20.
} 
an EIA was omitted. However, where an error other than the omission of the screening or EIA is at issue, courts still have to find that the claimant's rights were infringed.

To conclude, in 2014, claimants can request the annulment of an administrative decision where a screening was wrongfully omitted or where an EIA was wrongfully omitted (§ 4 (1) UmwRG). The courts have no discretion to grant or not to grant this remedy. A claimant can also request the annulment of an administrative decision if the screening is erroneous pursuant to $§ 4$ (1) s. 2 UmwRG. For errors within the EIA, § $46 \mathrm{VwVfG}$ is applicable, as interpreted in accordance with the ruling of the Court of Justice in Altrip.

bb) Correcting procedural errors in the screening or EIA

Next to the question to what extent a procedural error leads to the annulment of an administrative decision, the question arises to what extent there are possibilities to correct procedural errors which occur in the EIA process. § 4 (1) nr. 2 UmwRG (2013) provides that the annulment of an administrative decision can be requested if an obligatory screening was omitted and if it was not caught up at a later stage. Moreover $\S 4$ (1) sentence 3 refers to the general German legal framework for the correction of procedural errors which is codified in $\S 45 \mathrm{VwVfG}$ and to other more specific statutes allowing for the correction of procedural errors. In case the wrongful procedural action is properly corrected, the violation of the law is "healed". As a consequence, any further requests for the annulment of the administrative decision on the grounds of an infringement of the law are excluded. ${ }^{1176}$ However, a claimant may request a declaration by the court that the administrative act was unlawful until the procedural error was corrected.

With regard to the EIA process, the different types of errors which may occur have to be distinguished. In the following, first a description of the courts' approaches to omitted EIAs and screening will be provided, followed by an illustration of the courts' treatment of procedural errors within the EIA and screenings.

In case an obligatory EIA is wrongfully omitted, courts will in principle not place the administrative authority in the position to correct this procedural error during court proceedings. ${ }^{1177}$ A ruling from the OVG Magdeburg serves as an example of a case in which there was no possibility to rectify the procedural error of a wrongfully omitted EIA. ${ }^{1178}$ In this case, a claimant brought an action for the annulment of the permission for the construction of a pig fattening farm and a storage facility for liquid manure on the territory of a pig fattening farm that already existed during the times of the GDR. The court of first instance annulled the permission. ${ }^{1179}$ Subsequently, this judgment was appealed to the $O V G$

\footnotetext{
1176 Sachs, § 45 VwVfG, in: Stelkens et al. (eds.), VwVfG Kommentar, 2014, at 23.

1177 OVG Magdeburg, Judgment of 2 April 2012, Az.: 2 L 193/09, juris.

1178 Ibid., paras. $74 \mathrm{f}$.

${ }^{1179}$ VG Halle (Saale), Judgment of 25. August 2009, Az: 2 A 12/08 (not reported).
} 
Magdeburg which confirmed the judgment of the first instance judgment. The court held that the permission was unlawful as there was a procedural error that could not be corrected. The permission was granted without an obligatory EIA being conducted in advance. After having explained why this obligation existed, the court held that the claimant could request the annulment of the permission without alleging the infringement of a subjective right ( $\$ 4$ (1), (3) UmwRG). Moreover, the wording and the purpose of the norm explicitly require an annulment in the case of a wrongfully omitted EIA, without assessing whether the procedural error had an impact on the final administrative decision. ${ }^{1180}$ Finally, the court held that there was no reason to stay the procedure to give the authority the possibility to correct the procedural error. ${ }^{1181}$ Referring to a ruling of the Federal Administrative Court on the wrongful omission of a screening, ${ }^{1182}$ the court stated that generally only the wrongful omission of conducting a screening may be corrected during the court proceedings (until the second instance considering the facts of the case). However, in principle this does not apply to cases in which an obligatory EIA was not conducted. In these cases the permission usually has to be annulled. With respect to $§ 4$ (1) UmwRG, the court found that this norm does not create a possibility to correct procedural errors, but that it presupposes that there is a possibility for the procedural errors to be corrected according to the general administrative procedure rules. The court argued that even if § 4 (1) UmwRG would allow the correction of a wrongfully omitted EIA, there would be no obligation for the court to stay the proceedings.

In a case concerning a planning decision under special road legislation, the Federal Administrative Court held that in the case of a wrongfully omitted EIA, it is possible to declare that the administrative decision shall not be executed and to correct the EIA in an additional administrative procedure. ${ }^{1183}$

With regard to the wrongful omission of a screening, the Federal Administrative Court held:

"The purpose of the screening in a specific case according to $\S 3 \mathrm{c}$ UVPG is to determine whether there are significant negative impacts on the environment and that therefore there is the need for an EIA or not. In so far, there is no distinction between the EIA screening in a specific case from the necessity to conduct an EIA according to the thresholds and criteria determined by the member states. The purpose of the assessment, whether there is the need for an EIA, is also fulfilled, if the administrative authority conducts the assessment until the last instance of administrative proceedings in court that are competent to assess the facts of the case. [...]

\footnotetext{
1180 OVG Magdeburg, Judgment of 2 April 2012, Az.: 2 L 193/09, juris, paras. 66-70.

${ }^{1181}$ Ibid., para. 71.

1182 BVerwG, Judgment of 20 August 2008, Az.: 4 C 11/07, BVerwGE 131, 152.

${ }^{1183}$ BVerwG, Judgment of 20 December 2011, Az.: 9 A 31/10, BVerwGE 141, 282, 291 at 35; criticism about this judgment: Beckmann, Umweltverträglichkeitsprüfung in der praktischen Anwendung, ZUR 2014, p. 543 f.
} 
In case the screening is caught up in the process and in case it leads to the result that there is no need for an EIA, then the healing exercise is completed. There is no need to restart the administrative process for the grant of permission [...]

In case the screening is caught up in the process and in case that the project may have significant adverse effects on the environment, meaning that an EIA should have been done, then this EIA can in principle not be caught up during court proceedings."1184

Hence, if screening was wrongfully omitted, and if the court allows the reassessment by the public authority of whether or not an EIA has to be done, one has to distinguish two situations. If the result of the newly conducted screening is that no EIA is necessary, then the procedural error is corrected. In any other case, the procedure has to be conducted again from the point in time in which the screening concluded that there has to be an EIA. The necessary procedural steps cannot be made up for in the judicial procedure, as this would undermine the role of each single procedural step. ${ }^{1185}$

In case a court finds that an EIA is erroneous, these errors can be corrected in accordance with $§ 45$ (2) VwVfG. An example for this is a case decided by the $O V G$ Münster concerning an administrative decision for the alteration of a heating plant by erecting and by operating a new block-unit power station ${ }^{1186}$ The claimant alleged that the public consultation process was flawed, as the grant of permission was only publicised in a newspaper which was not commonly read in the area in which he was living. For this reason, he was unaware of the project and could not submit any objections to the project within the time limit set by the authority. The court found that the consultation process was erroneous, but that this error could be corrected afterwards. § 4 (1) s. 2 expressly refers to the possibility provided for in $\S 45$ (2) VwVfG to correct procedural errors. The court admitted that there is a potential danger that the authority might be biased when correcting the procedural error, in so far as the authority could try to simply uphold the administrative decision which had already been taken. But since the Court of Justice in Wells ${ }^{1187}$ even allowed the correction of the complete omission of an EIA, it must also be possible to correct minor flaws within the EIA. The OVG Münster held that $\S 45$ (1) VwVfG was - by analogy ${ }^{1188}$ - applicable to the case of the claimant. As a representative of an environmental organisation, the claimant participated in the inquiry which was held one month after the time limit for lodging written objections had lapsed. At this hearing, he became aware of the project and subsequently submitted objections. The court held that the procedural error was completely corrected because the disadvantages that the claimant had suffered by not being informed about the project were completely remedied by his

\footnotetext{
1184 Own translation. BVerwG, Judgment of 20 August 2008, 4 C 11/07, BVerwGE 131, 352, 359, 360, at 25, 26. ${ }_{1185}$ Kment, § 4 UmwRG, in: Hoppe, Beckmann (eds.), UVPG Kommentar, $4^{\text {th }}$ edition, 2012, at 16.

${ }^{1186}$ OVG Münster, Judgment of 9 December 2009, Az.: 8 D 12/08.AK, ZUR 2010, 316-322.

${ }^{1187}$ C-201/02, The Queen, on the application of Delana Wells $v$ Secretary of State for Transport, Local Government and the Regions [2004] ECR I-723, para. 70.

$1188 \S 45$ (1) VwVfG does not expressly refer to the insufficient publication of projects and the insufficient provision for information. But these two situations resemble the "omission of an obligatory hearing" which is enumerated under $\S 45$ (1) nr. $3 \mathrm{VwVfG}$.
} 
opportunity to submit comments at a later stage in the process and before the permit was granted to the developer. In the literature, concerns about this broad possibility to correct even significant errors are voiced and it is stressed that the application of this possibility must not lead to a circumvention of Union law. ${ }^{1189}$

Finally, it is also possible to correct procedural errors which occurred within a screening. An example of this is a case in which the claimant alleged that the public authority wrongfully conducted an assessment of the potential impacts on the environment focusing on the location of the project and not a general assessment of potential impacts on the environment. ${ }^{1190}$ The court of first instance found that the public authority first wrongfully made an assessment focusing on the location of the project, but that subsequently, the correct procedure was followed. ${ }^{1191}$ According to the court, § 4 (1) s. $1 \mathrm{nr}$. 2 UmwRG (2013) expressly allows that it is possible to make up for the screening at a later stage. The second instance court upheld the finding that the public authority in the end complied with the obligation to conduct a general assessment of potential impacts, which means that the procedure was corrected. ${ }^{1192}$

To conclude, § 4 (1) UmwRG (2013) expressly allows for the correction of procedural errors. German courts in principle do not allow the correction of the procedural error of a wrongfully omitted EIA, but it is possible to make up for a screening and to correct procedural errors within the EIA and the screening.

\section{b. Netherlands}

\section{National rules on remedies for procedural errors}

The remedies which can be sought in Dutch courts are set out in article $8.70 \mathrm{ff}$. Awb. As to the substance, the judge is entitled to declare that the claim is not "well founded" or that it is "well founded". ${ }^{1193}$ In case the claim is well founded, the judge has to annul the administrative decision either entirely or partially. ${ }^{1194}$ If the decision is annulled, the legal consequences of the decision are also annulled. ${ }^{1195}$ However, the judge has the possibility to annul the decision and leave the legal consequences in place. ${ }^{1196}$

When reviewing the procedural legality of decisions, there are two articles that are of paramount importance: article 3:2 Awb codifies the principle of due care and article 3:46 Awb sets out the duty to give reasons. When courts find that there is a violation of an EIA provision, this mostly means that there

\footnotetext{
${ }^{1189}$ Schiller, Fellenberg, § 4 UmwRG, in: Landmann, Rohmer (eds.), Umweltrecht, Kommentar, 2014, at 17.

${ }^{1190}$ Meaning the distinction between the allgemeine "Vorprüfung des Einzelfalls" ( $\$ 3 \mathrm{c}$ s. 1 UVPG) and the "standortbezogene Vorprüfung des Einzelfalls" (§ 3c s. 2 UVPG).

${ }^{1191}$ VG Regensburg, Judgment of 13 March 2014, Az.: RN 7 K 13.962, juris.

1192 Bayerischer VGH, Decision of 17 November 2014, Az.: 22 ZB 14.1035, juris, paras. 13, 14.

${ }^{1193}$ The Dutch expression is (on-)gegrondverklaring.

${ }_{1194}$ Art. 8:72 (1) Awb.

1195 Art. 8:72 (2) Awb.

1196 Art. 8:72 (3) Awb.
} 
is either a breach of article 3:2 or 3:46 Awb. For this reason, the court then annuls the administrative decision. In environmental litigation, $73 \%$ of the decisions annulled in courts are annulled because of procedural grounds. ${ }^{1197}$

Next to the annulment of the decision, other instruments may become relevant if the legal flaw is of minor importance. To begin with, article 6:22 Awb vests the court with the possibility "to pass by" 1198 procedural errors. According to this article, an administrative body that is deciding on an objection to an administrative decision or an administrative court that is deciding in administrative litigations on an administrative decision, may uphold a decision despite an infringement of a written or unwritten rule or general principle if it is plausible this does not prejudice interested parties. This rule has similarities with the German rule of $\S 46 \mathrm{VwVfG}$, as both rules allow the possibility to disregard procedural errors.

Moreover, the Dutch legislator created a new instrument called bestuurlijke lus in article 8:51a Awb. ${ }^{1199}$ Accordingly, the administrative judge may, by interim order, request the administrative authority to correct a violation of the law. Such a correction may either consist of the adoption of a new administrative decision or in a more detailed elaboration on parts of the decision. The court fixes the time in which this correction has to take place. The reason for introducing this possibility is the intention of the legislator to promote a "final dispute settlement", meaning that legal disputes concerning administrative decisions should be settled easier and quicker. ${ }^{1200}$ The promotion of "final dispute settlement" has to some extent influenced the development of judicial EIA enforcement as will be described in the following section.

Finally, the Dutch legislator has created the so-called relativiteitsvereiste (requirement of connection), which provides that "the administrative judge does not quash an administrative decision because it infringes written or unwritten rules or general principles if this rule or principle evidently does not aim at protecting the interest of those that want to rely on it." ${ }^{1201}$ To some extent, this provision resembles the German rule stipulating that an administrative decision cannot be quashed if it does not infringe the claimants' individual rights under public law. In the following paragraph it shall be seen how these rules were applied in EIA cases.

\footnotetext{
${ }^{1197}$ Jans, Marseille, The Role of NGOs in Environmental Litigation against Public Authorities: Some Observations on Judicial Review and Access to Court in the Netherlands, JEL 2010, p. 385.

1198 The Dutch expression is passeren van gebreken.

${ }^{1199}$ Wet van 14 december 2009 tot aanvulling van de Algemene wet bestuursrecht met een regeling voor herstel van gebreken in een besluit hangende beroep bij de bestuursrechter (Wet bestuurlijke lus Awb), Stb. 2009, 570 .

${ }^{1200}$ Kamerstuk II, 2007-2008, 31 352, nr. 3 (Memorie van Toelichting).

${ }^{1201}$ Own translation. The relativiteitsvereiste was introduced with the Wet van 18 maart 2010, houdende regels met betrekking tot versnelde ontwikkeling en verwenzelijking van ruimtelijke en infrastructurele projecten (Crisis - en herstelwet), Stb. 2010, 135; Article 1.9 Chw applied until 1 January 2013, Stb. 2012, 682. Since then, it has become generally binding for administrative law in article 8:69 a Awb (Wet van 20 december tot wijziging van de Algemene Wet bestuursrecht en aanverwnate wetten met het oog op enige verbeteringen en vereenvoudigingen van het bestuursprocesrecht (Wet aanpassing bestuursprocesrecht), Stb. 2012, 684).
} 


\section{National rules on remedies for procedural errors in EIA cases}

Parallel to the development of rules on access to court in the Netherlands, rules on remedies have been changing over the last years. These reforms do not only concern environmental law but administrative law in general. The main reason behind these developments is the aim of the Dutch legislator to promote "final dispute settlement", meaning the abolition of a practice in which developments were delayed because of infinite judicial disputes. ${ }^{1202} \mathrm{~A}$ consequence of this is that courts shall utilise instruments leading to a quick settlement of disputes. The starting point is however still that procedural errors in principle lead to the annulment of an administrative decision (aa). However, there are new possibilities to correct procedural errors (bb). Finally, the legislator introduced a requirement of connection which restricts the availability of remedies also in environmental matters (cc).

aa) The annulment of the administrative decision for breaches of EIA legislation

With regard to the enforcement of EIA legislation in the Netherlands, the starting point is that, in principle, courts annul an administrative decision if it was found that the EIA process was flawed. Since the beginning of EIA enforcement, the wrongful failure to conduct an obligatory EIA had the annulment of the administrative decision as a consequence. ${ }^{1203}$ In 2002, Jans and de Jong noted that they are

"not aware of any judgment of a Dutch court where the failure to submit an EIA did not lead to the annulment of the contested decision. Without exceptions these decisions were quashed. As far as Dutch administrative law is concerned, the question to what extent an impact assessment, if it had been made, might have affected that decision is irrelevant". ${ }^{204}$

Thus, contrary to what was described with regard to the early phase of EIA enforcement in Germany, in the Netherlands the wrongful omission of an EIA had the annulment of an administrative decision as consequence and there was no causality requirement. This is still the general position adopted by the courts in the Netherlands.

If a court finds that a screening was wrongfully omitted, courts in principle also annul the administrative decision. ${ }^{1205}$ For example, in a case concerning a permit granted for a pig rearing installation with a capacity of 8,000 pigs, the competent authority failed to assess whether an EIA was necessary. ${ }^{1206}$ The

\footnotetext{
${ }^{1202}$ Polak, Roelfsema, Bestuursrechtspraak, in: Muller, Cleiren (eds.), Rechterlijke Macht, $2^{\text {nd }}$ edition, 2013, pp. $213 \mathrm{ff}$.

${ }^{1203}$ See for example: ABRvS 18 September 2000, E03.98.1705, M\&R 2001/71 (with a comment by Verschuuren). ${ }^{1204}$ Jans, de Jong, Somewhere between Direct Effect and Rewe/Comet, Some remarks on Dutch administrative Law, Procedural Defects and the EIA Directive, in: Ladeur (ed.), The Europeanization of Administrative Law, 2002 , p. 84.

${ }^{1205}$ ABRvS 29 October 2003, nr. 200206313/1, ABRvS 19 October 2005, nr. 200504993/1; ABRvS 14 November 2012, nr. 201105329/1/A4; ABRvS 3 July 2013 nr. 201209539/1/R4, M\&R 2013/127 (with a comment by Soppe and Gudelach); ABRvS 11 December 2013, nr. 201207262/1/A4; Rechtbank Gelderland 16 December 2014, nr. AWB 13-4146; the same applies to omissions in plan-MER cases, where this will lead to annulment: ABRvS 19 December 2012, nr. 201112785/1/R4, JM 2013/26 (with a comment by van Velsen).

${ }^{1206}$ ABRvS 13 July 1999, nr. E03941402, AB 1999/411 (with a comment by Backes).
} 
court considered that, taking the size of the project into account, it cannot be excluded that there are environmental effects of the project, like for example the deposition of nitrogen and other effects on a nearby bird protection area. Therefore, the decision breached article 3:2 Awb and it was annulled. ${ }^{1207}$ In a recent case concerning a permit granted for the establishment and operation of an installation for anaerobic digestion, the court confirmed that if a screening is missing the administrative decision has to be annulled. ${ }^{1208}$ Moreover, the Council of State decided in a case concerning water works at the Meuse River that it was not possible to disregard the failure of the administrative authority not to conduct a screening in the case at hand. ${ }^{1209}$ Hence, this procedural error is excluded from the scope of article 6:22 Awb. ${ }^{1210}$

In cases in which Dutch courts find that an EIA is vitiated by an error, this will in principle ${ }^{1211}$ also lead to the annulment of the administrative decision. As explained in the chapter on the scope of review, the courts apply a very cautious test and in many cases no error is detected. This is often due to the role of the independent Commissie m.e.r. in the EIA process.

If a Dutch court finds that a screening was erroneous, the consequence will in principle be the annulment of the administrative decision. ${ }^{1212}$ For example, in a case concerning a permit granted for the establishment and operation of a composting installation, the court found that the screening was based on incorrect considerations concerning odour emissions. Therefore, the administrative decision was annulled. ${ }^{1213}$ At this point, it should be noted that the court may also decide to annul the administrative decision but to leave the legal consequences in place. An example of this is the case of a permit granted for the establishment and operation of a pig rearing installation, in which the administrative authority failed to consider the criteria listed in Annex III of the EIA Directive. ${ }^{1214}$ The court found a breach of the principle of proper motivation and for this reason concluded that the administrative decision had to be annulled. The legal consequences of the decision were however upheld. ${ }^{1215}$

This case law has illustrated that, in the Netherlands, the wrongful omission of a screening or an EIA and flaws within the screening and EIA will lead to the annulment of the administrative decision. However, there are also possibilities to disregard procedural flaws in accordance with article 6:22 Awb. It is in principle not possible to disregard the procedural error of an omitted EIA or screening. However,

\footnotetext{
${ }^{1207}$ Ibid., para. 2.6.5.

${ }^{1208}$ Rechtbank Gelderland, Judgment of 16 December 2014, nr. AWB-13-4146, para. 13.

${ }^{1209}$ ABRvS 8 February 2012, nr. 201109027/1/A4, AB 2012/57 (with a comment by van Hall) para. 2.8.2.

${ }^{1210}$ In the legislative records on article 6:22 Awb, reference is expressly made to the Council of State's judgment of 8 February 2012: Kamerstuk I 2012/13, 3240, nr. G, p. 4; van Buuren, Art. 6:22 Awb, in: van Buuren, Borman (eds.), $T \& C A w b, 8^{\text {th }}$ edition, 2013.

${ }^{1211}$ On the possibility to apply the bestuurlijke lus, refer to Part II, Chapter 4, Section 1.2. (b), bb.

1212 ABRvS 24 April 2004, nr. 200303118/1, M\&R 2004/65 (with a comment by Verschuuren and Jesse); ABRvS 5 June 2013, nr. 201109112/1/A4; Rechtbank Oost-Brabant 8 April 2014, nr. SHE 13/774; Rechtbank OostBrabant 29 December 2014, nr. SHE 13/4559.

1213 ABRvS 7 February 2007, nr. 200603204/1, M\&R 2007/47 (with a comment by Jesse).

${ }^{1214}$ ABRvS 28 November 2012, nr. 201106128/1/A4, JM 2013/41 (with a comment by Bokelaar) para. 3.3.

${ }^{1215}$ Ibid., Beslissing III.
} 
other flaws in the process are not excluded from this provision. For example, in a case concerning a permit for the alteration of a waste treatment installation, the results of the screening were published and in the publication, two locations were named where the public could consult the screening documents. ${ }^{1216}$ In fact, however, the documents were only available at one location. Hence, there was a flaw in the public consultation process. The court however considered that this flaw did not prejudice the claimants, as the documents were actually available at one of the two locations. Therefore the court decided to disregard this procedural error.

bb) Correcting procedural errors in the screening or EIA

The jurisprudence on the bestuurlijke lus with regard to EIA claims is not clear and very casuistic. ${ }^{1217}$ Compared to the number of administrative cases in general, the number of cases in which this instrument is used is rather small. ${ }^{1218}$ In the workshop in December, it was not possible to determine whether or not a correction would be ordered in the cases presented. Since 2010, on some occasions Dutch courts have applied the newly created instrument of the bestuurlijke lus, creating the possibility to order the correction of procedural errors during court proceedings. ${ }^{1219}$ For example, in the case of the pig rearing installation in Horst aan de Maas, permission was granted for the expansion of a farm for pigs, sheep and horses by 1,800 pigs. ${ }^{1220}$ After having considered that the thresholds of Annex C 14 to the Besluit m.e.r. were not exceeded, the court found that Annex III of the Directive was not taken into account by the competent authority. Therefore, there was a breach of articles 3:2 and 3:46 Awb. Hence, the claim was successful. However, as the Council of State wanted to settle the dispute quickly and ordered the authority by interim judgment to consider the criteria of Annex III. Hence, the administrative authority could try to repair the initial decision, by altering the initial decision or by taking another decision. ${ }^{1221}$ The correction had to take place within six weeks. The authority altered the initial decision, but found that no EIA was necessary. In the following, the claimants submitted that this new decision was wrongful. The Council of State however found that the competent authority gave sound reasons for the decision, meaning that the initial error was corrected. ${ }^{1222}$ Thus the renewed claim on a wrongful screening was unsuccessful. In its final judgment, the court annulled the initial decision as a whole.

\footnotetext{
${ }^{1216}$ Rechtbank Oost-Brabant, 8 April 2014, SHE 13/774, para. 7.5.

1217 According to van Velsen it is "understandable that the Council of State still carries out experiments with this relatively new instrument" (own translation) and that it is difficult to see when the Council of State will and will not apply the bestuurlijke lus; van Velsen, Case Comment on ABRvS 4 July 2012, nr. 201010565/1/A4, JM 2012/111.

1218 Backes et al., Evaluatie Bestuurlijke Lus Awb en internationale rechtsvergeleijking, 2014 (available online). 1219 See for example: ABRvS 8 February 2012, nr. 201010565/1/T1/A4 JM 2012/34 (with a comment by Hoevenaars and Flietstra) and ABRvS 4 July 2012, nr. 201010565/1/A4, JM 2012/111 (with a comment by van Velsen); ABRvS 6 Juni 2012, 201113326/1/T1/A1, ABRvS 10 October 2012, nr. 201113326/1/A1; Rechtbank Breda 11 October 2012, nr. 12/3996.

${ }^{1220}$ ABRvS 4 July 2012, nr. 201103782/1/T1/A4, Beslissing 1.

${ }^{1221}$ Ibid., para. 2.17.

1222 ABRvS 21 November 2012, 201103782/1/A4, para. 6.2.
} 
However, as the procedural error was repaired in revising the initial decision, the "new" decision could in principle stand, but it was annulled partially for other reasons.

Also in the case of Eneco Reusel, the Council of State applied the instrument of the bestuurlijke lus. In an interim order, the court held that, in its screening opinion, the competent authority did not assess whether a permission granted for the construction of five wind turbines with a capacity of $14.9 \mathrm{MW}$ would have adverse effects on the environment according to the criteria listed in Annex III of the Directive. ${ }^{1223}$ Therefore, the administrative authority was requested to correct this procedural error by submitting proper reasons and by altering the old decision or by taking a new decision. After the administrative authority had added reasons to the initial decision, stating why there would be no adverse effects by taking the criteria of Annex III into consideration, the court came to the conclusion in its final judgment that the competent authority sufficiently justified its finding that an EIA was not necessary and that the applicants were not able to show otherwise. ${ }^{1224}$ Therefore, the decision was quashed but the legal consequences could remain in place.

In another claim concerning the construction of a wind farm, it was the defendant authority which asked the court of first instance to stay the proceedings so that the authority could reconsider the question of an EIA screening. It was clear that the thresholds were not met, but the authority failed to consider the criteria of Annex III of the Directive. The court admitted the request and ordered the authority to try to correct the procedural error within four weeks. ${ }^{1225}$

Legal scholars feared that the application of the bestuurlijke lus would lead to sloppy decision making, in the sense that the authority could make the assessment with the aim of concluding that no EIA was necessary. ${ }^{1226}$ According to a recent empirical study on the application of this instrument in administrative litigations in general, this is however not the case. ${ }^{1227}$

cc) The relativiteitsvereiste

In how far the relativiteitsvereiste (requirement of connection) will prevent the annulment of administrative decisions infringing EIA legislation is not yet clear. A first case in which the requirement of connection became relevant concerned a wrongfully omitted strategic environmental impact assessment (SEA). ${ }^{1228}$ The claim was brought by an association, which, according to its statutes, wanted to preserve the cultural and historic heritage of the municipality of Bergen and other municipalities. Hence, the interest of this association was the protection of a good woon - en leefklimaat (good and healthy living environment). Due to the fact that in an SEA the effects of the plan on the cultural and

\footnotetext{
1223 ABRvS 6 June 2012, nr. 201113326/1/T1/A1.

${ }^{1224}$ ABRvS 10 October 2012, nr. 201113326/1/A1.

1225 Rechtbank Breda, Judgment of 11 October 2012, nr. 12/3996.

1226 Velsen, Case comment on ABRvS 4 July 2012, nr. 201010565/1/A4, JM 2012/111, p. 815; Hoevenaars, Flietstra, Case comment on ABRvS 8 February 2012, nr. 201010565/1/T1/A4, JM 2012/34.

${ }^{1227}$ Backes et al., Evaluatie Bestuurlijke Lus Awb en internationale rechtsvergelijking, 2014 (available online).

${ }^{1228}$ ABRvS 1 October 2014, nr. 201307140/1/R1.
} 
historic heritage also have to be described, the SEA rules also protected the interests of the association. Hence, the requirement of connection did not prevent the court from annulling the administrative decision. $^{1229}$

The exact application of the relativiteitsvereiste with respect to the EIA procedure is however far from clear. Generally speaking, the question of whether or not the interests of individual claimants are affected depends on the question on whether the project potentially has a negative impact on the good and healthy living environment and on the concrete designation of this area in a specific case. ${ }^{1230}$ According to the workshop, the claims of the property owner would not have been admissible, although this is debatable, and therefore there was no assessment of the relativiteitsvereiste at a later stage of the judicial process. But if he was granted standing, his claim could have been successful if there was an error in the EIA process and if the forest formed part of his good and healthy living environment. The action group in the village, if it had standing, would also have to show that the forest formed part of the good and healthy living environment in order to be successful with their claim. The environmental organisation and the competitor would not encounter problems with respect to the requirement of connection.

To conclude, if an EIA or a screening was wrongfully omitted, this would in principle lead to the annulment of the decision. Additionally, screenings and EIAs which are incorrect would lead to the annulment of the decision. The judge examines whether the steps in the EIA procedure were taken and examines them against the background of general administrative law. Hence, an insufficient reasoning for the decision to conduct or not to conduct an EIA would lead to a breach of articles 3:46 and 3.2 Awb. The cases presented show that there is tendency of the judges to utilise instruments to order the correction of an incorrect screening or EIA during the judicial process but it is not clear when this instrument is used. Finally, the introduction of a requirement of connection between the administrative decision and the interests of the claimant may prevent the annulment of administrative decisions. So far, there is only a little case law on that matter with regard to errors in the EIA procedure and it remains to be seen how courts will cope with this new restriction.

\section{c. England}

\section{National rules on remedies for procedural errors}

Remedies for judicial review claims are set out in section 54.2 CPR. Accordingly, claimants may request a quashing, prohibitory or mandatory order or an injunction under the Supreme Court Act 1981. The remedy which can be sought against decisions of the Secretary of State under section 288 of the TCPA (1990) is a quashing order. However, the judges have discretion whether or not to quash. In both cases the court will rule on the legality of the decision which comprises an assessment of its procedural and

${ }^{1229} \mathrm{Ibid}$., para. 4.8.

${ }^{1230}$ Crooijmans, Het relativiteitsvereiste: “Eigen huis en tuin”, M\&R 2014/67, pp. 341-348. 
its substantive legality. Contrary to the case in Germany (and the Netherlands), there is no doctrine on the possibility to disregard procedural errors or to correct procedural errors during the court proceedings. ${ }^{1231}$ Instead, courts are vested with the discretion to decide whether the decision will ultimately be quashed.

\title{
2. National rules on remedies for procedural errors in EIA cases
}

In this section, it will first be illustrated how the courts have been exercising their discretion to quash administrative decisions in EIA cases (aa), followed by some brief remarks on the possibility to correct procedural errors during court proceedings (bb). It should be noted that the ability to disregard procedural errors is covered by the discretion to quash a decision and will therefore be dealt with in this context.

\section{aa) Discretion to quash}

The question how judges exercise their discretion (not) to quash a decision has undergone some developments since the EIA procedure was created in England. In the beginning of EIA enforcement, judges decided not to quash a decision if this was contrary to the interests of the wider public. ${ }^{1232} \mathrm{An}$ example of this is the case of Twyford in which it was held that

\begin{abstract}
"Unless inhibited from doing so because the assumed breach was of a Council directive, I should not have exercised the discretion of the court in the applicants' favour because no prejudice resulted and because to have quashed this scheme would have occasioned considerable further delay to the building of this much needed section of road which would have been contrary to the interests of the wider public."1233
\end{abstract}

The consequence of this discretion was that, in practice, claimants were prevented from enforcing EIA legislation in courts even where non-compliance was established. ${ }^{1234}$

This situation seemed to have changed with the judgment of the House of Lords in Berkeley (no.1). ${ }^{1235}$ In this case, Lord Hoffmann allowed the appeal and suggested the quashing of the grant of planning permission, stressing the importance of a duly conducted EIA procedure, including an environmental statement that was not simply a "paper chase". Lord Hoffman stated that, although the statutory appeals regime allows for the discretion to quash an ultra vires planning decision, he doubted that

\footnotetext{
${ }^{1231}$ Kleve, Schirmer, England und Wales, in: Schneider (ed.), Verwaltungsrecht in Europa, vol. 1, 2007, p. 162.

${ }^{1232}$ Holder, Environmental Assessment, The Regulation of Decision Making, 2006, pp. $23 \mathrm{ff}$.

${ }^{1233}$ Twyford Parish Council and Others v Secretary of State for the Environment and Another [1992] 1 CMLR 276 (QB) [86].

${ }^{1234}$ McCracken, Edwards, Standing and discretion in environmental challenges: Walton, a curate's egg, JEPL 2014, p. 313.

${ }^{1235}$ Berkeley v Secretary of State for the Environment [2001] 2 AC 603 (HL).
} 
"consistently with its obligations under European law, the court may exercise that discretion to uphold a planning permission which has been granted contrary to the provisions of the Directive. To do so would seem to conflict with the duty of the court under article 10 (ex article 5) of the EC Treaty to ensure fulfilment of the United Kingdom's obligations under the Treaty. In classifying a failure to conduct a requisite EIA for the purposes of section 288 as not merely non-compliance with a relevant requirement but as rendering the grant of permission ultra vires, the legislature was intending to confine any discretion within the narrowest possible bounds. It is exceptional even in domestic law for a court to exercise its discretion not to quash a decision which has been found to be ultra vires." 1236

This judgment made clear that the court's discretion not to quash a decision violating EIA legislation, which has its roots in Union law, was very narrow. ${ }^{1237}$ The possibility to disregard a procedural error is therewith very restrictive. In this regard, Lord Hoffmann held:

"I would accept that if there was a failure to observe some procedural step which was clearly superfluous to the requirements of the Directive, it would be possible to exercise discretion not to quash the permission without any infringement of our obligations under European law." 1238

In the aftermath of Berkeley (no.1), there are several other examples in which the courts did quash decisions in which EIA legislation was breached. In Lebus, the court allowed the application for judicial review as there was no proper screening opinion although there should have been one. ${ }^{1239}$ In Friends of Basildon Golf Course, the court found that the screening opinion was seriously misleading, which was a sufficient reason to hold that the screening opinion and the planning permission should be quashed. ${ }^{1240}$ In Bateman, Moore-Bick L.J. held that the

"adoption of a screening opinion, if one is required, is part of a process that leads eventually to the grant or refusal of planning permission. If any step in that process is legally flawed, the process as a whole is flawed and the grant of permission must be quashed." ${ }^{1241}$

The issue of a procedural error was also at stake in the case of Threadneedle Property Investments. The discussion on the consequences of procedural errors for the administrative decision was "academic" as the court found first that there was no procedural error. ${ }^{1242}$ However, Lindblom J deemed it important to comment on this issue, whether the Secretary of State's error vitiated the Council's grant of planning

\footnotetext{
1236 Ibid., (616).

${ }^{1237}$ Lidbetter, Buchner, Withholding Relief for a Breach of EU Law: A Comparative Approach, JR 2003, p. 38, with a comparison of this judgment with the German law at that time.

${ }^{1238}$ Berkeley $v$ Secretary of State for the Environment [2001] 2 AC 603 (HL) 617.

${ }^{1239} R$ (Lebus) v South Cambridgeshire District Council [2002] EWHC 2009 (Admin); [2003] Env LR 17 [37].

${ }^{1240} R$ (Friends of Basildon Golf Course) v Basildon DC [2010] EWCA Civ 1432; [2011] Env LR 16 [55].

${ }^{1241} R$ (Bateman) v South Cambridgeshire District Council [2011] EWCA Civ 157.

1242 Threadneedle Property Investments Ltd. v Southwark LBC [2012] EWHC 885 (Admin); [2013] Env LR 1 [109].
} 
permission. The analysis was divided - as proposed in the submissions by the applicant - in two ways: a European and a domestic route. With regard to the "European way", the judge found that:

"If the Secretary of State had erred as alleged in ground A of the claim- which I have held he did not- it is, I accept arguable that the 'sequential and transparent consideration' of the environmental implications of this project would not have been lawfully achieved, and that the system by which the EIA Directive was transposed into domestic law would thus have failed." ${ }^{1243}$

He continued:

"The EIA directive recognises, in art. 1(3) that a member state may confer the duties it creates upon one or more 'competent authorities'. But the member state bears the obligation under arts 2 (1) and 4 (2) to establish a procedure for determining, before consent is given, whether Annex II projects require environmental assessment. A breach of the procedure enacted as the means of implementing that requirement will put the member state in breach of the EIA Directive, regardless of which of the particular authorities designated to play a role in that procedure was responsible for it."1244

To conclude, from this case law it can be followed that in the aftermath of Berkeley, in several cases the courts emphasised the importance of a proper administrative procedure and legal flaws would result in a quashing order. However, it was also stressed in some cases that the judgment of Berkeley had to be read in context. ${ }^{1245}$

The question of the discretion to quash an administrative decision was raised anew in the judgment of the Supreme Court in Walton. ${ }^{1246}$ This case is a Scottish case, but since it was decided by the UK Supreme Court, it also has relevance for the English legal system. Although in this case, there was no breach of Union legislation, as the project in question was not covered by the SEA directive, the court expressed its views on the discretion to withhold a remedy. Lord Reed, giving the leading judgment, omitted to elaborate on the issue of discretion as the "the Ministers accepted that, if there had been a substantial failure to accord Mr Walton proper participation as required under EU law, then the court should not withhold a remedy." 1247

\footnotetext{
${ }^{1243}$ Ibid. [115].

${ }^{1244}$ Ibid. [116].

${ }^{1245}$ Bown $v$ Secretary of State for Transport, Local Government and the Regions [2003] EWCA Civ 1170; [2004]

EnvLR 26, [47]; R (Jones) v Mansfield DC [2003] EWCA Civ 1408; [2004] Env LR 21 [59].

${ }^{1246}$ Walton $v$ The Scottish Ministers [2012] UKSC 44; [2013] 1 CMLR 28.

${ }^{1247}$ Ibid. [77].
} 
The issue of discretion was analysed in more depth in the speech of Lord Carnwath. He noted that:

"In this respect, I see discretion to some extent as a necessary counterbalance to the widening of rules of standing. The courts may properly accept as "aggrieved", or as having a "sufficient interest" those who, though not themselves directly affected, are legitimately concerned about damage to wider public interests, such as the protection of the environment. However, if it does so, it is important that those interests should be seen not in isolation, but rather in the context of the many other interests, public and private, which are in play in relation to a major scheme such as the AWPR."1248

In his analysis, Lord Carnwath first considered the domestic (Scottish) statutory regime which provides for a test according to which a remedy would be refused if a procedural error did not result in any substantial prejudice of the applicant. In applying this test to the case, he concluded that Mr. Walton would not have been entitled to the remedy, as his interests were not substantially prejudiced. Lord Carnwath found:

"In relation to the Fastlink, his legitimate interest extended to the right to be consulted, to make his views known on any aspect of the scheme, and to have those views considered. He did not have a legal right to have those views examined at a public inquiry, but an inquiry was held and he was heard. He had no right to dictate the result. Furthermore, the balance of the factors listed by Mr Mure QC point overwhelmingly to the exercise of discretion in favour of allowing the scheme to proceed." ${ }^{1249}$

After having considered the domestic statutory regime, he continued considering national and European case law. With regard to the judgment in Berkeley, he stressed that this ruling has to be seen in context, especially paying attention to the fact that it was not necessary to balance the interest of Lady Berkeley against the prejudice to public or private interest. At the time the case was dealt with by the House of Lords, the developer had already abandoned the project. With regard to the Union cases of Wells and Inter-Environnement Wallonie, Lord Carnwath held:

"It would be a mistake in my view to read these cases as requiring automatic "nullification" or quashing of any schemes or orders adopted under the 1984 Act where there has been some shortfall in the SEA procedure at an earlier stage, regardless of whether it has caused any prejudice to anyone in practice, and regardless of the consequences for wider public interests. As Wells makes clear, the basic requirement of European law is that the remedies should be "effective" and "not less favourable" than those governing similar domestic situations. Effectiveness means no more than that the exercise of the rights granted by the Directive should

\footnotetext{
1248 Ibid. [103].
}

1249 Ibid. [114]. 
not be rendered "impossible in practice or excessively difficult". Proportionality is also an important principle of European law.

Where the court is satisfied that the applicant has been able in practice to enjoy the rights conferred by the European legislation, and where a procedural challenge would fail under domestic law because the breach has caused no substantial prejudice, I see nothing in principle or authority to require the courts to adopt a different approach merely because the procedural requirement arises from a European rather than a domestic source.

Accordingly, notwithstanding Mr Mure's concession, I would not have been disposed to accept without further argument that, in the statutory and factual context of the present case, the factors governing the exercise the court's discretion are materially affected by the European source of the environmental assessment regime." 1250

This case emphasises that judges in England retain a broad discretion not to quash a decision which is contrary to Union law, so that in conclusion, in England, the award of a remedy for the breach of EIA legislation remains at the discretion of the courts.

bb) Correcting procedural errors

Whether and under which circumstances, it is possible for the court to order the correction of a procedural error during proceedings before the court is not entirely clear. Legal scholars refer to a Scottish case in which courts permitted the developer to submit an environmental statement even during court proceedings. ${ }^{1251}$ The scholars conclude that this would still be good law; ${ }^{1252}$ however for the present research it was not possible to find a similar case in the English legal system.

To conclude, under English law, judges have discretion whether or not to annul an administrative decision for a breach of Union legislation. In the workshop, the conclusion was that, for the complete omission of an EIA or screening in that specific case, the breach would probably be serious enough in order to quash the decision. However, it was stressed that these decisions require a certain "sense of proportion".

\section{d. Comparison: differences and convergence}

This section described the remedies which are available for procedural errors in EIA cases in the courts of the three legal systems. Thereby, it became clear that the rules on remedies have been very different between the legal systems and that they have been undergoing a process of change. This process was triggered by the Aarhus Convention and independent national reforms. In the following paragraphs, the developments shall be briefly summarised from a comparative perspective, starting with national rules

\footnotetext{
${ }^{1250}$ Ibid. [138]-[140].

${ }^{1251}$ Swan v Secreatry of State (No.1) [1998] Env LR 545; Bell et al., Environmental Law, 8 ${ }^{\text {th }}$ edition, 2013, p. 486.

1252 Bell et al., Environmental Law, $8^{\text {th }}$ edition, 2013, p. 486.
} 
on the annulment of administrative decisions for procedural breaches, followed by concluding observations on differences and convergence with regard to rules for the correction of procedural errors.

To begin with, the in the 1990s it was practically impossible for any claimant to succeed in having an administrative decision annulled because of an omitted or erroneous EIA in German courts, as it was required that claimants plausibly show that the procedural error had a concrete impact on the final administrative decision. At the same time, in the Netherlands, the wrongful omission of an EIA or screening led to the annulment of the administrative decision and claimants were also able to challenge flaws in the screening or EIA process successfully. In England, the beginning of EIA enforcement was characterised by a reluctance of the courts to exercise their discretion to quash a decision due to a focus on overriding interests of the public. This means that, in the beginning of the enforcement of EIA legislation in national courts, claimants had different chances to succeed with their claims due to different procedural rules.

Since these times, bits and pieces of convergence between the legal systems can be observed. To begin with, the German rules on remedies for breaches of EIA legislation have been broadened. This development was mainly triggered by the influence of the Aarhus Convention and the Court of Justice's rulings. The UmwRG (2006), which intended to implement the obligation of the Aarhus Convention and the respective Union legislation, provided that the annulment of an administrative decision can be requested if an obligatory EIA or screening was wrongfully omitted. Thus, there has been a nondiscretionary remedy under this statute for two types of breaches of Union legislation. In 2013, another category was added, namely certain violations within the screening process. For these breaches, the annulment of administrative decisions can be requested in national courts. Furthermore, the Court of Justice stressed in Altrip that flaws in an EIA also have to be challengeable, albeit recognising the possibility that some errors may not have an influence on the outcome. This process of broadening led to an approximation of the German system and the Dutch system, in which it had in principle always been possible to request the annulment of administrative decisions for the wrongful omission of an EIA or screening and in which errors within the screening or EIA process also had the annulment of the decision as consequence. Hence, as far as the rules on remedies for the wrongful omission of an EIA or screening is concerned, the differences between the two legal systems have diminished. In England, the remedy to quash a decision because of breaches of EIA legislation is at the discretion of the courts. In the beginnings of EIA enforcement, the courts did exercise their discretion not to quash decisions because of overriding public interests. Thus, under the English system similar effects were produced as under the original German legal system, namely that decisions were not quashed despite infringements of EIA legislation. The English approach seemed to have changed with the Berkeley judgment; however, according to the latest cases on this issue, the discretion of courts not to quash also remains broad for breaches under Union law. In comparison, this means that while in Germany there is a statutorily fixed possibility to request an annulment in cases of omitted EIA, screenings and wrongful screenings, and in 
the Netherlands breaches of procedural rules lead to the annulment of the administrative decision, in England, the courts decide on a case-by-case basis whether or not to annul. Thus far, differences between the legal systems remain.

Next, convergences can be observed with regard to rules preventing the annulment of a decision if there is no "special link" between the claimant and the rule infringed. Under German law, the general rule is that an administrative decision will only be annulled if the provision which was infringed at least also protects the rights of the claimant. An exception to this rule in environmental matters was introduced with the reform of the UmwRG in 2013, according to which environmental organisations can request the annulment of administrative decisions infringing EIA legislation without the necessity to allege the infringement of a subjective right under public law. Contrary to this, since the beginning of EIA enforcement in the Netherlands, environmental organisations could request the annulment of an administrative decision without the necessity to establish such a link. Hence, the German system has been in a process of approximation with the Dutch system as far as remedies granted to environmental organisations are concerned. In Germany, it is however disputed to what extent this exception influences the ability of individuals to succeed in claims relative to EIA legislation. In the Netherlands, no special link between the right infringed and the claimant was required for annulment for a long time. However, the introduction of the requirement of connection, according to which a decision is not annulled if the infringed rule does obviously not aim at the protection of the interests of the claimant, may trigger further converging tendencies between the German and the Dutch legal systems. So far, there is little case law on the Dutch rule with regard to the EIA procedure. The interpretation of what constitutes an "interest" under Dutch law seems to be broader than the German interpretation of what constitutes a "right". According to the traditional German interpretation of the law, procedural rules mostly do not provide for rights, whereas the ruling of the Dutch Council of State in October 2014 shows that the procedural rules of the SEA can protect the interests of the claimants. However, as explained, under German law it is no longer necessary for environmental organisations to allege the infringement of a rule which also protects rights. It remains to be seen how Dutch courts will apply the relativiteitsvereiste in EIA cases brought by environmental organisations and other claimants. In England, the grant of a remedy does not depend on a strict requirement of connection between the claimant and the rule infringed, but from case law it is clear that similar considerations play a role when courts exercise their discretion (not) to quash a decision. For example, in Jones $v$ Mansfield, Lord Carnwath observed that the appellant "shares with other local residents a genuine concern to protect her surroundings. However as far as we have been told, she has no special interest in, or knowledge of golden plovers or bats." ${ }^{1253}$ In Walton, he further stressed that Union law does not require an "automatic nullification" for procedural flaws regardless of whether the flaw prejudiced someone and regardless of the interest of the wider public. ${ }^{1254}$ Hence, in

${ }^{1253} R$ (Jones) v Mansfield [2004] [2003] EWCA Civ 1408; [2004] Env LR 21 [57].

1254 Walton v The Scottish Ministers [2012] UKSC 44; [2013] 1 CMLR 28 [138]. 
comparison, all three legal systems in principle require some kind of connection between the claimant and the rule infringed, but the concrete shape of this connection is different.

To conclude, despite the convergences between the legal systems, it is striking that during 30 years of EIA enforcement different remedies were awarded for the same procedural error depending on the national litigation system. 
The following tables shall provide for an overview of the situation as it is in 2014:

Table 15: Annulment of the administrative decision for breaches of EIA legislation in 2014

\begin{tabular}{|c|c|c|c|}
\hline & Germany & The Netherlands & England \\
\hline Omitted EIA & $\begin{array}{l}\S 4 \text { (1) Nr. } 1 \text { UmwRG } \\
\text { Annulment }\end{array}$ & $\begin{array}{l}\text { Art. 8:72 (1) Awb } \\
\text { Annulment }\end{array}$ & Discretion \\
\hline $\begin{array}{l}\text { Omitted } \\
\text { Screening }\end{array}$ & $\begin{array}{l}\S 4 \text { (1) Nr. } 2 \text { UmwRG } \\
\text { Annulment }\end{array}$ & $\begin{array}{l}\text { Art. 8:72 (1) Awb } \\
\text { Annulment }\end{array}$ & Discretion \\
\hline $\begin{array}{l}\text { Error in the } \\
\text { screening }\end{array}$ & $\begin{array}{l}\text { § } 4 \text { (1) s. } 2 \text { UmwRG, 3a s. } \\
4 \text { UVPG } \\
\text { Annulment }\end{array}$ & $\begin{array}{l}\text { Art. 8:72 (1) Awb } \\
\text { Annulment possible }\end{array}$ & $\begin{array}{l}\text { Discretion } \\
\text { Examples: } \\
\text { Lebus (improper } \\
\text { screening opinion) } \\
\text { Bateman (insufficient } \\
\text { reasons in screening } \\
\text { opinion) }\end{array}$ \\
\hline $\begin{array}{l}\text { Error in the } \\
\text { EIA }\end{array}$ & $\begin{array}{l}\text { Not regulated in the } \\
\text { UmwRG } \\
\text { Idea of } \S 46 \text { VwVfG: } \\
\text { would the error have had } \\
\text { an effect on the final } \\
\text { decision? }\end{array}$ & $\begin{array}{l}\text { Art. 8:72 (1) Awb } \\
\text { Annulment possible }\end{array}$ & $\begin{array}{l}\text { Discretion } \\
\text { Examples: } \\
\text { Berkeley; Walton }\end{array}$ \\
\hline
\end{tabular}

In some cases a procedural error does not result in the annulment of the administrative decision. In Germany and in the Netherlands, these cases are regulated by statute, whereas in England it is at the judges' discretion whether or not to quash a decision. The German rules have been in a process of change over the years, which led to convergences between the legal systems. In the beginnings of EIA enforcement, claimants in Germany had to show that there was a concrete possibility that the decision would have been different without the procedural error. If this could not be proven, the procedural error could be disregarded (if it was not corrected). In the Netherlands and England, such a strict requirement of causality did not exist and procedural errors were usually not disregarded. With the adoption of the UmwRG (2006), the German legislator created a rule according to which it was no longer possible to disregard the procedural error of a wrongfully omitted EIA or screening. The reform of the UmwRG (2013) added that certain flaws in the screening will lead to the annulment of the decision. In the Netherlands, it is not possible to "pass by" the procedural error of an omitted EIA or screening, but for 
other flaws which do not prejudice interested parties, this is possible. The following table gives an overview of the situation in 2014:

Table 16: Disregarding procedural errors in EIA cases in 2014

\begin{tabular}{|l|l|l|l|}
\hline & Germany & The Netherlands & England \\
\hline Omitted EIA & No § 46 VwVfG & No art. 6:22 Awb & Discretion \\
\hline Omitted Screening & No § 46 VwVfG & No art. 6:22 Awb & Discretion \\
\hline $\begin{array}{l}\text { Error in the } \\
\text { screening }\end{array}$ & $\begin{array}{l}\text { Not if error relates to } \\
\text { step in § 3 a s. 4 } \\
\text { UVPG }\end{array}$ & Art. 6:22 Awb & Discretion \\
\hline Error in EIA & $\begin{array}{l}\S 46 \text { VwVfG + } \\
\text { requirement of } \\
\text { causality }\end{array}$ & Art. 6:22 Awb & Discretion \\
\hline
\end{tabular}

Finally, in the three legal systems, it is in principle possible to correct procedural errors during court proceedings, although for the English legal system no case was found in which this happened. In the Netherlands, the possibility of the bestuurlijke lus was only introduced in 2010, and since then there has also been a process of convergence between the legal systems in this respect. In the Netherlands, it is in principle not possible to correct the procedural error of an omitted EIA or screening. Contrary to this, in Germany it is possible to correct the procedural error of a wrongfully omitted screening. Theoretically, this possibility also exists with regard to omitted EIAs, but in practice courts will usually not allow for this possibility. Moreover, in the Netherlands, it is generally possible to correct procedural errors in the screening process or EIA process; in Germany, this is also possible. However, the scope of $\S 45 \mathrm{VwVfG}$ is narrow if compared to the Dutch bestuurlijke lus. The two legal systems are also different as regards the consequences of this correction. Whereas in Germany the correction leads to a "cured" administrative decision which has full legal force, in the Netherlands the administrative decision has to be annulled and only the legal consequences of the decision remain in force. 
In 2014, the situation is as follows:

Table 17: Correcting procedural errors in EIA cases in 2014

\begin{tabular}{|l|l|l|l|}
\hline & Germany & The Netherlands & England \\
\hline Omitted EIA & $\begin{array}{l}\S 4(1) \text { UmwRG } \\
\text { In theory possible, in } \\
\text { practice seldom }\end{array}$ & No art. 8:51a Awb & \\
\hline Omitted Screening & $\S 4(1) \mathrm{nr}$. 2 UmwRG & No art. 8:51 a Awb & \\
\hline Error in screening & $\begin{array}{l}\S 4(1) \text { s. 3; } \S 45(2) \\
\text { VwVfG }\end{array}$ & Art. 8:51 a Awb & \\
\hline Error in EIA & $\S 45(2) \mathrm{VwVfG}$ & Art. 8:51 a Awb & \\
\hline
\end{tabular}

What are now the consequences of differences in national procedural rules for the enforcement of the EIA Directive? First, in making the annulment of a decision dependent on the infringement of a subjective right or an interest in some legal systems, while not requiring such a narrow link in other legal systems, there are different possibilities for groups to contribute to the enforcement of EIAs in courts. Second, as long as there is no clear determination by the Union legislator or the Court of Justice as to what can be considered a "significant procedural error", in some Member States an administrative decision may be annulled, whereas in another the error is disregarded. This leads to differences in the quality review of EIAs and in the speed of permission procedures. Hence, the possibilities of EIA enforcement differ. 


\section{Interim relief for procedural errors}

In environmental law cases, the possibility for applications for interim relief is of crucial importance because once a decision takes effect, environmental damage may occur which may be irreversible. This section will describe the international and European framework for actions for interim relief (2.1), followed by a comparison of national rules and their application in EIA cases (2.2).

\subsection{International and European Union rules on interim relief}

Article 9 (4) Aarhus Convention stipulates that Member States must provide "adequate and effective remedies, including injunctive relief as appropriate." At the Union level, article 11 of Directive 2011/92/EC remains silent on rules on injunctive relief. Nevertheless, the Court of Justice had to rule on national provisions on interim relief in several cases, not only concerning environmental law. To begin with, the Court had to rule on English rules on injunctive relief in the case of Factortame. ${ }^{1255}$ The European judges held that it was contrary to Community law if national procedural rules precluded national courts from doing

"everything necessary at the moment of this application to set aside national legislative provisions which might prevent, even temporarily, Community rules from having full force." 1256

Moreover, in the Tafelwein case, ${ }^{1257}$ the Court of Justice had to rule on the German suspensory effect of the objection or institution of a claim. ${ }^{1258}$ The Court held that the refusal of the German authorities to order the immediate execution of a Union regulation infringed the principle of sincere cooperation. ${ }^{1259}$ Furthermore, the Court of Justice held that national courts are allowed to order the suspensory effect of measures taken on the basis of Union law of which the validity is seriously doubtful under the condition that the national court refers a question for preliminary ruling to the Court of Justice if this has not yet been done, and under the condition that there is a threat of serious irreparable damage to the applicant and that the court takes the interest of the Community into account. ${ }^{1260}$

In environmental matters, the cases of Commission v UK and Northern Ireland ${ }^{1261}$ and Križan ${ }^{1262}$ have to be mentioned. The former concerned the common law practice of cross-undertakings, which

${ }^{1255}$ C-213/89, The Queen v Secretary of State for Transport, ex parte: Factortame Ltd and others [1990] ECR I2433.

1256 Ibid., para. 20.

1257 C-217/88, Commission of the European Communities v Federal Republic of Germany [1990] ECR I-2879.

1258 § 80 (1) VwGO.

1259 C-217/88, Commission of the European Communities v Federal Republic of Germany [1990] ECR I-2879, para. 16; Gellermann, $\$ 37$ Rechtsschutz durch deutsche Gerichte, in: Rengeling et al., Handbuch des Rechtsschutzes in der Europäischen Union, $3^{\text {rd }}$ edition, 2014, at 67.

${ }^{1260} \mathrm{C}-143 / 88$, Zuckerfabrik Süderdithmarschen AG v Hauptzollamt Itzehoe and Zuckerfabrik Soest GmbH $v$ Hauptzollamt Paderborn [1991] ECR I-415.

${ }^{1261}$ C-530/11, European Commission v United Kingdom of Great Britain and Northern Ireland (Judgment of 13 February 2014) para. 109.

${ }^{1262}$ C-416/10, Jozef Križan and Others v Slovenská inšpekcia životného prostredia (Judgment of 15 January 2013). 
practically bared individuals and organisations from claiming interim relief. The latter concerned the general possibility of application for interim relief and the Court of Justice emphasised that a lack of such a procedure would contravene the principle of effectiveness of Union law. With regard to the rules of the IPPC Directive, the Court held that the effective prevention of pollution could not take effect

"If it were impossible to prevent an installation which may have benefited from a permit awarded in infringement of that directive from continuing to function pending a definitive decision on the lawfulness of that permit." 1263

In this section, the requirements for applications for interim relief in the three Member States under consideration shall be traced and there will be an illustration of their application in EIA cases.

\subsection{National rules on interim relief}

\section{a. Germany}

\section{National rules on interim relief}

The constitutional basis for the German provisions on interim relief is the guarantee of effective judicial protection enshrined in article 19 (4) GG. ${ }^{1264}$ In the VwGO, a distinction is made between two types of actions for interim relief; the first concerns actions for annulment, ${ }^{1265}$ the second deals with any other actions in administrative courts. ${ }^{1266} \S 80$ (1) 1 VwGO stipulates that the "action for annulment has suspensory effect" ${ }^{1267}$, which means that the administrative authority or third parties must not act on the basis of the administrative decision from the moment that an action for annulment is brought to the administrative court. ${ }^{1268}$ As only the action for annulment has suspensory effect, in any other type of action, interim relief has to be sought in a separate procedure provided for in $\S 123 \mathrm{VwGO}$.

In exceptional cases, the direct execution of an administrative decision is ordered by statute ${ }^{1269}$ or by the administrative authority. ${ }^{1270}$ In these cases, a claimant has recourse to the action for the re-establishment of the suspensory effect according to section 80 (5) VwGO. ${ }^{1271}$ In this action for interim relief, which is separate from the action of annulment, ${ }^{1272}$ the court first has to assess the admissibility of the claim. ${ }^{1273}$

\footnotetext{
1263 Ibid.

${ }^{1264}$ Kopp, Schenke, VwGO Kommentar, 20 th edition, 2014, § 80, at 1-3; Puttler, $\S 80$ VwGO, in: Sodan, Ziekow (eds.), VwGO Kommentar, $4^{\text {th }}$ edition, 2014, at 7; Schoch, Vorb. $\S 80$ VwGO, in: Schoch et al. (eds.), VwGO Kommentar, 2014, at 11-15; Windhorst, $\S 80$ VwGO, in: Gärditz (ed.), VwGO Kommentar, 2013, at 35-45.

$1265 \S 80(5)$ VwGO.

$1266 \S 123$ VwGO.

${ }^{1267}$ Maastricht Collection.

${ }^{1268}$ Hufen, Verwaltungsprozessrecht, $9^{\text {th }}$ edition, 2013, $\S 32$, at 2- 4.

$1269 \S 80$ (2) s. 1 nr. 1-3, (2) s. 2 VwGO.

$1270 \$ 80$ (2) s. 4 nr. 4 VwGO.

${ }^{1271}$ Hufen, Verwaltungsprozessrecht, $9^{\text {th }}$ edition, 2013, § 32, at 28.

${ }^{1272}$ Kopp, Schenke, VwGO Kommentar, $20^{\text {th }}$ edition, 2014, § 80, at 124.

${ }^{1273}$ Würtenberger, Verwaltung sprozessrecht, $3^{\text {rd }}$ edition, 2011, § 28, at 529.
} 
By analogy, ${ }^{1274} \S 42$ (2) VwGO is applied in order to determine whether the claimant has standing in the action for interim relief. In cases falling under the UmwRG, an exception to this rule is formulated by which standing is extended to environmental organisations. ${ }^{1275}$ The application for the reestablishment of the suspensory effect can already be made before the action for annulment is brought. ${ }^{1276}$ After having found that the claim is admissible, the court proceeds with an examination of the "merits" of the action for interim relief. ${ }^{1277}$ The action for interim relief is successful if a weighing of interests between the parties leads to the finding that the interest of the applicant overweighs the interest of the public. ${ }^{1278}$ Thereby, the court will take its decision to re-establish or not to re-establish the suspensory effect of the action for annulment depending on the prospect of success of the claim in the main proceedings. ${ }^{1279}$ For this purpose, the court has to assess whether there are reasonable doubts about the legality of the administrative decision and whether the subjective rights of the claimants are infringed upon. ${ }^{1280}$ This examination follows several steps. ${ }^{1281}$ To begin with, the court embarks on a summary assessment ${ }^{1282}$ of the legality of the administrative decision, roughly analysing whether the decision was taken on the right legal basis and assessing its formal and substantive legality. Then, the court has to balance the public interest of execution of the administrative decision against the interest of the applicant to stay the execution of the administrative decision. In case that administrative decision is obviously illegal and if the applicant's rights are infringed, then the interest of the applicant outweighs the interest of the public. ${ }^{283}$ Consequently, the application for interim relief is well founded and the court has to restore the suspensory effect of the action for annulment. In case that the administrative decision is obviously legal, the interest of the public usually outweighs the interest of the applicant ${ }^{1284}$ and the court does not have to restore the suspensory effect of the action of annulment. In case the administrative decision is neither obviously illegal nor obviously legal, the interest to proceed has to be balanced

${ }^{1274}$ Windthorst, $\S 80$ VwGO, in: Gärditz (ed.), VwG,O Kommentar, 2013, at 199; Puttler, $\S 80$ VwGO, in: Sodan, Ziekow (eds.), VwGO Kommentar, $4^{\text {th }}$ edition, 2014, at 132.

$1275 \S 2$ (1) UmwRG; see Part II, Chapter 2, Section 1.2. a.

$1276 \S 80(5)$ s. 2 VwGO.

1277 Schenke, Verwaltungsprozessrecht, $14^{\text {th }}$ edition, 2014, $\S 25$, at 999-1003; Würtenberger, Verwaltungsprozessrecht, $3^{\text {rd }}$ edition, 2011, § 28, at 530-534.

${ }^{1278}$ Hufen, Verwaltungsprozessrecht, $\S 32$ at 37; Schmidt, Verwaltungsprozessrecht, 16 ${ }^{\text {th }}$ edition, 2014 , at 951.

${ }^{1279}$ Schenke, Verwaltungsprozessrecht, $14^{\text {th }}$ edition, 2014, $\S 25$ at 1001.

1280 Windthorst, $\S 80$ VwGO, in: Gärditz (ed.), VwGO, Kommentar, 2013, at 220.

1281 On the different steps and their (disputed) classification: Schoch, § 80, in: Schoch, et al. (eds.), VwGO Kommentar, 2014, at 373-374; Schmidt, $§ 80$, in: Eyermann, VwGO Kommentar, $14^{\text {th }}$ edition, 2014, at $72-80$; Windthorst, § 80 VwGO, in: Gärditz (ed.), VwGO, Kommentar, 2013, at 215, 223.

1282 Puttler, $\S 80$ VwGO, in: Sodan, Ziekow (eds.), VwGO Kommentar, $4^{\text {th }}$ edition, 2014, at 136; Schmidt, $\S 80$, in: Eyermann, VwGO Kommentar, $14^{\text {th }}$ edition, 2014, at 81; Schoch, $\S 80$ VwGO, in: Schoch et al. (eds.), VwGO Kommentar, 2014, at 399.

${ }^{1283}$ Külpmann, Der erstinstanzliche gerichtliche Rechtsschutz nach $\$ 80$ Abs. 5, in: Finkelnburg et al., Vorläufiger Rechtsschutz im Verwaltungsstreitverfahren, 6 ${ }^{\text {th }}$ edition, 2011, at 967; Schmidt, Verwaltungsprozessrecht, 16 $^{\text {th }}$ edition, 2014, at 951; on possible exceptions: Puttler, $\S 80$ VwGO, in: Sodan, Ziekow (eds.), VwGO Kommentar, $4^{\text {th }}$ edition, 2014, at 158 .

${ }^{1284}$ Külpmann, Der erstinstanzliche gerichtliche Rechtsschutz, nach $\$ 80$ Abs. 5, in: Finkelnburg et al., Vorläufiger Rechtsschutz im Verwaltungsstreitverfahren, $6^{\text {th }}$ edition, 2011, at 970-979; Schmidt, Verwaltungsprozessrecht, $16^{\text {th }}$ edition, 2014, at 951. 
against the interest to suspend the action. ${ }^{1285}$ In the following it shall be illustrated how this rule is applied in EIA cases.

\section{National rules on interim relief in EIA cases}

The development of rules on interim relief has undergone a similar development as the rules on the enforcement for the EIA procedure in the main proceedings. ${ }^{1286}$ As regards the admissibility of actions for interim relief in the first period of enforcement, which finds its conclusion with the ruling of the Court of Justice in Trianel, ${ }^{1287}$ applicants had to allege the possible infringement of subjective rights under public law so that they could have standing. The second period started with the reforms of the UmwRG (2013), granting environmental organisations standing in EIA cases without the need to allege the infringement of a subjective right. In a third step, after ruling of the Court of Justice in Altrip, ${ }^{1288}$ the categories of procedural errors that were challengeable in courts were broadened. In Altrip the Court of Justice made clear that in principle any procedural error must be challengeable and reviewable. With the reform of the UmwRG in 2013, a new rule was introduced, in order to mitigate the broadened access possibilities for environmental organisations. ${ }^{1289} \S 4 \mathrm{a}$ (3) UmwRG modifies the standard of assessment in proceedings for interim relief. Accordingly, the suspensory effect of the action for annulment may only be restored if there are serious doubts ${ }^{1290}$ about the legality of the administrative decision.

As stated in the introductory part of this section, bringing an action for annulment automatically has a suspensory effect on the administrative decision in question, unless the law or the authority orders the immediate enforcement of the administrative decision. For the first period of EIA enforcement in Germany, this meant that in cases in which there was no rule or order which deleted the suspensory effect and if the applicants were granted standing in an action for annulment under the restrictive standing requirements at that time, the administrative decision would not take effect until the case was decided by a judgment in the main proceedings. In cases in which there was an order for the immediate enforcement of the administrative decision, applicants had to bring an additional action for interim relief according to section 80 (5) VwGO. In the area of nature protection law, environmental organisations were also able to apply for interim relief if they were granted standing in the main proceedings. However, outside the area of nature protection law, standing for such organisations was not granted.

An example of this period of EIA enforcement is an action for interim relief brought to the administrative court of Neustadt in May 2012. ${ }^{1291}$ In this case, the applicant requested the restoration of the suspensory

\footnotetext{
${ }^{1285}$ Külpmann, Der erstinstanzliche gerichtliche Rechtsschutz nach $\$ 80$ Abs. 5, in: Finkelnburg et al., Vorläufiger Rechtsschutz im Verwaltungsstreitverfahren, 2011, $6^{\text {th }}$ edition, at 980- 997; Schmidt, Verwaltungsprozessrecht, $16^{\text {th }}$ edition, 2014, at 952.

1286 Part II, Chapter 2, Section 1.2.a; Chapter 4, Section 1.2. a.

1287 C-115/09, Bund für Umwelt und Naturschutz Deutschland, Landesverband Nordrhein-Westfalen eV $v$ Bezirksregierung Arnsberg [2011] ECR I-36.

1288 C-72/12, Gemeinde Altrip and Others v Land Rheinland-Pfalz (Judgment of 7 November 2013).

1289 BR Drs. 469/12, pp. 40 f.

1290 The German expression is ernstliche Zweifel.

${ }^{1291}$ VG Neustadt, Decision of of 23 May 2012, Az.: 4 L 321/12.NW, juris.
} 
effect of the action for annulment concerning a decision on the operation of an undertaking for the recycling of metal. The applicant lived in a house that was situated at a distance of 1,340 meters from the undertaking. Inter alia, he submitted that the screening was incomplete. According to the law as it stood in 2012, the applicant could not be granted standing in court. § 42 (2) VwGO could not be applied by analogy, as the applicant could not claim the possible infringement of his subjective rights under public law. ${ }^{1292}$ The applicant could not have standing, pursuant to the UmwRG (2006), as the procedural error of an incomplete screening was not listed in § 4 (1) UmwRG (2006). ${ }^{1293}$ Also, special provisions of emission law could not provide for standing of the applicant. Thus, the claim for interim relief was inadmissible.

As far as rules on standing are concerned, the reform of the UmwRG in 2013 changed the legal position of environmental organisations in EIA claims. An example of this is an appeal brought by a recognised environmental organisation against a refusal of the first instance court to grant interim relief in a case concerning the construction of a summer toboggan in an area declared to be UNESCO world heritage. ${ }^{294}$ The association claimed that a screening was wrongfully omitted. This action was admissible as the organisation could be granted standing on the basis of the UmwRG (2013). Since the ruling of the Court of Justice in Trianel and the reform of the UmwRG, it was no longer necessary to claim the possible infringement of a subjective right in order to be granted standing in court. ${ }^{1295}$ The action was however not successful on the merits as the screening was caught up, so that the procedural error was corrected. ${ }^{1296}$ The outcome of the screening was that an EIA was not necessary. The court considered that there were no obvious errors in the screening. ${ }^{1297}$ On this ground, no interim relief could be granted. To conclude, in Germany an application for the annulment of an administrative decision has a suspensory effect. In case that the administrative authority orders the immediate execution of the administrative decision, applicants may make an application for the restoration of the suspensory effect at the courts. Before 2013, the possibility was restricted in EIA cases in so far as all applicants had to prove an infringement of subjective rights or rules which at least also protect subjective rights. This is no longer the case for environmental organisations. However, many uncertainties remain and could not yet be clarified by case law. First, the UmwRG and Altrip make clear that not only the non-conduct, but also errors in the EIA must be challengeable. This means that also actions for interim relief must be possible for errors in an EIA. But it is not clear how judges will deal with such allegations in actions for interim relief which are limited to a summary assessment of the facts and in which there is a new restriction since the reform of the UmwRG (2013), namely that there must be "serious doubts" about the legality of the administrative decision.

\footnotetext{
1292 Ibid., para. 33.

${ }^{1293}$ Ibid., para. 36.

1294 OVG Koblenz, Decision of 31 January 2013, Az.: 1 B 11201/12, NVwZ 2013, 883-888.

1295 Ibid., NVwZ 2013, 883, 884; juris, para. 6.

1296 Ibid., NVwZ 2013, 883, 885; juris, paras. 19, 20.

${ }^{1297}$ Ibid., 883, 886; juris, para. 22.
} 


\section{b. Netherlands}

\section{National rules on interim relief}

In the Netherlands, contrary to what was described in the section on Germany, an application for judicial review does not have suspensory effect. In this respect, article 6:16 Awb stipulates that "the objection or the action for annulment does not halt the execution of the administrative decision against which the action is brought, unless statute provides otherwise." ${ }^{2298}$ The suspension of the execution of the administrative decision may be requested at the same time as an objection is made or an action of annulment is instituted. ${ }^{1299}$ Thus, if an action for interim relief is brought at the moment or after an action annulment was brought in the same case, there are two procedures pending in the administrative court, namely the bodemprocedure (main proceedings) and the action for voorlopige voorziening (action for interim relief). Judges can decide on both cases at once. ${ }^{1300}$

For the admissibility of an action for interim relief, the following requirements have to be fulfilled. The application must relate to an administrative decision in the sense of article 1:3 (1) Awb and must be made to the judge for interim relief cases of the competent court. Furthermore, the action for interim relief must be connected to a claim which is brought at the same time or which is pending in court. At the stage of objection to the administrative authority, the person objecting can apply for interim relief. ${ }^{1301}$ At the stage of court proceedings, any party to the main proceedings can make an application for interim relief. Other requirements for admissibility follow the requirements of admissibility in the main proceedings. ${ }^{1302}$

The court can grant interim relief in accordance with article 8:81 (1) Awb which states that the judge, deciding on interim relief "may, upon request, grant interim relief, in case instantaneous action is required due to the interests involved in the case." ${ }^{\prime 303}$ This article contains the three main issues which the judge has to consider when deciding on an application for interim relief. The starting point for analysis is whether the claim is urgent in the sense that the applicants cannot wait until the judge in the main proceeding has delivered his judgment. ${ }^{1304}$ This will usually be the case if it will not be possible to reverse the situation after the administrative decision becomes operational. Next, the judge has to carry out a preliminary assessment of the legality of the administrative decision. Finally, the interests of the parties have to be weighed against each other. ${ }^{1305}$ The most common form of interim relief is the schorsing which means that the legal consequences of the administrative decision may not take

\footnotetext{
1298 Own translation.

1299 Art. 8:81 Awb.

${ }^{1300}$ Art. 8:86 Awb.

${ }^{1301}$ Art. 8:81 (3) Awb.

1302 Damen et al., Bestuursrecht, vol. 2, $4^{\text {th }}$ edition, 2012, p. 384.

1303 Own translation.

${ }^{1304}$ Borman, Art. 8:81 Awb, in: van Buuren, Borman (eds.), $T \& C A w b, 8^{\text {th }}$ edition, 2013.

1305 Ibid.
} 
effect. ${ }^{1306}$ Besides this, the court may decide to order another preliminary measure. The judge can stipulate from which date onwards the preliminary measure will cease to have effect. ${ }^{1307}$ The law furthermore provides that "the provisional remedy shall in any event cease to have effect as soon as: (a) the time limit for appealing to the district court against the decision on the objection or the administrative appeal expires without an appeal being lodged, (b) the objection or the appeal is withdrawn, or (c) the district court has given judgment, unless a later date stipulated in the judgment." ${ }^{1308}$ In the following section it will be seen how these rules were applied in EIA cases.

\section{National rules on interim relief in EIA cases}

Contrary to what was observed in Germany, in the Netherlands interim relief for errors in an EIA procedure has been granted since the beginning of EIA enforcement. A rather early example of an action for interim relief in EIA cases concerned the filling of a gravel pit with slightly polluted ground. ${ }^{1309}$ The applicants alleged that the defendant did not conduct an EIA, although this was required by law. In this case, the developer had already started with his activities before applying for a permit. When he finally applied for permit, the application only concerned the amount of sand to be filled in after the application for the permit. In doing this, the thresholds laid down in EIA legislation were circumvented. The court, without elaborating on the admissibility of the claim, immediately turned to the substance. Considering the arguments brought forward by the parties in the files and at the oral hearing, the court came to the conclusion that it was not ondenkbaar (unthinkable) that in the main proceedings, the judge would decide that the application for the permit should have been inadmissible. Hence, the application for interim relief is well founded and the court decides that the legal effects of the decision shall not take effect.

In contrast to what was seen in Germany for a long time, environmental organisations always had the possibility to bring actions for interim relief in EIA cases in the Netherlands. Until the abolition of the multi-stage actio popularis in 2005, a precondition to this was that they participated in the preparation procedure. ${ }^{1310}$ This is illustrated by case in which three environmental organisations applied for interim relief against a permit granted to a developer for an installation generating electricity with biomass from a maximum of 441,000 tonnes of poultry manure and feathers and comparable biomass per year. ${ }^{1311}$ One of the environmental organisations did not submit any comments on the draft decision. Therefore, the organisation could not be granted standing in this application for interim relief, as the judge expected that standing will also be refused in the main proceedings. As regards the application by the other two parties, the court considered it necessary to grant interim relief. The applicants alleged that the thresholds

\footnotetext{
1306 Damen et al., Bestuursrecht, vol. 2. 1, $4^{\text {th }}$ edition, 2012, p. 390.

1307 Art. 8:85 (1) Awb.

${ }^{1308}$ Art. 8:85 (2) Awb; translation on the basis of the English version of the Awb as provided by the Ministry of Justice (available online).

${ }^{1309}$ ABRvS 20 March 1995, nr. F03940885, AB 1995/465 (with a comment by Backes).

${ }^{1310}$ Part II, Chapter 2, Section 1.2. b.

${ }^{1311}$ ABRvS 2 June 2006, nr. 200602517/2.
} 
of Annex D of the Besluit m.e.r. (1994) were exceeded and that, for this reason, an EIA should have been conducted. Before the permit was granted, the capacity of the installation amounted to 350,000 tonnes of biomass which meant that the new permit increased the capacity by more than 100 tonnes per day. The judge found that, in this action for interim relief, it was not possible to review the exact calculation of the increase of biomass, especially as it was not clear whether dry or wet biomass was meant. Therefore, the judge simply found that

"in this procedure the chairman shall limit his considerations to the question whether the interests of the applicants seen in relation to the interests of the party to whom the permit was granted require the grant of interim relief." 1312

Without providing for any further assessment of the positions of the parties, the court then found that it is "not excluded" that in the main proceedings the administrative decision will not be upheld. Therefore, the decision should not yet take effect. The court held that

"it was not shown that the interests of the party to which the permit was granted are of such a nature that a grant of interim relief must be left aside."1313

Therefore, interim relief was granted. In the main proceedings the judge then however found that the increase of biomass in the installation does not fall under the annexes of the EIA Directive. It was argued that the original permit for the construction of the installation in the year 2000 allowed the processing of 1,050 tonnes of chicken manure per day. The new permission allows for the processing of 1,260 tonnes per day. According to the case law of the courts, the decision whether an activity has to be submitted to an EIA does not depend on the increase of the material processed but on the technical expansion of the installation. In the present case, the court simply saw that the increase in the amount of manure processed per day in the same facilities reflected a more efficient use of the existing installation. ${ }^{1314}$ Therefore, according to the court, no EIA was necessary and the administrative decision was not annulled on that ground. However, it was finally annulled on other grounds.

In conclusion, in the Netherlands it has always been possible for individuals and environmental organisations to apply for interim relief in EIA cases. The courts have granted interim relief after having considered whether immediate action was necessary and whether the parties were likely to succeed in the main proceedings and after having balanced the interests involved against each other. In the next section these rules will be compared to the English framework for interim relief.

1312 Own translation; ABRvS 2 June 2006, nr. 200602517/2, para. 2.5

${ }^{1313}$ Own translation; ABRvS 2 June 2006, nr. 200602517/2, para. 2.8.

${ }^{1314}$ ABRvS 4 April 2007, nr. 200602517/1, para. 2.6.5. 


\section{c. England}

\section{National rules on interim relief}

Until the Court of Justices ruling in Factortame, the old common law rule applied that there could not be interim relief against the Crown. ${ }^{1315}$ In that case, the Court of Justice found that national systems must provide for interim measures against legal provisions contravening European law. This ruling led to the introduction of interim measures against the Crown not only in cases with Community dimension but also in purely national situations against the public administration. ${ }^{1316}$

Today, there are a number of interim measures which are applied at the discretion of the courts. First, according to section 54.10 (2) CPR, the Court may order the "stay of the proceedings to which the claim relates". Furthermore, the court may grant an interim injunction or make an interim declaration. The interim injunction is a private law remedy developed in the American Cyanamid case by the House of Lords in $1974 .{ }^{1317}$ In this case, it was stressed that a court deciding on the grant of an interim injunction must not consider the merits of the case. In this regard Lord Diplock held:

"It is no part of the court's function at this stage of the litigation to try to resolve conflicts of evidence on affidavit as to facts on which the claims of either party may ultimately depend nor to decide difficult questions of law which call for detailed argument and mature considerations. ”

Instead, the applicant must show that his application concerns a serious question. If this is can be shown, the court has the discretion to grant an interim injunction after assessing the "balance of convenience". The latter means that the hardship of the applicant is weighed against the hardship of the other party. ${ }^{1318}$ Thus, the potential damage to the applicant in case the injunction is not granted is balanced against the potential cost for the defendant in case the injunction is granted. If an injunction is not followed, the party breaching it will be in contempt of the court.

An important element in any application for interim relief are cross-undertakings which were usually required from the applicant in the case that his claim for judicial review is not successful. As was described in the section on costs, this cross-undertaking bared environmental organisations from applying for interim relief, which ultimately led to the Court of Justice to conclude that this rule was in breach of Union law. ${ }^{1319}$

The doctrine of American Cyanamid was developed in further case law and is subject to criticism in the literature. ${ }^{1320}$ Nevertheless, for the purpose of this study, it suffices to note that this case still provides

${ }^{1315} R$ (Factortame Ltd) v Secretary of State for Transport [1991] 1 AC 603.

${ }^{1316}$ M v Home Office [1994] 1 AC 377.

${ }^{1317}$ American Cyanamid Ltd v Ethicon Ltd [1975] AC 396.

1318 Andrews, Andrews on Civil Processes, vol. 1, 2013, p. 221.

${ }^{1319}$ Part II, Chapter 2, Section 3, c.

${ }^{1320}$ Keay, Whither American Cyanamid?: interim injunctions in the $21^{\text {st }}$ century, C.J.Q. 2004, p. $132 \mathrm{ff}$. 
the starting point for assessment ${ }^{1321}$ and gives guidelines to courts deciding on applications for interim relief.

\section{National rules on interim relief in EIA cases}

As was seen in the section on costs, applications for interim relief were seldom brought mainly because of the practice of cross-undertakings. Considering the limited number of applications for interim relief in environmental matters in general, there is hardly any example of interim relief in EIA cases. An example is the application made by Save Britain's Heritage (SAVE) against the demolition of 118 buildings in Gateshead. ${ }^{1322}$ When the demolition had started, SAVE applied for and received an injunction as the judge thought it was arguable that an EIA was required before a decision on the demolition could be taken. The issue underlying the application for an injunction and applications for its discharge was the question whether demolition works are covered by the EIA Directive. The case took place in a time before the Court of Justice had given a concluded view on this question in another case. ${ }^{1323}$ So far, the Secretary of State had been of the opinion that there could be significant adverse effects on the environment if the three phases of works were considered in accumulation but that demolitions would not fall under the scope of the Directive. The council found subsequently that there would be no adverse effects. The authority subsequently applied for a discharge of the injunction granted. Ouseley $\mathbf{J}$ agreed that it was arguable that demolition works could fall under the Directive. Nevertheless, even if this was the case - which would then render the decision of the Secretary of State unlawful - the Secretary of State would probably follow the local authority's analysis that there would be no adverse effects on the environment as there were certain measures taken to mitigate noise and vibration problems. The judge continued with the balancing of convenience and explained that if the injunction was discharged, demolition would follow. This would then put an end to blight, vandalism, theft and other forms of anti-social behaviour in the area. ${ }^{1324}$ Moreover, the funding of demolition works amounted to $£ 340,000$ which was only available in that year. In this respect, the court stated that "those amount to a compelling want of convenience arising from the grant of any injunction. It is inevitable that Save is not able to provide any cross-undertaking, which has to weigh to some extent the balance." 1325 The judge then continued by questioning "what is it that is gained by the injunction in terms of preventing arguable unlawfulness?" ${ }^{1326}$ First, he found that looking at phase 1 of the demolition works which the injunction addressed would not have significant impacts on the environment on its own. Next, concerning the Secretary of State's opinion he considered that

\footnotetext{
1321 Andrews, Andrews on Civil Processes, vol. 1, 2013, p. 226.

${ }^{1322}$ The Queen (Save Britain's Heritage) v Gateshead Metropolitan Borough Council [2010] EWHC 2919 (Admin).

${ }^{1323}$ C-50/09, European Commission v Ireland [2011] ECR I-837.

${ }^{1324} R$ (Save Britain's Heritage) v Gateshead Metropolitan Borough Council [2010] EWHC 2919 (Admin) [24].

${ }^{1325}$ Ibid. [25].

${ }^{1326} \mathrm{Ibid}$. [26].
} 
“[...] if demolition is a project, and his earlier direction revives, he can lawfully revise it, he would be asked to do so and would have the substantial new information which would enable him to do so. It is difficult to see why he would not revise it. [...]

The legal arguments are more technical than practically meritorious. I do not consider that the possibility that the Secretary of State's November 2009 decision might revive and might then not be overtaken by changes which are clearly designed to overcome the concerns, on their merits, can possibly make the balance of convenience favour SAVE and means that the public interest, to which the evidence of Mr Ellis is eloquent testimony, should be so imposed on."1327

For these reasons the injunction was discharged. SAVE brought an appeal for the continuation of the interim injunction. It was submitted that it was impossible to conclude that the Secretary of State would change his mind. ${ }^{1328} \mathrm{He}$ would have to reconsider also new materials submitted and then decide on their significance. ${ }^{1329}$ Moreover, the project would have to be considered in its entirety and not to be salamisliced. ${ }^{1330}$ Judge Sullivan was however satisfied with the finding that the demolition of phase 1 itself did not imply significant environmental effects. In this regard he contended:

"I quite accept of course that it is not right, in terms of the EIA Directive or the Regulations, to simply look at phase 1 in isolation. For the purposes of the directive and the Regulations one must consider the cumulative effect — what will happen in respect of phases 2 and 3 as well but it is only in that latter respect that there is any apparent difference of view between the Secretary of State and the respondent authority. I say "apparent" difference of view because it is plain that the Secretary of State did not have the advantage of the further material relating to noise and what might possibly be done to address it by way of hours of operation and other mitigating matters when making the direction in November 2009."1331

Therefore, the application to extend the injunction was dismissed.

To sum up, in England there is a possibility to apply for interim relief. Thereby, the focus is not on the legality of the administrative decision under consideration but on the weighing of interests between the parties. In this context, financial considerations have played an important role for a long time and are still relevant.

\footnotetext{
${ }^{1327}$ Ibid. [26], [27].

${ }^{1328} R$ (Save Britain's Heritage) $v$ Secretary of State for Communities \& Local Government, Gateshead Metropolitan Borough Council [2010] EWCA Civ 1500 [23].

${ }^{1329}$ Ibid. [24].

${ }^{1330} \mathrm{Ibid}$. [25].

${ }^{1331}$ Ibid. [31].
} 


\section{d. Comparison: differences and convergence}

All three legal systems under consideration provide for the possibility to apply for interim relief in EIA cases. Nevertheless, whereas in England and in the Netherlands standing possibilities have been comparably broad, this was for a long time not the case in Germany and differences continue to exist. In times in which in the Netherlands and England environmental organisations were able to apply for interim relief, this was not possible in Germany. Moreover, the case of SAVE shows that in England also organisations concerned with the protection of buildings can have standing. This would not be possible under the applicable German legislation in its current state. As far as costs are concerned, it was already observed in a previous section that they prevented individuals and organisations in England from applying for interim relief. Contrary to that, the financial barrier is comparably low in Germany and the Netherlands. As to the "merits" of the application for interim relief, the major divide can be found between the English legal system on the one side and the Dutch and German system on the other side. In the Netherlands and in Germany, the review consists of a rough assessment of the legality of the administrative decision and a balancing of interests between the applicant and the defendant. If there are reasonable doubts about the legality of the administrative decision, interim relief will be granted. In other cases, the interests of the parties are balanced against each other. In England, the rule is that the court should not rule on the merits of the case but focus mainly on a balancing of interests in terms of (financial) advantages or disadvantages. For 27 years, these differences had the effect that chances of EIA enforcement were different and that in some cases damage occurred although it was later found that there were flaws in the EIA process.

Table 18: Rules on interim relief in EIA cases in 2014

\begin{tabular}{|l|l|l|l|}
\hline & Germany & The Netherlands & England \\
\hline $\begin{array}{l}\text { Suspensory effect of } \\
\text { action for annulment }\end{array}$ & Yes & No & No \\
\hline $\begin{array}{l}\text { Test for grant of } \\
\text { interim relief }\end{array}$ & $\begin{array}{l}\S \text { 4a (3) UmwRG: } \\
\text { Are there "serious } \\
\text { doubts" about the } \\
\text { legality of the } \\
\text { administrative } \\
\text { decision? }\end{array}$ & $\begin{array}{l}\text { Article 8:81 Awb } \\
\text { Do the interests of the } \\
\text { parties involved } \\
\text { require an } \\
\text { instantaneous decision } \\
\text { by the court? }\end{array}$ & $\begin{array}{l}\text { (American Cyanamid) } \\
\text { "balance of } \\
\text { convenience" }\end{array}$ \\
\hline
\end{tabular}




\section{Interim conclusion}

In this chapter on remedies granted in courts for flaws in the EIA process, one thing is striking: in approximately 27 years of EIA enforcement, different remedies were awarded in different legal systems at the same point in time. Whereas in the 1990s any Dutch judge would annul a decision because of some error in the EIA process, judges in England were more hesitant, not always exercising their discretion to quash the EIA. In Germany, in practice no decision was annulled on grounds of a flawed EIA process. Today, the legal systems have in common that the omission of an obligatory screening or EIA can lead to an annulment of the administrative decision. However, they differ in the consequences of wrongfully conducted screenings and EIAs. Furthermore, interim relief is granted on the basis of different rules in different situations.

Thus, the overall conclusion is that, despite convergences between the systems as described in the previous sections, the courts grant different remedies for administrative decisions that are vitiated by an omitted EIA or screening or a wrongful conducted EIA or screening. This leads to substantially different enforcement chances, a different speed in decision making and differences in the prevention of irreversible environmental damage. 


\section{Conclusion of Part II}

This part of the thesis aimed at providing an answer to the first and the second research question. In summary, the following conclusions can be drawn. The Court of Justice has created a minimum standard for litigation in administrative matters at the national level, in requiring that Member States have to ensure the effet utile of Union law and by prescribing that national judicial rules should not make the enforcement of Union law impossible or excessively difficult. Moreover, claimants must have access to courts in order to guarantee compliance with the principle of effective judicial protection. These procedural requirements mark the outer limits of the national competence to create rules on the administrative enforcement system. In environmental matters, the European legislator, by implementing article 9 (2) and (4) of the Aarhus Convention, has created additional rules limiting national procedural autonomy in environmental matters. National courts have to provide for a wide access to justice. In courts, the procedural and substantive legality of provisions has to be reviewed, procedures must be timely, not prohibitively expensive and provide for adequate and effective remedies. These limits to national procedural autonomy are tighter than the usual limits, as they concretise the nature of litigation proceedings. This part has shown that, because of these rules, national legal systems were forced to reform their rules in order to comply with the Union standard. Through these reforms, national legal systems have been converging, leading to rising procedural judicial coherence. On the other side, it was explained that convergences were also triggered by national reforms independent of Union interference. After 27 years of EIA enforcement in national courts, coherence in national litigation rules has been established with regard to some rules. The most striking example for this establishment of coherence concerns rules on the admissibility of claims in courts. Whereas differences in rules on standing for environmental organisations have been enormous in the 1990s, national rules have been in a process of alignment under the obligations of the Aarhus Convention and due to independent national reforms. In 2014 , in all three legal systems under consideration, environmental organisations can have standing in EIA matters.

Despite the establishment of coherence with regard to some rules, it can be concluded that the requirements of the EIA Directive have been enforced differently in the three legal systems for a period of 27 years, as differences in national litigation rules continued to exist within the limits prescribed by the Union legislator and the Court of Justice. For example, the possibilities of individuals, competitors and other associations not qualifying as environmental organisations is very different in the three Member States. This was impressively demonstrated by the workshop. According to the leading jurisprudence in Germany, the claims of the property owner, the action group in the village and the operator of the ecological farm would have failed at the stage of admissibility as they would not have been granted standing. Contrary to this, in England, any of the claimants would have been granted standing. In the Netherlands, the competitor and the environmental organisation would have been admitted to court. Another example of the remaining differences are the rules on the scope of review. Whereas in Germany judges assess whether all steps of the screening were followed and review the 
plausibility of the result, Dutch judges rather cautiously review administrative decisions, formally assessing whether the steps in the screening were followed and laying the burden on the applicant to explain why the screening is erroneous. In England, judges still apply, despite strong criticism, the Wednesbury test of unreasonableness, which is, even if it is not taken literally, a very light test if compared to the German standard of review. In the workshop, it was explained that the German judges would try to understand the scheme of the direction of the wind and would inquire whether the right scientific standard was applied, whereas in England this assessment would primarily be a matter for the administrative authority or the argumentation of the claimant's lawyer.

Finally, as far as remedies are concerned, English judges are vested with a wide margin of discretion whether or not to annul an administrative decision, whereas in Germany and the Netherlands there are some rules prescribing the annulment of a decision and others providing for the possibility to disregard procedural errors. It is however not entirely clear which types of errors in a screening or EIA can be disregard or not.

To conclude, considerable differences between the legal systems exist. The consequences of these differences are threefold. First, very basically, claimants are confronted with different rules depending on the legal system in which they are bringing their claim although the Union rule they try to enforce is the same. Second, differences in national litigation rules result in different enforcement chances. For example, whereas in one legal system litigations are rather cheap, in another legal system, court proceedings are still rather expensive. The first and second consequences mean that there is procedural inequality before the same rule of Union law. Third, as the workshop has proven, judges come to different judgments because of different procedural rules. This fragmentation of enforcement runs contrary to the aim of achieving the uniform enforcement of Union law. On the basis of these findings, the next part will question in a normative debate whether and to what extent this situation, perfectly in line with the principle of national procedural autonomy, is acceptable in the process of the creation of an "ever closer" Union. 
Part III Beyond national procedural autonomy? 
In this part, the third research question will be answered, whether, considering the consequences of differences in national procedural rules analysed in Part II, it is necessary, desirable and possible to develop common rules of administrative litigation in environmental matters in the Union. For this purpose, it will first be examined whether or not the Member States currently comply with the European standard as described in the beginning of Part II (section 1). On the basis of this assessment, it will be discussed from different perspectives whether or not there is a necessity or desirability for Union-wide rules on administrative litigation going beyond the "outer limits" prescribed by Union law so far (section 2). Furthermore, it will be asked what rules are necessary or desirable (section 3). The argumentation for and against more harmonisation will be complemented by a discussion on the possibility to adopt common rules (section 4). Finally, this thesis will be concluded by reflecting on the principle of national procedural autonomy from a historic perspective and by placing the findings of the thesis in the context of European integration (section 5).

\section{Compliance with the European standard?}

In Part II, the European standard for national administrative litigation procedures was described and it was explained how the different Union rules triggered reform processes at the national level. In this section, it will be asked whether the three legal systems under consideration currently fully comply with the Union standard or whether further intervention by the Court of Justice is necessary. This seemingly easy question is rather difficult to answer. First, the European rules for national administrative litigation set a minimum standard with the aim to ensure that Union law is enforced in the courts of the Member States. So far, only "outer limits" are prescribed, which leaves, as was seen in Part II, room for many divergences. Second, these "outer limits" are not very concrete and are open for interpretation and argumentation. This section will discuss whether or not it is arguable that the "outer limits" are exceeded in the three legal systems under consideration.

\section{a. National rules on access to justice}

National administrative litigation rules on access to justice have to guarantee the effet utile of Union law and for this purpose they should not make the enforcement of rules impossible or excessively difficult (principle of effectiveness). Furthermore, effective judicial protection has to be ensured and the Aarhus rules prescribing a "wide access to justice" have to be observed.

The effet utile of environmental legislation depends on the ability of individuals, environmental organisations and other associations to institute proceedings in the national courts in case the administrative authorities failed to comply with their obligation to apply the respective Union rules correctly. As observed, the effet utile is "neutral" if it comes to the question of who has to ensure the enforcement of Union law and under which precise conditions. ${ }^{1332}$ Whether or not a specific procedural rule bars the effect utile of Union law is a matter of assessment in the concrete case and it is difficult to

1332 Part II, Chapter 1, Section 1; Wennerås, The Enforcement of European Environmental Law, 2007, p. 84. 
determine abstractly whether or not national litigation rules are in compliance with this principle at the moment. Moreover, it should be noted that, although the Court stresses the importance of the effet utile, this is not an absolute argument. For example, Member States are not prevented from setting time limits for litigations, which may factually exclude the enforcement of Union law in some concrete cases. ${ }^{1333}$

\section{(i) Standing}

In 2014, in all three legal systems, environmental organisations can be granted standing in EIA cases, so that there is a possibility that this piece of environmental Union law is enforced in the courts. In this regard, no further intervention by the Union on the basis that the effet utile of Union law was impaired is necessary. However, in Germany, environmental organisations need to be recognised by the German state before being able to access court, whereas in the Netherlands and in England, the judges decide on a case-by-case basis whether or not an association qualifies as environmental organisation which is able to bring litigations in the case at issue. In Germany, the formal requirement that an organisation has to be recognised before being able to access courts does not render the enforcement of environmental Union law impossible or excessively difficult (principle of effectiveness), and foreign environmental organisations are not discriminated against, as this procedure is equally applicable to foreign and national organisations (principle of equivalence). Foreign environmental organisations are even placed in a better position than national organisations, as they can still apply for recognition during court proceedings. The Aarhus Convention and the implementing legislation of the Union expressly leave the determination of whether or not associations, organisations and groups come under the scope of the "public" and the "public concerned" to the national legislation and practice. ${ }^{1334}$ Thus, in principle, the formal requirement of a recognition of environmental organisations is in line with the Aarhus Convention and the EIA Directive. Nevertheless, in the case of Djurgården, the Court stressed the importance of a wide access to justice, and decided that a Swedish rule according to which an environmental organisation had to have at least 2000 members in order to access courts, was not compatible with Union law. ${ }^{1335}$ Taking this judgment into consideration, some observations about the specific German criteria for the recognition of an environmental organisation have to be made. It was observed that only very little environmental organisations are officially recognised in Germany. The question arises whether one of the specific criteria for the recognition constitutes a violation of the requirement of a "wide access to justice". To begin with, in the case of Djurgården the Court of Justice held that Member States may require that environmental organisations pursue environmental goals. ${ }^{1336}$ Hence, at first sight, the German rule, according to which the protection of the environment must be an

${ }^{1333}$ Case 33/76, Rewe-Zentralfinanz eG und Rewe-Zentral AG v Landwirtschaftskammer für das Saarland [1976] ECR 1989; C-338/91, H. Steenhorst-Neerings v Bestuur van de Bedrijfsvereniging voor Detailhandel, Ambachten en Huisvrouwen [1993] ECR I-5435; C-410/92, Elsie Rita Johnson v Chief Adjudication Officer [1994] ECR I5483.

${ }^{1334}$ Art. 2 (4), (5) Aarhus Convention; Art. 1 (2) d), e) Directive 2011/92/EU.

1335 C-263/08, Djurgården Lilla Värtans Miljöskyddsförening v Stockholms kommun genom dess marknämnd [2009] ECR I-9967.

${ }^{1336}$ Ibid., para. 46. 
intrinsic value of the organisation, ${ }^{1337}$ is in line with the ruling of the Court of Justice in Djurgården. ${ }^{1338}$ However, considering the case of the Dutch Stichtig which would probably not have been recognised for the purpose of accessing courts, ${ }^{1339}$ it can be doubted that access to German courts is "wide" in the sense of the Aarhus Convention. This can also be doubted with respect to a German organisation which was not recognised, because it was primarily concerned with the development of the specific project at issue in the case, and not with environmental protection in general. ${ }^{1340}$ According to the definition of the "public concerned" provided by the Aarhus Convention, it is not required that the protection of the environment is the primary and intrinsic goal of the organisation, but it suffices that it "promotes" environmental protection. ${ }^{1341}$ Also, the Court of Justice did not require that the protection of nature and environment is the primary or only goal of the association, but environmental protection simply needs to be the "object" of the association. ${ }^{1342}$ For this reason, the German rule according to which environmental protection must be the primary aim of the organisation might conflict with the requirement of a "wide access to justice". Next, the German rules require that the organisation must have existed for at least three years and must have carried out environmental activities. ${ }^{1343}$ This means that many groups which are established on an ad hoc basis cannot be recognised. ${ }^{1344}$ It is at least questionable whether this constitutes a "wide access to justice". 1345

The requirement that the organisation must ensure that it is actually able to pursue its tasks and aims ${ }^{1346}$ is not problematic in the light of the requirement of a wide access to justice. In literature, it is debated whether a certain minimum number of member is necessary in order to fulfil this requirement. ${ }^{1347}$ However, the German rule allows for flexibility. For example, a German court considered that 40 members of an organisation are sufficient to pursue the aim of environmental protection. ${ }^{1348}$

What may be problematic in the light of the Aarhus Convention is the German requirement concerning the membership in the environmental organisation, ${ }^{1349}$ as this rule hinders many environmental associations from being recognised. ${ }^{1350}$ For example, any association which is organised as a Stiftung (foundation) ${ }^{1351}$ cannot be recognised as an environmental organisation under German law, because a foundation does not have "members". This is the reason why the WWF is not recognised under the

\footnotetext{
1337 § 3 (1) nr. 1 UmwRG (2013).

${ }^{1338}$ Fellenberg, Schiller, §3 UmwRG, in: Landmann/Rohmer (eds.), Umweltrecht, 2014, at 11; Schieferdecker, § 3 UmwRG, in: Hoppe, Beckmann (eds.), UVPG Kommentar, 2012, at 25.

1339 Judgement of 18 March 2011, Az.: 10 K 2540/09, juris.

${ }^{1340}$ VG München, Decision of 9 March 2015, Az.: M 1 SN 14.4679, juris at 16.

1341 Art. 2 (5) Aarhus Convention.

1342 C-263/08, Djurgården Lilla Värtans Miljöskyddsförening v Stockholms kommun genom dess marknämnd [2009] ECR I-9967, para. 46.

${ }^{1343} \S 3$ (1) nr. 2 UmwRG (2013).

1344 Schmidt et al., Die Verbandsklage im Umwelt- und Naturschutzrecht, 2014, p. 39 f.

1345 Contrary opinion: Fellenberg, Schiller, §3 UmwRG, in: Landmann, Rohmer (eds.), Umweltrecht, 2014 , at 16.

$1346 \S 3$ (1) nr. 3 UmwRG (2013).

1347 Schieferdecker, § 3 UmwRG, in: Hoppe, Beckmann (eds.), UVPG, Kommentar, 2012, at $39 \mathrm{ff}$.

${ }^{1348}$ VG Hamburg, Judgment of 28.11.2003, Az.: 22 VG 2478/2002, juris.

$1349 \S 3$ (1) nr. 5 UmwRG (2013).

${ }^{1350}$ Schmidt et al., Die Verbandsklage im Umwelt- und Naturschutzrecht, 2014, p. 48.

${ }^{1351} \S \S 80$ ff. BGB.
} 
UmwRG. Similarly, the organisational structure of Greenpeace does not comply with the requirement that in principle each member needs to have a vote at the general meeting. ${ }^{1352}$ Taking the essence of the ruling in the case of Djurgården into account, it can be argued that the scope of organisations eligible to recognition is too limited and that it contravenes the requirement of a "wide access to justice".

Another practical problem is that an additional burden is placed on foreign organisations if they want to institute litigations in German courts. For example, an organisation which is established in the Netherlands cannot reasonably be expected to draft its statutes and to conduct its activities according to the legislation of (all) neighbouring countries. Although in the absence of any precise rule of Union law on that matter, the Member States remain competent to regulate the recognition of environmental organisations, it can be argued that the specific recognition requirements render access to the courts in foreign countries excessively difficult and therewith hinder cross-border litigation.

Next, doubts on the compatibility with Union law arise with respect to rules preventing individuals from bringing actions before the courts in environmental matters. ${ }^{1353}$ This problem concerns specifically the German legal system, in which individuals are only granted standing in EIA cases if they can allege the infringement of a rule which at least also protects their rights. Such a rule can be considered to be incompatible with Union law for the following reasons. If individuals bring claims in cases in which Union environmental law was wrongfully or not applied at all and if these individuals are not granted standing in national courts, the rule of Union law will not be made operative in these particular cases. It then follows that it is impossible to enforce the rule of Union law, which contravenes the principle of effectiveness. ${ }^{1354}$ The Court of Justice however has consistently stressed that environmental Union law, and more specifically the EIA Directive, must take effect in the Member States. ${ }^{1355}$ Thus, from the perspective of the requirement of the "full" effectiveness of Union law, rules preventing individuals from enforcing claims in environmental matters are incompatible with Union law. Moreover, preventing individuals from bringing claims in court deprives them of an effective remedy for the infringement of a rule of Union law.

Furthermore, although the wording of the Aarhus Convention and its Union implementing legislation recognises that at a national level, legal systems may decide to make access dependent on the infringement of a right or interest, ${ }^{1356}$ this international treaty also states that "what constitutes a sufficient interest and impairment of a right, shall be determined by the Member States, consistently

\footnotetext{
${ }^{1352}$ Keupp, Zschiesche, Die Aarhus Konvention - Bürgerbeteiligung in neuer Qualität?, UFU-Paper, Juni 2010, p. 66 (available online).

${ }^{1353}$ In this regard, the Commission brought infringement proceedings against Germany: C-137/14, European Commission v Federal Republic of Germany (Action brought on 21 March 2014).

${ }^{1354}$ See in this regard the considerations of the OVG Münster, Decision of 23 July 2014, Az.: 8 B 356/14, NuR 2014, 664, 663; juris, paras. 22-30.

${ }^{1355}$ C-431/92, Commission of the European Communities v Federal Republic of Germany [1995] ECR I-2189, para. 40 (the rules of the EIA Directive provide for unequivocal duty to carry out an EIA); C-72/95, Aannemersbedrijf P.K. Kraaijeveld BV e.a. v Gedeputeerde Staten van Zuid-Holland [1996] ECR I-5403, para. 56; Sadeleer, EU environmental law and the internal market, 2014, p. 106.

${ }^{1356}$ Art. 9 (2) Aarhus Convention, Art. 11 (1) EIA Directive.
} 
with the objective of giving the public concerned wide access to justice" (emphasis added). ${ }^{1357}$ Article 1 (e) EIA Directive defines "the public concerned" as "the public affected or likely to be affected by, or having an interest in, the environmental decision-making procedures referred to in article 2 (2)". Specifically, environmental organisations are named as falling under this definition, but this does not per se exclude individuals from the scope of application of these articles. Individuals, which are affected or are likely to be affected by a decision in an EIA procedure are also the "public concerned" and have to fall under the definition, so that article 11 (4) EIA Directive can be read as "what constitutes a right should be determined ... consistently with the objective of giving also individuals wide access to justice". This means that the Member States are not completely free to qualify something as a right or not, but they have to ensure that also the access to the courts for individuals is wide. It is certainly not wide if their claims are not even admitted to the courts. This does not mean that in Germany, the entire doctrine of making access dependent of the infringement of a subjective right needs to be abandoned. It suffices to recognise that rules under the Aarhus Convention and Union law must be challengeable in court, also by individuals as members of the "public concerned". ${ }^{1358}$

Next, Member States are not free in their determination of rights, where the Union declares something to be a right. In environmental matters, the question arises in how far the right to a healthy environment is protected under Union law. Article 37 of the Charter and article 11 TFEU do not enshrine such a right. ${ }^{1359}$ However, the Court of Justice has ruled in cases with respect to Union air quality legislation that individuals must be placed in a position to enforce rules that protect their health. This was stressed in Janecek, in which the Court held that:

“...whenever the failure to observe the measures required by the directives which relate to air quality and drinking water, and which are designed to protect public health, could endanger human health, the persons concerned must be in a position to rely on the mandatory rules included in those directives." 1360

This argumentation could be extended to EIA claims, at least to the extent that also the EIA procedure requires the assessment of an impact on "human beings" ${ }^{1361}$ and that it intends to protect "human health" ${ }^{1362}$ Denying individuals the possibility to have access to the courts in EIA cases deprives them of their judicial protection with regard to the enforcement of a rule of Union law that intends to protect the individual's health. ${ }^{1363}$

\footnotetext{
${ }^{1357}$ Art. 11 (4) s. 1 EIA Directive.

${ }_{1358}$ Backes, Case Comment on C-115/09, Trianel (Judgment of 12 May 2011), AB 2011/212, at 5.

1359 Morgera, Marín Durán, Art. 37 - Environmental Protection, in: Peers et al. (eds.), The EU Charter of Fundamental Rights, A Commentary, 2014, at 37.44.

${ }^{1360}$ C-237/07, Dieter Janecek v Freistaat Bayern [2008] ECR I-6221, para. 38.

1361 Art. 3 (a) EIA Directive.

1362 Art. 14 and 19 Preamble to the EIA Directive.

${ }^{1363}$ For an argumentation that under the German legal system, the rules of the UVPG $d o$ intend to protect the individual's health: Gärditz, Verwaltungsgerichtlicher Rechtsschutz im Umweltrecht, NVwZ, 2014, pp. 2 f.; Greim, Das Urteil des EuGH in der Rechtssache Altrip - Meilenstein oder Mosaikstein auf dem Weg zum
} 
Going beyond this argumentation, it is even questionable whether in environmental, and more specifically EIA claims, it is necessary to search for a link between Union legislation and the protection of human health. As de Sadeleer has noted, rights are not a precondition for the supremacy of EU law and in the light of the necessity to effectively control whether the national administration applied Union law, access should not be made dependent from the infringement of a "right". ${ }^{1364}$

To conclude, it is highly doubtful that the German rule according to which individuals must allege the infringement of a rule which at least also protects the rights of individuals as currently interpreted and applied by the Federal Administrative Court in EIA cases are in conformity with Union law.

\section{(ii) Costs}

As far as rules on costs are concerned, the European standard is that procedures should not be prohibitively expensive. This principle was violated in the English legal system but, since the introduction of the section on Aarhus Convention claims in the CPR, this violation has been remedied. ${ }^{1365}$ In this regard, the English legal system now complies with the Aarhus rule that costs should not be prohibitively expensive. Doubts on the compatibility of national rules on costs with this requirement arise with regard to the German legal system. Empirical studies have shown that costs constitute high hurdles for environmental organisations when bringing litigations in environmental matters. ${ }^{1366}$ This is mainly due to the fact that in the absence of any statutory cost cap, cost orders can be very high. The sole fact that in some cases environmental organisations are not deterred and prevented from bringing claims is not sufficient in order to find that a national rule complies with the Union requirement that rules should not be excessively expensive. ${ }^{1367}$ Therefore, in Germany, national reforms or Union intervention may be necessary.

As regards rules on time limits for bringing litigations to court, no complications with Union law can be detected. Although the effectiveness of Union law is not guaranteed when a claim is not admissible because of exceeding a time limit, Member States are allowed restrict access to court for the purpose of guaranteeing legal certainty. ${ }^{1368}$

gebotenen Individualrechtsschutz bei UVP Fehlern, NuR 2014, p. 86; Scheidler, Rechtsschutz Dritter bei fehlerhafter oder unterbliebener Umweltverträglichkeitsprüfung, NVwZ 2005, p. 867.

${ }^{1364}$ Sadeleer, EU Environmental Law and the Internal Market, 2014, p. 106.

${ }^{1365}$ See Part II, Chapter 2, Section 2.2 (c).

${ }^{1366}$ See Part II, Chapter 2, Section 2.2 (a).

${ }_{1367}$ C-260/11, The Queen, on the application of David Edwards and Lilian Pallikaropoulos v Environment Agency and Others (Judgment of 11 April 2013) para. 48.

1368 Von Danwitz, Europäisches Verwaltungsrecht, 2008, p. 587 f.; Gellermann, § 37 Rechtsschutz durch deutsche Gerichte, in: Rengeling et al., Handbuch des Rechtsschutzes in der Europäischen Union, $3^{\text {rd }}$ edition, 2014, at 35 ff. 


\section{b. National rules on review}

\section{(i) Scope and intensity of Review}

As far as rules on review are concerned, the standard is that courts have to review the procedural and substantive legality of decisions. ${ }^{1369}$ In the three legal systems there is (since the Court of Justice's ruling in Altrip ${ }^{1370}$ ) the possibility to request the review of the procedural legality of a decision concerning the omission of a screening or an EIA or flaws in the screening or the EIA. As far as the intensity of review is concerned, the three legal systems comply with the Union standard. The rules on the intensity of review do not render the application of Union law impossible or excessively difficult, nor do they impair effective judicial protection. Moreover, the procedural legality of decisions is subject to review. The effet utile of Union law is ensured as the law is generally applied. The English intensity of review and to some extent also the Dutch intensity is light if compared to the German standard, but there is no European standard which a light intensity of review would violate. Again, it has to be stressed, that the Dutch system provides for a different quality mechanism for EIAs, namely the involvement of the independent Commissie m.e.r. in the EIA process.

\section{(ii) Rules on preclusion}

Next, doubts on the compatibility of national rules with Union law can arise with regard to rules on preclusion. ${ }^{1371}$ By means of these rules, the review of the procedural legality of administrative decisions is practically excluded and the Union law cannot take effect. However, it is questionable whether these rules are "absolute barriers", as claimants are not prevented from raising the argument of a breach of Union law at all. If they participated in the administrative procedure (Germany), or if they raised the point in time (Netherlands), there is no absolute barrier to being granted a review of the procedural legality of an administrative decision. The Commission initiated infringement proceedings with regard to the German rules on the substantive preclusion of arguments by environmental organisations that were only raised at the stage of court proceedings. ${ }^{1372}$ If the Court of Justice found that there was an infringement of the Union standard, then the Dutch rules on preclusion could also come under European scrutiny. However, the author of this thesis is not convinced that the Court of Justice will find a violation of the Union standard, as the Court recognises the necessity of legal certainty and thereby accepts, that, in some specific and limited cases, a certain rule of Union law does not take effect.

\footnotetext{
${ }^{1369}$ Art. 11 (1) EIA Directive.

${ }^{1370}$ C-72/12, Gemeinde Altrip and Others v Land Rheinland-Pfalz (Judgment of 7 November 2013); Part II Chapter 4, Section 1.2 (a).

${ }^{1371}$ Part II, Chapter 3, Sections 3.2 (a) and (b).

1372 C-137/14, European Commission v Federal Republic of Germany (Action brought on 21 March 2014).
} 
Additional incompatibilities with Union law may arise with regard to the burden to prove that a certain procedural flaw affects the final administrative decision. In the case of Altrip, the Court of Justice held that the burden of proof should not lie with the applicant. Otherwise, the exercise of rights under the EIA Directive would be excessively difficult, meaning that there would be a breach of the principle of effectiveness. The burden of proof should lie with the public authority, "without in any way making the burden of proof fall on the applicant" (emphasis added). ${ }^{1373}$ Whether and how the practice in the German courts will change remains to be seen. In the Netherlands and in England it is not necessary to prove that the decision would have been different without the procedural error. But in the Netherlands, an error can be "passed by" if this does not prejudice interested parties. The Court of Justice stresses that the establishment of the "impairment of a right" has to be derived from the evidence submitted by the developer and the public authority and not from any proof of the claimant. Hence, it is not for the claimant to prove this infringement, but for the authority to prove that there was no infringement. Also in the Netherlands it remains to be seen how the Altrip ruling will be interpreted by the courts. Similar considerations have to be made with regard to the English legal system, under which it is in principle up to the claimant to show why the decision would have been different or why the claimant was prejudiced by the decision.

\section{c. National rules on remedies}

In the three legal systems under consideration, different remedies for procedural infringements are available. In general, there is a constant tension between the interest to provide a procedure that guarantees the enforcement of Union law and the interest to accelerate procedures, to achieve a quick final dispute settlement and to guarantee legal certainty.

\section{(i) Annulment because of a procedural error or disregarding the error}

The Union requires that the EIA procedure is enforced (effet utile) and that errors are reviewable (requirement to review the procedural legality). In Germany, it was originally not possible to request the annulment of an administrative decision only because of a procedural error. However, under international and Union pressure, specific rules were introduced which allow the request for an annulment of an administrative decision if a mandatory screening or an EIA was omitted or where the screening did not comply with certain requirements of the UVPG. ${ }^{1374}$ Today, article 4 (1) UmwRG (2013) applies as lex specialis in cases in which an EIA or a screening was wrongfully omitted or in which the screening was vitiated by certain errors. However, this rule does not mention the case of a wrongful EIA, which is treated according to the general rules of administrative procedure. This means that the applicant has to show that the decision would have been different without the procedural error.

${ }^{1373}$ C-72/12, Gemeinde Altrip and Others v Land Rheinland-Pfalz (Judgment of 7 November 2013) para. 53.

$1374 \S 4$ (1) UmwRG (2006); § 4 (1) UmwRG (2013); Part II, Chapter 4, Section 1.2. (a). 
If such a causal connection cannot be shown, a procedural error remains without legal consequence in the litigation, i.e. the administrative decision is unlawful, but it is not annulled. This raises at least two problems under Union law. The first is that in such cases, there is no remedial consequence for a procedural error, which means that there is a potential infringement of the requirement of the effet utile of Union law. In the case of Altrip, the Court of Justice held that certain procedural errors will not influence the final administrative decision. ${ }^{1375}$ However, the Court did not specify which breach of the rules of the EIA procedure precisely qualifies as a serious defect. Hence, it is not entirely clear in which cases the German rule can be applied without infringing Union law. In this thesis, it is argued that the vast majority of the rules of the EIA Directive are relevant, meaning all the steps of the procedure and the content of the environmental statement. The EIA procedure is not an instrument to prohibit a certain project if certain negative impacts are expected, but an instrument to guarantee informed decision making with public participation. Therefore, it will be impossible in most of the cases to show that the decision would have been different (for example: denial of a permit where a flaw in the EIA is detected), as it is not the aim of the procedure to have a specific impact on the result. This means that the causality requirement contravenes the purpose of the directive which simply stresses the importance of a correctly conducted procedure. The second problem concerns the burden of proof as already explained above.

Another problem concerns the ability of individuals to successfully challenge flaws in the EIA, as they have to allege the infringement of a rule which at least also protects the rights of individuals and as the EIA as such does not provide for these rights. In these cases, there will be no remedial consequence for a procedural error, which contravenes the effet utile of Union law and the requirement of the review of the procedural legality. To conclude, it is doubtful that the current German legislation complies with the requirements of Union law.

In the Netherlands, it has always been possible to request the annulment of administrative decisions vitiated by errors in the EIA procedure. However, similar to the German legal system, there is a possibility to disregard certain procedural errors if these did not prejudice interested parties. In the Dutch legal system, a requirement of connection does not exist with regard to the error and the administrative decision, but with respect to the error and the interested parties. It is questionable whether this is in compliance with Union law, as the purpose of the EIA procedure is not to establish a legal position for interested parties, but to purely require informed decision making. Again, it will be difficult to prove that an error in an EIA prejudiced an in interested party and it has to be emphasised that Union law simply requires a correctly conducted procedure without requiring that this procedure has an impact on someone's position.

Moreover, it is not yet entirely clear how the relativiteitsvereiste will be applied in concrete cases. The question is in how far individual claimants are prevented from successfully challenging a flaw in the EIA procedure which does not have an impact on their individual situation, but which relates to impacts

${ }^{1375}$ C-72/12, Gemeinde Altrip and Others v Land Rheinland-Pfalz (Judgment of 7 November 2013) para. 49. 
on nature in general. ${ }^{1376}$ In case a flaw is challenged that only concerns the protection of nature, it may happen that the decision will not be quashed because of the relativiteitsvereiste. This would be contrary to the principle of effectiveness of Union law and it is highly doubtful that the Court of Justice would allow such a restriction.

With regard to the English legal system, it was illustrated that the courts are vested with a wide discretion (not) to annul an administrative decision which is vitiated by defects. In cases in which a remedy is refused although there is a breach of Union law, Union law cannot take effect, so that there is a breach of the principle of effectiveness, and it is doubtful whether this is in compliance with the principle of effective judicial protection. The Court of Justice stressed in Wells that it is necessary to remedy the omission of an EIA, and in Altrip, the Court held that flaws in the EIA process also need to be effectively challengeable. This means that in fact, the discretion of the national courts is very narrow, and there won't be many cases in which courts can exercise their discretion not to quash, without infringing Union law.

\section{Correction of procedural errors}

In the three legal systems, the correction of procedural errors is possible. This does not render the application of Union requirements impossible or excessively difficult (principle of effectiveness). On the contrary, correcting errors means that effect is actually given to Union law. Concerns about the (lack of) quality of a caught up screening (and EIA) arise, but at least for the case of the Netherlands, research has shown that the quality of decision making does not suffer. ${ }^{1377}$ Whether or not and to what extent these possibilities exist does not have a great impact on the effet utile of Union law, but on the speed of decision making and the provision of legal certainty.

\section{d. Conclusion}

To conclude, in many regards, the national legal systems are, in the meantime, complying with the Union standard as developed by the Court of Justice and prescribed by the Union legislator, but this section has also pointed to some rules which raise doubts on the compliance with the Union standard. The following table provides for a summarising overview over potential incompatibilities, reflecting the author's point of view. An (x) means that there may be incompatibilities, a (-) indicates that there are no incompatibilities and a (?) states that it is not clear from the case law analysis whether or not there is a clear incompatibility.

\footnotetext{
${ }^{1376}$ On this issue no concluded view could be formulated during the workshop. See the case study in the Annex.

1377 Part II, Chapter 4, Section 1.2 (b).
} 
Table 19: Incompatibilities of the national rules with the European standard in 2014

\begin{tabular}{|l|c|c|c|}
\hline & Germany & Netherlands & England and Wales \\
\hline Standing & $\mathrm{x}$ & - & - \\
\hline Costs & $\mathrm{x}$ & - & - \\
\hline Time-limits & - & - & - \\
\hline $\begin{array}{l}\text { Scope and Intensity of } \\
\text { Review }\end{array}$ & - & & $?$ \\
\hline Burden of proof & & $?$ & - \\
\hline Preclusion & - & - & - \\
\hline Annulment & $\mathrm{x}$ & $\mathrm{x}$ & - \\
\hline Correcting & - & - & - \\
\hline
\end{tabular}

As far as the compatibility of the German rules on preclusion and remedies are concerned, the Court of Justice will give a ruling in the infringement proceedings against Germany. This will ultimately serve as guideline for the Dutch rules. It remains to be seen whether or not the questions of costs and remedies will be dealt with by the Court. The rulings of the Court of Justice are likely to trigger further convergences between the administrative litigation systems of the Union, meaning that relevant differences between the Member States will diminish to a certain extent. However, focusing not only on the three legal systems under consideration, but on the Union as a whole with 28 different litigation systems, many differences will continue to exist. The question arises whether, under these circumstances, and taking the results of Part II into account, the creation of common rules on administrative litigation in environmental matters is necessary or desirable.

\section{Necessity or desirability of common rules?}

Part II of this analysis shows that there are three principal consequences of remaining differences between national litigation rules in environmental matters. The first is that, very basically, claimants are, depending on the legal system in which they want to make the claim, confronted with different litigation rules. Second, they have to cope with different hurdles meaning that there are different enforcement chances under the same set of European rules applicable to their situation. The third finding is that judges come to different judgements because of different procedural rules.

On the basis of these findings, the question arises whether it is necessary or desirable to develop common rules of litigation in environmental matters. It would be necessary, if intervention was required because of an (objective) distortion of the functioning of the enforcement system. It would be desirable, if intervention is required because the enforcement system could work better from the (subjective) perspective of a specific actor in this system. 
The enforcement system for Union EIA legislation is functioning to the extent that absolute barriers to justice have been eliminated, especially due to the intervention of the Court of Justice. However, focusing on the perspective of different actors in the enforcement system, arguments for and against the desirability of Union intervention can be found.

\section{a. The perspective of the individual}

Under the current enforcement system of Union law, individuals have to accept that they are treated unequally under the same rules of Union law, not because the law is interpreted differently, but because the path to receive an interpretation of the law in the courts is very different in the legal systems. Moreover, they are confronted with a situation in which courts will come to different judgements because of different litigation rules. This finding necessitates some reflections about the principle of equal treatment under Union law (i) and about the comparability of the enforcement of supranational law at the national level (ii). It has to be stressed that these reflections are seen as legal arguments which can be made from the perspective of the individual for the creation of common rules. These considerations are distinct from the question of the possibility to create common rules. The latter question concerns the choice of the appropriate legal basis in the Treaties, which will be discussed at a later stage in this part.

\section{(i) Equal treatment}

The requirement of equal treatment can be found in various provisions of Union legislation. ${ }^{1378}$ The general principle of equality is codified in article 20 of the Charter which stipulates that "any person is equal before the law" and which applies to every natural ${ }^{1379}$ and legal person. ${ }^{1380}$ Article 20 of the Charter binds Union organs and the Member States when applying Union law. ${ }^{1381}$ Therefore, the principle of equality has to be observed by the legislator, the administration and the judiciary of the Union and the Member States. ${ }^{1382}$ Substantively, the principle of equal treatment requires that persons have to be treated equally in equal situations and if this is not the case, there needs to be a justification for the unequal treatment. ${ }^{1383}$ Equal treatment is primarily understood as the equal application of the law to comparable factual situations. ${ }^{1384}$ In combination with the right to effective judicial protection as enshrined in article 47 of the Charter, it can be argued that the principle of equality also entails the equal

\footnotetext{
1378 Art. 2 TEU; art. 9 TEU; art. 18 TFEU, art. 19 TFEU; Craig, de Búrca, EU Law, 2011, p. 854 ff.

${ }^{1379}$ Hölscheidt, Art. 20, in: Meyer et al. (ed.), Charta der Grundrechte der Europäischen Union, $4^{\text {th }}$ edition, 2014, at 14 .

${ }^{1380}$ Sachs, Art. 20 Charter, in: Tettinger, Stern (eds.), Kölner Gemeinschaftskommentar, 2006, at 13.

1381 Art. 51 (1) s. 1 Charter.

1382 Rossi, Art. 20 Charter, in: Callies, Ruffert (eds.), EUV, AEUV, Kommentar, 4 ${ }^{\text {th }}$ edition, 2011, at 7-11; Hölscheidt, Art. 20, in: Meyer (eds.), Charta der Grundrechte der Europäischen Union, 4 ${ }^{\text {th }}$ edition, 2014 , at 17. ${ }_{1383}$ C-303/05, Advocaten voor de Wereld VZW v Leden van de Ministerraad [2007] ECR I-3672, para. 56; Odendahl, § 43 Gleichheit vor dem Gesetz, in: Heselhaus, Nowak (ed.), Handbuch der europäischen Grundrechte, 2006, at 17-38.

${ }^{1384}$ Höscheidt, Art. 20, in: Meyer, at 17; Lemke, Art. 20 Charter, in: von der Groeben et al. (eds.), Europäisches Unionsrecht, Nomoskommentar, $7^{\text {th }}$ edition, 2015, at 9.
} 
treatment in judicial review in comparable situations. On the European level there is no conclusive doctrine on the principle of equality and its relation with the principle of effective legal protection, but some basic observations can be made. To begin with, equal treatment in litigation cannot mean that judges come everywhere to the identical conclusion, as this would contravene the fundamental rule of the independence of judges. ${ }^{1385}$ But it can mean that there are equal chances to access courts, ${ }^{1386}$ especially as far as costs are concerned, ${ }^{1387}$ and that there is no negation of a forum for litigation. ${ }^{1388}$ Moreover, it implies that litigants are treated equally in courts meaning that there is equality of arms. ${ }^{1389}$ Finally, it implies that the judge, who is bound by the law, does not derogate from binding provisions and that he applies the law on an equal basis. ${ }^{1390}$

However, the "principle of equality" in the Union does not preclude a Member State from treating its subjects different vis-à-vis the treatment of subjects in another Member State. ${ }^{1391}$ Within the national legal systems, the principle of equality, which is the basis for the principle of equivalence, ${ }^{1392}$ only requires that there is no internal discrimination. As long as there is no harmonised rules of Union law, it is inherent in the European system, that one Member State may adopt different litigation rules and proceeds differently in the enforcement procedure than another Member State. ${ }^{1393}$ This is the reason why there is (so far) no principle of procedural equal treatment in the Union upon which an individual could rely.

In the case study of the workshop, the individual, who brought proceedings to the national courts, concerning exactly the same situation, involving the same rule of Union law, was confronted with different obstacles depending on the state in which he brought the claim. For example, whereas in

\footnotetext{
${ }_{1385}$ Art. 47 (2) s. 1 Charter; Rossi, Art. 20 Charter, in: Callies, Ruffert (eds.), EUV, AEUV, Kommentar, $4^{\text {th }}$ edition, 2011; at 11; similarly in the German legal system: Dürig, Art. 3 (1) GG, in: Maunz, Dürig (eds.), GG Kommentar, at 49, 409 ff; Kischel, Art. 3 GG, in: Epping, Hillgruber (eds.), GG Kommentar, 2014, at 106.

${ }^{1386}$ Similarly in the English legal system: Feldman (ed.), English Public Law, $2^{\text {nd }}$ edition, 2009, at 11.56; Woolf et al., De Smith' Judicial Review, $7^{\text {th }}$ edition, 2013, at 1-022.

${ }^{1387}$ Art. 47 (3) Charter; similarly the German legal system: Osterloh, Nußberger, Art. 3 GG, in: Sachs (ed.), GG Kommentar, $7^{\text {th }}$ edition, 2014, at 204.

1388 Art. 47 Charter; Hofmann, Art. 47 Charter, in: Peers et al., The EU Charter of Fundamental Rights, 2014, at 47.58; Voet van Vormizeele, Art. 47 Charter, in: Schwarze (ed.), EU Kommentar, $3^{\text {rd }}$ edition, 2012, at 12; similarly, the German legal system for access to courts that at least also protect the rights of individuals: Dürig, Art. 3 (1) GG, in: Maunz, Dürig, GG Kommentar, 2014, at 43, 44.

1389 Art. 47 (2) Charter; similarly in the German legal system: Heun, Art. 3 GG, in: Dreier (ed.), GG Kommentar, $3^{\text {rd }}$ edition, 2013, at 96; Eser, Art. 47 Charter, in: Meyer (ed.), Charta der Grundrechte der Europäischen Union, $4^{\text {th }}$ edition, 2014, at 34; similarly in the Dutch legal system: Damen et al., Bestuursrecht, vol. 2; 2012, p. 162; Wijk et al., Hoofdstukken van Bestuursrecht, 2014, p. 562.

${ }^{1390}$ Lemke, Art. 20 Charta, in: Von der Groeben, et al., Europäisches Unionrecht, $7^{\text {th }}$ edition 2015, at 9 (equal application of the law by the judiciary); Dürig, Art. 3 (1) GG, in: Maunz, Dürig, GG Kommentar, 2014, at 52, 53, 54, 55, 398 (right to an error-free exercise of discretion); in the Dutch legal system: Wijk et al., Hoofdstukken van Bestuursrecht, 2014, p. 38; in the English legal system: Woolf et al., De Smith' Judicial Review, $7^{\text {th }}$ edition, 2013, at 1-022 ("without unjustifiable differentiation").

${ }^{1391}$ Rossi, Art. 20 Charter, in: Calliess, Ruffert (eds.), EUV, AEUV, Kommentar, $4^{\text {th }}$ edition, 2011, at 14; Odendahl, $\S 43$ Gleichheit vor dem Gesetz, in: Heselhaus, Nowak (ed.), Handbuch der europäischen Grundrechte, 2006, at 24.

1392 Ward, Art. 47 Charter, in: Peers et al., The EU Charter of Fundamental Rights, 2014, at 47.03.

${ }^{1393}$ Jarass, Charta der Grundrechte der Europäischen Union, $2^{\text {nd }}$ edition, 2013, Art. 20 Charter, at 8.
} 
Germany, the property owner was not able to access court, in England, this would have been possible. Thus, because the property owner is a litigant in Germany, he will not receive an interpretation and application of the law by the court and because he is a litigant in England, he will be able to request the court to review the administrative decision. So, there is procedural unequal treatment before the same rule of Union law. The 'justification' for this is so far that in the absence of any harmonising Union rule, Member States can adopt different litigation rules.

This "state of the art" can be criticised from the perspective of the individual in the light of the principle of equality. In the decentralised enforcement system of the Union, national courts are considered to be "Union courts" with "Union judges", which have to ensure that the law is consistently interpreted and applied $^{1394}$ throughout the Union. The treaties have established a number of mechanisms for this purpose: To begin with, the Court of Justice has to ensure the (uniform) interpretation and application of Union law. ${ }^{1395}$ National courts can, or in certain instances must, refer questions for preliminary ruling on the interpretation of Union law to the Court of Justice. ${ }^{1396}$ Moreover, they are obliged to interpret national law in consistency with Union law. ${ }^{1397}$ Furthermore, the principles of direct effect and the supremacy of Union law aim at ensuring that Union law is invoked in and relied on in the national courts. ${ }^{1398}$ Nevertheless, the system does not provide for Union rules for the path to receive the interpretation and application of the law, although procedural rules have an impact on the enforcement of the law. This results in unequal treatment, since there are different enforcement chances. Thus, there is a discrepancy between the "substantive" and the "procedural" side of litigations. Therefore, from the perspective of the individual, it can be argued that the creation of equal rules, applicable in the entire Union requires equal enforcement chances of these rules.

\section{Comparability of enforcement}

In the workshop, it was shown that in the same case of a procedural (EIA) error, the administrative decision was annulled in one state, whereas it was not annulled in another state because of litigation rules. Instead that Union law is enforced similarly in all the Member States, there is legal fragmentation. If one compares this situation to the judicial enforcement systems within in the three Member States, it is striking that all of the national systems provide for uniform litigation rules. Even in the German federal system, in which there are many differences between the Länder, a single statute applies to litigation in

\footnotetext{
${ }^{1394}$ In the sense that the judge applies the law to the facts in court.

${ }^{1395}$ Art. 19 (1) TEU; Craig, de Búrca, EU Law, th $^{\text {th }}$ edition, 2011, p. 63; Lenaerts et al., EU Procedural Law, 2014, at 2.21 .

${ }^{1396}$ Art. 267 TFEU; Craig, de Búrca, EU Law, $5^{\text {th }}$ edition, 2011, pp. 442 ff; Lenaerts et al., EU Procedural Law, 2014, at $3.01 \mathrm{ff}$.

${ }_{1397}$ Case 14/83, Sabine von Colson and Elisabeth Kamann v Land Nordrhein-Westfalen [1984] ECR 1891, paras. 26,28 .

${ }^{1398}$ Case 6/64, Flaminio Costa v E.N.E.L. [1964] ECR 585; Craig, de Búrca, EU Law, $5^{\text {th }}$ edition, 2011, pp. 256 ff.
} 
courts. ${ }^{1399}$ The reason for adopting uniform rules was to prevent legal fragmentation. ${ }^{1400}$ Of course, the federal state of Germany is distinct from the Union, which is still an international treaty making use of federal techniques. ${ }^{1401}$ However, it can be argued that the Union mechanisms and the rules on the uniform interpretation and application of the law are only of limited use, where Union law is nevertheless enforced in a fragmented manner because of different procedural rules. In the words of Walter van Gerven (who refers to rights rather than to rules):

"Indeed, the need for harmonized legal remedies when it comes to protecting the individuals' basic and therefore uniform Community rights is, it would seem, inherent in the concept of uniformity: in the absence of (sufficiently) harmonized legal remedies, uniform rights cannot be adequately secured throughout the Community." 1402

From the perspective of the individual, the fact that there is legal fragmentation necessitates further discussions on the creation of a "uniform model of judicial protection" ${ }^{1403}$ of Union law in environmental procedures.

\section{b. The perspective of environmental organisations}

Similar to what has been observed with regard to individuals, environmental organisations have to accept that they have different chances to enforce environmental Union law depending on the legal system in which they are making a claim. In so far, the considerations about the principle of equality and the uniform enforcement of Union law as made above, also apply to environmental organisations. In all three legal systems, environmental organisations can be granted standing in EIA cases and they are able to challenge the procedural legality of administrative decisions. In this regard, there are no longer any differences in national litigation rules. However, the legal systems provide for different rules on the "recognition" of a group as an environmental organisation for the purpose of litigation. Whereas in the Netherlands and in England, judges decide whether or not an association qualifies as an environmental organisation, in Germany, a specific procedure for the recognition of environmental organisations applies. ${ }^{1404}$ Thus, for environmental organisations bringing litigations in Germany, there are higher administrative hurdles to access courts than in the other two states. This problem becomes especially relevant in cases in which foreign organisations bring litigations in transboundary cases in

\footnotetext{
${ }^{1399}$ According to the German constitution, the competence to create this statute is shared between the Federation and the states. Thus, different rules on administrative litigation could have been adopted in the states. However, the federal legislator has exhaustively made use of this competence in adopting the VwGO (Maunz, Art. 74 GG, in: Maunz, Dürig, GG Kommentar, 2014, at 79; Sannwald, Art. 74 GG, in: Schmidt-Bleibtreu, Hofmann (eds.), GG Kommentar, $13^{\text {th }}$ edition, 2014, at 47 ); the Länder have the possibility to derogate to a limited degree (for example: § 40 (1) s. 2 VwGO).

${ }^{1400}$ Schmidt-Assmann, Einleitung, in: Schoch et al.(eds.), VwGO Kommentar, 2014, at 65.

${ }^{1401}$ Grin, Méthode Communautaire et fédéralisme: le legs de Jean Monnet à travers ses archives, Lausanne, 2014.

${ }^{1402}$ Gerven, Bridging the Gap between Community and National Laws: Towards a Principle of Homogeneity in the Field of Legal Remedies?, CMLRev 1995, p. 690.

${ }^{1403}$ Wegener, § 3 Umweltrecht, in: Wegener (ed.), Europäische Querschnittpolitiken, 2014, at $69 \mathrm{f}$.

${ }^{1404}$ Part II, Chapter 2, Germany.
} 
Germany. ${ }^{1405}$ Morover, a very high burden is put on national environmental organisations in general, as they are expected to be aware of and to comply with foreign standards of recognition for the case that they want to enforce Union law in corss-border disputes. From this perspective, it may not only be desirable, but nessessary to develop common rules on the recognition of environmental organisations, in order to ensure that the access to courts in cross-border litigations in environmental matters is not rendered excessively difficult.

Moreover, costs play an important role for environmental organisations and also time limits may burden the preparation of claims. Thus, in one legal system, environmental organisations are in a substantially better position to contribute to the effective enforcement of Union (EIA) law than in another system.

Finally, in one legal system, environmental organisations can be sure that once a procedural (EIA) error as listed in legislation is found, the decision will be annulled (Germany), whereas in another legal system, this is a question of discretion of the judge (England). Although the inequality of these positions may be in line with the Union structure of decentralised enforcement and the procedural autonomy of the Member States, it may be questioned whether this is desirable from the perspective of the environmental organisations in the light of the principle of equal treatment and the uniform enforcement of the law.

\section{c. The perspective of developers and competitors}

From the perspective of market players, differences matter as soon as they impair economic activity. For this reason, private law scholars debate the possible harmonisation of procedural rules in civil matters at different levels. ${ }^{1406}$ In 2006, the "Principles and Rules of Transnational Civil Procedure" were adopted by the American Law Institute and UNIDROIT providing for considerations on a common civil procedure. ${ }^{1407}$ On the level of the European Union, there are two legal bases which are relevant for the harmonisation of litigation rules. To begin with, on the basis of article 114 TFEU, measures can be taken in order to eliminate distortions to the functioning of the internal market. Next, article 81 TFEU provides for a legal basis for the harmonisation of certain aspects of civil procedure. ${ }^{1408}$ Article 81 (2) e TFEU serves as a legal basis for the adoption of measures by ordinary legislative procedure to ensure "effective access to justice". Furthermore, article 81 (2) f TFEU stipulates that the same procedure applies to adopting measures to eliminate obstacles "to the proper functioning of civil proceedings, if necessary by promoting the compatibility of rules on civil procedure applicable in the member states." Moreover,

\footnotetext{
${ }^{1405}$ VG Münster, Judgment of 18 March 2011, Az.: 10 K 2540/09, juris, para. 21.

${ }^{1406}$ See for example the contributions in: Storme (ed.), Procedural Laws in Europe, 2003; Kramer, Rhee (eds.), Civil Litigation in a Globalising World, 2012.

1407 ALI/UNIDROIT, Principles and Rules of Transnational Civil Procedure (available online); Taruffo, Harmonisation in a Global Context: The ALI/UNIDROIT Principles, in: Kramer, van Rhee (eds.), Civil Litigation in a Globalising World, 2012, pp. 207-219.

${ }^{1408}$ On a predecessor of this legal basis (ex articles 61 (c), 65, 67 EC Treaty), Regulation 861/2007/EC was adopted establishing a European small claims procedure; Haibach, Zur Einführung des ersten europäischen Zivilprozessverfahrens (EG), nr. 861/2007, EuZW 2008, pp. 137-140.
} 
alternative dispute settlement shall be strengthened and there shall be a support for the training of the judiciary and judicial staff. Keeping this possible legal basis in mind, the ELI and UNIDROIT are currently working on a more comprehensive harmonisation of civil litigation in the European Union. ${ }^{1409}$ In developing harmonised rules for civil procedure, the focus is not so much on the question whether national rules have an impact on the empirical result of a procedure in terms of achieving the same result in every Member State. ${ }^{1410}$ Instead, emphasis is put on the advantages and disadvantages of differences in national litigation for market players operating in an international context. In the European context, the fear is that differences in national procedural rules might distort the functioning of the internal market. ${ }^{1411}$ Trade has a cross-and multi-national dimension so that conflicts between trading parties are conflicts involving parties from several legal systems. The question is then according to which rules disputes between private parties are settled. Additionally, distortions may result from legal uncertainty when operating cross-border and not knowing how to enforce claims in courts against contracting parties. Disadvantages may further result from the fact that in one state, litigation is cheap, easy and quick and in the other state it is expensive, cumbersome and slow. This could place competitors on an unequal footing or lead to forum shopping. ${ }^{1412}$ Therefore, in the light of the objective to guarantee the smooth functioning of the internal market, the harmonisation of civil procedural rules may seem reasonable to promote trading, to ensure legal certainty for undertakings and to avoid forum shopping. Are these considerations in the area of private law of any relevcance for considerations in public law? In the area of competition and merger law, it is argued that differences in national substantive, procedural and judicial review law are very costly for companies operating in the internal market. ${ }^{1413}$ Also in other areas governed by administrative law, developers might exploit the fact that in some systems judicial review is very weak, certain groups are barred from intervening and projects are easy to realise. This would disadvantage systems with very elaborate and expensive procedures in terms of foreign investment. ${ }^{1414}$ Additionally, market players could be put at a competitive disadvantage if in one legal system the rules are applied stricter than in another legal system. In the Commission proposal for a directive on access to justice in environmental matters, it was stressed that:

"the lack of a common framework has involved different levels of environmental protection and different standards of environmental law enforcement at Member States level that distort the

\footnotetext{
${ }^{1409}$ Initial report on the ELI-UNIDROIT $1^{\text {st }}$ Exploratory Workshop, 18-19 October 2013, Vienna (available online).

${ }^{1410}$ See however Andersson, Approximation of Procedural Law in Europe, in: Storme (ed.), Procedural Laws in Europe, 2003, p. 6: "Ultimately, court procedure determines the practical results of substantive law reforms and variations in procedure impair the uniform treatment in substance between the citizens of the member states."

${ }^{1411}$ Van Rhee, Harmonization of Civil Procedure: An Historical and Comparative Perspective, in: Kramer, van Rhee (eds.), Civil Litigation in a Globalising World, 2012, p. 50.

1412 Vernadaki, Civil Procedure Harmonization in the EU, JCER, 2013, pp. $300 \mathrm{ff}$.

1413 Temple Lang, Harmonizing National Laws, Procedures and Judicial Review of Mergers in the EU and EEA, 7 April 2011, p. 7 (available online).

${ }^{1414}$ Faure et al., Incentives, Costs and Benefits: A Law and Economic Analysis, in: Faure, Philipsen (eds.), Access to Justice in Environmental Matters, 2014, pp. $66 \mathrm{ff}$.
} 
functioning of the internal market by creating unequal conditions for economic competition in Member States." $" 1415$

In this respect, differences in litigation in administrative cases also matter for market players. Therefore, the creation of a levelling playing field in the Union on access to justice is desirable from the perspective of industry. ${ }^{1416}$

\section{d. The perspective of the Member States}

Europe is "united in diversity", which necessarily implies that there are differences between the legal systems of the Union. The treaties specifically protect the national identities and cultures in the Union. ${ }^{1417}$ Consequently, an argument against the harmonisation of litigation rules in the Union is that the differences between the legal systems are deeply rooted in national traditions and it would be hardly possible to agree on a common denominator in the Union. ${ }^{1418}$ Another argument which can be made against the creation of common rules is, that the enforcement system in place already provides for different mechanisms which aim at ensuring that Union law is complied with in the entire Union. ${ }^{1419}$ From the perspective of one Member State, it is not only important that their own litigation rules guarantee the enforcement of Union law, but it is equally important that other Member States do not silently withdraw from their obligations under the supranational legal system (free rider). Otherwise, the engagement in supranational binding decision making would be superfluous. ${ }^{1420}$ The European standard for national litigation rules aims exactly at ensuring that the supranational obligations are enforced Union-wide on the national level, ${ }^{1421}$ so that single Member States cannot silently withdraw from their obligations. Thus far, there is no necessity to create further common rules of environmental litigation at the Member State level. Moreover, the creation of common rules would imply the loss of competence to "autonomously" create rules on environmental litigation, which is, from the perspective of the Member States, a strong argument against any creation of further going standards. ${ }^{1422}$

\footnotetext{
${ }^{1415}$ Proposal for a directive of the European Parliament and the Council on access to justice in environmental matters, COM (2003) 624.

1416 On the different possible options for Union action: Backes et al., Examining the Four Options, in: Faure, Philipsen (eds.), Access to Justice in Environmental Matters, 2014; on advantages of drafting a new proposal for a directive on access to justice including the prespective of industry: Faure et al., Incentives, Costs and Benefits: A Law and Economic Analysis, in: Faure, Philipsen (eds.), Access to Justice in Environmental Matters, 2014, pp. $51 \mathrm{ff}$.

${ }^{1417}$ Art. 4 (2) TEU.

${ }^{1418}$ Eliantonio, Europeanisation of Administrative Justice?, 2009, p. 306.

${ }^{1419}$ Next to the European "standard" for national litigation rules as descrlbid in Part II, Chapter 1, there are several mechanisms for the enforcement of Union law: the Commission can start infringement proceedings against Member States for failing to comply with their obligations under Union law (art. 258 TFEU) and other Member States can trigger proceedings against another Member State (art. 259 TFEU).

${ }^{1420}$ Nettesheim, Der Grundsatz der Einheitlichen Wirksamkeit des Gemeinschaftsrechts, in: Randelzhofer (ed.), Gedächtnisschrift für Eberhard Grabitz, 1995, p. 451.

${ }^{1421}$ Part II, Chapter 1.

1422 To be further discussed in Part III, Section 4.
} 
However, there are also arguments for a more coherent standard of environmental litigation from the perspective of the Member States. To begin with, the arguments that the treaties protect national legal traditions and that it is difficult to agree on a common denominator are questionable in several regards: national traditions are not static and written in stone, but they have to adapt to new challenges and realities. This thesis has shown that, in some instances, national traditions had to be modified or abandoned in order to accommodate new requirements under Union law. Furthermore, some differences in legal traditions, which seem to be extreme on a first sight, might be less extreme in reality. The fact for example that in England, rules on administrative litigation are not laid down in a separate code as it is in Germany or the Netherlands, does not mean that in England civil and administrative procedures are treated identically. Moreover, the creation of the new European legal order necessitates changes to legal traditions: national legal systems are under an obligation to cooperate loyally with the Union and to adhere to Union obligations. ${ }^{1423}$ This means that their national litigation systems must ensure that Union law is enforced. ${ }^{1424}$

Another argument for a more coherent standard is that environmental pollution does not halt at nation state borders, and that environmental goals can only be achieved if all states contribute to better standards of environmental protection. For this purpose, it is not sufficient to only create common (substantive) rules on the protection of the environment, but Member States should also to think of common standards for the enforcement of these rules in order to finally achieve the common goal. Deleting absolute barriers to environmental justice is a first step in this direction, but it would at least be desirable if common quality standards for environmental litigations could be established, with the consequence that there are equal possibilities for the enforcement of environmental Union law and the achievement of common goals. Moreover, the creation of a common set of rules would have the advantage that a systematic and transparent approach could be taken, leading to less frictions and uncertainties as they exist in the current enforcement system. ${ }^{1425}$ Member States could actively contribute to the creation of common rules on the basis of experiences gained in their own national legal systems. In summary, despite the emphasis on the protection of national cultures and traditions, from the perspective of the Member States, there are strong arguments for more coherent rules on environmental litigation in the Union.

\section{e. Conclusion: the different perspectives}

This section has discussed the advantages and disadvantages for the creation of common rules from the perspectives of individuals, environmental organisations, market players and the Member States. The most important arguments against the creation of common rules can be forwarded by the Member States: the creation of common rules would imply a loss of competence to freely decide upon their litigation rules and it would mean the abandonment of national (legal) traditions which, according to the Treaties,

\footnotetext{
1423 Art. 4 (3) TEU.

${ }^{1424}$ Lenaerts et al., EU Procedural Law, 2014, at 2.02.

${ }^{1425}$ Eliantonio, Europeanisation of Administrative Justice?, 2009, pp. 304 f.
} 
deserve special protection. This argument is of specific importance in times of high euroscepticism, growing nationalism and the attempt of certain Member States, notably the UK, to renegotiate the division of competences in the Union. ${ }^{1426}$ It may be reasonable to discuss the division of substantive competences between the national and the supranational level. However, once that supranational laws are created on the basis of a substantive competence, these laws should be enforced on a similar basis within the Union. As a consequence, no Member State can withdraw from its obligations, by stating that according to their litigation system it is not possible to enforce certain rules of Union law by certain claimants or by making litigation difficult for claimants. The existing "outer limits" of national procedural autonomy "only" aim at ensuring that it is not impossible or excessively difficult to enforce Union law at the Member state level. Nevertheless, this thesis, has illustrated that it may be comparably easy for a litigant to access the courts in one state, whereas in another state, it is very difficult for the same litigant to access the court in order to enforce the same rule of Union law. It seems paradox that common substantive rules are created, but at the same time, different outcomes in litigations are accepted, because of differences in the rules on enforcement. Hence, also for the Member States, it is advantageous to discuss the creation of common litigation rules, which is different from the discussion of moving towards further integration with respect to certain substantive issues.

The strongest argument for the creation of common rules can be forwarded by civil society, comprising individual claimants and environmental associations, which from the perspective of equal treatment should be placed in a similar position to enforce the same rule of Union law everywhere in the Union, irrespective of the court in which they bring the claim. Of course the question remains whether members of the civil society actually want this equal treatment, but the answer to this question is firstly a political one, and secondly, it will depend on the specific framework of the common rules. From the perspective of developers and competitors, the most important argument for the creation of common rules has already been forwarded in the context of the implementation of article 9 (3) of the Aarhus Convention, which is that different litigation rules create unequal conditions for economic competition in the Union. In conclusion, from all the four perspectives, there are arguments for the creation of a common standard of litigation, meaning that the creation of common rules is desirable. Having discussed the advantages and disadvantages of the creation of common rules, the next section will question what the common rules could contain.

\section{What should the common rules address?}

When considering the creation of common rules, one first has to be clear about the scale of possible standards. So far, the general standard for the application and enforcement of Union law prescribes the bottom line necessary for the functioning of any legal system. The requirements mainly ensure that the law is applied if a rule bars the application or the enforcement of the law. This is described as the "outer

${ }^{1426}$ Smits, Who Does What? On Cameron, Rutte and the Optimal Distribution of Competences among the European Union and the Member States, in: Purnhagen, Rott (eds.), Varieties of European Economic Law and Regulation, 2014, pp. 343-357. 
limit" of national procedural autonomy, which can be found at the one side of the scale. On the other side, there is a uniform procedure in the European Union prescribing the uniform enforcement of uniform rules.

It has to be emphasised that the discussion on the creation of (concrete) common rules is not of a purely legal nature, but that it concerns political choices. The previous section has illustrated that arguments in favour of the creation of common standards can be found from the perspective of all actors involved in environmental litigations. Nevertheless, the respective political preferences are very different, and the opposing interests of the actors can collide. Some parts of the civil society may want to have a "very" wide access to justice, but contrary to that, economic operators may be interested in restricting access as far as possible. To give a concrete example: from the perspective of members of the civil society, it may be argued that as many litigants as possible should be granted standing in courts, whereas from the perspective of industry, it may be argued that the number of litigants should be reduced in order to accelerate proceedings.

Keeping these tensions between different political positions in mind, it should be stressed that at least at the international level, the Member States already took a political decision with regard to environmental litigations, when they signed the Aarhus Convention. Access to justice has to be "wide", allowing the "public concerned" to institute litigations, and providing litigants with "effective remedies". Next, the Member States took a political decision at the supranational level, when they agreed on article 191 (2) TFEU stipulating that the "Union policy on the environment shall aim at a high level of protection". Accordingly, the Union has to create substantive rules which foster environmental protection. However, in order to attain the goal of a high level of protection, the simple creation of substantive rules is not sufficient. In addition to substantive rules, procedures are necessary which guarantee the enforcement of substantive rules. It can be debated whether existing substantive environmental rules in the Union actually promote the aim of a high level of environmental protection. However, this thesis is not concerned with substantive flaws in environmental legislation, but with the quality of environmental litigation rules once that environmental rules have been created. In summary, by adopting the Aarhus Convention and Art. 191 (2) TFEU, the Member States have taken political decisions, which have to serve as guidelines when discussing the concrete creation of common rules on environmental litigation.

To begin with, as far as rules on the admissibility of a claim are concerned, individuals and environmental organisations should have equal chances to enforce environmental rules in order to help realising the policy aim of a high level of environmental protection in the Union. In the light of the requirements of the Aarhus Convention, this cannot mean that Member States engage in a race to the bottom towards a very restrictive access to courts. (In this context it should be noted that for example the introduction of the Dutch relativiteitsvereiste may contravene the existing Union standard. ${ }^{1427}$ )

${ }^{1427}$ Part III, Section 1 c (i). 
Instead, common rules should address comparably "wide" standing possibilities and comparably "reasonable" time limits for instituting the claim. Moreover, the standard for the burden of costs should be comparable and not excessive. Thus, in similar cases, there should be comparable standards for accessing courts for the enforcement of Union environmental law.

As far as rules on review are concerned, it was found that there are differences in the intensity of control as to how the rule was applied by the administration. The international framework prescribes that "the procedural and substantive legality of administrative decisions, acts and omissions" has to be reviewed. ${ }^{1428}$ Hence, it should be ascertained that courts review procedures in environmental matters. However, this does not prescribe how this review shall take place. Differences in that respect could only be minimised in developing a Union-wide understanding of administrative procedure and the role of the judge with regard to the control of administrative action involving the application of Union environmental law. As this goes to the core of any national legal system, to their understanding of the separation of powers and the role of judges, it will be difficult to achieve a consensus. From a purely environmental perspective one argue that a common high standard for assessing the application of environmental provisions is desirable in order to prevent that the level of protection remains low - even after the introduction of the EIA procedure and other environmental standards - because the procedure is badly conducted and hardly controllable. There may be other quality mechanisms, such as the involvement of the independent Commissie m.e.r. the Netherlands. However, their advice is restricted to some EIA matters. Beyond this, and in environmental matters in general, a common standard of litigation would need to ensure a comparable quality control of the application of environmental Union law.

As far as rules on remedies are concerned, it was found that there are differences regarding the legal consequences for procedural errors. The bottom line is that there have to be remedies for errors in environmental assessments. But there is no agreement as to what kind of errors will be remedied. As long as Union law does not prescribe the remedies for errors in an EIA, the courts will assess them in light of their understanding of the procedure and the influence it may have on the final administrative decision. In one state, procedural errors are "passed by" while in another they are not. More coherence could be achieved if there was a common understanding on what kind of steps in a procedure may be corrected at a later stage of the procedure and which ones are indispensable.

To conclude, a common standard would provide for similar enforcement chances and a similar control of the quality of the application of the law and similar remedies for procedural errors.

${ }^{1428}$ Art. 9 (2) Aarhus Convention. 


\section{Possibility to create common rules?}

The question to be answered finally is whether it is possible to create common rules on administrative litigation in environmental matters. This section will discuss hard law and soft law options for the creation of common rules.

\section{a. Legislative harmonisation}

To begin with, it has to be stressed that the Union can only legislate in accordance with the principle of conferral as enshrined in articles 4 (1) and 5 (1), (2) TEU. This means that, common rules can only be adopted where the competence to create legislation has been conferred upon the Union. Under title one of the TFEU, enumerating the different categories and areas of Union competence, general administrative litigation rules are not listed. Moreover, there is no explicit legal basis for the adoption of general rules on access to justice in administrative matters. Hence, there is no express conferral of powers in this area of law. Nevertheless, in the following, it will be examined on which basis the Union is competent to legislate in the area of environmental litigation rules.

First, the Union has the competence to conclude international treaties. ${ }^{1429}$ As the Union is a party to the Aarhus Convention, common litigation rules in environmental matters can be adopted by implementing and concretising the requirements of this international treaty. On this basis, the EIA (and IPPC) Directives could be amended, so that the existing articles, which aim at an implementation of the Aarhus Convention are further specified. Clear common rules on environmental litigation in the Union could be achieved by not simply copy-pasting the wording of article 9 (2) of the Aarhus Convention but by concretising the obligations. Furthermore, it has to be recalled that the Union has only partially complied with its obligations under article 9 of the Aarhus Convention. An implementation of article 9 (3) is still missing. The implementation of this article could lead to a further approximation of national litigation rules in environmental matters in general. Hence, the Union could, paying regard to the principles of subsidiarity and proportionality, adopt harmonising legislation specifying the Aarhus requirements and oblige Member States to comply with these standards.

Second, the creation of common rules in environmental litigation could be based on the legal basis for Union legislation in environmental matters, which is article 192 (1) TFEU. Accordingly, legal action may be taken by means of the ordinary legislative procedure in order to achieve the objectives enumerated in 191 TFEU. These objectives include the preservation, protection and improvement of the quality of the environment, the protection of human health, the prudent and rational utilization of natural resources and the promotion of measures at the international level to deal with regional and worldwide environmental problems and in particular to combat climate change. ${ }^{1430}$ In addition to this, the treaty provides that measures relating to town and country planning, water management and land use and

${ }^{1429}$ Art. 3 (2) TFEU.

${ }^{1430}$ Art. 191 (1) TFEU. 
energy have to be adopted by the Council acting unanimously after consulting the European Parliament, ECOSOC and the COR. ${ }^{1431}$ The plain wording of articles 191 and 192 TFEU is not restricted to the adoption of substantive measures on the protection of the environment. Therefore, the argument can be made that these articles imply the competence to create litigation rules which ensure that the "high level of environmental protection" can be achieved. This thesis has shown that the attainment of the goal of environmental protection is not only dependent on substantive rules, but that it is important that there are litigation rules which guarantee the enforcement of these substantive rules. In this regard the explanatory memorandum to the proposed directive on access to justice set out that:

\begin{abstract}
"Better access to justice in environmental matters for representative groups advocating environmental protection will have numerous positive effects, the most significant being a general improvement of the practical application of environmental law. In practice, access to justice is likely to be sought only as a last resort, hence contributing to the enforcement of environmental law. Given that, environmental law will have its desired effects only if its enforcement is guaranteed throughout the whole Union, it is absolutely crucial to ensure that the observance of environmental law can be reviewed in court." 1432
\end{abstract}

Hence, a new legislative instrument based on article 192 (1) TFEU could include rules on a "better admissibility" to courts, and on a "better review" and "better remedies" in courts, in order to improve the enforcement of Union environmental law.

Third, article 114 (1) TFEU has to be mentioned as a legal basis to harmonise laws with the object of "the establishment and functioning of the internal market". Article 114 (3) TFEU sets out that:

"The Commission in its proposals envisaged in paragraph 1 concerning [...] environmental protection [...] will take as a base a high level of protection, taking account in particular of any new development based on scientific facts."

This means that if a distortion of the functioning of the internal market was found, article 114 (1) TFEU could also serve as a legal basis for the creation of further going common administrative litigation rules in environmental matters. In the proposed directive on access to justice, it was recognised that

"the failure to fully enforce environmental laws can distort the functioning of the internal market by creating unequal terms of economic competition for the economic operators". ${ }^{1433}$

\footnotetext{
${ }^{1431}$ Art. 192 (2) TFEU.

${ }^{1432}$ Proposal for a directive of the European Parliament and the Council on access to justice in environmental matters, COM (2003) 624. ${ }_{1433}$ Ibid.
} 
A harmonised or even uniform administrative litigation procedure could reduce costs and uncertainties for undertakings, just like the case with rules on civil procedure. ${ }^{1434}$

Moreover, the flexibility clause of article 352 (1) TFEU might be considered as legal basis for the creation of common rules in environmental litigation, with the requirement that the Council would have to act unanimously. However, it follows from the case law of the Court of Justice that this legal basis cannot be taken if there are more specific competences in the treaty ${ }^{1435}$ and the two legal basis mentioned previously are more specific than article 352 (1) TFEU.

Hence, the question arises which of the two articles, 192 (1) or 114 (1) TFEU, is the appropriate legal basis for the creation of common rules on administrative litigation in environmental matters. To begin with, both legal bases provide for the ordinary legislative procedure, meaning that theoretically, the measure could be based on both articles, without being challenged for disturbing the institutional balance in the Union. However, according to the test of the "predominant purpose" as established by the Court of Justice, ${ }^{1436}$ the question is what the principal object of the measure is. The common rules would aim at an improvement of the enforcement of environmental law, taking the policy aim of a high level of environmental protection into account. The creation of a levelling playing field in litigation matters would certainly foster the smooth functioning of the internal market, but this aim is not "indissociably linked" 1437 with the aim of a better judicial enforcement of environmental Union law. Therefore, the measure should be based on article 192 (1) TFEU.

Against a harmonisation of litigation rules in administrative (and environmental) matters, it may be argued that article 197 (1) TFEU concerning administrative cooperation strongly stresses the principle of subsidiarity and expressly excludes the harmonisation of the laws and regulations of the Member States. However, according to the term "cooperation" and the systematic placement of this article in the treaties, this provision only concerns cooperation in administrative matters. Therefore, it does not preclude the creation of common rules of administrative litigation.

The advantages of creating common legislative rules have been summarised by Eliantonio: a sufficient and transparent system could be created, enhancing legal certainty and avoiding piecemeal solutions, and improving the level of judicial protection by not merely relying on minimum requirements. ${ }^{1438}$

\footnotetext{
${ }^{1434}$ Faure et al., Incentives, Costs and Benefits: A Law and Economic Analysis, in: Faure et al. (eds.), Access to Justice in Environmental Matters, 2014, p. 60.

${ }^{1435}$ Case 45/86, Commission of the European Communities v Council of the European Communities [1987] ECR 1493, para. 13 .

${ }^{1436}$ C-178/03, Commission of the European Communities v European Parliament and Council of the European Union [2006] ECR I-107, para. 42.

${ }^{1437}$ C-94/03, Commission of the European Communities v Council of the European Union [2006] ECR I-1, para. 36.

${ }^{1438}$ Eliantonio, Europeanisation of Administrative Justice?, 2009, pp. $302 \mathrm{ff}$. 
In conclusion, as far as the creation of administrative litigation rules in environmental matters is concerned, furthergoing common rules could be adopted by implementing and concretising the requirements of the Aarhus Convention and by taking article 192 (1) TFEU as a legal basis. However, no competence has been conferred upon the Union as far as general administrative litigation rules are concerned.

\section{b. Judicial harmonisation}

Another way for the creation of rules common to all legal systems in the Union is to leave any further concretisation of the international and European standards on access to justice to the Court of Justice. In interpreting the existing requirements, an approximation of national litigation rules can be achieved. However, the greatest difficulty in this regard is that the Court of Justice can only intervene on a caseby-case basis, which means that differences in 28 Member States will continue to exist for a long time. ${ }^{1439}$ An interference with the national litigation regimes by the Court of Justice can only take place if either the Commission starts infringement proceedings against Member States or if national courts make a reference for preliminary ruling. ${ }^{1440}$ Both actions can lead to an approximation of litigation systems at specific points, but will not, or only extremely slowly, lead to the creation of a comprehensive, consistent set of common rules. Moreover, proceedings by the Commission can only be brought if Member States fail to comply with their obligations under Union law, and the obligations for procedural rules set only minimum standards, which means that there is room for differences. Similarly, questions for preliminary rulings will only be referred to the Court of Justice if courts have (serious) doubts about the interpretation of Union law and about the compatibility of national litigation rules with the requirements of Union law. Finally, the Court of Justice so far holds on tightly to its self-created principle of national procedural autonomy and it did not develop a "principle of similar enforcement chances" or "similar quality control" in national courts for the purpose of ensuring the uniform enforcement of Union law in the Member States. To conclude, it is not likely that the establishment of a comprehensive set of litigation rules in environmental matters, which would be common to all 28 Member States, can be achieved by the intervention of the Court of Justice.

\section{c. National action}

Another way to create rules common to all legal systems in the Union is to leave the approximation to cross-loading alignment processes. In Part II, it was already observed that convergence between the different legal systems not only took place because of Union intervention but also because of independent national reforms. Leaving the creation of common rules entirely to national reform processes, is a method that makes approximation dependent on chance, i.e. whether or not a legal system deems it necessary to reform its national procedural rules, and it is unlikely that 28 Member States will

\footnotetext{
${ }^{1439}$ On the (limited) role of the Court of Justice in the development of national procedural rules: Ryall, Effective Judicial Protection and the Environmental Impact Assessment Directive in Ireland, 2009, pp. 239, 254-256.

${ }^{1440}$ Art. 258, 260 TFEU; Art. 267 TFEU.
} 
find common rules only by independent national reforms. It is additionally necessary to support and foster the exchange of experiences of national judges, which already takes place in many fora. ${ }^{1441}$ Through this exchange, problems can be discussed from a comparative perspective and common solutions can be found. This exchange should be complemented by comparative research which reveals differences which matter for the enforcement of Union law and which can explain strength and weaknesses of enforcement systems in the Union. On this basis, best-practice solutions could be developed which might influence the exchange between judges and other actors in the Member States.

\section{d. Conclusion}

The most reasonable solution in my opinion would be to have a mixture of these three processes. Academia could, in close cooperation with judges and other practitioners from the different legal systems, develop common standards which could serve as basis for argumentation for policy makers and for judges on European and national level.

\section{The greater context: national procedural autonomy and European integration from a historic perspective}

This last section aims at placing the findings of this thesis in the historic context of European integration. Thereby, European integration is understood as a "process of creating an ever closer union among the peoples of Europe". ${ }^{1442}$ In order to understand the role of the principle of national procedural autonomy in this process, the beginnings of European integration will be reconsidered. Thereby, three elements deserve specific attention. To begin with, the reason and aim of European integration has to be recalled and it will be briefly asked what the place of environmental law and the EIA procedure is in this context. Next, the foundations of the mechanism for achieving the aim of European integration will be reconsidered, and it will be asked, what the role of the principle of national procedural autonomy is in this regard. It will be questioned in how far there is a discrepancy between striving for an ever closer Union, in which common aims should be achieved by common rules, and the principle of national procedural autonomy, which means that the competence in procedural matters is not transferred to the Union, leading to a fragmented enforcement of Union rules. Finally, an important argument in this thesis was the idea of procedural equal treatment in the Union. It will be asked what the role of the principle of equal treatment was in the beginnings of the historic integration process, and what this can mean for the principle of national procedural autonomy and for the future process of European integration. For the purpose of this analysis, the early ideas of Jean Monnet representing the political side of European integration and Michel Gaudet, having contributed to the legal side of European integration, will be traced and it will be asked whether some inspiration can be drawn for the future development of the Union principles on litigation in national courts (in environmental matters).

${ }_{1442}^{141}$ Burgues et al., A Common Heritage: EU Environmental Law and National Judges, JEEPL 2010, pp. 221-233. 1442 Art. 1 TEU. 


\section{a. The reasons for and the aim of European integration}

The reasons for instigating the process of European integration are straightforward and generally known: after the experience of two horrific world wars, the driving force behind the "founding fathers" activities was the desire to create an international order that would guarantee stability and peace in Europe. ${ }^{1443}$ This was made explicit in the Schumann declaration which stated that:

"World peace cannot be safeguarded without the making of creative efforts proportionate to the dangers which threaten it. The contribution which an organized and living Europe can bring to civilization is indispensable to the maintenance of peaceful relations." 1444

Although the ambition of stability and peace between states was the primary reason for the creation of the Coal and Steel Community, Monnet was of opinion that this was not the only reason necessitating the unification of Europe. ${ }^{1445}$ Instead, according to him, it was important that European integration would instigate a change of behaviour among people, including a reform of economic and social policies. ${ }^{1446}$ According to Monnet, the basis for the unification of Europe was the "search for, understanding of and support of the common interest". ${ }^{1447}$ With the "common interest" he referred to situations in which there were problems at the level of the nation states which the states could no longer solve alone, but which have to be solved by a common effort.

Today, one of the problems which can only be solved by common effort is the protection of the environment. With the Single European Act, this was officially recognised by the European Community and a legal basis was created for the adoption of European legislation in this area. ${ }^{1448}$ The preamble of the EIA Directive explains the necessity for the support of the common interest as follows:

"Since the objective of this Directive, namely to ensure a high level of protection of the environment and of human health, (...), cannot be sufficiently achieved by the Member States but can rather, by reason of the scope, seriousness and transboundary nature of the environmental issues to be addressed, be better achieved at Union level, the Union may adopt measures..."1449

\footnotetext{
${ }^{1443}$ Monnet, Les Etats-Unis d'Europe ont Commencé, La communauté européenne du charbon et de l'acier, 1955, p. $115 \mathrm{ff}$; for this driving force throughout the process of European integration: Rieben, Instaurer et sauvegarder la Paix, in: L'intégration européenne : historique et perspectives, Lausanne 7 et 8 novembre 2001, Publications de l'Institut suisse de droit comparé, 2002, p. 13.

${ }^{1444}$ Translation on www.europa.eu.

1445 Monnet, Les Etats-Unis d'Europe ont Commencé, La communauté européenne du charbon et de l'acier, 1955, p. 110.

${ }^{1446}$ Lalumière, Rieben, Faire Entrer l'Europe dans le Cour des Citoyens, 1993, p. 65.

${ }^{1447}$ Own translation. Jean Monnet, L'Europe Unie, L'Europe et L'Organisation de La Paix, 1964, p. 6.

${ }^{1448}$ Art. 25 Single European Act.

${ }^{1449}$ Directive 2014/52/EU, of the European Parliament and of the Council of 16 April 2014 amending Directive 2011/92/EU on the assessment of the effects of certain public and private projects on the environment, OJ L 124, 25.04.2014, pp. 1-18, at 41.
} 
This preamble sets out that, paying regard to the principle of subsidiarity, it is no longer possible to solve environmental problems at the level of nation states alone. In order to achieve the common aim, common action of the Member States is necessary. But the protection of the environment is not only a concern of states. Similar to what has been stated about the creation of peace, a common effort among European citizens is required. Ensuring a high level of protection is an interest common to the citizens of Europe. ${ }^{1450}$

\section{b. The method of European integration}

The mechanism established to develop and ensure the protection of the common interest consists in the creation of law binding states in an equal manner and the establishment of institutions exercising powers. ${ }^{1451}$ This was made explicit by Monnet who stated that "only a common perspective, common rules, common institutions will allow us to compose us". ${ }^{1452}$ According to Monnet, the nature of humans would not change unless laws were created of which the observance was guaranteed. ${ }^{1453}$ The rules should not be adopted by concluding "simple" international treaties. Instead, as Jean Monnet emphasised in the announcement of the creation of the Action Committee for the United States of Europe:

"To achieve these objectives it is necessary to put aside all specious solutions. Mere cooperation between governments will not suffice. It is indispensable for States to delegate certain of their powers to European federal institutions mandated by all the participating countries taken as a whole." 1454

This declaration, and his use of terminology on many other occasions ${ }^{1455}$ makes clear that his idea was to transform the separate nation states into a federal construction. In this regard, he explicitly drew inspiration from existing federations. ${ }^{1456}$ In a speech, he explained that:

"it is not the first time in history, that several states undertake the formation of an economic and political union. What did the separate states of America do to form the federation of the United States of America? What did the separate cantons of Switzerland do to form the federation of

\footnotetext{
${ }^{1450}$ Lassalle, L'Europe de l'Intérêt Général, 2013, p. 232.

${ }^{1451}$ Grin, Méthode Communautaire et fédéralisme : le legs de Jean Monnet à travers ses archives, FJME, Collection débats et documents, numéro 2, Lausanne, Septembre 2014.

1452 Own translation ; "Seule une perspective commune, des règles communes, des institutions communes peuvent nous permettre de nous ressaisir." Monnet, Les Etats-Unis d'Europe ont Commencé, La communauté européenne du charbon et de l'acier, 1955, p. 37.

${ }^{1453}$ Monnet, La Communauté Européenne et L'Unité de L'Occident, 1961, p. 5.

${ }^{1454}$ Creation of the Action Committee for the United States of Europe, Press Communiqué, 13 October 1955, Paris, in: Action Committee for the United States of Europe, Statements and Declarations, 1955-67, 1969, p. 11.

1455 For the utilisation of the "federal terminology" by Monnet refer to: Grin, Méthode Communautaire et fédéralisme : le legs de Jean Monnet à travers ses archives, Lausanne, FJME, Collection débats et documents, numéro 2, Lausanne, Septembre 2014, pp. 17 f; see also : Fontaine, Jean Monnet, Actualité d'un bâtisseur de l'Europe Unie, FJME, Economica, Paris, p. 2.

${ }^{1456}$ Bowie, Rieben, Hallstein, Michel, Fédération Des États-Unis, Confédération Suisse, Fédération Allemande, Communauté Européenne, Rapports présentés au Comité d'Action pour les Etats-Unis d'Europe, Centre de Recherches Européennes Lausanne, 1972.
} 
Switzerland? What happened in Germany? In any of these cases, whatever the differences in the concrete form may be, whatever the circumstances and the spirit, one thing is clear: they could only achieve unification because they created a common organisation, with common rules and with institutions upon which they delegated real powers necessary to regulate together those questions which they decided to solve together."1457

Whether and to what extent the creation of this new European order can be classified as a "federation" has always been subject to discussions. ${ }^{1458}$ Already in 1958, five years before the Court of Justice's ruling in Van Gend en Loos, ${ }^{1459}$ Gaudet explained that with the creation of the Coal and Steel Community a "real new order was created" with an "autonomous law". ${ }^{1460}$ Two years later he stated that "the peculiar legal system of the community is rather unusual. It works through international law, as well as with federal techniques." ${ }^{1461}$ The essence of this federal technique is to reconcile the antagonism between attributing powers to a central authority and the autonomy of the parties involved. ${ }^{1462}$ In the Union, it was decided to delegate certain regulatory competences to a central authority. Thus, "federal" law is created in certain areas, but in other areas, the Member States retain national "substantive" autonomy. The competence to create (litigation) procedures to enforce the "federal" rules has been left to the autonomy of the contracting parties. Hence, in cases of conflict, the enforcement of Union legislation was considered to be an internal matter for the national courts. ${ }^{1463}$ Because of this decision for the division of competences, there was no need to create a separate judiciary for Union matters. ${ }^{1464}$ A constant concern however, ${ }^{1465}$ which has always existed with regard to this decentralised system of

\footnotetext{
${ }^{1457}$ Monnet, L'Europe Unie, De L'Utopie à la Réalité, Allocution prononcée au Congrès International de la Friedrich-Ebert-Stiftung, Centre de Recherches Européennes, Lausanne, 1972, p. 7.

${ }^{1458}$ Gaudet describes this dispute between federalists and intergovernmentalists with respect to the European Coal and Steel Community in: Gaudet, La structure de la C.E.C.A., 17. Septembre 1958, section: VI, FJME, Fonds Michel Gaudet, Conférences 58-60; Regassi : “L’Europe deviendra-t-elle une fédération celle des Etats-Unis et celle de la Suisse, ou une Confédération d'Etats souverains ? Tel est, grosso mondo, le grand problème qui se pose aujourd'hui et dont la solution déterminera l'échec ou le succès de l'Union européenne." in: Cardis, Fédéralisme et Intégration Européenne, Centre de Recherches Européennes École des H.E.C., Université de Lausanne, 1964, p. 8; for an overview over the development of the federal idea in European integration refer to: Ricard-Nihoul, Pour une Fédération Européenne D'Etats-Nations - La vision de Jacques Delors Revisitée, 2012.

${ }^{1459}$ Case 26/62, NV Algemene Transport- en Expeditie Onderneming van Gend \& Loos v Netherlands Inland Revenue Administration [1963] ECR 1.

${ }^{1460}$ Gaudet, La Structure de la CECA, Part V, 17. Septembre 1958, FJME, Fonds Michel Gaudet.

${ }^{1461}$ Address by Michael Gaudet on "The Legal Systems of the European Community " at the Institute on the Legal Aspects of the European Community, Washington, February 11 to February 13, 1960, FJME, Fonds Michel Gaudet, p. 21.

1462 Cardis, Fédéralisme et Intégration Européenne, Centre de Recherches Européennes École des H.E.C., Université de Lausanne, 1964, p. 42.

1463 Gaudet, La Structure de la CECA » 17. Septembre 1958, FJME, Fonds Michel Gaudet.

${ }^{1464}$ Gaudet, L'expérience institutionnelle des Communautés Européennes 1950-1971, in: Rapports présentés au Comité d'Action pour les Etats-Unis d'Europe, Lausanne, Centre de Recherches Européennes, 1972, p. 133.

1465 This subject matter was repeatedly of importance in the speeches delivered by Gaudet: Michel Gaudet, Les Rapports des Tribunaux Français avec les Organisations et Juridictions Communautaires, Centre National D'Etudes Judiciaires, Bordeaux 23 Mai 1964, FJME, Fonds Michel Gaudet, p. 32 ff.; Gaudet, Les Conflits du Droit Communautaire avec les Droits Nationaux des Etats Membres, Centre Européen Universitaire de Nancy, 10/11 Mars 1967, FJME, Fonds Michel Gaudet, p. 5; Gaudet, La Compétence de la Cour de Justice Pour l'Interprétation Uniforme du Droit Communautaire. Les Relations du Juge National et du Juge Communautaire, Conférence de Bogota 21-25 Novembre 1972, FJME, Fonds Michel Gaudet, p. 1 ff.
} 
enforcement, has been to avoid different interpretations of the same rules, meaning the guarantee of the uniform application of the newly created "autonomous law" in national courts. ${ }^{1466}$ According to Gaudet, this problem could be avoided by means of the preliminary ruling procedure, ${ }^{1467}$ as this mechanism vests the Court of Justice with the final power to give an interpretation of Community law in cases pending before national courts. ${ }^{1468}$ Moreover, the principles of direct effect, consistent interpretation and the supremacy of Union law should guarantee that there are no divergences in the application of Union law in the Member States. ${ }^{1469}$ Additionally, Gaudet was of the opinion that it was the duty of the national judges in their function as Community judges to have a sufficient knowledge of the legal differences between Member States to prevent solutions being put in place that would be incompatible with the legal perceptions of other Member States. ${ }^{1470}$ With this statement, he stressed the importance of comparative law in national cases law governed by Union law but went even further in requiring that no solutions should be found contrary to what other Member States would decide. This emphasised the necessity of the unity and coherence of Union law throughout the Member States. To conclude, in the newly created international legal order, which functioned with "federal techniques", Gaudet understood under the guarantee of the uniform application of Union law mainly the uniform interpretation of Union law. The question of "fragmentation" in enforcement because of differences in national procedural rules did not come to the surface. He was of opinion that, in order to develop and protect the common interest, it was sufficient to create substantive competences at the Union level and to leave procedural competences with the Member States, with the sole exception that courts had to refer questions for preliminary rulings in cases in which the uniform interpretation of the law was endangered.

It was only later that the question of the adequacy of national procedural rules for the enforcement of Union law became explicit. In the Rewe case, the Court of Justice could merely find that there was no harmonising Union legislation regulating judicial review, which as a consequence means that Member States are free to design their rules. ${ }^{1471}$ Thus, contrary to for example the federal system of Germany, where the regulation of judicial review is a shared competence, ${ }^{1472}$ of which the federal legislator made exhaustive use with the adoption of the $\mathrm{VwGO},{ }^{1473}$ in the Union, there is no comparable competence conferred on the Union level. In the German legal order, the reason for conferring this competence on

\footnotetext{
${ }^{1466}$ For example: Address by Gaudet on "The Legal Systems of the European Community" at the Institute on the legal Aspects of the European Community, Washington, February 11 to February 13, 1960, FJME, Fonds Michel Gaudet, p. 6.

1467 Gaudet, La Compétence de la Cour de Justice Pour l'Interprétation uniforme du droit Communautaire. Les Rélations du Juge National et du Juge Communautaire, Conférence de Bogota 21-25 Novembre 1972, FJME, Fonds Michel Gaudet.

1468 Address by Gaudet on "The Legal Systems of the European Community" at the Institute on the legal Aspects of the European Community, Washington, February 11 to February 13, 1960, FJME, Fonds Michel Gaudet, p. 18. ${ }^{1469}$ Gaudet, Les Conflits du Droit Communautaire avec les Droits Nationaux des Etats Membres, Centre Européen Universitaire de Nancy, 10/11 Mars 1967, FJME, Fonds Michel Gaudet, pp. 13, 19, 31.

${ }^{1470}$ Gaudet, L'expérience institutionnelle des Communautés Européennes 1950-1971, in: Rapports présentés au Comité d'Action pour les Etats-Unis d'Europe, Lausanne, Centre de Recherches Européennes, 1972, p. 133.

${ }^{1471}$ C33/76, Rewe [1976] ECR 1989, para. 5.

1472 Art. 74 (1) s. 1 GG.

${ }^{1473}$ Maunz, Art. 74 GG, in: Maunz, Dürig, GG Kommentar, 2014, at 79.
} 
the federation was to prevent legal fragmentation. ${ }^{1474}$ In the Union, legal fragmentation is accepted as an aspect of the diversity of national traditions. The principles as formulated by the Court of Justice in Rewe are still applicable, so that the interference with the national competence is generally governed by the minimum requirements established by the Court in this case. This interference by the Court with the "national procedural autonomy" aims at ensuring that Union law is applied at all at the national level. ${ }^{1475}$. Despite these developments in the case law of the Court of Justice, which induced the Europeanisation of national litigation rules at certain points, the competence to create general rules on administrative litigation still lies with the Member States. Thus, regarding the theoretical foundations of Union law enforcement, there has not been much change in the process of European integration. As far as administrative enforcement of Union law is concerned, the words of Gaudet can be repeated that the Union is an international order with some federal techniques. Whereas the Union developed ever closer ties with regard to many substantive issues, i.e. in that it decided to confer legislative competences on the Union to achieve a common aim, this is not the case with many procedural issues, where existing mechanisms seem to be regarded as satisfactory to achieve the common aim agreed upon. The result of this is, as this thesis has shown, that the common rules are enforced in a fragmented manner. Thus, there is a discrepancy between the aim to develop closer ties with regard to substantive issues in creating common rules, and reality, in which the common rules are enforced in a fragmented manner.

It was seen in the previous sections, that the development of civil procedural law has taken another path. In this area, legislative competences are conferred on the European legislator. ${ }^{1476}$ Furthermore, the previous sections in this thesis have shown that it could be desirable to develop closer ties also in the area of administrative litigation. So far, this may be difficult to achieve because of the absence of any express conferral of competences to the Union legislator for the creation of administrative litigation rules. Nevertheless, in environmental matters, the argument of an implied competence was made. Moreover, by signing the Aarhus Convention, the contracting parties agreed to adapt their litigation systems in environmental matters with international rules, which can form the basis for further going litigation standards in environmental matters.

\footnotetext{
${ }^{1474}$ Schmidt-Assmann, Einleitung, in: Schoch et al.(eds.), VwGO Kommentar, 2014, at 65.

${ }^{1475}$ Because of this - even if minimimum - interference, it may seem inappropriate to speak of a "procedural autonomy" and better to refer, as Galetta has formulated it, to the "functionalized procedural competence" of the Member States: Galetta, Procedural Autonomy of EU Member States : Paradise Lost ?, 2010.

${ }^{1476}$ Art. 81 TFEU.
} 


\section{c. A condition for European integration}

An important condition for the realisation of an ever closer Union is that states are in an equal position ${ }^{1477}$ and that citizens are treated equally under Union law. ${ }^{1478}$ The importance of the condition of equality of states was constantly stressed by Monnet. ${ }^{1479}$ This was rooted in the experiences he had with regard to the world order in the beginning and middle of the twentieth century, which was based on states trying to dominate each other. ${ }^{1480}$ Therefore, Monnet tried to develop a system in which the "spirit of superiority" ${ }^{1481}$ of states would be eliminated. Considering the experiences of the past and newly emerging threads to peace, he stressed that "equality should be the basis of pacific order of the world". ${ }^{1482}$ The point of reference of these considerations was the order already established within the borders of states, where laws and institutions guarantee the equality between citizens and solidarity between regions and the different layers in society. ${ }^{1483}$ A similar order should also develop between the states of Europe. ${ }^{1484}$ Even more, Monnet stressed that European integration was not only meant to create ever closer collaboration between states, but that the core of the entire process was the unification of people. ${ }^{1485}$ The aim was to create a "federation of European peoples". ${ }^{1486}$ In the common declaration of the Action Committee for the United States of Europe of 1 June 1964, section 1 (5) it was emphasised that:
"The transformation which is taking place is already changing men's behaviour towards each other; this is true above all of the younger generation. It is a fundamental transformation that we are seeking through the creation of the United States of Europe.

\footnotetext{
1477 "La Fédération est un pacte de confiance entre égaux", in : Ricard-Nihoul, Pour une Fédération Européenne D'Etats-Nations - La vision de Jacques Delors Revisitée, Larcier, Bruxelles, 2012, pp. 66 f.

1478 Gaudet, La Compétence de la Cour de Justice Pour l'Interprétation uniforme du droit Communautaire. Les Rélations du Juge National et du Juge Communautaire, Conférence de Bogota 21-25 Novembre 1972, FJME, Archives Michel Gaudet, p. 2.

1479 This was not limited to general considerations on the equality of states cited below, but Monnet wanted to establish a "partnership" based on equality especially with the United States: Elements de Reflexion en vue de preparer un projet de résolution, le 21 mars 1963, FJME, Fonds Jean Monnet, AMK 16/6/3 ; Projet de Declaration Commune, 8 avril 1963, FJME, Fonds Jean Monnet, AMK, 16/6/4, p. 2; these considerations found their voice in: Joint Declaration of 1 June 1964, Bonn, in: Action Committee for the United States of Europe, Statements and Declarations, 1955-67, London, Chatham House, P.E.P., 1969, pp. $71 \mathrm{ff}$.

${ }^{1480}$ See for example the considerations of Jean Monnet concerning the end of WW I "En 1919, nous avons perdu la paix. Nous l'avons perdue parce que nous avons reconstitué une Europe dont les nations blessées se sont repliées sur les marchés compartimentés et cartellisés derrière les protectionnismes nationaux virulents. La paix n'a pas établi une solidarité dans l'égalité entre vainqueurs et vaincus; elle a consacré les rapports de force nés de l'arbitrage des armes ", quoted in : Lalumière, Rieben, Faire Entrer l'Europe dans le Cour des Citoyens, FJME, Centre de recherches européennes, Lausanne, 1993, p. 49.

${ }^{1481}$ Own translation. Monnet, L'Europe et L'Organisation de La Paix, Centre de Recherches Européennes Ecole des H.E.C., Université de Lausanne, 1964, p. 5.

1482 Own translation. Ibid., p. 8.

${ }^{1483}$ Monnet, L'Europe Unie, De L'Utopie à la Réalité, Allocution prononcée au Congrès International de la Friedrich-Ebert-Stiftung, Centre de Recherches Européennes, Lausanne, 1972, p. 7.

1484 Ibid.

${ }^{1485}$ Monnet, Les Etats-Unis d'Europe ont Commencé, La communauté européenne du charbon et de l'acier, Robert Laffont, Paris, 1955, p. 109.

${ }^{1486}$ Notes for preparing the Declaration of 1 June 1964: Projet De Resolution, FJME, Fonds Jean Monnet, AMK $16 / 6 / 19$
} 
Within our nations, we have established institutions which enable the citizens of the same country to debate their problems and to find solutions for them which then become the law for all, the application of which is ensured by other institutions. We no longer permit the relations between citizens to be governed by notions of force, supremacy, or domination.

To establish these same conditions among the peoples of Europe, there is no other way than to apply to them the same methods that we all apply within our national frontiers- to adopt common rules which our nations and their citizens pledge themselves to follow, and to set up common institutions to ensure their application. Thus Europeans, while each remains profoundly attached to his nation, will together have the feeling that they belong to the same community, the affairs of which they will administer according to the democratic principles which govern the life of their nations." 1487

Fontaine observed with regard to these lines that Monnet has been repeating this message for years and because of which they may serve as the "spiritual testament of the father of Europe". ${ }^{1488}$ As regards the aim of unification of the people, Monnet proclaimed in a speech:

"The main reasons for my optimism is that we cannot fail in our ultimate aim which we want to achieve: unify people in equality and liberty." 1489

From the political perspective of Monnet, this means that the equal treatment under the same rule of Union law is an important prerequisite for European integration.

From a legal perspective, Gaudet emphasised the necessity that the Member States of the Union can "count on the equal application of common rules. Only if the rule is uniformly applied to anyone it can protect anyone." ${ }^{1490}$ Gaudet explained that in the judicial system of the Union, the focus was on the equality of the Member States: the obligations were equal in all Member States and the even more, the effects of Community law should be equal in any judicial order of the Union. ${ }^{1491}$ Moreover, he recognised that the principle of equality has importance for the functioning of the common market:

"The common rules must be applied and enforced on an equal basis. How could rules of fair competition for instance be interpreted and carried on separately by national governments

\footnotetext{
${ }^{1487}$ Joint Declaration adopted by the Committee, June 1, 1964, Bonn, FJME, Fonds Jean Monnet, AMK 16/6/210.

${ }^{1488}$ Fontaine, Le Comité d'Action pour les Etats-Unis de l'Europe de Jean Monnet, Centre de Recherches Européennes, Lausanne, 1974, p. 158.

${ }^{1489}$ Own translation. Monnet, L'Europe et L'Organisation de La Paix, Centre de Recherches Européennes École des H.E.C., Université de Lausanne, 1964, p. 14.

${ }^{1490}$ Gaudet, Les Rapports des Tribunaux Français avec les organisations et juridictions communautaires, Centre National D'Etudes Judiciaires, Bordeaux 23 May 1964, FJME, Fonds Michel Gaudet, pp. 32 f.

1491 “' L'accent est ainsi place sur l'égalité des Etats membres. Les obligations communautaires sont égales pour les Etats membres. Les effets du droit communautaire doivent être égaux dans tous les ordres juridiques" in : Gaudet, Les Conflits du Droit Communautaire avec les Droits Nationaux des Etats Membres, Centre Européen Universitaire de Nancy, 10/11 Mars 1967, FJME, Fonds Michel Gaudet, p. 38.
} 
without producing differences that would raise suspicion, discrimination and possibly retorsion [sic]?"1492

Finally, the principle of equality, as an "essential principle of democracies" ${ }^{1493}$ is not only of importance in the relations between states and market players. Gaudet stressed that a uniform interpretation is an "indispensable guarantee for the equality of citizens before the law". ${ }^{1494}$ In order to guarantee their equal treatment before the law, the application of the law must everywhere be the same. As was explained previously, this uniform interpretation and application could, according to Gaudet, be guaranteed by the mechanisms prescribed by the treaties, such as the preliminary ruling procedures and the principles as established by the Court of Justice, such as the doctrines of supremacy and direct effect. That the "equality of effects" does not solely depend on the uniform interpretation of a common rule but that it also depends on the circumstances surrounding the application was not addressed in his speeches and texts. Nevertheless, in conclusion, the idea of equal treatment under European law is clearly reflected in the early documents reflecting the ideas about European integration by Monnet and Gaudet. This is a lesson which can be learned also for future developments and strengthens the argument that for Union citizens, market players and the Member States the equal treatment before the same rules of law may also procedurally - be desirable.

\section{d. Conclusion}

Going back to the very beginnings of European Union (integration), when the peculiarities of the European legal order as opposed to usual international legal orders were slowly developing, the socalled "principle of national procedural autonomy" was not yet formulated. However, some of the early considerations on the application of law in the Union may be still of relevance for the question of this thesis to what extent common procedural rules may be desirable. A method for integration was, according to Monnet, the creation of common rules equally applicable to anyone, so that common interests could be achieved. Gaudet was concerned with the practical complications which could emerge when enforcing Union law and he stressed the importance that the supranational rules have to be complied with and that the application of the law happens on an equal basis. Both considerations are echoed in the jurisprudence of the Court of Justice, which emphasises the need for an effective and uniform enforcement of the law. This enforcement of Union law on an equal basis has become more difficult if compared to the beginnings of integration to the extent that many more competences have be conferred on the Union and that the number of participating states increased from six to twenty eight. Today, there is a very large body of substantive European Union law which has to be equally applied in

1492 The French word "rétorsion" would have been properly translated with "vengeance"; Address by Michael Gaudet on "The Legal Systems of the European Community" at the Institute on the legal Aspects of the European Community, Washington, February 11 to February 13, 1960, FJME, Fonds Michel Gaudet, p. 6.

${ }^{1493}$ Gaudet, La Compétence de la Cour de Justice Pour l'Interpretation uniforme du droit Communautaire. Les Rélations du Juge National et du Juge Communautaire, Conférence de Bogota 21-25 Novembre 1972, FJME, Fonds Michel Gaudet, p. 2.

1494 Ibid. 
a great number of Member States. This thesis has shown that because of different litigation rules, the enforcement of Union law is fragmented and claimants are treated procedurally unequal under the same rule of Union law. It seems even more astonishing that no real attempt was made to go beyond the "procedural autonomy" of Member States and to consider the conferral of an explicit procedural competence to the Union where (substantive) rules of Union law are at stake. The creation of common administrative rules could contribute to a Union-wide effective and uniform enforcement of Union law, and, by this means, create an ever closer Union among the peoples of Europe. What can be learned from the beginnings of European integration is that the effective enforcement of common rules on an equal basis is of paramount importance in order to achieve common goals. Henri Rieben explained:

“Jean Monnet, les homes d'Etat qu'il a inspirés, les responsables des partis politiques et des syndicats réunis dans le Comité d'Action pour les Etats Unis d'Europe et leurs successeurs ont voulu amener les Européens à réaliser une Communauté de destin dont les partenaires égaux devant la loi commune acceptent de substituer l'arbitrage du droit à celui de la force, dans laquelle une communauté de nations riches de leurs diversités, fières de leur identité, cherchent dans l'union la capacité accomplir ensemble ce qu'aucune de ces nations ne peut plus réaliser seule ${ }^{1495}$ (emphasis added).

(Jean Monnet, the statesmen which he inspired, the representatives of political parties who all were united in the Committee for the United States of Europe and their successors, wanted the European peoples to realise a community in which they, as equal partners before the law of the Community, would accept to substitute the power of force to the power of law, and to realise a community of different nation states which, being very diverse and proud of their identity, try to achieve together what none of the single nation states can achieve alone.)

${ }^{1495}$ Rieben, A Luxembourg au Cour du chantier européen avec Jean Monnet et Pierre Werner, FJME, 1993, p. 64. 


\section{Conclusion of Part III}

In this part, the third research question was discussed on whether it is necessary, desirable and possible to develop common rules on administrative litigation in environmental matters in the Union.

To begin with, it was shown that there is further potential for Union intervention, as at various points, it can be doubted that the national litigation rules comply with the European standard as developed by the Court of Justice and as emanating from the Aarhus Convention and its Union implementing legislation. An intervention by the Court of Justice on this basis may lead to further convergences between the different litigation systems, however, seeing the European Union with its 28 Member States, it is likely that differences will continue to exist for a long time.

Moreover, on the basis of the findings of Part II, the advantages and disadvantages of the creation of common administrative litigation rules in environmental matters were discussed. In conclusion, various arguments for the creation of similar enforcement chances and the guarantee of the uniform enforcement of Union law were found. In the author's point of view, the most important argument in favour of the creation of common rules is that individuals and environmental organisations would be treated procedurally equal under the same rule of Union law. However, there is no express conferral of powers for the creation of administrative litigation rules to the Union level. Nevertheless, common rules could be adopted by implementing and concretising the requirements of the Aarhus Convention and an implied competence can be found in article 192 TFEU. Furthermore, it should be stressed that in the Union context, common rules are not only created by means of Union legislation, but that also national crossloading alignment processes can lead to similar rules in the Union. This thesis has for example pointed at the alignment process between the German and the Dutch legal system, when the Netherlands introduced the relativiteitsvereiste (requirement of connection) which is, despite some differences, similar to the German Schutznorm theory. In any event, the advantage of legislation, as opposed to national alignment processes, is that a regulation or directive would provide for a comprehensive, binding and clear framework for the entire Union and it would not leave the development of similar enforcement rules to chance and piece-meal approaches.

Finally, looking back to the beginnings of European integration, it becomes clear that the idea was to create common rules which would be equally applicable to any person in the Union. This thesis has argued that not only the equal substantive application of the law is necessary in the Union legal order, but that also a procedural enforcement on an equal basis is desirable. Therefore, the creation of common rules, either by means of legislation, by means of further intervention of the Court of Justice, or by national cross-loading alignment processes is desirable, so that the premise is:

Ubi ius Europaeum, ibi remedium Europaeum. 
Annexes 


\section{Hypothetical Case Study}

\section{The Setting of the Case Study}

Developer D wants to establish and operate an intensive livestock installation. This installation shall be located in a rural, hilly area which is sparsely populated and which is covered by lakes, streams and forests.

In the west of the planned installation, there are several lakes surrounded by mixed forests and small fields for agricultural use.

At a distance of 480 meters in the north of the installation, there is a (public) deciduous forest.

Moreover, at a distance of 1.3 kilometers in the north-east, one finds "property A".

At a distance of 510 meters in the east of the planned installation, there is a village with 4392 inhabitants.

Map of the site:

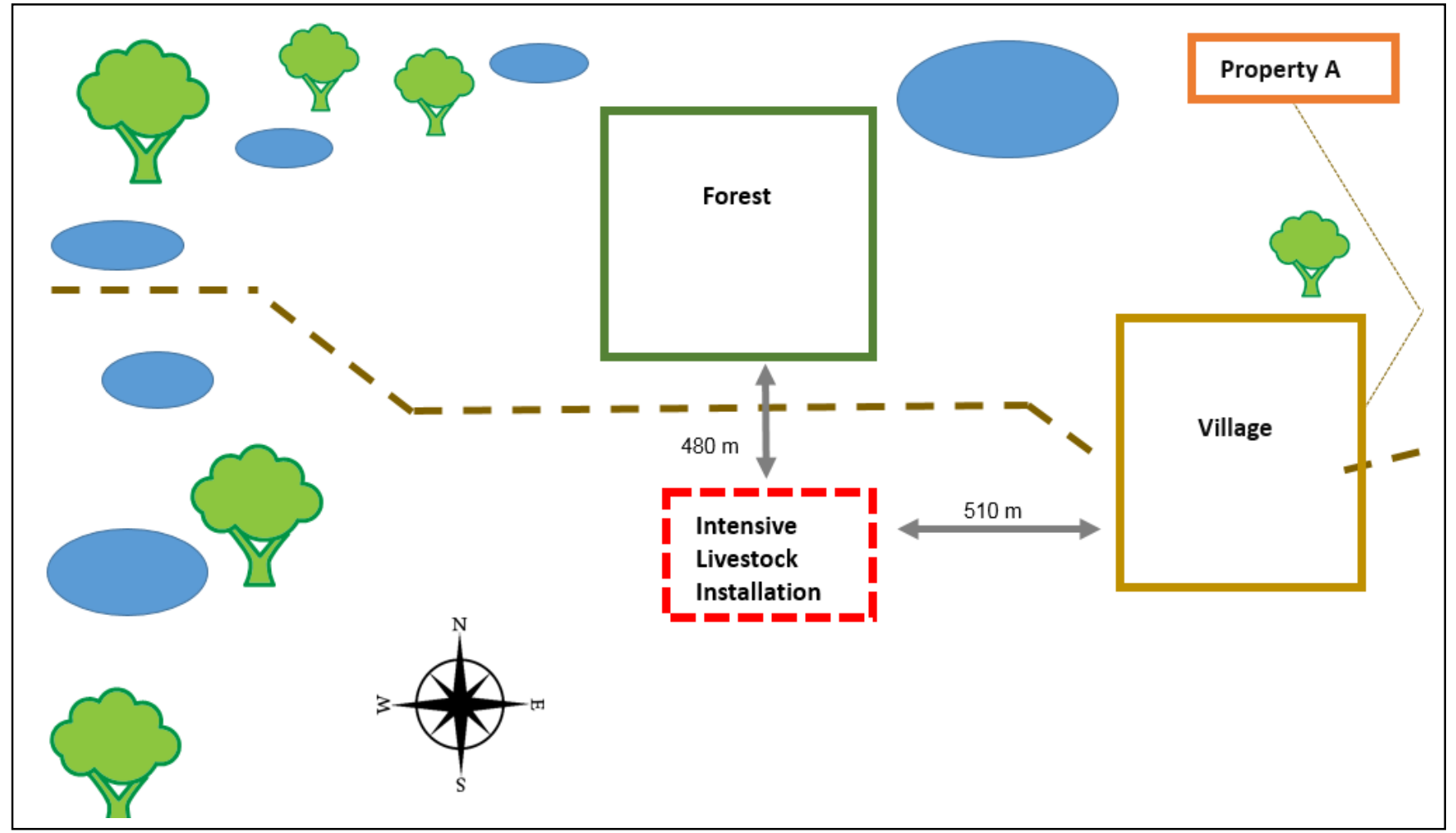




\subsection{Facts of Case One: The Screening}

$\mathrm{D}$ applies for permission to establish and to operate a pig fattening farm with a capacity of $\mathbf{2 , 8 0 0}$ pigs. According to the national EIA legislation, ${ }^{1496}$ the thresholds for making a screening are exceeded. Therefore, the competent public authority makes a rough assessment of potential significant impacts on the environment. The authority finds that no significant impacts are expected and concludes that no EIA needs to be carried out. The permission for the establishment and operation of the pig fattening farm is granted to D.

\subsection{Facts of Case Two: The Environmental Impact Assessment}

D applies for permission to establish and to operate of a pig fattening farm with a capacity of $\mathbf{3 , 5 0 0}$ pigs, meaning that the thresholds prescribed by the EIA Directive are exceeded, ${ }^{1497}$ so that an EIA is obligatory. The authority complies with this obligation, the developer submits the relevant information and an environmental statement is drafted. The authority takes the statement into consideration when determining the application. The permission for the establishment and operation of the installation is granted to D.

\section{The Claimants}

For the purpose of this case study, a distinction is made between four different claimants. Their cases will be dealt with separately, supposing each time that only one of them makes an application for judicial review.

Claimant A:

A is the owner of and lives in "property A". His property is located at a distance of $1.3 \mathrm{~km}$ from the planned installation. From the veranda of his house, he can see the deciduous forest. Every day, he takes a walk of one hour in the forest.

Claimant BP: $\quad$ B is a group of approximately 300 citizens in the village headed by their "elected president" BP. The group has been campaigning informally against the construction of the livestock installation by hanging up posters on the streets saying "No to Pigs" and they have "collected signatures" against D's installation which they submitted to the major of the village.

\footnotetext{
${ }^{1496}$ England: TCPR (EIA) 2011- Schedule 2, Nr. 1 c (500 sqm) and Circular 02/99 at A4 (indicative threshold > 2000); Germany: §3c S. 1 UVPG i.V.m. Anlage 1, Nr. 7.7.2 (> 2000; < 3000); The Netherlands: Art. 7.2 (1) b Wm jo. Bijlage behorende bij het Besluit milieueffectrapportage, D lijst Nr. 14 (2) (>2000).

${ }^{1497}$ Annex I, nr. 17 (b) EIA Directive (> 3000 places for the production of pigs); England: TCPR (EIA) 2011 Schedule 1 Nr. 17 b; Germany: $§ 3$ b Abs. 1 UVPG i.V.m. Anlage 1 Nr. 7.7.1 (> 3000); The Netherlands: Art. 7.2 (1) a Wm jo. Bijlage behorende bij het Besluit milieueffectrapportage C lijst Nr. 14 (2) (>3000).
} 

campaigning for the protection of the forests in the region where the development shall be located.

Claimant X: $\mathrm{X}$ operates an ecological pig farming installation in a village situated at a distance of 8 kilometers from D's installation. He fears that D's development would place him at a competitive disadvantage.

\section{The Claims}

In this case study, a distinction is made between ten different claims. Five claims concern the case of the screening (case one), the other five claims concern case of the environmental impact assessment (case two). The claims will be dealt with separately, supposing each time that this is the only claim made by the respective claimant.

With regard to claim 1 and claim 6, the case scenario is modified to the extent that the competent authority did not conduct a screening/ an EIA at all.

\subsection{The Claims in Case One: The Environmental Screening}

Claim 1: $\quad$ Modification of the case scenario: The competent authority granted permission without a screening.

The claim is that the screening was wrongfully omitted.

Claim 2:

The screening wrongfully omits to consider the effects of ammonia on the deciduous forest. The claimant submits that the trees would seriously suffer from the deposition of ammonia.

Claim 3:

The screening omits to explicitly consider the main direction of the wind and therefore it could not be concluded that claimant would not be affected by the odor emitted from the installation.

Claim 4:

The methodology used for analysing the potential effects of ammonia on the deciduous forest is insufficient. The screening materials provide for a scheme on the potential dispersion of ammonia. According to the scheme, national thresholds which are commonly taken as a basis in your national legal system are not exceeded. The authority therefore concludes that there will be no significant adverse effects on the environment. The claimant submits that in the forest there are various deciduous trees of a rare species which would seriously suffer from the deposition of ammonia also where these commonly used thresholds are not exceeded. 
The screening is based on incorrect data concerning the direction of the wind. According to the screening materials, the wind mainly blows from east to west, meaning that the inhabitants of the village would not be affected by the odor emitted by the installation. The claimant is of opinion that the dispersion calculation is wrong, arguing that the wind mainly blows from west to east, meaning that the village would be adversely affected by the odor emitted by the installation.

The graph on the direction of wind in the screening:

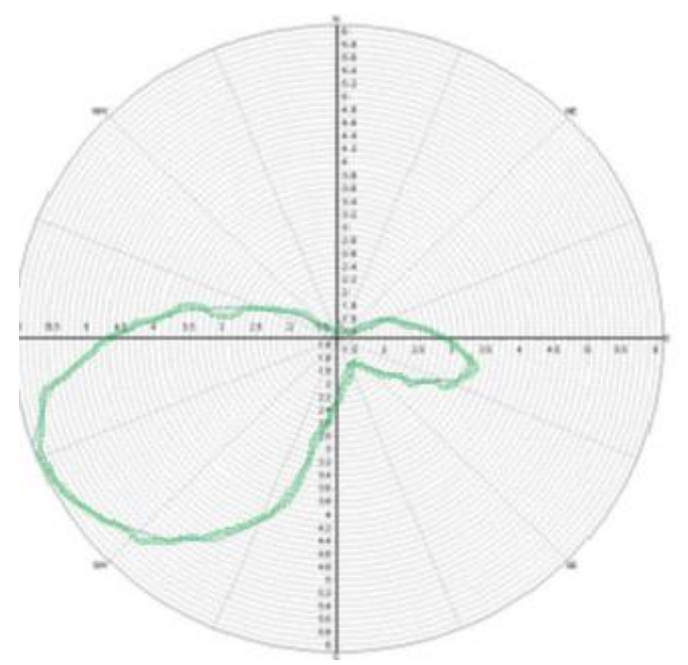

\subsection{The Claims in Case Two: The Environmental Impact Assessment}

Claim 6: $\quad$ Modification of the case scenario: The competent authority granted permission without an EIA.

The claim is that the EIA was wrongfully omitted

Claim 7:

The EIA wrongfully omits to consider the effects of ammonia on the deciduous forest. The trees would seriously suffer from the deposition of ammonia.

Claim 8:

The EIA lacks information on the direction of the wind and therefore wrongly concludes that claimant would not be affected by the odor emitted from the installation.

Claim 9:

The methodology used for analysing the potential effects of ammonia emissions for the forest is insufficient. The environmental statement provides for a scheme on the potential dispersion of ammonia. According to the scheme, the thresholds 
which are commonly utilised in your national legal system are not exceeded. The claimant submits that in the forest there are various deciduous trees of a rare species which would seriously suffer from the deposition of ammonia also where these commonly used thresholds are not exceeded.

\section{Claim 10:}

The environmental impact assessment is based on incorrect data concerning the direction of the wind. According to the environmental statement which provides for a graph on the dispersion of odor, the wind mainly blows from east to west, meaning that the inhabitants of the village would not be affected by the odor emitted by the installation. The claimant is of opinion that the dispersion calculation is wrong, arguing that the wind mainly blows from west to east, meaning that the village would be adversely affected by the odor emitted by the installation.

The graph on the direction of wind in the Environmental Statement

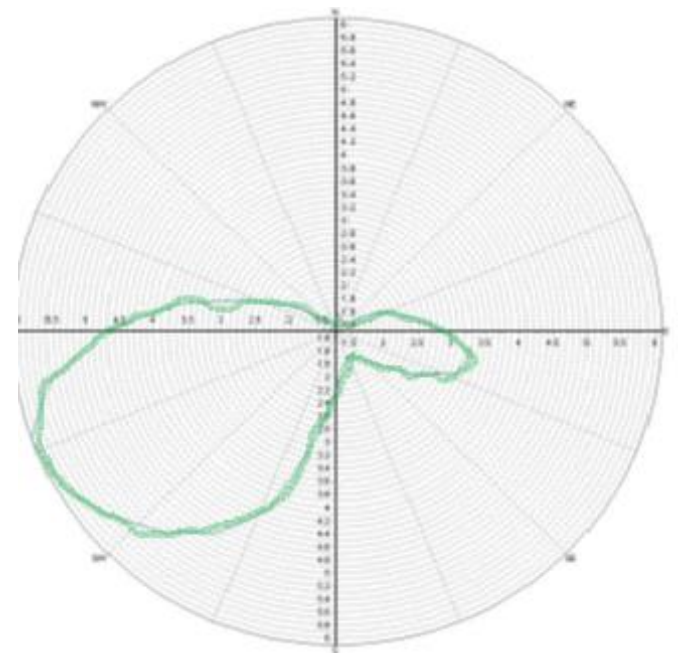




\section{Part I of the Hypothetical Case Study: Comparative Discussion on Standing Requirements}

In this part, national rules on standing will be compared. For this purpose, "case one" on the environmental screening will be taken as the basis for discussion.

$D$ applies for permission for the establishment and operation of a pig fattening farm with a capacity of $\mathbf{2 8 0 0}$ pigs. According to the national EIA legislation, the thresholds for making a screening are exceeded. Therefore, the competent public authority makes a rough assessment of potential significant impacts on the environment. The authority finds that no significant impacts are expected and concludes that no EIA needs to be done. The permission for the establishment and operation of the pig fattening farm is granted to $D$.

The question with regard to each claimant and each claim submitted is whether they will be granted standing in an administrative court in your legal system.

Claimant A:

$A$ is owner of and lives in "Property $A$ " which is located at a distance of 1.3 $\mathrm{km}$ from the planned installation.

\section{Claim 1}

Modification of the case scenario: The competent authority granted the permission without a screening.

The claim is that the screening was wrongfully omitted.

\section{Claim 2}

The screening wrongfully omits to consider the effects of ammonia on the deciduous forest. The trees would seriously suffer from the deposition of ammonia.

\section{Claim 3}

The screening lacks information on the direction of the wind and therefore wrongly concludes that A would not be affected by the odor emitted from the installation.

\section{Claim 4}

The methodology used for analysing the potential effects of ammonia on the deciduous forest is insufficient. The screening materials provide for a scheme 
on the potential dispersion of ammonia. According to the scheme, national thresholds which are commonly taken as a basis in your national legal system are not exceeded. The authority therefore concludes that there will be no significant adverse effects on the environment. The claimant submits that in the forest there are various deciduous trees of a rare species which would seriously suffer from the deposition of ammonia also where these commonly used thresholds are not exceeded.

\section{$\underline{\text { Claim } 5}$}

The screening is based on incorrect data concerning the direction of the wind. According to the screening materials, the wind mainly blows from east to west, meaning that the inhabitants of the village would not be affected by the odor emitted by the installation. The claimant is of opinion that the dispersion calculation is wrong, arguing that the wind mainly blows from west to east, meaning that the village and also his property would be adversely affected by the odor emitted by the installation.

\section{Claimant BP:}

B is a group of citizens in the village headed by their "elected president" BP. The group has been campaigning informally against the construction of the livestock installation by hanging up posters on the streets saying "No to Pigs" and they have “collected signatures" against D's installation.

\section{Claim 1}

Modification of the case scenario: The competent authority granted the permission without a screening.

The claim is that the screening was wrongfully omitted.

\section{$\underline{\text { Claim } 2}$}

The screening wrongfully omits to consider the effects of ammonia on the deciduous forest. The trees would seriously suffer from the deposition of ammonia.

\section{$\underline{\text { Claim } 3}$}

The screening lacks information on the direction of the wind and therefore wrongly concludes that A would not be affected by the odor emitted from the installation.

\section{Claim 4}


The methodology used for analysing the potential effects of ammonia on the forest is insufficient. The screening materials provide for a scheme on the potential dispersion of ammonia. According to the scheme, national thresholds which are commonly taken as a basis in your national legal system are not exceeded. The authority therefore concludes that there will be no significant adverse effects on the environment. The claimant submits that in the forest there are various deciduous trees of rare species which would seriously suffer from the deposition of ammonia also where these commonly used thresholds are not exceeded.

\section{Claim 5}

The screening is based on incorrect data concerning the direction of the wind. According to the screening materials, the wind mainly blows from east to west, meaning that the inhabitants of the village would not be affected by the odor emitted by the installation. The claimant is of opinion that the dispersion calculation is wrong, arguing that the wind mainly blows from west to east, meaning that the village would be adversely affected by the odor emitted by the installation.

\section{Claimant C:}

$C$ is an officially recognised environmental organisation and has been campaigning for the protection of the forests in the region where the development shall be located

\section{Claim 1}

Modification of the case scenario: The competent authority granted the permission without a screening.

The claim is that the screening was wrongfully omitted.

\section{Claim 2}

The screening wrongfully omits to consider the effects of ammonia on the deciduous forest. The trees would seriously suffer from the deposition of ammonia.

\section{$\underline{\text { Claim } 3}$}

The screening lacks information on the direction of the wind and therefore wrongly concludes that A would not be affected by the odor emitted from the installation. 


\section{Claim 4}

The methodology used for analysing the potential effects of ammonia emissions on the forest is insufficient. The screening materials provide for a scheme on the potential dispersion of ammonia. According to the scheme, national thresholds which are commonly taken as a basis in your national legal system are not exceeded. The authority therefore concludes that there will be no significant adverse effects on the environment. The claimant submits that in the forest there are various deciduous trees of rare species which would seriously suffer from the deposition of ammonia also where these commonly used thresholds are not exceeded.

\section{$\underline{\text { Claim } 5}$}

The screening is based on incorrect data concerning the direction of the wind. According to the screening materials, the wind mainly blows from east to west, meaning that the inhabitants of the village would not be affected by the odor emitted by the installation. The claimant is of opinion that the dispersion calculation is wrong, arguing that the wind mainly blows from west to east, meaning that the village would be adversely affected by the odor emitted by the installation.

\section{Additional questions concerning claimant $C$ :}

Q: Does it make a difference if $\mathrm{C}$ is a recognised environmental organization which is usually not active in the area in which the development is placed.

Q: Does it make a difference if $\mathrm{C}$ is a recognised environmental organization which in its statutes stipulates that it prime concern is the "protection of animals and rare species".

\section{Claimant X:}

$X$ operates an ecological pig farming installation in a village situated at a distance of 8 kilometers from D's installation. He fears that D's development would place him at a competitive disadvantage.

\section{Claim 1}

Modification of the case scenario: The competent authority granted the permission without a screening.

The claim is that the screening was wrongfully omitted 


\section{Claim 2}

The screening wrongfully omits to consider the effects of ammonia on the deciduous forest. The trees would seriously suffer from the deposition of ammonia.

\section{$\underline{\text { Claim } 3}$}

The screening lacks information on the direction of the wind and therefore wrongly concludes that A would not be affected by the odor emitted from the installation.

\section{$\underline{\text { Claim } 4}$}

The methodology used for analysing the potential effects of ammonia on the forest is insufficient. The screening materials provide for a scheme on the potential dispersion of ammonia. According to the scheme, national thresholds which are commonly taken as a basis in your national legal system are not exceeded. The authority therefore concludes that there will be no significant adverse effects on the environment. The claimant submits that in the forest there are various deciduous trees of rare species which would seriously suffer from the deposition of ammonia also where these commonly used thresholds are not exceeded.

\section{$\underline{\text { Claim } 5}$}

The screening is based on incorrect data concerning the direction of the wind. According to the screening materials, the wind mainly blows from east to west, meaning that the inhabitants of the village would not be affected by the odor emitted by the installation. The claimant is of opinion that the dispersion calculation is wrong, arguing that the wind mainly blows from west to east, meaning that the village would be adversely affected by the odor emitted by the installation. 


\section{Part II of the Hypothetical Case Study: Comparative Discussion on the Intensity of Review and the Burden of Proof}

In this part, national rules on review and the burden of proof shall be compared. For this purpose, there shall first be a discussion of case one, followed by a discussion of case two.

1. Case One: The Screening

D applies for permission for the establishment and operation of a pig fattening farm with a capacity of 2,800 pigs. According to the national EIA legislation, the thresholds for making a screening are exceeded. Therefore, the competent public authority makes a rough assessment of potential significant impacts on the environment. The authority finds that no significant impacts are expected and concludes that no EIA needs to be done. The permission for the establishment and operation of the pig fattening farm is granted to $D$.

Please suppose that at least one of the claimants presented above has standing in an administrative court in your legal system. This claimant also complied with any other requirement of admissibility (payment of court fees, time limits...)

The main questions to be comparatively discussed are:

1. How will you assess the claim, i.e. what "test" do you apply in your legal system to review the screening conducted by the public authority?

2. Who bears the burden of proof?

3. What needs to be proven? Is it necessary to establish a causal link between the error in the screening process and the grant of the permission?

4. Is it necessary that the claimant already raised this claim during the administrative procedure before the grant of the permission? What are the consequences if he did not raise this claim in the administrative procedure?

Claim 1:

Modification of the case scenario: The competent authority granted the permission without a screening.

The claim is that the screening was wrongfully omitted.

Claim 2:

The screening wrongfully omits to consider the effects of ammonia on the deciduous forest. The claimant alleges that the trees would seriously suffer from the deposition of ammonia. 
Claim 3:

Claim 4:

Claim 5:

Case Two: The Environmental Impact Assessment

$\mathrm{D}$ applies for permission for the establishment and operation of a pig fattening farm with a capacity of 3,500 pigs, meaning that the thresholds prescribed by the EIA Directive are exceeded, so that an EIA is obligatory. The authority complies with this obligation, the developer submits the relevant information and an environmental statement is drafted. The authority takes the statement into consideration when determining the application. The permission for the establishment and operation of the installation is granted to $D$.

Please suppose that at least one of the claimants presented above has standing in your court. He complied with every other requirement of admissibility (payment of court fees, time limits...)

1. How will you assess the claim, i.e. what "test" do you apply in your legal system to review the environmental impact assessment? Is this "test" regulated by statute?

2. Who bears the burden of proof? 
3. What needs to be proven? Is it necessary to establish a causal link between the error in the environmental statement and the grant of the permission?

4. Is it necessary that the claimant already raised this claim during the administrative procedure before the grant of the permission? What are the consequences if he did not raise this claim in the administrative procedure?

Claim 6:

Claim 7:

Claim 8:

Claim 9:

Claim 10:
Modification of the case scenario: The competent authority granted the permission without an EIA.

The claim is that the EIA was wrongfully omitted.

The EIA wrongfully omits to consider the effects of ammonia on the deciduous forest. Claimant alleges that the trees would seriously suffer from the deposition of ammonia.

The EIA lacks information on the direction of the wind and therefore wrongly concludes that claimant would not be affected by the odor emitted from the installation.

The methodology used for analysing the potential effects of ammonia on the deciduous forest is insufficient. The environmental statement provides for a scheme on the potential dispersion of ammonia. According to the scheme, the thresholds which are commonly utilised in your national legal system are not exceeded. The claimant submits that in the forest there are various deciduous trees of rare species which would seriously suffer from the deposition of ammonia also where these commonly used thresholds are not exceeded.

The environmental impact assessment is based on incorrect data concerning the direction of the wind. According to the environmental statement which provides for a graph on the dispersion of odor, the wind mainly blows from east to west, meaning that the inhabitants of the village would not be affected by the odor emitted by the installation. The claimant is of opinion that the dispersion calculation is wrong, arguing that the wind mainly blows from west to east, meaning that the village would be adversely affected by the odor emitted by the installation. 


\section{Part III of the Hypothetical case study: Comparative Discussion on Remedies}

In this part, rules on remedies will be discussed from a comparative perspective. For this purpose, there will first be a discussion of case one, followed by a discussion of case two.

\section{Case One: The Screening}

$D$ applies for permission for the establishment and operation of a pig fattening farm with a capacity of $\mathbf{2 8 0 0}$ pigs. According to the national EIA legislation, the thresholds for making a screening are exceeded. Therefore, the competent public authority makes a rough assessment of potential significant impacts on the environment. The authority finds that no significant impacts are expected and concludes that no EIA needs to be done. The permission for the establishment and operation of the pig fattening farm is granted to $D$.

The questions that shall be discussed are:

1. What is the remedy provided in your legal system with regard to breaches of EIA legislation? Would you quash the permission, would you ask the administrative authority for a correction of the procedural error or would you disregard the procedural error? Are there other possibilities?

2. Is it necessary for the claimant to have a certain interest or right in order to be successful in his claim?

A distinction is again made between the claimants $\mathrm{A}, \mathrm{BP}, \mathrm{C}$ and $\mathrm{X}$ and their different claims. If you decided previously that a claimant does not have standing in your legal system, then please skip the section on this claimant.

Claimant A:

A is owner of and lives in "property A", which is located at a distance of $1.3 \mathrm{~km}$ from the planned installation.

\section{$\underline{\text { Claim } 1}$}

Modification of the case scenario: The competent authority granted the permission without a screening.

The claim is that the screening was wrongfully omitted. 


\title{
Claim 2
}

The screening wrongfully omits to consider the effects of ammonia on the deciduous forest. The trees would seriously suffer from the deposition of ammonia.

\section{$\underline{\text { Claim } 3}$}

The screening lacks information on the direction of the wind and therefore wrongly concludes that A would not be affected by the odor emitted from the installation.

\section{$\underline{\text { Claim } 4}$}

The methodology used for analysing the potential effects of on the deciduous forest is insufficient. The screening materials provide for a scheme on the potential dispersion of ammonia. According to the scheme, national thresholds which are commonly taken as a basis in your national legal system are not exceeded. The authority therefore concludes that there will be no significant adverse effects on the environment. The claimant submits that in the forest there are various deciduous trees of rare species which would seriously suffer from the deposition of ammonia also where these commonly used thresholds are not exceeded.

\section{$\underline{\text { Claim } 5}$}

The screening is based on incorrect data concerning the direction of the wind. According to the screening materials, the wind mainly blows from east to west, meaning that the inhabitants of the village would not be affected by the odor emitted by the installation. The claimant is of opinion that the dispersion calculation is wrong, arguing that the wind mainly blows from west to east, meaning that the village and also his property would be adversely affected by the odor emitted by the installation.

\section{Claimant BP:}

\author{
B is a group of citizens in the village headed by their "elected president" \\ BP. The group has been campaigning informally against the construction \\ of the livestock installation by hanging up posters on the streets saying "No \\ to Pigs" and they have "collected signatures" against D's installation.
}




\section{Claim 1}

Modification of the case scenario: The competent authority granted the permission without a screening.

The claim is that the screening was wrongfully omitted.

\section{Claim 2}

The screening wrongfully omits to consider the effects of ammonia on the deciduous forest. The trees would seriously suffer from the deposition of ammonia.

\section{Claim 3}

The screening lacks information on the direction of the wind and therefore wrongly concludes that A would not be affected by the odor emitted from the installation.

\section{Claim 4}

The methodology used for analysing the potential effects of ammonia on the deciduous forest is insufficient. The screening materials provide for a scheme on the potential dispersion of ammonia. According to the scheme, national thresholds which are commonly taken as a basis in your national legal system are not exceeded. The authority therefore concludes that there will be no significant adverse effects on the environment. The claimant submits that in the forest there are various deciduous trees of rare species which would seriously suffer from the deposition of ammonia also where these commonly used thresholds are not exceeded.

\section{$\underline{\text { Claim } 5}$}

The screening is based on incorrect data concerning the direction of the wind. According to the screening materials, the wind mainly blows from east to west, meaning that the inhabitants of the village would not be affected by the odor emitted by the installation. The claimant is of opinion that the dispersion calculation is wrong, arguing that the wind mainly blows from west to east, meaning that the village would be adversely affected by the odor emitted by the installation. 

campaigning for the protection of the forests in the region where the development shall be located.

\section{$\underline{\text { Claim } 1}$}

Modification of the case scenario: The competent authority granted the permission without a screening.

The claim is that the screening was wrongfully omitted.

\section{$\underline{\text { Claim } 2}$}

The screening wrongfully omits to consider the effects of ammonia on the deciduous forest. The trees would seriously suffer from the deposition of ammonia

\section{$\underline{\text { Claim } 3}$}

The screening lacks information on the direction of the wind and therefore wrongly concludes that A would not be affected by the odor emitted from the installation.

\section{$\underline{\text { Claim } 4}$}

The methodology used for analysing the potential effects of ammonia on the deciduous forest is insufficient. The screening materials provide for a scheme on the potential dispersion of ammonia. According to the scheme, national thresholds which are commonly taken as a basis in your national legal system are not exceeded. The authority therefore concludes that there will be no significant adverse effects on the environment. The claimant submits that in the forest there are various deciduous trees of rare species which would seriously suffer from the deposition of ammonia also where these commonly used thresholds are not exceeded.

\section{Claim 5}

The screening is based on incorrect data concerning the direction of the wind. According to the screening materials, the wind mainly blows from east to west, meaning that the inhabitants of the village would not be affected by the odor emitted by the installation. The claimant is of opinion that the dispersion calculation is wrong, arguing that the wind mainly blows from west to east, 
meaning that the village would be adversely affected by the odor emitted by the installation.

Additional questions regarding claimant $\mathrm{C}$ :

Q: Does it make a difference if $\mathrm{C}$ is a recognised environmental organization which is usually not active in the area in which the development is placed.

Q: Does it make a difference if $\mathrm{C}$ is a recognised environmental organization which in its statutes stipulates that it prime concern is the "protection of animals and rare species"

\section{Claimant X:}

$X$ operates an ecological pig farming installation in a village situated at a distance of 8 kilometers from D's installation. He fears that D's development would place him at a competitive disadvantage.

\section{$\underline{\text { Claim } 1}$}

Modification of the case scenario: The competent authority granted the permission without a screening.

The claim is that the screening was wrongfully omitted.

\section{Claim 2}

The screening wrongfully omits to consider the effects of ammonia on the deciduous forest. The trees would seriously suffer from the deposition of ammonia.

\section{$\underline{\text { Claim } 3}$}

The screening lacks information on the direction of the wind and therefore wrongly concludes that A would not be affected by the odor emitted from the installation.

\section{Claim 4}

The methodology used for analysing the potential effects of ammonia on the forest is insufficient. The screening materials provide for a scheme on the potential dispersion of ammonia. According to the scheme, national thresholds which are commonly taken as a basis in your national legal system are not 
exceeded. The authority therefore concludes that there will be no significant adverse effects on the environment. The claimant submits that in the forest there are various deciduous trees of rare species which would seriously suffer from the deposition of ammonia also where these commonly used thresholds are not exceeded.

\section{Claim 5}

The screening is based on incorrect data concerning the direction of the wind. According to the screening materials, the wind mainly blows from east to west, meaning that the inhabitants of the village would not be affected by the odor emitted by the installation. The claimant is of opinion that the dispersion calculation is wrong, arguing that the wind mainly blows from west to east, meaning that the village would be adversely affected by the odor emitted by the installation.

\section{Case Two: the Environmental Impact Assessment}

D applies for permission for the establishment and operation of a pig fattening farm with a capacity of 3,500 pigs, meaning that the thresholds prescribed by the EIA Directive are exceeded, so that an EIA is obligatory. The authority complies with this obligation; the developer submits the relevant information and an environmental statement is drafted. The authority takes the statement into consideration when determining the application. The permission for the establishment and operation of the installation is granted to $D$.

The following questions will guide the discussion:

1. What is the remedy provided in your legal system with regard to these breaches? Would you quash the permission, would you ask the administrative authority for a correction of the procedural error or would you disregard the procedural error?

2. Is it necessary for the claimant to have a certain interest or right in order to be successful in his claim?

Distinction is again made between the claimants $\mathrm{A}, \mathrm{BP}, \mathrm{C}$ and $\mathrm{X}$ and their different claims. If you decided previously that a claimant does not have standing in your legal system, then please skip the section on this claimant. 

of $1.3 \mathrm{~km}$ from the planned installation

\section{Claim 6}

Modification of the case scenario: The competent authority granted the permission without an EIA.

The claim is that the EIA was wrongfully omitted.

\section{Claim 7}

The EIA wrongfully omits to consider the effects of ammonia on the deciduous forest. The trees would seriously suffer from the deposition of ammonia.

\section{$\underline{\text { Claim } 8}$}

The EIA lacks information on the direction of the wind and therefore wrongly concludes that A would not be affected by the odor emitted from the installation.

\section{$\underline{\text { Claim } 9}$}

The methodology used for analysing the potential effects of ammonia on the forest is insufficient. The environmental statement provides for a scheme on the potential dispersion of ammonia. According to the scheme, the thresholds which are commonly utilised in your national legal system are not exceeded. Claimant submits that in the forest there are various deciduous trees of rare species which would seriously suffer from the deposition of ammonia also where these commonly used thresholds are not exceeded.

\section{$\underline{\text { Claim } 10}$}

The environmental impact assessment is based on incorrect data concerning the direction of the wind. According to the environmental statement which provides for a graph on the dispersion of odor, the wind mainly blows from east to west, meaning that the inhabitants of the village would not be affected by the odor emitted by the installation. The claimant is of opinion that the dispersion calculation is wrong, arguing that the wind mainly blows from west to east, meaning that the village and also his property would be adversely affected by the odor emitted by the installation. 

BP. The group has been campaigning informally against the construction of the livestock installation by hanging up posters on the streets saying "No to Pigs" and they have "collected signatures" against D's installation.

\section{$\underline{\text { Claim } 6}$}

Modification of the case scenario: The competent authority granted the permission without an EIA.

The claim is that the EIA was wrongfully omitted.

\section{$\underline{\text { Claim } 7}$}

The EIA wrongfully omits to consider the effects of ammonia on the deciduous forest. The trees would seriously suffer from the deposition of ammonia.

\section{$\underline{\text { Claim } 8}$}

The EIA lacks information on the direction of the wind and therefore wrongly concludes that A would not be affected by the odor emitted from the installation.

\section{$\underline{\text { Claim } 9}$}

The methodology used for analysing the potential effects of ammonia on the forest is insufficient. The environmental statement provides for a scheme on the potential dispersion of ammonia. According to the scheme, the thresholds which are commonly utilized in your national legal system are not exceeded. The claimant submits that in the forest there are various deciduous trees of rare species which would seriously suffer from the deposition of ammonia also where these commonly used thresholds are not exceeded.

\section{Claim 10}

The environmental impact assessment is based on incorrect data concerning the direction of the wind. According to the environmental statement which provides for a graph on the dispersion of odor, the wind mainly blows from east to west, meaning that the inhabitants of the village would not be affected by the odor emitted by the installation. The claimant is of opinion that the dispersion calculation is wrong, arguing that the wind mainly blows from west to east, meaning that the village would be adversely affected by the odor emitted by the installation 

campaigning for the protection of the forests in the region where the development shall be located

\section{$\underline{\text { Claim } 6}$}

Modification of the case scenario: The competent authority granted the permission without an EIA.

The claim is that the EIA was wrongfully omitted.

\section{$\underline{\text { Claim } 7}$}

The EIA wrongfully omits to consider the effects of ammonia on the deciduous forest. The trees would seriously suffer from the deposition of ammonia.

\section{$\underline{\text { Claim } 8}$}

The EIA lacks information on the direction of the wind and therefore wrongly concludes that A would not be affected by the odor emitted from the installation.

\section{$\underline{\text { Claim } 9}$}

The methodology used for analysing the potential effects of ammonia emissions for the forest is insufficient. The environmental statement provides for a scheme on the potential dispersion of ammonia. According to the scheme, the thresholds which are commonly utilised in your national legal system are not exceeded. The claimant submits that in the forest there are various deciduous trees of rare species which would seriously suffer from the deposition of ammonia also where these commonly used thresholds are not exceeded.

\section{Claim 10}

The environmental impact assessment is based on incorrect data concerning the direction of the wind. According to the environmental statement which provides for a graph on the dispersion of odor, the wind mainly blows from east to west, meaning that the inhabitants of the village would not be affected by the odor emitted by the installation. The claimant is of opinion that the dispersion calculation is wrong, arguing that the wind mainly blows from west to east, meaning that the village would be adversely affected by the odor emitted by the installation 
Additional questions regarding claimant $\mathrm{C}$ :

Q: Does it make a difference if $\mathrm{C}$ is a recognised environmental organisation which is usually not active in the area in which the development is placed?

Q: Does it make a difference if $\mathrm{C}$ is a recognised environmental organisation which in its statutes stipulates that it prime concern is the "protection of animals and rare species"?

\section{Claimant X:}

$\mathrm{X}$ operates an ecological pig farming installation in a village situated at a distance of 8 kilometers from D's installation. He fears that D's development would place him at a competitive disadvantage.

\section{Claim 6}

Modification of the case scenario: The competent authority granted the permission without an EIA.

The claim is that the EIA was wrongfully omitted.

\section{$\underline{\text { Claim } 7}$}

The EIA wrongfully omits to consider the effects of ammonia on the deciduous forest. The trees would seriously suffer from the deposition of ammonia.

\section{$\underline{\text { Claim } 8}$}

The EIA lacks information on the direction of the wind and therefore wrongly concludes that A would not be affected by the odor emitted from the installation.

\section{Claim 9}

The methodology used for analysing the potential effects of ammonia on the forest is insufficient. The environmental statement provides for a scheme on the potential dispersion of ammonia. According to the scheme, the thresholds which are commonly utilised in your national legal system are not exceeded. The claimant submits that in the forest there are various deciduous trees of rare species which would seriously suffer from the deposition of ammonia also where these commonly used thresholds are not exceeded.

\section{Claim 10}


The environmental impact assessment is based on incorrect data concerning the direction of the wind. According to the environmental statement which provides for a graph on the dispersion of odor, the wind mainly blows from east to west, meaning that the inhabitants of the village would not be affected by the odor emitted by the installation. The claimant is of opinion that the dispersion calculation is wrong, arguing that the wind mainly blows from west to east, meaning that the village would be adversely affected by the odor emitted by the installation. 


\section{Table of Cases}

\section{European Case Law}

Case 26/62, NV Algemene Transport- en Expeditie Onderneming van Gend \& Loos v Netherlands Inland Revenue Administration [1963] ECR 1

Case 6/64, Flaminio Costa v E.N.E.L. [1964] ECR 585

Case 33/76, Rewe-Zentralfinanz eG und Rewe-Zentral AGv Landwirtschaftskammer für das Saarland [1976] ECR 1989

Case 45/76, Comet BV v Produktschap voor Siergewassen [1976] ECR 2043

Case 106/77, Amministrazione delle Finanze dello Stato v Simmenthal SpA [1978] ECR 629

Case 68/79, Hans Just I/S v Danish Ministry for Fiscal Affairs [1980] ECR 501

Case 158/80, Rewe-Handelsgesellschaft Nord mbH and Rewe-Markt Steffen v Hauptzollamt Kiel [1981] ECR 1805

Case 199/82, Amministrazione delle Finanze dello Stato v SpA San Giorgio [1983] ECR 3595

Joined cases 205-215/82, Deutsche Milchkontor GmbH and others v Federal Republic of Germany [1984] ECR 2633

Case 14/83, Sabine von Colson and Elisabeth Kamann v Land Nordrhein-Westfalen [1984] ECR 1891

Case 222/84, Marguerite Johnston v Chief Constable of the Royal Ulster Constabulary [1986] ECR 1651

Case 45/86, Commission of the European Communities $v$ Council of the European Communities [1987] ECR 1493

Case 222/86, Union nationale des entraîneurs et cadres techniques professionnels du football (Unectef) v Georges Heylens and others [1987] ECR 4079

Case 240/87, Deville v Administration des impôts [1988] ECR 3513

C-143/88, Zuckerfabrik Süderdithmarschen AGv Hauptzollamt Itzehoe and Zuckerfabrik Soest GmbH v Hauptzollamt Paderborn [1991] ECR I-415

C-213/89, The Queen v Secretary of State for Transport, ex parte: Factortame Ltd and others [1990] ECR I-2433

C-6/90, Andrea Francovich and Danila Bonifaci and others v Italian Republic [1991] ECR-I 5357

Joined cases C-87, 88, 89/90, A. Verholen and others $v$ Sociale Verzekeringsbank Amsterdam [1991] ECR I-3757

C-208/90, Theresa Emmott v Minister for Social Welfare and Attorney General [1991] ECR I-4269

C-97/91, Oleificio Borelli SpA v Commission of the European Communities [1992] ECR I-6313 
C-338/91, H. Steenhorst-Neerings v Bestuur van de Bedrijfsvereniging voor Detailhandel, Ambachten en Huisvrouwen [1993] ECR I-5435

C-410/92, Elsie Rita Johnson v Chief Adjudication Officer [1994] ECR I-5483

C-431/92, Commission of the European Communities v Federal Republic of Germany [1995] ECR I2189

C-312/93, Peterbroeck, Van Campenhout \& Cie SCS v Belgian State [1995] ECR I-4599

Joined Cases C-430 to 431/93, Jeroen van Schijndel v Stichting Pensioenfonds voor Fysiotherapeuten [1995] ECR I 4705

C-90/94, Haahr Petroleum Ltd v Åbenrå Havn et al. [1997] ECR I-4085

C-72/95, Aannemersbedrijf P.K. Kraaijeveld BVv Gedeputeerde Staten van Zuid-Holland [1996] ECR I-5431

C-188/95, Fantask A/S e.a. v Industriministeriet (Erhvervministeriet) [1997] ECR I-6783

Joined cases C-192/95 to C-218/95, Société Comateb (et al.) v Directeur général des douanes et droits indirects [1997] ECR I-165

C-261/95 Rosalba Palmisani v Istituto nazionale della previdenza sociale (INPS) [1997] ECR I-4025

C-81/96, Burgemeester en wethouders van Haarlemmerlide en Spaarnwoude v Gedupteerde Staten van Noord-Holland [1998] ECR I-3936

C-231/96, Edilizia Industriale Siderurgica Srl (Edis) v Ministero delle Finanze [1998] ECR I 4951

C-343/96, Dilexport Srl v Amministrazione delle Finanze dello Stato [1999]ECR I-579

C-120/97 Upjohn Ltd v The Licensing Authority established by the Medicines Act 1968 and Others [1999] ECR I-223

C-435/97, World Wildlife Fund (WWF) and Others v Autonome Provinz Bozen and Others [1999] ECR I-5613

Joined cases C-441/98 and C-442/98, Kapniki Michaïlidis AE v Idryma Koinonikon Asfaliseon (IKA) [2000] ECR I-7154

C-453/99, Courage Ltd v Bernard Crehan and Bernard Crehan v Courage Ltd and Others [2001] ECR I-6297

C-255/00, Grundig Italiana SpA v Ministero delle Finanze [2002] ECR I-8003

C-327/00, Santex SpA v Unità Socio Sanitaria Locale n. 42 di Pavia [2003] ECR I-1877

C-473/00, Cofidis SA v Jean-Louis Fredout [2002] ECR I-10875

C-13/01, Safelero Srl v Prefetto di Genova [2003] ECR I-8679

C-227/01, Commission v Spain [2004] ECR I-8253 
C-174/02, Streekgewest Westelijk Noord-Brabant v Staatssecretaris van Financiën [2005] ECR I-85

C-201/02, The Queen, on the application of Delana Wells v Secretary of State for Transport, Local Government and the Regions [2004] ECR I-723

C-216/02, Österreichischer Zuchtverband für Ponys, Kleinpferde und Spezialrassen v Burgenländische Landesregierung [2004]ECR I-10683

C-94/03, Commission of the European Communities v Council of the European Union [2006] ECR I-1

C-178/03, Commission of the European Communities v European Parliament and Council of the European Union [2006] ECR I-107

C-508/03, Commission of the European Communities v United Kingdom of Great Britain and Northern Ireland [2006] ECR I-3969

C-295/04 to C-298/04, Vincenzo Manfredi v Lloyd Adriatico Assicurazioni SpA [2006] ECR I-6619

C-303/05, Advocaten voor de Wereld VZWv Leden van de Ministerraad [2007] ECR I-3672

C-402/05, Yassin Abdullah Kadi and Al Barakaat International Foundation v Council of the European Union and Commission of the European Communities [2008] ECR I 6351

C-432/05, Unibet (London) Ltd and Unibet (International) Ltd v Justitiekanslern [2007] ECR I-2271

C-445/06, Danske Slagterier v Bundesrepublik Deutschland [2009] ECR I-2119

C-2/07, Paul Abraham and others v Région Wallonne and others [2008] ECR I-1197

C-142/07, Ecologistas en Acción-CODA v Ayuntamiento de Madrid [2008] ECR I-6097

C-237/07, Dieter Janecek v Freistaat Bayern [2008] ECR I-6221

C-427/07, Commission of the European Communities v Ireland [2009] ECR I-6277

C-75/08, The Queen on the application of Christopher Mellor v Secretary of State for Communities and Local Government [2009] ECR I-3799

Joined Cases C-317 to 320/08, Rosalba Alassini v Telecom Italia SpA (et al.) [2010] ECR I-2213

C-406/08, Uniplex (UK) Ltd v NHS Business Services Authority [2010] ECR I-817

C-255/08, Commission of the European Communities v Kingdom of the Netherlands [2009] ECR I-167

C-263/08, Djurgården-Lilla Värtans Miljoskyddsföreening [2009] ECR I-9967

C-50/09, European Commission v Ireland [2011] ECR I-837

C-115/09, Bund für Umwelt und Naturschutz Deutschland, Landesverband Nordrhein-Westfalen e.V. v Bezirksregierung Arnsberg [2011] ECR I-03673

C-240/09, Lesoochranárske zoskupenie VLK v Ministerstvo životného prostredia Slovenskej republiky [2009] ECR I-1255 
C-182/10, Marie-Noëlle Solvay and Others v Région wallonne (Judgment of 16 February 2012), n.y.r. in the ECR

C-416/10, Jozef Križan and Others v Slovenská inšpekcia životného prostredia (Judgment of 15 January 2013) n.y.r. in the ECR

C-41/11, Inter-Environnement Wallonie ASBL and Terre wallonne ASBL v Région wallonne (Judgment of 28 February 2012) n.y.r. in the ECR

C-260/11, The Queen, on the application of David Edwards and Lilian Pallikaropoulos $v$ Environment Agency and Others (Judgment of 11 April 2013) n.y.r. in the ECR

C-530/11, European Commission v United Kingdom of Great Britain and Northern Ireland (Judgment of 13 February 2014) n.y.r. in the ECR

C-583/11 P, Inuit Tapiriit Kanatami and Others $v$ European Parliament and Council of the European Union (Judgment of 3 October 2013) n.y.r. in the ECR

C-72/12, Gemeinde Altrip and Others v Land Rheinland-Pfalz (Judgment of 7 November 2013) n.y.r. in the ECR

C-137/14, European Commission v Federal Republic of Germany (Action brought on 21 March 2014) n.y.r. in the ECR

\section{German Case Law}

\section{Bundesverwaltungsgericht}

BVerwG, Decision of 22 June 1993, Az.: 4 B 45/93, juris

BVerwG, Decision of 12 January 1994, Az.: 4 B 163/93, juris

BVerwG, Decision of 23 February 1994, Az.: 4 B 35/94, juris

BVerwG, Decision of 30 August 1995, 4 B 185/95, NuR 1996, 198-199

BVerwG, Judgment of 25 January 1996, Az.: 4 C 5/95, BVerwGE 100, 238 - 256

BVerwG, Judgment of 21 March 1996, Az. 4 C 19/94, BVerwGE 100, 370 - 388

BVerwG, Judgment of 10 April 1997, Az.: 4 C 5 /96; BVerwGE 104, 236 - 254

BVerwG, Judgment of 15 September 1999, Az.: 11 A 22/98, UPR 2000, 116-117

BVerwG, Decision of 31 January 2006, Az.: 4 B 49/05, NVwZ 2006, 823-829

BVerwG, Judgment of 7 December 2006, Az.: 4 C 16/04, BVerwGE 127, 208

BVerwG, Judgment of 16 May 2007, Az.: 3 C 8/06, BVerwGE 129, 27 (42)

BVerwG, Judgment of 20 August 2008, Az.: 4 C 11/07, BVerwGE 131, 352 (369)

BVerwG, Decision of 11 November 2009, Az.: 4 B 57/09, NuR 2010, 339-342

BVerwG, Decision of 14 September 2010, Az.: 7 B 15/10, NuR 2011, 53-56

BVerwG, Decision of 17 June 2011, Az.: 7 B 79/10, juris

BVerwG, Judgment of 29 September 2011, Az.: 7C 21/09, NVwZ 2012, 176-180 
BVerwG, Judgment of 24 November 2011, Az.: 9 A 23/10, BVerwGE 141, 171-196

BVerwG, Judgment of 20 December 2011, Az.: 9 A 30/10, NVwZ 2012, 573-575

BVerwG, Judgment of 20 December 2011, Az.: 9 A 31/10, BVerwGE 141, 282-293

BVerwG, Decision of 10 January 2012, Az.: 7 C 20/11, NVwZ 2012, 448-451

BVerwG, Decision of 27 June 2013, Az.: 4 B 37/12, NuR 2014, 117-118

BVerwG, Judgment of 2 October 2013, Az.: 9 A 23/12, NVwZ 2014, 367-369

BVerwG, Judgment of 17 October 2013, Az.: 4 A 1/13, BVerwGE 148, 353-373

BVerwG, Judgment of 24 October 2013, Az.: 7 C 36/11, BVerwGE 148, 155-174

BVerwG, Judgment of 25 June 2014, Az.: 9 A 1/13, NuR 2014, 859-864

\section{Oberverwaltungsgericht/Verwaltungsgerichtshof}

VGH München, Judgment of 26 January 1993, Az.:8 A 92.40143, NVwZ 1993, 906

VGH München, Judgment of 19 October1993, Az.: 8 A 93.40070, NuR 1994, 244-247

VGH München, Judgment of 5 July 1994, Az.: 8 A 93.40056, Bay VBl 1995, 304- 307

OVG Münster, Decision of 30 April 2008, Az.: 8 D 20/08.AK, NuR 2009, 63-64

OVG Münster, Decision of 15 September 2008, Az.: 8 B 900/08.AK, juris

OVG Magdeburg, Decision of 17 September 2008 Az.: 2 M 146/08, juris

VGH Kassel, Judgment of 24 September 2008, Az.:6 C 1600/07.T, ZUR 2009, 87- 93

OVG Koblenz, Judgment of 29 October 2008, Az.: 1 A 11330/07, DVB1 2009, 390-395

OVG Lüneburg, Decision of 17 December 2008, Az.: 12 OA 347/08, juris

OVG Münster, Judgment of 11 February 2009, Az.:11 D 45/06.AK, juris

OVG Koblenz, Judgment of 12 February 2009, Az.: 1 A 10722/08, UPR 2009, 316-318

OVG Münster, Decision of 5 March 2009, Az.: 8 D 58/08, NVwZ 2009, 987- 991

VGH Kassel, Judgment of 16 September 2009, Az.: 6 C 1005/08.T, NuR 2010, 428-432

OVG Münster, Decision of 24 September 2009, Az.: 8 B 1342/09.Ak, NuR 2010, 198-202

OVG Münster, Decision of 5 November 2009, Az.: 8 B 1342/09.AK, NuR 2010, 202-204

VGH Mannheim, Decision of 17 November 2009, Az.: 10 S 1851/09, juris

OVG Münster, Judgment of 9 December 2009, Az.: 8 D 10/08.AK, ZUR 2010, 316-322

OVG Hamburg, Decision of 24 February 2010, Az.: 5 Bs 24/10, NuR 2010, 344-347

OVG Lüneburg, Decision of 10 March 2010, AZ.: 12 ME 176/09, NuR 2010, 290-296 
OVG Schleswig, Decision of 9 July 2010, Az.: 1 MB 12/10, juris

OVG Sachsen-Anhalt, Judgment of 26 October 2011, Az.: 2 K 10/10, juris

OVG Münster, Judgment of 1 December 2011, Az.: 8 D 58/08.AK, NuR 2012, 342-361

OVG Münster, Decision of 1 March 2012, Az.: 8 B 143/11, juris

VGH Kassel, Decision of 19 March 2012 , Az.: 9 B 1916/11 - juris

OVG Magdeburg, Judgment of 2 April 2012, Az.: 2 L 193/09, juris

OVG Koblenz, Decision of 31 January 2013, Az.: 1 B 11201/12, NVwZ 2013, 883-888

OVG Münster, Judgment of 14 October 2013, Az.: 20 D 7/09, DVBl 2014, 185-190

VGH Kassel, Decision of 30 January 2014, Az.: 9 A 727/13.Z

OVG Magdeburg, Decision of 13 February 2014, Az.: 2 L 4/13, juris

VGH München, Decision of 11 March 2014, Az.: 22 ZB 13.2381, juris

OVG Koblenz, Decision of 2 April 2014, Az.: 1 B 10249/14, DVBl 2014, 940-942

OVG Münster, Decision of 23 July 2014, Az.: 8 B 356/14, NuR 2014, 663-668

VGH München, Decision of 17 November 2014, Az.: 22 ZB 14.1035, juris

\section{Verwaltungsgericht}

VG Hamburg, Judgment of 28 November 2003, Az.: 22 VG 2478/2002, juris

VG Münster, Judgment of 17 June 2011, Az.: 10 K 1373/09, juris

VG Münster, Judgment of 18 March 2011, Az.: 10 K 2540/09, juris

VG Osnabrück, Decision of 21 December 2011, Az.: 2 B 16/11, NuR 2012, 362-367

VG Neustadt, Decision of 23 May 2012, Az.: 4 L 321/12.NW, juris

VG Aachen, Decision of 3 September 2012, Az.: 6 L 250/12, juris

VG Arnsberg, Judgment of 6 December 2012 Az.: 7 K 217/11, juris

VG Oldenburg, Judgment of 26 February 2014, Az.: 5 A 5671/13, juris

VG Regensburg, Judgment of 13 March 2014, Az.: RN 7 K 13.962, juris

VG Aachen, Decision of 28 November 2014, Az.: 3 L 224/13, juris

VG München, Decision of 9 March 2015, Az.: M 1 SN 14.4679, juris 


\section{Dutch Case Law}

\section{Raad van State (Afdeling Bestuursrechtspraak)}

ABRvS 20 March 1995, nr. F03940885, AB 1995/465

ABRvS 15 January 1996, nr. E03.94.0091, AB 1996/296

ABRvS 12 August 1996, nr. F03.96.0396, AB 1997/135

ABRvS 4 June 1999, nr. E03.98.0770, JB 1999/168

ABRvS 13 July 1999, nr. E03941402, AB 1999/411

ABRvS 8 August 2000, nr. E03.98.0103, M\&R 2000/213K

ABRvS 18 September 2000, nr. E03.98.1705, M\&R 2001/71

ABRvS 20 March 2002, nr. 200002278/1, M\&R 2002/86

ABRvS 20 March 2002, nr. 200002547/1, M\&R 2002/98

ABRvS 5 March 2003, nr. 200106102/1, M\&R 2003/100K

ABRvS 23 April 2003, nr. 200200160/1, M\&R 2003/130

ABRvS 29 October 2003, nr. 200206313/1

ABRvS 21 January 2004, nr. 200303529/1, JB 2004/122

ABRvS 24 April 2004, nr. 200303118/1, M\&R 2004/65

ABRvS 21 July 2004, nr. 200305714/1, M\&R 2004/124K

ABRvS 10 November 2004, nr. 200304823/1, AB 2005/40

ABRvS 7 February 2005, nr. 200409578/2

ABRvS 4 May 2005, nr. 200403894/1

ABRvS 13 July 2005, nr. 200408576/1

ABRvS 19 October 2005, nr. 200504993/1

ABRvS 2 June 2006, nr. 200602517/2

ABRvS 22 November 2006, nr. 200509477/1, M\&R 2007/10

ABRvS 7 February 2007, 200603204/1, M\&R 2007/47

ABRvS 4 April 2007, 200602517/1

ABRvS 28 May 2008, 200608226/1

ABRvS 1 October 2008, nr. 200801150/1, AB 2008/348

ABRvS 17 December 2008, nr. 200708825/1

ABRvS 14 January 2009, nr. 200800497/1

ABRvS 21 January 2009, nr. 200801408/1 
ABRvS 25 February 2009, 200800340/1

ABRvS 9 September 2009, nr. 200802966/1, JM 2009/141

ABRvS 16 December 2009, nr. 200809273/1/M2, JM 2010/24

ABRvS 13 January 2010, nr. 200902344/1/H1 and nr. 200902348/1/H1, JM 2010/33

ABRvS 17 March 2010, nr. 200904456/1/M2, JM 2010/62

ABRvS 7 July 2010, nr. 200902256/1/R1, JM 2010/110

ABRvS 14 July 2010, nr. 200900601/1/M2

ABRvS 29 September 2010, nr. 200905791/1/R3

ABRvS 6 October 2010, nr. 200904399/1/R2

ABRvS 17 November 2010, nr. 201004771/1/M2

ABRvS 15 December 2010, nr. 200903460/1/R3, JM 2011/ 22

ABRvS 23 March 2011, nr. 200906485/1/R3

ABRvS 23 March 2011, nr. 201001104/1/M2

ABRvS 29 June 2011, nr. 201011165/1/M2

ABRvS 24 August 2011, nr. 201002095/1/R3

ABRvS 14 September 2011, nr. 201011495/1/M2

ABRvS 5 October 2011, nr. 201003856/1/R3

ABRvS 9 November 2011, nr. 201002780/1/R1, JM 2011/140

ABRvS 28 November 2011, nr. 201106128/1/A4

ABRvS 9 December 2011, nr. 201110075/2/R4

ABRvS 8 February 2012, nr. 201109027/1/A4, AB 2012/57

ABRvS 8 February 2012, nr. 201010565/1/T1/A4

ABRvS 29 February 2012, nr. 201012388/1/A4

ABRvS 14 March 2012, nr. 201011045/1/A4

ABRvS 2 May 2012, nr. 201011273/1/A4

ABRvS 2 May 2012, nr. 201105967/1/R1

ABRvS 6 June 2012, nr. 201113326/1/T1/A1

ABRvS 4 July 2012, nr. 201010565/1/A4, JM 2012/34

ABRvS 4 July 2012, nr. 201103782/1/T1/A4

ABRvS 29 August 2012 nr. 201001848/1/T1/A4

ABRvS 6 October 2012, nr. 201107379/1/A4 
ABRvS 10 October 2012, nr. 201113326/1/A1

ABRvS 14 November 2012, nr. 201105329/1/A4

ABRvS 21 November 2012, nr.201103782/1/A4

ABRvS 28 November 2012, nr. 201106128/1/A4, JM 2013/41

ABRvS 21 November 2012, 201103782/1/A4

ABRvS 12 December 2012, nr. 201206403/1/T4

ABRvS 19 December 2012, nr. 201205119/1/R4

ABRvS 19 December 2012, nr. 201112785/1/R4, JM 2013/26

ABRvS 29 December 2012, nr. 201205119/1/R4

ABRvS 13 February 2013, nr. 201205534/1/R2

ABRvS 27 February 2013, nr. 201112182/1/R3

ABRvS 5 June 2013, nr. 201109112/1/A4

ABRvS 12 June 2013, nr. 201111410/1/A4

ABRvS 19 June 2013, nr. 201200972/1/A4

ABRvS 19 June 2013, nr. 201112097/1/A4

ABRvS 19 June 2013, nr. 201201163/1/A4

ABRvS 3 July 2013, nr. 201209539/1/R4, M\&R 2013/127

ABRvS 2 October 2013, nr. 201203981/1/A4

ABRvS 29 January 2014, nr. 201308001/1/A4

ABRvS 19 February 2014, nr. 201303313/1/A4

ABRvS 9 April 2014, nr. 201308340/1/R4

ABRvS 23 April 2014, nr. 201307589/1/R2

ABRvS 23 April 2014, nr. 201211728/1/R2

ABRvS 4 June 2014, nr. 201400140/1/R6

ABRvS 2 July 2014, nr. 201308160/1/R4

ABRvS 20 August 2014, nr. 201306769/1/R6

ABRvS 1 October 2014, nr. 201308398/1/R4, JM 2014/154

ABRvS 1 October 2014, nr. 201307140/1/R1

ABRvS 12 November 2014, nr. 201402491/1/R6 


\section{Rechtbanken}

Rechtbank Leeuwwaarden 17 July 1998, nr. 97/40 WET;97/41 WET;97/42 WET;97/44 WET;97/45

Rechtbank Arnhem15 March 2012 nr. 11/68, 11/69, 11/70, 11/71

Rechtbank Breda 11 October 2012, nr. 12/3996

Rechtbank Oost-Brabant 8 April 2014, nr. SHE 13/774, M\&R 2014, 95 with a comment by Arentz

Rechtbank Gelderland 16 December 2014, nr. AWB-13-4146

Rechtbank Oost-Brabant 29 December 2014, nr. SHE 13/4559

\section{English Case Law}

Associated Picture Houses Ltd. v Wednesbury Corporation [1948] 1 KB 223

American Cyanamid Ltd v Ethicon Ltd [1975] AC 396

Berkeley v Secretary of State for the Environment and Another [2001] 2 AC 603

Bown v Secretary of State for Transport, Local Government and the Regions [2003] EWCA Civ 1170; [2004] Env LR 26

Council of Civil Service Unions v Minister for the Civil Service [1985] 1 AC 374 (410)

Mv Home Office [1994] 1 AC 377

Morgan v Hinton Organics (Wessex) Ltd [2009] EWCA Civ 107; [2009] Env LR 30

$R v$ Attorny General, ex parte Imperial Chemical Industries PLC [1985] 1 CMLR 588

$R v$ Cornwall County Council, ex parte Hardy [2001] Env LR 25

$R v$ Her Majesty's Inspectorate of Pollution and Ministry of Agriculture Fisheries and Food, ex parte Greenpeace Ltd (No. 1) [1994] 2 CMLR 548 (QB)

$R v$ Inland Revenue Commissioners ex parte National Federation of the Self-Employed and Small Business Ltd [1982] AC 617

$R v$ Inspectorate of Pollution, ex parte Greenpeace Ltd (No. 2) [1994] 4 All ER 329

$R v$ Poole Borough Council, ex parte Bebee [1991] JPL 643 (QB)

$R v$ Secretary of State for Employment, ex parte Equal Opportunities Commission [1992] 1 All ER 545

$R v$ Secretary of State for Foreign and Commonwealth Affairs, ex parte World Development Movement [1995] 1 WLR 386

$R v$ Secretary of State for Social Services, ex parte Child Poverty Action Group [1990] 2 QB 540

$R v$ Secretary of State for the Environment, ex parte Kirkstall Valley Campaign Ltd [1996] 3 All ER 304

$R v$ Secretary of State for the Environment, ex parte Rose Theatre Trust [1990] 1 QB 504

$R v$ Secretary of State for the Environment, Transport and the Regions, ex parte Marson [1999] 1 CMLR 268 
$R v$ Secretary of State for the Home Department, ex parte Daly [2001] UKHL 26; [2001] 2 AC 532

$R v$ Secretary of State for Transport, ex parte Factortame Ltd [1991] 1 AC 603

$R v$ Somerset County Council, ex parte Dixon [1998] Env LR 111

$R v$ Swale Borough Council, ex parte Royal Society for the Protection of Birds [1991] JPL 39

$R($ Baker) v Bath and North East Somerset Council [2009] EWHC 595

$R$ (Bateman) v South Cambridgeshire District Council [2011] EWCA Civ 157

$R$ (Blewett) v Derbyshire CC [2003] EWHC 2775 (Admin), [2004] Env LR 29

$R$ (Burridge) v Brekland District Council [2012] EWHC 1102; [2012] Env LR 36

$R$ (Corner House Research Ltd) v Secretary of State for Trade and Industry [2005] EWCA Civ. 192; [2005] 1 WLR 2600

$R$ (Edwards) v Environment Agency (No.1) [2004] EWHC 736 (Admin); [2004] 3 All ER 21

$R$ (Edwards) v the Environment Agency (No. 2) [2008] UKHL 22; [2008] WLR 1587; EnvLR 34

$R$ (Edwards and another) $v$ Environment Agency and anoter [2013] UKSC 78; [2014] WLR 55

$R$ (Friends of Basildon Golf Course) v Basildon District Council [2010] EWCA Civ 1432, [2011] Env LR 16

$R$ (Garner) v Elmbridge Borough Council [2010] EWCA Civ 1006 ; [2012] PTSR 250

$R$ (Goodman) v London Borough of Lewisham [2003] EWCA Civ 140; [2003] EnvLR 28

$R$ (Gray) v London Borough of Southwark, Mayor of London, Secretary of State for Communities and Local Government, English Heritage [2012] EWHC 2653 (Admin).

$R$ (Jones) v Mansfield DC [2003] EWCA Civ 1408; [2004] Env LR 21

$R$ (Lebus) v South Cambridgeshire District Council [2002] EWHC 2009 (Admin), [2003] Env LR 17

$R$ (Loader) v Secretary of State for Communities and Local Government [2012] EWCA Civ.869; [2012] 3 CMLR 29

R (Long) v Monmouthshire City Council [2012] EWHC 3130 (Admin)

$R($ Mellor) $v$ Secretary of State for Communities and Local Government [2009] EWCA 1201

$R$ (Mellor) $v$ The Secretary of State for Communities and Local Government [2008] EWCA Civ 213; [2009] Env LR D1

$R$ (on the application of Save Britain's Heritage) v Gateshead Metropolitan Borough Council [2014] EWHC 896 (Admin)

$R$ (Save Britain's Heritage) v Secretary of State for Communities and Local Government and another [2010] EWHC 979 (Admin.); [2011] Env LR 6

$R(U \&$ Partners (East Anglia Ltd)) v Broads Authority [2012] Env LR 5; [2011] ACD 110

$R$ (Wye Valley Action Association Ltd) v Herefordshire Council [2011] EWCA Civ 20; [2011] Env LR 20

Swan v Secreatry of State for Scotland (No.1) [1998] Env LR 545 
Threadneedle Property Investments Ltd. v Southwark LBC [2012] EWHC 885 (Admin); [2013] Env LR 1

Twyford Parish Council and Others $v$ Secretary of State for the Environment and Another [1992]1 CMLR 276

Venn v Secretary of State for Communities and Local Government [2014] EWCA Civ 1539; [2015] CMLR 52

Walton v The Scottish Ministers [2012] UKSC 44; [2013] 1 CMLR 28 


\section{Bibliography}

Andenas (Mads), Jacobs (Francis) (eds.), European Community Law in the English Courts, Oxford University Press, Oxford, 1998

Andersen (Stine), The Enforcement of EU Law, The Role of the European Commission, Oxford University Press, Oxford, 2012

Andrews (Neil), Andrews on Civil Processes, Court Proceedings, vol. 1, Intersentia, Cambridge, 2013

Appel (Markus), Subjektivierung von UVP - Fehlern durch das Umweltrechtbehelfsgesetz?, NVwZ 2010, vol. 29, issue 8, pp. 473-479

Backes (Chris W.), Netherlands, in: Ebbesson (Jonas) (ed.), Access to Justice in Environmental Matters in the EU, Kluwer Law International, The Hague, 2002, pp. 379-396

Backes (Chris W.), Europeesrechtelijke implicaties van het relativiteitsvereiste, in: Addink (Gerrit H.), Jurgens (Gerarda T. J. M.), Langbroek (Philip M.), Widdershoven (Rob J. G. M.),

Grensverleggend bestuursrecht, Kluwer, Aalphen aan den Rijn, 2008, pp. 297-308

Backes (Chris W.), Crisistijden voor de waarborgfunctie van het bestuursrecht? De algemeen bestuursrechtelijke aspecten van de Crisis - en herstelwet, M\&R 2009, vol. 35, issue 10, pp. $622-627$

Backes (Chris W.), Case comment on C-115/12, Trianel (12 May 2011), AB 2011/212, pp. 1177-1187

Backes (Chris W.), Case comment on C-72/12, Altrip (7 November 2013), AB 2014/54, pp. 355-364

Backes (Chris W.), Eliantonio (Mariolina), Administrative Law, in: Hage (Jaap), Akkermans (Bram) (eds.), Introduction to Law, Springer, Cham, 2014, pp. 289-209

Backes (Chris W.), Faure (Michael), Fernhout (Fokke), Examining the Four Options, in: Faure (Michael), Philipsen (Niels) (eds.), Access to Justice in Environmental Matters, Eleven International Publishing, The Hague, 2014

Backes (Chris W.), Gilhuis (Pieter C.), Addink (Gerrit H.), Milieurecht, $6^{\text {th }}$ edition, Kluwer, Deventer, 2006

Backes (Chris W.), Verschuuren (Jonathan M.), The Precautionary Principle in International, European and Dutch Wildlife Law, Colo. J. Int'l Envl. L\&Pol'y, volume 9, issue 1, 1998, pp. $43-70$

Barkhuysen (Thomas), Damen (Leonardus. J. A.), de Graaf (K. J.), Marseille (A. T.), den Ouden (W.), Schuurmans (Y. E.), Tollenaar (A.), Feitenvaststelling in beroep, Boom Juridisch uitgevers, Den Haag, 2007

Balensiefen (Gotthold-Alexander), Umwelt-Rechtsbehelfsgesetz, Nomos, Baden-Baden, 2013

Beckmann (Martin), Der Rechtsschutz des Vorhabenträgers bei der Umweltverträglichkeitsprüfung, NVwZ 1991, vol. 10, issue 5, pp. 427-431

Beckmann (Martin), Umweltverträglichkeitsprüfung in der praktischen Anwendung, ZUR 2014, vol. 25 , issue 10 pp. $541-47$

Beijen (Barbara A.) (ed.), Hoofdlijnen Milieubestuursrecht, $2^{\text {nd }}$ edition, Boom Jurisdische uitgevers, Den Haag, 2012

Bell (Stuart), McGillivray (Donald), Pedersen (Ole W.) Environmental Law, $8^{\text {th }}$ edition, Oxford University Press, Oxford, 2013 
Berkemann (Jörg), Umweltrechtsbehelfsgesetz (UmwRG) auf dem gemeinschaftsrechtlichen Prüfstand - Vorlagebeschluss des OVG Münster vom 5. März 2009 und Urteil des OVG Schleswig vom 12. März 2009 - , NordOeR 2009, pp. 336-344

Berkemann (Jörg), Das "nicht übermäßig teure” gerichtliche Verfahren im Umweltrecht, jM 2014, pp. $470-474$

Besselink, The Kingdom of the Netherlands, in: Besselink (Leonard), Bovend'Eert (Paul), Broeksteeg (Hansko), de Lange (Roel), Voermands (Wim) (eds.), Constitutional Law of the EU Member States, Kluwer, Deventer, 2014, pp. 1187-1241

Blois (Matthijs de), Grondslagen van het recht 1, Hoofdlijnen, $6^{\text {th }}$ edition, Boom Juridische uitgevers, Den Haag, 2012

Bobek (Michal), Why there is No Principle of "Procedural Autonomy" of the Member States, in: Micklitz (Hans-Wolfgang), de Witte (Bruno E. F. M.) (eds.), The European Court of Justice and the Autonomy of the Member States, Intersentia, Cambridge, Antwerp, Portland, 2012, pp. 305-323.

Bok (Arie J.), Judicial Review of Administrative Decisions by the Dutch Administrative Courts, Recours Objectif or Recours Subjectif? A Survey including French and German law, in: Stroink (Frits), van der Linden (Eveline) (eds.), Judicial Lawmaking and Administrative Law, Intersentia, Antwerpen, Oxford, 2005, pp. 153-162

Bovend'Eert (Paulus P. T.) (ed.), Tekst \& Commentaar Grondwet, $3^{\text {rd }}$ edition, Kluwer, Deventer, 2013

Bowie (Robert R.) ; Rieben (Henri), Hallstein Walter, Gaudet (Michel), Fédération Des États-Unis, Confédération Suisse, Fédération Allemande, Communauté Européenne, Rapports présentés au Comité d'Action pour les Etats-Unis d'Europe, Centre de Recherches Européennes Lausanne, 1972

Broek (Jan van den), Bundeling van omgevingsrecht, Kluwer, Maastricht, 2012

Bunge (Thomas), Die Umweltverträglichkeitsprüfung von Projekten: Verfahrensrechtliche Erfordernisse auf der Basis der EG-Richtlinie vom 27. Juni 1985, DVB1 1987, vol. 102, issue 16 , pp. 819-826

Bunge (Thomas), Rechtsfolgen von Verfahrensfehlern bei der Umweltverträglichkeitsprüfung, NuR 2014, vol. 36, issue 5, pp. 305-313

Bunge (Thomas), Rechtsbehelfe in Umweltangelegenheiten, Vorgaben der Aarhus-Kovention und das deutsche Recht, NuR 2014, vol. 36, issue 9, pp. 605-614

Búrca (Gráinne de), Proportionality and Wednesbury Unreasonableness: The Influence of European Legal Concepts on UK law, EPL 1997, vol. 3, issue 4, pp. 561-586

Buuren (P.J.J. van), Borman (T.C.) (eds.), Tekst \& Commentaar Algemene Wet Bestuursrecht, $8^{\text {th }}$ edition, Kluwer, Deventer, 2013

Calliess (Christian), Ruffert (Matthias), EUV, AEUV, Das Verfassungsrecht der Europäischen Union mit Eurpäischer Grundrechtecharta, Kommentar, $4^{\text {th }}$ edition, C. H. Beck, München, 2011

Cane (Peter), Administrative Law, $5^{\text {th }}$ edition, Oxford University Press, Oxford, 2011

Chiti (Mario P.), Towards a Unified Judicial Protection in Europe (?), ERPL 1997, vol. 9, issue 3, pp. $553-573$

Craig (Paul), Administrative Law, $7^{\text {th }}$ edition, Sweet\&Maxwell, London, 2012 
Craig (Paul), A General Law on Administrative Procedure, Legislative Competence and Judicial Competence, EPL 2013, vol. 19, issue 3, pp. 503-524

Craig (Paul), The Nature of Reasonableness Review, Current Legal Problems 2013, vol. 66, issue 1, pp. 131-167

Craig (Paul), de Búrca (Gráinne), EU Law, Text, Cases and Materials, $5^{\text {th }}$ edition, Oxford University Press, Oxford, 2011

Cardis (Francois), Fédéralisme et Intégration Européenne, Centre de Recherches Européennes École des H.E.C., Université de Lausanne, 1964

Cremona (Marise) (ed.), Compliance and the enforcement of EU Law, Oxford University Press, Oxford, 2012

Commissie m.e.r., Environmental Impact Assessment in the Netherlands, Experiences and views presented by and to the Commission for EIA, Utrecht, June 1996

Crooijmans (Niels M. C. H.), Het relativiteitsvereiste: “Eigen huis en tuin”, M\&R 2014/67, vol. 41, issue 5, pp. 341-348.

Damen (Leonardus J. A.), Albers (C. L. G. F. H.), de Graaf (K. J.), Jans (J. H.), Klap (A. P.), Marseille (A.T.), Oliver (B. K.), Vermeer (F. R.), Klingenberg (A. M.), Tolsma (H. D.), Bestuursrecht, System, Bevoegdheid, Bevoegdheitsuitoefening, Handhaving, vol. 1, $4^{\text {th }}$ edition, Boom Juridische uitgevers, Den Haag, 2013

Damen (Leonardus J. A.), Bröring (H. E.), de Graaf (K. J.), Marseille (A. T.), Montfort (A. J. G. M. van), Schueler (Ben J.), Winter (H. B.), Bestuursrecht, Rechtsbescherming tegen de overheid, Bestuursprocessrecht, Vol. 2, 4 ${ }^{\text {th }}$ edition, Boom Juridische uitgevers, Den Haag, 2012

Danwitz (Thomas von), Europäisches Verwaltungsrecht, Springer, Berlin, Heidelberg, 2008

Dicey (Albert V.), Introduction to the Law of the Constitution, $8^{\text {th }}$ edition, Macmillan, London, 1915

Dippel (Martin), Niggemeyer (Jörg), Europarechtswidrigkeit des $\$ 2$ Abs. 1 Nr. 1 UmwRG? Zugleich Besprechung von OVG NRW Vorlagebschluss vom 5.3.2009, EurUP 2009, vol. 7, issue 4, pp. $199-202$

Dougan (Michael), National Remedies Before the Court of Justice, Issues of Harmonisation and Differentiation, Hart Publishing, Oxford and Portland Oregon, 2004

Dreier (Horst) (ed.), Grundgesetz, Kommentar, $3^{\text {rd }}$ edition, Mohr Siebeck, Tübingen, 2013

Ebbesson (Jonas) (ed.), Access to Justice in Environmental Matters in the EU, Kluwer Law International, The Hague, 2002

Ebbesson (Jonas) (ed.), Access to Justice at the National Level, Impact of the Aarhus Convention and European Union Law, in: Pallemaerts (Marc) (ed.), The Aarhus Convention at Ten, 2011, Europa Law Publishing, Groningen, pp. 245-279

Eckardt (Felix), Schenderlein (Kristin), Gerichtlicher Kontrollumfang zwischen EU Bürgerfreundlichkeit und nationaler Beschleunigungsgesetzgebung, NVwZ 2008, vol. 27, issue 10, pp. 1059-1065

Eliantonio (Mariolina), The Europeanisation of Administrative Justice?, The influence of the ECJ's case law in Italy, Germany and England, Europa Law Publishing, Groningen, 2009

Eliantonio (Mariolina), The Future of National Procedural Law in Europe: Harmonisation vs JudgeMade Standards in the Field of Administrative Justice, EJCL 2009, vol. 13 (3) 
Eliantonio (Mariolina), Collective Redress in Environmental Matters in the EU: A Role Model or a 'Problem Child'?, LIEI 2014, vol. 41, issue 3, pp. 257-273

Eliantonio (Mariolina), Backes (Chris W.), Rhee (C. H.van), Spronken (Taru), Berlee (Anna), Standing up for your Rights in Europe, A Comparative Study on Legal Standing (locus standi) before the EU and Member States' Courts, Intersentia, Cambridge, Antwerp, Portland, 2013

Ehlers (Dirk), Die Europäisierung des Verwaltungsprozeßrechts, Carl Heymanns, Köln, 1999

Endicott (Timothy A. O.), Administrative Law, $3^{\text {rd }}$ edition, Oxford University Press, Oxford, 2015

Epiney (Astrid), Verwaltungsgerichtlicher Rechtsschutz im Umweltrecht im Rechtsvergleich, NVwZ 2014, vol. 33, issue 8, pp. 465-476

Erbguth (Wilfried), Der Entwurf eines Gesetztes über die Umweltverträglichkeitsprüfung: Musterfall querschnittsorientierter Gesetzgebung aufgrund des EG Rechts?, NVwZ 1988, vol. 7, issue 11, pp. 969-977

Erbguth (Wilfried), Rechtliche Anforderungen an Alternativprüfungen in (abfallrechtlichen) Planfeststellungsverfahren und vorgelagerten Verfahren, NVwZ 1992, vol. 11, issue 3, pp. 209-219

Erbguth (Wilfried), Schink (Alexander), Gesetz über die Umweltverträglichkeitsprüfung, Kommentar, $2^{\text {nd }}$ edition, C. H. Beck, München, 1996

Erbguth (Wilfried), Das Bundesverwaltungsgericht und die Umweltverträglichkeitsprüfung, NuR 1997, vol. 19, issue 6, pp. 261-266

Ergbuth (Wilfried), Schlacke (Sabine), Umweltrecht, $5^{\text {th }}$ rev. edition, Nomos, Baden-Baden, 2014

Essens (Oda F.), Verhoeven (Maartje J. M.), Traditional Variations in the Dutch Administrative Judicial System, in: Caranta (Roberto), Gerbrandy (Anna) (eds.), Tradition and Change in European Administrative Law, Europa Law Publishing, Groningen, 2011

Eyermann (Erich), Verwaltungsgerichtsordnung, Kommentar, $14^{\text {th }}$ rev. edition, C. H. Beck, München, 2014

Faure (Michael), Moerland, Griffierechten, Een vergelijkende beschrijving van griffierechten- en vergelijkbare stelsels in een aantal landen van de Europese Unie, Boom Juridische uitgevers, Meppel, 2006

Faure (Michael), Mühl (Manuela), Philipsen (Niels), Incentives, Costs and Benefits: A Law and Economic Analysis, in: Faure (Michael), Philipsen (Niels) (eds.), Access to Justice in Environmental Matters, Eleven International Publishing, The Hague, 2014

Feldman (David) (ed.), English Public Law, $2^{\text {nd }}$ edition, Oxford University Press, Oxford, 2009

Finkelnburg (Klaus), Dombert (Matthias), Külpmann (Christoph), Vorläufiger Rechtsschutz im Verwaltungsstreitverfahren, C. H. Beck, München, 2011

Fontaine (Pascale), Le Comité d'Action pour les Etats-Unis d'Europe de Jean Monnet, Centre de Recherches Européennes, Lausanne, 1974

Fordham (Michael), Judicial Review Handbook, $6^{\text {th }}$ edition, Hart Publishing, Oxford, 2012

Franzius (Claudio), Objektive Rechtskontrolle statt subjektiver Rechtsschutz, NuR, 2009, vol. 31, issue 6, pp. 384-387

Führ (Martin), Dopfer (Jaqui), Bizer (Kilian), Evaluation des UVPG des Bundes, ZUR 2009, vol. 20, issue 2, pp. 59-65 
Führ (Martin), Schenten (Julian), Schulze (Falk), Schütte (Silvia), Verbandsklage nach UmwRGempirische Befunde und rechtliche Bewertung, NVwZ 2014, vol. 33, issue 16, pp. 1041-1046

Führ (Martin), Schenten (Julian), Schreiber (Melanie), Schulze (Falk), Schütte (Silvia), Evaluation von Gebrauch und Wirkung der Verbandsklagemöglichkeiten nach dem UmwRG, Dessau-Roßlau, Februar 2014

Galetta (Diana), Procedural Autonomy of EU Member States: Paradise Lost?, Springer, Berlin, 2010

Garcia Burgues (Julio), Heermann (Werner); Kreins (Yves), Lavrysen (Luc), Tiberghien (Frédéric), A Common Heritage: EU Environmental Law and National Judges, JEEPL 2010, vol. 7, issue 2, pp. 221-233

Gassner (Erich), Gesetz über die Umweltverträglichkeitsprüfung, Kommentar, C. F. Müller, Heidelberg, 2006

Gärditz (Klaus F.), Klagerechte der Umweltöffentlichkeit im Umweltrechtsbehelfsgesetz, EurUP 2010, vol. 8, issue 5, pp. 210-221

Gärditz (Klaus F.) (ed.), Verwaltungsgerichtsordnung ( $V w G O)$ mit Nebengesetzen, Kommentar, Carl Heymanns Verlag, Köln, 2013

Gärditz (Klaus F.), Verwaltungsgerichtlicher Rechtsschutz im Umweltrecht, NVwZ, 2014, vol. 33, issue 1, pp. 1- 10

Geismann (Maria), Schulz (Mathias), Ist die materielle Präklusion nach § 2 Abs. 3 UmwRG europarechtskonform?, NuR 2014, vol. 36, issue 9, pp. 624-630

Gellermann (Martin), Europäisierte Klagerechte anerkannter Umweltverbände, NVwZ 2006, vol. 25, issue 1, pp. 7-13

Genth (Mario), Ist das neue Umwelt-Rechtsbehelfsgesetz europarechtskonform?, NuR 2008, vol. 30, issue 1, pp. 28-32

Gerven (Walter van), Bridging the Gap Between Community and National Laws: Towards A Principle of Homogeneity in the Field of Legal Remedies? CMLRev 1995, vol. 32, issue 3, pp. 679-702

Gerven (Walter van), Of Rights, Remedies and Procedures, CMLRev 2000, vol. 37, issue 3, pp. 501536

Glaser (Andreas), Die Entwicklung des Europäischen Verwaltungsrechts aus der Perspektive der Handlungsformenlehre, Mohr Siebeck, Tübingen, 2013

Glasson Therivel (Riki), Weston (Joe), Wilson (Elizabeth), EIA - Learning from Experience: Changes in the Quality of Environmental Impact Statement for UK Planning Projects, JEPM 1997, vol. 40, issue 4, pp. 451-464

Glasson (John), The First 10 years of the UK EIA System: Strength and Weaknesses, Opportunities and Threads, Planning Practice \& Research 1999, issue 3, pp. 363-375

Glidewell LJ, English Administrative Law: Past, present and future, Liverpool L. R., vol. 15, issue 1, 1993, pp. 3-19

Goodwin (James), The last defense of Wednesbury, Public Law 2012, pp. 445-467

Graaf (K. J. de), Lam (T. E. P. A.), van der Linden (E. C. H. J.), Maas-Cooymans (M. G. J.), Spapens (T.) van der Veen (G. A.), Sdu Commentaar Algemene wet bestuursrecht, Sdu Uitgevers, 'sGravenhage, 2014 
Greim (Jeanine), Das Urteil des EuGH in der Rechtssache Altrip-Meilenstein oder Mosaikstein auf dem Weg zum gebotenen Individualrechtsschutz bei UVP Fehlern, NuR 2014, vol. 36, issue 2, pp. 81-88

Grin (Giles), Méthode Communautaire et fédéralisme : le legs de Jean Monnet à travers ses archives, Lausanne, Fondation Jean Monnet pour l'Europe, Collection débats et documents, numéro 2, septembre 2014

Groeben (Hans von der), Schwarze (Jürgen), Hatje (Armin) (eds.), Europäisches Unionsrecht, Nomoskommentar, $7^{\text {th }}$ edition, Nomos, Baden-Baden, 2015

Grünewald (Benedikt), Die Betonung des Verfahrensgedankens im deutschen Verwaltungsrecht durch das Gemeinschaftsrecht, Peter Lang, Frankfurt am Main, 2010

Haibach (Georg), Zur Einführung des ersten europäischen Zivilprozessverfahrens (EG), nr. 861/2007, EuZW 2008, vol. 19, issue 5, pp. 137-140

Harlow (Carol), A Common European Law of Remedies?, in: Kilpatrick (Claire), Novitz (Tonia), Skidmore (Paul) (eds.), The Future of Remedies in Europe, Hart Publishing, Oxford, 2000, pp. $69-83$

Harlow (Carol), Law and administration, $3^{\text {rd }}$ edition, Cambridge University Press, Cambridge, 2009

Hay (David), Words and Phrases Legally Defined, $4^{\text {th }}$ edition, Lexis Nexis, London, 2007

Held (Jürgen), Individualrechtsschutz bei fehlerhaftem Verwaltungsverfahren, NVwZ 2012, vol 31, issue 8, pp. 461-468

Heringa (Aalt Willem), Kiiver (Philipp), Constitutions Compared, An Introduction to Comparative Constitutional Law, $3^{\text {rd }}$ edition, Intersentia, Cambridge, 2012

Heringa (Aalt Willem), Velde (J. van der), Verhey (L. F. M.), Woude (W. van der), Staatsrecht, $11^{\text {th }}$ edition, Kluwer, Deventer, 2012

Heselhaus (Sebastian), Nowak (Carsten) (eds.), Handbuch der europäischen Grundrechte, C. H. Beck, München, 2006

Hien (Eckart), Die Umweltverträglichkeitsprüfung in der gerichtlichen Praxis, NVwZ 1997, vol. 16, issue 5, pp. 422-428

Hodges (Christopher), Vogenauer (Stefan), Tulibacka (Magdalena) (eds.), Costs and Funding of Civil Litigation: A Comparative Study, Legal Research Paper Series, Paper No 55/2009, December 2009

Hoevenaars (Gijs), M.e.r.: Omgevingswetinstrument bij uitstek!, TO 2013, issue 1, pp. 154-160

Hoevenaars (Gijs), Kroniek M.e.r.-regelgeving, M\&R 2014/51, issue 4, pp. 246-255

Hoevenaars (Gijs), Flietstra (Y.), Case comment on ABRvS 8 February 2012, nr. 201010565/1/T1/A4, JM 2012/34

Holder (Jane), Environmental Assessment, The Regulation of Decision Making, Oxford University Press, Oxford, 2006

Hoppe (Werner), Beckmann (Martin), Gesetz über die Umweltverträglichkeitsprüfung (UVPG), Kommentar, $4^{\text {th }}$ rev. edition, Carl Heymanns Verlag, Köln, 2012

Hufen (Friedhelm), Verwaltungsprozessrecht, $9^{\text {th }}$ rev. and updated edition, C. H. Beck, München, 2013 
Hufen (Friedhelm), Siegel (Thorsten), Fehler im Verwaltungsverfahren, $5^{\text {th }}$ edition, Nomos, BadenBaden, 2013

Jackson (Rupert), Review of Civil Litigation Costs: Final Report, The Stationery Office, 2010

Jackson (Rupert M.) (ed.), Civil Procedure, vol. 1, Sweet \& Maxwell, London, 2012

Jacobs (Francis G.), The Evolution of the European Legal Order, CMLRev 2004, vol. 41, issue 2, pp. 303-316

Jans (Jan H.), de Lange (Roel), Prechal (Sacha), Widdershoven (Rob J. G. M.), Europeanisation of Public Law, Europa Law Publishing, Groningen, 2007

Jans (Jan H.), Jong (Marianne de), Somewhere between Direct Effect and Rewe/Comet, in: Ladeur (ed.), The Europeanisation of Administrative Law, Transforming National Decision Making Procedures, 2002, pp. 68-92

Jans (Jan H.), Macrory (Richard), Molina (Angel-Manuel M.) (eds.), National Courts and EU Environmental Law, Europa Law Publishing, Groningen, 2013

Jans (Jan H.), Marseille (Albert T.), The Role of NGOs in Environmental Litigation against Public Authorities: Some Observations on Judicial Review and Access to Court in the Netherlands, JEL 2010, vol. 22, issue 3, pp. 373-390.

Jans (Jan H.), Vedder (Hans H. B.), European Environmental Law, after Lisbon, $4^{\text {th }}$ edition, Europa Law Publishing, Groningen, 2012

Jansen (Oswald), Schöndorf-Haubold (Bettina) (eds.), The European Composite Administration, Intersentia, Cambridge, 2011

Jarass (Hans D.), Charta der Grundrechte der Europäischen Union unter Einbeziehung der vom EuGH entwickelten Grundrechte und der Grundrechtsregelungen der Verträge, Kommentar, $2^{\text {nd }}$ edition, C. H. Beck, München, 2013

Keay (Andrew), Whither American Cyanamid?: interim injunctions in the $21^{\text {st }}$ century, C.J.Q. 2004, pp. 133-151

Kleve (Guido), Schirmer (Benjamin), England und Wales, Schneider (Jens-Peter) (ed.), Verwaltungsrecht in Europa, 1. England und Wales, Spanien, Niederlande, vol. 1, V\&R unipress, Osnabrück, 2007, pp. 85-180

Klap (Arnout P.), Rechterlijke toetsing aan vage normen in Nederland en Duitsland, in: Klap (Arnout P.), Groenewegen (F. Taco), van Angeren (Jan R.), Toetsing aan vage normen door de bestuursrechter in het Nederlandse, Duitse, Engelse en Franse recht, preadvies voor de Nederlandse Vereniging voor Rechtsvergelijking, Wolf Legal Publishers, Oisterwijk, 2014, pp. $1-78$

Klinger (Remo), Umweltverträglichkeitsprüfung und Rechtsschutz, ZUR 2014, vol. 25, issue 10, pp. $535-540$

Kment (Martin), Die Stellung nationaler Unbeachtlichkeits-, Heilungs- und Präklusionsvorschriften im europäischen Recht, EuR 2006, issue 2, pp. 201-235

Kment (Martin), Das neue Umwelt-Rechtsbehelfsgesetz und seine Bedeutung für das UVPG, Rechtsschutz des Vorhabenträgers, anerkannter Vereinigungen und Dritter, NVwZ 2007, vol. 26, issue 3, pp. 274-280

Kment (Martin), Europarechtswidrigkeit des $\$ 4$ I UmwRG?, NVwZ 2012, vol. 31, issue 8, pp. 481483 
Knack (Hans-Joachim), Henneke (Hans-Günter), Verwaltungsverfahrensgesetz (VwVfG), Kommentar, $10^{\text {th }}$ rev. edition, Carl Heymanns Verlag, Köln, 2014

Knill (Christoph), Winkler (Daniela), Convergence or Divergence of National Legal and Administrative Structures? Europeanisation Effects of the Environmental Impact Assessment in Germany and England (Part II), JEEPL 2006, issue 2, pp. 44-53

Koch (Hans-Joachim), Die Verbandsklage im Umweltrecht, NVwZ 2007, vol. 26, issue 4, pp. 369-378

Koeman (Niels S. J.), Uylenburg (Rosa) (eds.), Tekst \& Commentaar Milieurecht, $5^{\text {th }}$ edition, Kluwer, Deventer, 2013

Kopp (Ferdinand O.), Schenke (Wolf-Rüdiger), Schenke (Ralf Peter), Verwaltungsgerichtsordnung, Kommentar, $20^{\text {th }}$ rev. edition, C. H. Beck, München, 2014

Kornet (Nicole), Hardt (Sascha) (eds.), Selected national, European and international provisions from public and private law, the Maastricht Collection, $3^{\text {rd }}$ edition, Europa Law Publishing, Groningen, 2013

Kramer (Xandra E.), Rhee (Cornelis H. van) (eds.), Civil Litigation in a Globalising World, Springer, Berlin, 2012

Krämer (Ludwig), EU Environmental Law, $7^{\text {th }}$ edition, Sweet \& Maxwell, London, 2012

Kremer (Peter), Anmerkung zum Urteil des EuGH vom 13.2. 2014, Rs. C-539/11 und vom 11.4.2014, Rs. C-260/11, ZUR 2014, vol. 25, issue 6, pp. 347-349

Kulms (Katrin), Der Effektivitätsgrundsatz, Eine Untersuchung zur Rechtsprechung des Europäischen Gerichtshofs, Nomos, Baden-Baden, 2013

König (Julia), Der Äquivalenz - und Effektivitätsgrundsatz in der Rechtsprechung des EuGH, Nomos, Baden- Baden, 2011

Ladeur (Karl-Heinz), Prelle (Rebecca), Environmental Assessment and Judicial Approaches to Procedural Errors - A European and Comparative Analysis, JEL 2001, vol. 13, issue 2, pp. $185-198$

Lalumière (Catherine), Rieben (Henri), Faire Entrer l'Europe dans le Cour des Citoyens, Fondation Jean Monnet pour l'Europe, Centre de recherches Européennes, Lausanne, 1993

Landmann (Robert), Rohmer (Gustav) (eds.), Umweltrecht, Kommentar, C. H. Beck, München, 74. Ergänzungslieferung, November 2014

Lange (Roel de), The United Kingdom of Great Britain and Northern Ireland, in : Besselink (Leonard), Bovend'Eert (Paul), Broeksteeg (Hansko), de Lange (Roel), Voermands (Wim) (eds.), Constitutional Law of the EU Member States, Kluwer, Deventer, 2014, pp.1649-1639

Lassalle (Déborah), L'Europe de l'Intérêt Général, Publications de l'Institut Européen de L'Université de Genève no. 11, Academia-L'Harmattan, Louvain-La-Neuve, 2013

Leemans (Taco C.), De toetsing door de bestuursrechter in milieugeschillen, Over rechterlijke toetsingsintensiteit, bestuurlijke beslissingsruimte en deskundigenadvisering, Boom Juridische uitgevers, Den Haag, 2008

Lenaerts (Koen), Maselis (Ignace), Gutman (Kathleen), EU Procedural Law, Oxford University Press, Oxford, 2014

Lewis (Clive), Judicial Remedies in Public Law, $4^{\text {th }}$ edition, Sweet \& Maxwell, London, 2009 
Leyland (Peter), The Constitution of the United Kingdom, A Contextual Analysis, Hart Publishing, Oxford and Portland, Oregon, 2012

Lidbetter (Andrew), Buchner (Reimar), Withholding Relief for a Breach of EU Law: A Comparative Approach, JR 2003, pp. 36-40

Macrony (Richard) (ed.), Principles of European Environmental Law, Europa Law Publishing, Groningen, 2004

Marseille (Albert T.), Tolsma (Hanna), Geschilbeslechting door de bestuursrechter, Kluwer, Deventer, 2013

Maurer (Hartmut), Allgemeines Verwaltungsrecht, $18^{\text {th }}$ rev. and extended edition, C. H. Beck, München, 2011

Maunz (Theodor), Dürig (Günter), Grundgesetz, Kommentar, C. H. Beck, München, 72. Ergänzungslieferung, Juli 2014

Mayen (Thomas), Die UVP nach dem UVP Gesetz und der UVP Verwaltungsvorschrift, NVwZ 1996, vol. 15, issue 4, pp. 319-325

McCracken (Robert), Edwards (Denis), Standing and discretion in environmental challenges: Walton, a curate's egg, JPEL 2014, pp. 304-314

Meitz (Christoph), Zur Einklagbarkeit von Mängeln der Umweltverträglichkeitsprüfung (Altrip), Anmerkung zur Entscheidung des EuGH vom 7.11.2013, Rs. C-72/12, ZUR 2014, vol. 25, issue 1, pp. 36-44

Mertz (Steven W.), The European Economic Community Directive on environmental assessments: how will it affect United Kingdom developers?, JPEL 1989, pp. 483-498

Meyer (Jürgen) (ed.), Charta der Grundrechte der Europäischen Union, $4^{\text {th }}$ edition, Nomos, BadenBaden, 2014

Meyer-Ladewig (Jens), Europäische Menschenrechtskonvention, EMRK, Handkommentar, $3^{\text {rd }}$ edition, Nomos, Baden-Baden, 2011

Monnet (Jean), Les Etats-Unis d'Europe ont Commencé, La communauté européenne du charbon et de l'acier, Robert Laffont, Paris, 1955

Monnet (Jean), La Communauté Européenne et L'Unité de L'Occident, Centre de recherches européennes, Ecole des H.E.C., Université de Lausanne, 1961

Monnet (Jean), L'Europe Unie, L'Europe et L'Organisation de La Paix, Centre de Recherches Européennes Ecole des H.E.C., Université de Lausanne, 1964

Monnet (Jean), L'Europe Unie, De L'Utopie à la Réalité, Allocution prononcée au Congrès International de la Friedrich-Ebert-Stiftung, Centre de Recherches Européennes, Lausanne, 1972

Nettesheim (Martin), Der Grundsatz der Einheitlichen Wirksamkeit des Gemeinschaftsrechts, in: Randelzhofer (Albrecht) (ed.), Gedächtnisschrift für Eberhard Grabitz, Beck, München,1995, pp. $447-468$

Noble (Bram F.), Introduction to Environmental Impact Assessment, A Guide to Principles and Practice, $2^{\text {nd }}$ edition, Oxford University Press, Oxford, 2010

Pallemaerts (Marc) (ed.), The Aarhus Convention at Ten, Interactions and Tensions between Conventional International Law and EU Environmental law, Europa Law Publishing, Groningen, 2011 
Paluch (Daria), Werk (Klaus), Zum aktuellen Sachstand und zur Bewertung der europäischen Beschlüsse zur Änderung der UVP- Richtlinie, NuR 2014, vol. 36, issue 6, pp. 400-405

Peers (Steve), Hervey (Tamara), Kenner (Jeff), Ward (Angela) (eds.), The EU Charter of Fundamental Rights, A Commentary, Hart Publishing, Oxford and Portland, Oregon, 2014

Philipp-Gerlach (Ursula), Lukas (Andreas), Die UVP-Vorprüfung in der Rechtsprechung und Praxis, ZUR 2014, vol. 25, issue 10, pp. 548-553

Pieters (Steven), Katern Jurisprudentie Milieueffectrapportage, Jurisprudentie en Toelichting, Koninklijke Vermande, Den Haag, 2002

Pokorný-Versteeg (Wendy H.), Milieu-effectrapportage in Nederland en de aangrenzende EUlidstaten,een rechtsvergelijkende onderzoek, Kluwer, Deventer 2003

Polak (Jaap E. M.), Veranderende perspectieven van de bestuursrechter, in: Barkhuysen (Thomas), Ouden (Willemiena den), Polak (J. E. M.) (eds.), Bestuursrecht harmoniseren: 15 jaar Awb, Boom Juridische uitgevers, Den Haag, 2010, pp. 97-114

Polak (Jaap E. M.), Roelfsema (J. H.), Bestuursrechtspraak, in: Muller (Erwin R.), Cleiren (Christina P. M.), Rechterlijke macht, rechtspraak en rechtshandhaving in Nederland, $2^{\text {nd }}$ edition, Kluwer, Deventer, 2013

Poorter (Jurgen C. A.), De belanghebbende: een onderzoek naar de betekenis van het belanghebbende-begrip in het bestuurs(proces)recht, Boom Juridische uitgevers, Den Haag, 2003

Prechal (Sacha), Widdershoven (Rob), Redefining the Relationship between „REWE- effectiveness “ and Effective Judicial Protection, REALaw 2011, vol. 4, issue 2, pp. 31-50

Pünder (Hermann), Waldhoff (Christian) (eds.), Debates in German Public Law, Hart Publishing, Oxford and Portland, Oregon, 2014

Quaas (Michael), Zuck (Rüdiger) (eds.), Prozesse in Verwaltungssachen, $2^{\text {nd }}$ edition, Nomos, BadenBaden, 2011

Quabeck (Christian), Dienende Funktion des Verwaltungsverfahrens und Prozeduralisierung, Mohr Siebeck, Tübingen, 2010

Redeker (Konrad), Oertzen (Hans Joachim von), Verwaltungsgerichtsordnung, Kommentar, $16^{\text {th }}$ rev. edition, Kohlhammer, Stuttgart, 2014

Rengeling (Hans Werner), Middeke (Andreas), Gellermann (Martin), Handbuch des Rechtsschutzes in der Europäischen Union, $3^{\text {rd }}$ edition, C. H. Beck, München, 2014

Ricard-Nihoul (Graene), Pour une Fédération Européenne D'Etats-Nations - La vision de Jacques Delors Revisitée, Larcier, Bruxelles, 2012

Rieben (Henri), A Luxembourg au Cour du chantier européen avec Jean Monnet et Pierre Werner, Fondation Jean Monnet pour l'Europe, Lausanne, 1993

Rieben (Henri), Instaurer et sauvegarder la Paix, in: L'intégration européenne : historique et perspectives, Lausanne 7 et 8 novembre 2001, Publications de 1'Institut suisse de droit comparé, Schluthess Médias Juridiques SA, Zurich, Bâle, Genève, 2002

Ruffert (Matthias) (ed.), Administrative Law in Europe: Between Common Principles and National Traditions, Europa Law Publishing, Groningen, 2013

Runhaar (Hendrik A. C.), Arts (Eric J. M. M.), Laerhoven (Frank S. J.), Driessen (Petrus P. J.), Naar een toekomstbestendige m.e.r.: onderzoek naar 25 jaar milieueffectrapportage, Utrecht, 2011 
Ryall (Áine), Effective Judicial Protection and the Environmental Impact Assessment Directive in Ireland, Hart Publishing, Oxford, 2009

Sachs (Michael) (ed.), Grundgesetz, Kommentar, $7^{\text {th }}$ edition, C. H. Beck, München, 2014

Sadeleer (Nicolas de), Roller (Gerhard), Dross (Miriam), Access to Justice in Environmental Matters and the Role of NGOs, Empirical Findings and Legal Appraisal, Europa Law Publishing, Groningen, 2005

Sadeleer (Nicolas de), EU Environmental Law and the Internal Market, Oxford University Press, Oxford, 2014

Sales (Philip), Rationality, proportionality and the the development of the law, L.Q.R. 2013, vol. 129, issue 2 (April), pp. 223-241

Salter (John R.), Environmental assessment: the challenge from Brussels, JPEL 1992, pp. 14-20

Sauer (Matthias), Rechtsschutz in Umweltangelegenheiten im Umbruch?, ZUR 2014, vol. 25, issue 4, pp. 195-202

Scheidler (Alfred), Rechtsschutz Dritter bei fehlerhafter oder unterbliebener Umweltverträglichkeitsprüfung, NVwZ 2005, vol. 24, issue 8, pp. 863-868

Schenke (Wolf-Rüdiger), Verwaltungsprozessrecht, $14^{\text {th }}$ rev. edition, C. F. Müller, Heidelberg, 2014

Schink (Alexander), UVP in der Straßenplanung, Anmerkung zu OVG Koblenz, Urteil vom 29. Dezember 1994, 1 C 10893/92 OVG, ZUR 1995, vol. 6, issue 3, pp. 150-152

Schink (Alexander), Die Umweltverträglichkeitsprüfung - eine Bilanz, NuR 1998, vol. 20, issue 4, pp. $173-180$

Schink (Alexander), Auswirkungen des EG Rechts auf die Umweltverträglichkeitsprüfung nach deutschem Recht, NVwZ 1999, vol. 18, issue 1, pp. 11-19

Schlacke (Sabine), Rechtsschutz durch Verbandsklage, Zum Fortentwicklungsbedarf des umweltbezogenen Rechtsschutzsystems, NuR 2004, vol. 26, issue 10, pp. 629-635

Schlacke (Sabine), Zum Drittschutz bei der Nichtdurchführung einer gebotenen Umweltverträglichkeitsprüfung, ZUR 2006, vol. 17, issue 7-8, pp. 360-363

Schlacke (Sabine), Das Umwelt-Rechtsbehelfsgesetz, NuR 2007, vol. 29, issue 1, pp. 8-16

Schlacke (Sabine), Die Novelle des Umwelt-Rechtsbehelfsgesetzes, EuGH ante portas?, ZUR 2013, vol. 24, issue 4, pp. 195-202

Schlecht (Anna Maria), Die Unbeachtlichkeit von Verfahrensfehlern im deutschen Umweltrecht, Einwirkungen der Aarhus-Konvention und des Gemeinschaftsrechts auf die Grenzen gerichtlicher Kontrolle, Duncker \& Humblot, Berlin, 2010

Schlössels (Raymond J. N.), van Ettekoven (B.J.), Schueler (Ben), van Harten (M.), Een Schutznorm in het bestuursproces: selectief winkelen bij de buren?, NTB 2007/38, pp. 245-248

Schlössels (Raymond J. N.), Schuurmans (Ymre E.), Koopman (R. J.), Verburg (D. A.), Bestuursrechtelijk bewijsrecht: wetgever of rechter?, VAR-reeks nr. 142, Boom Juridische uitgevers, Den Haag, 2009

Schlössels (Raymond J. N.), Stroink (Frederik A. M.), Kern van het bestuursrecht, $4^{\text {rd }}$ edition, Boom Juridische uitgevers, Den Haag, 2013 
Schmidt (Alexander), Kremer (Peter), Das Umwelt-Rechtsbehelfsgesetz und der ,, weite Zugang zu Gerichten “, ZUR 2007, vol. 18, issue 2, pp. 57-63

Schmidt (Alexander), Zschiesche (Michael), Rosenbaum (Marion), Die naturschutzrechtliche Verbandsklage in Deutschland, Springer, Berlin, Heidelberg, 2004

Schmidt (Alexander), Schrader (Christian), Zschiesche (Michael), Die Verbandsklage im Umwelt- und Naturschutzrecht, C. H. Beck, München, 2014

Schmidt (Rolf), Verwaltungsprozessrecht, $16^{\text {th }}$ rev. and updated edition, Rolf Schmidt, Grasberg bei Bremen, 2014

Schmidt-Aßmann (Eberhard), Das allgemeine Verwaltungsrecht als Ordnungsidee, Grundlagen und Aufgaben der verwaltungsrechtlichen Systembildung, $2^{\text {nd }}$ rev. and extended edition, Springer, Berlin, 2004

Schmidt-Bleibtreu (Bruno), Hofman (Hans) (eds.), Kommentar zum Grundgesetz, $13^{\text {th }}$ edition, Heymann, Köln, 2014

Schneider (Jens-Peter) (ed.), Verwaltungsrecht in Europa, 1. England und Wales, Spanien, Niederlande, vol. 1, V\&R unipress, Göttingen, 2007

Schoch (Friedrich), Schneider (Jens-Peter), Bier (Wolfgang) (eds.), Verwaltungsgerichtsordnung, Kommentar, 27. Ergänzugslieferung, C. H. Beck, München, 2014

Schreuder-Vlasblom (Maria), Relativiteit in het bestuursrecht, een discussiebijdrage, NTB 2007/8, pp. $43-52$

Schueler (Ben), Een relativiteitsleer in wording, NTB 2011/38, pp. 265-271

Schuurmans (Ymre E.), Bewijslastverdeling in het bestuursrecht, Kluwer, Alphen aan den Rijn, 2005

Schwab (Martin), Die Umweltverträglichkeitsprüfung in der behördlichen Praxis, NVwZ 1997, vol. 16 , issue 5, pp. 428-435

Schwarze (Jürgen), Europäisches Verwaltungsrecht, $2^{\text {nd }}$ rev. edition, Baden-Baden, Nomos, 2005

Schwarze (Jürgen), Europarecht, Strukturen, Dimensionen und Wandlungen des Rechts der Europäischen Union, Ausgewählte Beiträge, Nomos, Baden-Baden, 2012

Schwarze (Jürgen), EU Kommentar, $3^{\text {rd }}$ edition, Nomos, Baden-Baden, 2012

Scotford (Eloise), Oliver (Rosie), The state of UK environmental legislation: opportunities for reform?, ELRev 2013, pp. 225-229

Seerden (René J. G. H.), Heldeweg (Michiel A.), Deketelaere (Kurt R.) (eds.), Public Environmental Law in the European Union and the United States, Kluwer Law International, The Hague, 2002

Seerden (René JGH) (ed.), Administrative Law of the European Union, its Member States and the United States, $3^{\text {rd }}$ edition, Intersentia, Cambridge, 2012

Seibert (Max-Jürgen), Verbandsklagen im Umweltrecht, Aktueller Stand, Perspektiven und praktische Probleme, NVwZ 2013, vol. 32, issue 16, pp. 1040-1049

Seyr (Sibylle), Der Effet Utile in der Rechtsprechung des Europäischen Gerichtshofs, Duncker \& Humblot, Berlin, 2008 
Sheridan, United Kingdom, in: Sadeleer (Nicolas de), Roller (Gerhard), Dross (Miriam) (eds.), Access to Justice in Environmental Matters and the Role of NGOs: empirical findings and legal appraisal, Europa Law Publishing, Groningen, 2005, pp. 156-159

Siegel (Thorsten), Zur Einklagbarkeit der Umweltverträglichkeit, DÖV 2012, vol. 65, issue 18, pp. $709-716$

Siegel (Thorsten), Ausweitung und Eingrenzung der Klagerechte im Umweltrecht, NJW 2014, vol. 67, issue 14, pp. 973-975

Slepcevic (Reinhard), Litigating for the Environment, EU Law, National Courts and Socio-Legal Reality, Verlag für Sozialwissenschaften, Wiesbaden, 2009

Smits (Jan), Who Does What? On Cameron, Rutte and the Optimal Distribution of Competences among the European Union and the Member States, in: Purnhagen (Kai), Rott (Peter) (eds.), Varieties of European Economic Law and Regulation: Liber Amicorum for Hans Micklitz, Springer, Cham, 2014, pp. 343-357

Soell (Hermann), Dirnberger (Franz), Wieviel Umweltverträglichkeit garantiert die UVP?Bestandsaufnahme und Bewertung des Gesetzes zur Umsetzung der EG-Richtlinie über die Umweltverträglichkeitsprïfung, NVwZ 1990, vol. 9, issue 8, pp. 705-713

Sodan (Helge), Ziekow (Jan) (eds.), Verwaltungsgerichtsordnung, Großkommentar, $4^{\text {th }}$ edition, Nomos, Baden-Baden, 2014

Soppe (Marcel A. A.), Gundelach (Jade), Witbreuk (Heino), En weer een moderniseringsslag...Of vormt de Omgevingswet dan toch het eindstation voor een eigentijds m.e.r.-systeem?, TO 2013, issue 2, pp. 55-67

Spieth (Wolf F.), Appel (Markus), Umfang und Grenzen der Einklagbarkeit von UVP Fehlern nach Umweltrechtsbehelfsgesetz, NuR 2009, vol. 31, issue 5, pp. 312-317

Steinberg (Rudolf), Chancen zur Effektuierung der Umweltverträglichkeitsprüfung durch die Gerichte?, DÖV 1996, vol. 49, issue 6, pp. 221-231

Stelkens (Paul), Bonk (Heinz Joachim), Verwaltungsverfahrensgesetz, Kommentar, $8^{\text {th }}$ edition, C. H. Beck, München, 2014

Storme (Marcel) (ed.), Procedural Laws in Europe, Towards Harmonisation, Maklu, Antwerpen, 2003

Tak (Antonius Q. C.), Het Nederlandse bestuursprocesrecht in theorie en praktijk, Procesrechtelijk organisatierecht en materieel procesrecht, vol. 1, $5^{\text {th }}$ edition, Wolf Legal Publishers, Oisterwijk, 2014

Tak (Antonius Q. C.), Het Nederlandse bestuursprocesrecht in theorie en praktijk, Rechtsmacht en Bewijsrecht, vol. 2, $5^{\text {th }}$ edition, Wolf Legal Publishers, Oisterwijk, 2014

Taruffo (Michele), Harmonisation in a Global Context: The ALI/UNIDROIT Principles, in: Kramer (Xandra E.), Rhee (Cornelis H. van) (eds.), Civil Litigation in a Globalising World, Springer, Berlin, 2012, pp. 207-219

Tettinger (Peter), Stern (Klaus) (eds.), Kölner Gemeinschaftskommentar zur Europäischen Grundrechte-Charta, C. H. Beck, München, 2006

Tolsma (Hanna), Graaf (Kars de), Jans (Jan), The Rise and Fall of Access to Justice in The Netherlands, JEL 2009, volume 21, issue 2, 2009, pp. 309-321

Velsen (Selma van), M.e.r.-beoordeling: geen drempelvrees!, JM 2011, pp. 585-594 
Velsen (Selma van), Case Comment on ABRvS 4 July 2012, nr. 201010565/1/A4, JM 2012/111, pp. $812-816$

Verburg (D. A.), De bestuursrechter: van des werkmans beste raadsman tot bewijsrechtelijke spelverdeler- 15 jaar bewijsrecht onder de Awb, in: Barkhuysen (Thomas), Ouden (Willemiena den), Polak (J. E. M.) Bestuursrecht harmoniseren: 15 jaar Awb, Boom Juridische uitgevers, Den Haag, 2010, pp. 261-279

Verburg (D. A.), Relativiteit in de Crisis- en herstelwet en in het voorstel Wet aanpassing bestuursprocesrecht of: Hoe moet het nou met het zeggekorfslakje, NTB 2011/3, pp. 10-17

Vernadaki (Zampia), Civil Procedure Harmonization in the EU: Unravelling the Policy Considerations, JCER 2013, vol. 9, issue 2, pp. 297-312

Waard (Boudewijn W. N. de), Relativiteit en rechtsbeschreming, NTB 2007/2, pp. 7-14

Waard (Boudewijn W. N. de), Bestuursrechtelijke rechtsbeschermingsleer en relativiteit, NTB 2007/9, pp. 53-60

Wade (William), Forsyth (Christopher), Administrative Law, $11^{\text {th }}$ edition, Oxford University Press, Oxford, 2014

Wegener (Bernhard W.), Europäische Querschnittpolitiken, Nomos, Baden-Baden, 2014

Wennerås (Pål), The Enforcement of EC Environmental Law, Oxford University Press, Oxford, 2007

Werlauff (Erik), Common European Procedural Law, DJØF Publishing, Copenhagen, 1999

Wesel (Uwe), Geschichte des Rechts in Europa, C. H. Beck, München, 2010

Widdershoven (Rob), Naar een Europese harmonisatie van het nationale bestuursrecht?, NTB 2014/33, pp. 261-264

Wienhues (Sigrid), Die Neufassung des Umwelt-Rechtsbehelfsgesetzes, NordOeR 2013, vol. 16, issue 5, pp. 185-191

Wijk (Hendrik D.), Konijnenbelt (Willem), Male (Ron van), Hoofdstukken van Bestuursrecht, $16^{\text {th }}$ edition, Kluwer, Deventer, 2014

Wood (Christopher), Environmental Impact Assessment: A Comparative Review, $2^{\text {nd }}$ edition, Prentice Hall, Harlow, 2003

Wood (Graham), Ten Years On: An empirical analysis of UK Environmental Statement Submissions since the Implementation of Directive 85/337/EEC, JEPM 2000, vol. 43, issue 5, pp. 721-747

Woolf (Harry), Jowell (Jeffrey), Le Sueur (Andrew), Hare (Ivan) (eds.), De Smith' Judicial Review, $7^{\text {th }}$ edition, Sweet \& Maxwell, London, 2013

Würtenberger (Thomas), Verwaltungsprozessrecht, ein Studienbuch, $3^{\text {rd }}$ rev. edition, C. H. Beck, München, 2011

Ziekow (Jan), Das Umwelt-Rechtsbehelfsgesetz im System des deutschen Rechtsschutzes, NVwZ 2007, vol 26, issue 3, pp. 259-267

Ziekow (Jan), Europa und der deutsche Verwaltungsprozess - Schlaglichter auf eine unendliche Geschichte, NVwZ 2010, vol. 29, issue 13, pp. 793-799

Ziekow (Jan), Verfahrensfehler im Umweltrecht - notwendige Nachjustierungen im deutschen Verwaltungsrecht, NuR 2014, vol. 36, issue 4, pp. 229-235 


\section{Online Sources}

Abbreviation in the text: "available online"; all sources have been last visited on 27 April 2015

ALI/UNIDROIT, Principles and Rules of Transnational Civil Procedure, available at:

http://www.unidroit.org/english/principles/civilprocedure/ali-unidroitprinciples-e.pdf

Backes (Chris W.), Hardy (Ellen) Jansen (Sander), Polleunis (Sofie), Timmers (R.), Evaluatie

Bestuurlijke Lus Awb en internationale rechtsvergelijking, 2014 available at:

http://www.rijksoverheid.nl/documenten-en-publicaties/kamerstukken/2014/12/11/tk-evaluatie-vande-bestuurlijke-lus.html

Lord Carnwath at the joint UCL-HKU conference 'Judicial review in a changing society', at Hong Kong University, From Rationality to Proportionality in the Modern Law ～, 14 April 2014, available at: https://www.supremecourt.uk/docs/speech-140414.pdf

Commissie m.e.r., Views and Experiences 2012, Series no. 11 available at:

www.commissiemer.nl/docs/mer/diversen/views experiences 2012.pdf

Commissie m.e.r., Jaarverslag 2005, available at: www.commissiemer.nl/docs/cms/tekst.pdf

Commissie m.e.r., Aanvullend Toetsingsadvies over het milieueffectrapport, 12 February 2009, nr.

1755-72, available at: www.commissiemer.nl/docs/mer/p17/p1755/a1755ats.pdf

Commissie m.e.r., Jaarverslag 2012, available at:

www.commissiemer.nl/docs/mer/diversen/commissie_mer_jaarverslag_2012.pdf

Commissie m.e.r., Jaarverslag 2013, available at:

http://www.commissiemer.nl/organisatie/jaarverslagen

Darpö (Jan), Effective Justice?, Synthesis Report of the study on the Implementation of Articles 9.3 and 9.4 of the Aarhus Convention in Seventeen of the Member States of the European Union, 2012, available at:

http://ec.europa.eu/environment/aarhus/pdf/synthesis\%20report\%20on\%20access\%20to\%20justice.pd f

Department for Communities and Local Government, Circular 02/99: Environmental impact assessment, 12 March 1999, available at:

https://www.gov.uk/government/uploads/system/uploads/attachment_data/file/7676/155958.pdf

Ebbesson (Jonas), Information, Participation and Access to Justice: the Model of the Aarhus Convention, Background Paper No. 5 to the joint UNEP-OHCHR Expert Seminar on Human Rights and the Environment, 14-16 Jan. 2002, Geneva, available at: 
http://www.ohchr.org/Documents/Issues/Environment/BP_Information_Participation_Access_Justice_ Model_AarhusConvention.pdf

Ebbesson (Jonas), Gaugitsch (Helmut), Jendroska (Jerzy), Marshall (Fiona), Stec (Steven), The Aarhus Convention: An Implementation Guide, $2^{\text {nd }}$ edition, 2014, available at:

http://www.unece.org/fileadmin/DAM/env/pp/Publications/Aarhus_Implementation_Guide_interactiv e_eng.pdf

European Commission, Guidance on EIA, Screening, June 2001, available at:

http://ec.europa.eu/environment/archives/eia/eia-guidelines/g-screening-full-text.pdf

Initial report on the ELI-UNIDROIT 1st Exploratory Workshop (18-19 October 2013, Vienna), available at: http://www.europeanlawinstitute.eu/fileadmin/user_upload/p_eli/Projects/ELI-

UNIDROIT_Workshop_initial_report.pdf

Institute of Environmental Management and Assessment, The State of Environmental Impact

Assessment in England, Special Report, June 2011, available at: http://www.iema.net/iema-special$\underline{\text { reports }}$

Keupp (Stefan), Zschiesche (Michael), Die Aarhus Konvention - Bürgerbeteiligung in neuer

Qualität?, UFU-Paper, Juni 2010, available at: http://www.aarhus-

konvention.de/media/content/files/Studien/Hintergrundpapier_Aarhus_Final.pdf

ReNEUAL Model Rules on EU Administrative Procedure 2014, available at:

http://www.reneual.eu/publications/ReNEUAL\%20Model\%20Rules\%202014/ReNEUAL-

\%20Model\%20Rules-Compilation\%20Books\%20I VI 2014-09-03.pdf

Report of the Working Group on Access to Environmental Justice, Ensuring Access to Environmental Justice in England and Wales, 2008, available at http://www.wwf.org.uk/filelibrary/pdf/

justice report 08.pdf

Streitwertkatalog für die Verwaltungsgerichtsbarkeit (in der Fassung der am 31. Mai/1. Juni 2012 und am 18 Juli 2013 beschlossenen Änderungen), available at the website of the BVerwG, http://www.bverwg.de/medien/pdf/streitwertkatalog.pdf

Temple Lang (John), Harmonising National Laws, Procedures and Judicial Review of Mergers in the EU and EEA, (7 April 2011), $18^{\text {th }}$ St. Gallen International Competition Law Forum ICF, April $7^{\text {th }}$ and $8^{\text {th }}$ 2011, available at: $\underline{\text { http://ssrn.com/abstract }=2173386}$

The Environmental Law Foundation, Cost Barriers to Environmental Justice, A Report in Association with BRASS, December 2008, available at: 
http://www.unece.org/fileadmin/DAM/env/pp/compliance/C2008-

33/correspondence/FrELF_Report2009.pdf

Translation by the Federal Ministry of Justice and Consumer Protection, http://www.gesetze-iminternet.de/englisch_vwgo/ (translated by Neil Musset)

Translation provided by the Ministry of Interior and Kingdom Relations,

http://www.rijksoverheid.nl/documenten-en-publicaties/besluiten/2006/06/21/engelse-tekst-awb.html

UBA, Vom Bund anerkannte Umwelt- und Naturschutzvereinigungen (10.3.2014), available at:

http://www.umweltbundesamt.de/sites/default/files/medien/371/dokumente/anerkannte umwelt-

_und_naturschutzvereinigungen.pdf 


\section{Curriculum Vitae}

Franziska Grashof was born in 1988 in Aachen (Germany). After having passed her Abitur in 2007 in Jülich (Germany), she studied International, European and Comparative law at Maastricht University (The Netherlands) and spent a semester at the Université Montesquieu Bordeaux IV (France). After graduating with distinction from the European Law School Programme in Maastricht in 2011, she wrote her Ph.D. thesis under the supervision of Professor Chris Backes and Dr. Mariolina Eliantonio. In September 2014, she spent one month at the Fondation Jean Monnet pour l'Europe in Lausanne (Switzerland). In addition to writing this thesis, she has been studying national law in Germany. 
